\title{
PREVENÇÃO À POLUIÇÃO INDUSTRIAL: IDENTIFICAÇÃO DE OPORTUNIDADES, ANÁLISE DOS BENEFÍCIOS E BARREIRAS
}

Tese apresentada à Escola de Engenharia de São Carlos, da Universidade de São Paulo, como parte dos requisitos para a obtenção do Título de Doutor em Ciências da Engenharia Ambiental.

Orientador: Prof. Dr. Valdir Schalch 
RESUMO

SANTOS, C. (2005). Prevenção à Poluição Industrial: Identificação de Oportunidades, Análise dos Benefícios e Barreiras. Tese (Doutorado). Escola de Engenharia de São Carlos. Universidade de São Paulo, São Carlos, 2005.

A prevenção à poluição éuma abordagem de gerenciamento ambiental que prioriza a redução dos resíduos na fonte como forma de preservar os recursos naturais e reduzir o desperdício de materiais, água e energia, em contraposição à abordagem tradicional, que se apóia nas tecnologias de controle e tratamento de resíduos. Apesar de resultar em benefícios ambientais e econômicos, existem uma série de barreiras que impedem uma maior disseminação das práticas de prevenção à poluição nas indústrias, dentre as quais a principal é a falta de conscientização em relação aos benefícios. Para eliminar esta barreira, faz-se necessário o desenvolvimento e a divulgação dos conceitos e ferramentas de apoio ao processo de identificação de oportunidades, ferramentas para o monitoramento e avaliação da performance ambiental dos processos produtivos, bem como de estudos de caso propondo alternativas de prevenção à poluição para os diferentes setores industriais. Esta pesquisa tem como objetivo fundamental apresentar os conceitos, sistemáticas e ferramentas necessárias ao entendimento da abordagem de prevenção à poluição, e ao desenvolvimento, implantação e monitoramento de programas de prevenção à poluição em processos industriais. Como forma de avaliar a aplicação do conceito e das ferramentas de identificação de oportunidades, e os benefícios e barreiras, foi realizada a avaliação de um processo produtivo industrial. Os resultados obtidos fornecem embasamento teórico para que outros trabalhos semelhantes sejam desenvolvidos, e servem como incentivo para que a empresa na qual foi realizada a avaliação, passe a adotar o conceito de prevenção à poluição como princípio norteador nas suas atividades de gestão ambiental.

Palavras-chave: prevenção à poluição, produção mais limpa, ecoeficiência, gestão ambiental, resíduos industriais. 


\section{ABSTRACT}

SANTOS, C. (2005). Industrial Pollution Prevention: Opportunities Assessment, Benefits and Barriers Analysis. Ph.D. Thesis. Escola de Engenharia de São Carlos. Universidade de São Paulo, São Carlos, 2005.

Pollution prevention is an environmental management approach that prioritizes the source reduction of wastes as a way to preserve natural resources and reduce material, water and energy losses, conversely to the traditional approach, based on end of pipe technologies. In spite of the environmental and economic benefits, many barriers can impede the widespreading of pollution prevention practices at industry, among them, the most important one is the lack of consciousness on the pollution prevention benefits. To overcome this barrier, it is necessary to develop and report concepts and tools to support the opportunity assessment process, tools to monitor and evaluate industrial processes environmental performance, as well as case studies on pollution prevention alternatives to different industrial sectors. This research fundamental aim is to present the concepts, approaches and tools necessary to understand the pollution prevention approach and to develop, implement and monitor industrial pollution prevention plans. A case study was conducted in a company to evaluate the concept application, the utilization of the apportunities assessment tools, and the benefits and barriers. The results provide a theoric framework so that other similar studies can be conducted, and also serve as an incentive for the company where the case study was conducted, to improve its environmental management activities by adopting pollution prevention concept as a guiding principle.

Keywords: pollution prevention, cleaner production, eco-efficiency, environmental management, industrial waste. 


\section{LISTA DE FIGURAS}

Figura 1- Relação entre desenvolvimento e problemas ambientais........................ 5

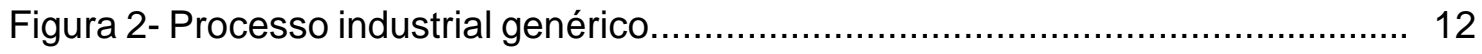

Figura 3- Rotas de exposição de poluentes no meio ambiente............................... 12

Figura 4- Geração de resíduos no ciclo de vida de um produto................................ 13

Figura 5- Fase de omissão aos danos ambientais............................................. 17

Figura 6- Fase do controle end of pipe........................................................ 18

Figura 7- Reutilização, reciclagem e recuperação de resíduos.............................. 20

Figura 8- Hierarquia do gerenciamento de resíduos........................................... 21

Figura 9- Formas de incorporação da dimensão ambiental nas atividades

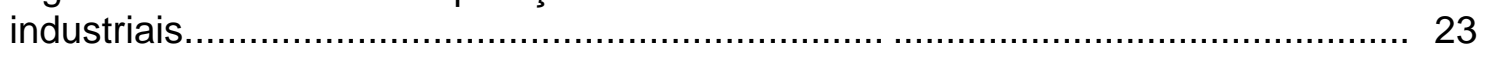

Figura 10- Práticas de produção mais limpa implementadas no Brasil................... 29

Figura 11- Geração de Resíduos Industriais no Brasil...................................... 31

Figura 12- Destinação Final dos Resíduos Industriais por Grandes Regiões............ 33

Figura 13- Distribuição Percentual da Disposição de Resíduos Industriais no

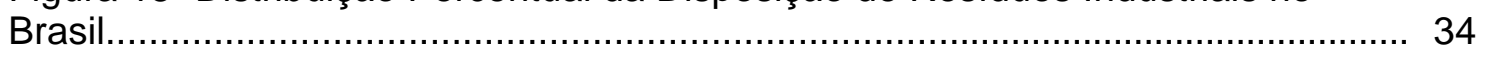

Figura 14- Síntese da sustentabilidade segundo o WBCSD.............................. 47

Figura 15- Estratégias de redução na fonte..................................................... 51

Figura 16- Uso de recursos em sistema aberto............................................ 51

Figura 17- Uso de recursos em sistema fechado............................................. 51

Figura 18- Relação de aceitabilidadde e custo das estratégias de prevenção à poluição. 52

Figura 19- Estratégias de produção mais limpa.............................................. 57

Figura 20- Modelo de ecossistema industrial..................................................... 63

Figura 21- Simbiose Industrial - Kalundborg (Dinamarca) ................................ 64

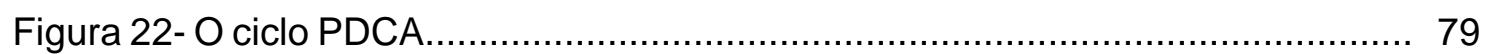

Figura 23- Elementos do sistema de gestão ambiental....................................... 79

Figura 24- Estrutura da Avaliação de Ciclo de Vida............................................ 84

Figura 25- Motivações e suas freqüências para a realização de estudos de ACV.... 85

Figura 26- Oportunidades para aplicação do ecodesign ao longo do ciclo de vida do produto......

Figura 27- Reciclagem e remanufatura de materiais no ciclo de vida..................... 89

Figura 28- Critério para a otimização da sustentabilidade de produtos e serviços.... 90

Figura 29- Delimitação da avaliação realizada no processo produtivo..................... 120

Figura 30- Fronteira do sistema de estudo...................................................... 122

Figura 31- Procedimento para a minimização de resíduos..................................... 127 
Figura 32- Procedimento para a identificação de oportunidades de prevenção à poluição.

Figura 33- Sistemática tradicional para o planejamento de um programa de prevenção à poluição.

Figura 34- Sistemática alternativa para o planejamento de um programa de prevenção à poluição.

Figura 35- Checklist para o planejamento da prevenção à poluição........................ 130

Figura 36- Etapas para a implementação de um programa de produção mais limpa 131

Figura 37- Sistemática para identificação de oportunidades de produção mais limpa.

Figura 38- Diagrama de fluxo de processo.................................................... 135

Figura 39- Mapa de um processo de manufatura de produtos metálicos.................. 136

Figura 40- Mapa de processo do tratamento de superfícies metálicas..................... 137

Figura 41- Mapa de processo do desengraxe no tratamento de superfícies............ 137

Figura 42- Diagrama de fluxo de materiais............................................................. 139

Figura 43- Volume ou sistema fechado onde são realizados balanços materiais..... 141

Figura 44- Gráfico de Pareto............................................................................. 149

Figura 45- Exemplos de custos ambientais em uma empresa.............................. 151

Figura 46- Diagrama de causa e efeito.............................................................. 156

Figura 47- Formulário para exercício de brainwriting ............................................. 159

Figura 48- Matriz de critérios para seleção de alternativas..................................... 163

Figura 49- Definição de fatores de escala para matriz de critério............................ 164

Figura 50- Modelo de formulário de plano de ação................................................ 167

Figura 51- Ciclo de melhoria de ações corretivas de uma auditoria........................ 170

Figura 52- Principais dimensões de um indicador de produção sustentável............. 174

Figura 53- Indicadores de produção sustentável................................................ 174

Figura 54- Síntese das ferramentas para implantação da prevenção à poluição...... 178

Figura 55- Mapa de processo da indústria de acabamento de metais..................... 179

Figura 56- Mapa do processo de tratamento de superfícies................................... 194

Figura 57- Mapa do processo de fosfatização..................................................... 195

Figura 58- Eficiência das formulações de fosfato................................................... 196

Figura 59- Fontes de poluição no processo de tratamento de superfície e pintura... 197

Figura 60- Pintura por spray de ar atomizado (overspray) .................................... 202

Figura 61- Mapa de processo da área de metalurgia........................................... 215

Figura 62- Área de estamparia..................................................................... 216

Figura 63- Matrizes da estamparia ................................................................ 216 
Figura 64- Mapa de processo da área de metalurgia............................................ 216

Figura 65- Sucata metálica da estamparia...................................................... 217

Figura 66- Caçamba de sucata metálica............................................................ 217

Figura 67- Caçamba de sucata de plástico............................................................ 217

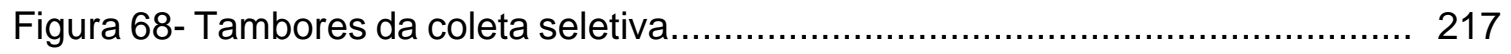

Figura 69- Sucata planejada e de processo gerada na metalurgia.......................... 219

Figura 70- Mapa de processo da área de pintura................................................ 220

Figura 71- Mapa de processo do tratamento de superfícies.................................. 220

Figura 72- Fluxograma do tratamento de superfícies........................................... 221

Figura 73- Mapa de processo do desengraxe ...................................................... 222

Figura 74- Mapa de processo do tratamento químico................................................ 224

Figura 75- Peças entrando na estufa de secagem............................................... 225

Figura 76- Estação de tratamento de efluentes..................................................... 226

Figura 77- Fluxograma da estação de tratamento de efluentes............................... 227

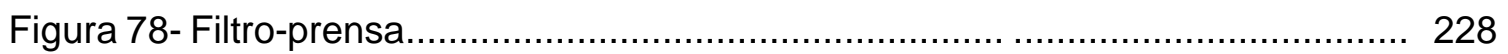

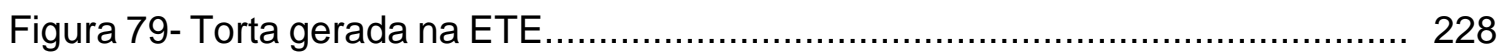

Figura 80- Gabinetes entrando na pintura..................................................... 229

Figura 81- Gabinetes pintados................................................................... 229

Figura 82- Processo de pintura a pó..................................................................... 229

Figura 83- Peças na cabine de pintura............................................................. 229

Figura 84- Variação consumo desengraxante................................................ 230

Figura 85- Variação consumo refinador.............................................................. 230

Figura 86- Variação consumo passivador inorgânico.......................................... 230

Figura 87- Variação consumo de insumos da fosfatização.................................... 230

Figura 88- Variação consumo de insumos da ETE............................................ 231

Figura 89- Mapa de processo da montagem da caixa interna do produto 1............ 235

Figura 90- Mapa de processo da montagem da caixa externa do produto 1............ 236

Figura 91- Mapa de processo da célula 1 da linha de montagem do produto $1 \ldots \ldots . .237$

Figura 92- Mapa de processo da célula 2 da linha de montagem do produto $1 \ldots \ldots . .237$

Figura 93- Mapa de processo da célula de pré montagem da tampa do produto $1 \ldots 238$

Figura 94- Mapa de processo da célula 3 da linha de montagem do produto 1 ........ 238

Figura 95- Mapa de processo da célula 4 da linha de montagem do produto 1 ........ 238

Figura 96- Mapa de processo da célula 1 da linha de montagem do produto 2....... 244

Figura 97- Mapa de processo das célula 2 da linha de montagem do produto 2...... 244

Figura 98- Mapa de processo da célula 3 da linha de montagem do produto $2 \ldots \ldots . .245$ 
Figura 99- Mapa de processo da célula 4 da linha de montagem do produto 2 ........ 245

Figura 100- Mapa de processo da célula 5 da linha de montagem do produto 2..... 246

Figura 101- Mapa de processo da célula 6 da linha de montagem do produto 2..... 246

Figura 102- Mapa de processo da célula 1 da linha de montagem do produto 3..... 251

Figura 103- Mapa de processo da célula 2 da linha de montagem do produto 3..... 251

Figura 104- Mapa de processo da célula 3 da linha de montagem do produto 3...... 251

Figura 105- Mapa de processo da célula 4 da linha de montagem do produto 3...... 252

Figura 106- Mapa de processo da montagem do vidro externo.............................. 252

Figura 107- Mapa de processo da montagem do vidro interno................................ 252

Figura 108- Mapa de processo da montagem da porta....................................... 252

Figura 109- Central de resíduos........................................................................ 255

Figura 110- Kit de emergência.................................................................... 255

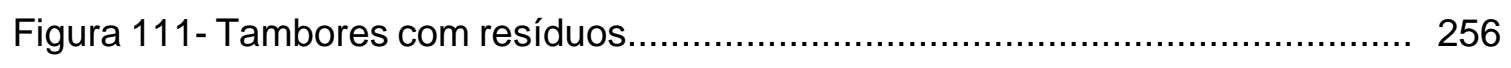

Figura 112- Resíduos de plásticos................................................................ 256

Figura 113- Sucatas metálicas.................................................................... 256

Figura 114- Resíduos de luvas de PVC ....................................................... 256

Figura 115- Resíduos recicláveis................................................................ 257

Figura 116- Destinação final dos resíduos....................................................... 257

Figura 117- Tensionadores de nylon usados na central de corte.......................... 259 


\section{LISTA DE TABELAS}

Tabela 1 - Geração de Resíduos Sólidos Industriais no Brasil.

Tabela 2 - Municípios com serviços de limpeza urbana e/ou coleta de resíduo sólido, por controle da disposição, segundo as grandes regiões. 32

Tabela 3 - Municípios que coletam resíduo industrial, por destinação do resíduo... 32

Tabela 4 - Custos das principais tecnologias de tratamento de resíduos industriais. 34

Tabela 5 - Geração de resíduos sólidos industriais no Estado de São Paulo. 35

Tabela 6 - Avaliação comparativa da destinação de resíduos perigosos na RMSP. 36

Tabela 7 - Áreas Contaminadas no Estado de São Paulo........................................ 37

Tabela 8 - Destinação final dos resíduos da área de metalurgia............................ 218

Tabela 9 - Inventário de sucata de aço da área de metalurgia.............................. 219

Tabela 10 - Caracterização dos banhos do tratamento de superfícies.................... 232

Tabela 11 - Resultados dos ensaios de solubilização e lixiviação da torta.............. 233

Tabela 12 - Destinação final dos resíduos da área de pintura................................. 234

Tabela 13 - Inventário de resíduos da linha de montagem do produto 1 ................. 240

Tabela 14 - Inventário de resíduos da linha de montagem do produto 2 ................. 247

Tabela 15 - Inventário de resíduos da linha de montagem do produto $3 \ldots \ldots \ldots \ldots \ldots . . . . .253$ 


\section{LISTA DE QUADROS}

Quadro 1 - Principais instrumentos legais aplicados às atividades industriais......... 40

Quadro 2 - Terminologia encontrada na literatura do gerenciamento ambiental..... 49

Quadro 3- Estratégias de prevenção de resíduos, envolvendo a participação da indústria e dos consumidores.................................................................... 54

Quadro 4- Tecnologias convencionais de produção mais limpa............................. 58

Quadro 5- Novas tecnologias com potencial aplicação na produção mais limpa..... 59

Quadro 6- Critérios ecológicos para o desing de produtos químicos...................... 60

Quadro 7- Normas da série ISO 14000, suas aplicações e objetivos..................... 75

Quadro 8- Critérios para a seleção de aspectos ambientais................................ 81

Quadro 9- Métodos de reciclagem e reúso...................................................... 104

Quadro 10- Tecnologias de tratamento para o reúso de água................................. 106

Quadro 11- Aplicações das abordagens prescritiva e descritiva............................. 134

Quadro 12 - Balanços materiais versus contabilidade de materiais....................... 142

Quadro 13- Fontes de informação para a contabilidade de materiais..................... 143

Quadro 14 - Questões a serem respondidas antes da implantação........................ 166

Quadro 15 - Categorias de indicadores de eco-eficiência, segundo o WBCSD....... 171

Quadro 16 - Indicadores de produção sustentável........................................... 175

Quadro 17- Propriedades dos solventes clorados............................................ 187

Quadro 18 - Alternativas de desengraxantes aquosos disponíveis para
substituição de solventes clorados.......................................................... 188

Quadro 19 - Alternativas disponíveis para a substituição de solventes clorados em processos de limpeza e desengraxe.............................................................. 189

Quadro 20 - Tecnologias disponíveis para processos de limpeza e desengraxe..... 193

Quadro 21- Sequência de etapas do processo de fosfatização............................... 195

Quadro 22 - Alternativas para melhoria da eficiência do processo de fosfatização. 199 
ABRELPE - Associação Brasileira de Resíduos e Limpeza

ABETRE - Associação Brasileira de Empresas de Tratamento, Recuperação e

Disposição de Resíduos Especiais

ABNT - Associação Brasileira de Normas Técnicas

ACV - Avaliação de Ciclo de Vida

CEMPRE - Compromisso Empresarial para a Reciclagem

CETESB - Companhia de Tecnologia de Saneamento Ambiental do Estado de São

Paulo

CFC's - Clorofluorcarbonos

CNTL - Centro Nacional de Tecnologias Limpas

CONAMA - Conselho Nacional do Meio Ambiente

EPI - Equipamento de Proteção Individual

FIESP - Federação das Indústrias do Estado de São Paulo

IBAMA - Instituto Brasileiro do Meio Ambiente e dos Recursos Renováveis

P2 - Pollution Prevention

SGA - Sistema de Gestão Ambiental

UNEP - United Nations Environmental Program

US EPA - United States Environmental Protection Agency

WBCSD - World Business Council for Sustainable Development 


\section{SUMÁRIO}

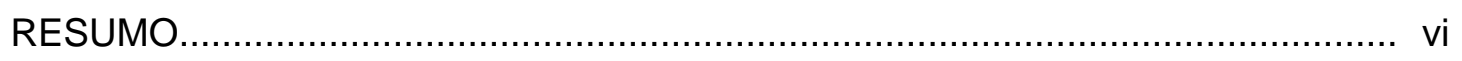

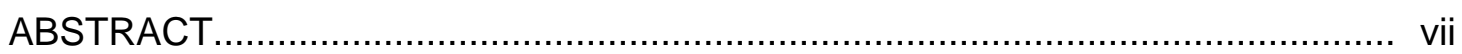

LISTA DE FIGURAS ................................................................................... vii

LISTA DE TABELAS ............................................................................. xii

LISTA DE QUADROS .................................................................................. $x$ iii

LISTA DE ABREVIATURAS E SIGLAS .......................................................... xiv

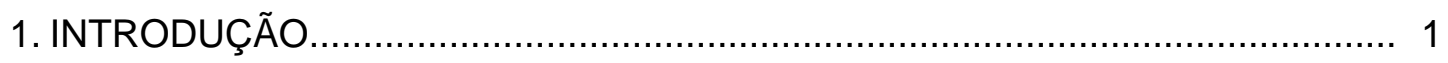

1.1. Considerações Iniciais....................................................................... 1

1.2. Justificativa e Relevância da Pesquisa..................................................... 2

1.3. Objetivos da Pesquisa.............................................................................. 3

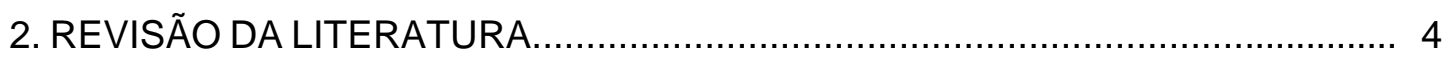

2.1. Indústria, Meio Ambiente e Desenvolvimento Sustentável........................... 4

2.2. Poluição Industrial............................................................................. 11

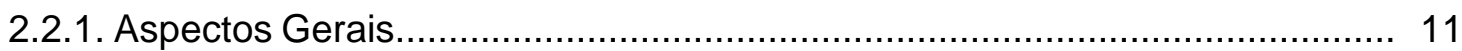

2.2.2. Resíduos Industriais - Definição e Classificação......................................... 15

2.2.3. A Evolução no Gerenciamento de Resíduos: do Descaso à Prevenção........ 16

2.2.4. Respostas das Indústrias frente às Questões Ambientais............................. 23

2.2.5. A Indústria e o Meio Ambiente no Brasil.................................................... 24

2.2.5.1. A Gestão Ambiental na Indústria Brasileira............................................... 24

2.2.5.2. Geração de Resíduos Industriais...................................................... 30

2.2.5.3. Regulamentos e Políticas Ambientais................................................. 38

2.2.5.4. Normas Internacionais Relacionadas à Poluição Industrial........................ 45

2.3. Produção e Consumo Sustentáveis: as diversas abordagens existentes......... 46

2.3.1. Prevenção à Poluição eRedução na Fonte............................................. 50

2.3.2. Prevenção, Minimização e Redução de Resíduos....................................... 53

2.3.2.1. Reutilização, Recuperação e Reciclagem de Fora do Processo................. 55

2.3.2.2. Compostagem............................................................................... 55

2.3.3. Produção Limpa (Clean Production) e Produção mais Limpa (Cleaner Production) ............................................................................................ 56

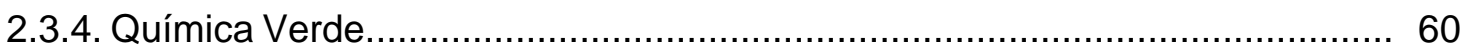

2.3.5. Eco-Eficiência ................................................................................ 61

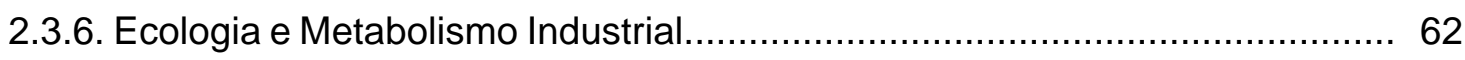

2.3.7. Fator 4, Fator 10 e Capitalismo Natural........................................................ 66 


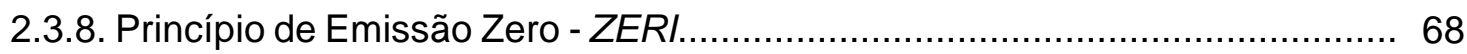

2.3.9. Normas de Padronização Ambiental....................................................... 69

2.3.9.1. Sistemas de Gestão Ambiental: visão geral........................................ 69

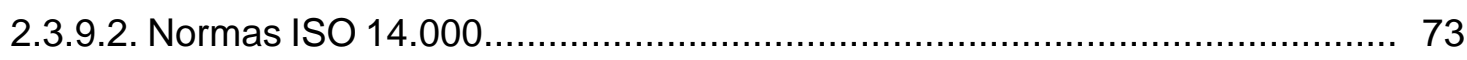

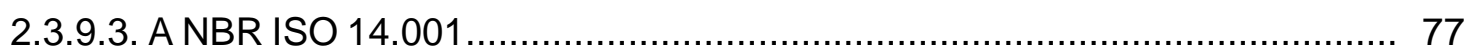

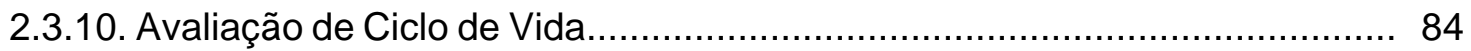

2.4. Categorias de Prevenção à Poluição......................................................... 87

2.4.1. Projeto e Reformulação de Produto....................................................... 87

2.4.2. Modificações nas Tecnologias, Processos e Equipamentos........................ 91

2.4.3. Modificações nas Matérias-Primas e Materiais.......................................... 92

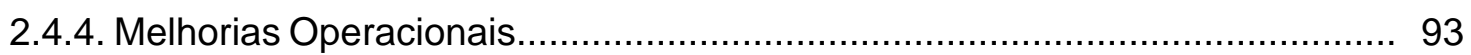

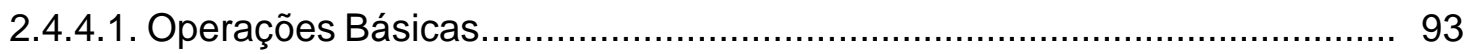

2.4.4.2. Limpeza e Manutenção......................................................................... 94

2.4.4.3. Manuseio e Estocagem de Resíduos e Materiais.................................... 95

2.4.4.4. Controle de Processo....................................................................... 96

2.4.4.5. Boas Práticas Operacionais (housekeeping) ........................................ 96

2.4.5. Aquisição Ambientalmente Favorável................................................ 97

2.4.5.1. Aquisição para Fins Específicos..................................................... 97

2.4.5.2. Especificações Ambientais (green specifications) ................................... 98

2.4.5.3. Proibição ou Limitação de Certas Substâncias......................................... 98

2.4.5.4. Listagem de Produtos Aprovados......................................................... 99

2.4.5.5. Qualificação de Fornecedores......................................................... 99

2.4.5.6. Parcerias com Fornecedores................................................................ 99

2.4.6. Gerenciamento de Inventário Ambientalmente Responsável....................... 100

2.4.6.1. Gerenciamento da Demanda de Materiais........................................... 100

2.4.6.2. Inspeções de Materiais.................................................................... 101

2.4.6.3. Identificação de Requerimentos de Estocagem..................................... 101

2.4.6.4. Movimentação de Estoque............................................................... 101

2.4.6.5. Redução de Estoque e Melhorias dos Procedimentos de Entrega.............. 101

2.4.7. Reciclagem e Reúso no Processo................................................................ 102

2.4.7.1. Técnicas de Segregação e Separação.................................................. 103

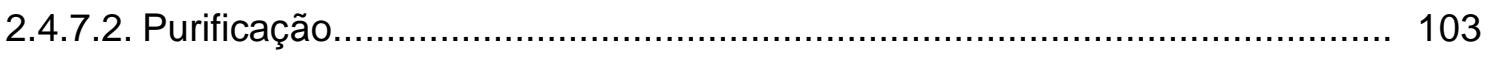

2.4.7.3. Métodos de Reciclagem e Reuso...................................................... 103

2.4.7.4. Reúso e Reciclagem de Água.............................................................. 105

2.4.8. Treinamento e Envolvimento dos Funcionários.......................................... 107

2.5. Benefícios da Prevenção à Poluição............................................................. 108

2.5.1. Redução de Custos Operacionais..................................................... 108 
2.5.2. Melhoria das Condições de Trabalho 108

2.5.3. Redução dos Custos com a Conformidade Ambiental................................ 109

2.5.4. Aumento da Produtividade................................................................... 109

2.5.5. Melhoria da Qualidade Ambiental......................................................... 109

2.5.6. Redução de Custos e Responsabilidades Futuras...................................... 110

2.5.7. Melhoria Contínua..................................................................................... 110

2.5.8. Conservação de Recursos...................................................................... 110

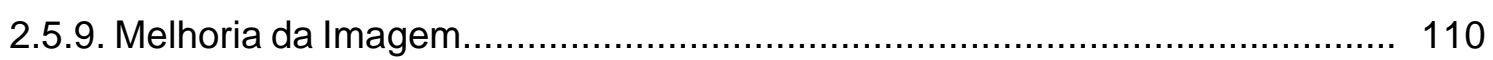

2.6. Barreiras à Implantação da Prevenção à Poluição na Indústria....................... 110

2.6.1. Investimentos.................................................................................. 111

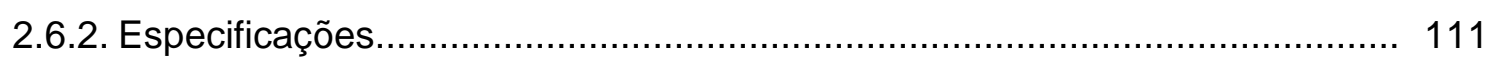

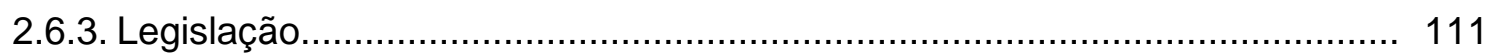

2.6.4. Padrão de Qualidade do Produto............................................................... 111

2.6.5. Comprometimento da Produção......................................................... 111

2.6.6. Preocupação com a Imagem................................................................ 112

2.6.7. Disponibilidade de Tempo e Capacitação Técnica...................................... 112

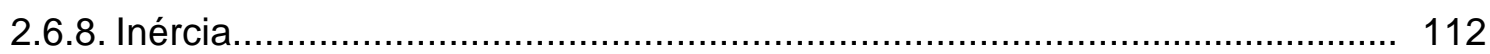

2.7. Integração entre Meio Ambiente e Saúde Ocupacional.................................... 112

2.8. O Papel das Universidades e dos Centros de Pesquisa................................. 114

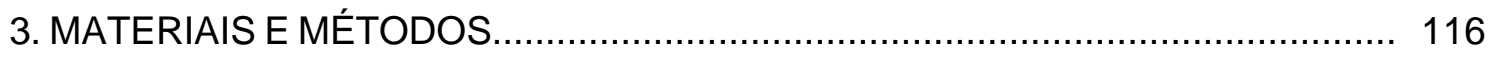

3.1. Considerações Iniciais........................................................................ 116

3.2. Prospecção de Informações.................................................................... 116

3.2.1. Principais Fontes de Informação................................................................ 116

3.3. Programa de Doutorado com Estágio no Exterior - PDEE............................ 118

3.3.1. Principais Atividades Desenvolvidas..................................................... 119

3.4. Avaliação de um Processo Produtivo para Identificação de Oportunidades..... 120

3.4.1. Delimitação e Sistemática da Pesquisa.................................................. 120

3.4.2. Escolha e Caracterização da Área de Estudo........................................... 120

3.4.3. Identificação de Oportunidades de Prevenção à Poluição............................ 121

3.4.3.1. Delimitação da Área de Estudo...................................................... 121

3.4.3.2. Procedimento para Coleta de Dados e Informações................................. 122

3.4.3.3. Mapeamento do Processo.................................................................. 123

3.4.3.4. Coleta e Caracterização de Resíduos..................................................... 123

3.5. Discussão e Apresentação dos Resultados.................................................. 124 
4. PREVENÇÃO À POLUIÇÃO: SISTEMÁTICA E FERRAMENTAS....................... 125

4.1. Considerações Iniciais..............................................................

4.2. Requisitos de um Programa de Prevenção à Poluição....................................... 126

4.3. Definição das Fronteiras do Programa........................................................ 133

4.4. Identificação de Oportunidades................................................................. 133

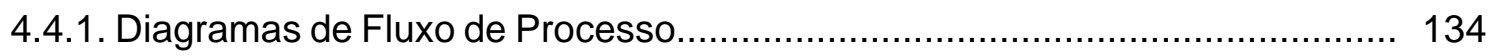

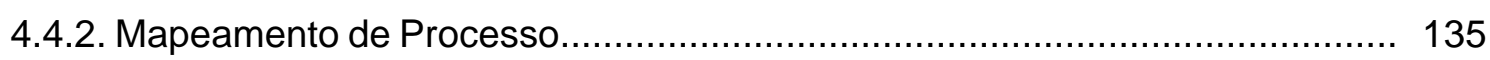

4.4.2.1. Desenvolvimento de um Mapa de Processo............................................ 136

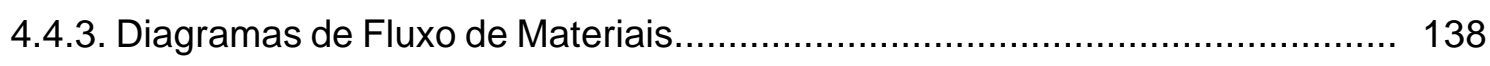

4.4.4. Inventários de Entradas e Saídas............................................................... 139

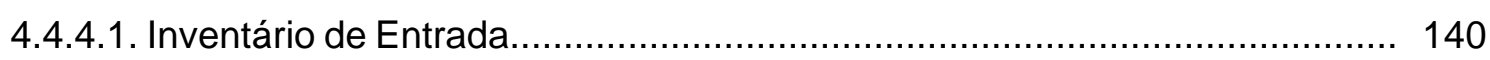

4.4.4.2. Inventário de Saída de Produto............................................................ 140

4.4.4.3. Inventário de Saída de Subprodutos e Perdas......................................... 140

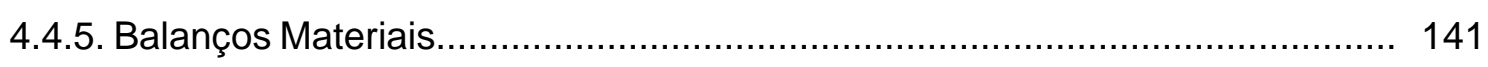

4.4.6. Contabilidade de Materiais ................................................................... 142

4.4.7. Questionários e Checklists..................................................................... 144

4.5. Seleção das Oportunidades...................................................................... 145

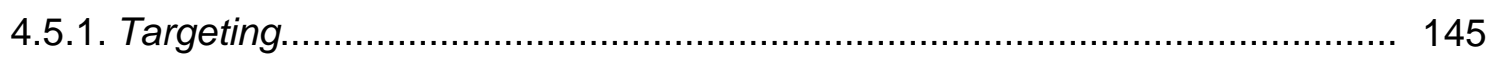

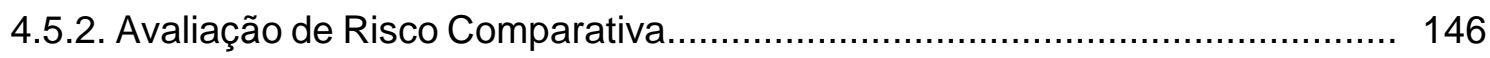

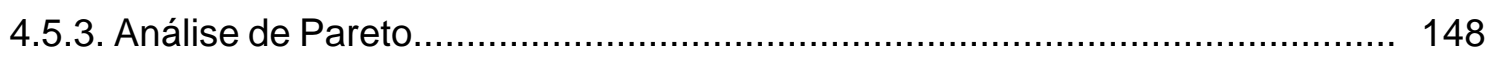

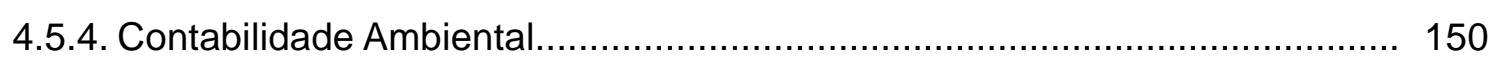

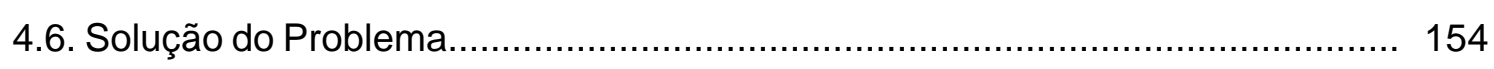

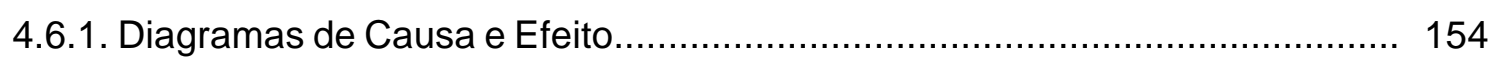

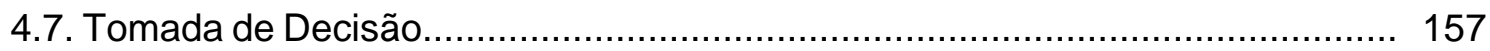

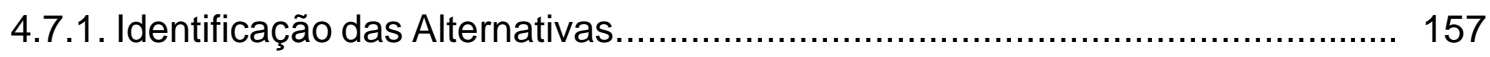

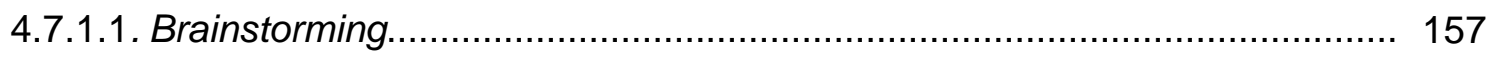

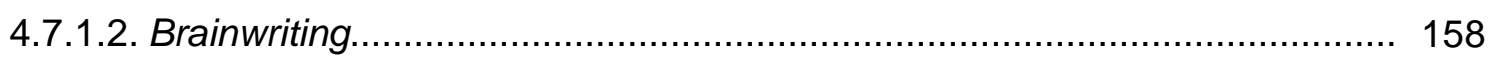

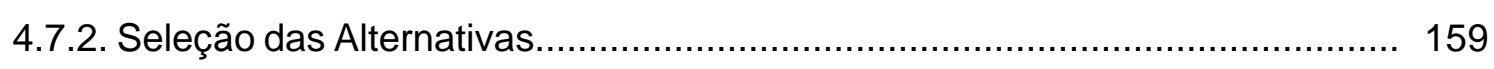

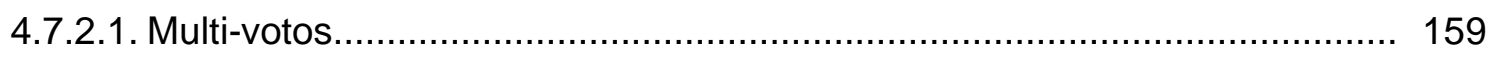

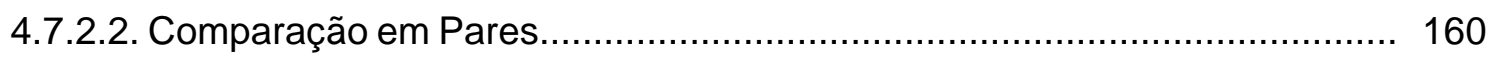

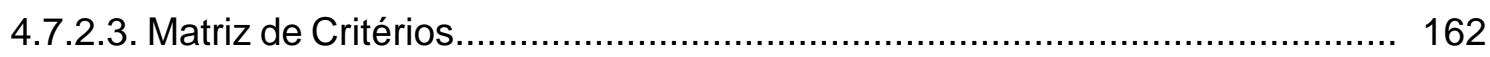

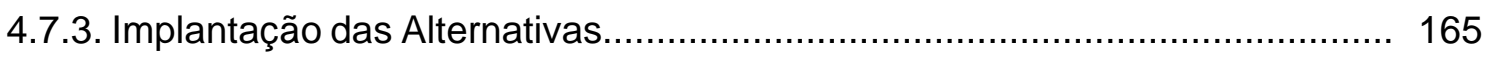

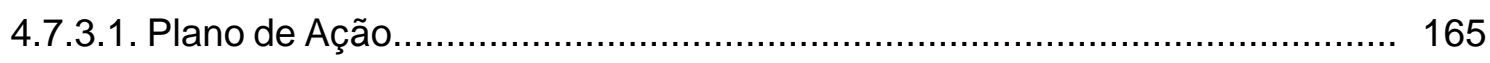

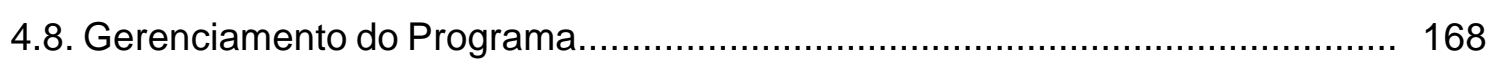

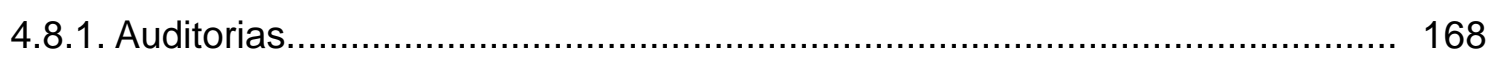

4.8.2. Indicadores de Desempenho Ambiental................................................. 171

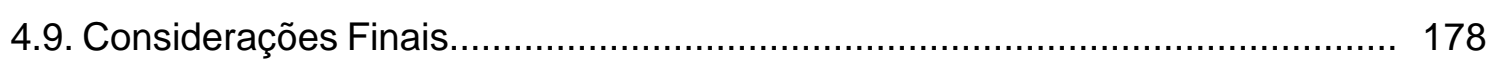


5. A INDÚSTRIA DE PRODUTOS METÁLICOS ............................................... 179

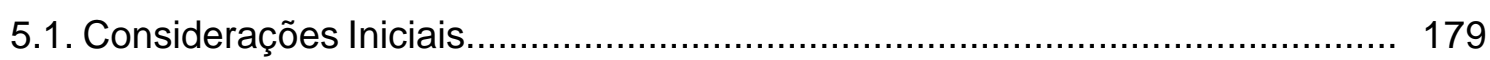

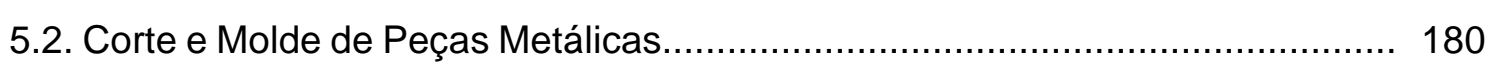

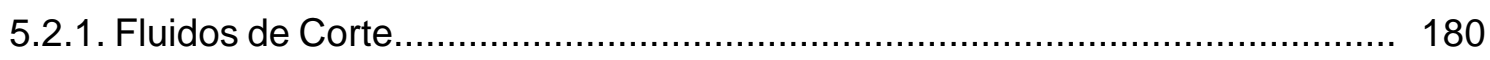

5.2.2. Características dos Resíduos Gerados..................................................... 180

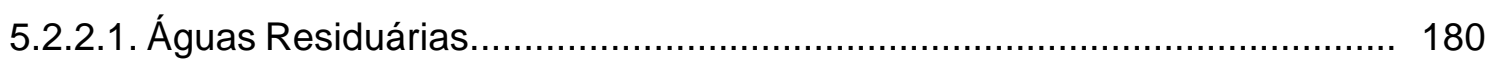

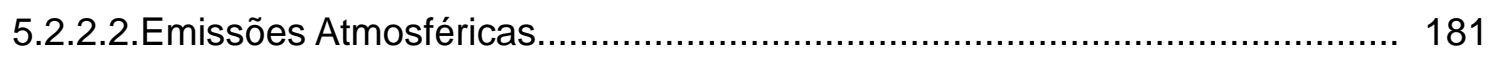

5.2.2.3. Resíduos Sólidos e Perigosos........................................................... 181

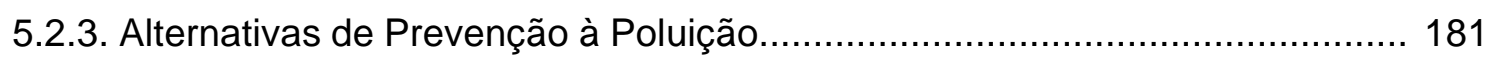

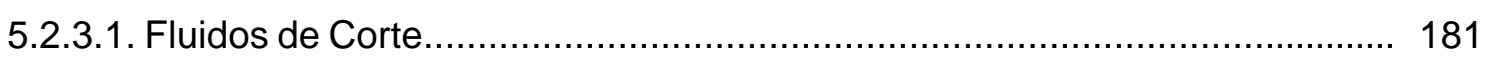

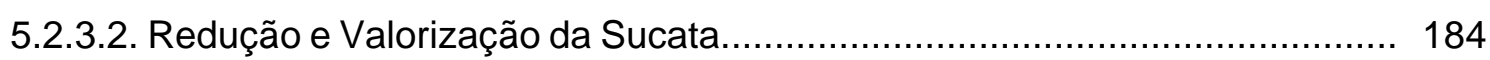

5.2.3.3. Manutenção de Equipamento e Prevenção de Vazamentos....................... 185

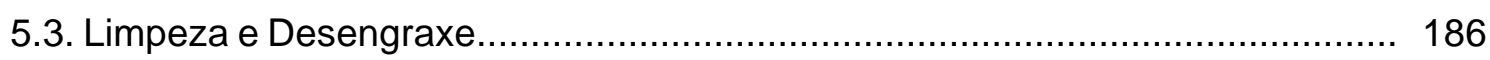

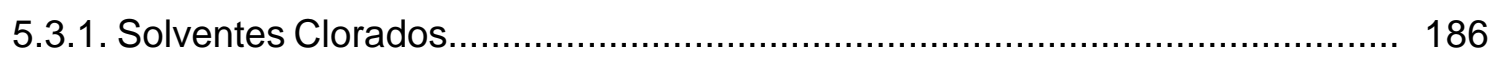

5.3.2. Características dos Resíduos Gerados.................................................... 187

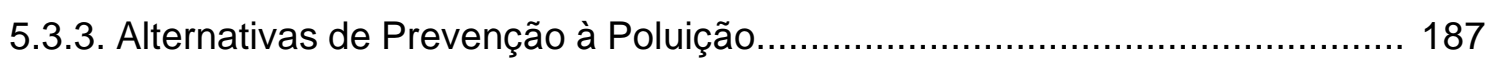

5.3.3.1. Uso de Desengraxantes Alternativos...................................................... 187

5.3.3.2. Modificações no Processo.................................................................. 192

5.3.3.3. Reciclagem e Reúso no Processo........................................................ 192

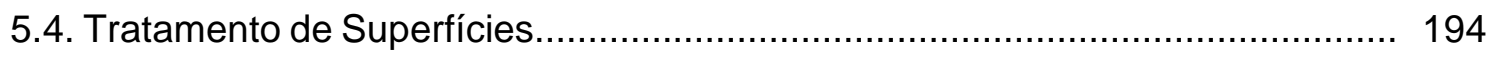

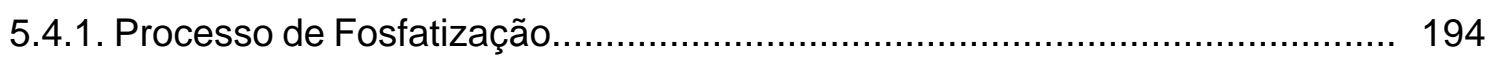

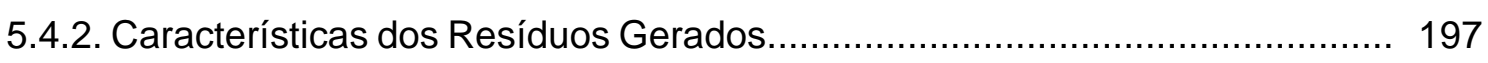

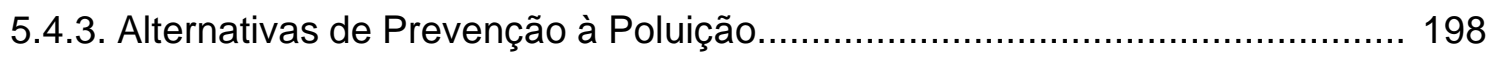

5.4.3.1. Melhorias na Eficiência do Processo..................................................... 198

5.4.3.2. Uso de Passivantes Alternativos............................................................. 200

5.4.3.3. Reciclagem e Reúso no Processo........................................................ 200

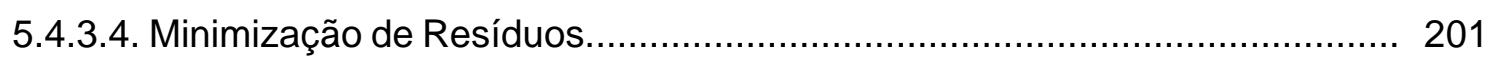

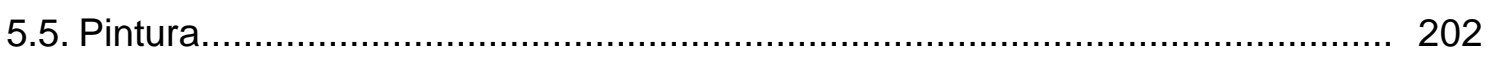

5.5.1. Características dos Resíduos Gerados................................................... 202

5.5.2. Alternativas de Prevenção à Poluição..................................................... 203

5.5.2.1. Eliminação da Necessidade de Pintura................................................ 203

5.5.2.2. Uso de Materiais e Processos Alternativos................................................ 203

5.5.2.3. Melhoria da Eficiência de Transferência em Sistemas de Spray................. 208

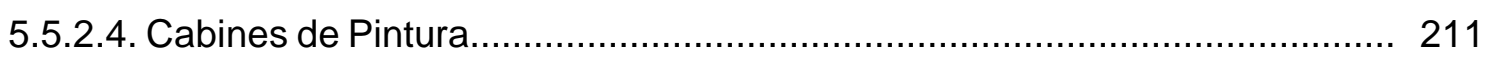

5.6. Considerações Finais.............................................................................. 213 
6. IDENTIFICAÇÃO DE OPORTUNIDADES DE PREVENÇÃO À POLUIÇÃO...... 214

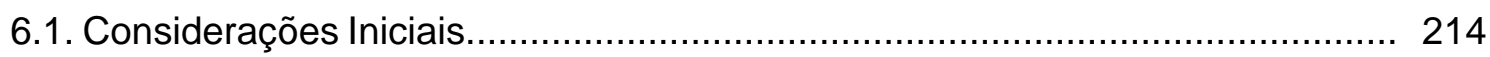

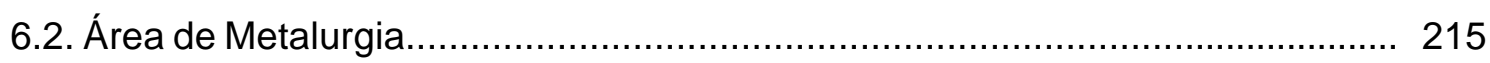

6.2.1. Descrição do Processo ........................................................................ 215

6.2.2. Características dos Resíduos Gerados...................................................... 216

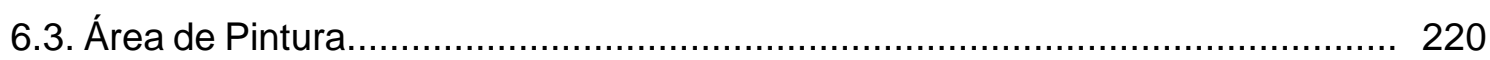

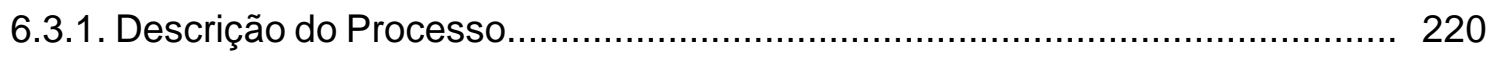

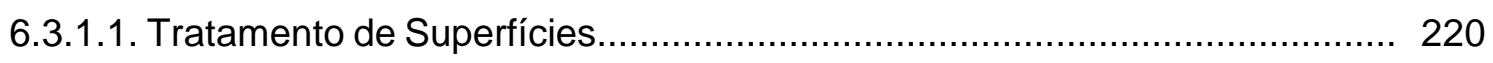

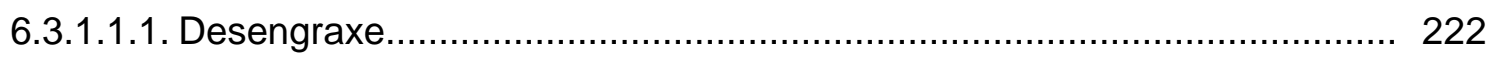

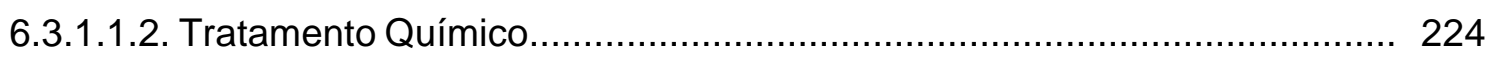

6.3.1.2. Estação de Tratamento de Efluentes........................................................ 226

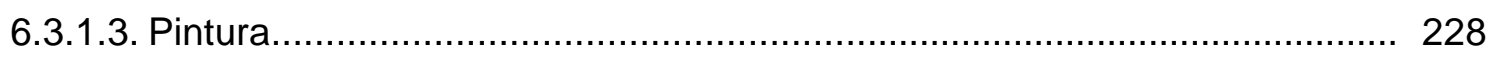

6.3.2. Características dos Resíduos Gerados................................................... 229

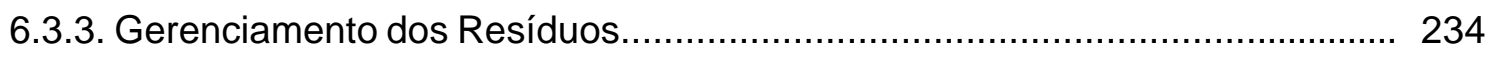

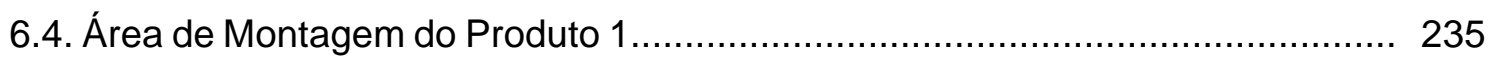

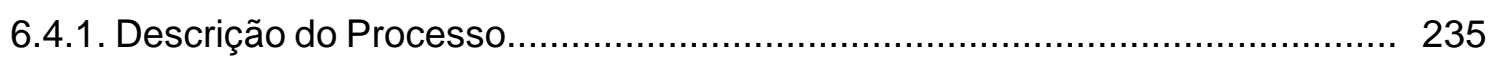

6.4.2. Características e Gerenciamento dos Resíduos........................................ 239

6.5. Área de Montagem do Produto 2........................................................ 244

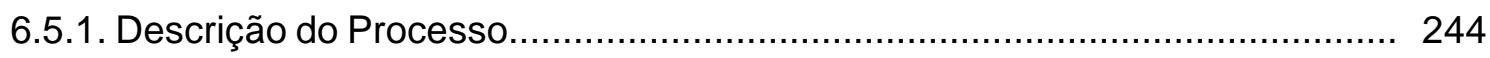

6.5.2. Características e Gerenciamento dos Resíduos........................................ 246

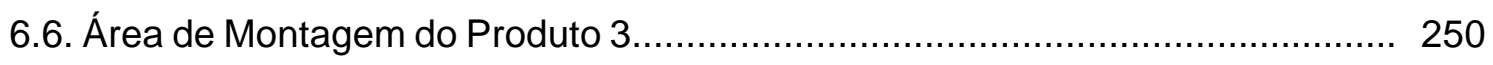

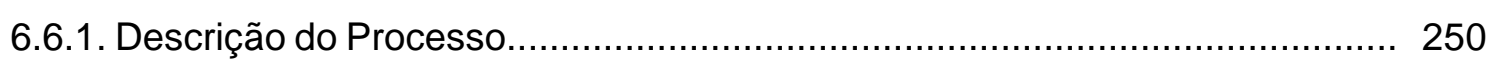

6.6.2. Características e Gerenciamento dos Resíduos.......................................... 253

6.7. Central de Resíduos....................................................................... 255

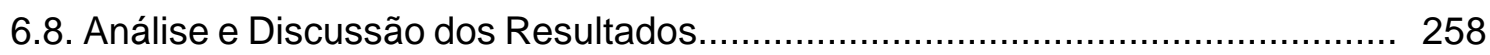

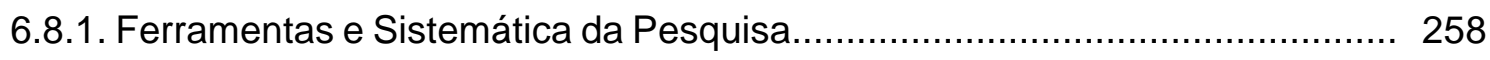

6.8.2. Práticas de Prevenção à Poluição Existentes.............................................. 259

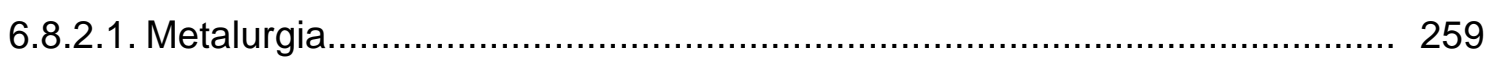

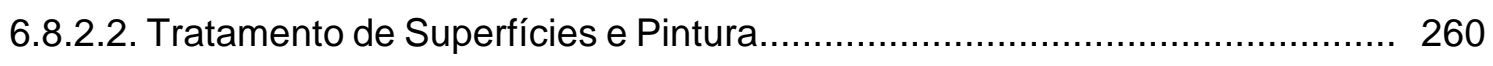

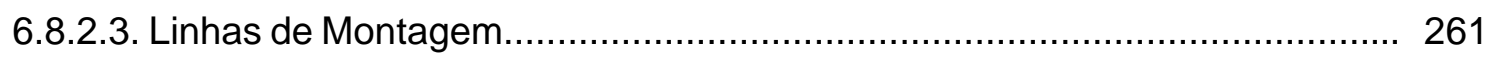

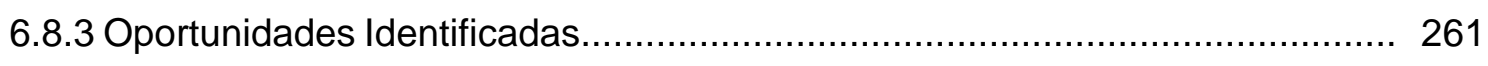

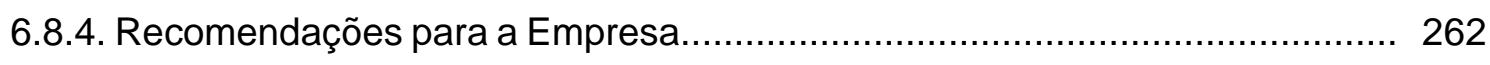

6.8.5. Limitações do Estudo............................................................................ 264

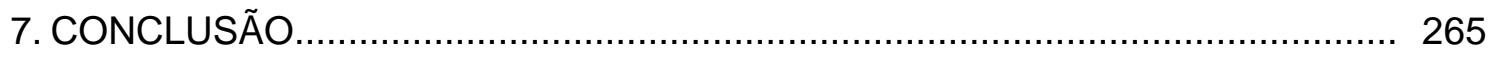

Sugestões para Pesquisas Futuras................................................................ 269 
8. REFERÊNCIAS BIBLIOGRÁFICAS.

Anexo I - Descrição do Programa Parceiros em Prevenção à Poluição da Universidade de Nebraska - Lincoln, Estados Unidos. 


\section{CAPÍTULO I}

\section{INTRODUÇÃO}

\subsection{Considerações Iniciais}

Atualmente diversos setores da sociedade têm concentrado seus esforços em buscar meios de tornar compatíveis os níveis de crescimento econômico e de produção com a manutenção da qualidade ambiental e a preservação dos recursos naturais, materiais e energéticos. Dentro deste contexto a indústria e a universidade desempenham papéis relevantes. A primeira, por ser a maior consumidora de recursos, produtora de riquezas e, por muitas vezes, grande geradora de resíduos e poluição. A segunda, por ser a formadora dos futuros tomadores de decisão, que poderão atuar no sentido de melhorar (ou piorar) a qualidade do nosso meio ambiente.

Em decorrência do modelo de desenvolvimento adotado desde a época da revolução industrial, a indústria e seus condutores, sempre trataram a questão dos resíduos e da poluição como uma consequência inevitável do desenvolvimento econômico. Esta relação de causa e efeito se mostrou, ao longo de décadas, perigosa e não verdadeira. São diversos os exemplos de acidentes, contaminações de rios, do ar, do solo, de cidades e mesmo de regiões inteiras, que comprovam que os efeitos danosos deste desenvolvimento não são compensatórios. O paradigma de que desenvolvimento significa sujar, consumir e deteriorar não se mostra mais verdadeiro. Hoje se sabe que é possível compatibilizar o crescimento econômico e a conservação ambiental por meio da produção sustentável, que integra às atividades econômicas das empresas preocupações de longo prazo com o meio ambiente e com a saúde e segurança do trabalhador e da comunidade.

As práticas de prevenção à poluição e produção mais limpa se apresentam como estratégias norteadoras para que as empresas alcancem a eco-eficiência, produzindo mais com menos, o que significa menos desperdício e poluição. Entretanto, existe um 
longo caminho a ser percorrido entre a teoria e a prática. A internalização de práticas de gestão ambiental baseadas no conceito de prevenção à poluição requer que uma série de barreiras sejam suplantadas. A principal delas é sem dúvida a conscientização para os benefícios a longo prazo que modificações nos processos e nas práticas operacionais podem trazer, tanto para o meio ambiente, quanto para a própria economia da empresa. Para se conscientizar no entanto, são necessários exemplos, incentivos, opções de tecnologias e ações que se mostrem praticáveis e que promovam o convencimento da viabilidade e dos benefícios da mudança.

\subsection{Justificativa e Relevância da Pesquisa}

A adoção de práticas de prevenção à poluição em um processo produtivo industrial requer um planejamento criterioso, onde são apontados e analisados os problemas (origens e causas da poluição) para que sejam encontradas, avaliadas e implantadas soluções (alternativas de prevenção à poluição).

No Brasil e em muitos países em desenvolvimento, as práticas de prevenção à poluição, quando existem, são adotadas por grandes companhias, geralmente multinacionais, que dispõem de recursos financeiros e incentivos para adotar tecnologias limpas e eficientes em seus processos produtivos. Não existe uma divulgação ampla de estudos de caso que possa fornecer uma fonte de informação para empresas de pequeno e médio portes. Do mesmo modo, não existem incentivos políticos para a disseminação de práticas de prevenção à poluição.

Neste trabalho, buscou-se estudar e avaliar as sistemáticas de prevenção à poluição disponíveis na literatura técnica especializada e as ferramentas de apoio que podem ser empregadas no processo de identificação de oportunidades e de implantação de práticas de prevenção à poluição. De modo a avaliar os benefícios potenciais da internalização destas práticas, bem como as barreiras e dificuldades que podem ocorrer no processo de implantação das mesmas, foi realizada a avaliação de um processo produtivo industrial.

Os resultados da pesquisa fornecem subsídios e embasamento para que trabalhos semelhantes sejam desenvolvidos, divulgando as práticas de prevenção à poluição tanto no meio acadêmico, quanto no meio industrial. As informações sobre sistemáticas, ferramentas e sobre as práticas de prevenção à poluição aplicáveis ao processo produtivo analisado foram obtidas exclusivamente em literatura estrangeira, ressaltando a necessidade do desenvolvimento e divulgação de pesquisas e informações adequadas ao contexto do país. 


\subsection{Objetivos da Pesquisa}

O objetivo principal desta pesquisa é sistematizar a metodologia de identificação de oportunidades de prevenção à poluição em processos produtivos industriais. Para tanto, os objetivos específicos da pesquisa são os seguintes:

* Levantar e analisar as sistemáticas e ferramentas de apoio ao planejamento de um programa de prevenção à poluição;

* Identificar alternativas de prevenção à poluição aplicáveis a uma indústria de manufatura de produtos metálicos, disponíveis na literatura técnica;

* Realizar uma avaliação preliminar do processo produtivo, usando ferramentas de avaliação estruturadas; e,

* Identificar os benefícios e as barreiras da implantação de práticas de prevenção à poluição no âmbito daempresa estudada. 


\section{CAPÍTULO II}

\section{REVISÃO DE LITERATURA}

\subsection{Indústria, Meio Ambiente e Desenvolvimento Sustentável}

A expansão do capitalismo no período pós-guerra trouxe consigo a intensificação dos sistemas de produção, a expansão dos parques industriais (principalmente para os países do terceiro mundo) e a massificação da cultura do consumo. O mundo adotou um modelo de desenvolvimento baseado na produtividade e no consumo, e as indústrias passaram a desempenhar papel fundamental no crescimento econômico.

Esse modelo de desenvolvimento foi (e continua sendo) baseado no consumo sem limites dos recursos naturais, onde a terra é tida como uma fonte inesgotável de matériasprimas. As indústrias estão inseridas nesse contexto, consumindo uma grande quantidade de recursos e energia, e descarregando suas emissões no meio ambiente, causando vários problemas, locais, regionais e globais.

A indústria converte recursos primários e outros materiais em uma grande diversidade de produtos, os quais em conjunto com a população e níveis de consumo determinam a quantidade de resíduos gerados (TOAKLEY e ARONI, 1998). Através do desenvolvimento de novos materiais e tecnologias de produção em massa, a indústria vem disponibilizando à sociedade uma maior oferta de produtos que, aliado a apelos econômicos e de marketing criam uma 'sociedade do consumo', aumentando significativamente o volume de resíduos produzidos e seus impactos no meio ambiente. A Figura 1 ilustra a relação entre estas variáveis. 


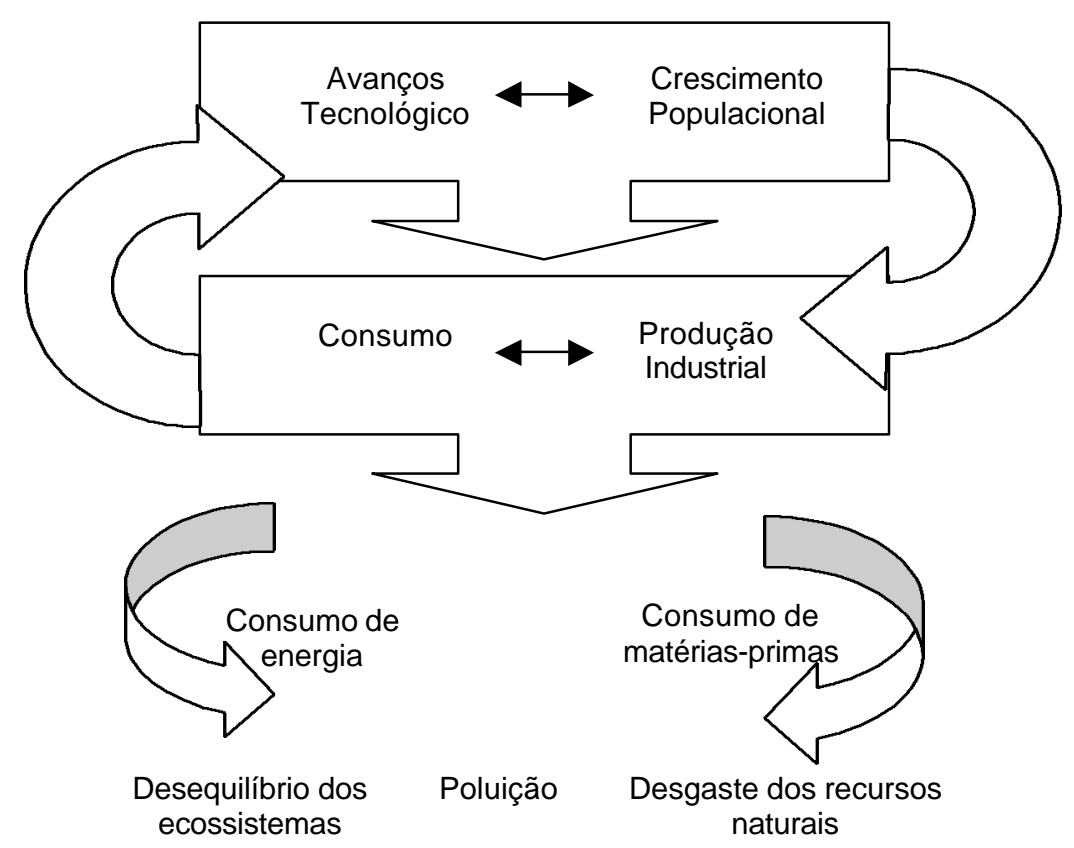

Figura 1- Relação entre desenvolvimento e problemas ambientais.

O cenário atual de expansão das atividades industriais e de aumento do consumo de bens industrializados torna as questões relacionadas à gestão e ao gerenciamento dos resíduos industriais cada vez mais complexas. Dentro deste contexto, cada cidadão na função de consumidor desempenha um papel de extrema relevância, uma vez que, se determinado produto ou serviço existe, é porque existe uma demanda por parte dos consumidores.

A responsabilidade dos consumidores na busca pela sustentabilidade é amplamente discutida por Manzini e Vezzoli (2002, p.64), que destacam que cada indivíduo, ao decidir como e o que adquirir e utilizar, legitima a existência de determinado produto ou serviço e está portanto, na origem dos efeitos ambientais ligados à produção, ao emprego e ao escoamento final daquele produto ou serviço. No entanto, os autores salientam que não se pode colocar toda a responsabilidade nos consumidores, pois suas escolhas são condicionadas por diversos fatores independentes de sua vontade, tais como o meio social no qual o indivíduo está inserido e as condições estruturais do sistema em que ele vive e das alternativas a ele oferecidas, que dependem das escolhas que o poder público e as empresas produtoras fizeram no passado. 
O mundo industrializado passou a prestar atenção às questões ambientais principalmente a partir da década de 1960, quando o meio ambiente passou a dar sinais evidentes de que sua capacidade de autodepuração estava sendo em muito excedida. Em 1968 foi criado o Clube de Roma, constituído de um pequeno grupo de pesquisadores de várias áreas, visando simular a interdependência e a interação de cinco fatores críticos: o aumento populacional, a produção de alimentos, a industrialização, a degradação dos recursos naturais e a poluição (O'BRIEN, 1999).

Deste encontro resultou a publicação do relatório conhecido como 'Limits to Growth' (Limites do Crescimento) em 1972, no qual foi apresentada uma previsão bastante alarmista sobre a relação entre os cinco fatores apontados pelo Clube de Roma e o futuro da humanidade:

Se a atual linha de desenvolvimento permanecer inalterada nesses cinco fatores, a humanidade está destinada a alcançar os limites naturais do desenvolvimento nos próximos 100 anos. O resultado mais provável será o súbito declínio no nível populacional e no sistema industrial. A aplicação de soluções tecnológicas pode estender o período de crescimento e desenvolvimento industrial e o crescimento demográfico, mas não pode eliminar os limites fundamentais do desenvolvimento. (MEADOWS ${ }^{1}$ apud O'BRIEN, 1999).

No mesmo ano de 1972 foi realizada a Conferência das Nações Unidas sobre o Meio Ambiente Humano, de 5 a 16 de junho em Estocolmo na Suécia, com a presença de 113 países. Nos quatro anos anteriores àConferência foram realizadas reuniões preparatórias para consolidar as bases conceituais do que seria discutido no encontro. Já nestas reuniões ficaria evidente a oposição entre os países desenvolvidos e os países em desenvolvimento. Os países desenvolvidos almejavam por uma reunião internacional na qual fosse dada ênfase aos aspectos relativos à poluição da água, do solo e da atmosfera. Além do esforço a ser empreendido pelos países industrializados, haveria a necessidade adicional de os países em desenvolvimento realizarem esforços de prevenção aos desequilíbrios ambientais em escala mundial. Os países em desenvolvimento por sua vez, se opuseram ao fato de as políticas preservacionistas que viessem a ser adotadas na Conferência pudessem servir como instrumentos de

\footnotetext{
${ }^{1}$ MEADOWS, D. L., et al (1972). The limits to growth. A report for the Club of Romes's project on the predicament of mankind. London apud O'BRIEN, C. (1999).
} 
interferência nos assuntos domésticos ou como uma barreira àindustrialização da África, América Latina e Ásia (SOARES, 2003, p.42).

Na Conferência foram votados: a) a Declaração das Nações Unidas sobre o Meio Ambiente Humano (Declaração de Estocolmo), com 26 Princípios; b) o Plano de Ação para o Meio Ambiente, conjunto de 109 recomendações centradas em políticas relativas à avaliação do meio ambiente mundial, denominado Plano Vigia (Earthwatch), àgestão do meio ambiente e às medidas de apoio, como a informação, educação e formação de especialistas; c) uma Resolução sobre aspectos financeiros e organizacionais no âmbito da ONU; e, d) a instituição de um organismo especialmente dedicado ao meio ambiente, o PNUMA ${ }^{2}$ - Programa das Nações Unidas para o Meio Ambiente (SOARES, 2003, p.44).

Os Princípios da Declaração de Estocolmo, aqui sumarizados por McCormick ${ }^{3}$ (1989 apud TOAKLEY e ARONI, 1998), ressaltam que:

I. Os recursos naturais devem ser protegidos e conservados, a capacidade da Terra em produzir recursos renováveis deve ser mantida, e os recursos não renováveis devem ser racionalmente utilizados;

II. Desenvolvimento e meio ambiente devem andar lado a lado, e os países menos desenvolvidos devem receber assistência e incentivo para promover 0 gerenciamento ambiental racional;

III. Cada país deve estabelecer seus padrões de gerenciamento ambiental e explorar seus recursos do modo que desejarem, desde que não coloquem em risco outros países. Deve existir cooperação internacional visando a melhoria da qualidade ambiental;

IV. A poluição não deve exceder a capacidade do meio ambiente em absorvê-la. E a poluição oceânica deve ser prevenida; e,

V. Ciência, tecnologia, educação e pesquisa devem ser usadas para promover a proteção ambiental.

A Conferência de Estocolmo representa um marco nas discussões sobre meio ambiente e desenvolvimento, já que estabeleceu pela primeira vez uma ligação entre os problemas que afetam o bem estar das populações e do meio ambiente, o crescimento

\footnotetext{
${ }^{2}$ Sigla em português de UNEP (United Nations Environmental Programme), órgão subsidiário da Assembléia Geral da ONU, composto de um conselho de administração de 58 membros, delegados dos Estados, e de um secretariado integrado por 181 administradores, funcionários internacionais, com sede em Nairóbi, no Quénia (SOARES, 2003).

${ }^{3}$ McCORMICK, J. (1989). The Global Environmental Movement. London: Belhaven Press apud TOAKLEY e ARONI (1998).
} 
econômico nos países desenvolvidos e o crescimento populacional nos países subdesenvolvidos (ADAMS, 1990).

Conforme o exposto por Soares (2003, p.47), as conseqüências e frutos da Conferência de Estocolmo foram incalculáveis, tanto do ponto de vista das relações internacionais, quanto de seu reflexo nos ordenamentos internos dos Estados. Foram diversos os tratados e convenções multilaterais adotados a partir de 1972, que passaram a versar sobre temas cada vez mais técnicos, agora negociados sob o âmbito do PNUMA. Um exemplo significante dos resultados desta conferência é o caso do Brasil. A delegação oficial brasileira ao retornar ao país, conseguiu obter do governo federal um decreto criando a Secretaria Especial do Meio Ambiente, que iniciou suas atividades em janeiro de 1974. Ainda segundo Soares (2003), o fato de o Brasil hoje contar com uma legislação ambiental bastante desenvolvida e ter os ideais preservacionistas consagrados na Constituição Federal de 1988, deve-se em grande parte àconsciência ambiental que a Conferência de Estocolmo provocou no país.

Em 1985 a ONU conferiu ao PNUMA a tarefa de enquadrar as questões ambientais globais e esboçar políticas relativas ao meio ambiente até o ano de 2000 e para os anos seguintes. Para tal foi criada a Comissão Mundial sobre o Desenvolvimento e Meio Ambiente (WCED), presidida pela primeira-ministra da Noruega, Gro Harlem Brundtland, e mais 21 participantes (dentre os quais o professor Paulo Nogueira Neto, na época ocupante da Secretaria do Meio Ambiente do Brasil). Em outubro de 1987 a WCED apresentou àONU o Relatório de Brundtland, uma síntese dos problemas ambientais da atualidade e um repertório de estratégias sugeridas para o seu equacionamento (SOARES, 2003, p.54).

Também conhecido como 'Our Common Future' (Nosso Futuro em Comum), o relatório de Brundtland definiu Desenvolvimento Sustentável como:

A humanidade é capaz de fazer desenvolvimento sustentável, assegurando que a sociedade atual encontre as necessidades do presente sem comprometer a capacidade de gerações futuras em alcançar suas próprias necessidades (WCED, 1987).

Enquanto o Clube de Roma se apresentou alarmista e pessimista, o Relatório de Brundtland por sua vez, foi mais otimista, enfatizando a necessidade de se criar novas estratégias para alcançar o desenvolvimento sustentável. 
O Relatório de Brundtland fez a comunidade internacional enxergar a pobreza, o crescimento populacional, os desenvolvimentos industrial e social, o esgotamento e a destruição dos recursos naturais como problemas inter-relacionados (BROWN e LEMONS, 1995).

No período de 20 anos que se seguiu à realização da Conferência de Estocolmo, apesar de ter havido grande conscientização mundial sobre as necessidades de preservação do meio ambiente, ocorreram grandes catástrofes ambientais localizadas, como o acidente industrial na cidade de Seveso na Itália e o de Bhopal na Índia, entre outros tantos reportados na literatura. Num clima de urgência de uma regulamentação enérgica sobre o meio ambiente mundial, a ONU, motivada pelos graves acidentes ocorridos no período, pela pressão da opinião pública e pela avaliação de cientistas sobre a situação de desequilíbrio do meio ambiente, decidiu realizar a Conferência das Nações Unidas sobre Meio Ambiente e Desenvolvimento, para discutir a questão da preservação do meio ambiente, do desenvolvimento e das disparidades de níveis econômicos existentes entre os Estados (SOARES, 2003, p.48-52).

Esta conferência, que ficou conhecida como ‘Rio-92' e também chamada de 'Cúpula da Terra' foi sediada no Rio de Janeiro em 1992, e contou com a presença de representantes de 178 governos e mais de 100 chefes de estado ou de governos. Esta conferência deu origem, entre outros documentos igualmente importantes, àAgenda 21 , um documento-programa de ação que visa pôr em prática as declarações firmadas durante a conferência, e propõe entre outras coisas a redução da quantidade de energia e materiais utilizados na produção de bens e serviços, a disseminação de tecnologias ambientais e a promoção de pesquisas que visem o desenvolvimento de novas fontes de energia e recursos naturais renováveis. Outro ponto abordado é a incorporação dos custos ambientais nas decisões dos produtores e consumidores, de forma que os preços reflitam o valor total dos recursos utilizados e previnam a degradação ambiental (BROWN e LEMONS, 1995; O’BRIEN, 1999; SOARES, 2003; VALLE, 1995).

A Declaração do Rio sobre Meio Ambiente e Desenvolvimento é um documento solene que os Estados proclamaram no final da Rio-92. De maneira bastante revolucionária em relação à Declaração de Estocolmo, que Ihe servira de modelo, a Declaração do Rio consagra 'o direito ao progresso em todos os níveis da sociedade, e não meramente em termos econômicos', reivindicado por países em desenvolvimento. A Declaração do Rio não é mera repetição dos 26 princípios consagrados na Declaração de 
Estocolmo. Alguns deles são reafirmados, porém com uma nova conotação de preocupação com a disparidade existente entre as nações (SOARES, 2003, p.62-63).

A Conferência de Estocolmo e a Rio-92 representam os dois eventos de maior significância mundial, nos quais se buscou questionar e avaliar os modelos de desenvolvimento e propor soluções e alternativas para os problemas ambientais decorrentes do modelo de expansão econômica adotado desde a Revolução Industrial. Estes eventos demonstram em grande parte, a ampliação da consciência a respeito das questões ambientais por parte dos governos, da sociedade e da indústria. Atualmente estas três entidades estão percebendo que apenas tratar e dispor os resíduos corretamente não é suficiente. É preciso reduzir a geração de resíduos das atividades industriais em todas as etapas do seu ciclo de vida e promover a recuperação e o reúso dos resíduos. Estas ações contribuem para preservar as reservas de recursos naturais, prevenir a contaminação ambiental, prolongar a vida útil dos aterros, reduzir custos com o desperdício de materiais e com o tratamento e a disposição de resíduos, e vão ao encontro dos princípios do desenvolvimento sustentável.

Como destaca Shen (1995), o desenvolvimento sustentável requer o reconhecimento das inter-relações entre a economia e as metas ambientais. É necessário que exista um equilíbrio entre os avanços tecnológicos e a preservação ambiental, bem como um balanço entre o desenvolvimento econômico e a proteção ambiental. E para tanto, é preciso desenvolver novas estratégias para os desafios ambientais não apenas no presente, mas também no futuro. Esta tarefa requer um esforço conjunto do setor produtivo e dos consumidores, e segundo Braga et al. (2002), deve se apoiar nas premissas que formam a base do desenvolvimento sustentável, que compreendem os seguintes preceitos:

> Uso racional da energia e dos recursos materiais com ênfase na conservação em contraposição ao desperdício;

> Prevenção da poluição, gerando menos resíduos a serem absorvidos pelo meio ambiente;

> Promoção da reciclagem e do reúso de materiais;

$>$ Controle do crescimento populacional de modo a propiciar perspectivas de estabilização da população; e,

$>$ Mudança de padrões de consumo. 


\subsection{Poluição Industrial}

\subsubsection{Aspectos Gerais}

A poluição é uma alteração indesejável nas características físicas, químicas ou biológicas da atmosfera, litosfera ou hidrosfera, provocada pelas atividades e intervenções humanas no meio ambiente, que possa causar dano àsobrevivência ou às atividades dos seres humanos e outras espécies, ou ainda deteriorar materiais. Os poluentes são os resíduos gerados pelas atividades humanas que causam um impacto negativo no meio ambiente. Deste modo, a poluição está associada à concentração de poluentes presentes no ar, na água ou no solo (BRAGA et al., 2002).

A poluição resulta das atividades humanas em geral, entretanto, são as atividades industriais as maiores fontes geradoras de resíduos perigosos e impactos ambientais. À medida que a sociedade evolui tecnologicamente estes impactos têm sido ampliados em diversidade e intensidade. $O$ esgotamento dos recursos naturais utilizados como fonte de energia e matérias-primas, a poluição do solo, da água e do ar são os principais problemas ambientais decorrentes da industrialização.

Embora a preservação dos recursos naturais seja vital para a manutenção da vida do planeta e objeto de amplas discussões, a poluição se apresenta como um problema com dimensões muito maiores, por representar ameaça direta à saúde da população e do meio ambiente. Como destacam Toakley e Aroni (1998): "[...] a poluição é um problema muito mais grave do que a escassez de recursos, porque em alguns casos os limites de absorção de resíduos descarregados na atmosfera, no solo e na água já foram em muito ultrapassados [...]".

O potencial poluidor de uma atividade industrial ou produto depende principalmente do processo empregado. Os resíduos industriais (sólidos, líquidos ou gasosos) são produzidos a partir de diversos processos, e a quantidade e a toxicidade do resíduo varia de acordo com os processos industriais específicos (SHEN, 1995). A Figura 2 mostra um processo industrial típico, onde são gerados resíduos contendo diferentes tipos de poluentes, de acordo com a entrada de materiais e o design do processo. 


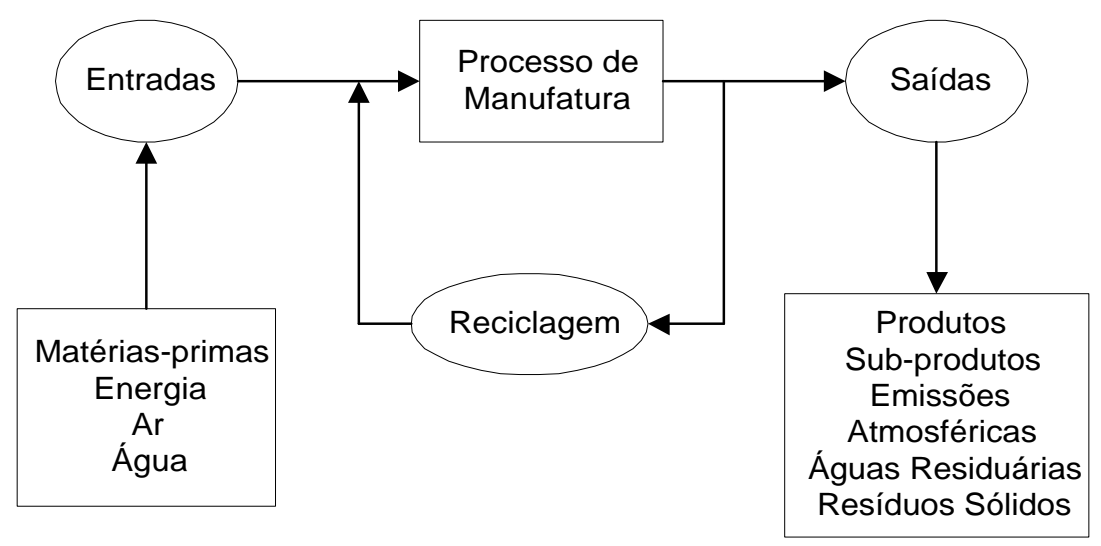

Figura 2- Processo industrial genérico.

Fonte: Modificado de SHEN (1995)

O setor industrial é um fator determinante na qualidade ambiental de uma determinada região, principalmente porque alguns processos industriais são muito mais "sujos" do que outros, ou porque geram muito mais emissões, devido a características próprias. Por exemplo, os setores de celulose e papel e de mineração e siderurgia geram muito mais emissões do que o setor de eletro-eletrônicos. No Brasil estudos apontam os setores de ferro e aço, petróleo e derivados, metal-mecânico, celulose e papel, química e derivados e de alimentos como sendo os mais poluentes (DASGUPTA, LUCAS e WHEELER, 1998).

A emissão de substâncias tóxicas para o ar, água e solo degradam a qualidade ambiental, e resultam na destruição de ecossistemas, na bioacumulação de substâncias na cadeia alimentar, e provocam efeitos prejudiciais à saúde humana a curto e longo prazos, como mostra a Figura 3.

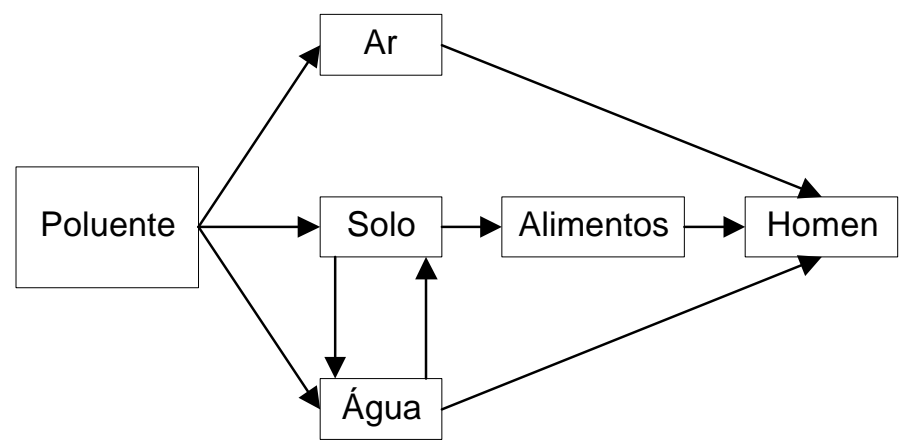

Figura 3. Rotas de exposição de poluentes no meio ambiente Fonte: Modificado de CHAABAN (2001) 
A preocupação atual em relação aos resíduos industriais se estende ao longo de todo o ciclo de vida de um produto, desde a extração das matérias-primas, passando pela produção de energia que sustenta o processo, a produção, o transporte, a distribuição, a utilização e a manutenção do produto, até que este, após o término de sua vida útil, transforme-se em resíduo, que precisa ser tratado e/ou disposto de maneira adequada, como mostra o esquema da Figura 4.

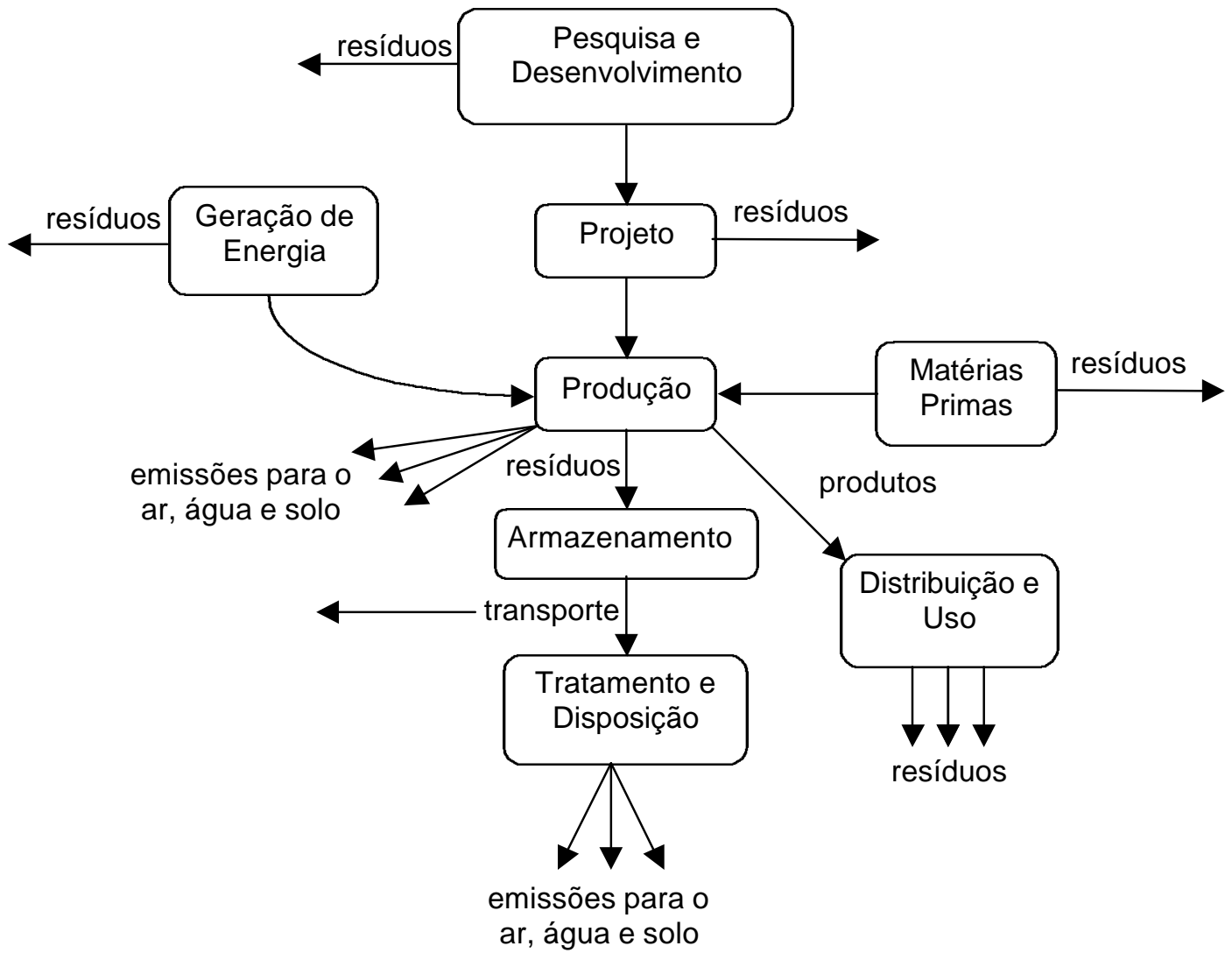

Figura 4 - Geração de resíduos no ciclo de vida de um produto.

A identificação dos impactos de cada estágio do ciclo de vida de um produto não é fácil, porque cada indústria define e controla a natureza de seus produtos e processos de manufatura, que podem variar significativamente mesmo dentro de um mesmo segmento. Para identificar impactos no processo produtivo, é preciso conhecer as operações e as fontes geradoras de resíduos, para que sejam desenvolvidas soluções que permitam eliminar os problemas antes mesmo que sejam criados. 
O crescente aumento das atividades econômicas tem inevitavelmente ocasionado um grande aumento na carga de resíduos, que precisa ser reutilizada ou disposta de alguma forma, e isto implica em custos ambientais e econômicos.

O gerenciamento inadequado dos resíduos sólidos pode resultar na poluição do ar, da água e do solo. Apesar de a natureza ser capaz de diluir, dispersar, degradar, absorver ou reduzir os impactos provocados pelos resíduos, alguns desequilíbrios ecológicos têm ocorrido em locais onde a capacidade de assimilação natural é excedida (TCHOBANOGLOUS ${ }^{4}, 1993$ apud LOPES et al., 2004).

Além de contaminar o solo, as substâncias químicas tóxicas presentes nos resíduos podem, através da lixiviação, atingir o lençol freático provocando poluição das águas subterrâneas. Segundo Hirata (2004), mesmo pequenas quantidades de compostos químicos podem gerar grandes plumas de contaminação, sobretudo quando o aqüífero apresenta grande velocidade de circulação de água e está sendo atingido por compostos muito tóxicos, como por exemplo hidrocarbonetos halogenados.

As principais fontes de poluição do solo são as atividades industriais que armazenam e manipulam produtos químicos e geram efluentes e resíduos, áreas de estocagem, tratamento e descarte de efluentes e resíduos, atividades extrativistas, a agricultura, a aplicação de efluentes e resíduos no solo, postos de combustíveis e obras que demandam a remoção da cobertura vegetal de áreas extensas (ROCCA, 2004).

Outra fonte de poluição, amplamente discutida por Sánchez (2001, p.21), é o passivo ambiental decorrente da desativação de empreendimentos. Segundo o autor, uma nova era iniciou-se no fim do século XX, a qual denomina de 'era pós-industrial', na qual a força do desenvolvimento não é mais a produção industrial, e sim a produção de conhecimento, informação e tecnologia. O processo de globalização da economia vem estimulando a relocalização e a remodelação de empresas e mesmo de segmentos industriais inteiros, e assim, muitas indústrias e sítios industriais vêm sendo desativados, deixando para trás um grande passivo ambiental.

A disposição de resíduos sólidos urbanos ou industriais é uma atividade que, na ocasião da desativação do empreendimento requer cuidados. Um aterro de resíduos tem sua vida útil determinada em função da capacidade de estocagem e da quantidade de resíduos disposta. Uma vez esgotada a capacidade de um aterro, o local não poderá ser

${ }^{4}$ TCHOBANOGLOUS (1993). Integrated solid waste: engineering principles and management issues. McGraw-Hill apud LOPES et al. (2004). 
simplesmente abandonado, porque comporta riscos, como de explosão do gás metano, de poluição de aqüíferos e de efeitos sobre a saúde dos moradores do entorno, devido a liberação de outros gases tidos como carcinogênicos. Muitas áreas de disposição de resíduos foram utilizadas para outros fins, incluindo usos residenciais. Essa modificação do uso requer uma série de providências para assegurar a estabilidade física da área, evitar que ela funcione como um foco de disseminação de poluentes no meio e ainda garantir um ambiente saudável para os futuros moradores. Essas providências necessitam de um planejamento criterioso seguido de uma execução cuidadosa de medidas de controle e monitoramento (SÁNCHEZ, 2001, p.60-63).

\subsubsection{Resíduos Industriais - Definição e Classificação}

Com base na norma técnica NBR $10.004^{5}$ da Associação Brasileira de Normas Técnicas (ABNT), a Companhia de Tecnologia de Saneamento Ambiental do Estado de São Paulo (CETESB) define resíduos sólidos industriais como:

Resíduos em estado sólido e semi-sólido que resultam da atividade industrial, incluindo os lodos provenientes das instalações de tratamento de águas residuárias, aqueles gerados em equipamentos de controle da poluição, bem como determinados líquidos cujas particularidades tornem inviável seu lançamento na rede pública de esgotos ou corpos d'água, ou exijam para isto soluções economicamente inviáveis, em face a melhor tecnologia disponível. (ROCCA et al., 1993, p.13).

O estado físico do resíduo não é importante para definir sua periculosidade e os cuidados especiais necessários no seu manuseio e destinação final. A periculosidade é conferida por certas características ou pela presença de substâncias que tornam o resíduo perigoso àsaúde humana ou ao meio ambiente. Dentre essas características, a toxicidade e a carcinogênese são as mais relevantes. Incluindo também inflamabilidade, reatividade, explosividade, corrosividade, radioatividade, patogenicidade, irritabilidade e 0 potencial para a bioacumulação (LA GREGA, BUCKINGHAM e EVANS, 1994).

Segundo a definição adotada pela ABNT, periculosidade é a característica apresentada por um resíduo que, em função de suas propriedades físicas, químicas ou infecto contagiosas pode representar risco à saúde pública, provocando mortalidade,

\footnotetext{
${ }^{5}$ A NBR 10.004 foi editada pela ABNT em 1987, e passou por uma revisão em 2004. Complementares à essa norma, são as Normas 10.005, 10.006 e 10.007 que estabelecem as condições para a realização de ensaios de amostragem e caracterização de resíduos, tendo em vista a sua classificação.
} 
incidência de doenças ou acentuando seus índices; e, riscos ao meio ambiente, quando o resíduo for gerenciado de forma inadequada (ABNT, 2004).

Em função da periculosidade oferecida pelos resíduos, a NBR 10.004 classifica os resíduos da seguinte maneira:

a) Resíduos Classe I - Perigosos: aqueles que representam periculosidade ou características de inflamabilidade, corrosividade, reatividade, toxicidade e patogenicidade.

b) Resíduos Classe II - Não Perigosos

b.1) Resíduos Classe II A - Não inertes: resíduos que não se enquadram nas classificações de resíduos Classe I ou Classe II B nos termos da Norma. Estes resíduos podem apresentar propriedades tais como biodegradabilidade, combustibilidade ou solubilidade em água.

b.2) Resíduos Classe II B - Inertes: quaisquer resíduos que, quando amostrados de uma forma representativa segundo a NBR 10.007, e submetidos ao contato dinâmico e estático com água destilada ou desionizada, à temperatura ambiente, conforme a NBR 10.006, não tiverem nenhum de seus constituintes solubilizados a concentrações superiores aos padrões de potabilidade da água, excetuando-se aspecto, cor, turbidez, dureza e sabor.

As decisões técnicas e econômicas tomadas em todas as fases do gerenciamento dos resíduos sólidos industriais (manuseio, acondicionamento, armazenagem, coleta, transporte e disposição final) devem estar fundamentadas na classificação dos mesmos (ROCCA et al., 1993, p.13).

\subsubsection{A Evolução no Gerenciamento de Resíduos: do Descaso àPrevenção}

Antes do estabelecimento de leis ambientais, o ar, a água e o solo eram tratados como propriedades livres, disponíveis para receber resíduos. Isso não causava problemas quando a população era esparsa e os produtos industrializados eram poucos comparados aos índices atuais (BUCHHOLZ, 1998).

Essa fase caracterizou-se pela completa omissão aos danos resultantes do descarte de resíduos no meio ambiente, onde as matérias-primas e a energia eram extraídas da 
natureza, se transformavam em produtos e as sobras do processo eram descartadas no meio ambiente, como mostra a Figura 5.

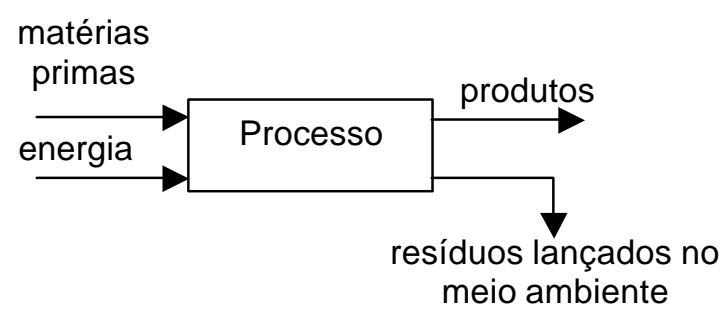

Figura 5 - Fase de omissão aos danos ambientais

Fonte: Modificado de BISHOP (2000a).

A partir do momento que o meio ambiente passou a dar sinais de que não era capaz de absorver a carga de poluentes lançada, as indústrias potencialmente poluidoras passaram a adotar a estratégia da diluição como forma de mascarar os impactos ambientais de suas atividades, conforme expõe Rodhe (2000, p.16): "[...] a poluição era dispersada em uma grande área ou volume, de modo a reduzir a concentração dos poluentes no meio receptor [...]". Na prática isto se verificava através do uso de chaminés mais altas e de tubulações mais compridas.

Quando a estratégia da diluição passou a ser insuficiente para resolver o problema, o agravamento dos problemas de poluição localizada levou ao estabelecimento de leis ambientais. Estas, como destaca Sánchez (2001, p. 16), foram sistematizadas em alguns países industrializados a partir da metade do século $X X$, eram de caráter corretivo e voltavam-se essencialmente para o controle de emissões de poluentes das atividades de produção, particularmente a produção industrial.

$\mathrm{Na}$ maioria dos países, o desenvolvimento de programas de gerenciamento de resíduos seguiu uma tendência similar. Os primeiros esforços no sentido de promover melhorias na qualidade ambiental eram direcionados àqueles problemas que representavam ameaça direta à saúde pública, como a proteção de mananciais de abastecimento e a redução da poluição atmosférica. Tipicamente, iniciativas focando o correto gerenciamento de resíduos sólidos representavam uma segunda fase na agenda dos países, e eram colocadas em prática quando os problemas mais urgentes já tivessem sido resolvidos. Nos países em desenvolvimento, os programas de proteção ambiental foram estabelecidos com até duas décadas de atraso em relação aos países 
desenvolvidos. Enquanto países como Estados Unidos, Canadá, Alemanha e Dinamarca tiveram seus programas de gerenciamento de resíduos implementados no final da década de 1970, a maioria dos países em desenvolvimento sequer tinham conhecimento da extensão de seus problemas ambientais até 1990 (PROBST e BEIERLE, 1999).

De maneira geral, as leis ambientais eram estabelecidas à medida que os danos ambientais eram detectados. Este sistema, conhecido como 'comando e controle', impõe o cumprimento de padrões de emissões de resíduos. Para atender a estes padrões, surgiram as tecnologias de controle 'end of pipe, ${ }^{6}$ que consistem no controle da poluição através da instalação de equipamentos para o tratamento das emissões geradas, no final do processo (Figura 6).

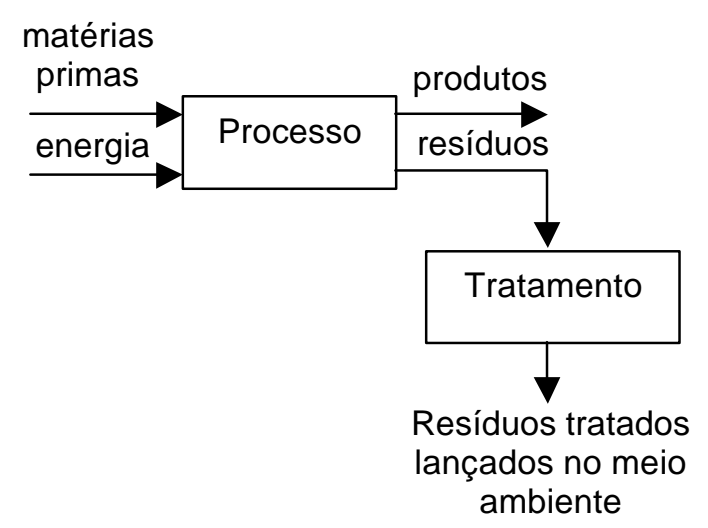

Figura 6 - Fase do controle end of pipe

Fonte: Modificado de BISHOP (2000a).

As tecnologias de controle no fim do tubo promovem tratamentos químicos, físicos ou biológicos dos poluentes, resultando na redução de volume e toxicidade dos resíduos. Se tornaram a principal estratégia para o gerenciamento dos resíduos industriais, tendo sido bastante difundidas entre as décadas de 1970 e 1980 como o único meio de controlar a poluição.

O controle no fim do tubo apresenta restrições quanto a sua eficiência na promoção da sustentabilidade. A principal delas é o fato de promover a transferência de poluentes de um meio para outro, uma vez que o controle atua no sentido de neutralizar ou concentrar a carga poluente, para que o resíduo possa então ser adequadamente

\footnotetext{
${ }^{6} \mathrm{O}$ termo 'end of pipe' pode ser encontrado na literatura sem tradução ou ainda traduzido como 'controle no fim-do-tubo'.
} 
disposto em aterros, lançado na atmosfera ou em rios. O tratamento de resíduos gera subprodutos, que precisam tratados. Por exemplo, no controle de poluentes atmosféricos usando um scrubber ${ }^{7}$ como medida de controle, o poluente da corrente gasosa é transferido para a água, que necessita passar por um tratamento secundário para a remoção dos contaminantes antes que esta seja descartada como efluente líquido. Outro exemplo é a incineração de resíduos que gera, além de emissões gasosas, cinzas e escórias que precisam ser dispostas em aterros especiais, dadas as suas características de periculosidade. Convém ressaltar que muitas vezes os resíduos secundários produzidos no tratamento são mais tóxicos ou difíceis de tratar do que os resíduos originais. Outro inconveniente é que este tipo de medida não reduz responsabilidades a longo prazo (THOMAS, 1995).

Ao enviar resíduos para terceiros, seja para a disposição em aterros industriais, para incineração ou outras formas de tratamento, a empresa geradora do resíduo está sujeita a riscos futuros, como o tratamento e disposição inadequada do resíduo ou o fechamento da firma para a qual o resíduo foi enviado. Cabe lembrar que a empresa geradora é coresponsável pelos danos ambientais que o resíduo possa causar, mesmo que este tenha sido enviado para uma empresa de tratamento legalizada (FREITAS, 2001; LAGE, 2004).

Deve-se considerar ainda o fato destas tecnologias serem onerosas, uma vez que requerem equipamentos específicos, necessitam operação e controle rigorosos e consomem, na maioria dos casos, grandes quantidades de água e energia, somados ao desperdício de matéria-prima na forma de resíduo (SCHNITZER, 1995; THOMAS, 1995).

A crescente preocupação em relação às questões ambientais - desde aquecimento global até problemas locais de disposição de resíduos - ocasionou um aumento na pressão sobre os governos e os setores industriais para a redução dos impactos ambientais envolvendo a produção e o consumo de bens e serviços. À partir da década de 1980 algumas companhias passaram a mudar o foco de suas atenções, até então centrado nas tecnologias 'end of pipe', partindo em busca de novas abordagens e de processos mais limpos, que gerassem menos poluição e resíduos em primeiro lugar, ou que fizessem um uso mais eficiente das matérias-primas e energia (ROY, 2000).

\footnotetext{
7 Scrubber é o nome técnico de um equipamento utilizado para o controle de emissões gasosas em chaminés, também conhecido como lavador de gases. Consiste de um fluxo de água em contra-corrente ao fluxo gasoso, que capta as partículas em suspensão no gás, evitando que as mesmas sejam dispersadas na atmosfera.
} 
Em um primeiro momento as indústrias passaram a adotar estratégias para reduzir o montante de resíduos gerados, dispostos ou tratados, através da recuperação, reutilização e reciclagem dos materiais, como mostra o esquema da Figura 7.

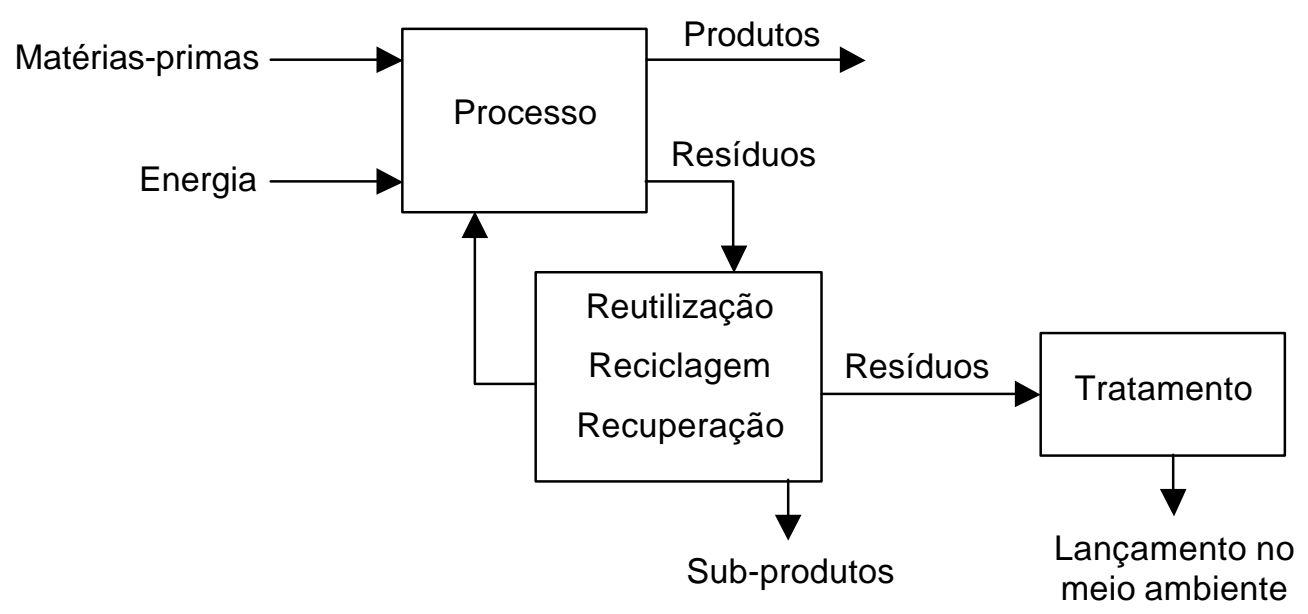

Figura 7 - Reutilização, reciclagem e recuperação de resíduos.

Fonte: Modificado de BISHOP (2000a).

As definições de reutilização, reciclagem e recuperação freqüentemente são objetos de dúvida. Após consulta a diversas fontes (Compromisso Empresarial para a Reciclagem - CEMPRE, 2000, THOMAS, 1995, Environment Canada - EC, 2001) só para citar as mais relevantes, pode-se dizer que:

- Na reutilização ou reúso, os materiais ou produtos são reutilizados praticamente sem transformação, na sua aplicação original ou para uma nova função, e isto pode ocorrer no processo ou fora deste.

- A reciclagem, do mesmo modo, pode ocorrer dentro ou fora do processo, no entanto o material passa necessariamente por um processo de transformação, com consumo de energia para que possa ser novamente utilizado como matériaprima.

- A recuperação envolve a separação de uma substância ou componente de um fluxo de resíduo para que esta substância no seu estado original possa ser reutilizada. Geralmente a recuperação envolve processos de purificação com consumo de energia. 
Os debates em torno dos problemas ambientais globais - amplamente discutidos por ocasião da Rio-92 - fizeram com que o gerenciamento de resíduos passasse a ser tratado de uma forma mais holística, transcendendo os muros da fábrica e contabilizando os danos ambientais a longo prazo. Na busca deste novo paradigma de sustentabilidade ambiental, estratégias preventivas baseadas nos conceitos de prevenção àpoluição e produção mais limpa têm ganhado espaço.

A prevenção à poluição e a produção mais limpa têm o objetivo de promover o uso sustentável dos recursos e de prevenir a geração de resíduos e poluentes nas atividades industriais, tomando como princípio básico a redução dos resíduos na fonte. No que se refere à hierarquia do gerenciamento de resíduos, a prevenção à poluição deve ser priorizada em relação àreciclagem e ao reúso de materiais, ao tratamento, disposição e remediação, como mostra a Figura 8.

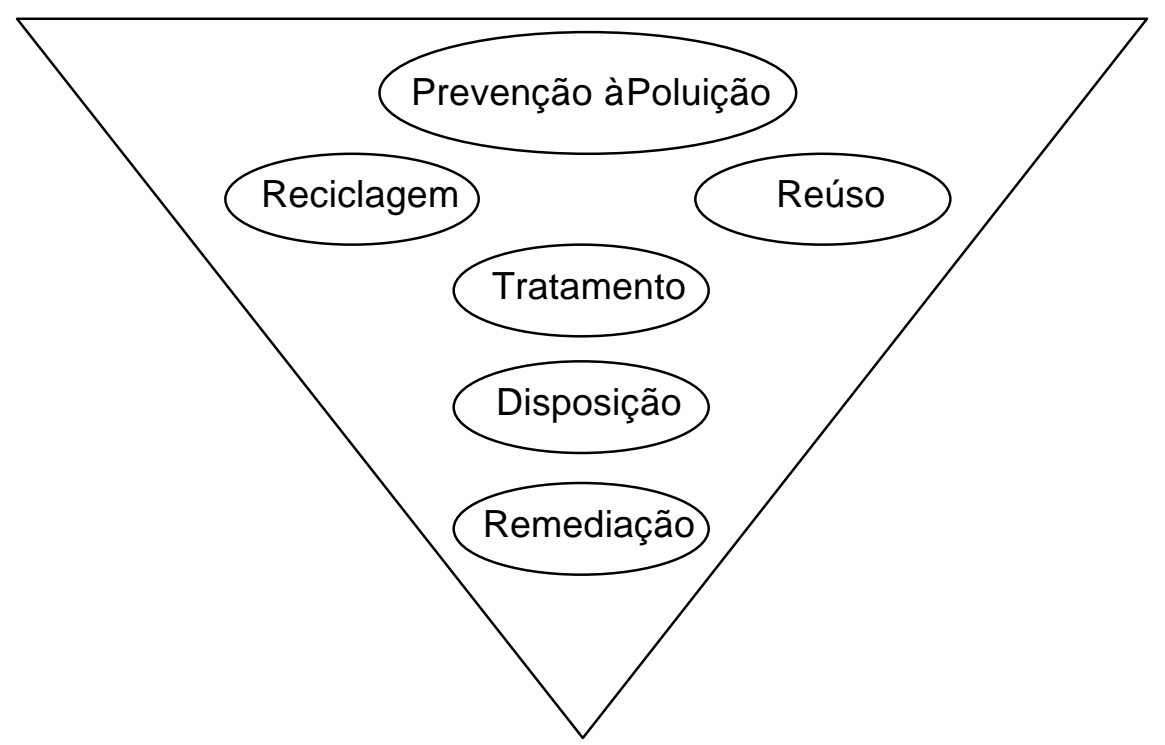

Figura 8 - Hierarquia do gerenciamento de resíduos

Fonte: Modificado de Environment Canada (2001)

Os conceitos de produção mais limpa e prevenção à poluição têm suas raízes na década de 1970. Nesta época, a ONU e outras organizações internacionais já iniciavam discussões sobre a necessidade da minimização de resíduos industriais na fonte. Inicialmente as estratégias preventivas foram denominadas por algumas organizações de 'Low - waste technologies' ou 'Non - waste technologies', ou ainda de tecnologias limpas 
(clean technologies) ou minimização de resíduos. A maioria das iniciativas internacionais ou nacionais desenvolvidas neste período não obtiveram sucesso (RHODE, 2000).

O termo prevenção à poluição tem sua origem relacionada ao programa de redução de resíduos desenvolvido em 1975 nos Estados Unidos pela 3M, denominado 3P 'Pollution Prevention Pays'. Este programa é mundialmente reconhecido e considerado um dos programas pioneiros no uso de técnicas de redução na fonte ao demonstrar com sucesso, ainda na época em que o foco do gerenciamento de resíduos concentrava-se na diluição e nas tecnologias 'end of pipe', que os investimentos em estratégias de redução na fonte são compensados pela redução de custos com o tratamento e disposição de resíduos e pela otimização no uso de matérias-primas ( HIGGINS, 1995; BISHOP, 2000).

Inspirada nos resultados positivos do 3P, a Agência de Proteção Ambiental dos Estados Unidos (US EPA) criou o programa Pollution Prevention, conhecido também como $\mathrm{P} 2$, com o objetivo de difundir a estratégia de prevenção àpoluição por todo o país na forma de política ambiental. A política da US EPA foi firmada em 1990, pelo Pollution Prevention Act, Decreto que estabeleceu a Política de Prevenção àPoluição nos Estados Unidos, após o Congresso concluir que mesmo quando possível, as possibilidades envolvendo a redução na fonte não eram executadas porque as leis existentes estavam focadas no tratamento e na disposição final dos resíduos (THOMAS, 1995).

Um importante passo para a disseminação e internacionalização das estratégias preventivas foi a criação do Programa de Produção mais Limpa (Cleaner Production Programme), pelo PNUMA em 1989 (RHODE, 2000).

Seguindo esta tendência, a Carta de Princípios para o Desenvolvimento Sustentável, instituída pela Câmara Internacional do Comércio (ICC) em 1991, propõe dezesseis princípios de gestão ambiental baseados no conceito de Produção Limpa, dos quais destacam-se a adoção de processos de melhoria, desenvolvimento de produtos e serviços não agressivos e enfoque preventivo (DONAIRE, 1995).

Os termos prevenção à poluição e produção mais limpa são intercambiáveis. A distinção dos termos é geográfica: o termo prevenção àpoluição é usado principalmente nos Estados Unidos e Canadá, enquanto o termo produção mais limpa é mais freqüente nos países da Europa e em outros lugares. Os dois termos referem-se à estratégia de redução contínua da poluição através da redução dos resíduos na fonte - que implica na eliminação do resíduo no processo antes mesmo de sua geração (UNEP, 2003). 
As respostas mais recentes da indústria surgiram durante a segunda metade da década de 1990, e levam em conta não só a melhoria de eficiência de processo, mas também melhorias no produto. Para tal, empregam-se metodologias como a avaliação de ciclo de vida (ACV) e o design ecológico, também conhecido como ecodesing ou design for the environment (DfE) (SANCHÉZ, 2001).

\subsubsection{Respostas das Indústrias frente d̀ Questões Ambientais}

A inserção da questão ambiental no âmbito das indústrias aconteceu em um primeiro instante como resposta a pressões para que fossem adotadas práticas ambientais coerentes, e em um segundo momento em decorrência da conscientização do próprio setor industrial, que passou a enxergar a variável ambiental como uma oportunidade de expandir seus negócios, reduzir custos de produção e melhorar sua imagem perante a opinião pública.

Segundo Sanches (1996), a conscientização de grupos de interesses leva ao surgimento de pressões sobre as empresas industriais, para que estas incorporem considerações ambientais em suas decisões de negócios e se responsabilizem pelos efeitos de suas atividades no meio ambiente. Como resultado de um conjunto de articulações executadas pelos diferentes grupos de interesse, diferentes tipos de respostas das empresas frente às questões ambientais são obtidas (Figura 9).

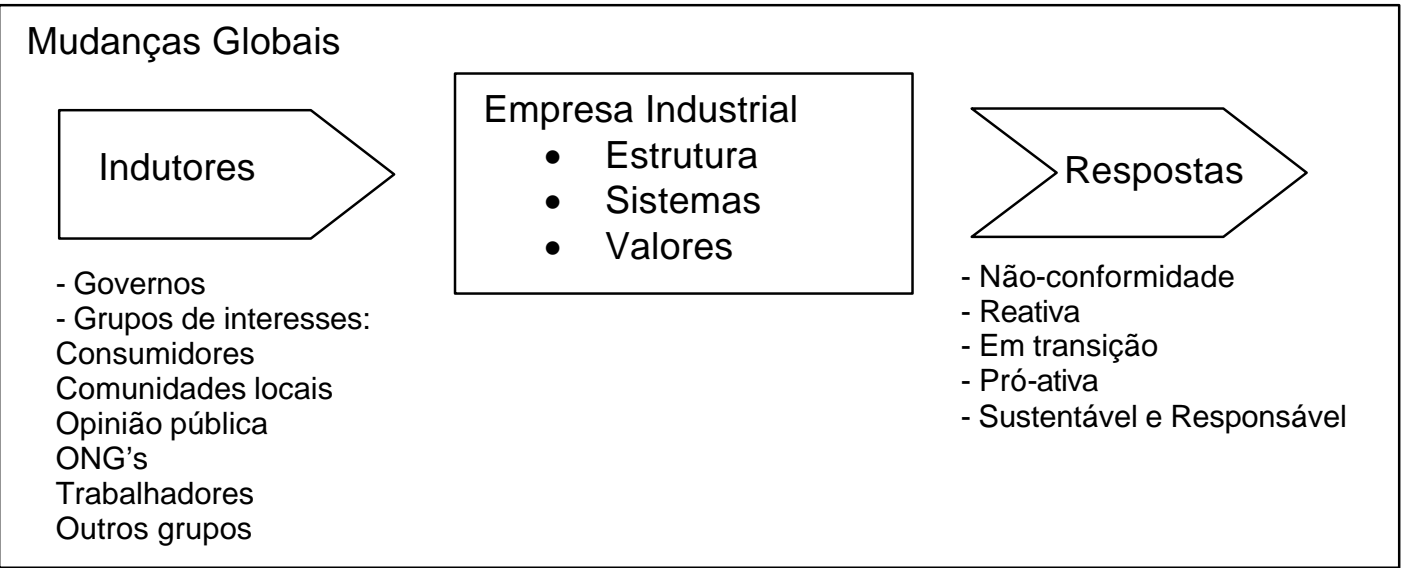

Figura 9 - Formas de incorporação da dimensão ambiental nas atividades industriais Fonte: SANCHES (1996) 
Cada nível de resposta corresponde a uma percepção da pressão, de problemas e de suas causas e conseqüências, que se traduzem em barreiras e oportunidades para a ação da empresa no presente e no futuro. A não conformidade representa uma omissão ou não-resposta aos problemas ambientais; a resposta reativa demonstra um atendimento às pressões mais evidentes, externas, em um momento posterior ao surgimento dos problemas e pressões; a postura em transição denota que a empresa reconhece as falhas internas e coloca suas respostas concomitantes ao surgimento de problemas ambientais; a postura pró-ativa antecipa-se æ̀s pressões e ao surgimento do problema. Outra característica das respostas é que são contínuas e dinâmicas, podendo também ser evolutivas. Como decorrência da evolução da relação pressão/resposta e as percepções, conceitos e práticas envolvidos, se chegará a um quinto nível de resposta, denominado de 'sustentável e responsável' (SANCHES, 1996). Esta resposta sustentável e responsável está situada em um patamar superior àquele no qual se encontram as empresas mais avançadas no tratamento da questão ambiental, ditas pró-ativas, e resulta do reconhecimento por parte das empresas que o sucesso a longo prazo não depende apenas do desempenho financeiro, mas também de sua performance ambiental e social. Segundo Fiksel (2002), 'empreendimentos sustentáveis' são aqueles empreendimentos capazes de antecipar e encontrar as necessidades das gerações presentes e futuras, adotando 'três fatores decisivos' (triple botton line):

1) Prosperidade econômica e manutenção do empreendimento;

2) Bem-estar e equidade social para seus empregados, consumidores e comunidade;

3) Proteção ambiental e conservação dos recursos, em nível local e global.

\subsubsection{A Indústria e o Meio Ambiente no Brasil}

\subsubsection{A Gestão Ambiental na Indústria Brasileira}

A extensão do território nacional, a diversidade do parque industrial brasileiro, e ainda a escassez de dados sobre o assunto, torna difícil a definição de um perfil da gestão ambiental nas indústrias. Corrobora para esta dificuldade o fato de existirem empresas que adotam práticas de gestão inovadoras, comparáveis aos países mais avançados da Europa, enquanto que de outro lado, existem aquelas que sequer conseguem cumprir os requisitos da legislação ambiental vigente. Este distanciamento de posturas geralmente está relacionado com o estágio tecnológico e com o porte da indústria. 
Em um estudo publicado pelo Grupo de Infra-estrutura e Meio Ambiente do Banco Mundial (DASGUPTA, LUCAS e WHEELER, 1998), que relaciona a poluição atmosférica de origem industrial com os índices populacional e de renda e com o porte da indústria, constatou-se que no Brasil as pequenas indústrias concentram-se nos municípios de menor renda e estas representam uma grande fonte de poluição nestas regiões. Apesar disso, o estudo conclui que as expectativas de mortalidade devido a problemas de saúde causados pela poluição atmosférica de origem industrial se concentram nas áreas de maior renda, onde as indústrias de grande porte são as responsáveis pela poluição.

Segundo trabalho realizado por Monteiro ${ }^{8}$ (1981 apud PETILLO, 1997), no período compreendido entre as décadas de 1960 e 1980 do século passado, não existiu nenhuma novidade na tomada de consciência ambiental no país. Enquanto que na década de 1970 os países industrializados, já sentindo os reflexos de décadas de consumo desenfreado de recursos e dos efeitos das emissões tóxicas no meio ambiente, externavam sua preocupação com a degradação ambiental na Conferência de Estocolmo, o Brasil tinha como objetivo prioritário em sua agenda o desenvolvimento industrial a qualquer custo, como forma de resolver seus problemas econômicos. Como destaca Petillo (1997, p.14): "[...] o posicionamento do Brasil nesta conferência se reflete até hoje na gestão ambiental, essencialmente voltada para a mitigação dos impactos, postura conflitante com o conceito de comportamento ambiental pró-ativo que se defende atualmente [...]".

Pode-se dizer que, de maneira geral, a gestão ambiental encontra-se defasada em relação aos países desenvolvidos de uma a duas décadas. Tomando como exemplo o Estado de São Paulo, onde as primeiras indústrias foram instaladas em 1945, a agência ambiental (CETESB) foi criada em 1973, e as primeiras leis ambientais do Estado foram estabelecidas em 1976, fica nítida esta defasagem. Por mais de duas décadas as indústrias puderam exercer suas atividades sem qualquer tipo de controle, e hoje considera-se que parte do passivo ambiental existente no estado decorre desta época. Só a partir da regulamentação das primeiras leis, na década de 1970, é que as indústrias passaram a adotar medidas de controle. Nesta época Cubatão era considerado um dos lugares mais poluídos do mundo, e as indústrias começavam a concentrar seus esforços em adquirir tecnologias de tratamento end-of-pipe, vendo o resíduo como um subproduto indesejável e inevitável, enquanto que nos países industrializados as discussões já apontavam para estratégias de minimização da quantidade e da toxicidade dos resíduos.

\footnotetext{
${ }^{8}$ MONTEIRO, C.A.F. (1981). A Questão Ambiental no Brasil: 1960-1980. São Paulo: GBOG/USP. Teses e Monografias apud PETILLO, (1997).
} 
Esta postura foi confirmada também no trabalho realizado por Leão (1998), que ao avaliar o modelo de gestão de resíduos perigosos adotado na região metropolitana de São Paulo, constatou que este segue as características básicas daqueles implementados nos países industrializados na década de 1970 e início de 1980, onde os regulamentos de comando e controle constituíam os instrumentos gerenciais utilizados para alcançar os objetivos propostos.

Pode-se dizer que na década de 1980, o comportamento das indústrias, com raras exceções, oscilou entre a omissão e a reação, em virtude da falta de conscientização do setor industrial, da regulamentação precária e da pouca ação por parte dos grupos de interesse. A situação começou a mudar a partir da Rio-92, quando as discussões passaram a ocorrer não apenas entre grupos ambientalistas, mas com uma participação mais efetiva da sociedade.

A globalização da economia, o estabelecimento de leis ambientais mais efetivas, e o surgimento das Normas ISO 14.000 de gestão ambiental vêm contribuindo para uma evolução contínua no modo de pelo menos parte da indústria gerir suas atividades com relação aos impactos no meio ambiente. Os debates mais recentes envolvendo segmentos industriais e do governo, bem como a comunidade científica e representantes da sociedade civil, tem apontado para uma ampliação da conscientização na busca do desenvolvimento sustentável no seu verdadeiro sentido, buscando a prevenção no lugar da mitigação, e a preservação em contraposição ao desperdício.

Como destacam Almeida, Mello e Cavalcanti (2004, p. 10), algumas mudanças já são visíveis no comportamento empresarial de setores de maior impacto sobre o meio ambiente, como os químicos, de papel e celulose, siderúrgico e de mineração, entre outros. Entretanto, a imensa maioria das empresas brasileiras ainda restringe sua responsabilidade ambiental ao atendimento àlegislação de controle da poluição da água, do ar e do solo. E no caso de novos empreendimentos ou instalações, seguem exigências da avaliação de impactos ambientais, o que denota um comportamento majoritariamente reativo.

Uma avaliação realizada pela Divisão de Tecnologia, Indústria e Economia da UNEP (UNEP DTIE) em parceria com a CETESB, e divulgada no relatório "Produção mais Limpa na América Latina e Caribe" (UNEP, 2002a), aponta algumas iniciativas que vêm sendo tomadas pelo setor privado e pelo setor público no sentido de fomentar e promover 
estratégias de produção mais limpa e prevenção à poluição no país, dentre as quais merecem destaque:

> Declaração dos Princípios da Indústria para o Desenvolvimento Sustentável, desenvolvida pela Confederação Nacional das Indústrias (CNI) através do Conselho Empresarial para o Meio Ambiente (COEMA), que vem desde 1998 sendo introduzida nas indústrias.

> Centro Nacional de Tecnologias Limpas (CNTL), é o centro da UNEP de Produção mais Limpa no Brasil. Está sediado no Rio Grande do Sul, junto à sede da Federação das Indústrias do Estado do Rio Grande do Sul (FIERGS). O CNTL concentra suas atividades na disseminação de informação sobre os conceitos de produção mais limpa e informações técnicas através do acesso àbases de dados da UNEP e de parcerias entre universidades locais e estrangeiras; na implantação de programas de produção mais limpa em indústrias e na participação no processo de desenvolvimento de políticas ambientais, dando suporte aos diversos setores industriais na busca por linhas de crédito para melhoria das políticas ambientais e da produtividade industrial, entre outras ${ }^{9}$.

> Conselho Empresarial Brasileiro para o Desenvolvimento Sustentável (CEBDS), instituído em 1997, é o escritório brasileiro do WBCSD (World Business Council for Sustainable Development). Através de grupos de discussão especializados tem estabelecido parcerias com o CNTL, SEBRAE, BNDES e CNI, para a criação de escritórios regionais com o objetivo de desenvolver e divulgar atividades de prevenção àpoluição e produção mais limpa. A partir de 1999 o CEBDS passou a coordenar a Rede Brasileira de Produção mais Limpa, formada por sete centros estaduais, em Minas Gerais, Bahia, Santa Catarina, Mato Grosso, Rio de Janeiro, Ceará e Pernambuco, além do CNTL. Os centros estaduais são responsáveis por multiplicar os conhecimentos fomentados pelo CNTL para micro e pequenas empresas.

- Carta de São Paulo para a Prevenção à Poluição e Produção mais Limpa, publicada durante a Conferência das Américas sobre Produção mais Limpa, realizada em São Paulo, de 17 a 19 de agosto de 1998, na qual ocorreu também o

\footnotetext{
${ }^{9}$ O CNTL lançou em 2004 o projeto TTN - Technology Transfer Networks Brazilian Local Desk, que se propõe a ser uma rede latino americana para troca de informações sobre produção mais limpa. A rede disponibilizou para a comunidade de interesse um site na internet no endereço www.sustainablealternative.net (Informação verbal fornecida por Marlise Keller dos Santos do CNTL, no I Congresso Interamericano de Resíduos Sólidos Industriais, realizado em Porto Alegre, em setembro de 2004
} 
lançamento da Mesa Redonda das Américas para Produção mais Limpa. A Carta de São Paulo contem recomendações para a implementação da produção mais limpa e prevenção àpoluição nas Américas, e suas recomendações são dirigidas aos governos, setor privado, organizações não governamentais e outros segmentos da sociedade civil.

> Programa "Atuação Responsável" ${ }^{10}$, instituído no país pela Associação Brasileira de Indústrias Químicas (ABIQUIM), conta com a participação obrigatória dos associados desde 1998, e estabelece metas anuais para o ajuste dos programas de gestão ambiental internos das indústrias do setor químico.

Projeto Prevenir - criado em parceria entre a CETESB e a US EPA, este programa voluntário visa interagir com grandes multinacionais para que estas influenciem seus fornecedores no Brasil a adotar práticas de prevenção àpoluição, fornecendo a eles assistência técnica.

Do mesmo modo, representantes dos governos, indústrias, centros nacionais de tecnologias limpas e ONGs, têm criado fóruns de discussões e tomado iniciativas positivas em relação ao desenvolvimento de práticas de gerenciamento ambiental preventivas. O resultado pode ser verificado no crescimento do interesse em práticas de prevenção àpoluição nos últimos anos por parte das indústrias. Isso se deve também à abertura do mercado para produtos estrangeiros, que forçou os empresários brasileiros a melhorarem e renovarem seus processos industriais para garantir competitividade e para conquistar novos mercados, o que tem colaborado também para o aumento no número de empresas que buscam certificações ambientais (UNEP, 2002a).

Esta tendência é confirmada em números, no ano de 2000 existiam no estado de São Paulo 80 empresas certificadas pela norma de gestão ambiental ISO 14.001, em junho de 2002, esse número havia subido para 339. Na mesma data existiam no Brasil 600 empresas certificadas (A INICIATIVA...,2002), e em 2004 o número já havia atingido a marca de 1.500 (MEIO AMBIENTE INDUSTRIAL, 2005).

Segundo dados do CEBDS, na prática em torno de 200 empresas brasileiras investem em tecnologias limpas, no entanto, estas são na maioria grandes empresas, e

\footnotetext{
${ }^{10}$ O programa "Atuação Responsável" é a versão brasileira do Responsible Care criado pela Canadian Chemical Producers Association - CCPA, e começou a ser implantado em diversos países desde 1984. Este programa de forma ampla inclui a segurança das instalações, processos e produtos, e a preservação da saúde ocupacional dos trabalhadores, além da proteção do meio ambiente, por parte das empresas do setor e ao longo da cadeia produtiva (PETILLO, 1997; ARANGOALZATE e KRUGLIANSKAS, 1999).
} 
representam apenas 5\% do total. Estes investimentos nem sempre implicam em somas de milhões de reais, já que muitas vezes apenas o remanejo do processo industrial pode diminuir bastante a quantidade de resíduos gerada (USO DE TECNOLOGIAS..., 2002).

No período entre 1999 e 2002 a Rede Brasileira de Produção mais Limpa e as instituições parceiras investiram $\mathrm{R} \$ 3$ milhões em um projeto para a implementação de práticas de produção mais limpa. Setenta e seis companhias de todos os tamanhos participaram da fase piloto, e investiram um total de $R \$ 2,8$ milhões na implementação de medidas recomendadas pelos consultores da Rede. Em uma etapa seguinte outras 77 companhias investiram $\mathrm{R} \$ 1,1$ milhão. Como resultados desses investimentos, as companhias participantes economizaram $R \$ 18$ milhões por ano em gastos com matériasprimas, água e energia, o que equivale a uma redução anual de 6 milhões de toneladas de matérias-primas, 350 milhões de $\mathrm{m}^{3}$ de água, 3 milhões de $\mathrm{kWh}$ de eletricidade e 1 milhão de $\mathrm{m}^{3}$ de gás natural. As companhias pertencem a 33 diferentes segmentos, sendo mais representativos os setores de eletro-eletrônicos (14\% do total), curtume (12\%), calçados (8\%), construção civil (7\%), metalurgia (6\%), metal-mecânico (6\%), alimentos $(4 \%)$ e hotelaria (3\%). As práticas de produção mais limpa adotadas pelas companhias estão representadas no gráfico da Figura 10, onde nota-se que as práticas mais freqüentes envolvem as melhorias em práticas operacionais, que representam uma alternativa de baixo custo (BARROS, PAIVA e SISINNO, 2003).

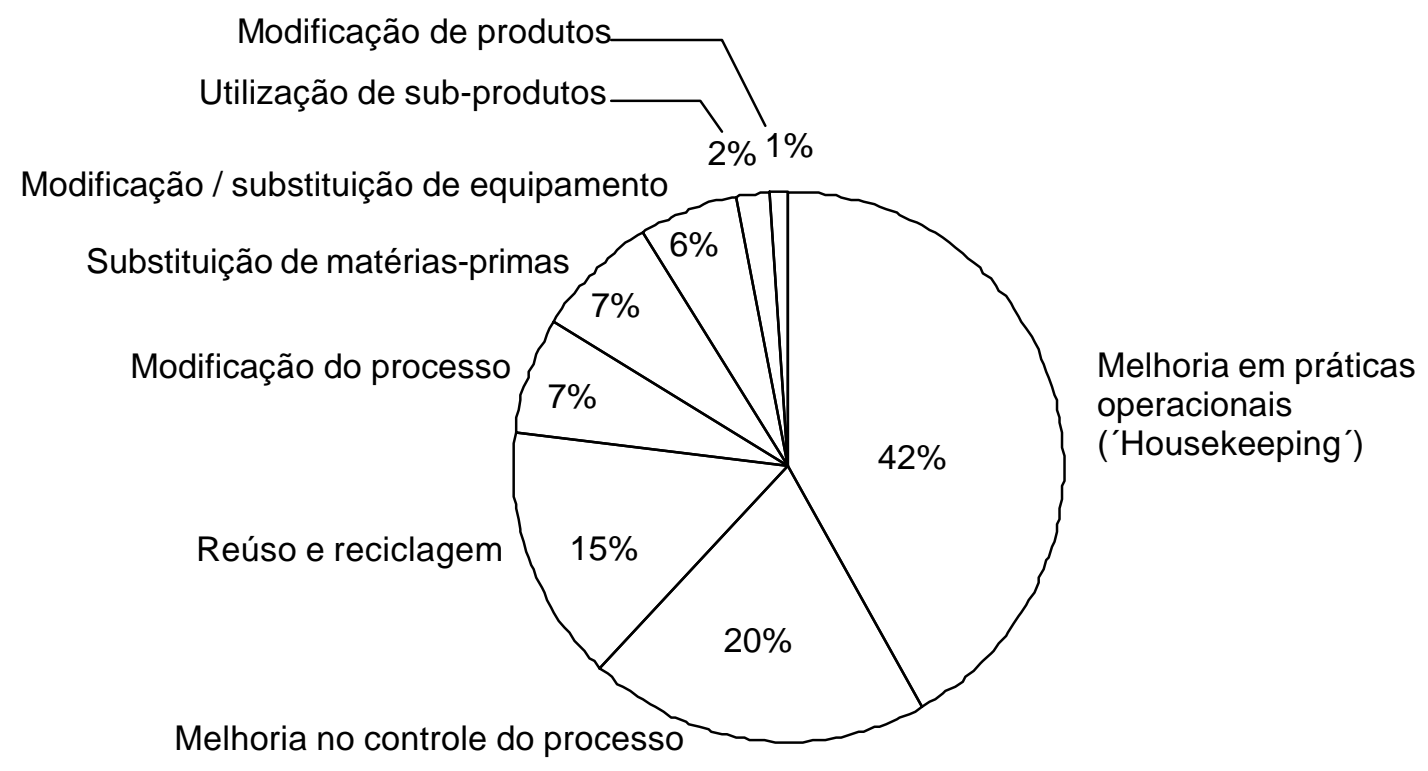

Figura 10 - Práticas de produção mais limpa implementadas no Brasil

Fonte: Modificado de BARROS, PAIVA e SISINNO (2003) 


\subsubsection{Geração de Resíduos Industriais}

Os dados referentes àgeração de resíduos industriais em nível nacional e por setores relevantes da indústria são precários. Estes dados, quando existem estão em posse das próprias indústrias.

A Resolução CONAMA no 313 de 29/10/02 estipulou o prazo de outubro de 2004 para que os órgãos ambientais estaduais elaborassem inventários estaduais e os repassassem ao IBAMA, para que os dados fossem compilados e agrupados de modo a criar o Inventário Nacional de Resíduos Sólidos Industriais. Em uma primeira fase do levantamento participaram os estados do Ceará, Espírito Santo, Mato Grosso, Minas Gerais, Paraná, Pernambuco, Rio de Janeiro e Rio Grande do Sul (LIXO..., 2002). Até então, além dos dados obtidos pela CETESB no levantamento realizado no Estado de São Paulo em 1997, nenhuma pesquisa ou levantamento havia sido concluído nos outros estados. Até o presente, o Inventário Nacional de Resíduos Sólidos Industriais ainda não foi publicado, provavelmente porque os inventários estaduais não foram concluídos na sua totalidade.

Em maio de 2003 a Fundação Getúlio Vargas (FGV), em um estudo encomendado pela Associação Brasileira de Empresas de Tratamento de Resíduos (ABETRE), apresentou um panorama dos inventários de resíduos sólidos industriais no Brasil. Um dos objetivos iniciais deste estudo consistia em viabilizar a projeção da estimativa do mercado de resíduos industriais no Brasil, por estado e por segmento industrial. Estes indicadores, na medida do possível, deveriam relacionar a produção industrial e a geração de resíduos em cada segmento industrial relevante. O projeto se caracterizou fundamentalmente como sendo de gestão de conhecimento, em função da impossibilidade da realização de levantamentos detalhados ou pesquisas junto ao setor industrial no âmbito do contrato (ASSOCIAÇÃO BRASILEIRA DE RESÍDUOS ESPECIAIS E LIMPEZA - ABRELPE, 2003).

Os dados sobre geração de resíduos industriais apresentados no estudo consistiram de uma compilação dos dados apresentados nos relatórios dos estados que tinham seus inventários já concluídos: São Paulo, Rio de Janeiro, Rio Grande do Sul, Paraná, Pernambuco e Goiás. Os dados, agrupados de acordo com a classificação dos resíduos são mostrados na Tabela 1. A Figura 11 mostra os dados em forma de gráfico, considerado a geração de resíduos nos Estados em $10^{6}$ toneladas por ano. 
Tabela 1 - Geração de resíduos sólidos industriais no Brasil (ABRELPE, 2003).

\begin{tabular}{lllll}
\hline Estado & Classe I & Classe II & Classe III & Total \\
\hline São Paulo $^{1}$ & 535.615 & 25.038 .167 & 1.045 .895 & 26.619 .677 \\
Rio de Janeiro $^{2}$ & 293.953 & $5.768 .552{ }^{*}$ & & 6.062 .515 \\
R. Grande do Sul $^{3}$ & 205.326 & 1.404 .732 & 25.632 & 1.835 .890 \\
Paraná $^{4}$ & 634.543 & $15.106 .393^{*}$ & & 15.740 .936 \\
Pernambuco $^{5}$ & 12.622 & 1.325 .791 & 4.071 & 1.342 .483 \\
Goiás $^{6}$ & 4.405 & 1.488 .989 & & 1.491 .374 \\
\hline Total & $\mathbf{1 . 6 8 6 . 4 6 4}$ & $\mathbf{5 0 . 1 3 0 . 6 1 4}$ & $\mathbf{1 . 0 7 5 . 5 9 8}$ & $\mathbf{5 2 . 8 9 2 . 6 7 5}$ \\
\hline
\end{tabular}

1 CETESB. Inventário de Resíduos Estaduais, 1995. Universo da amostra: 1.432 indústrias.

2 FEEMA. Relatório de Atividades do Projeto de Controle Ambiental, setembro 2000. Dados originais referentes à geração mensal de resíduos no período de 1996-2000. Geração total de resíduos: 505.209,66 t/mês; Geração de resíduos classe I: $24.496,11$ t/mês.

3 FEPAM. Relatório sobre a geração de resíduos sólidos industriais na Região Hidrográfica do Guaíba, agosto 2002 . Os dados são do ano 2000 e referentes a 9.341 indústrias da região.

${ }^{4}$ IAP. Inventário Estadual dos Resíduos Sólidos Industriais - Diagnóstico, dezembro 2002. Universo da amostra: 683 indústrias

${ }^{5}$ CPRH-GTZ. Inventário de Resíduos Sólidos Industriais, 2001. Universo da amostra: 100 indústrias.

${ }^{6}$ Agência Ambiental. In: Resol - Notícias, 18 de janeiro de 2003 (www.resol.com.br). Os dados apresentados são parciais e cobrem um universo de 75 indústrias.

* Resíduos classes II e III.

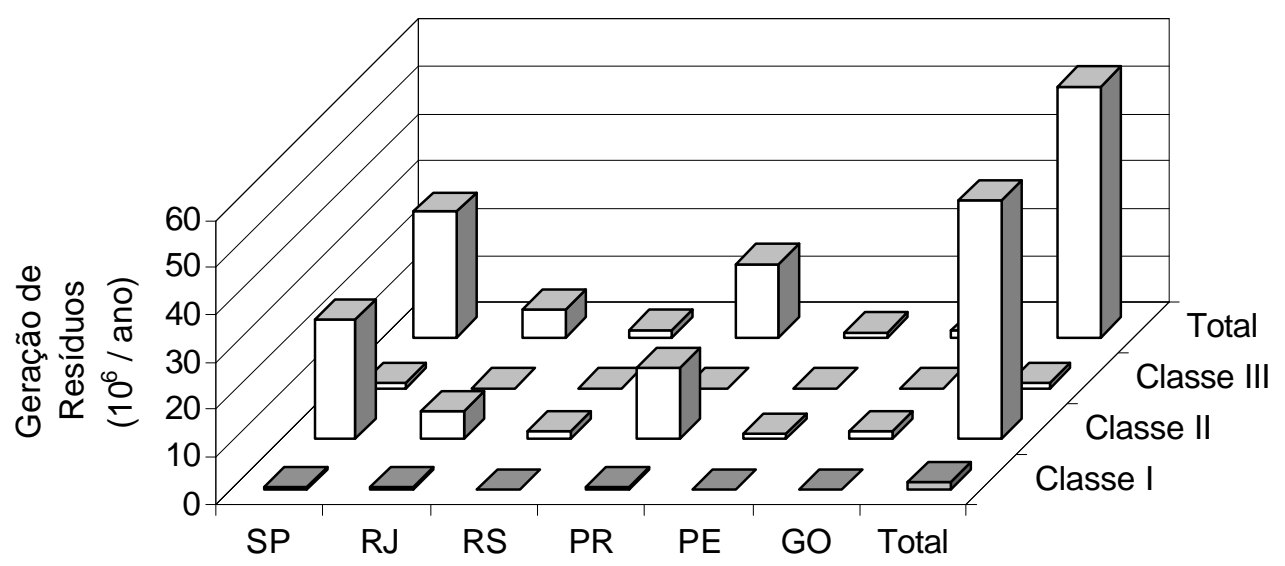

Figura 11 - Geração de Resíduos Industriais no Brasil (106 ton/ano)

Fonte: Modificado de ABRELPE (2003).

Observa-se que os resíduos industriais perigosos (classe I) representam a menor parcela na composição dos resíduos.

A Tabela 2 apresenta, para o universo dos municípios com serviços de limpeza pública e/ou coleta de resíduos sólidos urbanos, a quantidade de municípios por controle 
da disposição final dos resíduos sólidos industriais, com base nos resultados da Pesquisa Nacional de Saneamento Básico (PNSB) de 2003.

Tabela 2- Municípios com serviços de limpeza urbana e/ou coleta de resíduo sólido, por controle da disposição, segundo as grandes regiões.

\begin{tabular}{lcccc}
\hline & Controla & Não controla & Sem declaração & Total \\
\hline Norte & 16 & 424 & 5 & 445 \\
Nordeste & 82 & 1681 & 6 & 1769 \\
Sudeste & 230 & 1377 & 59 & 1666 \\
Sul & 196 & 941 & 12 & 1149 \\
Centro-Oeste & 27 & 418 & 1 & 446 \\
Brasil & 551 & 4841 & 83 & 5475 \\
\hline
\end{tabular}

Fonte: ABRELPE, 2003.

A Tabela 3 apresenta a destinação final dos resíduos industriais segundo os municípios que realizam a coleta desses resíduos, e a Figura 12 mostra os dados na forma de gráfico.

Tabela 3 - Municípios que coletam resíduo industrial, por destinação do resíduo.

\begin{tabular}{|c|c|c|c|c|c|c|c|c|c|c|c|}
\hline & 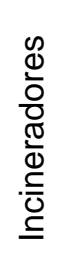 & 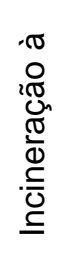 & 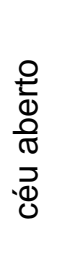 & $\begin{array}{l}\text { 윽 } \\
\text { 음 } \\
\text { ত্ } \\
\text { ত্ }\end{array}$ & 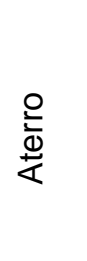 & 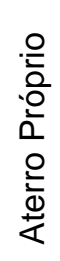 & 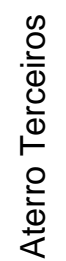 & $\begin{array}{l}\frac{0}{0} \\
\text { 음 } \\
\text { 完 }\end{array}$ & 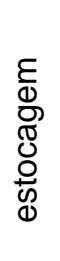 & 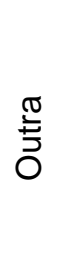 & $\begin{array}{l}\frac{0}{0} \\
\frac{\pi}{0} \\
\frac{\varepsilon}{D} \\
\infty\end{array}$ \\
\hline Norte & 0 & 2 & & 15 & 6 & 1 & 0 & 0 & & 0 & 0 \\
\hline Nordeste & 1 & 5 & & 109 & 36 & 5 & 2 & 0 & & 1 & 0 \\
\hline Sudeste & 5 & 14 & & 68 & 124 & 20 & 4 & 1 & & 8 & 6 \\
\hline Sul & 1 & 15 & & 68 & 105 & 14 & 10 & 4 & & 14 & 0 \\
\hline Centro-Oeste & 1 & 1 & & 15 & 17 & 0 & 2 & 1 & & 1 & 0 \\
\hline Brasil & 8 & 37 & & 275 & 288 & 40 & 18 & 6 & & 24 & 6 \\
\hline
\end{tabular}

Fonte: ABRELPE, 2003.

Convém salientar que termo "incineração àcéu aberto", usado pela ABRELPE e que consta na Tabela 3, está incorreto. Segundo Dempsey e Oppelt (1999), a incineração é um processo de engenharia, controlado, que emprega a decomposição térmica, por meio da oxidação a alta temperatura (usualmente $900^{\circ} \mathrm{C}$ ou superior) para destruir a fração 
orgânica do resíduo e reduzir o volume. Geralmente, resíduos combustíveis ou resíduos com teor significativo de orgânicos são considerados os mais apropriados para incineração. Entretanto, tecnicamente qualquer resíduo que contenha uma fração orgânica perigosa, não importando o total desta fração, é um candidato funcional à incineração. Logo, o termo correto a ser empregado para se referir a queima de resíduos sem dispositivos de controle de temperatura e de emissões atmosféricas deve ser "queima àcéu aberto"

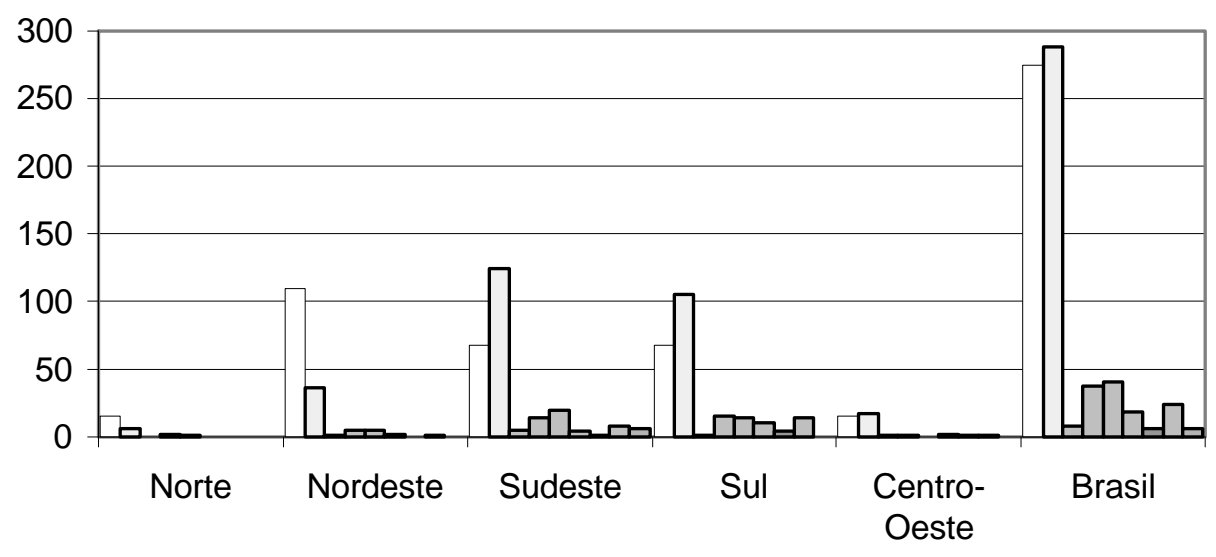

\begin{tabular}{|ll|}
\hline$\square$ Vazadouro & $\square$ Aterro \\
$\square$ Incineradores & $\square$ Queima à céu aberto \\
$\square$ Aterro Res. Esp. Próprio & $\square$ Aterro Res. Esp. Terceiros \\
$\square$ Pátio de estocagem & $\square$ Outra \\
$\square$ Sem dado & \\
\hline
\end{tabular}

Figura 12 - Destinação final dos resíduos industriais por grandes regiões.

Fonte: Modificado de ABRELPE (2003).

A maioria absoluta dos municípios que coletam resíduos industriais utiliza vazadouro (lixões) ou aterro para disposição final dos resíduos. Apenas 8,26\% desses municípios dispõem os resíduos industriais em aterro de resíduos especiais (ABRELPE, 2003). A Figura 13 mostra a distribuição percentual da disposição de resíduos industriais no Brasil. 


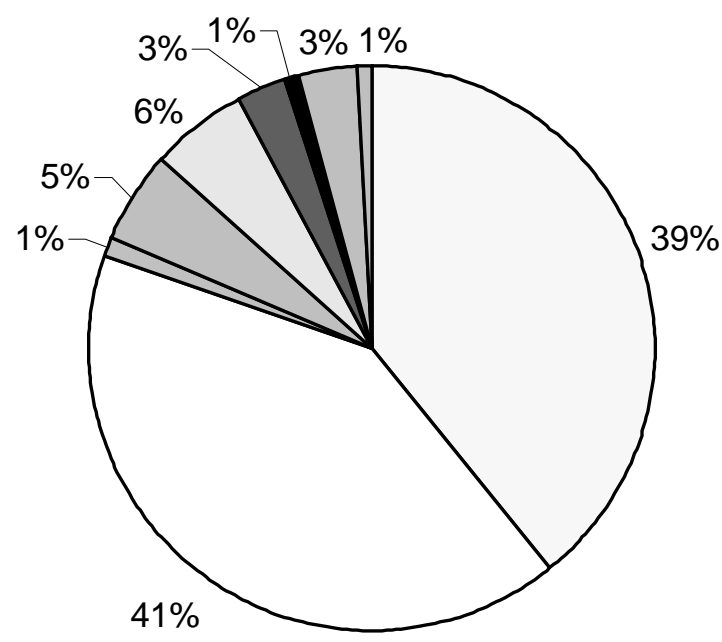

\begin{tabular}{|l|}
\hline Vazadouro \\
$\square$ Aterro \\
$\square$ Incineradores \\
$\square$ Queima à céu aberto \\
$\square$ Aterro Res. Esp. Próprio \\
$\square$ Aterro Res. Esp. Terceiros \\
$\square$ Pátio de estocagem \\
$\square$ Outra \\
$\square$ Sem dado
\end{tabular}

Figura 13 - Distribuição percentual da disposição de resíduos industriais no Brasil Fonte: Modificado de ABRELPE (2003).

Os dados da pesquisa sobre os resíduos industriais publicados em 2003, foram atualizados e divulgados na versão de 2004. De acordo com a ABRELPE, os dados de 2003 permaneceram válidos para 2004. Apesar de ainda carecer de dados e informações, a nova versão trouxe algumas complementações, como os custos das principais tecnologias de tratamento de resíduos industriais disponíveis no Brasil (Tabela 4).

Tabela 4 - Custos das principais tecnologias de tratamento de resíduos industriais.

\begin{tabular}{ll}
\hline Tecnologia & Variação do custo $(\mathrm{R} \$ /$ ton $)$ \\
\hline Aterros industriais Classe I & $150,00-400,00$ \\
Aterros industriais Classe II & $50,00-100,00$ \\
Co-processamento & $200,00-500,00$ \\
Incineração & $1.200,00-3.000,00$
\end{tabular}

Fonte: ABRELPE (2004)

A partir dos dados de 2003, estimou-se que foram tratadas 3 milhões de toneladas de resíduos sólidos industriais. Ainda, levantou-se que no Brasil existem 7.924 locais de disposição inadequada de resíduos (lixões, aterros controlados, etc.) que recebem resíduos industriais (ABRELPE, 2004). Segundo a ABETRE, do total de resíduos gerados 
apenas 600 mil toneladas são dispostas de maneira adequada. Os mais de dois milhões de toneladas de resíduos que são dispostos inadequadamente em lixões representam futuras contaminações e agressões ao meio ambiente (LIXO..., 2002).

No Estado de São Paulo, segundo dados obtidos pela CETESB em 1997, são geradas 26.619.678 toneladas de resíduos por ano, excluindo-se bagaço de cana (24.794.000 t/ano), vinhoto (25.752.000 t/ano) e resíduo de mineração de rocha fosfática (5.400.000 t/ano). A Tabela 5 traz os dados de geração de resíduos por classes e destinação final.

Tabela 5 - Geração de resíduos sólidos industriais no Estado de São Paulo.

\begin{tabular}{l|c|c|c|c|c}
\hline \multicolumn{1}{c|}{ Resíduo } & \multicolumn{2}{c|}{ Geração } & Tratamento & Estocagem \\
& $(\mathrm{t} / \mathrm{ano})$ & $(\%)$ & $\begin{array}{c}\text { Disposição no Solo } \\
(\mathrm{t} / \mathrm{ano})\end{array}$ & $\begin{array}{c}\text { (t/ano) } \\
\text { (t/ano) }\end{array}$ \\
\hline Classe I & 535.615 & 2,01 & 286.930 & 164.520 & 84.165 \\
\hline Classe II & 25.038 .167 & 94,06 & 8.816 .065 & 571.314 & 15.650 .788 \\
\hline Classe III & 1.045 .896 & 3,93 & 352.463 & 103.988 & 589.455 \\
\hline Total & 26.619 .678 & 100 & 9.455 .458 & 839.822 & 16.324 .398 \\
\hline$\%$ & & & 35,52 & 3,15 & 61,32 \\
\hline
\end{tabular}

Fonte: Federação das Indústrias do Estado de São Paulo (2001).

Quanto à destinação final, predomina a disposição no solo $(61,32 \%)$, seguida por tratamento $(35,52 \%)$ e estocagem (3,15\%). Este padrão é determinado pelos resíduos Classe II, presentes em maior quantidade. A maior parte dos resíduos Classe I, cerca de $53 \%$, sofre algum tipo de tratamento (incineração, queima em fornos industriais ou caldeiras, reprocessamento ou reciclagem, tratamento biológico e outros, e a quantidade estocada (31\%), é maior que a quantidade disposta no solo (16\%) (FIESP, 2001).

No entanto, segundo Alves (1998), é pouco provável que 53\% dos resíduos Classe I gerados sejam tratados, como mostram os dados da CETESB, porque não existem tantas formas de tratamento disponíveis para tal, e portanto, parte destes resíduos podem estar sendo dispostos de forma inadequada.

De acordo com as conclusões do trabalho executado por Leão (1998), o mesmo acontece na Região Metropolitana de São Paulo (RMSP), onde a autora constatou não existirem instalações suficientes para a destinação de todos os tipos de resíduos produzidos pelas indústrias da região. Apesar da região ser considerada o maior parque 
industrial da América Latina, não existem aterros industriais para o recebimento de resíduos perigosos de terceiros, nem instalações de tratamentos físico-químicos.

A Tabela 6 mostra uma avaliação comparativa da destinação final dos resíduos perigosos na RMSP nos anos de 1989 e 1996, a partir de dados levantados pela CETESB nos respectivos anos.

Tabela 6 - Avaliação comparativa da destinação de resíduos perigosos na RMSP.

\begin{tabular}{ccccccccc}
\hline Ano & \multicolumn{2}{c}{ Geração } & \multicolumn{2}{c}{ Tratamento } & \multicolumn{2}{c}{ Estocagem } & \multicolumn{2}{c}{ Disposição Final } \\
\hline & t/ano & $\%$ & t/ano & $\%$ & t/ano & $\%$ & t/ano & $\%$ \\
1989 & 187.680 & 100 & 86.259 & 46 & 18.301 & 9,7 & 83.121 & 44,3 \\
1996 & 176.671 & 100 & 102.992 & 58,3 & 55.408 & 31,4 & 18.271 & 10,3
\end{tabular}

Fonte: Compilado de Leão (1998)

A diminuição da percentagem de resíduos dispostos em aterros, como mostram os dados da Tabela 6, deve-se ao aumento no tratamento e na estocagem dos resíduos em áreas dentro das próprias indústrias. Entretanto, segundo comentários da autora, existem indícios que parte destes resíduos pode estar sendo estocada ou tratada de maneira irregular ou ainda disposta ilegalmente em aterros municipais ou clandestinos.

A disposição irregular de resíduos no solo tem sido historicamente negligenciada, principalmente devido ao fato do aporte dos contaminantes no solo ocorrer de forma indireta, não deixando aparente o risco de contaminação. Hoje no mundo inteiro existem milhares de áreas contaminadas, e o custo para a remediação destas áreas é extremamente alto, e muitas vezes inviável economicamente.

Segundo dados levantados pela CETESB, até 2001 haviam sido detectadas cerca de 100 grandes áreas contaminadas por resíduos industriais no Estado de São Paulo, decorrentes da disposição inadequada de resíduos ao longo de décadas e da falta de punição às empresas poluidoras. Estas, em grande parte estrangeiras, ao se instalar no Brasil não adotaram as mesmas medidas de prevenção àpoluição que são obrigadas a adotar nos países de origem, gerando aqui grandes quantidades de resíduos que são dispostos sem as devidas precauções (ÁREAS CONTAMINADAS..., 2001). Em nova avaliação divulgada em 2004, foram detectadas cerca de 750 novas áreas contaminadas, e de acordo com estimativas da própria CETESB, o número real de áreas deve ser muito 
maior, principalmente se forem consideradas também as áreas contaminadas por vazamentos em postos de gasolina (RAMOS, 2004).

A Tabela 7 mostra as áreas contaminadas no Estado de São Paulo, de acordo com a região e a atividade.

Tabela 7 - Áreas Contaminadas no Estado de São Paulo.

\begin{tabular}{lllllll}
\hline Região/Atividade & Comercial & Industrial & Disposição & Postos Gas. & Outros & Total \\
\hline São Paulo & 19 & 28 & 14 & 250 & 1 & 312 \\
RMSP & 7 & 45 & 10 & 103 & 2 & 167 \\
Interior & 20 & 46 & 15 & 63 & 6 & 150 \\
Litoral & 1 & 19 & 11 & 44 & 4 & 79 \\
Vale do Paraíba & 1 & 14 & 0 & 4 & 0 & 19 \\
Total & $\mathbf{4 8}$ & $\mathbf{1 5 2}$ & $\mathbf{5 0}$ & $\mathbf{4 6 4}$ & $\mathbf{1 3}$ & $\mathbf{7 2 7}$
\end{tabular}

* Inclui contaminações por acidentes ferroviários, rodoviários, dutos e atividades de serviços.

Fonte: ABRELPE (2004).

Diante da situação aqui exposta, com base nos dados existentes (embora precários), nota-se que existe um grande trabalho a ser realizado no campo da gestão de resíduos sólidos industriais. Primeiramente é necessário o conhecimento da realidade, a partir da análise de dados mais consistentes a respeito das quantidades de resíduos geradas em todas as regiões do país, bem como o destino que vem sendo dado a estes resíduos. Só a partir disso é que será possível o delineamento de estratégias eficazes para o equacionamento do problema, que envolve a adoção de tecnologias de tratamento e disposição adequadas ao contexto de cada região.

Convém salientar que a existência de instalações adequadas para o armazenamento, tratamento e disposição final dos resíduos é fundamental para o bom desempenho de um sistema de gestão de resíduos. Apesar da tendência atual apontar para a redução dos resíduos na fonte, a partir da implementação de estratégias de prevenção àpoluição e produção mais limpa, estas não eliminarão a necessidade do tratamento e disposição final de resíduos a curto e médio prazos. 


\subsubsection{Regulamentos e Políticas Ambientais}

Segundo Almeida, Mello e Cavalcanti (2004, p. 136), as políticas ambientais são aquelas políticas que apresentam uma preocupação explícita quanto à proteção, conservação e uso dos recursos naturais e do meio ambiente. Essas políticas, expressas na legislação e na organização institucional correspondente, definem os instrumentos de intervenção do Estado na administração dos recursos e da qualidade do meio ambiente.

A gestão ambiental no Brasil tem se pautado exclusivamente pelo uso de regulação, isto é, por instrumentos de comando e controle. Na Política Nacional do Meio Ambiente estes instrumentos são classificados em quatro categorias: I) padrões ambientais (de qualidade e emissão); II) controle do uso do solo (zoneamento e unidades de conservação); c) licenciamento (estudo de impacto ambiental, planos de manejo); e, IV) penalidades (multas, compensações, etc) (MOTTA,1996).

Como resultado da participação do Brasil na Conferência de Estocolmo em 1972, foi criada a Secretaria Especial do Meio Ambiente (SEMA), a qual iniciou suas atividades em janeiro de 1974 inaugurando uma nova fase no tratamento das questões ambientais no país (SOARES, 2003, p. 47). A criação da SEMA serviu também como uma saída diplomática para suavizar a imagem negativa que o Brasil deixou na Conferência, ao deixar claro através da postura dos seus representantes, que para o país os cuidados com o meio ambiente representavam uma barreira ao desenvolvimento econômico e que a poluição era o resultado inevitável do desenvolvimento (ALMEIDA, MELLO e CAVALCANTI (2004, p. 140-141).

As primeiras leis ambientais brasileiras surgiram em resposta aos problemas decorrentes do período de industrialização intensa, principalmente a partir da década de 1970, como a Lei Federal № 5.357/67, que estabelece penalidades pela descarga de resíduos ou óleo em águas brasileiras, e a Lei Federal nº 6.803/80, que estabelece regras básicas para o zoneamento industrial em áreas com níveis de poluição críticos.

A Lei Federal no 6938 de 31/08/81, que instituiu a Política Nacional do Meio Ambiente, é na realidade a primeira Lei Federal a abordar o meio ambiente como um todo, abrangendo os diversos aspectos envolvidos e alcançando as várias formas de degradação ambiental, e não apenas a poluição causada pelas atividades industriais ou o uso dos recursos naturais. De acordo com esta Lei, poluição é a degradação da qualidade ambiental resultante das atividades que direta ou indiretamente: 
I) Prejudiquem a saúde, segurança e o bem-estar da população;

II) Criem condições adversas æ̇̀ atividades sociais e econômicas;

III) Afetem adversamente a biota;

IV) Afetem as condições estéticas ou sanitárias do meio ambiente; e,

V) Lancem matéria ou energia em desacordo com os padrões ambientais.

A legislação ambiental atual é sustentada pela Constituição Federal, promulgada em 05 de outubro de 1988, sendo a primeira constituição brasileira a abordar amplamente a questão do meio ambiente, dedicando um capítulo inteiro àproteção ambiental. $\mathrm{O}$ artigo 255, que trata especificamente do Meio Ambiente ressalta o seguinte texto:

"Todos têm direito ao meio ambiente ecologicamente equilibrado, bem de uso do povo e essencial à sadia qualidade de vida, impondo-se ao Poder Público e à coletividade o dever de defendê-lo e preservá-lo para as presentes e futuras gerações."

A grande maioria dos estados brasileiros abriga dentro de suas constituições ampla legislação ambiental, que segue basicamente os mesmos preceitos da legislação federal. Da mesma maneira, a maioria dos municípios introduziu, em suas Leis Orgânicas reformuladas após a promulgação da Constituição Federal de 1988, artigos voltados para a preservação do meio ambiente. Os principais instrumentos legais relativos ao controle da poluição ambiental, aplicados às atividades industriais em geral, encontram-se resumidos no Quadro 1. 
Quadro 1 - Principais instrumentos legais aplicados às atividades industriais.

\begin{tabular}{|c|c|}
\hline \multicolumn{2}{|r|}{ Poluição das Águas } \\
\hline $\begin{array}{l}\text { Lei Federal no } 9433 \\
08 / 01 / 97\end{array}$ & $\begin{array}{l}\text { Instituiu a Política Nacional dos Recursos Hídricos e criou o Sistema } \\
\text { Nacional de Gerenciamento de Recursos Hídricos. } \\
\text { Prevê a fixação de valores para o uso dos recursos hídricos de acordo com } \\
\text { o volume retirado e o volume e características físico-químicas, biológicas e } \\
\text { de toxicidade do efluente lançado. }\end{array}$ \\
\hline $\begin{array}{l}\text { Resolução CONAMA } \\
\text { no } 357 \text { - 17/03/05 }\end{array}$ & $\begin{array}{l}\text { Substitui a Resolução no } 20 \text {, de 08/06/86 e classifica as águas de todo o } \\
\text { Território Nacional em cinco classes: especial, 1, 2, 3,e 4, de acordo com a } \\
\text { qualidade. Para cada uma dessas classes são estabelecidos limites ou } \\
\text { condições para o lançamento de efluentes. }\end{array}$ \\
\hline $\begin{array}{l}\text { Portaria MINTER } \mathrm{n}^{0} \\
124-20 / 08 / 80\end{array}$ & $\begin{array}{l}\text { Estabelece em } 200 \text { metros a distância mínima de corpos hídricos para o } \\
\text { armazenamento de produtos químicos. }\end{array}$ \\
\hline \multicolumn{2}{|r|}{ Poluição do Ar } \\
\hline $\begin{array}{l}\text { Portaria IBAMA nº } 85 \\
17 / 10 / 96\end{array}$ & $\begin{array}{l}\text { Dispõe sobre o Programa Interno de Auto fiscalização da Manutenção da } \\
\text { Frota de Veículos quanto à emissão de fumaça preta a toda empresa que } \\
\text { possuir frota própria de transporte de carga ou de passageiros. }\end{array}$ \\
\hline $\begin{array}{l}\text { Resolução CONAMA } \\
\text { no } 03-28 / 06 / 90\end{array}$ & $\begin{array}{l}\text { Estabelece os Padrões Nacionais de Qualidade do Ar. Define os padrões } \\
\text { primários e secundários de qualidade do ar para partículas totais em } \\
\text { suspensão, fumaça, partículas inaláveis, dióxido de enxofre, monóxido de } \\
\text { carbono, ozônio e dióxido de nitrogênio. }\end{array}$ \\
\hline $\begin{array}{l}\text { Resolução CONAMA } \\
\text { no } 08 \text { - 06/12/90 }\end{array}$ & $\begin{array}{l}\text { Estabelece a nível nacional, os limites máximos de emissão de poluentes } \\
\text { no ar para processos de combustão externa em novas fontes fixas } \\
\text { (caldeiras, geradores de vapor, fornos, estufas, etc.). }\end{array}$ \\
\hline \multicolumn{2}{|r|}{ Resíduos Sólidos } \\
\hline $\begin{array}{l}\text { Resolução CONAMA } \\
\text { no } 06-15 / 06 / 88\end{array}$ & $\begin{array}{l}\text { Cria o inventário para o controle de estoques e/ou destino final de resíduos } \\
\text { industriais, agrotóxicos e PCB's (bifenilas policloradas). } \\
\text { Estabelece que indústrias geradoras de resíduos com mais de quinhentos } \\
\text { funcionários e/ou que possuam sistemas de tratamento de efluentes devem } \\
\text { apresentar ao órgão ambiental competente informações sobre a geração, } \\
\text { características e destino final de seus resíduos. }\end{array}$ \\
\hline
\end{tabular}


Quadro 1 - Principais instrumentos legais aplicados à atividades industriais (continuação)

\begin{tabular}{|ll|}
\hline $\begin{array}{l}\text { Resolução CONAMA } \\
\text { no 13-13/12/95. }\end{array}$ & $\begin{array}{l}\text { Determina que todo óleo lubrificante usado ou contaminado deve } \\
\text { obrigatoriamente ser recolhido e destinado adequadamente, de forma a não } \\
\text { afetar negativamente o meio ambiente e dá outras providências. }\end{array}$ \\
\hline $\begin{array}{l}\text { Resolução CONAMA } \\
\text { no 257 de 30/06/99. }\end{array}$ & $\begin{array}{l}\text { Dispõe sobre o uso de pilhas e baterias que contenham em sua composição } \\
\text { eletro-eletrônicos que as contenham integradas em suas estruturas e dá } \\
\text { outras providências. }\end{array}$ \\
\hline $\begin{array}{l}\text { Resolução CONAMA } \\
\text { no 258-26/08/99. }\end{array}$ & $\begin{array}{l}\text { Obriga as empresas fabricantes e as importadoras de pneumáticos a coletar } \\
\text { na proporção definida na Resolução relativamente às quantidades } \\
\text { fabricadas e/ou importadas. }\end{array}$
\end{tabular}

Resolução CONAMA Dispõe sobre o Inventário Nacional de Resíduos Sólidos Industriais. ํo 313-29/10/02. Estabelece critérios para a realização de inventários estaduais de resíduos industriais e deu o prazo até outubro de 2004 para que os órgãos ambientais estaduais encaminhassem seus inventários ao IBAMA.

\section{Poluição Sonora}

Resolução CONAMA Estabelecem as Normas a serem obedecidas no interesse da saúde, no no 01 e 02 - 08/03/90 tocante à emissão de ruídos em decorrência de quaisquer atividades.

\section{Requisitos Ambientais de Caráter Geral}

Decretos 1.413 de Definem medidas de prevenção e controle da poluição industrial. Autorizam 14/08/1975 e 76.389 a criação de sistemas de licenciamento nos estados e municípios para a de 03/10/1975 instalação e o funcionamento das atividades industriais potencialmente poluidoras. Têm seu foco na adoção de normas anti-poluição e do estabelecimento de regras de localização industrial nas regiões densamente urbanizadas.

Resolução CONAMA Estabelece as responsabilidades, os critérios básicos e as diretrizes gerais no 01 - 23/01/86 para o uso e implementação da Avaliação de Impacto Ambiental como um dos instrumentos da Política Nacional do Meio ambiente.

Resolução CONAMA Dispõe sobre o cadastramento junto ao IBAMA das empresas que no $13-13 / 12 / 95 \quad$ produzem, importam, exportam, comercializam ou utilizam substâncias controladas conforme estabelecido no Protocolo de Montreal. 
Quadro 1 - Principais instrumentos legais aplicados à atividades industriais (continuação) Portaria Normativa Dispõe sobre a obrigatoriedade de registro no Cadastro Técnico Federal de no $113-25 / 09 / 97$ Atividades Potencialmente Poluidoras ou Utilizadoras de Recursos Ambientais, as pessoas físicas ou jurídicas que se dedicam a atividades potencialmente poluidoras e/ou extração, produção, transporte e comercialização de produtos potencialmente perigosos ao meio ambiente, assim como de minerais, produtos e sub-produtos da fauna, flora e pesca.

Resolução CONAMA Dispõe sobre os procedimentos e critérios utilizados no Licenciamento n $0237-19 / 12 / 97 \quad$ Ambiental. Prevê que os empreendimentos e atividades devem ser licenciados em um único nível de competência (federal, estadual ou municipal), e que devem ser estabelecidos critérios para agilizar e simplificar os procedimentos de licenciamento das atividades que implementem planos e programas voluntários de gestão ambiental.

Lei Federal no 9605 Dispõe sobre as sanções penais e administrativas derivadas de condutas e $12 / 02 / 98$ atividades lesivas ao meio ambiente. A partir dessa Lei, a pessoa jurídica, autora ou co-autora da infração ambiental pode ser penalizada, levando

"Lei de Crimes

Ambientais" inclusive ao fechamento da empresa. Por outro lado, a punição pode ser extinta quando houver a comprovação da recuperação do dano ambiental.

Apesar de ser considerada bastante avançada e rigorosa, a legislação ambiental vigente apresenta deficiências no tocante aos resíduos sólidos e saneamento. Até o presente não existe uma lei específica, em nível nacional que trate de maneira consistente estes assuntos. Os projetos das Políticas Nacional de Resíduos Sólidos e de Saneamento tramitaram no Congresso há anos, sem avanços e sem um consenso para o estabelecimento destas leis. O projeto atualmente em discussão pretende unificar todas as políticas de saneamento ambiental em uma única Política Nacional de Saneamento. As regulamentações em cada área serão posteriormente separadas. No caso do saneamento, não há consenso no que se refere àdisputa entre municípios e empresas estaduais de saneamento sobre a titularidade da concessão e não se consegue definir como serão financiadas as redes coletoras de esgotos nas áreas de baixa renda. No tocante aos resíduos sólidos, o principal entrave está na recusa das empresas do setor de embalagens (plásticos, alumínio, papelão e papel) em assumir a responsabilidade pósconsumo dos resíduos produzidos (NOVAES, 2003). 
Enquanto a responsabilidade pós-consumo não for institucionalizada através de uma política nacional, associada ao processo de conscientização da sociedade no sentido de gerar menos resíduos em todos os níveis, o país continuará a enfrentar dificuldades para resolver o problema (RECICLANDO..., 2003). A Pesquisa Nacional de Saneamento Básico realizada pelo IBGE constatou que $68,5 \%$ dos resíduos sólidos das grandes cidades são jogados em lixões e alagados (PAÍS SUJO..., 2002). Se cada fabricante ao colocar seu produto no mercado se responsabilizar pelo destino final deste produto após o término de sua vida útil, bem como pelas embalagens, com certeza o volume de resíduos a ser coletado e disposto em aterros será em muito reduzido.

O grande problema é que na formulação das leis não são considerados os aspectos do ciclo de vida dos produtos. Os instrumentos legais se concentram no controle da poluição industrial, através do estabelecimento de padrões de emissão de poluentes, sem atentar para o que venha a ocorrer antes ou depois do processamento industrial. Como destaca Petillo (1997), a legislação pública de controle da poluição industrial acabou adquirindo um formato com base em padrões máximos de emissão, que indiretamente instaura o que se pode chamar de 'direito de poluir', levando à falsa noção de que o desenvolvimento econômico deva necessariamente resultar em poluição. Segundo Almeida, Mello e Cavalcanti (2004, p. 143), esta abordagem se caracteriza por uma negociação restrita entre as empresas privadas e os órgãos do Estado, negociação esta que se concentra nos meios técnicos do controle da poluição, sem um questionamento maior quanto ao modelo de industrialização, à localização industrial ou æ̀ tecnologias utilizadas.

Na prática este comportamento se reflete na postura das empresas especializadas no gerenciamento de resíduos, que tem seu foco principal no tratamento e na disposição adequada dos resíduos.

Este sistema resulta em um ônus para a sociedade, pois cabe ao Estado fiscalizar o cumprimento da lei, vistoriar equipamentos e instalações de tratamento, conceder licenças para o funcionamento de estações de tratamento, entre outras obrigações que consomem tempo, demandam mão de obra especializada e investimentos financeiros, e ainda acaba por inibir iniciativas no sentido de promover a redução e minimização dos resíduos, a partir da adoção de tecnologias mais limpas. Motta (1996) destaca que os órgãos ambientais vêm enfrentando problemas na utilização plena dos instrumentos de 
comando e controle, que se resumem na escassez de recursos financeiros e econômicos e na fraca integração inter e intragovernamental.

A ação de controle volta-se prioritariamente para o problema da poluição industrial que se manifesta a curto prazo e que afeta áreas limitadas, em especial nas regiões metropolitanas, onde a população afetada pelo problema dispõe de alguns meios de pressão política. Os efeitos a longo prazo entretanto são relegados a um segundo plano, mesmo sendo irreversíveis ou de grandes dimensões. Do mesmo modo, as regiões menos povoadas são excluídas do campo de intervenção (ALMEIDA, MELLO E CAVALCANTI, 2004). O ideal seria que as políticas ambientais e ações visassem o desenvolvimento sustentável também das áreas mais pobres, de modo a preservar o meio ambiente daquelas regiões. A incorporação dos conceitos de ciclo de vida e de prevenção àpoluição nas políticas ambientais representaria um grande avanço, pois só assim as indústrias potencialmente poluidoras seriam forçadas a adotar tecnologias mais limpas e quem sabe chegar ao patamar da real conscientização ambiental, diminuindo deste modo o encargo do Estado em fiscalizar instalações de tratamento.

Segundo relatório da UNEP, que faz uma avaliação das práticas de Produção mais Limpa nos países da América Latina e Caribe, no Brasil, apesar de existirem iniciativas e preocupação do governo em relação à adoção de práticas de prevenção à poluição, existem poucas políticas realmente direcionadas ao assunto. Em alguns estados, a prevenção à poluição é uma questão que já está sendo incorporada na formulação de políticas ambientais e em ações por parte do poder público. No estado de São Paulo o conceito de prevenção à poluição tem sido considerado na reformulação da Política Ambiental do Estado, bem como em aspectos estratégicos e organizacionais da CETESB, de forma a integrar a prevenção à poluição nas atividades de controle da poluição e licenciamento. Em Minas Gerais foi criada no estado a Secretaria de Desenvolvimento Ambiental Sustentável, especialmente designada para desenvolver e divulgar práticas de prevenção à poluição. No Paraná têm sido priorizadas medidas para evitar a geração de efluentes e resíduos. As diretrizes para o licenciamento de atividades no estado estão baseadas no conceito da melhor tecnologia disponível para a prevenção de resíduos e no controle da poluição, o que tem forçado as industrias a adotar medidas internas para a minimização de resíduos (UNEP, 2002a). 


\subsubsection{Normas Internacionais Relacionadas àPoluição Industrial ${ }^{11}$}

As primeiras normas internacionais de proteção do meio ambiente referentes a poluição de origem industrial surgiram da atuação da Organização Internacional do Trabalho (OIT), como a Convenção Relativa à Proteção aos Trabalhadores contra Radiações lonizantes, adotada na OIT em 1960 e no Brasil promulgada em janeiro de 1968 e a Convenção sobre a Proteção dos Trabalhadores contra Riscos Profissionais devidos à Contaminação do Ar, ao Ruído e às Vibrações no Local de Trabalho, adotada na OIT em 1977 e no Brasil em 1986.

Sobre o tema de controle de produção, uso, estocagem e comercialização interna e/ou internacional de produtos químicos, resíduos de alta toxicidade ou mesmo que apresentem algum dano ao meio ambiente local, regional e global, foram promulgadas convenções internacionais das quais o Brasil é signatário ou está em vias de ser, dentre as quais se destacam:

> Convenção da Basiléia sobre Movimentos Transfronteiriços de Resíduos Perigosos e seu Depósito - Promulgada em 1989 na cidade de Basiléia na Suíça, consiste na exigência de que qualquer movimento transfronteiriço de resíduos perigosos seja realizado na condição de haver autoridades governamentais especialmente indicadas para legitimar aquele movimento, tanto nos países exportadores quanto nos importadores ou de trânsito, as quais deverão tomar conhecimento de tais movimentos e Ihes dar uma autorização expressa. Esta convenção surgiu em decorrência de escândalos internacionais envolvendo a exportação de grandes quantidades de resíduos perigosos por empresas européias, norte-americanas e japonesas a empresas da África, Ásia e América Latina. Foi promulgada no Brasil pelo Decreto no 875 de 19 de julho de 1993.

> Convenção de Roterdã sobre Procedimento de Consentimento Fundamentado Prévio, Aplicável a Certos Pesticidas e Produtos Químicos Perigosos Objeto de Comércio Internacional, assinada em Roterdã em 11 de setembro de 1999.

> Convenção de Estocolmo sobre Poluentes Orgânicos Persistentes, assinada em Estocolmo em 22 de maio de 2001.

Estas duas convenções foram subscritas pelo Brasil, sem entretanto ter havido até o momento a remessa de seus textos ao Congresso Nacional.

\footnotetext{
${ }^{11}$ As informações contidas neste tópico foram extraídas de SOARES (2003, p.116-151).
} 
Protocolo de Montreal sobre Substâncias que Destroem a Camada de Ozônio adotado em Montreal em 1987, e promulgado no Brasil pelo Decreto nº 99.280 de 6 de junho de 1990. Este protocolo propõe um cronograma para as reduções das emissões de CFC's, visando diminuir gradativamente o seu uso até a completa eliminação no ano 2000 para os países desenvolvidos e no ano 2010 para os países subdesenvolvidos. Em 1992, os países desenvolvidos, responsáveis por 67\% dos CFC's mundiais, reuniram-se em Copenhague onde ficou decidido que o fim da produção dos CFC's seria antecipada para 1996.

\subsection{Produção e Consumo Sustentáveis: as diversas abordagens existentes}

Os conceitos de produção e consumo sustentável surgiram como requisitos-chave para o desenvolvimento sustentável durante a Rio-92, onde governos e empresas foram convocados a implementar medidas para promover padrões de consumo e produção sustentáveis. Neste cenário, empresas, governos, comunidade e consumidores devem contribuir através da produção e uso eficiente dos recursos naturais, da minimização dos resíduos e da otimização dos produtos e serviços (WBCSD, 1995).

Independente dos esforços, regulações e incentivos dos governos para a viabilização do desenvolvimento sustentável, iniciou-se um movimento por parte das indústrias em favor das questões levantadas na Rio-92. Um fator significante para este movimento foi a criação, em 1990, do 'World Business Council for Sustainable Development' (WBCSD), um consórcio de mais de 100 empresas com sede em Genebra na Suíça, com o objetivo de desenvolver uma perspectiva global do desenvolvimento sustentável no meio industrial. O livro Changing Course ${ }^{12}$, lançado pelo WBCSD em 1992 é uma importante referência sobre os desafios e oportunidades da sustentabilidade corporativa (FIKSEL, 2002). Nesta publicação, o autor Stephan Schmidheiny introduziu o conceito de ecoeficiência como a força motora da excelência ambiental corporativa, e a partir de então o WBCSD tem publicado uma série de trabalhos e estudos que demonstram os benefícios da sustentabilidade nos negócios e agendas para a promoção das mudanças necessárias nos diversos setores industriais. A Figura 14 mostra uma síntese da sustentabilidade segundo o WBCSD, seus mecanismos e inter-relações temporais.

12 SCHMIDHEINY, S.; WBCSD (1992). Changing Course: A Global Business Perspective on Development and the Environment. MIT Press: Cambridge, MA. 


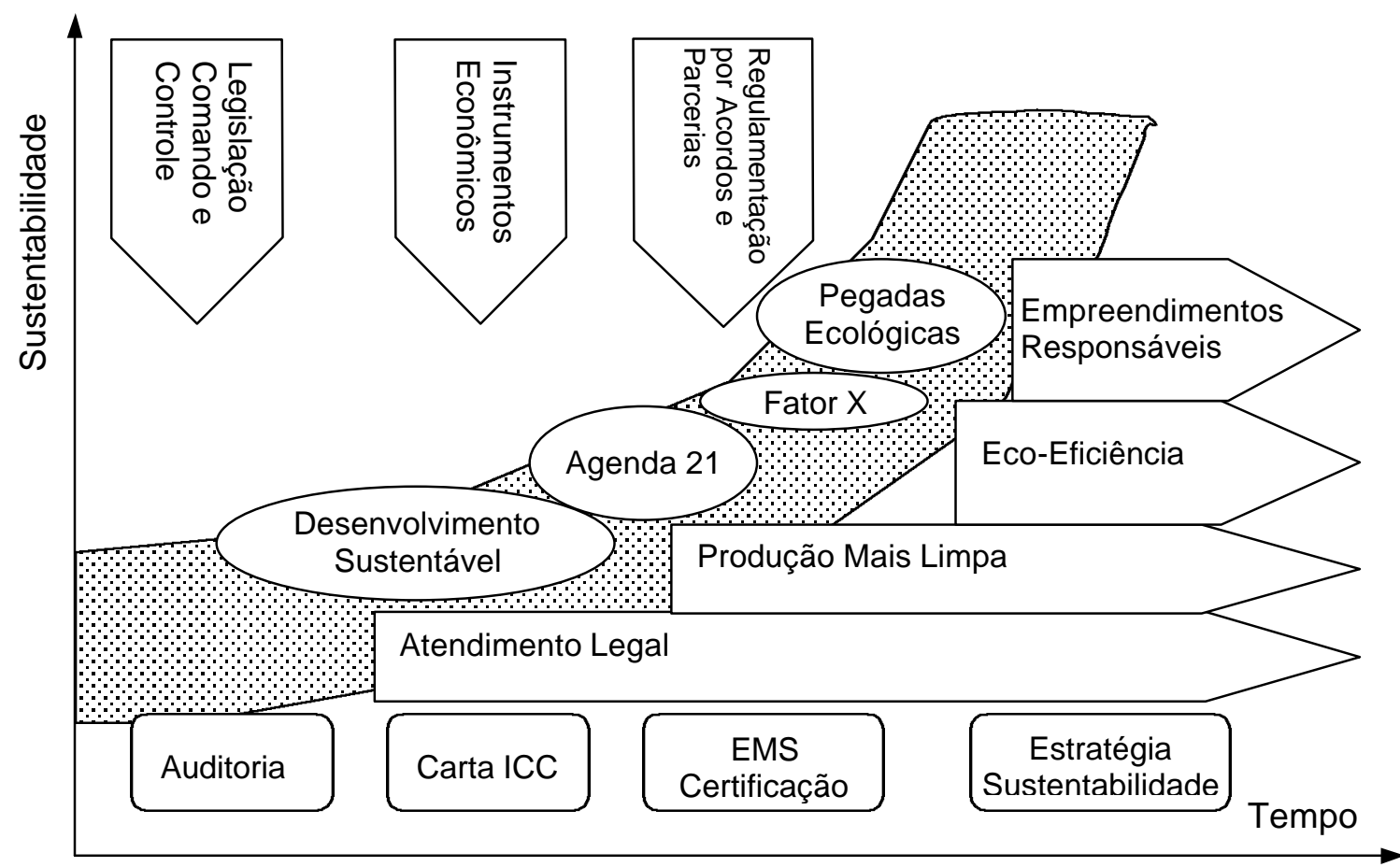

Figura 14 - Síntese da sustentabilidade segundo o WBCSD.

Fonte: Modificado de WBCSD (2000a)

Como mostram as setas horizontais na Figura 14, as companhias evoluíram da atenção focada apenas no atendimento legal, rumo às práticas pró-ativas de prevenção à poluição, através da produção mais limpa e da eco-eficiência, que estabelece uma ligação entre a qualidade ambiental e os benefícios econômicos, até alcançar o patamar do empreendedorismo responsável, através do qual o setor privado busca um balanço entre os três pilares da sustentabilidade (justiça social, prosperidade econômica e equilíbrio ecológico). Em busca deste equilíbrio sustentável, as empresas têm usado uma série de ferramentas para internalizar estes conceitos, como as auditorias ambientais, a Carta de Desenvolvimento Sustentável da Câmara Internacional do Comércio (ICC), e os sistemas de gestão ambiental (EMS). Paralelamente, a agenda política evolui da idéia inicial do Desenvolvimento Sustentável, que se tornou uma ação mais concreta com a Agenda 21, passando pelo conceito do Fator-X, que demanda a quantificação de metas para a melhoria da eco-eficiência e redução de impactos ao longo de toda a economia, até a noção das Pegadas Ecológicas, que fundamenta-se no fato de o espaço disponível para as atividades humanas ser limitado e portanto deve ser distribuído de maneira mais equitativa. Passada a fase da legislação comando e controle, os responsáveis pelas 
políticas têm introduzido incentivos econômicos e parcerias para complementar ou mesmo substituir sua dependência na legislação ambiental (WBCSD, 2000a).

Uma das grandes barreiras para a internalização do desenvolvimento sustentável é o amplo escopo e complexidade das questões a serem equacionadas, o que dificulta a tarefa dos tomadores de decisão, que precisam avaliar uma série de relações de causa e efeito que norteiam os benefícios ou impactos dos seus investimentos ou inovações tecnológicas. De forma a suplantar esta dificuldade, a indústria tem adotado princípios normativos, que geralmente levam a resultados positivos, apesar de não garantirem a ausência de problemas e desvantagens. Uma série de abordagens normativas têm surgido e evoluído ao longo da última década do século passado, como os princípios de engenharia reversa, prevenção àpoluição, gerenciamento para a qualidade total, ecologia industrial, entre outros, que fornecem diretrizes sistemáticas para a melhoria da performance ambiental de novos produtos e processos. Esta evolução foi acompanhada de perto pelo desenvolvimento de abordagens analíticas para a avaliação da performance ambiental de produtos e processos, dentre as quais a mais notória é a avaliação de ciclo de vida (FIKSEL, 2002).

Hoje podem ser encontrados na literatura especializada sobre gerenciamento ambiental, bem como nos debates sobre o assunto, uma infinidade de abordagens, termos, conceitos, estratégias e ferramentas para a avaliação de impactos ambientais de processos e produtos e implementação de estratégias preventivas. Alguns destes termos são intercambiáveis, outros podem diferir na definição, nos objetivos e no escopo e/ou na forma de alcançar os objetivos. Esta diversidade de termos e denominações pode levar ao uso e aplicação incorreta das abordagens, estratégias e ferramentas. No que se refere à definições e conceitos, são freqüentes na literatura discussões e divergências sobre os termos empregados (GEISER e OLDENBURG, 1997; DUNCAN, 1999; HILSON, 2003).

Como destaca Hilson (2003): "[...] Recentemente diversos conceitos foram criados para se referir aos vários aspectos do gerenciamento ambiental. Entretanto, a maioria destes termos são ambíguos, são mal interpretados e mal utilizados, ou são re-definidos com o passar do tempo, tornando difícil o entendimento correto do seu significado, e mais importante, a aplicação destas terminologias em diferentes setores da indústria vem se tornando um grande desafio [...]". Freeman et $\mathrm{al}^{13}$ (1992, apud HILSON, 2003) listam

13 FREEMAN et al (1992). Industrial Pollution Prevention: a critical review. Journal of the Air and Waste Management Association, v.42, n.5, p.618-656, apud HILSON (2003). 
várias terminologias referentes æ̇ políticas organizacionais, tecnologias e estratégias, freqüentemente encontradas na literatura (Quadro 2).

Quadro 2 - Terminologia encontrada na literatura do gerenciamento ambiental ${ }^{14}$.

\begin{tabular}{|ll|}
\hline \multicolumn{1}{|c|}{ Políticas Organizacionais } & \multicolumn{1}{c|}{ Tecnologias } \\
\hline Anticipate-and-prevent-strategy & New technologies \\
Avoidance strategy & Environmental technology \\
Front and resource management & Prevention aimed environmental technology \\
Waste prevention research & Process integrated environmental technology \\
Product management procedure & Apropriate technology \\
Preventive activities & Clean technologies \\
Humane chemistry & Cleaner technologies \\
Source reduction & Now-waste technology \\
Source control & Low and now-waste technology \\
\hline \multicolumn{1}{|c|}{ Resíduos e Poluição } & Low polluting technology \\
\hline Pollution prevention & Pollution control technology \\
Waste prevention & Add-on technology \\
Waste minimization & End-of-pipe technologies \\
Waste reduction & Recycling technologies \\
Pollution abatement, etc. & Cleaning-up technologies, etc. \\
\hline
\end{tabular}

Alguns dos termos apresentados no Quadro 2 tornaram-se mais notáveis que outros; e outros ainda surgiram e vêm sendo correntemente empregados. Os termos mais relevantes, referentes às práticas de gestão preventivas, bem como ferramentas importantes, foram agrupados e são apresentados nos tópicos a seguir, com o intuito de salientar suas diferenças e estabelecer um vínculo entre estas abordagens e o conceito de desenvolvimento sustentável.

\footnotetext{
${ }^{14}$ As terminologias apresentadas não foram traduzidas intencionalmente, para salientar a dificuldade da interpretação e contextualização destes termos.
} 


\subsubsection{Prevenção àPoluição e Redução na Fonte}

A Prevenção à Poluição, como prática de gerenciamento ambiental, surgiu no início dos anos 90, como um método alternativo para o controle da poluição através da redução da quantidade e da periculosidade dos resíduos lançados no meio ambiente. Freeman (1995), define prevenção àpoluição como o uso de tecnologias e estratégias de produção que resultem na eliminação ou na redução de resíduos.

A US EPA define Prevenção à Poluição como o uso de materiais, processos ou práticas que reduzam ou eliminem a geração de poluentes ou resíduos na fonte, além de reduzir o uso de materiais (ou substâncias) perigosos, água e outros recursos, protegendo os recursos naturais através da conservação e/ou uso mais eficiente (US EPA, 1992).

A redução na fonte é definida como qualquer prática que reduza a quantidade de substâncias perigosas, poluentes ou contaminantes nos fluxos de resíduos e que possam alcançar o meio ambiente, prioritariamente àreciclagem, tratamento e disposição; e que reduza os riscos à saúde pública e ao ambiente, associados com a descarga de substâncias, poluentes e contaminantes (US EPA, 2001).

No Canadá a Prevenção à Poluição é definida como o uso de processos, práticas, materiais, produtos, substâncias ou energia que evite ou minimize a criação de poluentes e resíduos, e reduza o risco ao ambiente e àsaúde humana (EC, 2001).

A prevenção àpoluição visa eliminar as causas fundamentais da poluição, em vez de tratar os sintomas, partindo do princípio que os poluentes e resíduos representam ineficiências no processo produtivo, e para isso, encoraja todos os tipos de mudanças que possam conduzir a uma redução nos custos de produção, aumento na eficiência de processos e na melhoria da proteção ambiental, como mostra a Figura 15. 


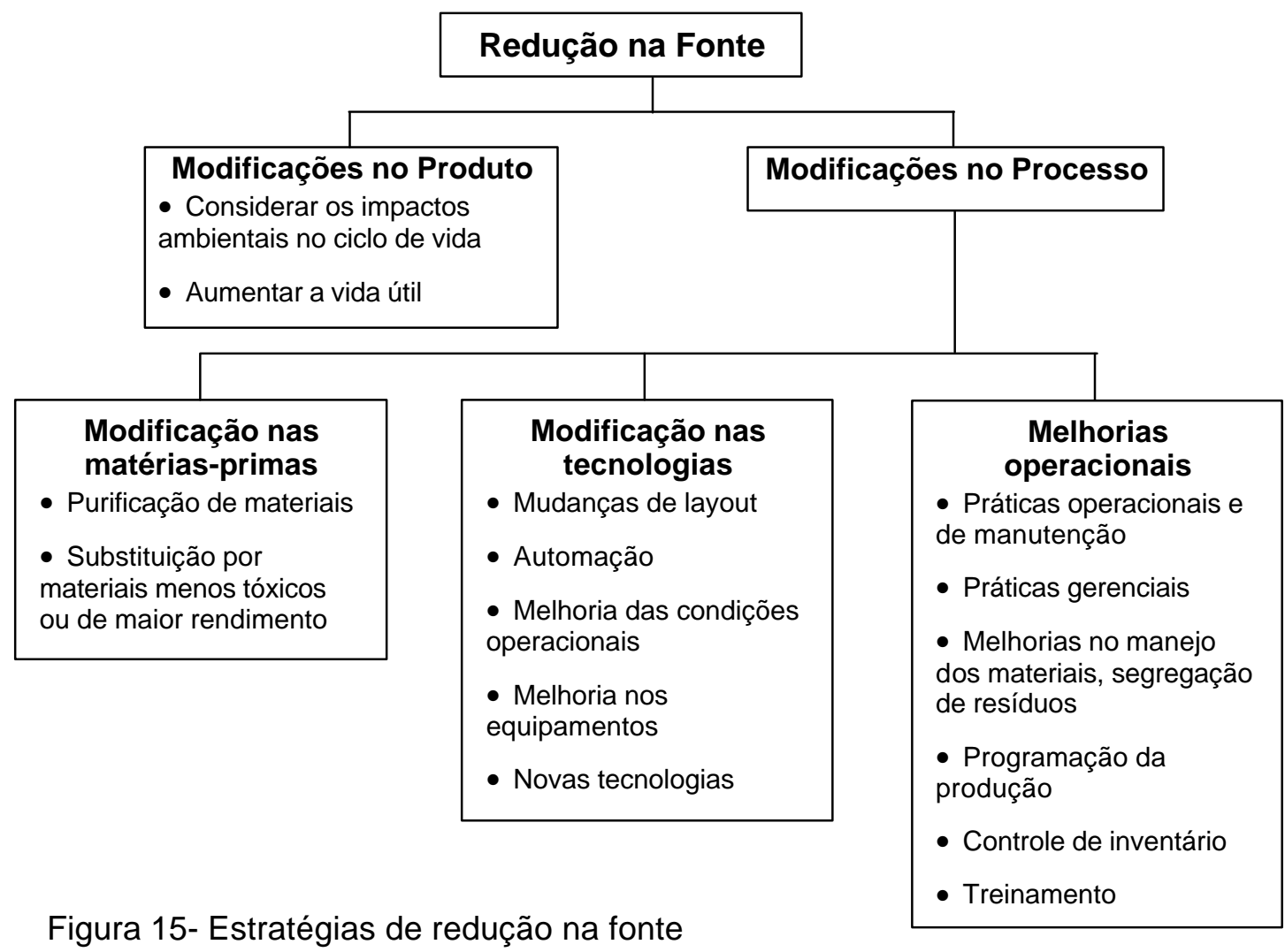

Fonte: Modificado de US EPA, 1992.

Além da redução na fonte, é considerada como estratégia de prevenção àpoluição o reúso e a reciclagem de materiais e resíduos no processo (EC, 2001). No entanto é importante ressaltar que o reúso no processo difere da abordagem tradicional, na qual o resíduo é gerado e encaminhado para outra planta para ser reprocessado e reutilizado para outro fim (Figura 16). A reciclagem e o reúso no processo representam uma importante alternativa de prevenção à poluição, e consistem em reciclar ou reutilizar os materiais no mesmo processo onde os resíduos são gerados (Figura 17).
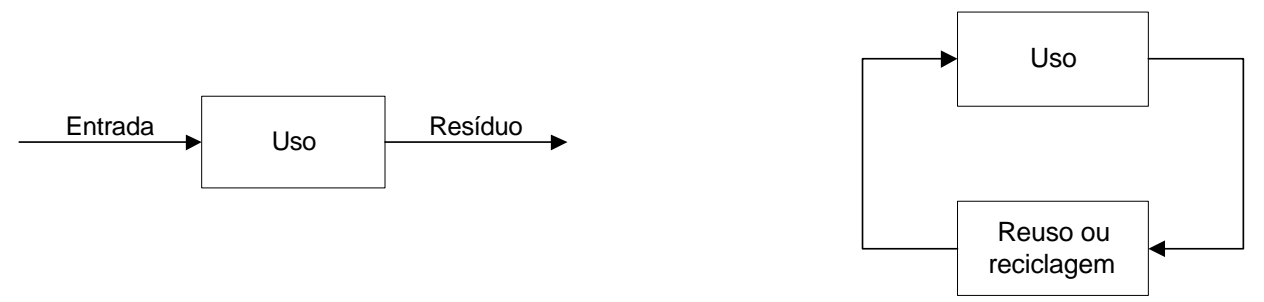

Figura 16 - Uso de recursos em sistema aberto Figura 17 - Uso de recursos em sistema fechado Fonte: KIRKWOOD e LONGLEY, 1995 
Em relação aos investimentos necessários para implementação, as estratégias de prevenção àpoluição se dividem em estratégias de custo elevado, de custo moderado e de baixo custo (Figura 18).

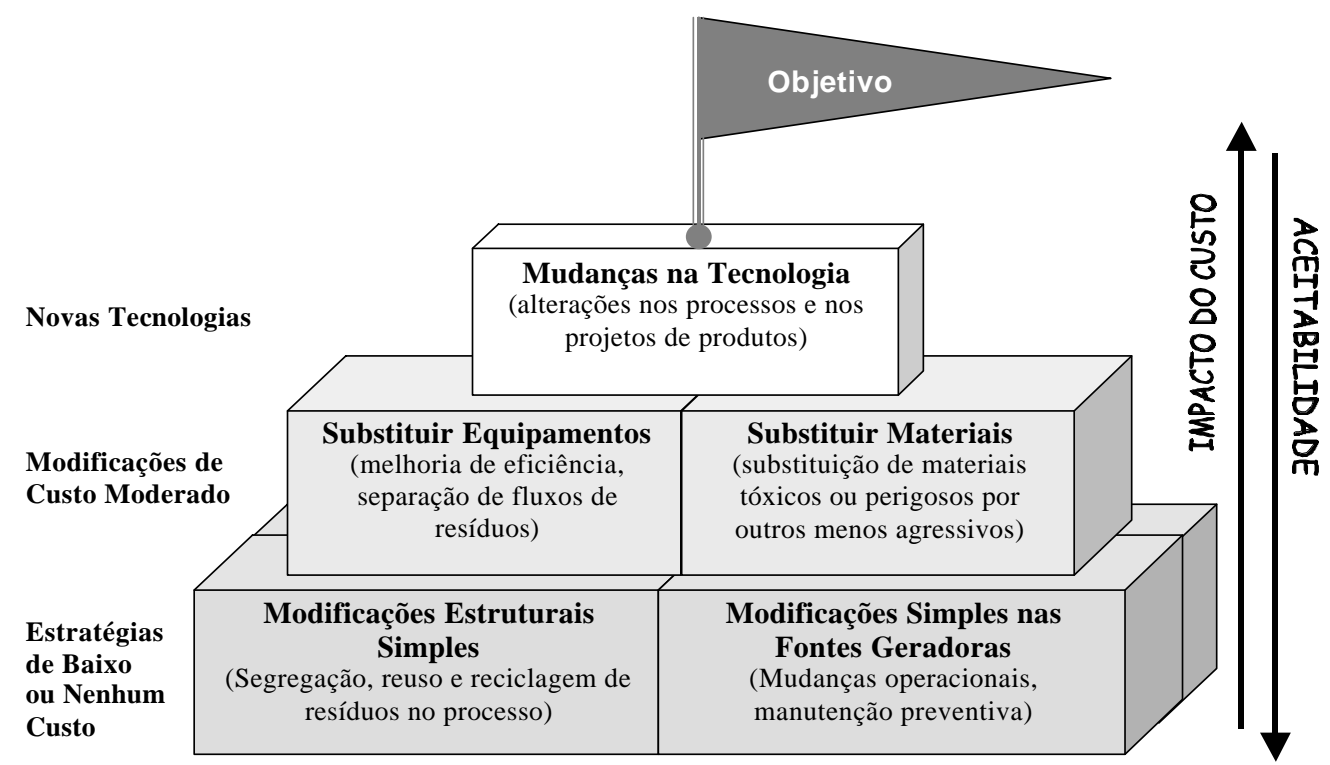

Figura 18 - Relação de aceitabilidade e custo das estratégias de prevenção à poluição

Fonte: NOURELDIN e EL-HAWAGI (1999)

A dimensão econômica pode ser estimada por uma variedade de critérios, tais como custo de capital, retorno de investimentos, e tempo de resposta. O impacto, neste caso, é uma medida da efetividade da solução proposta para reduzir danos ambientais decorrentes do processo, tais como redução de emissões e de efluentes na planta industrial. A aceitabilidade é uma medida da probabilidade de uma estratégia proposta ser aceita e implementada. Além dos custos, a aceitabilidade depende de outros fatores tais como cultura corporativa, credibilidade, segurança e operacionalidade (NOURELDIN e EL-HAWAGI, 1999). 


\subsubsection{Prevenção, Minimização e Redução de Resíduos}

O termo prevenção de resíduos é uma derivação do termo prevenção àpoluição, mais empregado no contexto do gerenciamento dos resíduos sólidos. A prevenção de resíduos envolve estratégias para promover o aumento da vida útil dos materiais, facilitar o reúso e a reciclagem, de modo a reduzir a toxicidade e o volume dos resíduos sólidos enviados a aterros, como resíduos de embalagens e outros materiais.

Segundo Crampton (1998), prevenção de resíduos é o mesmo que redução na fonte, mas não é o mesmo que prevenção à poluição, pois esta abordagem apresenta um escopo mais amplo, envolve aspectos relacionados ao consumo de água e energia, substituição de substâncias tóxicas nos diversos fluxos de materiais dentro de um processo produtivo, entre outros. Como destaca o autor, a prevenção de resíduos se baseia no modo como os materiais são utilizados, e as estratégias consistem em:

$>$ eliminar materiais desnecessários;

$>$ reduzir o peso ou espessura dos materiais;

$>$ aumentar a capacidade de embalagens e materiais;

> trocar materiais descartáveis por materiais não-descartáveis;

> considerar critérios de durabilidade ao adquirir materiais;

$>$ re-projetar materiais; e,

$>$ transformar resíduo em produto.

A prevenção de resíduos envolve ainda a co-responsabilidade entre o produtor e o consumidor, o que requer uma mudança de comportamento, que pode ser fomentada por parcerias entre o governo, autoridades locais, indústria, comércio, meios de comunicação e organizações comunitárias (COGGINS, 2001).

Como destaca Duncan (1999), no ciclo de vida de qualquer produto, tanto fabricantes quanto consumidores têm oportunidades de se engajar na redução dos resíduos na fonte. Esta participação pode envolver uma série de ações e atitudes que podem ser assumidas pela indústria e pelos consumidores, sumarizadas por Coggins (2001) e agrupadas no Quadro 3. 
Quadro 3 - Estratégias de prevenção de resíduos, envolvendo a participação da indústria e dos consumidores.

\begin{tabular}{|c|c|}
\hline Indústria & Consumidor \\
\hline $\begin{array}{l}\text { Disponibilizar produtos isentos de materiais } \\
\text { perigosos (ex: eliminar metais pesados da } \\
\text { composição de embalagens) }\end{array}$ & $\begin{array}{l}\text { Dispor os resíduos domésticos perigosos de } \\
\text { maneira correta e segura (ex: embalagens de } \\
\text { produtos químicos, baterias, etc) }\end{array}$ \\
\hline $\begin{array}{l}\text { Desenvolver produtos com materiais passíveis } \\
\text { de reúso e reciclagem e usar materiais } \\
\text { reciclados* }\end{array}$ & $\begin{array}{l}\text { Ao adquirir produtos dar preferência às } \\
\text { embalagens retornáveis ou recicláveis }\end{array}$ \\
\hline Diminuir o uso de compósitos nos produtos & Encaminhar materiais para a reciclagem \\
\hline Prolongar sua vida útil de materiais e produtos & Adquirir produtos de qualidade e duráveis \\
\hline Desenvolver produtos 'reparáveis' & Consertar equipamentos sempre que possível \\
\hline Disponibilizar produtos na forma de refil & Uitilizar produtos com embalagens multi-uso \\
\hline Reduzir peso e a quantidade de embalagens ${ }^{\star *}$ & Evitar o consumo desnecessário \\
\hline $\begin{array}{l}\text { Disponibilizar materiais reutilizáveis em vez dos } \\
\text { descartáveis }\end{array}$ & $\begin{array}{l}\text { Participar de programas de doação, como forma } \\
\text { de se desfazer de bens desnecessários }\end{array}$ \\
\hline
\end{tabular}

${ }^{*}$ Os produtos devem ser competitivos em termos de preço, qualidade, confiabilidade, durabilidade e aceitabilidade.

**Sem esquecer as funções da embalagem, de proteção do produto, segurança, saúde, informação sobre o produto, etc.

O termo minimização de resíduos foi bastante empregado nos Estados Unidos entre os anos de 1986 e 1989, para definir uma estratégia de redução dos resíduos na fonte. No entanto, como o termo não deixava clara a intenção de 'reduzir na fonte', o propósito do termo acabou sendo mal interpretado, o objetivo proposto não foi alcançado, e este termo foi substituído pelo termo prevenção àpoluição (THOMAS, 1995).

No atual estado-da-arte, o termo 'minimização de resíduos' compreende estratégias para reduzir a quantidade de resíduos a ser enviada para disposição em aterros, quando as alternativas de prevenção de resíduos são inviáveis técnica ou economicamente (HIGGINS, 1995), e significa o mesmo que 'redução de resíduos'.

A redução ou minimização de resíduos incorpora estratégias de reúso e reciclagem de materiais fora do processo, e outras técnicas, como a compostagem de materiais orgânicos. 


\subsubsection{Reutilização, Recuperação e Reciclagem Fora do Processo}

A reutilização, recuperação e reciclagem oferecem uma oportunidade de evitar a disposição dos resíduos que não possam ser prevenidos. No entanto, estas estratégias requerem a segregação dos materiais na fonte geradora e a definição de pontos de coleta e estocagem. Em um processo produtivo é grande a variedade de resíduos passíveis de reutilização, recuperação e reciclagem. Algumas estratégias propostas pela US EPA (1993), são a seguir sumarizadas:

> Reutilizar pellets de isopor, plásticos bolha, caixas de papelão e outros materiais usados para proteção de produtos, ou doar estes materiais a outras organizações;

$>$ Promover o retorno de embalagens (pallets, tambores, bombonas, etc), aos fornecedores para reutilização;

> Utilizar o papel usado picotado como material para proteger produtos na embalagem, em substituição àplástico bolha e pellets de isopor;

> Promover campanhas educativas entre os funcionários;

> Contactar empresas externas para a venda dos materiais;

> Promover campanhas de doação de materiais, que não possam ser comercializados, para instituições assistenciais;

> Participar de programas municipais de coleta de materiais;

> Participar de programas de troca de resíduos, as chamadas bolsas de resíduos, onde o material que é considerado resíduo para uma determinada empresa, pode servir como matéria-prima para outra.

A recuperação e a reciclagem dependem de alguns fatores, como a proximidade das instalações de processamento, custos de transporte dos resíduos, volume de resíduos produzidos disponíveis para processamento e custos de estocagem. Estas técnicas estão associadas ao preço de mercado, e se tornam uma alternativa interessante quando resultam em um produto mais barato e quando os custos com transporte e processamento são inferiores aos de tratamento e disposição final (US EPA, 1993).

\subsubsection{Compostagem}

A compostagem é uma técnica eficaz para reduzir a quantidade de material orgânico fácil ou moderadamente biodegradável a ser enviado para aterros. Esta técnica resulta em ganhos significativos principalmente quando esta classe de resíduos representa uma 
grande parcela do total de resíduos gerados em uma determinada indústria (US EPA, 1993). A compostagem é um processo biológico controlado (na maior parte dos casos aeróbio, mas que também pode ser anaeróbio) de transformação de resíduos orgânicos em adubo humidificado. Logo, como em qualquer outro processo biológico, deve-se levar em consideração os fatores que afetam a atividade dos microorganismos que transformam a matéria orgânica crua em matéria orgânica humidificada. Estes fatores envolvem os tipos de microorganismos usados, grau de umidade, níveis de oxigenação, temperatura, relação carbono/oxigênio, $\mathrm{pH}$ e tamanho das partículas de resíduos (BIDONE e POVINELLI, 1999; SCHALCH et al., 2000).

Do mesmo modo que na reciclagem, a segregação e o acondicionamento dos resíduos é um fator importante para que sejam alcançados os resultados esperados. $\mathrm{Na}$ segregação deve-se garantir que apenas os resíduos orgânicos sejam encaminhados para a compostagem, para que se obtenha um composto de boa qualidade (BIDONE e POVINELLI, 1999). O produto resultante da compostagem, denominado composto, é definido como sendo um adubo preparado com restos de animais e/ou vegetais. Estes resíduos, em estado natural, não têm nenhum valor agrícola. No entanto, após passarem pelo processo de compostagem, podem transformar-se em excelente adubo orgânico (SCHALCH et al., 2000). O composto pode ser usado na manutenção das áreas verdes da própria empresa, em substituição aos fertilizantes químicos quando adicionado a substratos, pode ser doado a funcionários e, se apresentar qualidade e for produzido em quantidades satisfatórias, pode ser comercializado (US EPA, 1993).

\subsubsection{Produção Limpa (Clean Production) e Produção mais Limpa (Cleaner Production)}

A expressão Produção Limpa foi proposta pela organização ambientalista nãogovernamental Greenpeace, para representar o sistema de produção industrial que levasse em conta:

$>$ a auto-sustentabilidade de fontes renováveis de matérias-primas;

$>$ a redução do consumo de água e energia;

> a prevenção da geração de resíduos tóxicos e perigosos na fonte de produção;

> a reutilização e o reaproveitamento de materiais de maneira atóxica e eficiente; 
$>$ a geração de produtos de vida útil longa, seguros e atóxicos, para o homem e o ambiente, cujos restos (inclusive as embalagens), tenham reaproveitamento atóxico e eficiente do ponto de vista energético.

Diversos princípios e critérios passaram fazer parte do conceito de Produção Limpa e a serem promovidos, em várias partes do mundo, especialmente nos países europeus, com atenção especial aos princípios da precaução, prevenção, integração, controle democrático, direito de acesso a informações sobre riscos e impactos de produtos e processos e responsabilidade continuada do produtor (FURTADO, 1997).

O termo Produção mais Limpa (cleaner production) foi desenvolvido pela UNEP em 1989, que o define como a aplicação contínua de uma estratégia ambiental preventiva, integrada e aplicada a processos, produtos e serviços. Incorpora o uso mais eficiente dos recursos naturais e, conseqüentemente minimiza a geração de resíduos e da poluição, bem como os riscos à saúde humana. Pode ser aplicada a processos, produtos e serviços, de forma a conservar matérias-primas e energia, eliminar o uso de materiais tóxicos, reduzir a quantidade e a toxicidade de todas as possíveis emissões e resíduos, reduzir os efeitos negativos do produto ao longo do seu ciclo de vida, e a planejar e executar serviços de maneira ambientalmente adequada (UNEP, 2003).

As diferenças entre os modelos de Produção Mais Limpa e Produção Limpa são pequenas. Segundo FURTADO et al. (1998), a maior abrangência dos princípios da Produção Limpa tornam este modelo mais relevante do ponto de vista ambiental, social e político. Entretanto, a proposta da UNEP foi adotada por diversos países, inclusive pelo Brasil. Atualmente os termos mais usados são produção mais limpa e prevenção à poluição, considerados pelos próprios criadores dos conceitos como idênticos nos seus princípios e propósitos (US EPA, 2001a; UNEP, 2003). Analogamente à prevenção à poluição, a produção mais limpa utiliza as mesmas estratégias (Figura 19).

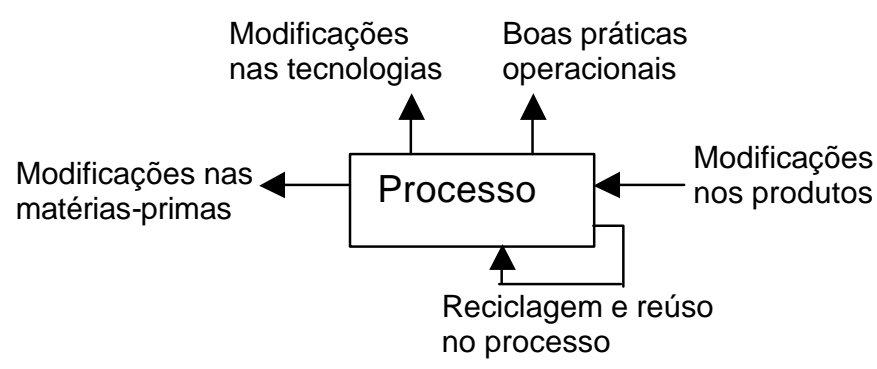

Figura 19 - Estratégias de produção mais limpa.

Fonte: Modificado de UNEP (2003). 
Independente da terminologia, estas abordagens dependem da disponibilidade de tecnologias para o alcance dos seus objetivos. Segundo Geiser (2002a), nos últimos dez anos uma série de tecnologias tem sido identificadas, algumas aplicáveis a um grande número de processos, enquanto outras se aplicam a processos específicos (Quadro 4). Quadro 4 - Tecnologias convencionais de produção mais limpa.

Tecnologias para a redução de resíduos
Envolvem diversas operações e melhorias nas tecnologias para reduzir vazamentos, acidentes,
contaminações, etc. Estas tecnologias podem variar desde soluções simples como coberturas de
tanques de processo para evitar volalilização de substâncias, até equipamentos de controle de
processo automatizados.
Tecnologias para a eficiência energética

Inclui a adoção de bombas e outros equipamentos mais eficientes, redução de atrito entre superfícies, transportadores, veículos e sistemas de aquecimento e resfriamento eficientes e com baixo consumo de energia.

\section{Tecnologias para a eficiência produtiva}

Estas tecnologias envolvem equipamentos de controle de processos químicos e físicos que permitem o monitoramento e o gerenciamento mais efetivo do processo.

\section{Tecnologias para materiais mais limpos}

Envolvem a substituição de substâncias tóxicas nos processos químicos e materiais, substituição de solventes orgânicos por solventes aquosos nos processos de limpeza, entre outras práticas.

\section{Tecnologias de reciclagem e reúso no processo}

Envolvem tecnologias de separação que permitem que os materiais sejam segregados, purificados ou tratados para posterior reciclagem ou reúso. Dentre estas tecnologias estão a destilação, a filtragem e a purificação.

\section{Produtos mais limpos}

Compreende a utilização de materiais que prolonguem a vida útil do produto, que conservem energia, que não sejam perigosos e não gerem resíduos ao longo do ciclo de vida do produto.

\section{Tecnologias para o gerenciamento limpo de produtos}

Tecnologias para facilitar a reciclagem, reúso e remanufatura dos materiais que compõem o produto.

Fonte: GEISER (2002a).

Muitas destas tecnologias já estão bem estabelecidas e têm mostrado resultados efetivos. Entretanto, como destaca o autor, os sistemas produtivos estão em constante modificação em função dos avanços da ciência e tecnologia, e estes avanços são fatores importantes na evolução da produção mais limpa. Embora deva-se em primeiro lugar buscar estratégias simples e que já estejam disponíveis e tenham sua eficiência 
comprovada, é importante que sejam buscadas novas tecnologias para a promoção da produção mais limpa. Novas áreas de avanço da tecnologia oferecem oportunidades para a melhoria da performance ambiental (Quadro 5).

Quadro 5 - Novas tecnologias com potencial aplicação na produção mais limpa.

\section{Tecnologias para a sustentabilidade energética}

Novas tecnologias permitem operar processos a temperatura e pressão ambiente, reduzindo a necessidade de aquecimento e resfriamento e aumentado as opções de fontes de energia renováveis. As energias fotovoltaica e eólica vem ganhando espaço, bem como células de hidrogênio.

\section{Tecnologias para processos químicos}

Inovações tecnológicas em processos e sínteses químicas envolvem novos tipos de catalisadores (não metálicos) e reagentes, processos utilizando fluidos supercríticos, novas rotas de reação com maior seletividade e processos sem geração de resíduos ('zero waste'), que trabalham em ciclo fechado de água e materiais, eliminando a geração de resíduos e a entrada de materiais.

\section{Tecnologias de informação}

Os avanços da tecnologia de informação fornecem novas oportunidades de monitoramento, medição, gerenciamento de dados e troca de experiências sobre novas tecnologias existentes, o que pode melhorar a performance das tecnologias de processo.

\section{Biotecnologias}

As ciências da vida fornecem várias novas oportunidades para o uso de materiais renováveis e para o bio-processamento e a biodegradação. Reações catalisadas por enzimas e processos microbiológicos oferecem novas rotas para sínteses de compostos químicos, particularmente para a produção de ácidos, bases e polímeros.

\section{Nanotecnologias}

Avanços recentes em nanotecnologias de larga escala oferecem oportunidades de processos mais seletivos, refinados e específicos, com grande potencial de não geração de resíduos.

Fonte: GEISER (2002a).

As tecnologias acima oferecem oportunidades para melhorar a performance ambiental de processos produtivos, entretanto, é importante ressaltar que essas tecnologias não foram desenvolvidas com o objetivo específico de promover a melhoria ambiental e portanto, podem representar riscos para o meio ambiente (GEISER, 2002a). 


\subsubsection{Química Verde}

O termo química verde, também encontrado na literatura como 'química sustentável' (GEISER, 2002a), refere-se àutilização de princípios que reduzam ou eliminem a geração de substâncias tóxicas nos processos químicos (ANASTAS e LANKEY, 2002). Um produto químico pode ser obtido por meio de diferentes caminhos, e as matérias-primas, os solventes, as rotas e as condições de reação utilizadas podem representar um impacto significativo na performance ambiental do processo. Idealmente, uma reação química deve ser simples, segura, seletiva, eficiente no consumo de energia e matérias-primas e na medida do possível usar materiais e reagentes renováveis e recicláveis (ALLEN e SHONNARD, 2002). O Quadro 6 sumariza os critérios ecológicos que podem ser adotados no design de produtos químicos.

Quadro 6 - Critérios ecológicos para o design de produtos químicos.

\begin{tabular}{|clc|}
\hline Categoria & \multicolumn{1}{c|}{ Princípios } & Características desejáveis \\
\hline Matérias-primas & A síntese de uma substância química tem As matérias-primas devem ser \\
início na escolha dos reagentes, fator inócuas, eficientes, seletivas e \\
determinante no impacto que o processo gerar poucos resíduos
\end{tabular}

Fonte: Construída com base em informações obtidas em (ALLEN e SHONNARD, 2002).

É importante salientar que o termo química verde (green chemistry) não tem o mesmo significado que o termo produtividade verde (green productivity), que é o termo usado pela Confederação Asiática das Indústrias (Asian Productivity Organization - APO) para se referir às práticas de produção sustentáveis, tais como aquelas definidas no escopo da produção mais limpa e da prevenção àpoluição (UNEP, 2002b). 


\subsubsection{Eco-Eficiência}

O termo Eco-eficiência foi usado pela primeira vez pelo WBCSD em 1991 e lançado mundialmente em 1992 através da publicação do livro Changing Course, escrito pelo industrial suíço Stephan Schmidheiny, onde uma companhia eco-eficiente é definida como sendo aquela que é capaz de desenvolver produtos e serviços cada vez mais eficientes. Em outras palavras, uma empresa eco-eficiente é capaz de criar mais valores e reduzir de forma contínua o consumo de recursos e a poluição gerada.

No primeiro workshop sobre eco-eficiência, realizado pelo WBCSD em 1993, os participantes chegaram a um consenso e partir de então, a eco-eficiência passou a ser definida como a produção de bens e serviços economicamente competitivos que satisfaçam as necessidades da sociedade e promovam a melhoria da qualidade de vida, e ao mesmo tempo reduzam os impactos ecológicos e o consumo de recursos no ciclo de vida destes produtos e serviços, a um nível no mínimo compatível com a capacidade de suporte da terra (WBCSD, 2000a).

A OECD considera a eco-eficiência como a eficiência ecológica com a qual os recursos ecológicos são utilizados para alcançar as necessidades da humanidade, e define a eco-eficiência como sendo a razão entre uma saída (o valor dos produtos e serviços produzidos por uma firma, setor ou economia como um todo) pela soma das pressões ambientais geradas pela firma, setor ou economia. Através da OECD, do Conselho para o Desenvolvimento Sustentável dos Estados Unidos e da Comissão Européia e outras instituições governamentais, a eco-eficiência tem se estabelecido como um conceito norteador das políticas em um nível macro nos países industrializados, bem como para as economias em desenvolvimento e em transição (WBCSD, 2000a).

Pode-se dizer que a eco-eficiência é um princípio normativo amplo, que, como destaca o WBCSD, não é uma solução para todos os problemas, nem uma regra rígida ou um sistema de gestão ambiental ou uma norma certificável, e nem uma garantia contra danos ambientais. A eco-eficiência é um conceito-chave que visa ajudar empresas, indivíduos, governos e outras instituições a se tornarem mais sustentáveis, seguindo sete elementos básicos:

> Reduzir o consumo de materiais em produtos e serviços;

> Reduzir o consumo de energia em produtos e serviços;

$>$ Reduzir a dispersão de substâncias tóxicas; 
$>$ Promover a reciclagem;

$>$ Maximizar o uso de recursos renováveis;

Prolongar a vida útil dos produtos; e,

$>$ Aumentar a intensidade do uso de produtos e serviços.

Para se colocar em prática as sete dimensões na qual a eco-eficiência se apóia, podem ser usados diversos princípios e ferramentas, como a produção mais limpa, prevenção àpoluição, design ecológico, entre outros. Por exemplo, Piotto (2003), em seu trabalho considera a produção mais limpa e a prevenção àpoluição, a análise de ciclo de vida, o ecodesign, a contabilidade ambiental, os indicadores de eco-eficiência e de desempenho ambiental, os relatórios de desempenho ambiental e os sistemas de gestão ambiental, todos como sendo ferramentas para promover a eco-eficiência.

\subsubsection{Ecologia e Metabolismo Industrial}

O conceito de Metabolismo Industrial foi criado por Robert Ayres em 1988, que o define como o conjunto integrado de todos os processos físicos que convertem matériaprima, energia e trabalho em produtos acabados (AYRES ${ }^{15}, 1994$ apud ANDERBERG, 1998). Através da análise dos fluxos de massa e energia podem ser identificadas ineficiências nos produtos e processos que resultem em resíduos e poluição, bem como podem ser identificadas formas de reduzí-los. Com base no conceito de metabolismo industrial, Robert Frosch e Nicholas Gallopoulos ${ }^{16}$ (1989 apud GARNER e KEOLEIAN, 1995), criaram o termo ecossistema industrial, que deu origem em seguida ao termo Ecologia Industrial. Os autores propõe uma analogia entre os ecossistemas biológicos e os sistemas industriais: "[...] em um ecossistema biológico alguns organismos usam luz solar, água, e minerais para crescer, enquanto outros organismos consomem os primeiros, vivos ou mortos, e produzem resíduos. Estes resíduos servem de alimento para outros organismos, e alguns destes organismos podem converter os resíduos em minerais usados pelos produtores primários, em uma rede de processos complexa na qual tudo o que é produzido é usado por algum organismo para seu próprio metabolismo. Analogamente, em um ecossistema industrial, o resíduo produzido por uma companhia

\footnotetext{
15 AYRES, R.U. (1994). Industrial Metabolism: Theory and policy. In: Ayres, R.U., Simonis, U.K. (Eds.). Industrial Metabolism: Restructuring for Sustainable Development. United Nations University Press, Tokyo apud ANDERGERG (1998).

${ }_{16}$ FROSH, R., GALLOPOULOS, N. (1989). Strategies for Manufacturing. Scientific American, v.261, p.144-152 apud GARNER E KEOLEIAN (1995).
} 
deve ser usado como recurso material por outra companhia, de modo que nenhum resíduo deixe o sistema industrial ou cause impacto negativo nos sistemas naturais, formando um ecossistema industrial fechado, que consome recursos limitados e produz quantidades mínimas de resíduos [...]". A Figura 20 mostra este modelo de ecossistema industrial.

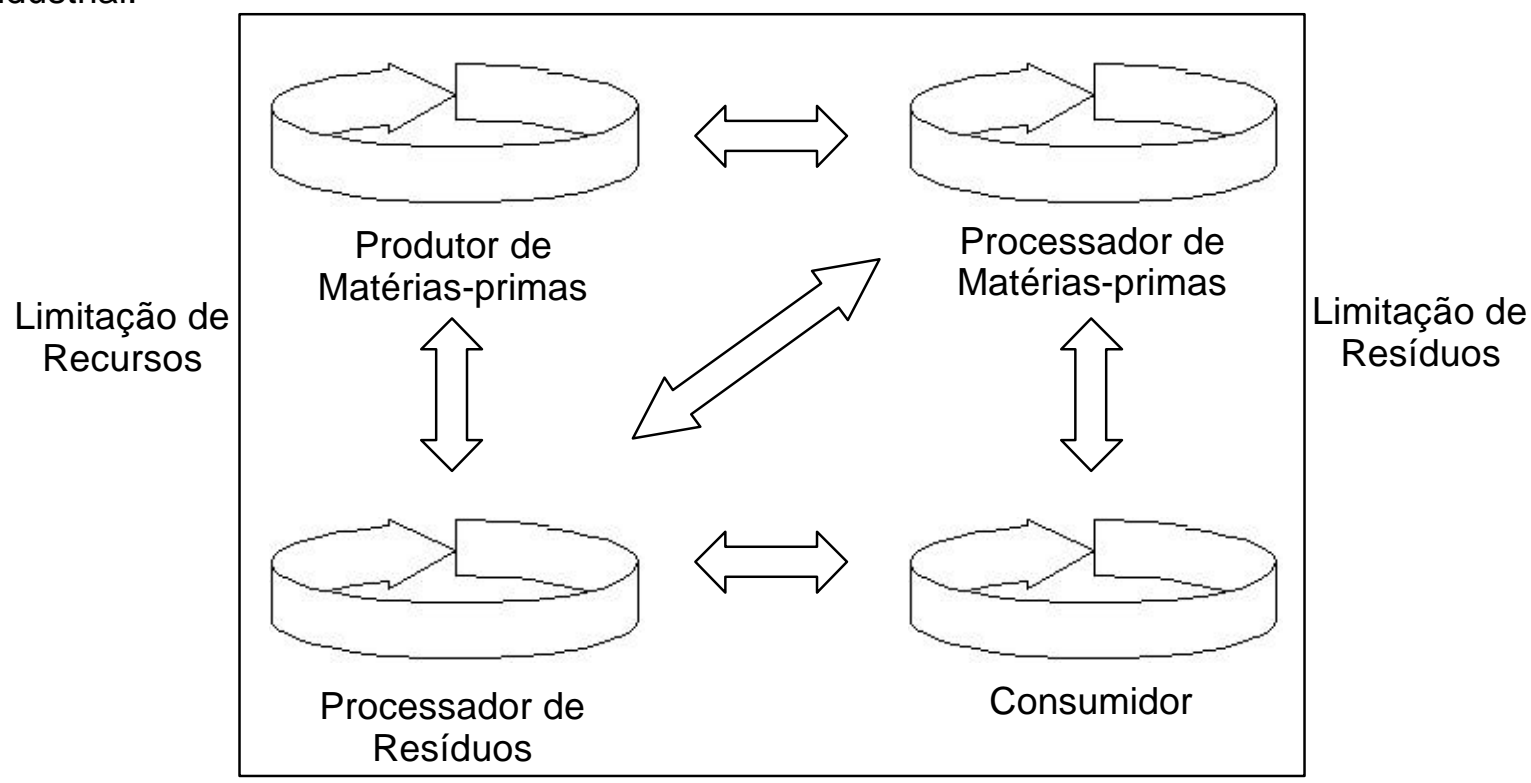

Figura 20 - Modelo de ecossistema industrial

Fonte: Modificado de JELINSKI et al. (1992)

$\mathrm{Na}$ prática um ecossistema industrial consiste de um número de indústrias (de preferência grandes e de segmentos variados) atuando de forma sinérgica umas com as outras, utilizando os produtos e resíduos das indústrias que compõe o sistema. Com base nos conceitos de metabolismo e ecossistema industrial, a ecologia industrial, pode ser definida como uma abordagem baseada nos sistemas de engenharia e nos princípios ecológicos que integra aspectos de produção e consumo ao design, produção, uso e descarte de produtos e serviços de forma a minimizar os impactos ambientais e ao mesmo tempo otimizar a utilização dos recursos, energia e capital (GARNER e KEOLEIAN, 1995).

O exemplo mais notório da aplicação do conceito de ecologia industrial, mundialmente reconhecido e referenciado na literatura (GARNER e KEOLEIAN, 1995; WBCSD, 1995; FIKSEL, 2002), é o projeto Simbiose Industrial, implantado no distrito industrial da cidade de Kalundborg, na Dinamarca. Este projeto é resultado do desenvolvimento de 
cooperação gradual de quatro companhias vizinhas: uma usina de geração de energia termelétrica a carvão, com capacidade de $1.500 \mathrm{MW}$ e com 600 empregados (maior planta energética da Dinamarca); uma refinaria de petróleo, com capacidade para processar 3 milhões de toneladas de óleo por ano, que emprega 250 funcionários (maior refinaria da Dinamarca); uma planta de agregados para construção civil, que emprega 175 funcionários; uma indústria farmacêutica (biotecnologia), responsável por $45 \%$ da produção mundial de insulina e $50 \%$ da produção mundial de enzimas, que emprega 1.100 funcionários, e o município de Kalundborg, que distribui água, eletricidade e aquecimento (Figura 21).

\section{Refinaria Stat Oil}

Fornece: gás excedente, água para resfriamento, enxofre removido das emissões

Recebe: vapor de processo

Termelétrica a carvão Asnael Fornece: vapor de processo, cinzas e calcário Recebe: gás excedente, água para resfriamento, efluentes líquidos limpos

Farmacêutica Novo Nordisk Fornece: borra Recebe: vapor de processo

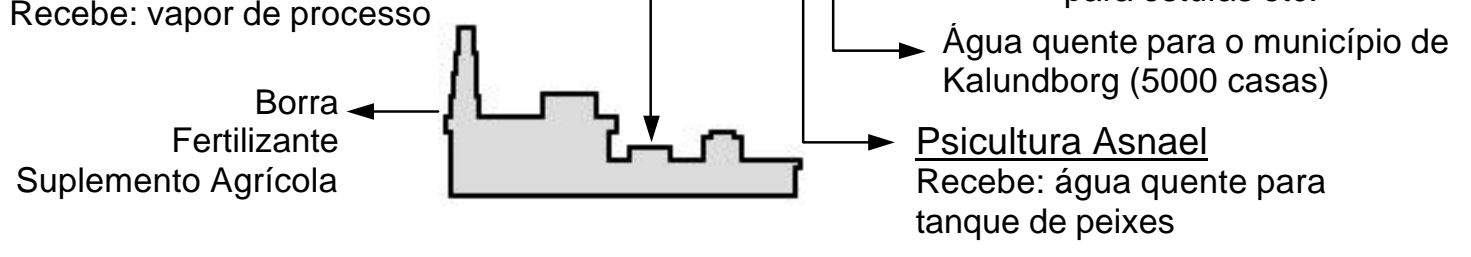

Figura 21 - Simbiose Industrial - Kalundborg (Dinamarca)

Fonte: Modificado de WBCSD (1995).

A seguir é apresentado um histórico da evolução das atividades de cooperação entre as quatro companhias e o município de Kalundborg, com base em informações obtidas em GARNER e KEOLEIAN (1995):

- 1959: a planta termelétrica Asnael, que é o parceiro central na simbiose deu início às suas atividades; 
- 1961: foi implantada a refinaria Stateoil, para suprir a demanda de água, foi construída uma linha de captação do lago Tisso;

- 1972: a planta de agregados foi implantada (Gyproc), e foi construída uma linha para recebimento do gás excedente da refinaria;

- 1973: a termelétrica foi expandida, e para o suprimento adicional de água, foi construída uma conexão na linha de captação de água da refinaria;

- 1976: a indústria farmacêutica (Novo Nordisk) passou a fornecer lodo biológico (borra) para as áreas agrícolas da região circunvizinha;

- 1979: a termelétrica passou a fornecer cinzas de chaminé (até então um resíduo problemático) para indústrias de cimento da região;

- 1981: o município de Kalundborg passou a utilizar calor excedente da termelétrica em seu sistema de distribuição de calor;

- 1982: a indústria farmacêutica e a refinaria instalam linhas para o recebimento de vapor da termelétrica;

- 1987: a refinaria instala uma linha para fornecimento do efluente da água de resfriamento para uso na caldeira da termelétrica;

- 1989: a termelétrica passa a usar excesso de calor para aquecimento da água para criação de peixes;

- 1990: a refinaria completa a construção de uma planta para recuperação de enxofre para produção de enxofre elementar, vendido como matéria-prima para a produção de ácido sulfúrico;

- 1991: a refinaria passa a fornecer efluente biologicamente tratado para a termelétrica, para uso em operações de limpeza;

- 1992: a refinaria passa a fornecer gás para a termelétrica, como combustível suplementar;

- 1993: a termelétrica implanta um projeto de dessulfurização de gás, que converte $\mathrm{SO}_{2}$ em sulfato de cálcio, que é vendido como matéria-prima para a planta de agregado para construção civil (Gyproc).

Os resultados mais significativos obtidos no projeto de simbiose industrial de Kalundborg compreendem a redução significativa do consumo de energia e utilidades 
(carvão, óleo e água), melhoria da qualidade ambiental decorrente da redução de emissões de $\mathrm{SO}_{2}$ e $\mathrm{CO}_{2}$ e do volume de efluente líquido, conversão de resíduos tradicionais, como cinzas de chaminé, enxofre, lodo biológico e cal em matérias-primas, desenvolvimento gradual de uma 'maneira de pensar ambiental sistematizada', que pode ser aplicável a muitas outras indústrias e que pode trazer benefícios futuros a outros complexos industriais e, a criação de uma imagem positiva da cidade de Kalundborg, que é internacionalmente reconhecida como um pólo industrial limpo.

O conceito de simbiose industrial é recomendado como uma abordagem prática para minimizar os impactos ambientais de complexos industriais já existentes e de complexos futuros. Para tanto, é necessário que as indústrias participantes operem de forma integrada, que haja uma diversidade de atividades, que as melhorias ambientais, a conservação de recursos e os incentivos econômicos caminhem lado a lado, que haja uma distância física pequena entre as indústrias participantes, e que haja 0 comprometimento mútuo da cooperação e comunicação efetiva entre as partes (GARNER e KEOLEIAN, 1995).

Geiser e Oldenburg (1997), ao comparar a aplicação prática dos conceitos de prevenção à poluição e de ecologia industrial, apontam dois aspectos da ecologia industrial que podem representar fontes de ineficiência. Primeiro, a forte dependência de materiais entre as indústrias, que estão ligadas entre si por uma relação resíduo/matériaprima, pode inibir inovações tecnológicas. Se as indústrias precisam garantir uma determinada quantidade ou condição de resíduo para seus consumidores potenciais (as outras indústrias que compõem a simbiose), elas podem relutar em adotar modificações no manuseio e no tratamento dos resíduos que poderiam de outra forma ser técnica, econômica e ambientalmente vantajosas. Segundo, esta dependência resíduo/matériaprima pode reduzir o incentivo para a implantação de projetos de prevenção àpoluição. Investimentos que poderiam reduzir ou eliminar certos materiais e resíduos perigosos podem enfrentar resistências internas porque isto poderia afetar a relação com os consumidores dos resíduos.

\subsubsection{Fator 4, Fator 10 e Capitalismo Natural}

Os conceitos Fator 4, Fator 10 e Capitalismo Natural visam a internalização de estratégias para reduzir dramaticamente o consumo de recursos nas atividades produtivas. As três iniciativas baseiam-se na desmaterialização da produção, na qual a 
intensidade dos recursos naturais utilizados é reduzida por vários fatores por unidade de produção (ASIAN DEVELOPMENT BANK, 2002). Estes conceitos foram desenvolvidos por pesquisadores do Rocky Mountain Institute nos Estados Unidos.

O conceito do Fator 4 considera que para se alcançar a sustentabilidade, e para que esta seja mantida durante um período no qual a população duplique em tamanho e seu padrão de vida aumente significativamente ${ }^{17}$, a indústria deve aumentar a eficiência da conversão dos recursos em um fator mínimo de quatro vezes (isto é, a produtividade deve quadruplicar, mantendo-se o mesmo índice de consumo dos recursos). Uma vez que as sociedades desenvolvidas consomem tipicamente 20 a 30 vezes mais recursos do que as nações em desenvolvimento, o conceito do Fator 10 considera que a eficiência da conversão dos recursos pelos países desenvolvidos deve aumentar em um fator de 10 vezes, de modo a acomodar o crescimento almejado pelas nações em desenvolvimento de forma sustentável (UNEP, 2002b; ROHDE, 2004).

Segundo os autores do termo Capitalismo Natural (LOVINS, LOVINS e HAWKEN, 1999), esta abordagem 'visa proteger a biosfera e ao mesmo tempo aumentar os lucros e a competitividade'. Para se colocar em prática o capitalismo natural são necessárias quatro mudanças no modo de gerir as práticas de negócios, todas elas interligadas:

Aumentar dramaticamente a produtividade dos recursos naturais - através de mudanças fundamentais nas tecnologias e processos de produção, de modo a aumentar a eficiência na extração de recursos naturais (energia, minerais, água, recursos florestais).

> Alterar modelos de produção com base nos sistemas de produção biológicos - adotar sistemas de produção fechados, onde os resíduos são retornados ao meio ambiente de forma harmônica como nutriente, ou então se transformam em matéria-prima de outros produtos.

$>$ Reestruturar o modelo dos negócios - o modelo tradicional se concentra na venda de bens de consumo. Em um novo modelo, o valor estaria agregado no fornecimento dos bens de consumo, como por exemplo, fornecer iluminação ao invés de vender lâmpadas.

> Reinvestir no capital natural - investir na restauração, manutenção e expansão dos recursos naturais.

\footnotetext{
17 A referência consultada não entra em detalhes de como chegou-se a esse fator, nem de quanto seria este aumento significativo do padrão de vida destas sociedades, que já possuem um padrão de consumo elevado.
} 
Segundo Rohde (2004), as propostas do Fator 4, Fator 10 e do Capitalismo Natural podem ser todas colocadas no contexto da eco-eficiência, pois tomam como princípio base $o$ fato de os processos e as empresas atuais serem ineficientes no uso das matérias-primas e energia, fato este que gera desperdício, representado pela poluição e pelos resíduos. Assim sendo, estas propostas visam o estabelecimento de estratégias para otimizar o uso dos recursos, de modo que os empreendimentos continuem a produzir na mesma escala, reduzindo os impactos adversos ao meio ambiente.

\subsubsection{Princípio de Emissão Zero - ZERI}

Segundo Pauli ${ }^{18}$ (1996 apud Rohde, 2004), a proposta do Princípio de Emissão Zero é 'uma alteridade radical àvisão tradicional dos negócios, e representa a busca do novo paradigma ambiental através daquilo que os negócios podem oferecer àsociedade'. Esta proposta foi lançada mundialmente pela Universidade das Nações Unidas - UNU (Tóquio, Japão) a 6 de abril de 1994, quando um brasileiro, o Prof. Heitor Gurgulino de Souza, era seu reitor (ROHDE, 2004). O que torna a proposta do Princípio de Emissão Zero radicalmente diferente das demais propostas ambientais voltadas à indústria e aos negócios são duas visões inexistentes nas outras:

> a eliminação do próprio conceito de "resíduo" ("A Natureza não conhece resíduos; só a espécie humana é capaz de produzir coisas que ninguém deseja ter".);

> uma posição ética (ambiental e social) que implica no banimento de certas substâncias (CFCs, dioxinas, etc.), alguns materiais (por exemplo, asbestos), processos, objetos (por exemplo, cigarros e charutos) e determinados artefatos (por exemplo, minas terrestres).

Ainda segundo Rohde (2004), a filosofia da Zero Emissions Research Initiative (ZERI) não é apenas um modelo a mais de reciclagem industrial, e sim uma visão que propõe uma revolução profunda no sistema industrial vigente, a favor de sistemas integrados de indústrias, nos quais os resíduos de uma unidade não mais serão resíduos, mas inputs de outro sistema, e assim por diante, em uma nuvem industrial sistêmica. Deste modo a proposta ZERI tem como objetivos principais:

${ }^{18}$ PAULI, G. (1996) Emissão zero: a busca de novos paradigmas. In: O que os negócios podem oferecer à sociedade. Porto Alegre: EDIPUCRS apud Rohde (2004). 
$>$ Aumentar a produtividade input-output;

$>$ Buscar criativamente a utilização do output;

$>$ Modelar conglomerados industriais;

$>$ Identificar as tecnologias necessárias; e

$>$ Desenhar a política industrial.

A proposta do princípio de emissão de resíduo zero, a princípio parece similar à proposta da ecologia industrial, entretanto, ao se analisar os exemplos de cases observase que o princípio de emissão zero vem sendo aplicado em atividades extrativistas ou que usem biomassa como principal fonte de matéria-prima. Pauli (1997), coloca em seu artigo que as práticas de produção mais limpa precisam evoluir da abordagem focada na melhoria da performance de cada indústria para uma abordagem que considere grupos de indústrias, que incorporem o uso da biomassa e o reúso de minerais. O autor cita exemplos da aplicação do princípio de emissão zero em indústrias de processamento de sisal na Tanzânia e de cervejarias nas Ilhas Fiji, Panamá e Tanzânia.

No Brasil, a proposta ZERI está representada pela Fundação ZERI Brasil, situada em Porto Alegre-RS, desde 1997. Um dos cases de maior relevância ambiental e econômica da aplicação do Princípio de Emissão Zero no Brasil foi a implementação de biosistemas integrados de combate à degradação ambiental da suinocultura no estado do Paraná (2001-2003), especialmente no município de Toledo. O projeto foi apoiado pela Prefeitura Municipal de Toledo, pela Fundação Banco do Brasil, pelo Instituto de Tecnologia do Paraná, Frigobrás (Sadia), Unioeste e suinocultores da região. No Rio Grande do Sul, desde 1997, está em andamento a experiência da Diversificação em Torno do Arroz, no município de Santa Vitória do Palmar (ROHDE, 2004).

\subsubsection{Normas de Padronização Ambiental}

\subsubsection{Sistemas de Gestão Ambiental: visão geral}

Um sistema de gestão ambiental é definido como o conjunto de procedimentos que irão ajudar uma organização atender, controlar e diminuir os impactos ambientais de suas atividades, produtos e/ou serviços. Está baseado no cumprimento da legislação ambiental vigente e na melhoria contínua do desempenho ambiental, o que significa que não basta estar dentro da lei, mas deve haver também uma decisão clara por parte da organização 
de melhorar cada vez mais seu desempenho em relação ao meio ambiente, por meio da adoção de novas tecnologias, de práticas de prevenção à poluição, do envolvimento e conscientização dos funcionários e da educação ambiental em todos os níveis hierárquicos (VALLE, 1995; VITERBO Jr., 1998; CEMPRE, 2000; MOREIRA, 2001; ALMEIDA, MELLO e CAVALCANTI, 2004).

Nos últimos anos os sistemas de gestão ambiental têm ganhado muito espaço na agenda das empresas, devido à difusão de padrões internacionais certificáveis para a gestão ambiental, sendo que os países europeus foram pioneiros na adoção da padronização ambiental. A padronização de procedimentos de gestão ambiental ocorreu com a institucionalização da EMAS (Eco-Management and Audit Scheme, adotada na União Européia) e da BS 7750 (British Standard, adotada na Inglaterra). Mais tarde, como uma iniciativa para a padronização global das práticas ambientais, foi criada a série de normas ambientais ISO 14000, dentre as quais a ISO 14001 foi a primeira a ser consolidada, em 1996, e estabelece os requisitos fundamentais para o estabelecimento de um sistema de gestão ambiental (HONKASALO, 1998). Apesar de o modelo proposto pela ISO 14001 ser adotado mundialmente, convém salientar que existem outros modelos de sistema de gestão ambiental, alguns criados para um segmento específico, outros mais generalistas, dentre os quais destacam-se:

> GEMI (Global Environmental Management Institute): compreende um grupo de aproximadamente 27 companhias cujos membros colaboram para a ética nos negócios visando a promoção da gestão ambiental e do desenvolvimento sustentável, a melhoria da performance ambiental dos negócios através de exemplos e liderança e o diálogo entre os empresários e seus consumidores. O GEMI é considerado como sendo a primeira iniciativa de integração da gestão ambiental e da filosofia do gerenciamento para a qualidade total, uma abordagem para a melhoria contínua da qualidade ambiental (WELCH, 1997).

> Princípios CERES (Coalition for Environmentally Responsible Economies): a CERES é uma sociedade sem fins lucrativos composta por investidores, grupos ambientalistas, organizações trabalhistas e grupos independentes de interesse. Os princípios são uma modelo de código corporativo de conduta ambiental. As companhias que adotam os princípios CERES precisam se comprometer com os seguintes princípios: a) proteção da biosfera; b) uso sustentável dos recursos naturais; c) redução de resíduos; d) conservação de energia; e) redução de riscos; f) produtos e serviços 
seguros; g) restauração ambiental; h) comunicação com o público; i) comprometimento; e, j) realização de auditorias e relatórios de desempenho. Ainda, as companhias devem fornecer informações específicas sobre suas ações e desempenho ambiental, que são publicadas em um relatório anual (WELCH, 1997).

> BS 7750 (British Standards Institute): norma britânica que especifica os requisitos para os sistemas de gestão ambiental. Publicada em março de 1992, é o primeiro modelo padronizado desenvolvido na Inglaterra. Um grande número de companhias têm sido certificadas pela BS 7750, incluindo algumas na América do Norte. Esta norma serviu como modelo para o desenvolvimento da norma ISO 14001 (WELCH, 1997).

> EMAS (European Union Eco-Management and Audit Scheme): é uma norma para especificação de sistemas de gestão ambiental aprovada pela União Européia em 1993. A EMAS é parte da política ambiental oficial da União Européia e as autoridades ambientais nos países membro têm a responsabilidade de promover sua adoção, embora esta seja de caráter voluntário. Esta norma entretanto aplica-se somente às empresas industriais, ao contrário da ISO 14001, que é aplicável a qualquer tipo de organização (HONKASALO, 1998).

> CSA-2750 (Canadian Standards Association): norma canadense, baseada na BS 7750 que visa fornecer orientação sobre sistemas de gestão ambiental a companhias, indústrias e outras organizações, inclui definições, princípios e procedimentos para a implementação do modelo (WELCH, 1997).

> US EPA Compliance-based EMS (Sistema de Gestão Ambiental proposto pela US EPA): modelo desenvolvido em 1994, que propõe diretrizes para o estabelecimento de um sistema de gestão ambiental fortemente baseado no cumprimento da legislação ambiental e na melhoria da performance ambiental. Este modelo faz parte de uma iniciativa da US EPA de padronizar ainda mais as ações ambientais no país, e ainda incentivar a adoção de sistemas de gestão por pequenas e médias empresas. O modelo requer ainda que as companhias adotem programas de prevenção àpoluição e reciclagem de materiais (WILSON, 1998).

> Programa Atuação Responsável (Responsible Care): é o sistema de gestão integrada de saúde, segurança e meio ambiente adotado mundialmente pelas indústrias químicas (PIOTTO, 2003). 
Embora cada um destes modelos tenha suas particularidades, eles apresentam muitos elementos em comum, e requerem das companhias que os adotam as seguintes ações:

- Implantar um sistema de gestão ambiental (SGA);

- Auditar seu SGA para verificar se o mesmo está alcançando as metas propostas;

- Avaliar o impacto de seus produtos no meio ambiente;

- Envolver a comunidade, consumidores e fornecedores.

Cabe salientar que nenhuma das normas mencionadas, incluindo a ISO 14001, impõe qualquer tipo de padrão ou parâmetro de performance ambiental que a organização seja obrigada a seguir. Ao contrário, estas normas foram criadas para ajudar as organizações a desenvolver um código de ética que leve em consideração os impactos de suas atividades no meio ambiente. O sistema de gestão ambiental numa empresa, deve compreender ações de controle ambiental através da adoção de novas tecnologias, de práticas de prevenção à poluição, envolvimento e conscientização de funcionários, educação ambiental e melhoria contínua. No entanto, a grande parte dos sistemas são designados, ou no mínimo operados, para responder leis e regulamentações, tais sistemas são ditos 'baseados na conformidade ambiental' (WELCH, 1997).

Em muitos casos, a adoção dos sistemas de gestão ambiental, especialmente aqueles certificáveis, vem acontecendo em decorrência de pressões externas de mercado, mais do que em decorrência de um conscientização ambiental, simplesmente. Almeida, Mello e Cavalcanti (2004, p.13) destacam que a adesão voluntária das empresas aos certificados ambientais e aos códigos de liderança é impulsionada pelos seguintes interesses:

- Desejo de obter um diferencial de mercado;

- Vantagens competitivas;

- Pressões de agências financiadoras, clientes e seguradoras;

- Crescimento da consciência ambiental; e,

- Modernização do processo produtivo. 
Um sistema de gestão ambiental no entanto, representa uma oportunidade de as organizações obterem uma série de benefícios, que vão muito além de vantagens competitivas e de mercado. Dentre as principais vantagens, Moreira (2001), destaca as seguintes:

- Garantia de melhor desempenho ambiental;

- Redução de desperdícios;

- Prevenção de riscos (acidentes, multas, ações judiciais, etc);

- Disseminação da responsabilidade ambiental para toda a empresa;

- Homogeneização do gerenciamento ambiental por todas as unidades, especialmente quando as atividades são dispersas;

- Possibilidade de demonstrar sua consciência ambiental;

- Boa reputação junto aos órgãos de interesse;

- Possibilidade de obter financiamento a taxas reduzidas;

- Possibilidade de reduzir custos de seguro; e,

- Melhoria do gerenciamento como um todo.

Um sistema de gestão ambiental representa ainda uma oportunidade para a internalização de práticas de prevenção à poluição, nos casos onde há resistência por parte da alta gerência em adotar programas específicos de prevenção à poluição. $O$ sistema de gestão ambiental (uma vez implementado e operado corretamente) pode servir como instrumento de conscientização a cerca dos benefícios embutidos nas ações de melhoria contínua, que envolvem entre outras coisas, a adoção de práticas de prevenção àpoluição (CICHOWICZ, 1996).

\subsubsection{Normas ISO 14000}

A ISO (International Organization for Standardization) é uma federação mundial, não governamental, com sede em Genebra, que tem por objetivo propor normas que representem consenso dos diferentes países para homogeneizar métodos, medidas, 
materiais e seu uso, em todos os domínios da atividade, exceto no campo eletroeletrônico, cuja responsabilidade é da IEC (International Electrotechnical Commission).

A ISO realiza seus trabalhos por meio de comitês técnicos (TC), compostos por especialistas representantes dos diversos países membros, cada qual com responsabilidades específicas no âmbito de determinado tema a ser padronizado. Em conseqüência da Rio-92, foi proposta a criação de um grupo para elaborar normas ambientais, o ISO/TC-207, responsável por elaborar as normas ISO 14000, interrelacionando-se com o ISO/TC-176, comitê responsável pelas normas ISO 9000 da qualidade. O Brasil participou ativamente da elaboração das normas ambientais, por meio do GANA - Grupo de Apoio àNormalização Ambiental, da ABNT (MOREIRA, 2001).

A série ISO 14000 é derivada da experiência acumulada na elaboração das normas ISO 9000 e da necessidade que diversos países sentiram em criar suas próprias normas de gestão ambiental. A partir do estabelecimento dos princípios da qualidade total, e do surgimento da série de normas ISO 9000, o conceito de defeito e re-trabalho foram incorporados à linguagem das empresas. De lá pra cá, o conceito de defeito foi sendo associado à poluição e o tratamento e disposição final dos resíduos ao conceito de retrabalho (CEMPRE, 2000).

As normas que compõem a série dividem-se em duas categorias: a) normas de avaliação organizacional e, b) normas de avaliação de produtos. As normas de avaliação organizacional referem-se àpadronização de sistemas de gestão ambiental, avaliação da performance ambiental e procedimentos para auditorias ambientais. As normas de avaliação de produtos compreendem normas de avaliação de ciclo de vida e de rotulagem ambiental de produtos. O Quadro 7 mostra as normas da série ISO 14000, de acordo com a sua aplicação e objetivos. 
Quadro 7 - Normas da Série ISO 14000, suas aplicações e objetivos.

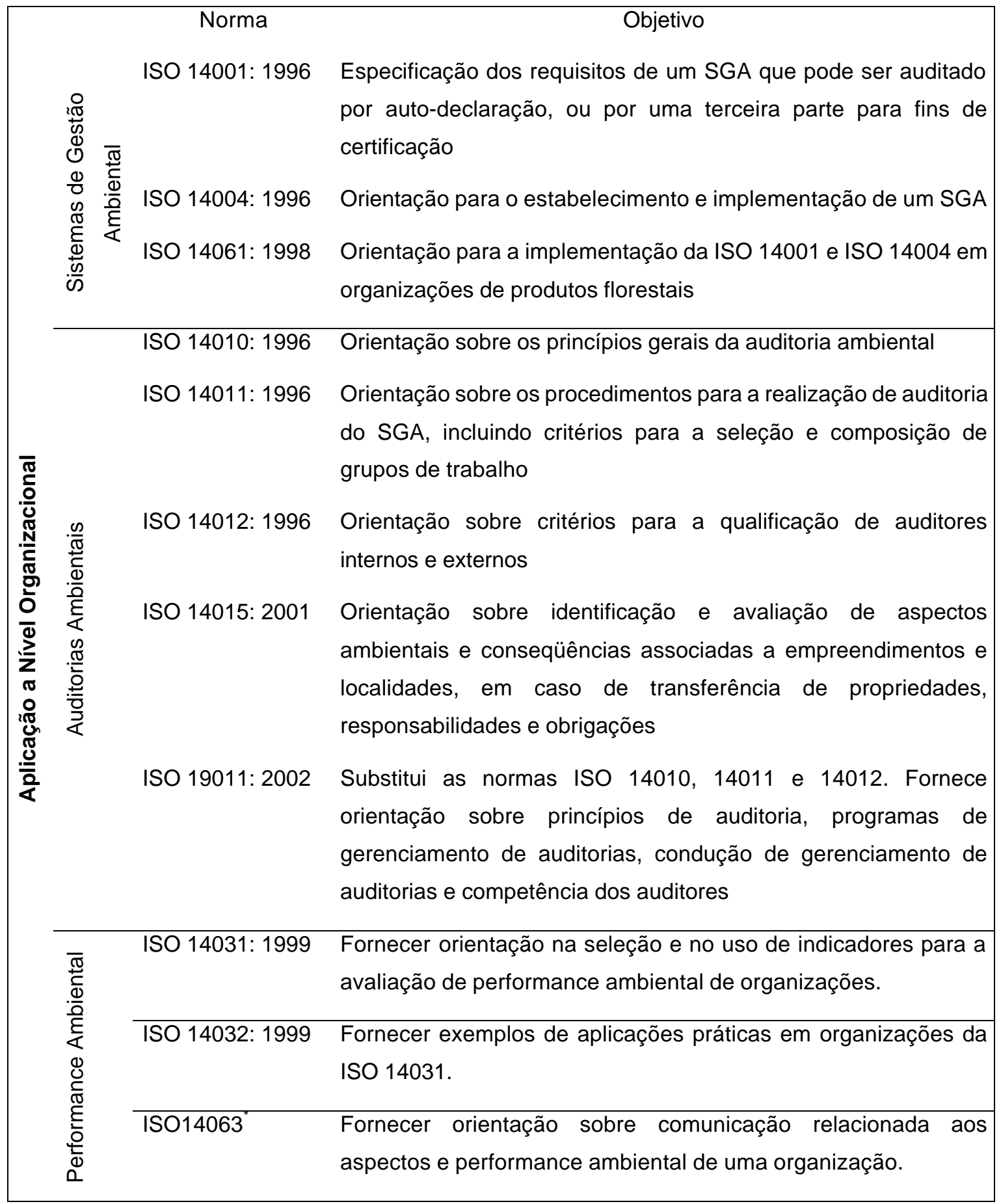


Quadro 7 - Normas da Série ISO 14000, suas aplicações e objetivos (continuação).

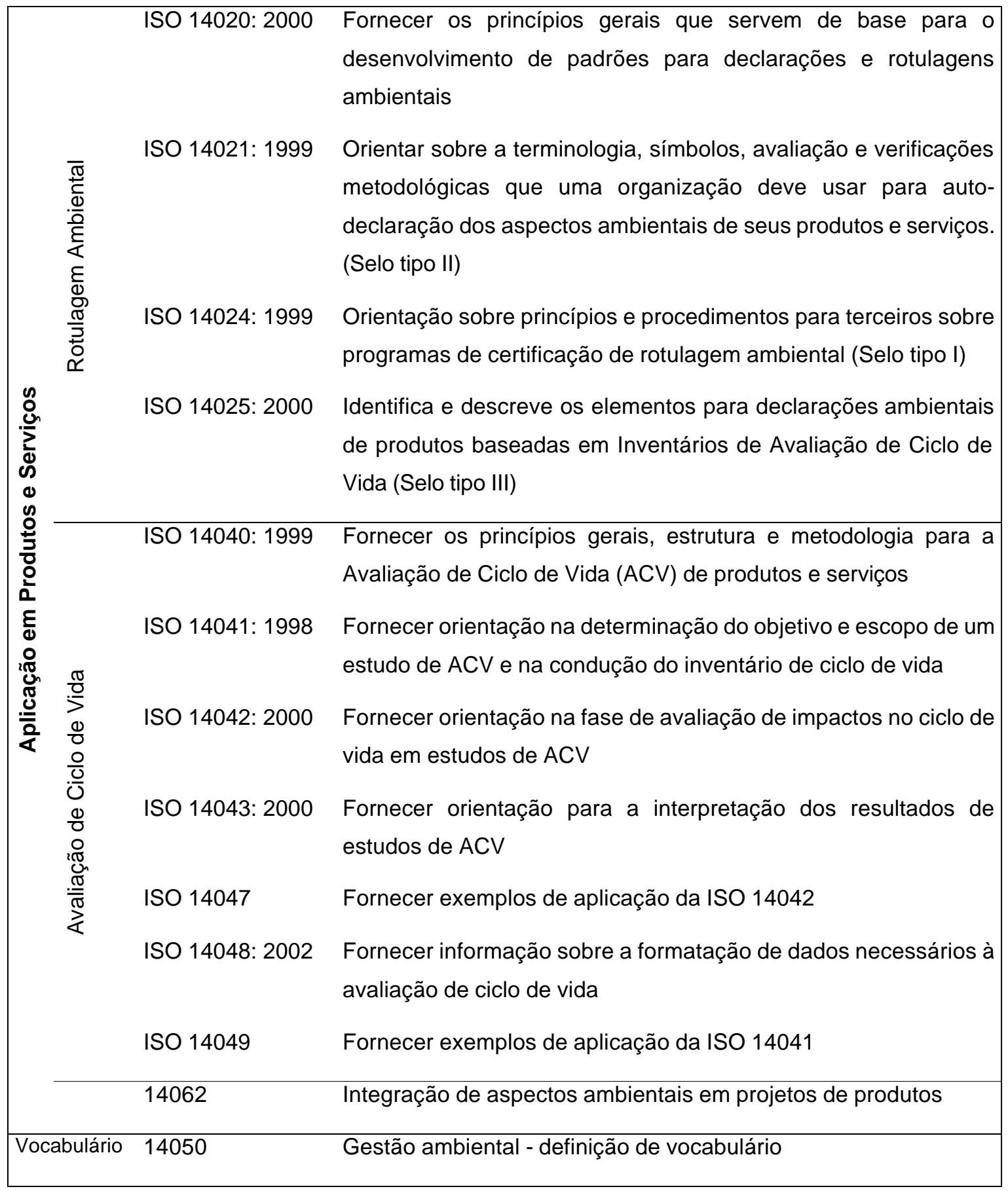




\subsubsection{A NBR ISO 14001}

A norma NBR ISO 14001 é o carro-chefe do conjunto de normas da Série ISO 14000, e tem como objetivo implantar um sistema de gestão ambiental (SGA) visando garantir o aprimoramento contínuo do trabalho ambiental e sua conformidade com a legislação ambiental aplicável (ABNT, 1996). A Norma aplica-se a qualquer organização que deseje:

- Implementar, manter e aprimorar um sistema de gestão ambiental;

- Assegurar-se de sua conformidade com a política ambiental definida;

- Demonstrar tal afinidade a terceiros;

- Buscar certificação/registro do seu SGA por uma organização externa; e,

- Realizar uma auto-avaliação e emitir auto-declaração de conformidade com a norma.

Para a implantação do sistema de gestão ambiental é necessário que primeiramente sejam alocados os recursos necessários para a execução de todas as atividades necessárias (VITERBO Jr., 1998). A implantação de um SGA é um processo trabalhoso que requer, além do envolvimento e comprometimento dos funcionários em todos os níveis organizacionais, a alocação dos recursos financeiros e a criação de incentivos. Os custos envolvidos na implementação de um SGA incluem (McLAUGHLIN e ELWOOD, 1996):

- Horas de trabalho dos funcionários, gastas na elaboração do planejamento estratégico;

- Treinamento dos funcionários e outros (gerentes, operadores, engenheiros, supervisores, pessoal da manutenção, terceirizados e fornecedores) nos requisitos do SGA, no uso de novas tecnologias e em novas práticas operacionais;

- Desenvolvimento ou aquisição de novas tecnologias, sistemas de informações, equipamentos de monitoramento;

- Pagamento de consultores externos;

- Taxas e custos extras para empresas de consultoria externas e órgãos certificadores.

A seguir deve ser preparado um cronograma de implantação, que segundo a NBR ISO 14001 (ABNT, 1996) deve envolver a realização das seguintes etapas: 
> Desenvolvimento de uma Política Ambiental;

> Planejamento, que envolve a definição dos seguintes requisitos:

- Aspectos ambientais

- Requisitos legais e outros requisitos

- Objetivos e metas

- Programas de gestão Ambiental

$>$ Implementação, que envolve a definição dos seguintes requisitos:

- Estrutura e responsabilidade

- Treinamento, conscientização e competência

- Comunicação

- Documentação

- Controle de Documentos

- Controle Operacional

- Preparação e atendimento a emergências

$>$ Medição e avaliação, que envolve:

- Monitorização e medição

- Ação corretiva e preventiva

- Registros

- Auditoria do sistema de gestão ambiental

- Análise crítica pela administração e melhoria.

O cronograma de implantação do SGA deve seguir o ciclo PDCA (Figura 22), ou seja, deve reconhecer o problema e planejar as atividades necessárias para resolvê-los (Plan), desenvolver estas atividades, através da determinação de autoridades e responsabilidades para as funções que irão trabalhar no projeto (Do), verificar o cumprimento das atividades através de auditorias internas (Check) e estabelecer as ações corretivas necessárias para corrigir as não-conformidades encontradas (Action). 


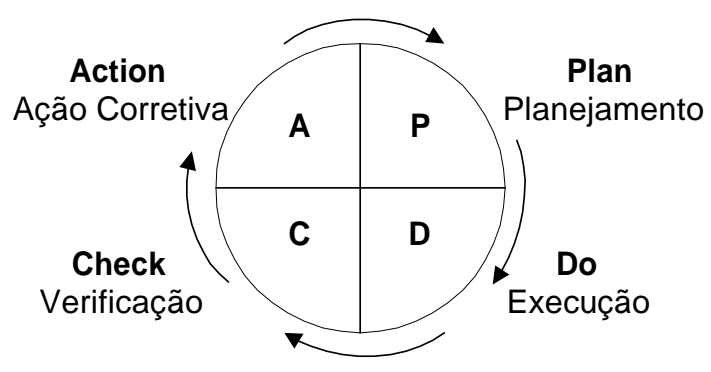

Figura 22 - O ciclo PDCA

Fonte: Moreira (2001).

A Figura 23 mostra os elementos fundamentais do sistema de gestão ambiental, do qual o ciclo PDCA é parte integrante.

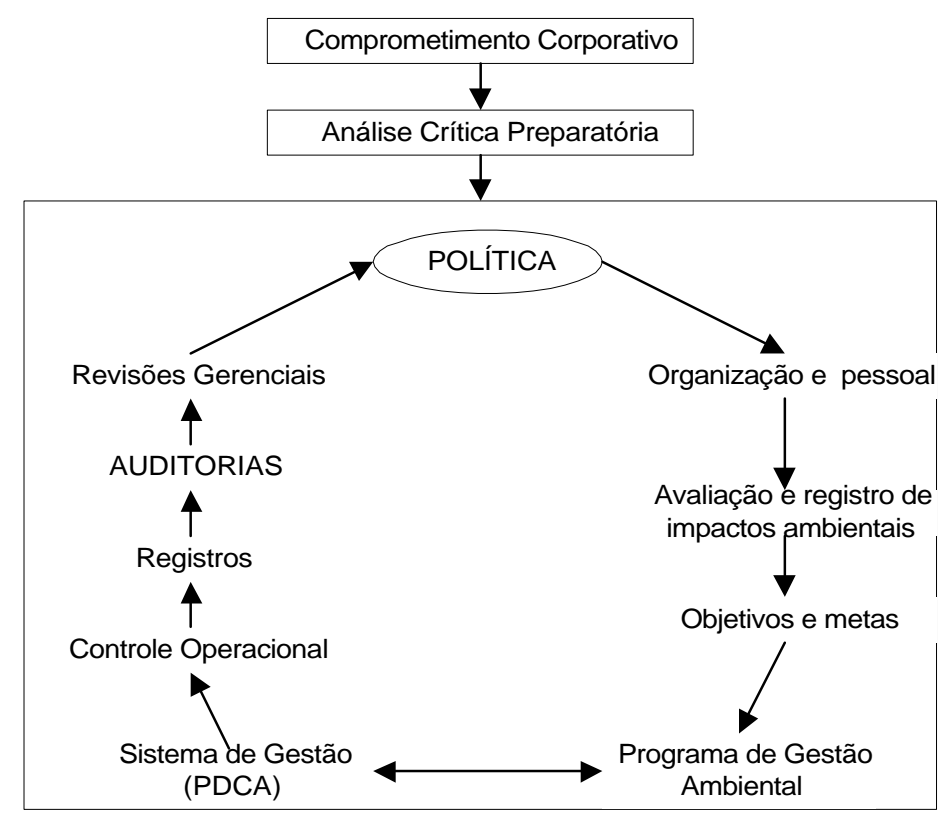

Figura 23 - Elementos do sistema de gestão ambiental Fonte: VITERBO Jr. (1998).

A identificação dos aspectos ambientais é a etapa fundamental durante a fase de planejamento. A NBR ISO 14001 (ABNT, 1996) define aspecto ambiental como sendo um elemento das atividades, produtos ou serviços de uma organização que pode interagir com o meio ambiente, e um aspecto ambiental significativo é aquele que tem ou pode ter um impacto ambiental significativo. 
A princípio, é necessário priorizar quais destes aspectos ambientais serão trabalhados. Não se deve esperar, porque quase sempre é inviável, que todos os aspectos ambientais identificados serão trabalhados em um primeiro instante. A melhoria contínua propõe que inicialmente sejam resolvidos os problemas mais imediatos, e que se estabeleçam objetivos e metas futuras, para que os demais problemas possam ser adequadamente solucionados. Cada operação dentro de um processo ou planta industrial pode apresentar diversos e distintos aspectos ambientais, mas nem todos são necessariamente significantes (US EPA, 2000a).

A ISO 14001 não apresenta um roteiro de como devem ser estabelecidos os requisitos da norma, cabendo a cada empresa estabelecer sua própria política ambiental, estabelecer critérios para a identificação dos seus aspectos ambientais, bem como identificar os impactos ambientais de suas atividades, propor seus objetivos e metas e forma de alcançá-los.

Um método prático para determinar e priorizar os aspectos ambientais significativos proposto pela US EPA (2000a), consiste de duas etapas:

- Estabelecer um ranking de cada aspecto ambiental de acordo com uma série de critérios ambientais (tais como toxicidade, quantidade de material desperdiçado na forma de resíduo, etc.) para determinar quais são os aspectos mais significantes.

- Estabelecer um segundo ranking, agora dos aspectos tomados como significativos de acordo com critérios práticos (viabilidade técnica e econômica) e benefícios potenciais (por exemplo, melhoria da qualidade ambiental, saúde ocupacional, redução de custos, etc.) para determinar quais aspectos significativos serão trabalhados. Para os critérios selecionados, devem-se estabelecer objetivos e metas a serem alcançadas.

Uma forma de identificar os aspectos ambientais significativos é através da análise de informações de risco. Apesar desta análise ser um tanto trabalhosa, ela pode gerar uma lista de aspectos ambientais menor a serem trabalhados, o que compensa o tempo e mão de obra gastos na análise.

Com relação aos critérios usados para o estabelecimento do ranking (que podem ser critérios práticos, ambientais, legais e de custo-benefício), convém salientar que cabe a cada empresa adotar os critérios adequados ao seu contexto. A US EPA (2000a) propõe uma série de questões que podem ser utilizadas como critérios de seleção de aspectos ambientais, das quais as mais relevantes estão sumarizadas no Quadro 8. 
Quadro 8 - Critérios para a seleção de aspectos ambientais.

- Identificar qual ou quais aspectos ambientais podem afetar a conformidade da empresa com relação a leis ambientais e outros requerimentos legais;

- Avaliar se existem oportunidades de prevenção àpoluição para o(s) aspecto(s);

- Avaliar potenciais oportunidades de redução de custos ou de negócios;

- Avaliar se existem problemas que podem ser divididos com clientes e/ou fornecedores;

- Avaliar se existem soluções que podem fornecer resultados a curto prazo e que sirvam também como exemplo para treinamento dos funcionários e assim aumentar a credibilidade do plano de prevenção àpoluição;

- Avaliar se existe a possibilidade de integrar requisitos ambientais com questões de saúde e segurança ocupacional;

- Avaliar se existem preocupações da comunidade com relação æ̇ atividades da empresa, e quais aspectos contribuem para estas preocupações;

- Verificar se produtos químicos perigosos utilizados podem ser substituídos ou melhor gerenciados;

- Avaliar se as soluções ou práticas ambientais correntemente utilizadas contribuem para a transferência de poluentes de um meio para outro; e,

- Avaliar se os recursos podem ser utilizados de maneira mais eficiente.

Fonte: Construído com base em informações da US EPA (2000a).

Após terem sido adotados os critérios para estabelecimento do ranking, e este ter sido realizado, com uma lista reduzida dos aspectos ambientais, pode ser realizada a avaliação dos aspectos ambientais significativos utilizando a informação de risco ambiental. Uma avaliação de risco, de forma resumida, é um processo que integra diversas áreas de estudo para determinar o tipo e o grau dos impactos ambientais e à saúde humana potencialmente produzidos pela exposição àuma substância química ou material. O risco é composto de duas partes: toxicidade e exposição. A toxicidade é a capacidade que determinada substância ou material possui de causar perigo a saúde humana, a fauna ou a flora. A exposição refere-se a quantidade de substância ou material com a qual os trabalhadores, a comunidade ou o ambiente está em contato. A exposição é determinada pela severidade e pelo tempo de contato (US EPA, 2000a). 
Conforme explicitado na Norma, a implementação de um sistema de gestão ambiental segundo a ISO 14001 por uma organização, quer dizer que esta possui uma política ambiental definida e um sistema de controle do seu desempenho ambiental, além de atender à legislação e regulamentos aplicáveis, entretanto, a norma ISO 14001 não garante a excelência do desempenho ambiental, podendo ocorrer de duas empresas do mesmo segmento, ambas certificadas, apresentarem níveis de desempenho ambiental bastante divergentes.

Segundo Piotto (2003), a norma estabelece, permite ou induz as seguintes ações:

a) sistemática para gerir as questões ambientais, identificando falhas na gestão de alguns aspectos e permitindo a sua integração àgestão da empresa;

b) gestão adequada dos objetivos e metas, validando essa gestão por um organismo certificador externo;

c) melhoria do desempenho ambiental das organizações; e,

d) a redução de pressões regulatórias o que permite o atendimento à demandas legais com menores gastos de fiscalização pelo governo.

No entanto a norma não estabelece; permite ou induz:

a) mudanças nos requisitos legais;

b) garantia do cumprimento æ̀ normas e requerimentos legais, ela só indica que a gestão do atendimento æ̀s exigências legais é feita pela empresa;

c) padrões de desempenho ambiental;

d) maior divulgação de informações relativas ao desempenho ambiental da empresa, conforme é mandatário no sistema EMAS.

Uma falha da ISO 14001 é que esta norma, no que se refere à definição do termo prevenção àpoluição, não distingue a prevenção do controle da poluição (PIOTTO, 2003). A norma, no seu item referente a definições, define prevenção àpoluição como o uso de processos, práticas, materiais ou produtos que evitem, reduzam ou controlem a poluição, os quais podem incluir reciclagem, tratamento, mudanças no processo, mecanismos de controle, uso eficiente de recursos e substituição de materiais (ABNT, 1996). No entanto, a norma não especifica como e em que nível tais práticas preventivas devem ser 
adotadas. Caberá a organização estabelecer os objetivos e metas a serem alcançadas, que poderão variar de acordo com o segmento industrial, país de origem, legislações vigentes, pressões de mercado, nível de conscientização e política ambiental adotada pela empresa. É justamente essa flexibilidade que permite que indústrias adotem as práticas que julgarem melhores (que na realidade podem não ser) ou mais convenientes, que leva a divergências quanto a eficácia desses sistemas de gestão ambiental. Segundo Furtado (2001): "[...] do ponto de vista ambiental, os sistemas de gestão ambiental baseados no modelo ISO 14001 podem tornar-se mais um sistema administrativo do que um recurso tecnologicamente eficiente, isto porque, apesar da norma estabelecer um compromisso da empresa em buscar a melhoria contínua, o modelo privilegia o controle end of pipe e atua no limite da conformidade com a legislação ambiental vigente no país onde a empresa está atuando [...]".

No entanto, não se pode deixar de levar em conta os aspectos positivos da adoção de uma certificação ISO 14000. O sistema de gestão ambiental permite que sejam apontados os impactos reais e potenciais que determinada atividade ou organização está causando, o que é um ponto de partida para a proposição de objetivos e metas de melhoria.

Consciente desta falha da norma, a US EPA elaborou um manual (US EPA, 2000a) de apoio às organizações, no qual os aspectos de prevenção à poluição e de design ecológico são integrados aos requisitos da ISO 14001. Como pôde-se observar nos critérios para a identificação dos aspectos ambientais, mostrados anteriormente no Quadro 8, e que foram compilados do referido manual, nestes constam questões relacionadas àprevenção àpoluição, como a avaliação da existência de oportunidades, a possibilidade de substituição de materiais perigosos do processo e a verificação da ocorrência de transferência de poluentes de um meio para outro.

A US EPA vem trabalhando no sentido de promover a integração da prevenção à poluição nos sistemas de gestão ambiental já existentes, e daqueles que estão sendo implementados, por meio da divulgação de materiais de apoio, inclusive para pequenas e médias empresas. Para estas, foi elaborado um manual especial (US EPA, 2000b). 


\subsubsection{Avaliação de Ciclo de Vida}

A avaliação de ciclo de vida ( $A C V$ ) é uma metodologia de avaliação da interação de uma dada atividade com o meio ambiente, desde a extração das matérias-primas até a disposição final dos resíduos (VIGON, 1993). De modo geral, os estudos de ACV compreendem as seguintes fases: 1) extração das matérias-primas; 2) fabricação do produto; 3) utilização; e, 4) descarte. A princípio, todos os fluxos secundários de emissões para o ar, solo e água são incluídos, o que resulta em uma avaliação mais abrangente do impacto ambiental potencial de um produto, processo ou serviço (AZAPAGIG, 1999; CHEHEBE, 1998). De acordo com a NBR ISO 14040 (ABNT 2001), as principais fases de um estudo de ACV são a definição do objetivo e escopo, o levantamento do inventário, o levantamento dos impactos e a interpretação dos dados (Figura 24).

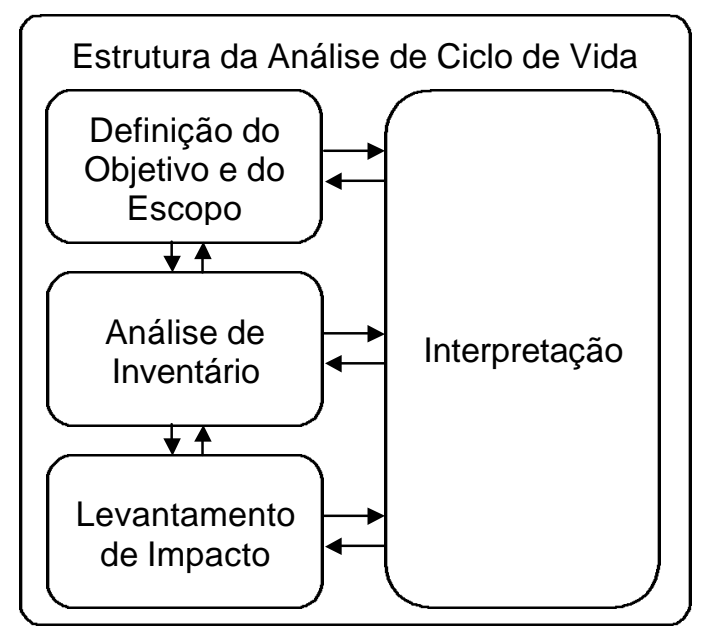

Figura 24 - Estrutura da Avaliação de Ciclo de Vida

Fonte: ABNT (2001)

$\mathrm{Na}$ definição do objetivo e escopo, define-se o objeto do estudo, a finalidade do estudo, as condições de contorno e as hipóteses. Em muitos casos, um estudo de ACV é realizado para responder a questões específicas sobre um produto ou processo específico. A definição do escopo do estudo estabelece os estágios do ciclo de vida que precisam ser considerados para se alcançar os objetivos propostos. Os estágios do ciclo de vida e os fluxos de materiais e energia são detalhados e esquematizados através de diagramas, definindo o sistema. Os sistemas elaborados para estudos de ACV são sempre complexos, envolvem muitos passos e requerem uma grande quantidade de dados (ALMEIDA, 2002). O levantamento do inventário do ciclo de vida é um procedimento sistemático, gradual e objetivo para quantificar os fluxos de materiais e 
energia no ciclo de vida. A obtenção de dados primários (dados brutos) pode ser difícil ou até impossível. Esse fato se deve ao elevado custo de coleta de dados ou ao caráter sigiloso de informações proprietárias de empresas. Dados secundários podem ser encontrados em uma variedade de fontes de informações, como relatórios internos das empresas, especificações técnicas de materiais e equipamentos, documentos e bases de dados privadas e públicas, etc. Embora esses dados não tenham sido coletados para o fim específico do estudo em que serão utilizados, eles podem ser utilizados com as devidas precauções quanto àconfiabilidade da fonte e as conseqüências para o resultado final do estudo (ALMEIDA, 2002).

Estudos de avaliação de ciclo de vida podem ter várias finalidades. A Figura 25 apresenta alguns fatores motivadores e suas freqüências para a realização de estudos de ACV segundo estudo desenvolvido por pesquisadores da Universidade de Tufts, Estados Unidos (BREVILLE, $1994{ }^{19}$ apud BISHOP, 2000a).

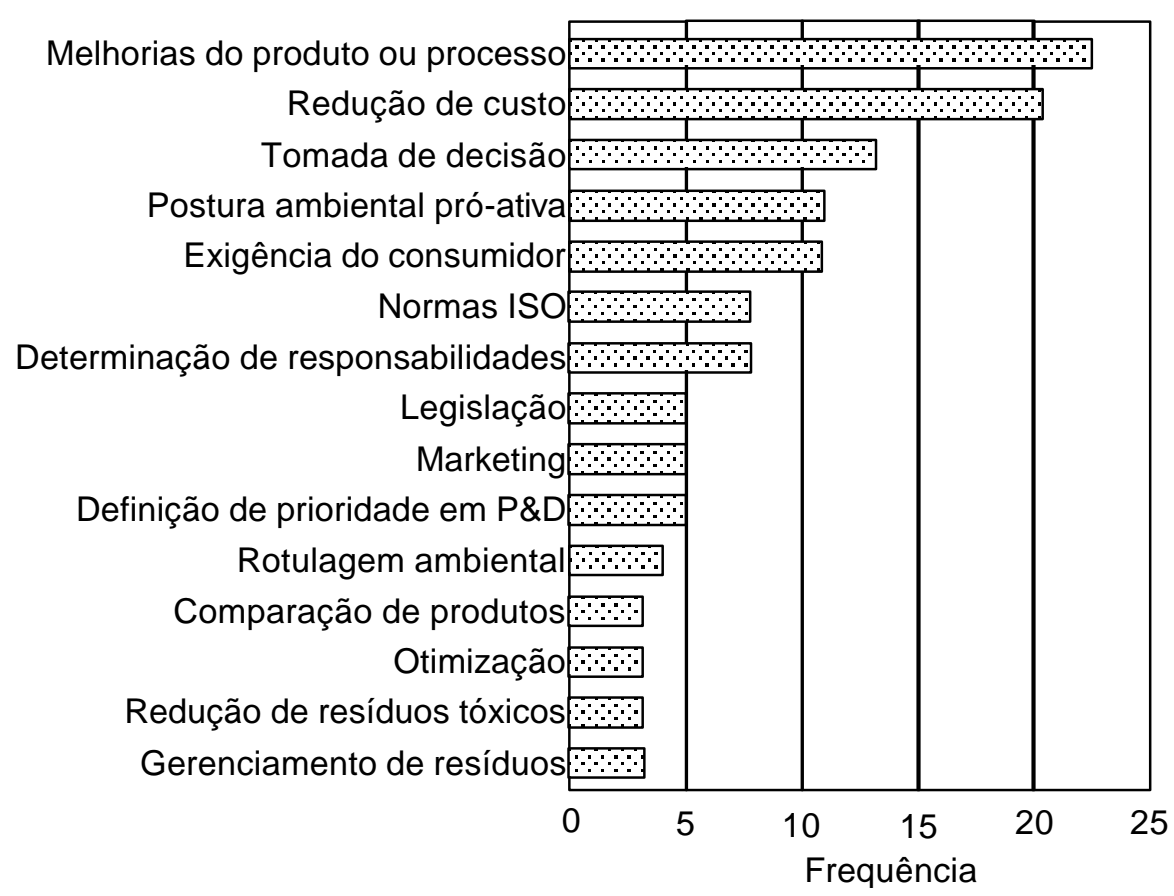

Figura 25 - Motivações e suas freqüências para a realização de estudos de ACV.

Fonte: Modificado de BISHOP (2000a)

A melhoria em produtos e processos e a redução de custos são os fatores motivadores mais importantes para a realização de estudos de ACV. A importância da

\footnotetext{
${ }^{19}$ BREVILLE, B. et al. (1994). Life cycle assessment, trends, methodologies and current implementation. Department of Civil and Environmental Engineering. Tufts University. Medford, MA. apud BISHOP (2000a).
} 
redução de custos como fator motivador deve aumentar devido aos crescentes custos de disposição de resíduos (FOUST e GISH ${ }^{20}, 1996$ apud BISHOP, 2000a).

O uso mais comum da ACV é para identificar pontos críticos onde a performance ambiental de um produto pode ser melhorada. A produção de resíduos durante a fabricação de um produto é um sinal direto da ineficiência do processo de fabricação. Resíduos gerados na utilização do produto e após o descarte e reaproveitamento (reciclagem ou reutilização) que podem ser evitados, além do consumo excessivo de energia, também são sinais de ineficiência. Essa ineficiência pode ser reduzida e até eliminada nos estágios do ciclo de vida de um produto, através de tomadas de decisão baseadas em resultados de estudos de ACV (BISHOP, 2000a).

Muitos trabalhos de ACV relacionados a vários segmentos industriais já foram realizados. Um resultado freqüente é que os impactos relacionados às atividades de fabricação do produto são quase sempre superados pelos impactos em outras etapas do ciclo de vida do produto, como por exemplo durante seu uso (NASH e STOUGHTON ${ }^{21}$, 1994 apud BISHOP, 2000a). Outro resultado comum é o fato de que nem sempre a reciclagem ou a redução da toxicidade do resíduo são alternativas vantajosas para o desempenho ambiental do produto como um todo (BISHOP, 2000a).

Alguns trabalhos têm sugerido a integração de estudos de ACV aos sistemas de gestão ambiental. A aplicação da ACV como uma ferramenta no planejamento de um sistema de gestão ambiental é particularmente útil na identificação dos aspectos ambientais, na determinação da escala e significância dos impactos ambientais, na identificação da contribuição dos diferentes estágios do ciclo de vida nos impactos ambientais associados, na comparação de estratégias de manufatura e na confecção de relatórios de desempenho ambiental. $\mathrm{O}$ fato da $\mathrm{ACV}$ fornecer uma análise quantitativa dos fluxos de materiais e energia é de particular importância no estabelecimento dos objetivos e metas, que irão ajudar companhias conscientes a aproveitar seus recursos materiais e reduzir os impactos de seus produtos e serviços de maneira mais efetiva (STEWART, COLLINS e MURPHY, 1999; KHAN e HUSAIN, 2002; ROSS e EVANS, 2002; ZOBEL, et al., 2003).

\footnotetext{
${ }^{20}$ FOUST, T. D.; GISH, D. D. (1996). Future perspective. In: Environmental Life cycle Assessment. Edited by CURRAN, M. A. McGraw-Hill: New York apud BISHOP (2000a).

${ }_{21} \mathrm{NASH}$, J.; STOUGHTON, M. D. (1995). Learning to live with Life Cycle Assessment. Environmental Science and Technology,.n.28, p. 236-237 apud BISHOP (2000a).
} 


\subsection{Categorias de Prevenção àPoluição}

\subsubsection{Projeto e Reformulação de Produto}

O projeto de produto ou ecodesign, denominação traduzida do termo "Design for the Environment" (DfE), visa integrar considerações ambientais aos critérios usuais de projeto (desempenho, custo, qualidade e variáveis técnicas, culturais e legais). Inclui métodos para prevenir a poluição associada ao ciclo de vida do produto (Figura 26), através do projeto de novos produtos ou da reformulação de produtos existentes.

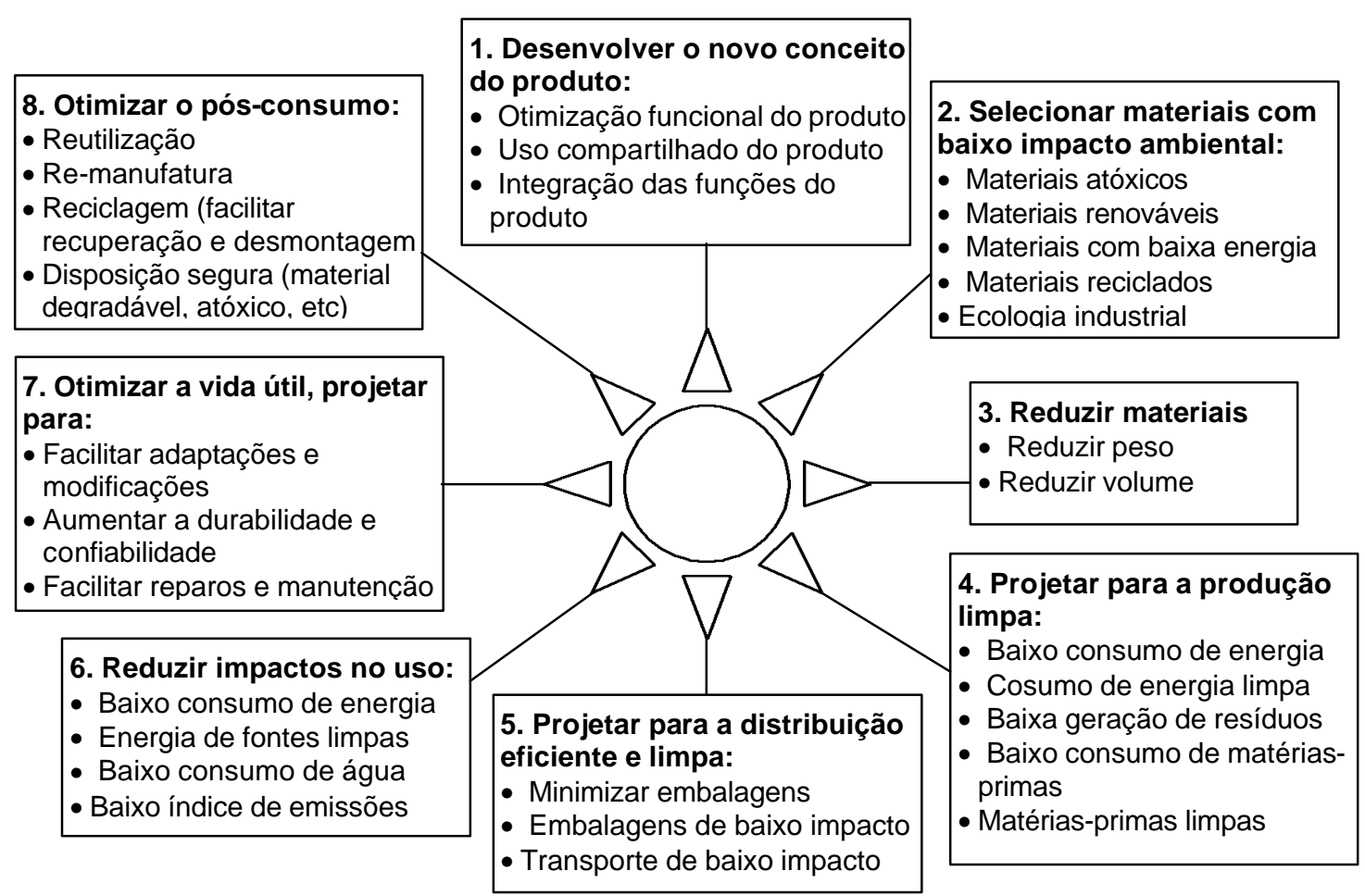

Figura 26 - Oportunidades para aplicação do ecodesign ao longo do ciclo de vida do produto Fonte: Modificado de ENVIRONMENT CANADA (2001)

Segundo Manzini e Vezzoli (2002, p.17), “o ecodesign é um modelo 'projetual' ou de projeto (design), orientado por critérios ecológicos".

O ecodesign integra uma combinação de estratégias para minimizar os impactos ambientais totais ao longo do ciclo de vida do produto, que inclui: a) seleção de materiais de baixo impacto (renováveis ou recicláveis); b) redução do peso ou volume de materiais nos produtos; c) uso de técnicas mais limpas no processo de manufatura; d) redução dos impactos ambientais das embalagens e da distribuição dos produtos; e) redução dos 
impactos ambientais no uso do produto; f) otimização do ciclo de vida do produto (desenvolvimento de materiais e produtos mais duráveis); e, g) reúso, remanufatura e reciclagem dos produtos ao término de sua vida útil (ROY, 2000).

Os impactos ambientais associados com o término da vida útil de um produto podem ser reduzidos através de uma série de conceitos projetuais, conforme exposto em Environment Canada (2001):

$>$ Projeto para o reúso (design for reuse): em muitos casos, projetar um produto para que este seja 'reusável' pode diminuir significativamente os impactos associados a todo o ciclo de vida do produto. Se os impactos mais significativos ocorrem no processo de manufatura do produto, o reúso diminuirá o impacto global do ciclo de vida do produto. Entretanto nos casos onde os impactos ocorrem na distribuição, coleta e limpeza, o design para o reúso pouco influenciará na redução dos impactos ou por vezes pode até contribuir de maneira negativa.

$>$ Projeto para a remanufatura (design for remanufacturing): a remanufatura envolve a restauração de produtos usados ou componentes à uma condição na qual as características de performance do produto ou componente é muito próxima àquelas do produto novo. Equipamentos industriais e outros produtos de alto valor econômico estão entre os produtos que mais se enquadram nesta categoria. $\mathrm{O}$ desing para a remanufatura é usado nos setores de equipamentos industriais e automotivo.

$>$ Projeto para a reciclagem (design for recycling): esta categoria de projeto divide-se em:

- Projeto para a recuperação (design for recovering): utiliza tecnologias para a recuperação de materiais. Critérios de projeto que podem melhorar a recuperação de materiais incluem: a) uso de materiais facilmente recicláveis; b) evitar a contaminação por meio da combinação adequada dos materiais; e, c) eliminar ou evitar o uso de substâncias tóxicas.

- Projeto para a desmontagem (design for disassembly): permite a reciclagem de grande parte dos materiais (incluindo plásticos) agregados a um produto através da separação das partes do produto em seus componentes básicos. 
A diferença entre a remanufatura e a reciclagem reside no fato de que na remanufatura os materiais recuperados do produto retornam para o processo de manufatura daquele mesmo produto, já os materiais recuperados através da reciclagem retornam para a etapa inicial do ciclo de vida, na fase de extração e preparação da matéria-prima (Figura 27).

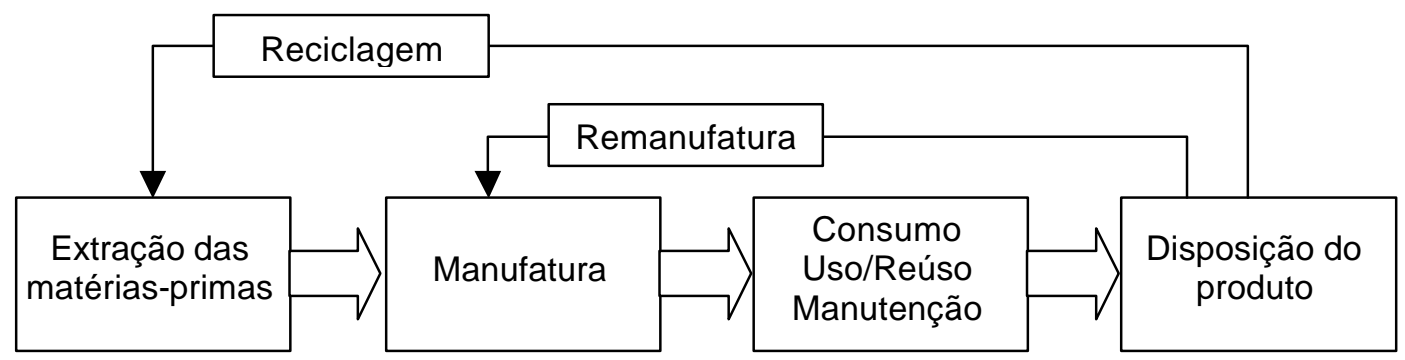

Figura 27 - Reciclagem e remanufatura de materiais no ciclo de vida. Fonte: Modificado de HIGGINS, 1995, p.71

> Projeto para a disposição segura (design for safe disposal): finalmente, o projeto de um produto deve assegurar que os materiais agregados ao produto possam ser dispostos de maneira segura, caso não possam ser reutilizados ou reciclados. Considerações para a disposição segura incluem a escolha de materiais não tóxicos, materiais facilmente degradáveis ou que não liberem substâncias tóxicas durante a incineração.

O ecodesign é uma abordagem relativamente nova no desenvolvimento de produtos, mas vem sendo aceita em diversas companhias, especialmente no setor de eletroeletrônicos e eletrodomésticos, representadas por empresas multinacionais que adotam políticas de eco-eficiência em seus negócios (ROY, 2000). Especialmente na Europa, onde políticas públicas que incorporam a responsabilidade dos fabricantes no pós consumo de seus produtos - embalagens, carros, eletrônicos, etc. - já estão bem estabelecidas, existe uma forte pressão sobre as indústrias para que sejam desenvolvidos produtos sustentáveis (MAXWELL e VAN DER VORST, 2003).

Segundo Roy (2000), o ecodesign é essencialmente uma tentativa de permitir que os padrões atuais de produção e consumo possam continuar no futuro, ao menos nos países mais industrializados, e de maneira isolada não é suficiente para conter as pressões do 
desenvolvimento econômico e do crescimento populacional mundiais. Para que o mundo possa seguir em direção ao desenvolvimento sustentável estima-se que seja necessária uma redução nos fluxos de matéria e energia consumidas e nos fluxos de resíduos da ordem de 4 a 20 vezes por habitante nos países industrializados. Assim os países em desenvolvimento poderiam elevar seus padrões de consumo a um mesmo nível. Segundo Maxwell e Van der Vorst (2003), questões econômicas, sociais e éticas não são consideradas na abordagem tradicional do ecodesign, e portanto o uso desta abordagem (na qual o objetivo é reduzir os impactos ambientais no ciclo de vida dos produtos) não conduz ao verdadeiro sentido da sustentabilidade. Os autores propõem uma nova abordagem: o 'Desenvolvimento de Produtos e Serviços Sustentáveis' (Sustainable Product and Service Development - SPSD), que incorpora aspectos econômicos, ambientais e sociais no projeto de produtos, visando um balanço ótimo entre proteção ambiental, equidade social e prosperidade econômica, preservando os requisitos tradicionais de qualidade, custo, mercado e funcionalidade (Figura 28).

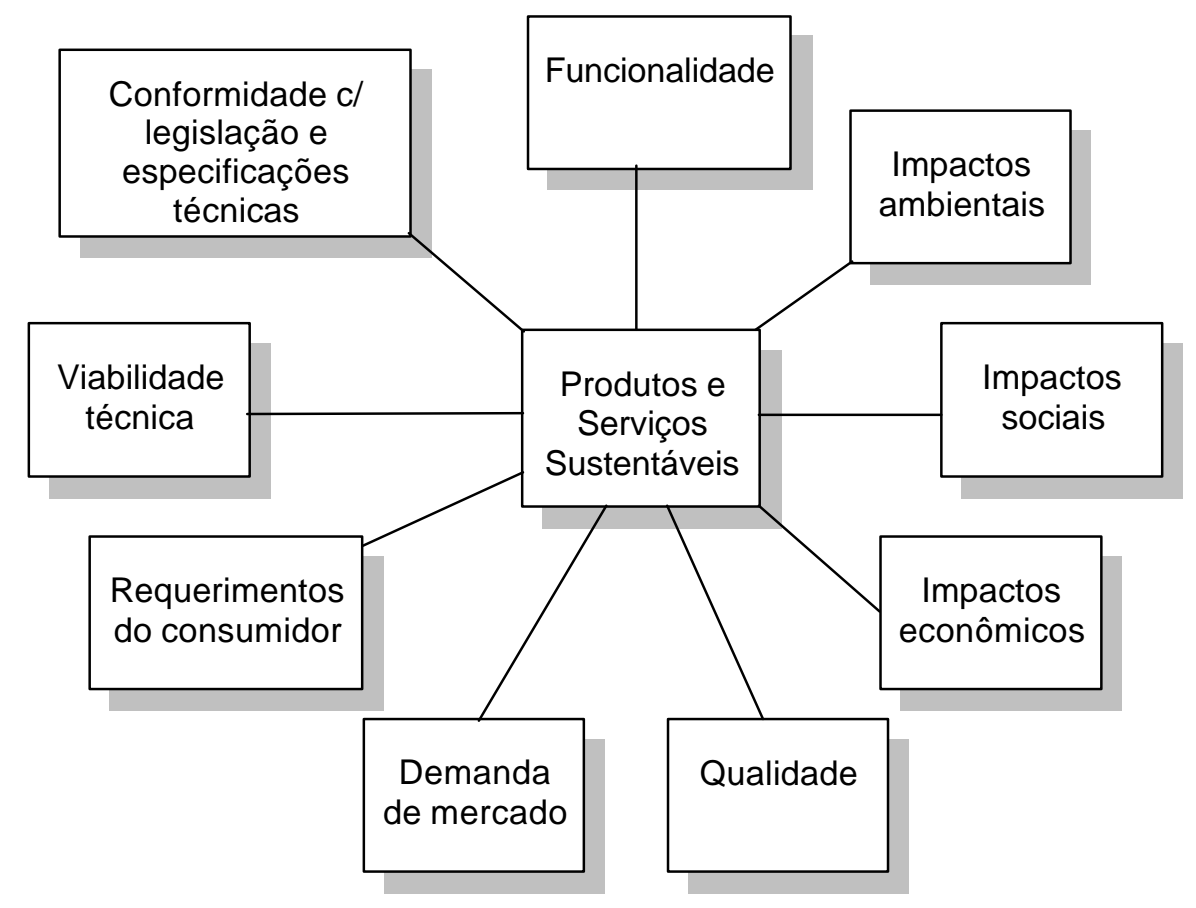

Figura 28 - Critério para a otimização da sustentabilidade de produtos e serviços Fonte: Modificado de MAXWELL e VAN DER VORST, 2003 


\subsubsection{Modificações nas Tecnologias, Processos e Equipamentos}

$\mathrm{Na}$ operação dos sistemas produtivos geralmente o principal objetivo é otimizar o sistema em função da eficiência produtiva e da qualidade do produto final. Entretanto, o fato de um processo operar de maneira eficiente no que diz respeito a estes dois requisitos, não quer dizer que este processo não gere substâncias e resíduos indesejáveis ou que não esteja desperdiçando matérias-primas, insumos e energia (EC, 2001). Como destaca Geiser (1997): "[...] um processo muito eficiente pode ser altamente tóxico, como por exemplo o processo de curtimento de couro, que usa cromo hexavalente e gera resíduos tóxicos [...]".

Em um sistema produtivo, os poluentes, os resíduos, e as perdas de materiais e energia podem ocorrer no processo principal ou em qualquer sub-sistema, como nos sistemas de troca de calor, nos sistemas de aquecimento e resfriamento, nos sistemas de tratamento de água, entre outros. As estratégias de prevenção àpoluição podem envolver modificações no processo principal, melhorias nos sistemas de aquecimento e resfriamento, modificações nos processos e sub-sistemas incorporando equipamentos e operações para recuperar, reciclar e reutilizar materiais e poluentes potenciais. Entretanto, modificações de processo são ações complexas que requerem um profundo conhecimento do processo e suas inter-relações com os sub-sistemas (SPRIGGS, 1994).

A modificação de um processo requer um estudo criterioso, que envolve cálculos e simulações computacionais. Noureudin e El-Halwagi (1999; 2000), apresentam critérios para a simulação de modificações em processos, de forma a reduzir as emissões de poluentes e destacam que antes de tudo, devem ser identificados os pontos do processo onde se deseja realizar a modificação, de acordo com o poluente que se queira eliminar. Para isso os autores sugerem que sejam consideradas as seguintes estratégias:

> Eliminação da espécie poluente, que pode ser realizada de duas formas: a) uso de uma rota de reação alternativa, que não envolva a espécie poluente em questão, nos processos químicos; e, b) substituição dos materiais usados (ex: substituição de solvente, quando o poluente é um de seus componentes).

> Modificação da tecnologia de forma a evitar a dispersão da espécie poluente em outras fases do processo. Como por exemplo: a) uso de processo de limpeza a seco no lugar do processo aquoso convencional para evitar o carreamento da espécie no efluente líquido; b) adotar processos livres de solvente. 
> Usar processos de separação para remover poluentes do fluxo de resíduos, como por exemplo, a remoção de compostos orgânicos por meio de colunas de adsorção seletivas.

> Usar reações químicas ou biológicas para descontaminar fluxos de poluentes, se possível convertendo-os em espécies e componentes que possam ser reutilizados no processo.

\subsubsection{Modificações nas Matérias-Primas e Materiais}

Esta estratégia visa eliminar a quantidade de materiais poluentes, tóxicos ou perigosos nos processos e produtos, reduzindo riscos aos trabalhadores, consumidores, comunidade e meio ambiente. Consiste na substituição de materiais poluentes usados no processo produtivo ou agregados ao produto final por materiais menos poluentes. Inclui também a purificação dos materiais antes destes entrarem no processo produtivo, de forma a remover impurezas e contaminantes (EC, 2001). A substituição de materiais recai em duas categorias:

$>$ Substituição de insumos ${ }^{22}$ : consiste em substituir materiais auxiliares do processo por outros alternativos. Esta substituição nem sempre contribuirá para a prevenção da poluição na etapa do processamento, mas pode refletir na redução dos impactos na etapa de extração e de preparação destes materiais (EC, 2001).

> Substituição da matéria-prima: esta categoria envolve a completa substituição de um material base do processo, por outro menos poluente ou com maior eficiência de conversão. Em alguns casos este tipo de modificação pode envolver também modificações no processo ou nos equipamentos (EC, 2001). Por exemplo, a substituição de tinta a base de solvente por tinta em pó reduz significativamente o consumo de tinta, as emissões atmosféricas e riscos aos trabalhadores. Entretanto esta substituição requer modificação nos equipamentos e no processo.

A substituição de materiais e insumos representa uma ótima estratégia de prevenção à poluição, que em muitos casos requer pouco investimento financeiro. No entanto, é

\footnotetext{
22 São considerados insumos de um processo industrial todas as substâncias e materiais auxiliares, como combustíveis, desengraxantes, produtos químicos diversos, entre outros. Por exemplo em um processo de transformação metal-mecânico a matéria-prima principal é o substrato metálico, e os desengraxantes, solventes, soluções de limpeza e produtos anticorrosivos são insumos deste processo.
} 
preciso que haja a disponibilidade de materiais substitutos efetivos, o que remete à pesquisa e ao desenvolvimento de novos materiais e produtos. Como destaca Geiser (2002b): "[...] a produção e o uso de materiais tóxicos, persistentes e bioacumulativos deve ser substituída através de modificações nos materiais, processos e grupos funcionais, e isto deve incluir substâncias reconhecidamente impactantes como o mercúrio, cobalto, vanádio e bifenilas policloradas, bem como hidrocarbonetos poliaromáticos. A substituição destes materiais representa um grande desafio e um campo vasto para a pesquisa nas áreas de engenharia química, materiais e outras [...]".

\subsubsection{Melhorias Operacionais ${ }^{23}$}

Estas estratégias são simples, geralmente de baixo custo e resultam em ganhos ambientais e em eficiência significativos. Oportunidades vantajosas envolvendo a melhorias operacionais existem tanto em pequenas quanto em grandes empresas, e são aplicáveis particularmente àindústrias com uso significativo de água e solventes, com produção de efluentes líquidos e resíduos perigosos. Estes objetivos podem ser alcançados através de melhorias básicas nas operações e procedimentos de rotina, tais como programação da produção de modo a minimizar trocas de equipamentos e insumos; melhorias em atividades e escalas de manutenção; separação de sub-produtos na fonte; treinamento de funcionários para minimizar perdas no manuseio de insumos e incentiválos a implementar boas práticas de manutenção e a identificar oportunidades de prevenção à poluição. Tradicionalmente as técnicas e ações envolvendo melhorias nas práticas operacionais podem ser agrupadas em cinco categorias, descritas a seguir.

\subsection{Operações básicas}

\section{$>$ Melhorias gerais:}

- Treinar funcionários sobre o manuseio seguro de materiais e resíduos;

- Formular procedimentos escritos sobre o uso correto de equipamentos de forma clara e compreensível;

- Tampar containeres e tambores com tampas perfeitamente ajustáveis, de forma a evitar a volatilização de substâncias e a contaminação dos produtos;

\footnotetext{
${ }^{23}$ As informações contidas em todos os itens deste tópicos foram extraídas de Environment Canada (2001).
} 
- Usar mangueiras com controladores de fluxo e corta-respingos em containeres e bombonas para prevenir respingos e gotejamentos;

- Treinar os funcionários para que retornem os containeres vazios antes de utilizar outros;

- Usar as matérias-primas e insumos apenas para o seu uso especificado;

- Retornar containeres usados para os fornecedores e aceitar recipientes retornáveis de clientes;

- Avaliar a viabilidade de modificar tamanho e forma de containeres para reduzir a geração de resíduos e melhorar a eficiência de manuseio dos produtos.

\section{Melhorias na operação de equipamentos e programação da produção:}

- Maximizar o volume das cargas dos processos em batelada, para minimizar a necessidade de limpeza dos tanques;

- Dedicar um equipamento para um único produto ou operação;

- Vistoriar vazamentos em containeres, reatores, tanques, bombas, tubulações e válvulas;

- Manter e operar adequadamente equipamentos e processos para prevenir produtos fora de especificação, excessos e gastos desnecessários de materiais, insumos, soluções, catalisadores, etc.

- Instalar alarmes de sobre-fluxo e válvulas de alívio;

- Manter boa vedação em tubulações, bombas e válvulas;

- Testar containeres periodicamente; e,

- Usar bacias de contenção em containeres, tanques, reatores, etc, para conter possíveis vazamentos.

\subsection{Limpeza e Manutenção}

Se adequadamente realizadas, as operações de limpeza e manutenção previnem e corrigem fontes de resíduos e poluição, reduzem custos operacionais e aumentam a qualidade dos produtos. Dentre as oportunidades destacam-se:

- Esperar a drenagem completa de líquidos dos equipamentos antes de executar a limpeza; 
- Desenvolver e usar rotinas de manutenção preventiva de equipamentos;

- Programar atividades de limpeza e manutenção regulares para evitar a contaminação do produto, remover depósitos, manter a eficiência do processo, prolongar a vida útil dos equipamentos, etc.;

- Programar operações e tarefas em batelada para reduzir a freqüência das operações de limpeza;

- Usar sprays de alta pressão em tanques de enxague;

- Realizar inspeções visuais mensais para verificar vazamentos e danos em todos os processos, tanques de estocagem, e todos equipamentos ligados ao processo;

- Regular e calibrar todos os controladores automáticos para aumentar a produtividade e evitar perdas.

\subsection{Manuseio e Estocagem de Resíduos e Materiais}

Exemplos de ações envolvendo o manuseio e estocagem de resíduos e materiais incluem:

- Estocar materiais em áreas que assegurem condições para preservação da qualidade e requerimentos destes materiais;

- Usar tanques e containeres grandes o suficiente para evitar derramamentos;

- Usar funis para o enchimento de tambores e bombonas;

- Manter materiais cobertos para evitar perdas e contaminações;

- Estocar materiais sobre pallets para facilitar a detecção de vazamentos;

- Rotular e armazenar resíduos de acordo com sua classificação e com a regulamentação;

- Rotular os resíduos ainda na fonte, enquanto este ainda pode ser identificado corretamente;

- Separar resíduos armazenados de acordo com a toxicidade, tipo de contaminante e propriedades físicas, para facilitar as operações de manuseio, transporte e disposição;

- Prevenir a contaminação de materiais inertes por resíduos e substâncias tóxicas, através da segregação e estocagem corretas; 
- Evitar tanques de estocagem subterrâneos sempre que possível;

- Providenciar bacias de contenção ao redor de áreas de armazenamento de substâncias;

- Armazenar resíduos e substâncias tóxicas em áreas seguras e que não apresentem riscos de contaminação do lençol freático, em caso de vazamentos acidentais;

- Providenciar kits de emergência para limpeza e contenção de vazamentos, e treinar os funcionários no seu uso;

\subsection{Controle de Processo}

O controle do processo é crucial no que diz respeito àeficiência do sistema produtivo e independente de preocupações ambientais, é sempre o foco central da atenção dos responsáveis pela produção nas plantas industriais. Em muitos casos, melhorias no controle do processo podem representar boas oportunidades de prevenção àpoluição. $A$ otimização do controle de processo requer um levantamento detalhado da dinâmica do processo. De maneira simplificada, as oportunidades envolvendo o controle de processo podem ser divididas nas seguintes categorias:

- Redução da geração de resíduos através de melhorias na eficiência do processo;

- Pré-tratamento de efluentes que contenham contaminantes por meio de reações químicas;

- Segregação e reciclagem de resíduos contendo poluentes.

A introdução de controladores auto-ajustáveis que se adaptem à dinâmica do processo e que selecionem automaticamente os parâmetros de controle é um exemplo de controle de processo que contribui para a melhoria da eficiência. Ainda, técnicas de controle estatístico de processo que determinam parâmetros ótimos para o processo, melhoram a eficiência e reduzem perdas e consumo desnecessário de materiais e energia.

\subsection{Boas Práticas Operacionais (housekeeping)}

As boas práticas operacionais envolvem rotinas e ações que todos os funcionários envolvidos podem executar, e incluem: 
- Manter as áreas de trabalho e os locais de estocagem de materiais limpos e bem organizados, e containeres corretamente identificados;

- Verificar ocorrências de vazamentos (mesmo que pequenos) para assegurar a limpeza e manutenção;

- Usar adsorventes para a limpeza de vazamentos;

- Tomar cuidado ao executar operações de manuseio e transferência de materiais, para evitar respingos, gotejamentos e derramamentos.

\subsubsection{Aquisição Ambientalmente Favorável}

As estratégias de aquisição ambientalmente favorável envolvem a integração de considerações ambientais nas práticas de aquisição de matérias-primas e insumos de produção e de serviços. Através delas, as companhias podem reduzir consumo de materiais e energia, evitar substâncias tóxicas desnecessárias em seus produtos, minimizar a geração de resíduos e, em muitos casos reduzir os custos associados à aquisição de materiais (EC, 2001). Estas estratégias podem envolver acordos e parcerias com toda a cadeia de fornecedores, de modo a permitir que os materiais sejam adquiridos dentro dos requisitos ambientais estabelecidos pela companhia, como especificação do produto, volume, forma de embalagem e retorno ao fornecedor (US EPA, 2000c) ${ }^{24}$. As técnicas de aquisição ambientalmente favorável disponíveis podem ser agrupadas nas seguintes categorias: a) aquisição para fins específicos, b) especificações ambientais (green specifications), c) proibição e limitação do uso de certas substâncias, d) listagem de produtos aprovados, e) qualificação de fornecedores, f) parcerias com fornecedores.

\subsubsection{Aquisição para Fins Específicos}

Existem diversos exemplos de redução de resíduos através da aquisição de materiais para fins específicos. Dentre as estratégias destacam-se:

- Minimização do uso de diferentes produtos para uma mesma função: uma revisão cuidadosa dos relatórios de compra frequentemente revelam a compra de diversos produtos, em pequenas quantidades, que têm uma função idêntica ou similar. Entretanto, produtos tais como solventes, lubrificantes entre outros, são

\footnotetext{
${ }^{24}$ A US EPA elaborou um manual específico para orientar sobre como efetuar o gerenciamento da cadeia de fornecedores: The Lean and Green Supply Chain: A Practical Guide for Materials Managers and Supply Chain Managers to Reduce Costs and Improve Environmental Performance. Washington: EPA 742-R-00-001, 58p.
} 
encontrados em diferentes composições e embalagens. Uma análise criteriosa na compra destes materiais deve levar em consideração os impactos ambientais dos produtos e a possibilidade da compra em embalagens retornáveis, de maior volume.

- Adquirir materiais no tamanho necessário: grandes quantidades de sobras de materiais e sucatas podem ser evitadas se materiais como tecidos, plásticos, chapas metálicas, papelão, isopor, embalagens, entre outros, forem adquiridos nas medidas especificadas para a função que irão executar, eliminando a necessidade de cortes.

- Aquisição de materiais em containeres ou bombonas: a aquisição de materiais em grandes volumes reduz a geração de resíduos de embalagens e aumenta a eficiência na entrega e distribuição dos materiais. Entretanto, deve-se prestar atenção na demanda para a quantidade dos materiais, bem como prazos de validade dos mesmos, para evitar a geração de resíduos na forma de produtos vencidos ou não-usados. Com relação aos produtos químicos, deve-se prever as condições de segurança para garantir a estocagem segura dos produtos (EC, 2001).

\subsubsection{Especificações Ambientais (Green Specifications)}

A cada dia as companhias e consumidores corporativos vêm adotando especificações ambientais em seus produtos e embalagens. Estas especificações podem estar relacionadas a uma série de atributos, incluindo o produto ou o conteúdo da embalagem, rotulagem, critérios de design, reusabilidade do produto e políticas de retorno ao fabricante de produtos fora de especificação ou gastos. O principal desafio desta estratégia está na dificuldade em se obter informações sobre os impactos ambientais de certos produtos no seu ciclo de vida; para muitos produtos esta informação não existe. Para suprir esta limitação, as companhias podem adotar programas de rotulagem ambiental, extendendo-os àcadeia de fornecedores (EC, 2001).

\subsubsection{Proibição ou Limitação de Certas Substâncias}

A proibição ou limitação do uso de determinados produtos ou substâncias geralmente está relacionada ao cumprimento de regulamentações que proíbem o uso destas substâncias. Este tipo de atitude faz com que os fornecedores alterem seus produtos a uma nova formulação livre das substâncias proibidas. Na prática, é necessário que as 
companhias criem um inventário das substâncias proibidas, fornecendo uma lista de opções de novos produtos e substâncias. Este tipo de medida envolve diversas áreas, como de pesquisa e desenvolvimento, produção, engenharia de fábrica, segurança, saúde e meio ambiente, e a área de compras, que é a responsável por comunicar a decisão aos fornecedores (EC, 2001).

\subsubsection{Listagem de Produtos Aprovados}

A criação de uma lista de produtos aprovados, de acordo com os requisitos e atributos ambientais específicos da companhia simplifica o processo de compra, uma vez que não requer que os funcionários façam julgamentos individuais sobre os impactos ambientais de diferentes produtos, o que pode gerar distorções na aquisição de produtos (EC, 2001).

\subsubsection{Qualificação de Fornecedores}

Algumas companhias podem requerer de seus fornecedores uma pré-qualificação, que pode envolver a adoção de uma política ambiental corporativa por parte do fornecedor ou a adoção de códigos de conduta ambiental específicos, como o Responsible Care, para o caso do fornecedor pertencer ao segmento químico, e normas de certificação ambiental, como a ISO 14001. Estes requisitos geralmente são um componente dos programas de gerenciamento de risco ambiental corporativo das companhias (EC, 2001).

\subsubsection{Parcerias com Fornecedores}

Nos últimos anos, em decorrência da necessidade adequação das especificações de produtos e materiais, da redução do volume de resíduos e outras necessidades voltadas à satisfação de requisitos ambientais, as empresas têm estabelecido iniciativas para trabalhar conjuntamente com seus fornecedores, este tipo de colaboração pode ocorrer a partir das seguintes iniciativas:

- Desenvolvimento de programas para o retorno de produtos fora de especificação ou sucatas aos fabricantes para reciclagem e reúso;

- Uso de embalagens reusáveis para o transporte e entrega de componentes;

- Envolvimento dos fornecedores em programas de pesquisa e desenvolvimento;

- Criação de parcerias visando a adoção de critérios de desmontagem, reciclagem, entre outros no projeto dos produtos; 
- Adoção de sistema de consignação de equipamentos e serviços, onde o fornecedor detêm a propriedade e a responsabilidade por certos equipamentos (ou partes); e,

- Treinamento de fornecedores visando aumentar sua capacidade no gerenciamento ambiental (EC, 2001).

\subsubsection{Gerenciamento de Inventário Ambientalmente Responsável}

O gerenciamento de inventário ambientalmente responsável está relacionado à estratégias de recebimento e entrega de produtos através da garantia que os materiais estocados não permaneçam em estoque após seus prazos de validade, e do controle de qualidade de matérias-primas para prevenir produtos fora de especificação. Uma série de técnicas podem ser adotadas para o gerenciamento de inventário, descritas a seguir.

\subsubsection{Gerenciamento da Demanda de Materiais}

A primeira consideração a ser feita na aplicação da estratégia de gerenciamento de inventário é o gerenciamento da demanda de materiais, um processo que fornece um entendimento amplo das necessidades de material da companhia. O gerenciamento da demanda de materiais envolve as seguintes etapas:

- Previsão da produção e outras atividades com base em programação de atividades agendadas;

- Divisão de cada atividade em tarefas identificáveis;

- Avaliação de cada tarefa com o foco nos materiais requeridos, níveis de uso e taxas de consumo;

- Combinação de requerimentos de materiais de atividades e tarefas individuais, de modo a determinar os requerimentos da atividade operacional como um todo;

- Determinação das taxas de suprimento do estoque requeridas para as operações agendadas; e,

- Identificação de uma central de fornecimento para suprir a demanda operacional. 


\subsubsection{Inspeções de Materiais}

Matérias-primas e outros materiais devem ser inspecionados criteriosamente no ato do seu recebimento, de modo que materiais e produtos defeituosos ou fora de especificação sejam imediatamente retornados ao fabricante. Produtos e materiais defeituosos que por ventura possam, por desconhecimento ou falha no controle de qualidade, entrar no processo produtivo resultam numa série de problemas, como baixa qualidade e/ou performance do produto final, perda de materiais no processo por falhas e rupturas, ou no caso de produtos químicos, contaminação do produto final e risco potencial àsaúde e segurança dos funcionários.

\subsubsection{Identificação de Requerimentos de Estocagem}

Cada material apresenta requerimentos de estocagem específicos, tais como temperatura, luminosidade, compatibilidade e tempo de armazenagem. A determinação e a observação destes requisitos pode reduzir a geração de resíduos e manter a qualidade das matérias-primas e insumos do processo. Os requerimentos de estocagem devem ser identificados para todos os materiais passíveis de estoque, e os procedimentos devem ser divulgados e disponibilizados para garantir que estas condições sejam cumpridas.

\subsubsection{Movimentação de Estoque}

Procedimentos de movimentação de estoque podem garantir que os materiais sejam utilizados em uma base entrada-uso, ou seja, garante que os materiais já estocados sejam usados antes daqueles recém-chegados ao estoque. É comum que ao estocar materiais, estes sejam empilhados ou enfileirados, e aqueles recentemente adquiridos acabam ficando mais acessíveis ao uso (nas porções superiores da pilhas). A movimentação do estoque previne a geração de resíduos associados aos materiais vencidos. O gerenciamento de inventário pode ser usado para monitorar a efetividade destes procedimentos, por meio da inspeção de datas de validade de materiais em estoque.

\subsubsection{Redução de Estoque e Melhorias dos Procedimentos de Entrega}

Ao realizar um inventário da quantidade mínima de materiais e substâncias tóxicas e perigosas requeridas para não interromper a produção, as companhias podem reduzir significativamente os riscos associados àarmazenagem destes produtos. Melhorias nos procedimentos de entrega, adotando o sistema just-in-time, também podem reduzir danos aos materiais durante a movimentação e estocagem (EC, 2001). 


\subsubsection{Reciclagem e Reúso no Processo}

A reciclagem e o reúso no processo compreendem processos para a reutilização e a reciclagem dos materiais e resíduos no mesmo processo onde estes foram originados. $O$ reúso corresponde ao re-emprego de sub-produtos ou materiais no processo ou operação onde foi originalmente produzido ou em outras aplicações, regenerando-o à sua especificação original ou outra, quando necessário. A reciclagem é a extensão da vida efetiva de recursos renováveis e não-renováveis, utilizando para isso processos ou outras práticas, com a adição de energia. Se conduzidas de forma adequada, a reciclagem e o reúso são ambientalmente mais aceitáveis que o tratamento no fim do tubo (EC, 2001).

No entanto, é necessário que se faça uma avaliação criteriosa com relação ao consumo de energia e às interferências que o material reciclado ou reutilizado possa ter na qualidade do produto final. Convém salientar que a reciclagem não representa uma solução definitiva para o problema de geração e disposição de resíduos, já que implica em custos e possui limitações teóricas e práticas, em termos da porcentagem de um determinado resíduo que pode ser utilizada no processo da reciclagem (KIRKWOOD e LONGLEY, 1995).

A reciclagem e o reúso no processo são aplicáveis tanto para grandes indústrias quanto pequenas. No caso de indústrias com elevada geração de resíduos e consumo de água, ou com geração de resíduos de elevado valor agregado, os benefícios ambientais e econômicos da reciclagem e do reúso são significativos. Estas estratégias no entanto podem ter pouca aplicabilidade no caso de pequenas indústrias, com pouca geração de resíduos, pois neste caso a relação custo-benefício pode ser desfavorável, ou o material recuperado pode não ter uma aplicação no processo $(E C, 2001)$. Materiais que podem ser reusados e reciclados incluem matérias-primas, produtos químicos e águas residuárias tratadas e não tratadas. Como exemplos podem ser citados os processos de recuperação de metais por troca iônica ou osmose reversa, reciclagem de água de resfriamento, etc. Em alguns casos o reúso pode ser viabilizado pela ação cooperativa entre duas ou mais plantas industriais, em um esquema de simbiose industrial (item 2.3.6). Este esquema se mostra de grande valia naqueles casos onde as estratégias de prevenção à poluição in site não são viáveis econômica ou tecnicamente (KIRKWOOD e LONGLEY, 1995). 


\subsubsection{Técnicas de Segregação e Separação}

Tanto a reciclagem quanto o reúso implicam na separação dos materiais em seus fluxos. Existem diferentes tecnologias de separação, que dividem-se em técnicas de separação de fluxos sólido-sólido, sólido-líquido e gás-líquido.

Para a separação de materiais na fase sólida podem ser empregadas técnicas de peneiramento e separação magnética, além da separação manual. Para remover resíduos na fase líquida podem ser empregadas técnicas de precipitação por meio de ajuste de pH, troca iônica, osmose reversa, diálise e eletrodiálise, micro e ultra-filtração, desaguamento e extração. Para separar resíduos na fase gasosa, podem ser usadas técnicas de adsorção, separação por membranas, absorção e condensação.

Para aumentar a taxa de recuperação de resíduos, frequentemente é preciso separar os resíduos tóxicos ou recuperáveis do fluxo total. As técnicas aplicáveis vão desde a segregação simples até o emprego de tecnologias complexas. Um dos melhores e mais eficientes lugares para recuperar resíduos de processo é o seu ponto de geração. Neste ponto, a possibilidade de contaminação do material por outro resíduo é mínima. A segregação de resíduos, perigosos ou não, na fonte pode reduzir o volume e os custos com o manuseio (EC, 2001).

\subsubsection{Purificação}

Após a recuperação dos resíduos, pode ser necessária a purificação destes materiais antes do seu reúso ou reciclagem. As técnicas de purificação podem ser físicas ou químicas e envolvem técnicas tais como filtração simples, troca iônica, evaporação, destilação, precipitação, osmose reversa, entre outras. A maioria dos processos de recuperação in site produz algum tipo de rejeito (contaminantes removidos do material recuperado), que pode ainda ser processado para reutilização posterior. Caso a reutilização não seja possível, este deve ser adequadamente disposto (EC, 2001).

\subsubsection{Métodos de Reciclagem e Reúso}

Existem vários métodos para a reciclagem e o reúso de materiais, de acordo com as fontes e os tipos de resíduos e com as várias operações e processos industriais. Quadro 9 ilustra alguns métodos de reciclagem e reúso correntemente empregados, de acordo com diferentes fontes geradoras. 
Quadro 9 - Métodos de reciclagem e reúso.

\begin{tabular}{|c|c|c|}
\hline Fonte & Resíduo & Métodos \\
\hline $\begin{array}{c}\text { Recebimento de } \\
\text { materiais }\end{array}$ & $\begin{array}{l}\text { Embalagens, materiais } \\
\text { fora de especificação, } \\
\text { containeres e tambores } \\
\text { contaminados ou } \\
\text { danificados, resíduos de } \\
\text { derramamentos e de } \\
\text { operações de } \\
\text { transferência. }\end{array}$ & $\begin{array}{l}\text { Criar um inventário de produtos químicos passíveis } \\
\text { de serem enviados para uso em outros setores; } \\
\text { Encontrar usos para materiais fora de } \\
\text { especificação; } \\
\text { Receber e encaminhar materiais em containeres } \\
\text { reusáveis; } \\
\text { Usar tambores e containeres laváveis e recicláveis. }\end{array}$ \\
\hline $\begin{array}{c}\text { Estocagem de } \\
\text { produtos e } \\
\text { matérias-primas }\end{array}$ & $\begin{array}{l}\text { Resíduos de fundo de } \\
\text { tanque, materiais fora de } \\
\text { especificação ou em } \\
\text { excesso, resíduos de } \\
\text { vazamentos, containeres } \\
\text { vazios ou danificados }\end{array}$ & $\begin{array}{l}\text { Usar sistemas de recuperação a vapor; } \\
\text { Esvaziar containeres e tambores completamente } \\
\text { antes da limpeza ou disposição; } \\
\text { Encontrar usos para materiais fora de } \\
\text { especificação. }\end{array}$ \\
\hline Laboratórios & $\begin{array}{l}\text { Reagentes contaminados } \\
\text { ou gastos, produtos } \\
\text { químicos fora de } \\
\text { especificação, frascos } \\
\text { vazios. }\end{array}$ & $\begin{array}{l}\text { Encontrar usos para produtos fora de } \\
\text { especificação; } \\
\text { Reusar e reciclar solventes gastos; } \\
\text { Recuperar metais de catalisadores. }\end{array}$ \\
\hline $\begin{array}{c}\text { Operações e } \\
\text { processos }\end{array}$ & $\begin{array}{l}\text { Vazamentos, efluentes de } \\
\text { enxague, solventes, } \\
\text { borras de desengraxante, } \\
\text { areia de jateamento, } \\
\text { sucatas metálicas, óleos e } \\
\text { graxas, borra e ácido } \\
\text { gasto da limpeza de } \\
\text { trocadores de calor. }\end{array}$ & $\begin{array}{l}\text { Reusar materiais não contaminados; } \\
\text { Reciclar água em enxague contra-corrente; } \\
\text { Reciclar óleos e tintas; } \\
\text { Limpar e reutilizar tapetes e absorventes; } \\
\text { Recuperar produtos químicos e metais de fluxos de } \\
\text { efluentes; } \\
\text { Reciclar solventes; } \\
\text { Segregar fluxos de resíduos perigosos daqueles } \\
\text { não perigosos, resíduos recicláveis dos não- } \\
\text { recicláveis, por tipo. }\end{array}$ \\
\hline
\end{tabular}

Fonte: Environment Canada (2001). 


\subsubsection{Reúso e Reciclagem de Água}

O reúso e a reciclagem de água em processos industriais, além de contribuírem para a economia e a preservação dos recursos hídricos, também contribuem para a minimização dos resíduos gerados nas estações de tratamento de efluentes. Uma vez que uma parcela menor de efluente é enviada para o tratamento, uma quantidade menor de borra é gerada. Ainda, é reduzida a quantidade de produtos químicos auxiliares usados na planta de tratamento, o que implica em uma redução do volume de embalagens destes produtos.

De acordo com as definições adotadas por Brega Filho e Mancuso (2003), o reúso e a reciclagem de água industrial recaem em duas categorias, de acordo com o escopo deste trabalho:

- Reúso direto planejado da água: ocorre quando os efluentes, após tratamento, são encaminhados diretamente de seu ponto de descarga até o local do reúso. Neste caso, o reúso enquadra-se como 'Reúso não potável para fins industriais', no qual os efluentes não são, em momento algum descarregados no meio ambiente. Abrange os usos industriais de refrigeração, águas de processo, utilização em caldeiras, etc.

- Reciclagem da água ${ }^{25}$ : é o reúso interno da água, antes de sua descarga em um sistema geral de tratamento ou local de disposição, para servir como fonte suplementar de abastecimento do uso original. É um caso particular de uso direto.

As oportunidades para a reciclagem de água industrial são muitas, mas dependem dos requerimentos de qualidade do processo que a receberá. Exemplos de aplicações de reciclagem de água industrial incluem:

- Efluentes de torres de resfriamento: podem ser reciclados para uso em operações de limpeza, em caldeiras e em lavadores de gases.

- Efluentes de tanques de enxague: podem ser recicladas para uso em sistemas de enxague contra-corrente.

- Condensados de tanques e processos: podem ser reciclados como água para uso em caldeiras (EC, 2001).

\footnotetext{
${ }^{25}$ Ao contrário da 'reciclagem de resíduos', que implica em uma transformação para posterior uso, a água reciclada não passa por nenhum processo de tratamento.
} 
O reúso de águas residuárias (após tratamento), do mesmo modo que a reciclagem, também depende de fatores relacionados aos requisitos de qualidade da água. Depende ainda da disponibilidade de tecnologias de tratamento que sejam economicamente viáveis. Oportunidades para o reúso de água industrial incluem o reúso em torres de resfriamento, trocadores de calor, caldeiras e no processo. Exemplos de tecnologias de tratamento de águas residuárias para reúso são mostrados no Quadro 10 (EC, 2001).

Quadro 10 - Tecnologias de tratamento para o reúso de água.

\begin{tabular}{|c|c|}
\hline Tecnologia & Aplicação \\
\hline Osmose reversa & Remoção de $\mathrm{DBO}^{1}, \mathrm{DQO}^{2}, \mathrm{SDT}^{3}, \mathrm{SST}^{4}, \mathrm{NH}_{3}$ e fósforo \\
\hline Eletrodiálise & Remoção de SDT e recuperação de sais metálicos \\
\hline Ultrafiltração & Remoção de SDT, turbidez e óleos \\
\hline Troca iônica & Remoção de SDT, íons metálicos e dureza \\
\hline Carvão ativado & Remoção de compostos orgânicos e inorgânicos \\
\hline Sedimentação & Remoção de sólidos mais densos que a água \\
\hline Filtração & $\begin{array}{l}\text { Desaguamento de lodos, remoção de sólidos suspensos, pré- } \\
\text { tratamento }\end{array}$ \\
\hline Evaporação & $\begin{array}{l}\text { Tratamento de solventes, separação de sólidos suspensos e } \\
\text { dissolvidos }\end{array}$ \\
\hline Ajuste de pH e precipitação & $\begin{array}{l}\text { Remoção de metais na forma de sais de banhos ácidos de } \\
\text { processos de tratamento de metais, neutralização de ácidos e } \\
\text { bases }\end{array}$ \\
\hline Desaguamento & Redução da umidade de borras \\
\hline
\end{tabular}

Fonte: Environment Canada, (2001). 


\subsubsection{Treinamento e Envolvimento dos Funcionários}

O treinamento e o envolvimento dos funcionários em todos os níveis é fundamental nas questões relacionadas ao gerenciamento ambiental em uma indústria, especialmente durante as etapas de implantação de projetos de prevenção àpoluição e minimização de resíduos. O treinamento e envolvimento é um requisito fundamental de diversos códigos de conduta ambiental, como os sistemas de gestão ambiental, a norma ISO 14001, o programa Atuação Responsável e outras iniciativas citadas anteriormente.

As estratégias de prevenção à poluição envolvem o projeto ou a reformulação dos produtos, modificações em tecnologias, processos e equipamentos, substituição de materiais e modificações e melhorias em procedimentos e práticas operacionais. $\mathrm{O}$ sucesso na implementação de qualquer uma destas estratégias depende da cooperação e do envolvimento de um grande número de pessoas, como encarregados de produção, operadores, técnicos, engenheiros, supervisores, gerentes e coordenadores de projetos.

Pesquisas realizadas em companhias que têm adotado práticas formais para o envolvimento de seus funcionários (formando eco times) mostram que estas companhias obtêm três vezes mais redução nas emissões do que companhias que adotaram as mesmas estratégias, sem uma integração mais profunda dos seus funcionários. Isto decorre do fato de a prevenção requerer a identificação 'das melhores práticas', e isso por sua vez requer o profundo conhecimento do processo e de todas as atividades relacionadas, e quem detém estas informações são aqueles funcionários envolvidos nas rotinas diárias (operadores e encarregados de produção), que muitas vezes não recebem o treinamento ou a motivação necessária. A integração e a participação dos funcionários pode ser alcançada adotando-se as seguintes práticas (OCHSNER, 2001):

- Promover palestras de conscientização, destacando a importância da participação e da responsabilidade de cada um no resultado global;

- Estabelecer uma forma de reconhecer o funcionário por sua contribuição na melhoria da qualidade ambiental;

- Enfatizar que as estratégias de prevenção à poluição resultam em benefícios comuns, e não apenas na redução de custos com tratamento de resíduos e desperdício de materiais;

- Divulgar os resultados positivos alcançados pelos eco-times, e se possível criar mecanismos de compensação e gratificação para os envolvidos. 


\subsection{Benefícios da Prevenção àPoluição}

A justificativa para a implementação de práticas de prevenção à poluição parte da premissa básica de que a prevenção não irá requerer no futuro, o consumo de recursos e energia para controlar (isto é, tratar e dispor) a poluição hoje gerada. A prevenção à poluição traz benefícios para o meio ambiente e para a indústria, como redução do desperdício de recursos naturais, matérias-primas e insumos; redução da poluição associada à extração de matérias-primas e manufatura de produtos; redução de substâncias tóxicas nos resíduos, redução de custos com tratamento, transporte e disposição de resíduos; aumento nos lucros e na produtividade. Os principais benefícios resultantes da adoção de práticas de prevenção àpoluição, segundo a US EPA (2001a) são sumarizados nos tópicos a seguir.

\subsubsection{Redução de Custos Operacionais}

As práticas de prevenção à poluição geralmente resultam na redução de custos. Muitos projetos têm bons retornos dos investimentos em um curto período de tempo. A prevenção à poluição pode resultar em redução de custos decorrentes da redução do consumo de água e energia e do aumento da produtividade. Pode representar ainda redução de custos com o tratamento e disposição de resíduos.

\subsubsection{Melhoria das Condições de Trabalho}

A redução do uso de substâncias tóxicas e materiais perigosos proporciona melhoria nas condições de trabalho, que também resulta na redução do uso de equipamentos de proteção individual (EPl's) obrigatórios. Esta redução no uso de EPl's por sua vez resulta nos seguintes benefícios:

- aumento da satisfação e conforto do trabalhador;

- redução de gastos com aquisição dos EPl's;

- redução da geração de resíduos sólidos.

Ao se reduzir vazamentos, gotejamentos e emissões de substâncias tóxicas, reduz-se a exposição de trabalhadores e outras pessoas que possam estar na área de processo aos seguintes riscos:

- inalação de substâncias tóxicas;

- contato de substâncias tóxicas ou perigosas na pele; e, 
- riscos de fraturas físicas devido a escorregamentos.

Com a redução da exposição dos trabalhadores a riscos de acidentes, reduz-se custos com seguros de saúde e com afastamentos. No entanto, existem alguns casos onde as práticas de prevenção àpoluição podem inadvertidamente diminuir a segurança do trabalhador. Esta questão será abordada no item 2.7 deste capítulo.

\subsubsection{Redução dos Custos com a Conformidade Ambiental}

Estes custos envolvem todos os gastos relacionados ao cumprimento da legislação aplicável à atividade industrial, processo produtivo, produto ou serviço em questão. A adoção de práticas de prevenção à poluição pode reduzir a vulnerabilidade daquele empreendimento em relação aos órgãos de controle e fiscalização ambientais e em alguns casos eliminar a necessidade de autorizações, manifestos, monitoramento e relatórios, que demandam tempo e dinheiro.

\subsubsection{Aumento da Produtividade}

As práticas de prevenção à poluição resultam em aumento da produtividade uma vez que promovem o uso mais eficiente das matérias-primas, através de melhorias no processo e nas práticas operacionais. De maneira geral, indústrias que geram grandes volumes de resíduos (efluentes, emissões gasosas, produtos defeituosos, perda de material por contaminação, etc) usam tecnologias de produção ultrapassadas ou seus processos são mal controlados ou operados de maneira ineficiente. Nestes casos, melhoria nos processos (algumas vezes muito pequenas e de baixo custo) que envolvem a substituição de material e modificações de procedimentos operacionais podem resultar no aumento da produtividade e na melhoria da qualidade do produto.

\subsubsection{Melhoria da Qualidade Ambiental}

Algumas formas de tratamento e disposição de resíduos resultam em uma proteção ambiental menor do que aquela que havia sido previamente estipulada nas etapas de projeto das instalações de tratamento. O tratamento e a disposição final de resíduos (apesar de fundamentais e imprescindíveis), quase sempre atuam no sentido de transferir os contaminantes de um meio para o outro, e podem representar riscos ambientais futuros. A prevenção à poluição reduz a geração de contaminantes na fonte, logo, assegura a proteção do meio ambiente a longo prazo. 


\subsubsection{Redução de Custos e Responsabilidades Futuras}

As responsabilidades decorrentes da disposição de resíduos em aterros industriais, emissões e descargas de efluentes têm se tornado recentemente uma grande preocupação. Algumas formas de disposição utilizadas no passado, embora legais na época, causaram danos ambientais pelos quais as indústrias foram responsabilizadas, resultando em despesas com recuperação ambiental e no comprometimento da imagem da empresa perante os órgãos ambientais e a opinião pública. A prevenção à poluição pode reduzir o risco de responsabilidades futuras através da redução do volume e toxicidade dos resíduos.

\subsubsection{Melhoria Contínua}

A implantação de um programa ou de práticas de prevenção àpoluição pode se tornar parte integrante do sistema de gestão ambiental ou de programas de melhoria contínua ou de qualidade da companhia. A redução de perdas de processo (resíduos) e o aumento da eficiência são metas comuns da prevenção à poluição, da melhoria contínua da qualidade e dos sistemas de gestão ambiental.

\subsubsection{Conservação de Recursos}

As práticas de prevenção à poluição sempre levam à redução do consumo de recursos (água, energia e matérias-primas). Tradicionalmente as companhias têm programas distintos para a conservação de recursos (conservação de água e energia) e de prevenção àpoluição. Ao unir estes programas, aumentam as chances de melhoria da eficiência e de se alcançar as metas de sustentabilidade da companhia.

\subsubsection{Melhoria da Imagem}

A adoção de práticas de prevenção àpoluição pode ajudar a companhia a criar uma imagem positiva perante a comunidade ao mostrar que adota medidas para melhorar 0 ambiente (que é comum a todos).

\subsection{Barreiras àlmplantação da Prevenção àPoluição na Indústria}

Segundo Schmidheiny (1992), existem três impedimentos principais que servem como barreiras para a adoção de posturas ambientalmente corretas: as preocupações econômicas, a falta de informações e as atitudes da administração. 
Segundo a US EPA (2001a) as barreiras àimplementação de programas ou práticas de prevenção àpoluição são as seguintes:

\subsubsection{Investimentos}

A implementação de um programa de prevenção à poluição ou de estratégias isoladas, normalmente requer algum investimento financeiro. Este tipo de projeto precisa ser justificado economicamente e está sujeito à disponibilidade de capital. No entanto, muitas vezes os relatórios de justificativa dos projetos envolvendo as práticas de prevenção à poluição podem não reconhecer os ganhos embutidos que o projeto pode conceder àcompanhia e as reduções orçamentárias futuras.

\subsubsection{Especificações}

Determinadas especificações de produtos podem representar tanto um incentivo quanto um impedimento à intervenções visando a implementação de estratégias de prevenção à poluição. Alguns produtos podem requerer que materiais específicos (os quais não dispõem de substitutos efetivos no mercado) sejam usados, ou que estes materiais sejam necessariamente materiais virgem, em vez de materiais reciclados.

\subsubsection{Legislação}

A mudança de um processo, a substituição de um material ou a modificação de um produto pode requerer a obtenção de uma nova licença ambiental ou outro tipo de aprovação por parte dos órgãos ambientais. Tais procedimentos levam tempo e são onerosos, o que acaba por inibir iniciativas de prevenção àpoluição.

\subsubsection{Padrão de Qualidade do Produto}

Muitas vezes a equipe de controle de qualidade do produto (por falta de suporte técnico que Ihes dêem garantias de confiabilidade) podem ficar receosas de que as alterações no projeto do produto ou no processo possam resultar em comprometimento da qualidade do produto. Em alguns casos, uma intervenção pode de fato ocasionar perdas na qualidade do produto.

\subsubsection{Comprometimento da Produção}

A implementação de qualquer medida visando a melhoria ambiental, frequentemente é vista pela produção como uma medida que irá lhes roubar tempo, dinheiro e mão-de-obra. As metas de produção precisam ser alcançadas e são para eles prioridade. Deste modo, para que um projeto de prevenção àpoluição seja implementado, é preciso que todos os 
funcionários sejam esclarecidos sobre os objetivos e benefícios que o programa irá trazer não só para o meio ambiente, mas também para os resultados da produção. Ainda, eles precisam do respaldo da gerência e demais superiores. Normalmente, os preconceitos acabam quando todos os funcionários em todos os níveis estão envolvidos no projeto e têm a oportunidade de participar ativamente nos processos de tomada de decisão.

\subsubsection{Preocupação com a Imagem}

Algumas companhias podem reagir à adoção de novas medidas por receio que ao tornar público o fato de estarem adotando novas práticas ambientais, isso possa significar que no passado estas companhias não estavam em conformidade com a legislação ambiental e para não correr esse risco, preferem permanecer na inércia.

\subsubsection{Disponibilidade de Tempo e Capacitação Técnica}

De maneira geral, as fases de planejamento, avaliação e implementação de práticas de prevenção à poluição implicam na paralisação da produção (ou parte dela), ou na mobilização de funcionários para a execução das tarefas relacionadas a este novo projeto, e isto demanda um tempo que nem sempre existe. Também, é necessário um corpo de funcionários tecnicamente capacitados (ou treinados especialmente para executar as tarefas relacionadas a estes projetos), que significa retirar funcionários de suas funções originais no processo produtivo, o que nem sempre é possível.

\subsubsection{Inércia}

Finalmente, um sentimento comum a todos os seres humanos e portanto, difícil de ser superado: a inércia, que pode se traduzir no seguinte ditado: "se ainda não quebrou (ou vazou, ou deixou de funcionar, ou resultou em um dano ambiental), porque consertar?"

\subsection{Integração entre Meio Ambiente e Saúde Ocupacional}

Uma série de estudos conduzidos no Departamento de Ambiente do Trabalho e no Toxics Use Reduction Institute (TURI), na Universidade de Massachussets-Lowel, nos Estados Unidos, avaliam a transferência de riscos para os trabalhadores ao se implantar estratégias de produção mais limpa e prevenção à poluição (QUINN et al., 1998; ROELOFS, MOURE-ERASO e ELLENBECKER, 2000; ARMENTI, 2001; ROSEMBERG et al, 2001). 
A transferência de riscos para o ambiente de trabalho ocorre porque em alguns casos são feitas modificações nos processos produtivos, rotinas operacionais ou substituição das matérias-primas considerando-se apenas os aspectos de melhoria da qualidade ambiental, de forma pontual, e sem levar em conta o ambiente do trabalhador (OCHSNER, 2001), este fato ocorre principalmente porque de maneira geral o controle da poluição ambiental está dissociado do controle de riscos no ambiente de trabalho (QUINN et al., 1998; ARMENTI, 2001).

Rosenberg et al. (2001), propõe uma metodologia para a avaliação dos impactos no ambiente de trabalho. Segundo a metodologia, antes de se modificar, substituir ou mesmo banir uma substância ou processo, devem ser examinadas as seguintes questões:

I. Função e propósito da substância ou processo em questão

II. Identificação de alternativas ou substitutos disponíveis

III. Avaliação dos efeitos das alternativas ou substitutos na saúde dos trabalhadores:

- Efeitos carcinogênicos, mutagênicos, teratogênicos, neurotóxicos, respiratórios, reprodutivos, cardíacos, hepáticos, dérmicos, etc.

- Riscos físicos: calor, ruído, vibração, etc.

- Riscos ergonômicos e psicológicos: esforço repetitivo, postura, stress, limitação social, etc.

IV. Outros efeitos

- Efeitos nas habilidades (estimulantes ou 'estupidificantes')

- Efeitos na comunidade e na saúde pública

- Efeitos econômicos

- Efeitos internacionais

Roelofs, Moure-Eraso e Ellenbecker (2001) identificam as seguintes barreiras à integração do meio ambiente e da saúde e segurança ocupacional:

I. Treinamento inadequado dos fornecedores de assistência técnica em saúde e segurança do trabalho;

II. O fato de os equipamentos de proteção individual continuarem sendo vistos como a melhor solução para a proteção do trabalhador (no que os autores chamam de tratamento end-of-pipe dos riscos do ambiente de trabalho);

III. A pressuposição de que as novas substâncias e tecnologias (pelo fato de serem novas) são seguras para os trabalhadores; 
IV. A falta de informações sobre os impactos dos novos substitutos e tecnologias na saúde do trabalhador;

V. O foco na conformidade ambiental, que não considera explicitamente o ambiente de trabalho; e,

VI. A pouca coordenação e comunicação entre as agências ambientais e de saúde e segurança do trabalho.

Como destacam Green et al. (2000): "[...] para que haja uma harmonização das estratégias de proteção da qualidade ambiental e de proteção da saúde humana, deve haver o diálogo e a ação concentrada por parte de todos os envolvidos no gerenciamento de risco ambientais e de riscos àsaúde, em todos os níveis de atividade [...]".

\subsection{O Papel das Universidades e dos Centros de Pesquisa}

A educação e o treinamento são componentes essenciais na dinâmica da proteção ambiental e são fundamentais na busca do desenvolvimento sustentável. O entendimento das questões relacionadas com os problemas ambientais que hoje nos deparamos, como aquecimento global, escassez de recursos naturais, contaminação dos recursos hídricos e do solo, requer uma abordagem multi e interdisciplinar, na qual os fatores éticos também devem fazer parte (GUTIERREZ-MARTIN e DAHAB, 1998; MARTIN e RIGOLA, 2001; GUTIERREZ-MARTIN e HUTTENHAIN, 2003).

Como destaca Pelicioli (2004), a interdisciplinaridade é inerente à educação ambiental. Se os problemas ambientais que hoje enfrentamos são muito complexos e causados pelos modelos de desenvolvimento adotados, suas soluções dependem de diferentes saberes e de pessoas com diferentes formações voltadas para o objetivo comum de resolvê-los.

A ética no exercício da gestão ambiental precisa estar presente de modo que o profissional possa, além de tomar a melhor decisão tecnológica, também escolher a opção eticamente correta, quando entram em cena conflitos de interesses. A ética ambiental está baseada nos valores fundamentais como a integridade, a honestidade e o interesse coletivo, em contra-posição aos interesses individuais. Valores ambientais como a sustentabilidade e a conservação, bem como valores sociais que incluem a preocupação com as gerações futuras também dão suporte àética ambiental (THOMAS, 2002). 
A sustentabilidade ética deve estar presente nos cursos de engenharia, e pode ser ensinada através da inserção de conceitos de prevenção à poluição, minimização de resíduos e avaliação de ciclo de vida nas disciplinas de todos os programas de engenharia, para que estes não se baseiem em conceitos puramente técnicos e possam formar engenheiros competentes e, técnica e ambientalmente conscientes (WAREHAM e ELEFSINIOTIS, 1996; BISHOP, 2000b).

Apesar de todos os benefícios inerentes, na prática, a prevenção à poluição não é adotada no verdadeiro sentido de seu significado. No Brasil (e em muitos outros países), muitos ainda tratam a poluição com as mesmas medidas de controle empregadas desde a década de 70, que muitas vezes sequer satisfazem as condições exigidas nas leis ambientais. Na verdade, existem barreiras que dificultam a adoção da prevenção à poluição. Essas barreiras são culturais, econômicas, operacionais e administrativas, derivadas da escassez (ou ineficiência) de políticas públicas e ações que estimulem a adoção de tecnologias e práticas de gestão e gerenciamento inovadoras e eficientes, agravadas pela carência de informação técnica sobre as práticas de prevenção àpoluição adequadas ao contexto do país.

Neste cenário, segundo Toakley e Aroni (1998), as universidades podem contribuir de maneira singular para a promoção da sustentabilidade:

I. nos cursos de graduação, orientando o foco das disciplinas das diversas áreas;

II. na pós-graduação, através do desenvolvimento de pesquisas aplicadas;

III. por meio de intercâmbios internacionais, dando aos estudantes a oportunidade de aprender e contribuir com uma diferente cultura, que pode ainda oferecer uma infra-estrutura às vezes não disponível no país de origem;

IV. através de seus professores, que representam um recurso valioso, que além de ensinar, desenvolvem pesquisas e prestam consultorias; e,

V. através de centros de pesquisa, fornecendo um meio de aliar as capacidades de seu corpo técnico, formando um conjunto interdisciplinar.

Convém lembrar que muitos dos envolvidos nas diversas posições dentro de uma universidade, desempenham ou virão a desempenhar posições de influência e liderança, o que pode representar uma importante contribuição na busca da sustentabilidade. 


\section{CAPÍTULO III}

\section{MATERIAIS E MÉTODOS}

\subsection{Considerações Iniciais}

Neste capítulo são descritas as etapas que foram seguidas para a realização da pesquisa, de modo a cumprir os objetivos propostos.

A pesquisa se dividiu em três etapas: 1) Prospecção de Informações; 2) Realização do Programa de Doutorado com Estágio no Exterior (PDEE), na Universidade de Nebraska-Lincoln (UNL), nos Estados Unidos; e, 3) Avaliação de um processo produtivo para identificação de oportunidades de prevenção à poluição.

\subsection{Prospecção de Informações}

Foi realizado um levantamento com base em diversas fontes de informação, visando identificar e analisar as sistemáticas e ferramentas usadas no planejamento de programas de prevenção à poluição, e identificar estratégias de preverção à poluição aplicáveis aos processos e operações existentes no processo produtivo tomado para estudo.

\subsubsection{Principais Fontes de Informação}

Bases de dados de teses, dissertações e livros

- Banco de Dados Bibliográfico da USP (DEDALUS), permite a busca de referências disponíveis para empréstimo e consulta nas bibliotecas de todas as Unidades da USP.

- Banco de Dados da Universidade de Nebraska (UNL), disponibiliza ferramentas para a busca de referências disponíveis nas bibliotecas da UNL e de outras bibliotecas de Universidades Americanas. 
Base de dados de artigos técnico-científicos

- SIBINET - USP, acessível para computadores das Unidades da USP, permite o acesso a revistas eletrônicas e a recuperação de artigos completos de periódicos de diversas editoras estrangeiras.

- Periódicos CAPES, acessível para computadores de Universidades Públicas e Instituições de Pesquisa do país, permite a consulta e a recuperação de artigos completos de periódicos, através do endereço www.periodicos.capes.gov.br.

- Science Direct, acessível para computadores de Universidades cadastradas, permite a busca por palavras e a recuperação de artigos completos de periódicos da editora Elsevier através do endereço www.sciencedirect.com

- Bases de dados da UNL, acessível para alunos regulares da Universidade de Nebraska, permite o acesso a diversas bases de dados de revistas eletrônicas e a recuperação integral de artigos.

Bases de dados de manuais, normas e relatórios técnicos

- Agência de Proteção Ambiental dos Estados Unidos (US EPA), disponibiliza informações gerais sobre prevenção à poluição e permite a recuperação de manuais, artigos e relatórios técnicos sobre metodologias e estratégias de prevenção à poluição para diferentes setores industriais, através dos sites www.epa.gov/p2 e www.epa.gov/oppt/library/ppicindex.htm.

- Pollution Prevention Resource Exchange (P2RIC), disponibiliza publicações, manuais, folhetos e outros materiais sobre prevenção àpoluição desenvolvidos por centros regionais de informação dos Estados Unidos. Também disponibiliza links para diversas livrarias virtuais através do endereço www.p2rx.org.

- Toxics Use Reduction Institute (TURI), este instituto é vinculado àUniversidade de Massachussets - Lowel, e disponibiliza artigos, relatórios técnicos, manuais e estudos de casos desenvolvidos por pesquisadores da instituição, no endereço www.turi.org.

- Northeast Waste Management Officials' Association (NEWMOA), disponibiliza informações, relatórios técnicos e alguns manuais setoriais. Envolve as agências ambientais dos estados americanos de Connecticut, Maine, Massachussets, New Hampshire, New York, Rhode Island e Vermont, e tem como objetivo desenvolver e dar assistência a programas de prevenção à poluição, gerenciamento de resíduos perigosos e assuntos relacionados, através do site www.newmoa.org. 
- United Nations Environmental Program (UNEP), disponibiliza informações sobre produção mais limpa e links para acesso a sites de programas e relatórios técnicos de diversos países. Permite o acesso integral aos artigos da revista Industry and Environment, através do site www.uneptie.org/pc/cp.

- Companhia de Tecnologia de Saneamento Ambiental do Estado de São Paulo (CETESB), disponibiliza informações sobre conceitos e definições, manuais e casos de sucesso de prevenção à poluição através do endereço www.cetesb.sp.gov.br/Ambiente/prevenção_poluição/conceitos.asp.

- Federação das Indústrias do Estado de São Paulo (FIESP), disponibiliza publicações sobre meio ambiente, desenvolvimento e indústria sustentável através do endereço www.fiesp.com.br/publicações.

$\underline{\text { Internet }}$

- Google, foi a principal ferramenta utilizada para localizar e recuperar informações diversas na internet, através do endereço www.google.com.

Eventos técnico-científicos

- 2003 National Pollution Prevention Roundtable, é o evento mais importante sobre prevenção à poluição nos Estados Unidos. Com peridiocidade anual, reúne profissionais do meio acadêmico, industrial e representantes da US EPA.

- I Congresso Interamericano de Resíduos Sólidos Industriais - Políticas e Tecnologias para a Redução na Geração. Evento promovido pela Associação Brasileira de Engenharia Sanitária e Ambiental (ABES), seção do Rio Grande do Sul, foi o primeiro evento realizado no Brasil para discutir e apontar tendências no gerenciamento de resíduos industriais com foco na redução da geração. Reuniu representantes da indústria, do meio acadêmico, do Centro Nacional de Tecnologias Limpas (CNTL), de ONG's e órgãos ambientais.

\subsection{Programa de Doutorado com Estágio no Exterior - PDEE}

O programa de estágio no exterior (doutorado sanduíche) foi realizado na Universidade de Nebraska - Lincoln, UNL, junto ao Departamento de Engenharia Civil, sob orientação do Prof. Dr. Mohamed F. Dahab e cooperação do Prof. Dr. Bruce I. Dvorak, no período de setembro de 2002 a agosto de 2003. A realização do estágio foi viabilizada pela concessão de bolsa-balcão da Capes ao Programa de Pós-graduação em Ciências da Engenharia Ambiental (PPG/SEA), processo BEX 0595/02-0. 
O estágio no exterior teve como objetivos principais realizar a complementação da revisão da literatura, aprofundar conhecimentos sobre a metodologia, sistemática e ferramentas, levantar práticas de prevenção à poluição aplicáveis ao processo produtivo analisado e participar do programa Partners in Pollution Prevention (P3).

O P3 é um programa de treinamento em prevenção à poluição oferecido pela Universidade de Nebraska, através de uma parceria entre os departamentos de engenharia civil (programa de pós graduação em engenharia ambiental) e de engenharia de sistemas biológicos.

\subsubsection{Principais Atividades Desenvolvidas}

\section{$\underline{\text { Participação em seminários e disciplinas }}$}

- ENVE 990 - Environmental Engineering Seminar Series.

- CIVE 498 - Pollution Prevention Principles and Practices Training Course.

Participação em eventos, encontros e congressos

- Region 7 Pollution Prevention Fall Roundtable Meeting.

- Nebraska Recycling \& Pollution Prevention Training and Vendor Show.

- 2003 Spring National Pollution Prevention Roundtable Conference.

- Pfizer Talk \& Tour.

\section{Participação no Programa Partners in Pollution Prevention - P3}

Este programa foi o principal motivo pela escolha da UNL para a realização do estágio no exterior. O programa tem como principais metas oferecer experiência educacional em prevenção à poluição a estudantes de graduação e pós-graduação, fornecer assistência técnica a pequenas e médias empresas, disseminar a cultura da prevenção à poluição para a comunidade, e desenvolver projetos para a solução de problemas complexos, através de pesquisa.

O programa oferece um curso teórico intensivo, dividido em módulos, onde são abordados temas relacionados à sustentabilidade, questões ambientais globais, poluição industrial, entre outros. De maneira mais direcionada são abordados os conceitos, ferramentas e aplicação da metodologia de prevenção àpoluição.

Após o treinamento teórico, os estudantes desenvolvem individualmente um estudo de caso em uma indústria da região, sob orientação dos professores e coordenadores que integram o programa. O Anexo I traz maiores detalhes sobre a estrutura e resultados do programa. 


\subsection{Avaliação de um Processo Produtivo para Identificação de Oportunidades}

\subsubsection{Delimitação e Sistemática da Pesquisa}

A implantação de um programa ou de práticas de prevenção à poluição em um processo produtivo requer um planejamento detalhado, que compreende em primeiro lugar o comprometimento da alta administração e a alocação dos recursos necessários. A etapa seguinte consiste no levantamento dos dados necessários para a avaliação do processo produtivo, de modo a detectar os pontos do processo onde são geradas as fontes de poluição, resíduos e perdas de materiais, e identificar as oportunidades de prevenção à poluição. Uma vez identificadas as oportunidades, estas devem ser avaliadas de acordo com critérios técnicos, ambientais e econômicos. A partir desta avaliação, é realizada a seleção das oportunidades e o planejamento dos requisitos necessários à sua implantação. Uma vez implantado o programa (ou práticas isoladas), este deve ser adequadamente monitorado, avaliado e revisado.

A execução de todas estas etapas requer o envolvimento de diversos colaboradores, com profundo conhecimento do processo produtivo, a análise de dados e informações do processo, que nem sempre são facilmente acessíveis, e tempo para que as práticas de prevenção à poluição possam ser implantadas, monitoradas e avaliadas. Considerando estas variáveis, a pesquisa limitou-se a uma avaliação preliminar do processo produtivo, para a identificação de oportunidades de prevenção àpoluição, como mostra a Figura 29.

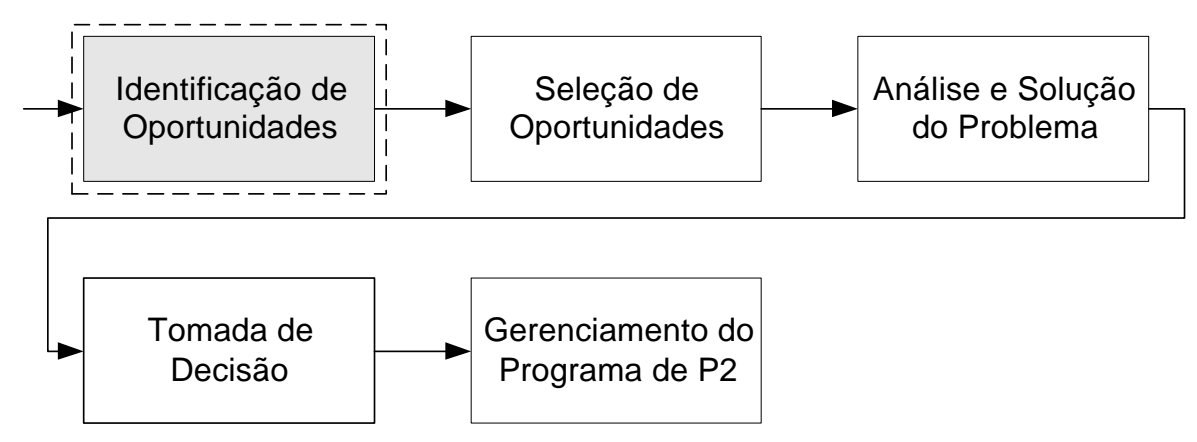

Figura 29 - Delimitação da avaliação realizada no processo produtivo.

Fonte: Modificado de US EPA (2001a)

\subsubsection{Escolha e Caracterização da Área de Estudo}

A avaliação foi realizada no processo produtivo de uma empresa do setor de eletrodomésticos da linha branca. A empresa foi escolhida levando-se em consideração os seguintes fatores: 
- Comprometimento da empresa com as questões ambientais: que propiciou a abertura para o estudo, o acesso àplanta e æ̀ informações necessárias para a execução do trabalho; e,

- O segmento: o processo produtivo analisado envolve operações e processos característicos do segmento metal-mecânico e de acabamento de metais, como operações de corte e estampagem de peças metálicas e tratamento de superfícies, que se apresenta como um objeto de estudo muito rico, no que se refere à representatividade e à diversidade de aspectos ambientais passíveis de análise.

\subsubsection{Identificação de Oportunidades de Prevenção àPoluição}

\subsubsection{Delimitação da Área de Estudo}

A área industrial da empresa divide-se em dois setores: fornecedores internos e linhas de montagem. O primeiro se subdivide em componentes plásticos, metalurgia e pintura, e o segundo em três linhas de montagem, onde são manufaturados três produtos distintos, neste trabalho denominados de Produto 1, Produto 2 e Produto 3. Existem ainda áreas de apoio, a área de manutenção e os laboratórios de confiabilidade e de engenharia da qualidade, onde são realizados testes de confiabilidade de produto, de metrologia, ensaios elétricos, controle de calibração dos produtos e ensaios físico-químicos.

Foi estabelecida uma fronteira para o sistema, de forma a delimitar o estudo dentro da planta industrial, uma vez que esta apresenta processos distintos. A Figura 30 mostra a fronteira do sistema tomado para o estudo.

Foram consideradas as áreas de metalurgia, pintura, e as linhas de montagem, além da central de resíduos, para onde todos os resíduos produzidos na planta são encaminhados. Esta consideração foi feita de modo a limitar o estudo ao processo de transformação metal-mecânico e de tratamento de superfícies, excluindo o processo de transformação de plásticos e demais processos auxiliares. 


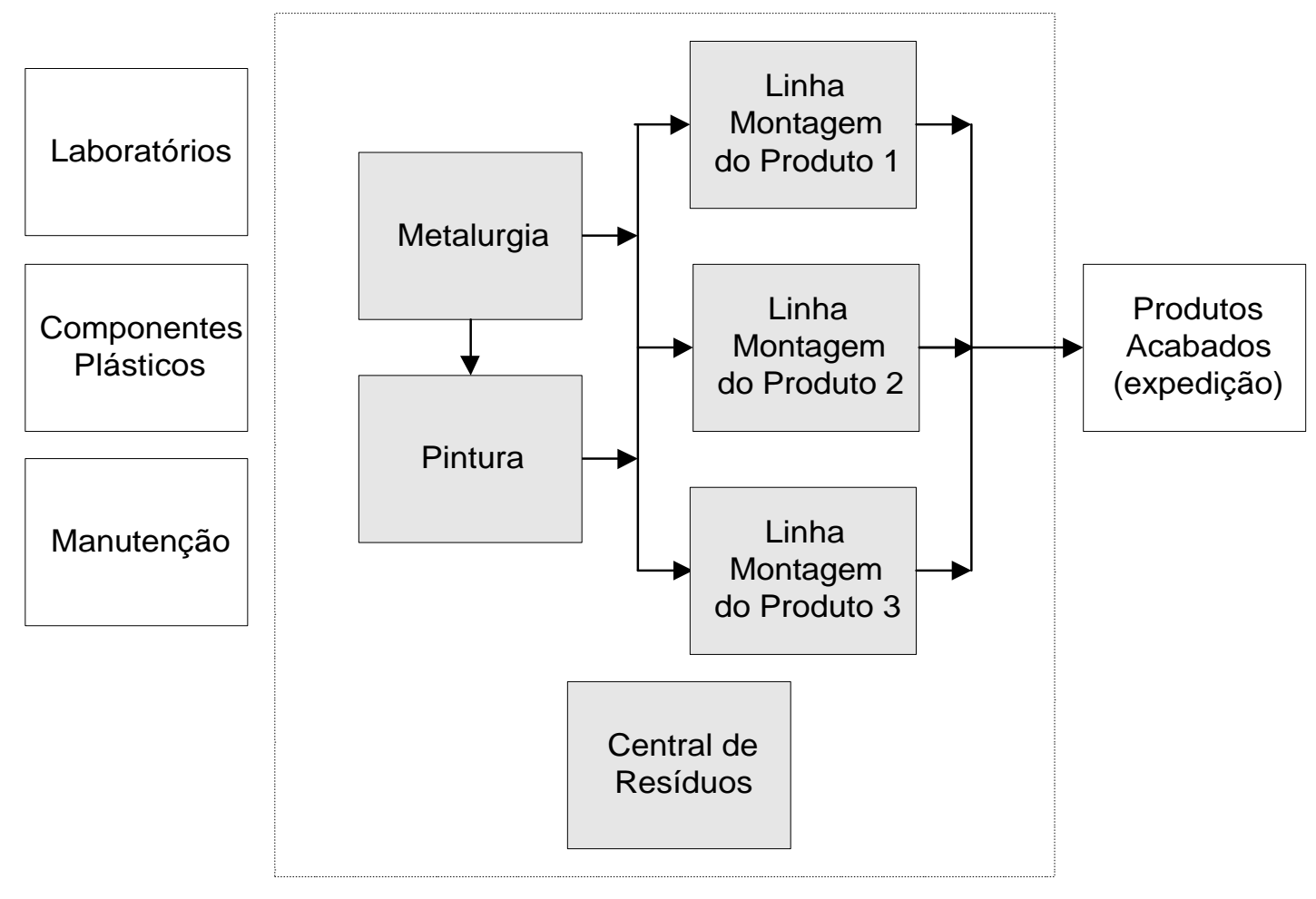

Figura 30 - Fronteira do sistema de estudo

De forma simplificada, o processo industrial consiste na transformação de chapas metálicas em peças que formam a estrutura dos produtos, que são pintadas (ou não, dependendo da peça) e enviadas àlinha de produção correspondente. Paralelamente, na área de plásticos são produzidos os componentes plásticos dos produtos, que também são enviados às respectivas linhas de montagem.

Nas linhas de montagem, os componentes plásticos e demais componentes do produto, provenientes de fornecedores internos e externos são agregados \&̀ peças provenientes da metalurgia e da pintura. Os resíduos gerados em cada área são segregados e encaminhados para uma central de resíduos, de onde seguem para empresas de reciclagem ou para a disposição final.

\subsubsection{Procedimento para Coleta de Dados e Informações}

A coleta de dados e informações foi realizada através de visitas no local, mediante a autorização do supervisor de cada área analisada. A visita era acompanhada pelo responsável (facilitador) de cada área.

Além das informações verbais obtidas dos responsáveis das áreas, foram coletados dados e informações das seguintes fontes: 
- Plantas e fluxogramas de processo das áreas;

- Planilhas de controle do processo e de movimentação de materiais;

- Análises laboratoriais de efluentes e resíduos;

- Fichas de segurança de produtos (MSDS);

- Manuais de procedimentos operacionais;

- Certificados de aprovação de destinação de resíduos industriais (CADRI);

\subsubsection{Mapeamento do Processo}

Para a coleta dos dados e informações foi utilizada como principal ferramenta o mapeamento de processo. Em cada uma das áreas foi realizada uma vistoria preliminar, para reconhecimento das atividades realizadas e operações e processos envolvidos. Com base nestas informações e nos fluxogramas dos processos foram construídos os mapas de processo de cada área, os quais eram revisados mediante uma segunda (ou terceira) visita à planta. Com base nos mapas de processo foram identificadas as principais fontes geradoras de resíduos. Buscou-se detalhar as características e a forma de gerenciamento adotada para cada resíduo.

Foram criadas tabelas de inventário dos resíduos para as áreas, onde constam informações sobre o processo, operação e entrada que gera o resíduo, a classificação, a quantidade e a destinação final. Nem sempre foi possível realizar a quantificação de todos os resíduos na fonte geradora, porque os mesmos são segregados e enviados à central de resíduos, onde os resíduos das diversas áreas são agrupados de acordo com a classe e as características, e só então são contabilizados.

\subsubsection{Coleta e Caracterização de Resíduos}

Foram coletadas amostras de efluentes do processo de tratamento de superfície, para identificação de poluentes potenciais. As amostras foram coletas nos tanques de processo pelo operador da área, em garrafas plásticas apropriadas para este tipo de coleta, e encaminhadas para o Laboratório de Saneamento da Escola de Engenharia de São Carlos. As análises foram efetuadas pelos técnicos do laboratório, seguindo a metodologia da $20^{a}$ edição do Standard Methods for the Examination of Water and Wastewater.

Foi realizada a caracterização da borra produzida na estação de tratamento de efluentes. A amostra foi coletada e encaminhada ao laboratório, onde foi submetida a 
ensaios de lixiviação e solubilização, de acordo com os procedimentos descritos nas normas NBR 10.005 e 10.006. A classificação dos demais resíduos foi realizada mediante o uso de informações já existentes na empresa, como caracterizações anteriores e CADRI disponíveis.

\subsection{Discussão e Apresentação dos Resultados}

Os resultados do trabalho foram divididos em três capítulos. No Capítulo IV são apresentadas as sistemáticas e as ferramentas de prevenção àpoluição. No Capítulo $\checkmark$ são apresentados os aspectos relacionados aos processos e àgeração de resíduos e de poluição na indústria de produtos metálicos, e as principais alternativas disponíveis para a prevenção àpoluição neste setor. No Capítulo VI são apresentados os resultados obtidos na avaliação do processo produtivo. 


\section{CAPÍTULO IV}

\section{PREVENÇÃO À POLUIÇÃO: SISTEMÁTICA E FERRAMENTAS}

\subsection{Considerações Iniciais}

A prevenção à poluição é ainda um campo de pesquisa relativamente novo. Por meio da revisão de literatura realizada, verificou-se uma evolução do foco nas pesquisas. No início da década de 1990, os trabalhos se concentravam na discussão dos benefícios das estratégias preventivas em relação às estratégias de controle no fim do tubo, e na proposição de sistemáticas para a implantação de programas de prevenção à poluição, sem maiores discussões a respeito de ferramentas auxiliares. A partir segunda metade da década de 1990, aparecem trabalhos mostrando resultados de estudo de casos e artigos propondo o uso de ferramentas auxiliares, principalmente para a identificação de oportunidades. Já a partir do ano de 2000, a prevenção à poluição é tratada de uma forma mais sistêmica, aparecem trabalhos relacionando diferentes abordagens, como a integração da prevenção à poluição aos sistemas de gestão ambiental baseados no modelo ISO 14001, utilização de ferramentas para a identificação de oportunidades, como a avaliação de ciclo de vida, discussões sobre o desenvolvimento de indicadores para o monitoramento dos programas de prevenção à poluição, e avaliação e comparação do desempenho ambiental de processos, companhias e segmentos industriais, de forma a estabelecer uma homogeneização das práticas de produção sustentáveis nos diferentes níveis.

Neste Capítulo serão apresentados os requisitos de um programa de prevenção à poluição, segundo as sistemáticas propostas pela US EPA, pela Environment Canada, pela UNEP e pelo Centro Nacional de Tecnologias Limpas (CNTL), e as ferramentas reportadas na literatura para a identificação e seleção de oportunidades, e para a implantação, avaliação e monitoramento de programas de prevenção à poluição. 


\subsection{Requisitos de um Programa de Prevenção à Poluição}

A implantação de um programa de prevenção à poluição, do mesmo modo que qualquer outro programa de gestão ambiental, requer o cumprimento de uma série de requisitos que vão do comprometimento da alta administração e envolvimento dos funcionários nos diversos níveis hierárquicos, seguido de um exaustivo trabalho de levantamento de dados e informações para avaliação do processo e identificação de oportunidades, busca e análise de viabilidade de alternativas para os problemas identificados e implantação das alternativas. Se faz necessária ainda a implantação de um sistema de monitoramento do desempenho, para que o programa possa ser avaliado, revisado e corrigido, de forma a garantir a melhoria contínua.

Segundo a Environment Canada (2001), o planejamento de um programa de prevenção à poluição é um método sistemático de identificação de opções para minimizar ou evitar a geração de poluentes ou resíduos. Pode envolver um único poluente ou vários, uma única unidade ou processo, ou a planta industrial como um todo. Pode envolver ainda o consumo de água e energia.

WHITMAN e SHIN (1995) propõem uma sistemática para o planejamento de programas de prevenção à poluição, segundo os requisitos do Decreto de Prevenção à Poluição do Estado de New Jersey, que compreende doze etapas:

1. Entendimento do conceito de prevenção à poluição;

2. Estabelecimento de uma política de prevenção à poluição;

3. Escolha de um líder e formação de um grupo de trabalho;

4. Identificação de fontes e processos poluidores;

5. Agrupamento das fontes e processos similares;

6. Realização de inventário de entradas e saídas;

7. Escolha de fontes e processos para análise detalhada;

8. Busca e análise de alternativas de prevenção à poluição;

9. Desenvolvimento de metas numéricas;

10. Planejamento e implementação das ações;

11. Monitoramento e documentação dos progressos; e,

12. Revisão do planejamento.

A US EPA já vem desenvolvendo manuais de apoio à implantação de programas de prevenção à poluição desde antes da institucionalização do Pollution Prevention 
Act, em 1990. Em 1988 foi lançado o manual 'Waste Minimization Opportunity Assessment Manual ${ }^{26}$ com um procedimento para a implantação de projetos de minimização de resíduos (Figura 31).

Reconhecer a necessidade de minimizar resíduos

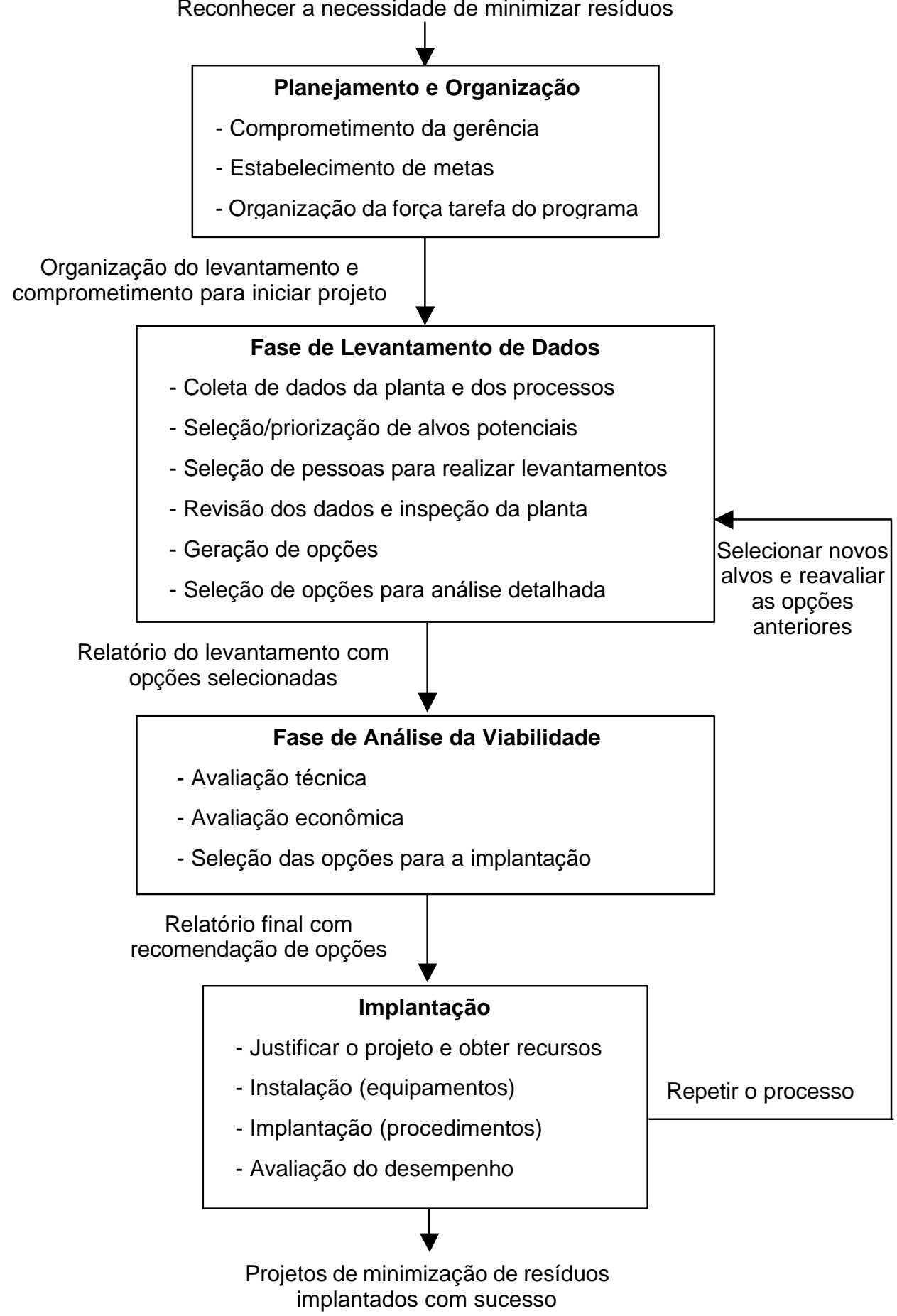

Figura 31 - Procedimento para a minimização de resíduos

Fonte: US EPA (1988)

${ }^{26}$ US EPA (1988). Waste Minimization Opportunity Assessment Manual. Office of Research and Development. Ohio: EPA/625/7-88/003. 
Em 1992, após a institucionalização do Pollution Prevention Act, a US EPA lançou o seu primeiro manual de prevenção à poluição ${ }^{27}$. Este manual integrou novos aspectos, até então não considerados, como conservação de energia e projeto de produtos. No manual é apresentado o procedimento para a identificação de oportunidades de prevenção à poluição, com algumas modificações em relação ao procedimento anterior, para a identificação de oportunidades de minimização de resíduos (Figura 32).

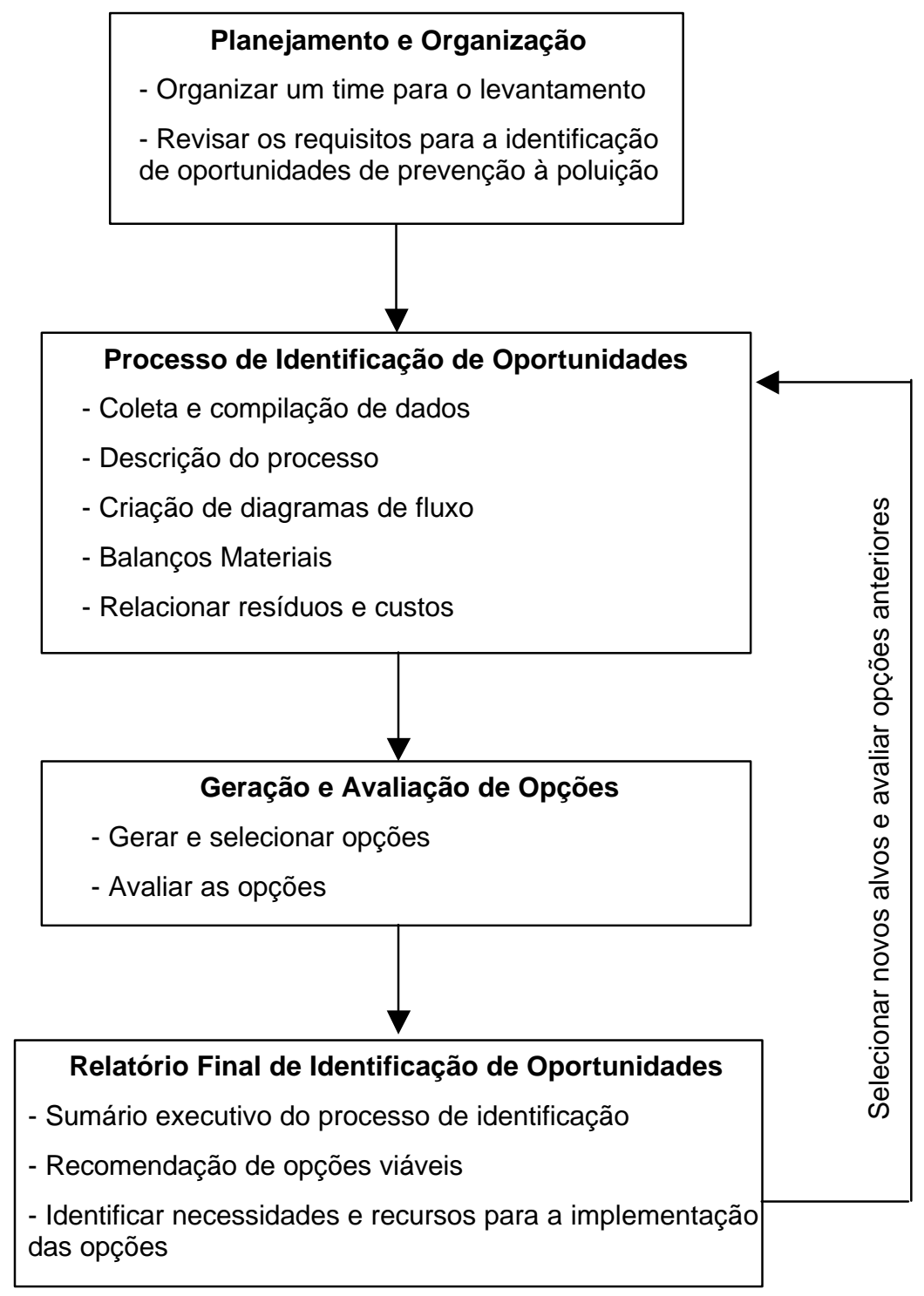

Figura 32 - Procedimento para a identificação de oportunidades de prevenção à poluição Fonte: US EPA (1992)

${ }^{27}$ US EPA (1992). Facility Pollution Prevention Guide. US EPA Pollution Prevention Office. Ohio: EPA/600/R-92/088. 
Com base neste procedimento, a US EPA desenvolveu uma série de estudos de caso de identificação de oportunidades setoriais. Em 2001, foi divulgada uma nova versão do primeiro manual ${ }^{28}$, na qual a sistemática até então adotada é apresentada na forma de diagrama de blocos, e passou a ser referida como 'abordagem tradicional para o planejamento de programas de prevenção àpoluição' (Figura 33).

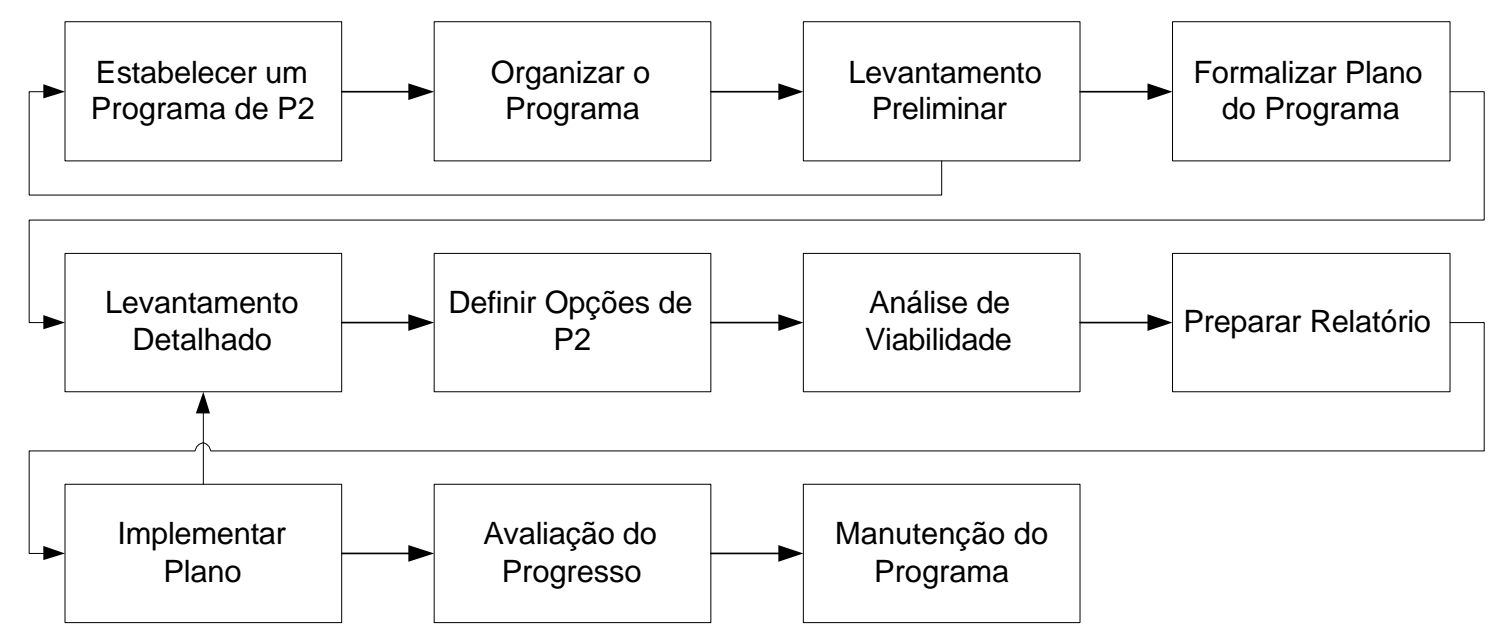

Figura 33 - Sistemática tradicional para o planejamento de um programa de prevenção à poluição Fonte: US EPA (2001a)

Neste manual, a US EPA apresentou uma 'abordagem alternativa' para o planejamento de um programa de prevenção à poluição (Figura 34). A diferença básica em relação à sistemática tradicional, é que o programa é estabelecido após grande parte das informações terem sido levantadas.

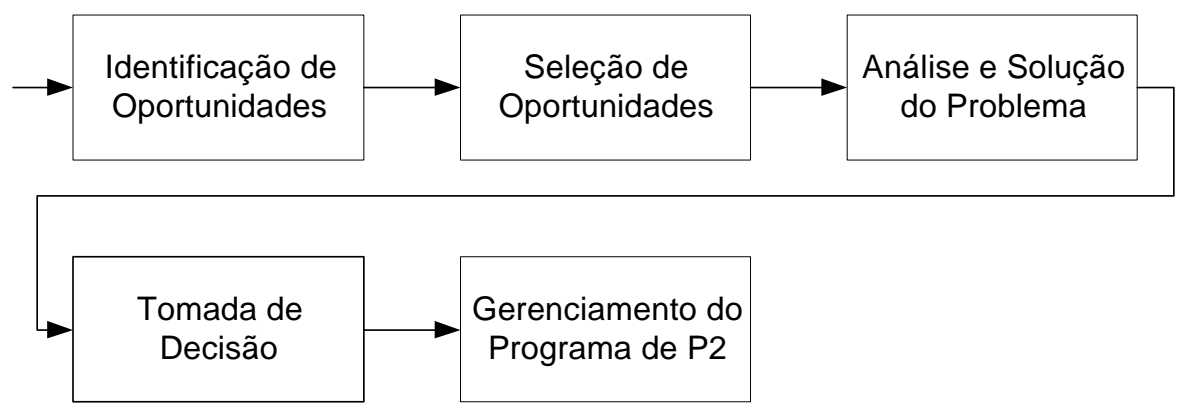

Figura 34- Sistemática alternativa para o planejamento de um programa de prevenção à poluição Fonte: US EPA (2001a)

${ }^{28}$ US EPA (2000a). Integrated Environmental Management Systems - Implementation Guide. Washington: EPA 744-R00-011. 
A Agência Ambiental Canadense ${ }^{29}$, em um manual publicado em 2001, propõe a sistemática mostrada na Figura 35, que compreende uma sequência de seis etapas.

1. Comprometimento e Política
- Obter o comprometimento da alta gerência
- Preparar e divulgar uma política de prevenção à poluição
- Designar um responsável
- Criar um grupo de prevenção à poluição e fornecer os recursos necessários
- Integrar o plano de prevenção à poluição com outros sistemas já existentes
2. Levantamento de Informações

- Definir as fronteiras do sistema (escopo do plano)

- Avaliar a situação real

- Criar um perfil de processo e fluxo de material para operações e processos relevantes

- Quantificar as entradas e saídas

- Calcular os custos totais e benefícios das medidas correntes

- Identificar os requisitos legais relevantes (internacional, nacional, estadual e municipal)

- Identificar políticas e metas pertinentes da companhia

- Identificar as prioridades de acionistas e questões de mercado

\section{Planejamento}

- Identificar oportunidades de prevenção à poluição

- Estabelecer objetivos, metas e indicadores de desempenho

- Definir a comunidade e funcionários envolvidos

- Desenvolver um plano de ação para alcançar os objetivos e metas

- Identificar opções de prevenção à poluição específicas e seus aspectos ambientais, técnicos e econômicos

- Avaliar e priorizar opções com base nos aspectos ambientais, técnicos e econômicos

- Selecionar as opções mais vantajosas, estabelecer responsabilidades, recursos e cronogramas

\section{Implementação}

- Implementar as opções selecionadas

- Identificar necessidades de treinamento de funcionários e promover o treinamento

- Promover a integração com sistemas de gerenciamento já existentes

- Criar mecanismos de suporte (incentivos, multas, relatórios de comunicação interna e externa)

\section{Monitoramento}

- Monitorar a implementação do plano e seu desempenho de acordo com os objetivos e metas

- Documentar os resultados, incluindo custos, economia e outros benefícios

- Adotar medidas corretivas, se necessário

- Comunicar resultados à gerência e demais partes interessadas

\section{Revisão, Avaliação e Melhoria}

- Efetuar revisões periódicas para avaliação do desempenho

- Identificar mudanças internas e circustâncias externas

- Revisar os objetivos e metas, alocação de recursos e plano de ação

Figura 35 - Checklist para o planejamento da prevenção à poluição

Fonte: Environment Canada (2001)

${ }^{29}$ ENVIRONMENT CANADA - EC. (2001). Pollution Prevention Planning Handbook. Canadian Environment Protection Agency, Canada. 
A UNEP propõe uma sistemática para a implantação de um programa de produção mais limpa, seguindo os mesmo requisitos das sistemáticas da US EPA e da Agência Ambiental Canadense (Figura 36).

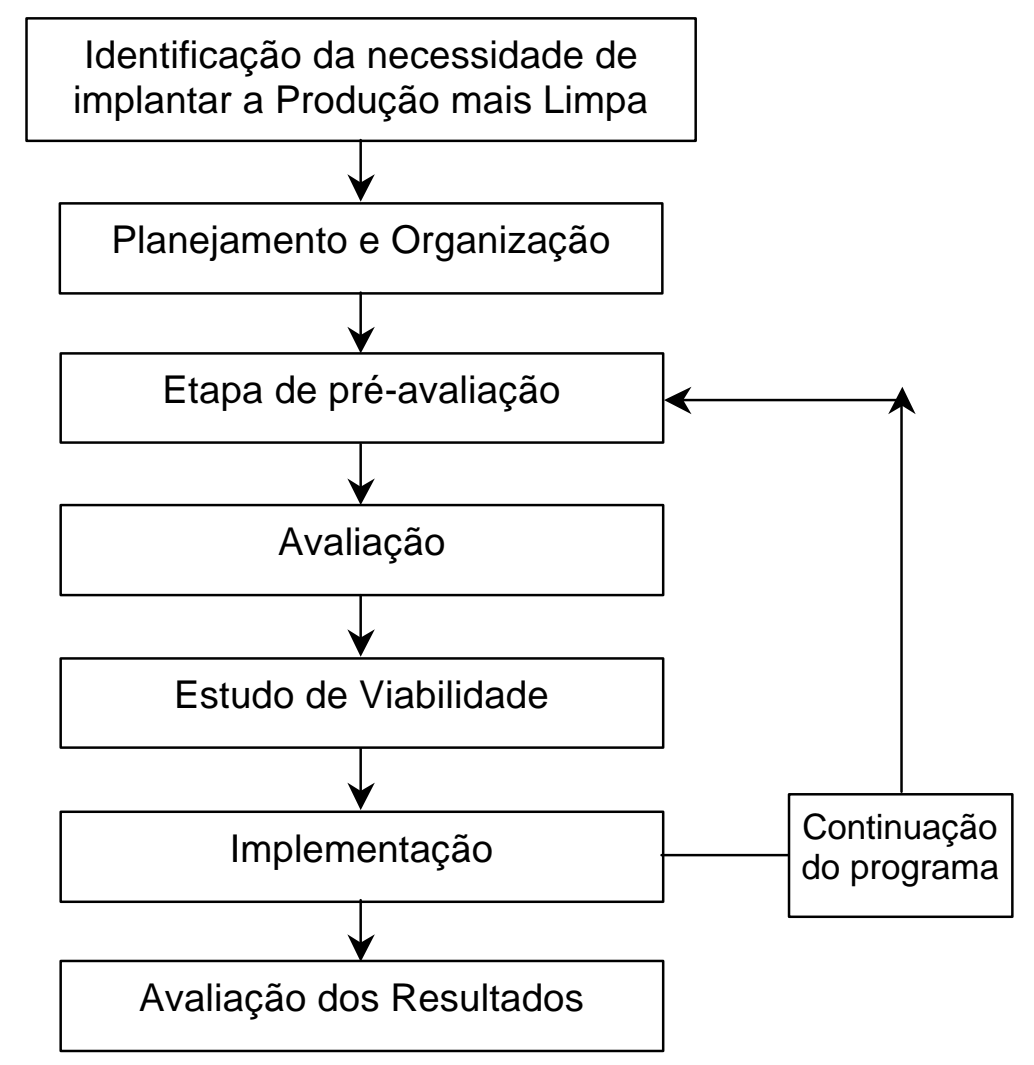

Figura 36 - Etapas para a implantação de um programa de produção mais limpa Fonte: Modificado de UNEP (2003)

O Centro Nacional de Tecnologias Limpas (CNTL), em seus materiais de divulgação sugere a sistemática mostrada na Figura 37 , onde constam todos os requisitos das outras propostas, enfatizando o uso de algumas ferramentas auxiliares nas etapas de pré-avaliação e de avaliação, como diagramas de fluxo de processo, balanços materiais e indicadores de eco-eficiência.

Em suma, todas as sistemáticas apresentadas, com poucas diferenças, propõem as mesmas etapas fundamentais. Como ressalta a US EPA (2001a), cada organização deve procurar a melhor forma de implantar seu programa, desde que este siga os requisitos fundamentais de comprometimento, avaliação, estabelecimento de objetivos e metas, implantação, monitoramento e revisão. O programa pode ser implantado a partir de programas já existentes na organização, como sistemas de gestão ambiental e programas para o gerenciamento da qualidade total.

A obtenção de resultados significativos e duradouros, do ponto de vista ambiental e econômico, requer que o programa seja formalmente integrado æ̀s operações da 
organização, sendo mantido e monitorado por um mínimo de três anos (US EPA, 2001a). O sucesso de programas de prevenção à poluição requer suporte integral e irrestrito da alta gerência, bem como suporte financeiro para se colocar em prática as ações necessárias.

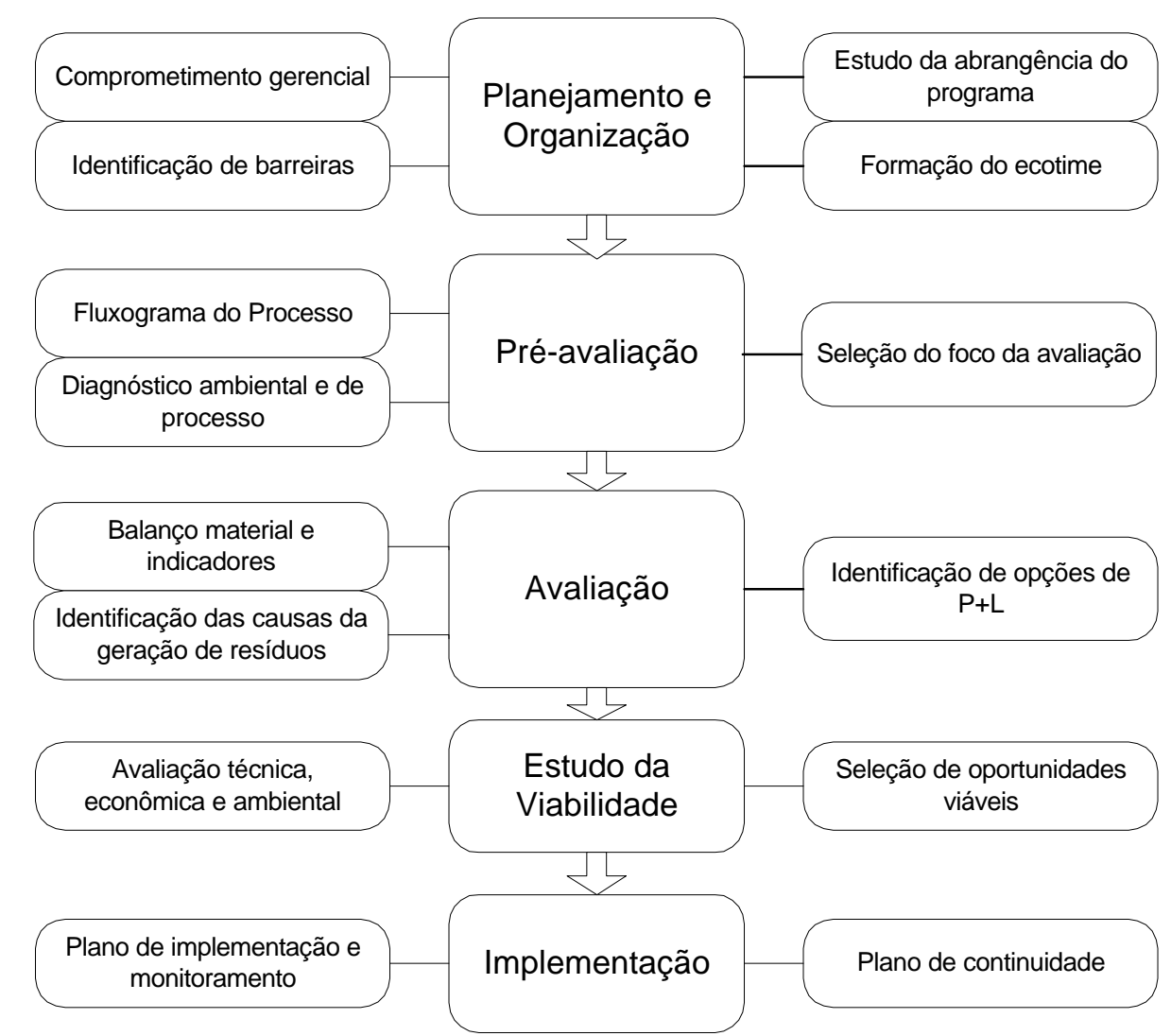

Figura 37 - Sistemática para identificação de oportunidades de produção mais limpa Fonte : Centro Nacional de Tecnologias Limpas ${ }^{30}$ (2004)

Após a garantia do comprometimento e do suporte financeiro, a formação do ecotime é outro fator de extrema relevância. A identificação de oportunidades requer a análise de todas as operações, o que implica no envolvimento de pessoal de todas as áreas da planta industrial. O tamanho do grupo varia de acordo com o tamanho e a complexidade de cada operação ou processo. Além do pessoal diretamente relacionado às atividades onde será realizado o levantamento, pessoas de outras áreas como saúde e segurança, manutenção e serviços gerais, controle de qualidade, contabilidade, finanças e compras também devem estar envolvidas no processo. Cada uma destas pessoas pode contribuir fornecendo dados e informações importantes que permitirão visualizar todos os aspectos de uma determinada atividade (US EPA, 2001b).

${ }^{30}$ Extraído do encarte produzido pelo CNTL para divulgação do conceito de produção mais limpa, distribuído no I Congresso Interamericano de Resíduos Sólidos Industriais - Políticas e Tecnologias para a Redução na Geração, realizado em Porto Alegre, em setembro de 2004. 


\subsection{Definição das Fronteiras do Programa}

A primeira etapa para a avaliação de um processo produtivo ou de uma planta industrial com vistas à implementação de um programa de prevenção à poluição, é a definição da fronteira do sistema no qual será implantado o programa.

Antes de se iniciar o processo de identificação de oportunidades, deve-se definir até onde se quer chegar. O programa pode considerar uma área funcional ou um processo específico, ou a planta industrial inteira. Pode também incluir variáveis externas, como impactos da disposição dos resíduos, dos fornecedores e do uso do produto. A definição da fronteira é importante e pode influenciar significativamente a etapa de identificação de oportunidades. Por exemplo, se o maior impacto produzido por um determinado produto está no seu fim de vida, mas a fronteira do sistema adotada engloba apenas o processo industrial, o plano não identificará opções de prevenção à poluição que compreendam projeto e modificação de produto. $\mathrm{Na}$ definição da fronteira do sistema deve-se levar em consideração os estágios do ciclo de vida de um produto, processo ou serviço que causem os impactos ambientais mais significativos (EC, 2001).

\subsection{Identificação de Oportunidades}

A identificação de oportunidades é a etapa mais importante do planejamento, quando é realizado o detalhamento do processo, de modo a identificar as fontes de poluição e de desperdício de materiais, de água e de energia. Quanto maior o nível desse detalhamento, maior $o$ número de oportunidades identificadas e consequentemente, maior o número de alternativas de prevenção à poluição implantadas (WANZENRIED et al., 1999).

Segundo Pojasek e Cali ${ }^{31}$ (1991 apud WANZENRIED et al., 1999) existem duas diferentes abordagens para a identificação de oportunidades: a abordagem prescritiva e a abordagem descritiva. A primeira utiliza como ferramentas investigativas checklists, questionários e planilhas. A segunda, se concentra no detalhamento do processo e no desenvolvimento de inventários e balanços materiais. A abordagem descritiva $^{32}$ pode resultar em custos mais elevados, uma vez que requer mão-de-obra e tempo maiores do que a abordagem prescritiva. As duas abordagens têm vantagens e aplicações diferenciadas, mostradas no Quadro 11.

\footnotetext{
${ }^{31}$ POJASEK, R.B., CALI, L.J. (1991). Contrasting approaches to pollution prevention auditing. Pollution Prevention Review, v.1, n.3, p.225-235 apud WANZENRIED et al., 1999.

${ }^{32}$ A US EPA refere-se à abordagem descritiva como 'abordagem sistêmica' (US EPA, 2001a).
} 
Quadro 11 - Aplicações das abordagens prescritiva e descritiva.

\begin{tabular}{|ll|}
\hline \multicolumn{1}{|c|}{ Abordagem prescritiva } & \multicolumn{1}{c|}{ Abordagem descritiva } \\
\hline - Quando uma companhia, independente & - Quando o processo é pequeno, \\
do tamanho, deseja modificar & $\begin{array}{l}\text { relativamente simples e tem a } \\
\text { possibilidade de implicações financeiras } \\
\text { significantes. }\end{array}$ \\
- Quando uma companhia deseja alocar & - Quando a companhia não está \\
relativamente poucos recursos para & interessada em uma modificação de alto \\
investigar oportunidades. & custo (por exemplo, modificação de \\
& tecnologia) \\
- Quando uma companhia tem um & - Quando o processo é grande e \\
grande número de problemas no & complexo, e já passou por uma \\
processo, e deseja identificar os & avaliação prescritiva. \\
problemas mais urgentes. &
\end{tabular}

Fonte: Construído com base em informações extraídas de WANZENRIED et al. (1999).

De maneira geral, a abordagem prescritiva detecta oportunidades mais evidentes, normalmente de alto custo (modificações no processo, tecnologia e equipamentos), de forma mais rápida. Entretanto, como destaca Pojasek (1997), os levantamentos realizados por meio de checklists, questionários e planilhas (abordagem prescritiva), não permitem a visualização das relações entre as diferentes etapas e operações que compõem o processo.

Já a abordagem descritiva ou sistêmica, por ser mais detalhada, detecta problemas mais ocultos, que podem resultar em grandes benefícios ambientais, com investimentos financeiros de menor expressão. Todas as operações auxiliares são examinadas e todos os recursos (água, energia, matérias-primas) são contabilizados. Dentre as ferramentas que podem ser usadas na abordagem descritiva, estão o mapeamento de processo, os diagramas de fluxo de processo e de materiais, inventários de entradas e saídas, contabilidade de materiais e balanços materiais.

\subsubsection{Diagramas de Fluxo de Processo}

Os diagramas de fluxo de processo identificam a sequência de etapas que compõem o processo produtivo (unidades de processo). Uma unidade de processo é uma unidade discreta que tem entradas e saídas de material, energia e trabalho distintos. A separação do processo global em unidades de processo permite isolar e 
quantificar impactos ambientais que passariam desapercebidos ao se analisar o processo de forma global. É preciso identificar se a unidade de processo faz parte de um processo contínuo, em batelada ou semi-contínuo (EC, 2001). A Figura 38 mostra o diagrama de fluxo de processo para um processo produtivo genérico.

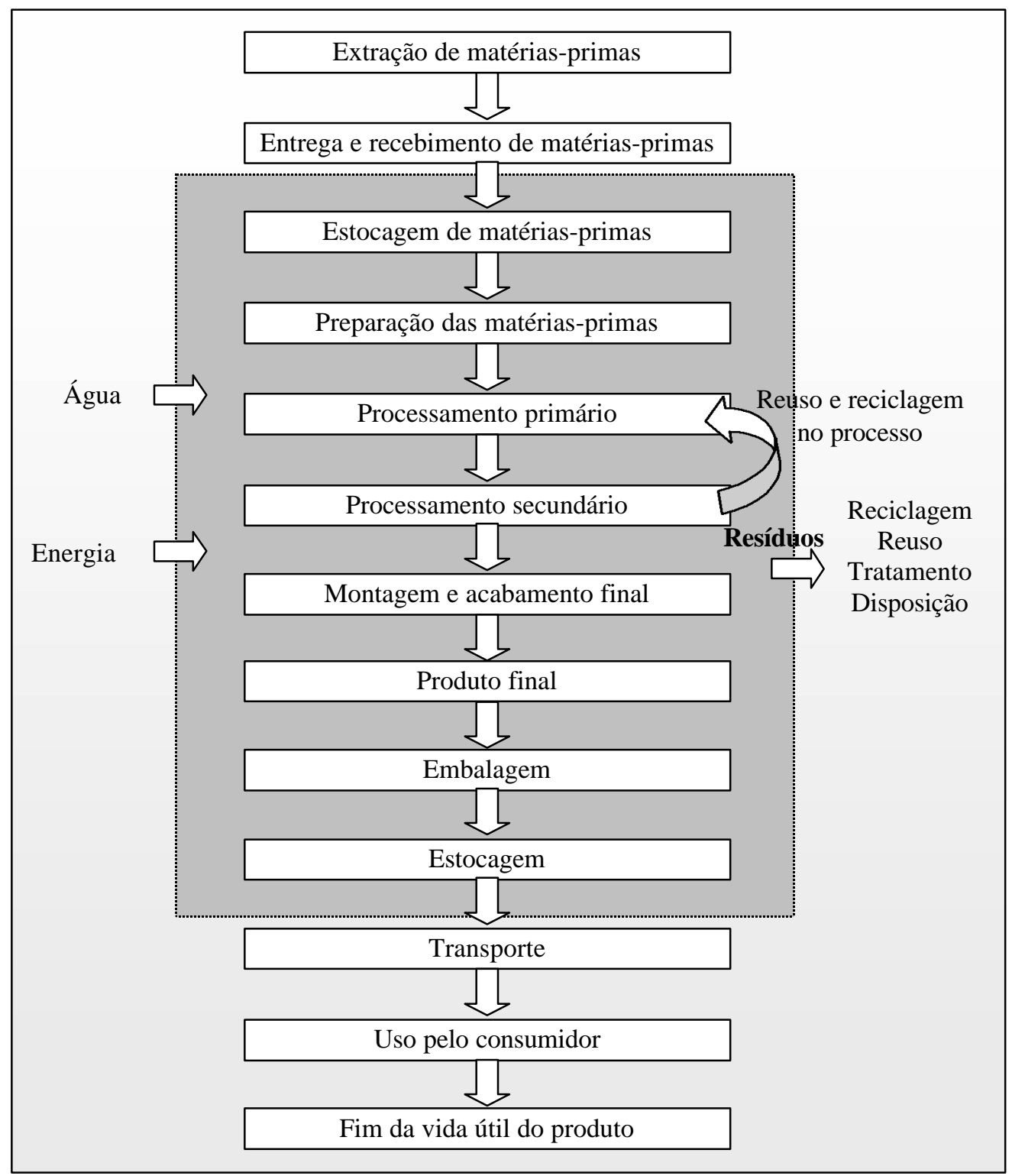

Figura 38- Diagrama de fluxo de processo

Fonte: Modificado de Environment Canada (2001).

\subsubsection{Mapeamento de Processo}

O entendimento do processo é crucial no que se refere à implantação de estratégias de prevenção à poluição, uma vez que não se pode melhorar ou modificar um processo se não há o conhecimento de como ele funciona. O mapeamento de processo permite um refinamento maior dos diagramas de fluxo de processo. 
O mapeamento de processo é uma ferramenta visual que consiste na descrição esquemática de todos os estágios do processo. A partir das conexões entre os diferentes estágios do processo são identificadas as causas das perdas de recursos e da geração de resíduos. O mapeamento de processo envolve o levantamento, organização e comparação de informações e dados, e permite visualizar as entradas e saídas de material do processo (US EPA, 2001a).

Um mapa de processo é uma descrição detalhada do processo na forma de diagramas de bloco, onde cada bloco representa uma etapa (unidade) do processo e as setas representam o fluxo de materiais ao longo deste processo. Ao se construir um mapa de processo percebe-se que muitos problemas podem estar associados a uma única unidade de processo, o que simplifica o trabalho de rastreamento das causas da geração de resíduos, e permite que a modificação seja realizada diretamente naquele ponto (POJASEK, 1997a).

\subsubsection{Desenvolvimento de um Mapa de Processo}

Um processo produtivo é uma sequência funcional de etapas, ou seja, de unidades de processo. O mapa de processo deve identificar todas as unidades de processo de modo a visualizar as relações entre cada uma delas. Em uma planta com muitos processos, podem ser criados conjuntos de mapas, tantos quanto forem necessários para descrever a série de etapas percorridas pelas entradas até a sua transformação em produto. O mapa inicial deve fornecer uma visão global do processo, sem muitos detalhes, e não deve conter mais de seis etapas. Essa limitação forçará a criação de um segundo mapa com um nível de detalhamento maior (POJASEK, 1997a).

A Figura 39 mostra o mapa de um processo de manufatura de produtos metálicos, que envolve as etapas de recebimento de matéria-prima (neste caso, chapas metálicas), corte e a estampagem das chapas, tratamento de superfícies, pintura, linha de montagem (onde as partes metálicas são agregadas às outras partes integrantes do produto), embalagem e expedição do produto final.

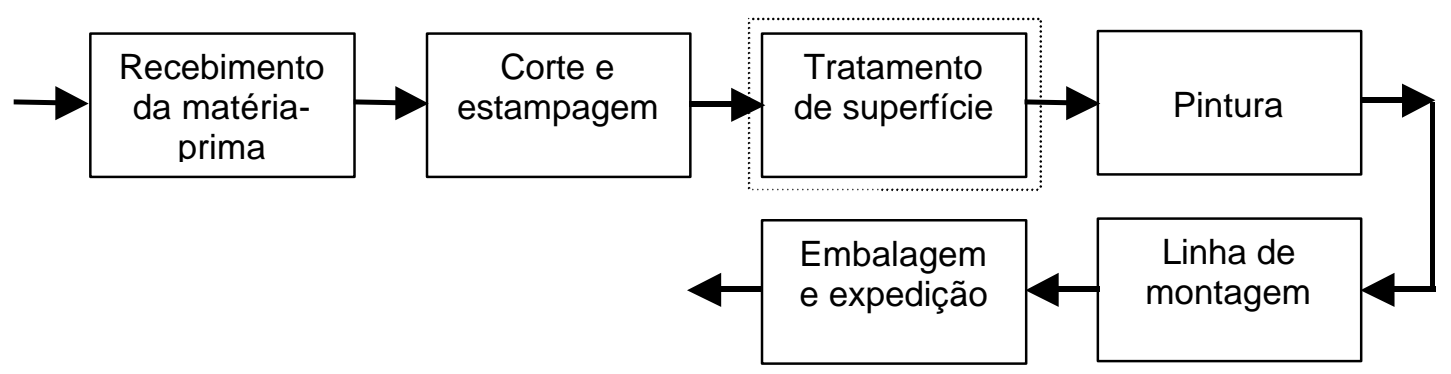

Figura 39- Mapa de um processo de manufatura de produtos metálicos ${ }^{33}$

\footnotetext{
${ }^{33}$ Construído pelo autor com base em visita em indústria.
} 
Cada uma das seis etapas mostradas na Figura 39 representa uma unidade de processo, que por sua vez agrega outros processos e operações. Para um melhor entendimento do processo, é necessária a construção de um segundo mapa, de modo a identificar os subprocessos e operações que constituem cada uma das etapas do processo global. Por exemplo, tomando o terceiro bloco do mapa anterior, pode ser criado um mapa mostrando as etapas constituintes do processo de tratamento de superfícies, como mostra a Figura 40.

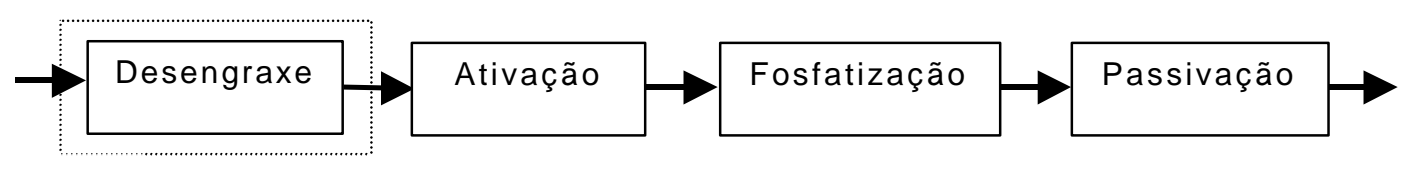

Figura 40- Mapa de processo do tratamento de superfícies metálicas ${ }^{34}$

Geralmente após a construção do segundo mapa, é necessário realizar uma inspeção na planta, para a verificação da sequência das etapas e dos materiais usados e perdidos em cada etapa. Esta inspeção permitirá um refinamento do mapa, e a correção de eventuais modificações que possam ter ocorrido no processo, e que não tenham sido mostradas nas plantas e fluxogramas consultados, fato muito comum em indústrias.

Seguindo o exemplo adotado, a Figura 41 traz o mapa para o processo de desengraxe, onde agora, todas as etapas desse processo com todas as entradas e saídas são visualizadas.

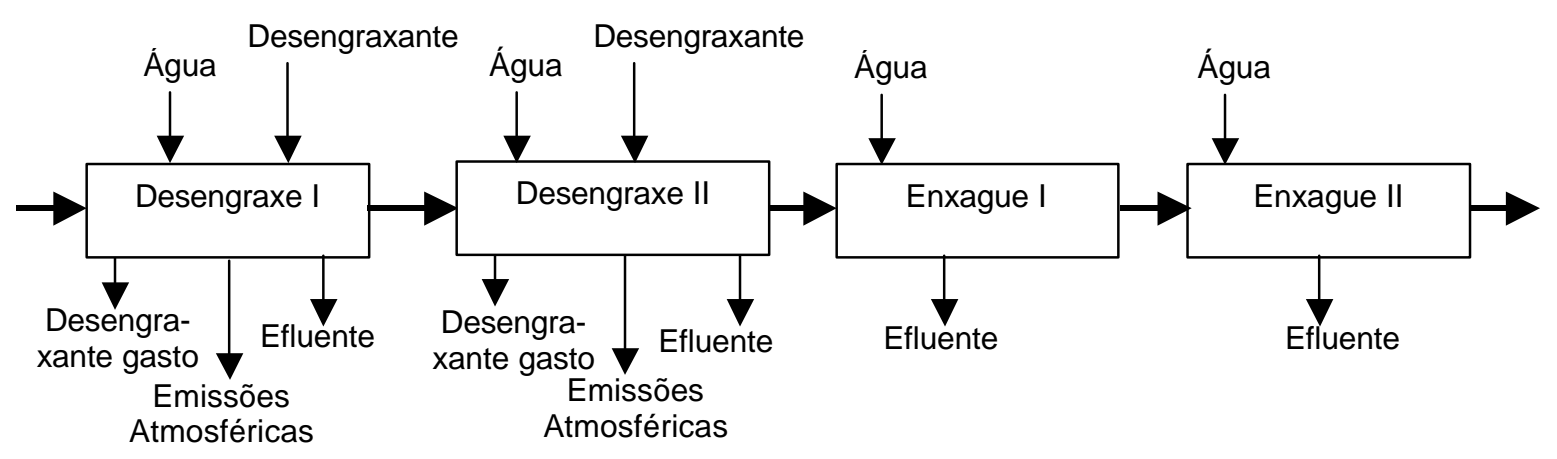

Figura 41 - Mapa de processo do desengraxe no tratamento de superfícies ${ }^{34}$.

As entradas são representadas pelas matérias-primas, insumos estruturados (materiais agregados ao produto final) e pelos insumos não-estruturados (materiais auxiliares no processo, mas que não entram na composição do produto). A saída principal do processo é o produto, e todas as demais saídas, que não fazem parte do produto, são consideradas perdas ou resíduos.

${ }^{34}$ Construído pelo autor com base em visita em indústria. 
Todos os fluxos de materiais e insumos usados na planta podem ser alocados em uma unidade de processo, seja no processo principal ou em processos auxiliares ou intermitentes. Processos auxiliares são os processos que dão suporte ao processo principal, e os intermitentes são os processos que ocorrem de tempos em tempos, como por exemplo, operações de limpeza e manutenção. Tanto os processos auxiliares quanto os intermitentes não devem ser esquecidos durante o mapeamento de processo, pois frequentemente, esses dois processos geram mais resíduos do que o processo principal (POJASEK, 1997a).

O mapeamento de processo pode servir como matriz para o desenvolvimento de uma série de análises no processo, como a construção de diagramas de fluxo de materiais, inventários de entradas e saídas de materiais, água e energia, balanços materiais, contabilidade de materiais e inventários de custos. O mapa de processo é uma ferramenta muito útil no planejamento de um programa prevenção à poluição porque permite identificar fontes de geração de resíduos e de desperdício, identificar oportunidades de melhoria da eficiência do uso de água e energia, entender os custos relacionados com o processo e mostrar a terceiros como o processo funciona e como pode ser melhorado (POJASEK, 1997a).

\subsubsection{Diagramas de Fluxo de Materiais}

Os diagramas de fluxo de materiais permitem identificar e quantificar as perdas de cada unidade de processo, com um nível de detalhamento tal que permite quantificar uma determinada substância em todas as etapas, rastreando todas as entradas e saídas de cada unidade de processo. A melhor maneira de iniciar o desenvolvimento do diagrama de fluxo de material é através de inspeções visuais na planta, para identificar discordâncias entre a realidade atual de processos, operações e equipamentos e o que consta na planta e diagramas originais do processo. A inspeção visual é também a melhor maneira de se identificar fontes de perdas e emissões não usuais (EC, 2001). Na construção do diagrama de fluxo de materiais precisam ser feitas as seguintes considerações:

- identificar fluxos de reuso e reciclagem no processo;

- incluir materiais que são usados ocasionalmente e/ou não aparecem no fluxo de entrada (tais como catalisadores, óleos lubrificantes, etc); e,

- catalogar todos os fluxos de saída de acordo com sua periodicidade (se contínuo ou batelada). 
A Figura 42 mostra um exemplo de diagrama de fluxo de materiais para um processo hipotético, no qual é rastreado o fluxo de uma substância $X$.

$\begin{array}{ll}\text { Entradas } & \text { Atividade }\end{array}$

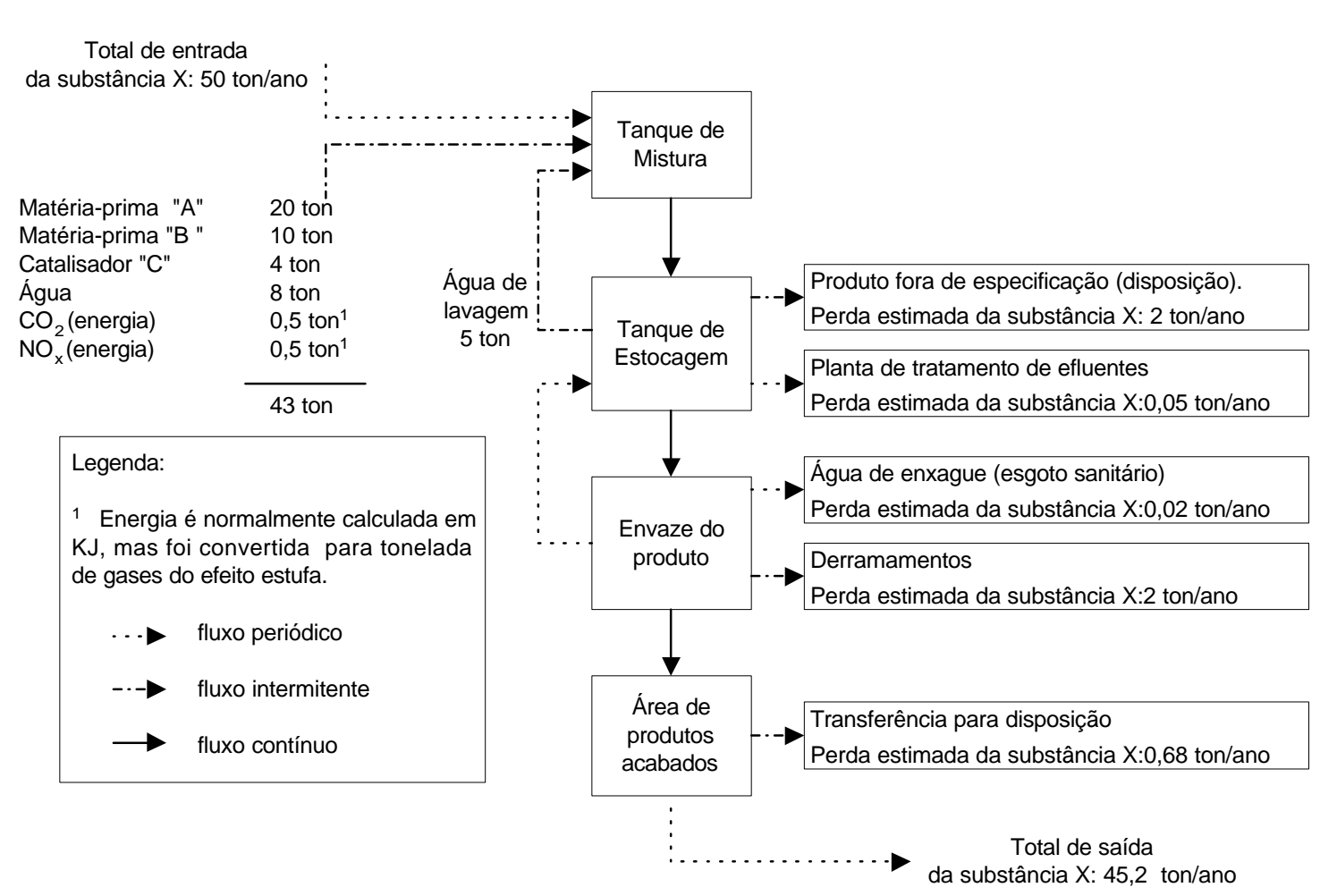

Figura 42 - Diagrama de fluxo de materiais

Fonte: Modificado de Environment Canada (2001)

\subsubsection{Inventários de Entradas e Saídas}

Com base nos diagramas de fluxo de materiais e nos mapas de processo, pode ser realizada uma quantificação sistemática de todas as entradas e saídas do processo. Os dados dos inventários têm três funções:

- confirmar ou melhorar o entendimento das operações e dos processos a partir da perspectiva de fluxo e de perda de materiais;

- fornecer um meio de priorizar processos que necessitam de análise mais detalhada; e,

- determinar os dados principais com os quais serão efetuadas análises mais detalhadas, avaliação de opções e monitoramentos futuros. 
O inventário pode ser realizado tanto para o sistema como um todo (em nível de planta), como para uma unidade de processo específica, que tenha sido identificada como uma fonte de impacto ambiental significativo. Pode ainda ser realizado para todos os fluxos de materiais, ou para uma substância específica (EC, 2001).

As entradas correspondem a todos os materiais, energia, serviços e trabalho que entram na fronteira do sistema ou da unidade de processo. As saídas se apresentam de suas formas: produtos ou serviços acabados, que representam a saída desejada do sistema, e as perdas e subprodutos, na forma de resíduos sólidos, águas residuárias, emissões gasosas e perda de calor. São consideradas perdas tudo aquilo que deixa o processo antes do tratamento (EC, 2001).

\subsubsection{Inventário de Entrada}

No inventário de entrada é importante estabelecer um calendário para a coleta dos dados (diário, semanal, mensal, etc.) de acordo com as rotinas operacionais e com o regime do processo (contínuo ou batelada), de forma a identificar variações anormais.

Os dados de entrada podem ser obtidos em relatórios da planta ou unidade, que normalmente armazenam registros de compra de materiais, inventários de estoque, relatórios de prestação de contas, etc. Outras entradas, como água e energia podem ser medidas diretamente com equipamentos adequados (EC, 2001).

\subsubsection{Inventário de Saída de Produto}

O inventário de saída de produto determina o volume ou massa de cada produto final que deixa a fronteira do sistema. Os dados podem ser obtidos em relatórios de vendas ou outros relatórios de controle interno. As receitas anuais de cada produto final devem ser documentadas para uso subseqüente na etapa de análise de viabilidade econômica.

Se o planejamento está focado em uma substância específica, é preciso realizar o inventário da massa ou volume da substância que está contida no produto final. A determinação destas quantidades pode requerer cálculos e estimativas, que envolvem técnicas de contabilidade de materiais e de balanços materiais (EC, 2001).

\subsubsection{Inventário de Saída de Subprodutos e Perdas}

O inventário de saída de subprodutos e perdas é a parte mais difícil do inventário completo, uma vez que de maneira geral as companhias não costumam medir suas perdas rotineiramente e de maneira sistemática. As perdas podem ocorrer na forma de emissões atmosféricas, efluentes líquidos, resíduos diversos que são encaminhados para disposição ou reciclagem fora da planta, e resíduos armazenados na planta. 
Neste tipo de inventário também devem ser considerados os materiais e resíduos que são reusados ou reciclados no processo ou na planta.

Os dados de saídas de subprodutos e perdas podem ser obtidos através de notas de transferência (transporte, tratamento e disposição final) de resíduos sólidos ou líquidos, relatórios de emissões da planta, medições e amostragens diretas, monitoramento, cálculos e estimativas.

Todos os custos relacionados com cada categoria de subproduto devem ser registrados. Os custos podem incluir custos diretos, como custos com tratamento e disposição de resíduos e indiretos, como por exemplo, os custos relacionados ao monitoramento e a expedição de licenças junto aos órgãos ambientais (EC, 2001).

\subsubsection{Balanços Materiais}

Um balanço material é uma contabilidade de fluxos de materiais dentro de um sistema com base na lei da conservação de massa, aplicável a processos com ou sem reação química, expressado pela seguinte equação de balanço (HIMMELBLAU ,1984):

$$
\left\{\begin{array}{c}
\text { Acúmulo } \\
\text { de massa } \\
\text { dentro do } \\
\text { sistema }
\end{array}\right\}=\left\{\begin{array}{l}
\text { Entrada de } \\
\text { massa nos } \\
\text { limites do } \\
\text { sistema }
\end{array}\right\}-\left\{\begin{array}{c}
\text { Saída de } \\
\text { massa nos } \\
\text { limites do } \\
\text { sistema }
\end{array}\right\}+\left\{\begin{array}{c}
\text { Geração } \\
\text { de massa } \\
\text { dentro do } \\
\text { sistema }
\end{array}\right\}-\left\{\begin{array}{c}
\text { Consumo } \\
\text { de massa } \\
\text { dentro do } \\
\text { sistema }
\end{array}\right\}
$$

O balanço material é realizado em um sistema fechado, onde o interesse está na passagem dos materiais pelos limites do sistema, sem a necessidade de avaliação dos detalhes internos do sistema, como mostra a Figura 43.

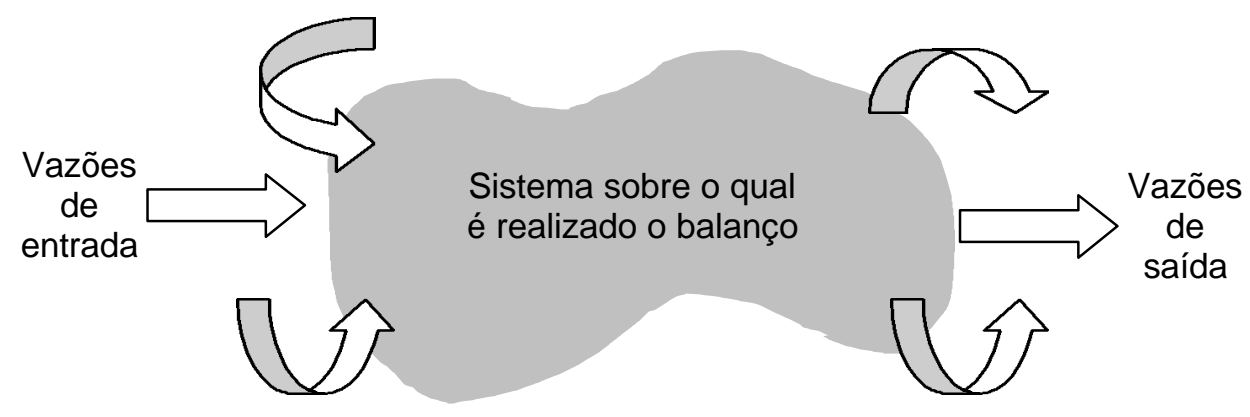

Figura 43 - Volume ou sistema fechado onde são realizados balanços materiais Fonte: HIMMELBLAU (1984) 
O balanço material oferece grande confiabilidade, no entanto é muito trabalhoso de se fazer. O fato de requerer um sistema fechado implica em uma contabilidade quantitativa rigorosa, onde todos os materiais precisam ser identificados, e os dados precisam ser acurados, de modo a fechar a equação do balanço. Devido a estas dificuldades, normalmente os balanços materiais são utilizados apenas quando um novo processo ou equipamento é projetado (POJASEK, 1997b).

\subsubsection{Contabilidade de Materiais}

A contabilidade de materiais é uma ferramenta que permite uma quantificação dos materais no processo bastante próxima da realidade, sem requerer a quantidade e a acuracidade de dados necessários para se realizar um balanço material. O Quadro 12 mostra as diferenças e características dos balanços materiais e da contabilidade de materiais.

Quadro 12 - Balanços materiais versus contabilidade de materiais

\begin{tabular}{|lll|}
\hline \multicolumn{1}{|c}{ Característica } & \multicolumn{1}{c}{ Balanço material } & Contabilidade de materiais \\
\hline Fechamento do sistema & Mandatório & Opcional \\
Acuracidade dos dados & Elevada & Variável \\
Necessidade de dados & Muitos e detalhados & Facilmente disponíveis \\
Nível de dificuldade & Altamente técnico & Moderadamente técnico \\
Custos adicionais & Altos & Moderados a baixos \\
\hline
\end{tabular}

Fonte: Compilado de POJASEK (1997b)

A contabilidade de materiais estabelece um equilíbrio entre as entradas e saídas de cada material. Baseia-se na premissa que, para o processo como um todo ou para unidades de processo individuais, todos os materiais que entram no processo precisam sair de uma forma ou de outra, como mostra a equação a seguir:

$$
(\text { Massa/volume })_{\text {entrada }}=(\text { Massa } / \text { volume })_{\text {saída }}
$$

onde a saída engloba o produto e materiais não estruturados (subprodutos gerados no processo que não fazem parte do produto).

Se a razão da equação estiver próxima de 1 , significa que todas as saídas de materiais não estruturados foram identificadas, e pode-se iniciar a identificação das causas da geração das mesmas. Se a equação diferir significativamente de 1 , 0 desequilíbrio entre massa e volume significa que existem saídas não identificadas, que 
precisam ser investigadas. Se a razão da discrepância não for encontrada, a contabilidade de materiais pode ser efetuada para cada unidade específica de processo ou, havendo a necessidade de uma investigação mais acurada, através de balanços materiais.

Uma série de fontes de informação podem ser usadas para a aquisição de dados. A maioria das plantas industriais mantém registros de produtos químicos sujeitos a regulação, de resíduos perigosos e de emissões para o ar e para a água, registros de aquisição de materiais, entre outros. O Quadro 13 mostra uma lista de possíveis fontes de informação para aquisição de dados.

Quadro 13 - Fontes de informação para a contabilidade de materiais

Aquisição de Materiais
Registros de compra de matérias-primas e insumos
Registros de recebimento de materiais
Registros de planejamento de materiais do processo
$\quad$ Inventário de Materiais
Registros de estocagem
Registros de inventário
Procedimentos operacionais
Especificação de produtos
Documentação de transferência de produtos
Registros de produção Agregados ao Produto Final
Especificação de produtos
Registros de planejamento da produção
Rerda de Materiais
Registros de reciclagem de materiais
Registros de recuperação e reuso de materiais
Registros de venda de materiais
Registros de contratação de serviços de tratamento e disposição
Registros de descarga de resíduos em estações de tratamento

Fonte: Compilado de POJASEK (1997b) 
As fontes de informação do Quadro 13 fornecem um bom ponto de partida para a contabilidade de materiais. Entretanto, convém ressaltar que a contabilidade de materiais vai além dos inventários de produtos químicos e resíduos, e representa um bom exercício para que sejam identificadas lacunas nos registros de informação da empresa. São poucas as empresas que registram o fluxo de materiais internamente, a maioria se preocupa apenas com aquelas substâncias sujeitas a regulação ou materiais de custo elevado ou críticos para suas operações. Normalmente não são feitos registros de resíduos sólidos, perdas por vazamentos ou derramamentos acidentais. Ainda, são poucas as empresas que costumam alocar os custos com água e energia para cada etapa específica do processo (POJASEK, 1997b).

A realização da contabilidade de materiais, usando como roteiro mapas de processo criteriosamente construídos, pode garantir que todos os consumos e todas as perdas, seja na forma de matéria, água ou energia sejam contabilizadas.

\subsubsection{Questionários e Checklists}

Os questionários e checklists têm sua importância no processo de identificação de oportunidades, e freqüentemente são úteis, mesmo quando se adota a abordagem sistêmica (descritiva) no planejamento. Os cheklists podem ajudar na coleta e organização de dados para avaliação do status atual do programa, e de como este está sendo operado. Fornecem um roteiro para ações futuras a serem empreendidas, processos a serem visitados, pessoas a serem entrevistadas e perguntas a serem feitas. Para que o checklist possa efetivamente auxiliar no planejamento da prevenção à poluição, devem ser observados os sequintes aspectos:

- Determinar o propósito e a intenção do uso do checklist;

- Garantir que o checklist cobre todos os requisitos, registra dados específicos, e que nenhum item importante tenha sido esquecido ou omitido;

- Deixar espaço reservado para anotações complementares, idéias ou itens adicionais que se façam necessários; e,

- Revisar e realizar testes-piloto antes de estabelecer seu uso definitivo.

Os checklists são ferramentas úteis para o levantamento de dados e informações, entretanto, são ineficazes como ferramenta de comunicação com a administração e as demais partes interessadas. As ferramentas visuais descritas anteriormente são mais eficientes para a comunicação, e servem ainda como uma boa ferramenta de convencimento (US EPA, 2001a). 


\subsection{Seleção das Oportunidades}

A maioria das plantas industriais, por mais organizadas e comprometidas com a causa ambiental, apresentam muitas fontes de perdas de materiais. Entretanto, dificilmente todos os problemas serão resolvidos de uma única vez, sendo necessária a seleção e a priorização de oportunidades de prevenção à poluição. As informações levantadas na etapa de identificação de oportunidades devem ser organizadas de forma tal, que permitam priorizar as fontes (unidades de processo) onde serão implantadas as alternativas de prevenção à poluição.

Pojasek (1998a) apresenta três métodos para a seleção de oportunidades: Targeting ${ }^{35}$, Avaliação de Risco Comparativa e a Análise de Pareto. Ainda é conveniente neste tópico apresentar o conceito de Contabilidade Ambiental, uma vez que esta ferramenta também é descrita como útil em diversas etapas do planejamento de um programa de prevenção à poluição, como na seleção de oportunidades, no monitoramento do programa e na avaliação do desempenho ambiental. Todas estas ferramentas serão descritas a seguir.

\subsubsection{Targeting}

Este método envolve a seleção de oportunidades com base em restrições ou requerimentos regulatórios. É comumente usado por companhias que participam de programas para redução de resíduos perigosos voluntários promovidos por agências ambientais, que determinam a redução do uso de substâncias listadas em normas regulatórias ${ }^{36}$ ou a redução do consumo de recursos específicos, como por exemplo os programas para redução do consumo de energia. Os programas para a redução do uso de substâncias reguladas de maneira geral identificam todas as indústrias que potencialmente utilizam determinada substância e pesquisam substitutos seguros para oferecer a estas companhias.

Muitas companhias também adotam este critério para encontrar metas específicas de programas regulatórios ou para atender a legislação ambiental. Entretanto, o método têm suas limitações: a) em alguns casos, o 'substituto seguro' encontrado pode apresentar efeitos colaterais; b) o método se concentra em oferecer a resposta correta, ao invés de estimular as companhias a considerar uma variedade de alternativas, limitando as opções de melhoria; e, c) as perdas de materiais e a geração de resíduos podem ocorrer devido a uma série de fatores, não apenas materiais, mas tecnológicos, operacionais e humanos (POJASEK, 1998a).

\footnotetext{
${ }^{35}$ Não foi encontrado um termo em português que traduzisse fielmente a definição original.

${ }^{36}$ No Brasil, seriam aquelas susbstâncias que conferem periculosidade aos resíduos, e que constam no Anexo $\mathrm{C}$ da NBR 10.004 (ABNT, 2004).
} 


\subsubsection{Avaliação de Risco Comparativa}

A avaliação de risco comparativa é uma metodologia simplificada para a geração de informações de riscos usando dados facilmente acessíveis. Esta avaliação fornece orientação sobre os riscos apresentados por determinados poluentes e substâncias, na ausência de estudos e análises científicas detalhadas, e na maioria das aplicações visa identificar os riscos mais relevantes à saúde decorrentes dos poluentes que estão sendo analisados. Os fatores a serem avaliados incluem:

- Tipo e duração da doença causada (crônica ou aguda, ocupacional, etc);

- População afetada (trabalhadores, crianças, asmáticos, etc);

- Efeitos ecológicos sobre as populações de diferentes ecossistemas, sobre a biodiversidade, e sobre habitats sensíveis.

A avaliação de risco comparativa pode ser usada pelas companhias para entender e reduzir os riscos à saúde dos trabalhadores e das comunidades vizinhas, para avaliar os aspectos ambientais em sistemas de gestão ambiental e, no âmbito deste trabalho, para selecionar oportunidades de prevenção à poluição. Neste caso, é estabelecida uma matriz de critérios para identificar as atividades e materiais que causam risco à saúde humana e ao meio ambiente. A matriz fornece um ranking das atividades e dos materiais, com base em suas conseqüências à saúde ou na severidade do impacto (POJASEK, 1998a).

A US EPA (1988) usa o método de matriz de critério (também denominado método da soma dos pesos) para avaliar opções de minimização de resíduos. O modelo de matriz usado pela US EPA envolve uma sequência de três etapas:

1) Determinação dos critérios relevantes em termos das metas do programa de prevenção à poluição. Exemplos de critérios incluem:

- Redução na quantidade de resíduos

- Redução na periculosidade dos resíduos

- Redução nos custos com tratamento e disposição

- Redução nos custos com matérias-primas

- Resultados positivos anteriores

- Impacto na qualidade do produto

- Baixo custo capital 
- Baixo custo operacional e gerencial

- Período de implantação curto

- Facilidade de implantação

Para cada critério devem ser determinados valores (pesos) em uma escala de 0 a 10, em função da sua importância. Por exemplo, se a redução dos custos com tratamento e disposição de resíduos é muito importante, enquanto o fato de resultados positivos anteriores das opções não ser relevante, o critério redução de custos deve receber um peso 10 e o outro critério um peso 1 ou 2. Critérios que não são importantes não devem ser incluídos ou então receber peso 0.

2) Avaliação de cada opção em relação ao potencial de atendimento aos critérios, também em uma escala de 0 a 10.

3) Os valores atribuídos aos critérios (pesos) e às opções (potencial) são multiplicados. A soma dos valores obtidos na multiplicação indica a opção com maior potencial de implantação. No exemplo a seguir, as opções $X$ e $Z$ apresentam os valores altos e próximos entre si. Estas duas opções devem ser selecionadas para avaliação mais detalhada.

Critério

$\begin{array}{lcccc} & \text { Peso } & \text { Opção X } & \text { Opção Y } & \text { Opção Z } \\ \text { Redução de custos com tratamento } & 10 & 8 & 6 & 3 \\ \text { Periculosidade do resíduo } & 8 & 6 & 3 & 8 \\ \text { Risco à segurança } & 7 & 4 & 4 & 5 \\ \text { Facilidade de implantação } & 5 & 2 & 2 & 8 \\ & \sum \text { (Peso x Potencial) } & 166 & 122 & 169\end{array}$

Para apresentar resultados efetivos, os critérios precisam ser estabelecidos, descritos e valorados de forma criteriosa, e o sistema de valores estabelecido deve ser utilizado de maneira consistente (US EPA, 1988).

Segundo Pojasek (1998a), de maneira geral o método da matriz de critérios, se usado como única ferramenta de priorização de oportunidades, é considerado ineficiente. De forma a gerenciar os riscos efetivamente, a empresa precisa ir além do risco propriamente dito, e deve considerar outros aspectos como custos de abatimento do risco, viabilidade técnica do abatimento e comprometimento gerencial para o abatimento do risco. Sendo assim, a avaliação de risco deve ser vista como a primeira 
de muitas etapas necessárias para a priorização de oportunidades de prevenção à poluição.

\subsubsection{Análise de Pareto}

A análise de Pareto consiste na construção de um gráfico de barras para avaliar os impactos ambientais relativos de uma planta industrial, ordenando-os de acordo com a sua importância. Este nome tem sua origem no 'Princípio de Pareto', um postulado que diz que $80 \%$ de tudo pode ser atribuído a $20 \%$ dos fatores envolvidos. Esta ferramenta data de 1897 e desde então vem sendo extensivamente usada para a avaliação de diversos aspectos. Se todas as atividades identificadas no mapeamento de processo forem ordenadas de acordo com seu custo real, se chegará a conclusão que $20 \%$ das oportunidades de prevenção à poluição fornecerão aproximadamente $80 \%$ dos benefícios financeiros efetivos. A análise de pareto é também conhecida como ‘Regra 80/20' (POJASEK, 1998a; US EPA 2001a).

Antes de iniciar a construção do gráfico, deve-se assegurar que todas as perdas ao longo do processo e todas as substâncias e materiais regulados tenham sido identificadas no mapeamento do processo. Deve-se selecionar uma unidade de medida padrão, que pode ser em termos de unidades produzidas ou outra forma de medida de quantidade, ou ainda uma unidade de custo. Normalmente esta última é mais eficiente por representar um fator muito importante em um negócio e alvo permanente de atenção. A próxima etapa consiste na coleta e organização dos dados, que é a parte mais trabalhosa. Se o volume de dados for muito grande, como regra geral o estudo pode ser realizado usando $20 \%$ do total dos resíduos ou perdas, concentrando-se nos mais problemáticos. Para cada resíduo ou perda é atribuído um valor de custo (que pode ser o custo real ou estimado). No eixo horizontal do gráfico são mostradas as oportunidades (todas as perdas e usos de materiais regulados identificadas). No lado esquerdo do eixo vertical são mostrados os custos envolvidos com cada uma das perdas ou materiais regulados em unidade monetária; no lado direito os custos na forma de porcentagem. Em seguida são plotadas as barras no gráfico em uma altura decrescente da esquerda para a direita. Uma linha acumulativa pode ser traçada unindo os pontos correspondentes ao eixo vertical direito de cada barra, da esquerda para a direita, terminando no ponto em $100 \%$ do lado direito do eixo, como mostra o exemplo da Figura 44 (POJASEK, 1998a). 
O Manual 'Nothing to Waste' ${ }^{37}$, desenvolvido no Estado do Novo México, nos Estados Unidos, com apoio da US EPA, fornece um bom roteiro e exemplos simples para a construção de um gráfico de Pareto.

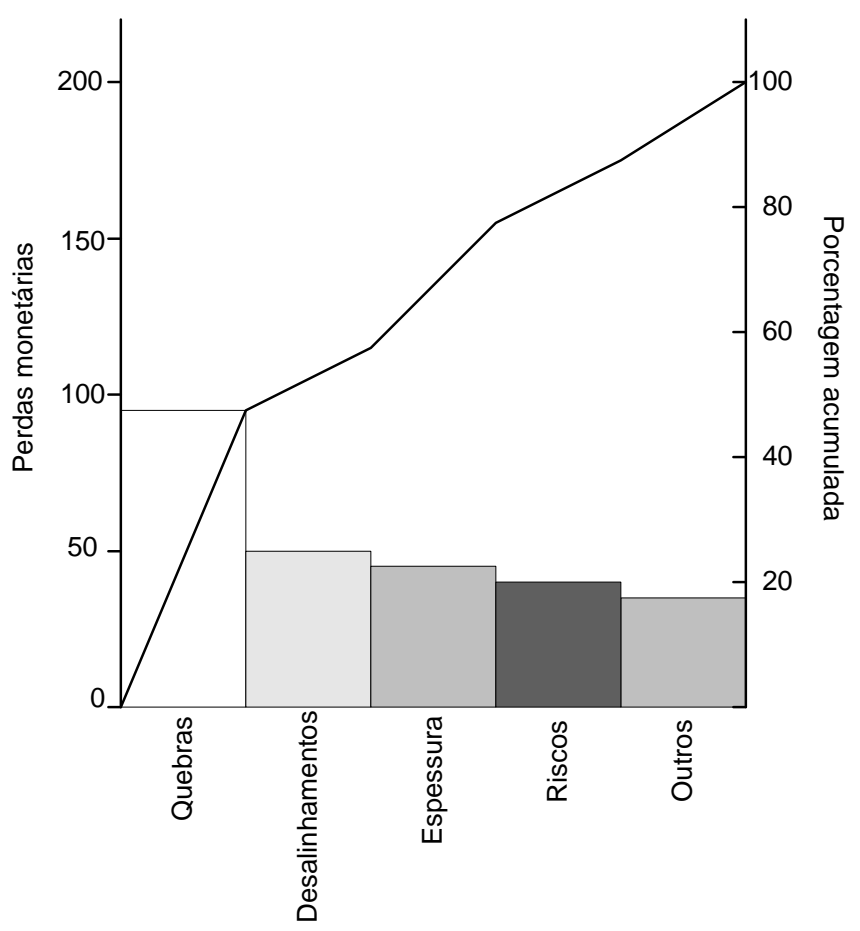

Figura 44 - Gráfico de Pareto

Fonte: Modificado de POJASEK (1998a)

De maneira geral, a atenção deve se voltar para os problemas mais significativos (representados pelas colunas mais altas do gráfico). Entretanto, o fato de uma oportunidade implicar em custos elevados não significa necessariamente que esta mereça toda a atenção de um projeto. Algumas vezes a eliminação de um número maior de problemas menores (as vezes considerados insignificantes) pode representar um retorno acumulativo maior (POJASEK, 1998a). Especialmente na fase inicial do programa de prevenção à poluição, os projetos devem ser selecionados cuidadosamente para garantir as chances de sucesso. É preciso tomar cuidado para não cair na armadilha de iniciar os trabalhos pelos projetos maiores ou difusos, com elevado risco de se incorrer em erros e colocar o entusiamo e os esforços de todos os envolvidos em xeque. Também é importante notar que avaliar perdas e resíduos através do seu volume ou peso pode fazer com que resíduos importantes sejam ocultados. Em alguns casos, pequenos volumes de resíduos podem ser responsáveis por custos elevados (US EPA, 2001a).

\footnotetext{
${ }^{37}$ GREEN ZIA ENVIRONMENTAL EXCELLENCE PROGRAM. [200?] Nothing to Waste Manual: Incorporating Pollution Prevention into Small Business. Disponível em <http://.nmenv.state.nm.us>.
} 


\subsubsection{Contabilidade Ambiental}

Segundo a US EPA (1995a) a contabilidade ambiental é uma ferramenta gerencial que se refere ao uso de dados de custos e de performance ambiental nas tomadas de decisão de negócios e operações. Uma série de decisões de gestão interna podem ser tomadas em razão dos custos ambientais, tais como: projeto de produtos e processos, localização da planta industrial; decisões relacionadas a aquisição de materiais e insumos; decisões operacionais; gerenciamento de riscos; estratégias para atendimento da legislação ambiental; investimentos; controle de custos; gerenciamento de resíduos; alocação de custos; determinação de preços dos produtos; e, avaliação de desempenho ambiental.

Os custos ambientais estão intimamente relacionados ao desempenho ambiental da empresa, e merecem atenção especial por diversas razões:

- Muitos custos ambientais podem ser significativamente reduzidos ou eliminados como resultado de tomadas de decisão, variando de mudanças operacionais e boas práticas de manutenção a investimentos em tecnologias e modificações dos produtos e processos.

- Alguns custos ambientais significativos podem estar escondidos e passar desapercebidos.

- Muitas companhias têm descoberto que os custos ambientais podem ser compensados pela geração de renda proveniente da venda de resíduos e subprodutos (bolsa de resíduos) ou pelo licenciamento de tecnologias limpas, por exemplo.

- Um melhor gerenciamento dos custos ambientais pode resultar em melhorias no desempenho ambiental e benefícios significativos a saúde coletiva e ambiental.

- O entendimento dos custos ambientais e da eficiência dos processos e produtos pode promover uma estimativa de preços mais acurada dos produtos e auxiliar a companhia a desenvolver processos, produtos e serviços ambientalmente melhores, o que se reflete em vantagens competitivas.

- A contabilidade dos custos e do desempenho ambiental pode dar suporte para a companhia desenvolver e operar seu sistema de gestão ambiental, bem como seu programa de prevenção à poluição, uma vez que deixa clara as vantagens financeiras das práticas de prevenção à poluição. 
O reconhecimento dos custos ambientais associados a um produto, processo, sistema ou companhia é muito importante para tomadas de decisão efetivas. $O$ estabelecimento de metas como redução de despesas com atividades ambientais, aumento de lucros e melhoria do desempenho ambiental requer atenção aos custos ambientais correntes, futuros e potenciais. A maneira como a companhia define um custo ambiental depende de como ela pretende usar a informação, e em que escala e abrangência. Em muitas situações não está claro o que é um custo ambiental e o que não é. O que não é custo ambiental não é crítico, o problema é quando um custo ambiental real não recebe a devida atenção (US EPA, 1995a). A Figura 45 lista alguns exemplos de custos ambientais, classificando-os em convencionais, potencialmente escondidos, contingenciais e associados a imagem da empresa.

\begin{tabular}{|c|c|c|}
\hline \multicolumn{3}{|c|}{ Custos Potencialmente Escondidos } \\
\hline $\begin{array}{l}\quad \text { Regulatórios } \\
\text { Notificação } \\
\text { Relatórios } \\
\text { Monitoramento } \\
\text { Estudos } \\
\text { Remediação } \\
\text { Planejamento } \\
\text { Treinamento } \\
\text { Inspeções } \\
\text { Manifestos } \\
\text { EPl's } \\
\text { Seguros de saúde } \\
\text { Seguros ambientais } \\
\text { Controle da poluição } \\
\text { Atendimento a } \\
\text { emergência } \\
\text { Gerenciamento de } \\
\text { resíduos e effluentes } \\
\text { Taxas }\end{array}$ & \begin{tabular}{l} 
Capital e equipamentos \\
Materiais, insumos \\
Mão de obra \\
Utilidades, estrutura \\
\multicolumn{1}{c}{ Fechamento } \\
Disposição de inventários \\
Monitoramento \\
Avaliação
\end{tabular} & \begin{tabular}{l}
\multicolumn{1}{c}{$\begin{array}{c}\text { Voluntários } \\
\text { (pró-ativos) }\end{array}$} \\
Programas comunitários \\
Monitoramento/testes \\
Treinamento \\
Auditorias \\
Qualificação fornecedores \\
Relatórios ambientias \\
Seguros \\
Planejamento \\
Estudos de viabilidade \\
Remediação \\
Reciclagem \\
Pesquisas e estudos \\
Preservação Ambiental \\
Suporte financeiro a ONG's \\
e pesquisas \\
Outros projetos ambientais
\end{tabular} \\
\hline \multicolumn{3}{|c|}{ Custos Contingenciais } \\
\hline $\begin{array}{l}\text { Cumprimento regulação } \\
\text { futura } \\
\text { Multas e penalidades } \\
\text { Controle de emissões }\end{array}$ & $\begin{array}{l}\text { Remediação } \\
\text { Danos a propriedade } \\
\text { Danos a pessoas }\end{array}$ & $\begin{array}{l}\text { Despesas legais } \\
\text { Danos ambientais } \\
\text { Danos econômicos }\end{array}$ \\
\hline \multicolumn{3}{|c|}{ Custos Relacionados à Imagem } \\
\hline $\begin{array}{l}\text { Imagem corporativa } \\
\text { Relação com consumidores } \\
\text { Relação com investidores } \\
\text { Relação com seguradoras }\end{array}$ & $\begin{array}{l}\text { Relação com profissionais } \\
\text { da companhia } \\
\text { Relação com trabalhadores } \\
\text { Relação com fornecedores }\end{array}$ & $\begin{array}{l}\text { Relação com líderes } \\
\text { Relação com a comunidade } \\
\text { Relação com órgãos } \\
\text { ambientais }\end{array}$ \\
\hline
\end{tabular}

Figura 45- Exemplos de custos ambientais em uma empresa Fonte: Modificado de US EPA (1995a)

Os custos convencionais, relacionados ao uso das matérias-primas, utilidades, bens de capital e insumos, são geralmente considerados na contabilidade e na 
previsão orçamentária da empresa, e usualmente não são considerados como custos ambientais. Entretanto, a diminuição do uso de recursos, redução de perdas, de uso de utilidades, insumos e bens de capital reduz a degradação ambiental e o consumo de recursos não-renováveis. A linha pontilhada na Figura 45 atenta para o fato de que mesmo estes custos podem não ser levados em consideração em alguns casos.

Os custos potencialmente escondidos (ou ocultos) englobam uma série de custos que podem passar desapercebidos pela gerência, e se dividem em custos anteriores ao estabelecimento do processo industrial ou da planta, custos relacionados a operação do processo ou da planta e custos posteriores, relacionados a ações futuras de desativação do empreendimento, ou de partes, como desativação de um laboratório onde existam resíduos tóxicos estocados, fechamento de uma célula de um aterro, substituição de um tanque de estocagem de óleo subterrâneo, etc.

Os custos contigenciais são aqueles que podem ou não ocorrer em algum momento futuro, e incluem custos com remediação e compensações por acidentes, multas e penalidades.

Os custos relacionados a imagem são chamados de intangíveis porque afetam dimensões subjetivas (embora mensuráveis) do gerenciamento, de consumidores, empregados, comunidade e órgãos ambientais. Podem incluir ainda custos com atividades voluntárias e apoio a pesquisas.

Os custos com cumprimento da legislação ambiental, remediação, equipamentos de controle da poluição, multas e penalidades, e outros custos com proteção ambiental, mesmo que não sejam explicitamente requeridos pelas regulações, são claramente custos ambientais. Entretanto existem outros custos que podem cair em uma zona obscura no que diz respeito ao seu enquadramento como custo ambiental. Por exemplo, o custo de um equipamento de produção pode ser considerado 'ambiental' se este equipamento for considerado uma 'tecnologia limpa'? A melhoria na eficiência energética é um custo ambiental?. Outra dificuldade está em distinguir alguns custos ambientais dos custos com saúde e segurança e dos custos com gerenciamento de riscos.

Entretanto, convém salientar que a aplicação efetiva da contabilidade ambiental não depende da classificação 'correta' de todos os custos da companhia, mas sim da garantia de que as informações relevantes estejam disponíveis. As companhias podem definir o que deve constituir um custo ambiental e como classificá-lo com base nas metas e propósitos de uso da contabilidade ambiental. 
A contabilidade ambiental é uma ferramenta flexível que pode ser aplicada em diferentes escalas de uso e diferentes escopos. Dependendo das necessidades, interesses, metas e recursos, a contabilidade ambiental pode ser aplicada a processos individuais ou grupos de processos; a sistemas (ex: tratamento de efluentes, iluminação, etc.), a um produto ou a uma linha de produtos, a uma planta, departamento ou todas as plantas e departamentos de uma companhia, em grupos regionais e geográficos distintos e a corporação toda. $A$ abrangência (escopo) pode incluir todos os custos listados na Figura 45 (US EPA, 1995a).

O controle dos custos ocultos é um dos maiores desafios das empresas. As atividades relacionadas ao meio ambiente e a segurança e saúde ocupacional representam as principais contribuições para este tipo de custo, e se apresentam como uma excelente oportunidade para redução de custos. A eliminação de atividades desnecessárias através de iniciativas de prevenção à poluição pode reduzir os custos ocultos e conseqüentemente aumentar os lucros e a competitividade da companhia. Entretanto, a maioria dos gerentes desconhecem a contribuição das atividades relacionadas ao meio ambiente, segurança e saúde ocupacional nos custos totais. Uma das melhores maneiras de chamar a atenção de gerentes e demais responsáveis por tomada de decisões é mostrar a eles os custos reais das atividades ambientais da companhia (POJASEK, 1998b). Os sistemas tradicionais de contabilidade tendem a ocultar os custos ambientais, alocando estes custos entre custos de processo e de produtos. Esta lacuna pode ocultar os benefícios financeiros de iniciativas de prevenção à poluição (McLAUGHLIN e ELWOOD, 1996).

Dentro deste contexto, a contabilidade ambiental se apresenta como uma ferramenta útil no planejamento da prevenção à poluição, principalmente pelo fato de elucidar os custos desnecessários envolvendo atividades ambientais, e fornecer uma base substancial de convencimento para a aprovação de projetos de prevenção à poluição por parte da gerência. Especificamente no que se refere à discussão deste Capítulo, a contabilidade ambiental se apresenta como uma ferramenta auxiliar na identificação de oportunidades de prevenção à poluição, nas etapas posteriores do planejamento, que envolvem o monitoramento do programa e a avaliação do desempenho ambiental.

Pojasek (1998b) sugere um roteiro para a contabilidade ambiental, visando a identificação de oportunidades, que se inicia pela análise dos mapas de processo de modo a identificar: 
- Custos de todas as matérias-primas;

- Custos com manuseio de materiais;

- Custos com disposição e tratamento de resíduos;

- Custos ocultos.

O mapeamento de processo permite que o processo seja desmembrado em diversas partes, facilitando a visualização dos custos envolvidos em cada uma das operações. Para auxiliar no registro dos dados podem ser empregadas planilhas, para cada processo/operação que está sendo analisado. As informações levantadas por meio da contabilidade ambiental podem ser representadas em gráficos de Pareto, tornando visível as oportunidades de redução de custos com perdas de materiais e com o gerenciamento de resíduos.

A principal vantagem da utilização da contabilidade ambiental associada ao mapeamento de processo como ferramenta auxiliar na seleção de oportunidades, é a garantia de que todos os custos serão contabilizados, incluindo os custos ocultos, normalmente deixados de lado quando outros métodos de avaliação menos detalhistas são empregados (POJASEK, 1998b).

\subsection{Solução do problema}

Um vez selecionadas as oportunidades de prevenção à poluição, estas passam a ser enxergadas como problemas que precisam ser resolvidos, e a melhor forma de se resolver um problema é buscar a sua causa. Deste modo, deve-se examinar como as matérias-primas, equipamentos, tecnologias, métodos e práticas operacionais podem estar contribuindo para o problema. Esta análise pode ser realizada por meio da construção de diagramas de causa e efeito.

\subsubsection{Diagramas de Causa e Efeito}

Um diagrama de causa e efeito é uma ferramenta estruturada que pode ajudar a companhia e todos os envolvidos no programa a alcançar o entendimento comum do porque da geração dos resíduos e pode ainda revelar lacunas no entendimento do processo. Esta ferramenta é também conhecida como 'diagrama de espinha de peixe', dada a similaridade do diagrama completo com o esqueleto de um peixe.

O propósito de se usar diagramas de causa e efeito para a prevenção à poluição, deve-se ao fato desta ferramenta forçar o foco da atenção nas perdas e nas fontes de geração de resíduos, de modo a entender as suas causas. O resultado da análise é 
uma lista de possíveis 'causas raíz' (root causes) do problema, ao invés de uma única e potencial causa, normalmente encontrada quando a análise do problema é realizada sem um critério estruturado. Uma causa raíz pode ser definida como um fator controlável e equacionável, que em última análise explica o problema que está sendo avaliado.

Para encontrar a causa raíz de uma perda no processo é importante que em primeiro lugar se entenda a perda. Neste caso, muitas questões podem ser levantadas, tais como: a) O que está causando a perda? b) Porque a perda existe? c) Quando a perda se inicia e de onde ela vem? d) Porque a perda não é eliminada na fonte? e) O que acontece na etapa anterior ao surgimento da perda?

O desenvolvimento e a análise de um diagrama de causa e efeito pode trazer a resposta para todas estas perguntas. Esta ferramenta permite a investigação das perdas e a elucidação da funcionalidade do processo. Somente quando a funcionalidade do processo é entendida é que ele pode ser modificado para eliminar a perda. Informações adicionais podem ser obtidas por meio da caracterização da perda ou do resíduo.

Os diagramas de causa e efeito mais empregados dividem a análise em quatro categorias principais de causas: pessoas, métodos, equipamentos e materiais.

- Pessoas: inclui todos os funcionários e gerentes e fatores a eles relacionados como conhecimento, treinamento, capacidade e atitude.

- Métodos: inclui questões como fluxo do processo, procedimentos de trabalho, procedimentos operacionais, etc.

- Equipamentos: inclui todos os maquinários, equipamentos, instrumentos de controle, bem como fatores relacionados, como ajustes, manutenção, etc.

- Materiais: inclui todas as entradas do processo e suas características, tais como fornecedores, modificações e variabilidade.

Outras categorias de causas que podem ser incluídas são:

- Medição: inclui todas as variáveis que podem ser medidas, bem como fatores como disponibilidade, amostragem, reprodutibilidade, e definição operacional;

- Vizinhanças: inclui itens como iluminação, temperatura, rotinas operacionais e de manutenção, número de ciclos e cronogramas de teste.

A construção de um diagrama de causa e efeito se inicia com a construção de uma linha horizonal com uma caixa do lado direito, onde coloca-se o problema a ser 
resolvido. A Figura 46 mostra um exemplo de um diagrama de causa e efeito, onde o objetivo é investigar a causa do excesso de sal no efluente do processo (efeito).

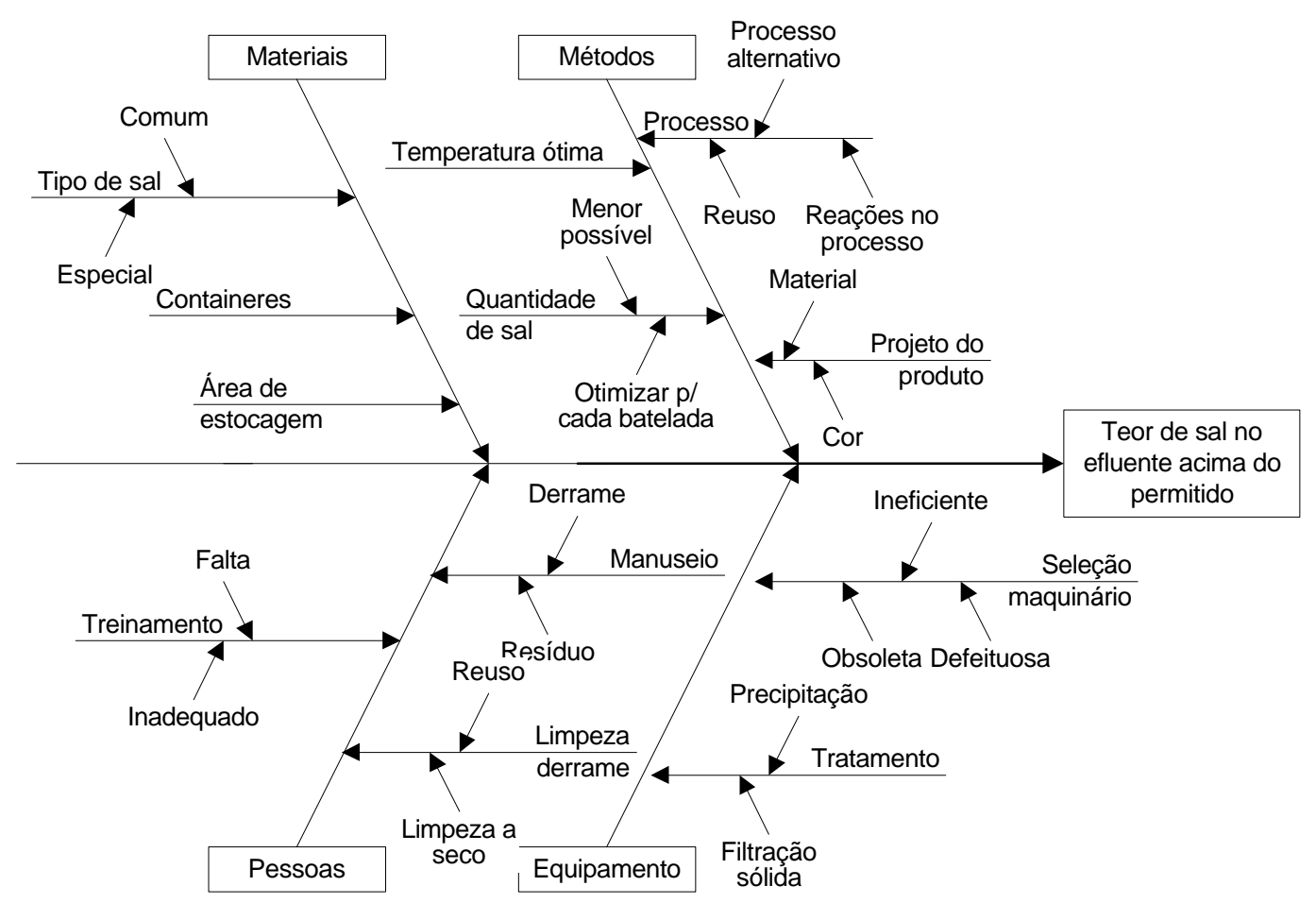

Figura 46 - Diagrama de causa e efeito

Fonte: Modificado de POJASEK (1996a)

Determinado o problema que se pretende resolver, o trabalho pode ser iniciado por qualquer uma das quatro categorias principais (materiais, métodos, pessoas, equipamentos), representadas no diagrama pelas linhas diagonais maiores. Para cada uma dessas categorias são feitas as perguntas-chave, cujas respostas (causas) são mostradas no diagrama nas linhas horizontais. As causas são continuamente definidas e relacionadas umas as outras, subcausas apontadas são mostradas nas linhas diagonais menores.

Quando o diagrama está completo, o grupo deve revisar cada uma das categorias principais, de modo a refinar a análise, identificando as causas que aparecem mais de uma vez no diagrama (este é um indicador da 'causa mais provável' do problema). As causas mais prováveis devem ser revisadas de modo a possibilitar a visualização do porque da sua ocorrência, e se necessário novas informações devem ser levantadas.

O diagrama de causa e efeito pode também ajudar o grupo a preparar uma lista de alternativas para solucionar o problema. Esta é uma importante etapa a ser realizada após a descoberta da causa do problema (POJASEK, 1996a). 


\subsection{Tomada de Decisão}

Identificada a causa do problema (perda, geração de resíduo ou outra forma de desperdício de matéria-prima, insumo, água ou energia) devem ser buscadas alternativas para a solução deste problema, o que envolve três etapas básicas: a) a identificação de possíveis alternativas; b) a seleção da melhor alternativa dentre as opções existentes; e, c) a implantação da alternativa escolhida.

\subsubsection{Identificação das Alternativas}

De maneira geral, as pessoas envolvidas nos projetos de prevenção à poluição tendem a se concentrar na identificação de um número pequeno de alternativas (quando não em uma única alternativa), principalmente porque nestes casos não foi realizada uma análise causa e efeito (logo faltam informações chave) ou porque o grupo não está suficientemente envolvido no processo. A literatura sobre prevenção à poluição (publicações, manuais e estudos de caso) pode ser usada como fonte de informação para problemas específicos. No entanto, em muitos casos a melhor alternativa é aquela desenvolvida pelo grupo, especialmente para solucionar aquele problema específico no qual seus esforços estão voltados. A abordagem sistêmica se concentra na seguinte teoria: "a única maneira de encontrar uma boa alternativa de prevenção àpoluição é dispor de muitas alternativas" (US EPA 2001a).

Pojasek (1996b) sugere dois métodos para a identificação de múltiplas alternativas para a solução de um problema: o 'brainstorming' e o 'brainwriting'.

\subsubsection{Brainstorming}

O brainstorming tem por objetivo gerar tantas idéias e alternativas quanto forem possíveis, sem a princípio uma maior preocupação com o fato destas alternativas serem praticáveis ou não. Exercitar a prática do brainstorming implica em deixar a criatividade fluir e prevenir idéias negativas que possam inibir a criatividade do grupo, para isso algumas regras básicas devem ser seguidas:

- Não avaliar ou julgar idéias: quando as idéias estão sendo oferecidas, ninguém deve julgá-las em um primeiro momento. Comentários negativos ou críticas podem inibir os membros do grupo em oferecer novas idéias. Normalmente as pessoas têm receio de parecer tolas perante o seu grupo de trabalho. Mesmo comentários positivos, tais como 'boa idéia', podem inibir alguns participantes.

- Produzir idéias extravagantes: seguindo a regra anterior, os participantes podem se sentir a vontade em produzir idéias não-convencionais, que podem simplesmente funcionar. A base da criatividade é olhar as coisas de uma 
perspectiva diferente, buscando soluções fora do convencional e do prédeterminado.

- Produzir idéias em quantidade: o brainstorming trabalha segundo o princípio da busca de quantidade de idéias, não da qualidade. Chegará o momento em uma etapa posterior onde a qualidade das idéias será avaliada.

- Trabalhar em cima das idéias alheias: uma idéia fornecida por um participante pode servir como base inicial e ser aprimorada por outro integrante do grupo. Este tipo de comportamento deve ser motivado, e não visto como algo incorreto ou anti-ético.

O brainstorming é uma ferramenta para a identificação de alternativas de prevenção à poluição muito boa. Entretanto, alguns grupos a consideram um pouco restritiva, e muitas pessoas (com boas idéias), por timidez ou dificuldade de se expressar verbalmente podem ficar inibidas perante um grupo (especialmente se não há um contato anterior entre os participantes (POJASEK, 1996b).

\subsubsection{Brainwriting}

O brainwriting é uma técnica bastante similar ao brainstorming, que funciona melhor quando os participantes não estão familiarizados uns com os outros. A técnica permite que o trabalho seja realizado mesmo quando os participantes do grupo não se encontram no mesmo lugar, por meio de programas de computador especializados.

Durante um exercício de brainwriting cada um dos participantes sentados em uma mesma mesa recebem um formulário, como o exemplo mostrado na Figura 47. Deve haver uma folha a mais do que o número de pessoas presentes, que deve ficar ao centro da mesa. Cada participante inicialmente escreve duas alternativas em seu formulário (célula 1 e 2), retornando-o ao centro da mesa. A primeira pessoa a retornar o formulário para o centro da mesa pega a folha remanescente, e os outros pegam formulários de seus colegas, de forma aleatória. Cada participante escreve mais duas alternativas e repete o processo de devolução e troca dos formulários, até que se chegue ao consenso de que todas as idéias se esgotaram. Quando se chega a este estágio, as alternativas geradas nos formulários são lidas, discutidas e anotadas em uma nova folha, as alternativas que aparecem mais de uma vez não devem ser repetidas sem entretanto, excluir alternativas 'aparentemente' similares. As discussões podem levar ao surgimento de novas alternativas e fazer com que todos compreendam melhor cada uma das alternativas propostas por seus colegas. 


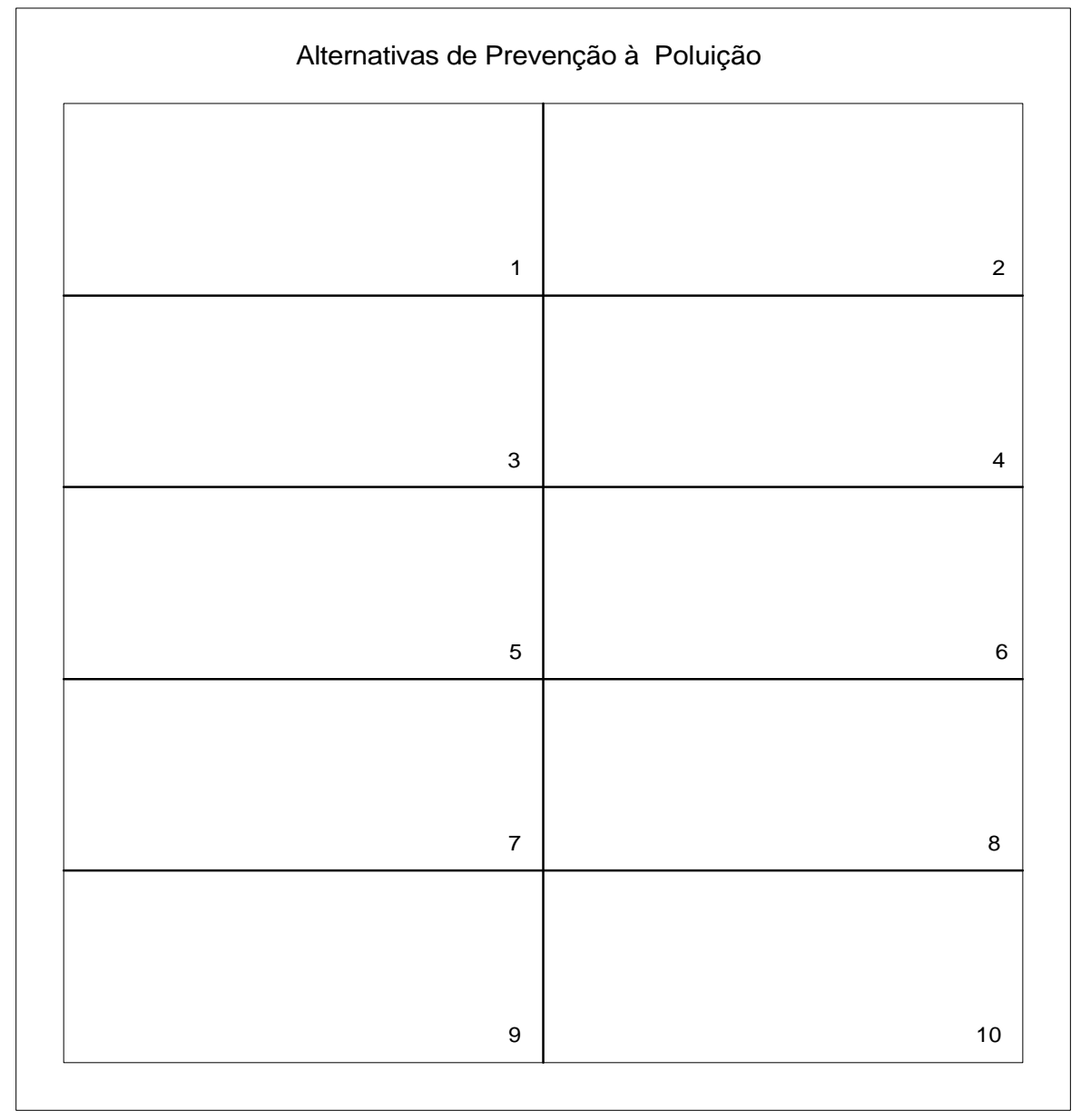

Figura 47 - Formulário para exercício de brainwriting

Fonte: Modificado de POJASEK (1996b)

É importante que antes de se iniciar os trabalhos, tanto usando o brainstorming quanto o brainwriting, o grupo tenha o conhecimento pleno do problema que se quer resolver, e para isso deve-se revisar o mapeamento de processo e os diagramas de causa e efeito construídos nas etapas anteriores (POJASEK, 1996b).

\subsubsection{Seleção das Alternativas}

De posse de uma lista de possíveis alternativas para a solução do problema, é preciso usar ferramentas estruturadas para selecionar uma alternativa em particular para implantação. Pojasek (1997c) descreve três ferramentas que podem auxiliar nesta etapa de decisão: a) multi-votos; b) comparação em pares (bubble-up/bubble down) e c) matriz de critérios.

\subsubsection{Multi-votos}

O método de multi-votos é freqüentemente empregado para obter a opinião da maioria em relação às várias alternativas disponíveis, e serve ainda para estreitar a 
lista de alternativas. A forma mais comum de se realizar a votação consiste em listar todas as alternativas e fornecer a cada participante um certo número de votos. Cada participante coloca um voto em cada alternativa particular, e alternativa que receber 0 maior número de votos é a selecionada. Um ponto negativo deste método é que não permite uma discussão substantiva entre os participantes durante a votação. A discussão é importante porque leva a um melhor entendimento das alternativas e pode agregar considerações importantes que facilitarão a etapa seguinte de implantação. Outro ponto negativo é que este método pode criar uma atmosfera de 'ganhador' e 'perdedor' entre os participantes (POJASEK, 1997c).

\subsubsection{Comparação em Pares}

O método da comparação em pares (bubble up/bubble down) é uma ferramenta útil quando a seleção envolve um grande número de alternativas. O método força a comparação em pares, na qual os participantes focam sua atenção em duas alternativas de cada vez, e escolhem dentre estas duas a melhor. Neste caso o que torna uma alternativa melhor do que a outra são três atributos fundamentais: eficácia, viabilidade de implantação e custo.

A eficácia refere-se ao potencial da alternativa em eliminar ou minimizar as perdas ou a geração de resíduos do processo em questão. Para se avaliar o potencial de eficácia da alternativa, algumas questões devem ser respondidas: a) A alternativa diminui o uso de substâncias perigosas? b) A alternativa permite a recuperação de subprodutos com valor agregado? c) A alternativa permite que o processo seja simplificado? d) A substituição de material levará a uma redução global dos resíduos perigosos e perdas e ao mesmo tempo contribuirá para a segurança no ambiente de trabalho? e) A quantidade de material/resíduo sob regulação irá diminuir de forma a cumprir a legislação?

Questões relativas à implantação da alternativa também são importantes e precisam ser discutidas antes que a implantação seja iniciada. Questões típicas a serem respondidas sobre este quesito envolvem: a) Existem casos documentados que detalham como outras firmas empregaram esta alternativa? b) Os supervisores, gerentes e funcionários irão apoiar esta alternativa? c) Quais são os requisitos de engenharia envolvidos no projeto? d) A alternativa irá requerer um planejamento longo? e) Qual é a disponibilidade comercial dos equipamentos e tecnologias necessários para implantar a alternativa?

Esta última questão é de extrema relevância. Antes de se optar pela alternativa deve-se verificar a disponibilidade de fornecedores dos equipamentos e/ou tecnologias 
que serão necessários. Se existirem vários fornecedores oferecendo o equipamento é um bom indicativo de que a alternativa já vem sendo amplamente utilizada. Se as opções de equipamentos disponíveis estiverem alinhadas com as necessidades do projeto, a implantação da alternativa será muito mais fácil.

O aspecto custo é uma preocupação bastante óbvia, principalmente se a alternativa implicar em recursos financeiros de médio a grande portes. Normalmente os custos ambientais não são considerados na análise de custos de projetos. De forma a viabilizar a liberação de recursos para os projetos de prevenção à poluição deve-se assegurar que os custos ambientais sejam levados em consideração. Como já foi visto anteriormente no item 4.7.2.4, a contabilidade ambiental é uma ferramenta indicada para a avaliação dos custos ambientais.

De maneira geral, deve-se buscar a garantia de que a alternativa contribuirá para a redução dos custos com o atendimento à legislação ambiental (monitoramento, inspeções, auditorias, treinamento, licenças, etc.), para a diminuição dos custos com a garantia da segurança e saúde dos funcionários, para a diminuição dos custos com insumos, água e energia usados no tratamento dos resíduos, entre outros.

Uma vez conhecidos os atributos de cada alternativa (eficácia, viabilidade de implantação e custo), o grupo pode iniciar a comparação das alternativas. As alternativas geradas nas sessões de brainstorming e brainswriting, são listadas aleatoriamente em uma folha, cada uma com um número em ordem sequencial. $O$ trabalho começa pela análise das duas primeiras alternativas que aparecem no topo da lista, discutindo qual das duas é melhor em termos de efetividade, viabilidade e custo. A alternativa que for considerada a melhor é colocada no topo da lista e a outra é colocada em último lugar da lista. O processo reinicia, sempre comparando as duas primeiras opções da lista e movendo-as para cima ou para baixo, até que os pares comecem a se repetir.

As alternativas que aparecem no topo da lista são consideradas as melhores, e as que se concentram no meio da lista devem ser consideradas como boas opções futuras para e melhoria contínua do programa de prevenção à poluição. Na maioria dos casos, não se tem muito conhecimento destas alternativas posicionadas no centro, que normalmente requerem investimentos financeiros elevados. As alternativas implantadas no início do programa normalmente são aquelas que requerem investimentos baixos ou moderados (POJASEK, 1997c). 


\subsubsection{Matriz de Critérios}

A matriz de critério é uma ferramenta para a seleção de alternativas que combina alguns aspectos das duas ferramentas discutidas anteriormente. A primeira etapa necessária para o uso desta ferramenta é a seleção de critérios a serem considerados na avaliação das alternativas listadas. Os critérios escolhidos devem enfatizar os aspectos já discutidos de eficácia, viabilidade e custo. Deve haver um consenso geral a respeito do sistema de pesos a ser adotado para valorar cada critério e para estabelecer uma escala de valores para cada alternativa. A US EPA e o Departamento de Energia dos Estados Unidos (DOE) adotam um método de soma dos pesos para avaliar as alternativas. A Figura 48 mostra a matriz de critérios usada pelo DOE. Para o seu preenchimento são válidas as seguintes instruções:

a. Os valores da coluna Peso (W) representam a prioridade da empresa em relação ao critério, e devem variar de 0 a 10.

b. Na coluna Escala (S), deve-se adotar um valor entre 0 e 10 para cada alternativa em relação a cada um dos critérios (usar as definições da Figura 49 para determinar estes valores).

c. Na coluna W x S entrar com o valor do produto entre o peso (W) e escala (S).

d. Somar a coluna $\mathrm{W} \times \mathrm{S}$ para cada alternativa para obter o subtotal.

e. Multiplicar o subtotal para cada alternativa pela probabilidade de sucesso.

f. Multiplicar o valor obtido no estágio (e) para cada alternativa pela probabilidade de resultados esperados.

g. Entrar com o produto obtido no estágio (f) na coluna Total para cada alternativa.

h. Designar um rank de prioridade para cada alternativa; \#1 para o valor mais alto, 2\# para o próximo, etc. 


\begin{tabular}{|c|c|c|c|c|c|c|c|c|c|c|c|}
\hline & & & Matri & de & érios $(\mathrm{Mc}$ & odel & & & & & \\
\hline & & & & & & & & & & Revis & $n^{\circ}$ \\
\hline Avaliaça & de Op & ortun & de de P & eve & ò Polui & ção & & & & $\mathrm{Da}$ & \\
\hline & & & & alia & de Alte & rnat & & & & & \\
\hline Critério & Peso & & $n^{0}-$ & & n-⿳- & Opc & n- & & $\mathrm{n}^{\circ}$ & & no- \\
\hline & & Esc & & & & Esc & & Esc & (S) & Esc & (S) \\
\hline & & $S$ & $\mathrm{~W} \times \mathrm{S}$ & $S$ & $\mathrm{~W} \times \mathrm{S}$ & $S$ & $\mathrm{~W} \times \mathrm{S}$ & $S$ & $\mathrm{~W} \times \mathrm{S}$ & $S$ & $\mathrm{~W} \times \mathrm{S}$ \\
\hline $\begin{array}{l}\text { Segurança Saúde } \\
\text { e Meio Ambiente }\end{array}$ & 10 & & & & & & & & & & \\
\hline $\begin{array}{l}\text { Segurança e } \\
\text { Saúde } \\
\text { Ocupacional }\end{array}$ & 10 & & & & & & & & & & \\
\hline Legislação & 8 & & & & & & & & & & \\
\hline Custo & 6 & & & & & & & & & & \\
\hline $\begin{array}{l}\text { Tempo de } \\
\text { implantação }\end{array}$ & 4 & & & & & & & & & & \\
\hline $\begin{array}{l}\text { Melhoria } \\
\text { produto/produção }\end{array}$ & 2 & & & & & & & & & & \\
\hline Subtotal & & & & & & & & & & & \\
\hline $\begin{array}{l}\text { Probabilidade de } \\
\text { sucesso técnico }\end{array}$ & & & & & & & & & & & \\
\hline $\begin{array}{l}\text { Probabalidade de } \\
\text { resultados }\end{array}$ & & & & & & & & & & & \\
\hline Total & & & & & & & & & & & \\
\hline Rank & & & & & & & & & & & \\
\hline
\end{tabular}

Figura 48 - Matriz de critérios para seleção de alternativas

Fonte: Modificado de POJASEK (1997c)

Uma das dificuldades encontradas ao se trabalhar com matrizes é encontrar os valores de escala para as alternativas em relação aos critérios. A Figura 49 fornece um roteiro para a determinação destes valores. Definidos os valores deve-se realizar uma última avaliação, que consiste em verificar se a alternativa responde de forma satisfatória às seguintes questões: a) soluciona o problema e a causaraíz; b) satisfaz a todos os critérios usados na matriz; c) satisfaz a todos os participantes e pessoas afetadas; d) permite o desenvolvimento de um plano de ação praticável; e) existe tempo suficiente para a implantação; f) existem os recursos humanos e financeiros necessários à execução; g) a implantação levará efetivamente à pevenção à poluição e à minimização de resíduos; h) todos os riscos, desvantagens e possíveis consequências foram considerados; e, i) é a melhor alternativa em termos de custos, benefícios, riscos, comprometimento e praticabilidade. 


\begin{tabular}{|c|c|}
\hline & $\begin{array}{l}\text { Saúde Pública, Segurança e Meio Ambiente } \\
\text { - Risco àsaúde e segurança da população } \\
\text { em geral e de danos ao meio ambiente }\end{array}$ \\
\hline 10 & $\begin{array}{l}\text { Reduz risco de perda de vida ou dano } \\
\text { ambiental a longo prazo. Alta concentração } \\
\text { de substâncias perigosas }\end{array}$ \\
\hline 8 & $\begin{array}{l}\text { Reduz risco de problemas à saúde e danos } \\
\text { ambientais moderados a longo prazo. Conc. } \\
\text { de substâncias perigosas moderada. }\end{array}$ \\
\hline 6 & $\begin{array}{l}\text { Reduz risco de problemas à saúde ou } \\
\text { emissões acidentais a curto prazo. Baixa } \\
\text { conc. substâncias perigosas. }\end{array}$ \\
\hline 4 & Sem efeito \\
\hline \multirow[t]{2}{*}{0} & Efeito negativo \\
\hline & $\begin{array}{l}\text { Segurança e Saúde Ocupacional - Risco a } \\
\text { funcionário, contratado ou visitante }\end{array}$ \\
\hline 10 & $\begin{array}{l}\text { Reduz risco de perda de vida por acidentes } \\
\text { ou exposição. }\end{array}$ \\
\hline 8 & $\begin{array}{l}\text { Reduz risco de afastamento longo ou } \\
\text { permanente por acidente ou exposição }\end{array}$ \\
\hline 6 & $\begin{array}{l}\text { Reduz risco de afastamento ou perda de } \\
\text { tempo por acidente ou exposição }\end{array}$ \\
\hline 4 & Sem efeito \\
\hline \multirow[t]{2}{*}{0} & Efeito negativo \\
\hline & $\begin{array}{l}\text { Atendimento à Legislação - Risco de não } \\
\text { atendimento à leis ambientais com respeito } \\
\text { àgerentes e funcionários }\end{array}$ \\
\hline 10 & Reduz o risco ou evita penalidades criminais \\
\hline 8 & Reduz o risco ou evita penalidades civis \\
\hline 6 & Reduz riscos \\
\hline 4 & Sem efeito \\
\hline \multirow[t]{2}{*}{0} & Efeito negativo \\
\hline & $\begin{array}{l}\text { Economia - Potencial de redução de custos } \\
\text { e período de retorno }\end{array}$ \\
\hline 10 & Economia elevada e curto período de retorno \\
\hline 8 & Economia e período de retorno moderados \\
\hline 6 & Economia positiva e período de retorno longo \\
\hline 4 & Sem possibilidade de economia e retorno \\
\hline 0 & Economia negativa \\
\hline
\end{tabular}

\begin{tabular}{|c|l|}
\hline & $\begin{array}{l}\text { Período de Implantação - Potencial para } \\
\text { implantação rápida das alternativas de } \\
\text { prevenção àpoluição }\end{array}$ \\
\hline 10 & Imediato (dentro de 1 mês) \\
\hline 8 & Curto-prazo (dentro de 1 ano) \\
\hline 6 & Intermediário (dentro de 2 anos) \\
\hline 4 & Longo-prazo (dentro de 3 anos) \\
\hline 0 & Mais de 3 anos \\
\hline 0,1 & $\begin{array}{l}\text { Melhoria da Qualidade do Produto, das } \\
\text { Práticas Operacionais e do Processo } \\
\text { Existem sérias reservas quanto à geração de } \\
\text { iscos. Custos elevados em relação aos }\end{array}$ \\
\hline 10 & Melhorias significativas \\
\hline 8 & Melhorias moderadas \\
\hline 6 & Melhorias positivas \\
\hline 4 & Nenhuma melhoria \\
\hline 0 & Efeito negativo \\
\hline 1 & $\begin{array}{l}\text { Média. Projeto ainda não demonstra atender } \\
\text { qto a possibilidade de criar riscos. Benefícios } \\
\text { ainda não estão claros. }\end{array}$ \\
\hline 1 & $\begin{array}{l}\text { Pltababilidade de Sucesso Técnico } \\
\text { que a implanto demonstra quão não acarretará riscos. } \\
\text { Benefícios ultrapassam impedimentos técnicos. Planos } \\
\text { bem executados e casos de sucesso } \\
\text { relatados e documentados. }\end{array}$ \\
\hline 0,5 & $\begin{array}{l}\text { Média. Necessidade de ajustes técnicos. } \\
\text { Requisitos-chave identificados sem a } \\
\text { realização de planejamento. }\end{array}$ \\
\hline 0,1 & $\begin{array}{l}\text { Baixa. Grandes ajustes técnicos requeridos. } \\
\text { Planejamento e requerimentos-chave não } \\
\text { identificados }\end{array}$ \\
\hline Probabilidade de Resultados Positivos \\
\hline
\end{tabular}

Figura 49 - Definição de fatores de escala para matriz de critério Fonte: Fonte: Modificado de POJASEK (1997c) 


\subsubsection{Implantação das Alternativas}

Como foi visto na sequência dos itens discutidos anteriormente, a qualificação de uma alternativa para implantação requer muito trabalho. Falhas na implantação das alternativas podem contribuir para a perda credibilidade do programa e do próprio conceito de prevenção à poluição. Para o processo de implantação de alternativas deve-se estabelecer um plano de ação, que consiste no detalhamento e organização de todas as tarefas necessárias à implantação das alternativas selecionadas. $O$ uso correto desta ferramenta é vital para a garantia da implantação e da melhoria contínua do programa (POJASEK, 1997d).

\subsubsection{Plano de Ação}

De modo a desenvolver um plano de ação efetivo é preciso extrair informações relevantes sobre a alternativa escolhida, o que pode ser feito mediante a formulação de uma série de perguntas:

a) Porque implantar esta alternativa é importante para a companhia?

b) Porque é importante para os clientes?

c) Quais os riscos envolvidos na implantação desta alternativa?

d) Que modificações serão necessárias para implantação da alternativa?

e) Quem deverá fazê-las e quando?

f) Qual é a programação e o orçamento mais indicado?

g) Como se sabe que esta é a direção correta?

h) Como será realizado o acompanhamento para garantir a implantação adequada?

Podem ser analisadas estas e outras questões que se fizerem pertinentes. Em alguns casos informações adicionais são necessárias para responder algumas das questões. Algumas das respostas podem ser obtidas já na fase inicial da implantação, e uma forma de garantir estas respostas é através da execução de um plano piloto do programa. Questões adicionais que podem ser feitas são mostradas no Quadro 14.

A princípio pode parecer desnecessário gastar tempo respondendo a estas questões após o exaustivo trabalho realizado em todas as etapas anteriores, entretanto esta etapa não deve ser subestimada, as questões devem ser respondidas uma a uma, pois a discussão irá permitir a formulação de um plano de ação flexível, livre de incertezas, resultando em um processo de implantação mais tranquilo. 
Quadro 14 - Questões a serem respondidas antes da implantação.

\section{Questões adicionais a serem respondidas antes de implantar uma alternativa}

- Quais são os objetivos e metas globais?

- Quais licenças e recursos são necessários?

- Quais ações precisam ser executadas?

- Quem será responsável por cada ação?

- Quanto tempo consumirá cada etapa e quando serão finalizadas?

- Qual sequência de etapas é requisitada?

- Quais são os pontos de verificação?

- Onde se encontram as etapas críticas?

- Quais treinamentos são necessários nas etapas de implantação?

- Quais são os padrões aplicáveis?

- Qual é a escala apropriada?

- Como serão medidos os resultados?

- Como será medido o follow-up?

- O que pode acontecer de errado e como isso será gerenciado?

- Como o plano pode ser modificado sem prejudicar os resultados?

- Como será realizada a comunicação do plano de modo a garantir o suporte da gerência e demais funcionários?

- Quais as respostas à mudança e outros fatores humanos são esperados?

- Como serão vencidas as resistências e as barreiras?

Fonte: Modificado de POJASEK (1997d)

A estratégia de implantação pode ser sumarizada em uma formulário como o mostrado na Figura 50, de modo a permitir a visualização clara e objetiva da sequência de ações requerida para a implantação da alternativa. Neste formulário deve constar uma descrição suscinta da alternativa e a listagem das tarefas (ações) específicas necessárias. É importante definir um responsável por cada ação e um padrão de desempenho para avaliação do nível de qualidade alcançado na implantação de cada uma das ações, que determinará como cada ação precisa ser realizada. Estes aspectos culminam com o monitoramento criterioso do processo de implantação, que implica na determinação de objetivos e metas mensuráveis. 
Dependendo das circunstâncias, diversas técnicas podem ser usadas para monitorar a implantação de uma alternativa de prevenção à poluição:

- Inspeções de controle de qualidade;

- Estatísticas de produção;

- Relatórios de conformidade;

- Pesquisas e questionários;

- Auditorias;

- Controle de custos.

O plano de ação inclui ainda a alocação dos recursos necessários para cada ação. O planejamento dos recursos definirá todo o cronograma do plano, e ainda servirá como uma justificativa para a gerência dos custos, do tempo e do pessoal envolvido no programa.

\begin{tabular}{|c|c|c|c|c|c|}
\hline \multicolumn{6}{|c|}{ PLANO DE AÇÃO } \\
\hline \multicolumn{6}{|c|}{ ALTERNATIVA: DESCRIÇÃO BREVE E CLARA DA ALTERNATIVA A SER IMPLANTADA } \\
\hline AÇÃO & RESPONSÁVEL & $\begin{array}{l}\text { INDICADOR DE } \\
\text { PERFORMANCE }\end{array}$ & $\begin{array}{c}\text { TÉCNICA DE } \\
\text { MONITORAMENTO }\end{array}$ & $\begin{array}{l}\text { CUMPRIMENTO } \\
\text { DA META (DATA) }\end{array}$ & $\begin{array}{l}\text { RECURSOS } \\
\text { NECESSÁRIOS }\end{array}$ \\
\hline 1. & & & & & \\
\hline 2. & & & & & \\
\hline 3. & & & & & \\
\hline 4. & & & & & \\
\hline 5. & & & & & \\
\hline 6. & & & & & \\
\hline$\therefore$ & & & & & \\
\hline n. & & & & & \\
\hline
\end{tabular}

Figura 50 - Modelo de formulário de plano de ação

Fonte: Modificado de POJASEK (1997d) 


\subsection{Gerenciamento do Programa}

A implantação de um programa de prevenção à poluição não é um processo linear, e sim um processo contínuo de melhoria. O plano de ação elaborado não deve ser um documento estático, ao contrário, precisa ser monitorado regularmente e revisado sempre que necessário.

Enquanto as etapas e ferramentas de identificação e seleção de oportunidades, de solução do problema, de identificação e seleção de alternativas e de tomada de decisão discutidas anteriormente se aplicam a diversas organizações, o plano de gerenciamento do programa deve ser elaborado de maneira que se encaixe na cultura de cada companhia, e cabe a ela definir o plano de gerenciamento, bem como a maneira de relacionar o programa de prevenção à poluição com os demais programas organizacionais existentes (US EPA, 2001a).

O plano de gerenciamento precisa estar comprometido a realizar o monitoramento, a revisão e a modificação do plano de ação. Uma vez alcançadas as metas no plano de ação, o mapeamento de processo pode ser revisado e novas oportunidades podem ser selecionadas (POJASEK, 1997d).

\subsubsection{Auditorias}

Segundo a US EPA (2001a), o progresso de um programa de prevenção à poluição pode ser avaliado por meio de auditorias, que podem ser internas ou realizadas por uma terceira parte.

Segundo Philippi Jr. e Aguiar (2004), uma auditoria ambiental é um processo sistemático e formal de verificação, por uma parte auditora, se a conduta e/ou o desempenho ambiental de uma entidade atendem a um conjunto de critérios especificados. Ainda segundo os autores as auditorias se caracterizam pelos seguintes aspectos:

a) São realizadas por profissionais que conhecem o assunto a ser auditado e que não estão envolvidos na atividade auditada;

b) Podem ter escopo variado, havendo necessidade de definição de sua abrangência;

c) Dela participam o cliente (interessado nos resultados e quem a contrata); o auditado (responsável pelas atividades que devem ser verificadas); e, o auditor (que é quem conduz a auditoria).

Uma auditoria eficiente deve ainda apresentar objetivos e escopo explicitamente definidos, abrangência que priorize as unidades mais importantes (sem desprezar as 
demais), ter uma abordagem compatível com os objetivos, deve ser conduzida por profissionais experientes e capacitados e ainda contar com suporte gerencial e organização eficazes (HEDSTROM ${ }^{38}$, 1994 apud PHILIPPI Jr. e AGUIAR, 2004).

Segundo Philippi Jr. e Aguiar (2004), a auditoria difere de outros métodos de avaliação por dois motivos: 1) as auditorias são programadas, e o auditado é informado com antecedência sobre o objetivo, escopo, data e horário dos trabalhos; 2) as auditorias são processos cujo resultado principal é a verificação do cumprimento ou não de padrões especificados. Os autores classificam as auditorias da seguinte forma:

- De acordo com a parte interessada: auditoria de primeira, segunda e terceira parte;

- De acordo com os critérios de auditoria: auditoria de conformidade legal, de desempenho ambiental e de sistemas de gestão ambiental;

- De acordo com os objetivos da auditoria: auditoria de certificação, de acompanhamento e de verificação de correções, de responsabilidade, de sítio e compulsória.

Para propósito de discussão neste trabalho, convém elucidar as definições apresentadas pelos autores para dois tipos de auditorias:

- Auditoria de desempenho ambiental: são verificados indicadores de desempenho, a serem comparados com padrões, geralmente setoriais, ou com metas definidas.

- Auditoria de sistemas de gestão ambiental: avalia o cumprimento das normas, critérios e procedimentos de gestão ambiental estabelecidos pela própria organização auditada. Estas auditorias podem ainda ser de adequação (para verificar se o sistema atende ao que é exigido pela norma); de conformidade (para verificar se o sistema está sendo utilizado); e de eficácia (para verificar se os objetivos e metas propostos pelo sistema vêm sendo atingidos).

Considerando os requisitos de um programa de prevenção à pduição e as definições apresentadas acima, pode-se dizer que uma auditoria para avaliação de programas de prevenção à poluição se aproxima de uma auditoria de sistemas de gestão ambiental, por requerer que sejam avaliados os procedimentos estabelecidos para o programa (alternativas implantadas), sua adequação (se a alternativa foi

${ }^{38}$ HEDSTROM, G.S. (1994). Environmental, health and safety auditing comes of age. In: Harrison, L. Environmental, health and safety auditing handbook. $2^{\text {nd }}$ ed. New York: McGraw-Hill apud PHILIPPI Jr. e AGUIAR (2004). 
implantada de forma correta) e sua eficácia (se o programa está atingindo os objetivos e metas propostos, de redução de perdas e resíduos). Pode apresentar ainda aspectos de uma auditoria de desempenho ambiental, com o estabelecimento de indicadores para comparação do desempenho entre diferentes plantas de uma mesma corporação ou entre diferentes companhias de um mesmo setor.

A auditoria deve funcionar como um ciclo (Figura 51), e uma vez apontada uma não-conformidade (a alternativa implantada não responde de maneira satisfatória aos objetivos e metas propostos no plano de ação), devem ser avaliadas as causas desta não-conformidade, com o apoio das ferramentas estruturadas apresentadas nos tópicos anteriores deste capítulo, como o mapeamento de processo (4.4.2) e os diagramas de causa e efeito (4.6.1). Uma não-conformidade pode ser resultado de falhas em diversas etapas do planejamento:

a) falhas no mapeamento de processo e na identificação de oportunidades;

b) escolha inadequada da alternativa;

c) escolha inadequada do(s) equipamento(s) e tecnologia(s);

d) falhas na implantação da alternativa;

e) falta de treinamento dos funcionários, entre outras.

Neste caso, devem ser definidas ações corretivas (que podem envolver a correção dos problemas apresentados pela(s) alternativa(s) implantada(s), ou a escolha de uma nova alternativa. As correções ou as novas alternativas são implantadas, fechando o ciclo de avaliação.

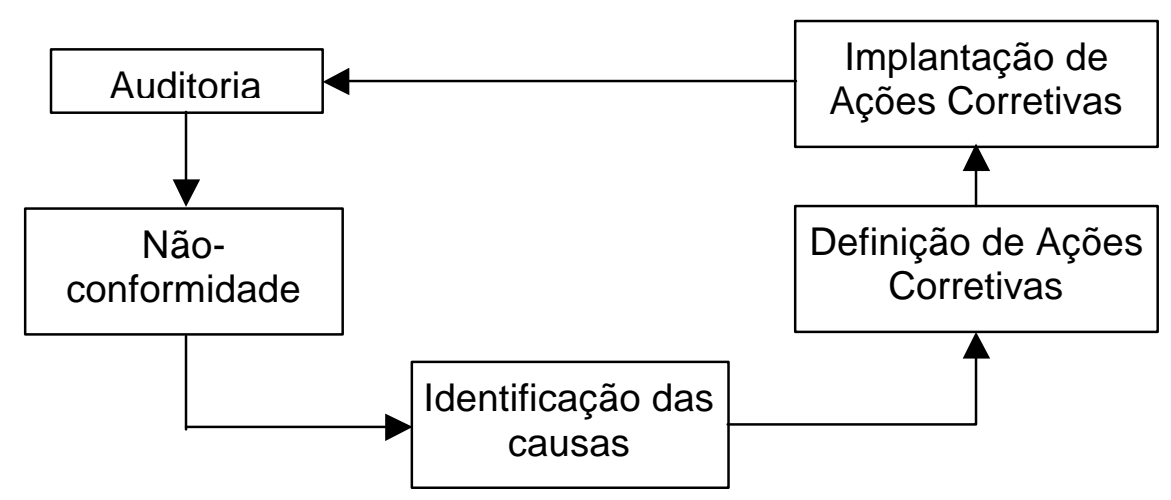

Figura 51- Ciclo de melhoria de ações corretivas de uma auditoria Fonte: PHILIPPI Jr. e AGUIAR (2004) 


\subsubsection{Indicadores de Desempenho Ambiental}

Segundo o WBCSD (2000b), indicadores de desempenho ambiental são medidas específicas de um aspecto individual que podem ser usadas para avaliar e demonstrar o desempenho de uma companhia em relação a sua eco-eficiência. O WBCSD divide os indicadores de eco-eficiência em três grandes categorias, relacionadas com seus aspectos de influência, mostradas no Quadro 15.

Quadro 15 - Categorias de indicadores de eco-eficiência, segundo o WBCSD.

\begin{tabular}{|c|c|}
\hline Categoria de indicador & Aspecto \\
\hline Valor do produto ou serviço & $\begin{array}{l}\text { - } \text { Volume ou massa } \\
\text { - } \quad \text { Valor monetário } \\
\text { - } \quad \text { Função }\end{array}$ \\
\hline $\begin{array}{l}\text { Influência ambiental associada à } \\
\text { manufatura de produtos e serviços }\end{array}$ & $\begin{array}{l}\text { - } \text { Consumo de energia } \\
\text { - } \text { Consumo de materiais } \\
\text { - } \quad \text { Consumo de recursos naturais } \\
\text { - } \text { - Eeração de subprodutos e resíduos } \\
\text { - Eventos não programados }\end{array}$ \\
\hline $\begin{array}{l}\text { Influência ambiental associada ao uso } \\
\text { dos produtos e serviços }\end{array}$ & $\begin{array}{l}\text { - } \text { Características do produto ou serviço } \\
\text { - } \text { Resíduos de embalagem } \\
\text { - } \text { Consumo de energia } \\
\text { - Emissões durante o uso ou disposição }\end{array}$ \\
\hline
\end{tabular}

Fonte: Contruído com base em informações do WBCSD (2000b)

Segundo Phillipi Jr., Malheiros e Aguiar (2004), na prática os indicadores de ecoeficiência mais aplicados são aqueles que expressam estratégias para reduzir a intensidade de material e energia; reduzir a dispersão de substâncias tóxicas; aumentar a durabilidade dos produtos e a intensidade dos serviços; ampliar a reciclabilidade e maximizar o uso de fontes renováveis.

Os indicadores têm uma série de aplicações e agregam uma grande quantidade de informações de diferentes fontes em um formato que permite o entendimento, a comparação e a manipulação dos aspectos. Segundo Phillipi Jr., Malheiros e Aguiar (2004), uma vez aplicados os indicadores, a companhia pode estabelecer objetivos e metas, e através do ciclo PDCA (Plan, Do, Check, Act), gerenciar as ações que serão implantadas para obter a melhoria do desempenho. Segundo Krajnc e Glavic (2003), a 
interpretação dos resultados se torna mais fácil se as metas forem usadas como indicadores.

Segundo Gallopín ${ }^{39}$ (1997 apud KRAJNC e GLAVIC, 2003), os indicadores têm como principais funções:

- Avaliar condições e tendências em relação aos objetivos e metas;

- Refletir o status de um sistema;

- Fornecer sinais de advertência antecipatórios;

- Antecipar condições e tendências futuras;

- Comparar diferentes lugares e situações;

- Salientar o que está acontecendo em um sistema amplo.

Segundo Azapagic e Perdan ${ }^{40}$ (2000 apud KRAJNC e GLAVIC, 2003), no contexto da produção sustentável, um indicador deve permitir a identificação de alternativas mais sustentáveis através das seguintes ações:

- Comparação de produtos similares produzidos por diferentes companhias;

- Comparação de diferentes processos para a produção de um mesmo produto;

- Comparação de unidades dentro de uma corporação;

- Comparação de companhias dentro de um setor;

- Avaliação dos progressos em relação ao desenvolvimento sustentável de um setor.

Entretanto, segundo Richards (1999), a avaliação de desempenho ambiental de companhias está ainda na sua infância, se comparada à avaliação de desempenho de produção e de desempenho econômico.

Nos últimos anos diversas organizações vêm tentando desenvolver indicadores para avaliar o progresso das companhias na busca do desenvolvimento sustentável. Dentre as iniciativas mais conhecidas estão a do WBCSD, a da ISO (através da norma ISO 14031), a da Global Reporting Initiative (GRI) e do CWRT (Center for Waste Reduction Technologies). Veleva e Ellenbecker (2001) ao avaliar as quatro iniciativas concluíram que a maioria dos indicadores estão ainda em desenvolvimento e nenhum destes é aplicável como um todo para a avaliação da produção sustentável. Outra

\footnotetext{
${ }^{39}$ GALLOPÍN, G. (1997). Indicators and their use: information for decision making, sustainability indicators. Report on the project on indicators for sustainable development. Wiley: Chichester. apud KRAJNC e GLAVIC (2003).

${ }^{40}$ AZAPAGIC, A., PERDAN, S. (2000). Indicators of sustainable development for industry: a general framework. Trans. Inst. Chem. Eng., v.78B, p. 244-246, apud KRAJNC e GLAVIC (2003).
} 
constatação é que estes indicadores dão pouca atenção aos aspectos sociais, que juntamente com os aspectos ambientais e econômicos formam as bases do desenvolvimento sustentável.

O problema em relação ao desenvolvimento de indicadores padronizados, que sejam aplicáveis a qualquer companhia ou organização, está na dificuldade de se introduzir uma medida quantitativa de produção sustentável, uma vez que alguns aspectos da sustentabilidade, especialmente o aspecto social, não pode ser expresso de forma quantitativa. Para outros aspectos, como o uso de água ou energia, não existem dificuldades em se estabelecer um indicador, uma vez que são comuns à todas as companhias. Indicadores mais específicos precisam ser definidos separadamente, dependendo do setor de atividade da companhia. Para enfrentar a complexidade dos aspectos relacionados à sustentabilidade em diferentes sistemas, os indicadores devem refletir a totalidade do sistema e as interações destes sistemas com seus subsistemas. O propósito dos indicadores está em refletir quão bem o sistema está funcionando e eles são extremamente dependentes do sistema que estão monitorando (KRAJNC e GLAVIC, 2003). Neste sentido, o WBCSD (2000b), avalia que os indicadores devem apresentar as seguintes características:

1. Ser relevantes e significativos com relação à proteção ambiental e humana e/ou à melhoria da qualidade de vida;

2. Informar a decisão de melhoria do desempenho ambiental da organização;

3. Reconhecer a diversidade inerente aos negócios da organização;

4. Promover a comparação e o acompanhamento ao longo do tempo;

5. Ser bem definidos, mensuráveis, transparentes e verificáveis;

6. Ser compreensíveis e significativos às partes interessadas;

7. Abranger todas as operações, processos, produtos e serviços, especialmente aquelas áreas de gestão e controle direto da organização;

8. Reconhecer aspectos relevantes da cadeia produtiva antes (fornecedores) e depois (uso do produto).

Segundo Krajnc e Glavic (2003) os critérios de avaliação da sustentabilidade de uma companhia devem refletir os aspectos relacionados ao uso dos recursos e dos produtos, aspectos ambientais, econômicos, sociais e de qualidade. Ao incorporar um indicador de produção sustentável, a companhia precisa identificar um período para monitorar e calcular o indicador, definir unidades de medida, identificar o tipo de medida (absoluta ou ajustada) e as fronteiras, que determinarão até onde a companhia 
deseja seguir monitorando o indicador. A Figura 52 mostra as principais dimensões dos indicadores de produção sustentável.

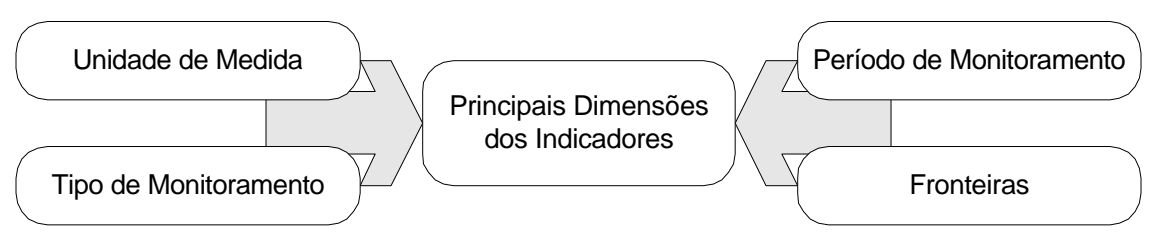

Figura 52 - Principais dimensões de um indicador de produção sustentável Fonte: Modificado de Krajnc e Glavic (2003)

Veleva e Ellenbecker (2001) recomendam que incialmente a companhia adote um sistema de monitoramento da conformidade e do desempenho ambiental que seja simples e fácil de implantar, e siga gradativamente em busca de indicadores mais complexos, que envolvam aspectos relacionados a cadeia de fornecedores, efeitos sociais e impactos dos produtos no ciclo de vida. O uso de indicadores de produção sustentável é um dos degraus da melhoria contínua, onde a meta é fazer com que a organização evolua a partir de medidas de avaliação primárias, chegando à utilização de todos os níveis de indicadores de produção sustentável.

Krajnc e Glavic (2003) dividem os indicadores de produção sustentável em sociais, ambientais e econômicos, como mostra o esquema da Figura 53. Os autores fornecem uma lista com vários exemplos de cada categoria de indicador, com base em dados disponíveis e em aspectos comumente mensurados da produção, alguns dos quais foram compilados e mostrados no Quadro 16.

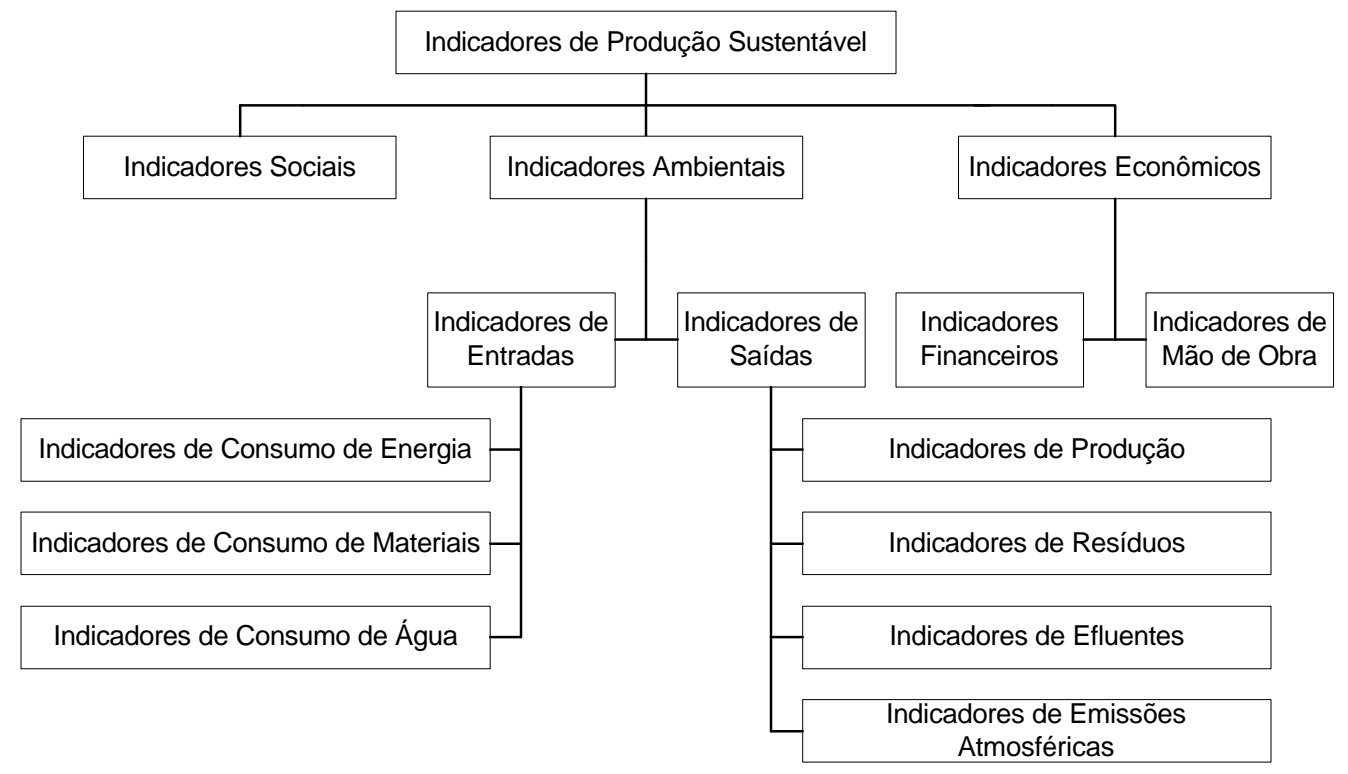

Figura 53 - Indicadores de produção sustentável Fonte: Modificado de Krajnc e Glavic (2003) 
Quadro 16 - Indicadores de produção sustentável.

\begin{tabular}{|c|c|c|c|}
\hline & Indicador & Fator & Unidade \\
\hline & Número de empregados & Número empregados & 1/UP \\
\hline & & $\overline{\text { Unidade de produção }}$ & \\
\hline & Razão de pagamento & Salário dos $10 \%$ empregados mais bem pagos & $\mathrm{R} \$ / \mathrm{R} \$=1$ \\
\hline क् & & Salário dos $10 \%$ empregados menos pagos & \\
\hline$\frac{\pi}{8}$ & Taxa de promoção & Número de promoções & $1 / 1=1$ \\
\hline & & $\overline{\text { Número de empregados }}$ & \\
\hline & $\begin{array}{l}\text { Tempo de afastamento } \\
\text { Número de projetos } \\
\text { comunitários }\end{array}$ & $\begin{array}{l}\text { Dias perdidos devido a acidentes ou doenças } \\
\text { Número de projetos realizados pela companhia } \\
\text { com a comunidade }\end{array}$ & $\begin{array}{l}\text { dias } \\
1\end{array}$ \\
\hline & Consumo específico de & Consumo total de energia & J/UP \\
\hline & & Total da produção & \\
\hline & Fração de energia & Consumo de energia renovável & $J / J=1$ \\
\hline & & Consumo total de energia & \\
\hline & Consumo específico de & (Entrada total de materiais) massa & $\mathrm{Kg} / \mathrm{UP}$ \\
\hline & & Total da produção & \\
\hline & Eficiência no uso de & (Produção) massa & $\mathrm{Kg} / \mathrm{Kg}=1$ \\
\hline & & (Entrada total de materiais) massa & \\
\hline & Fração de materiais & (Entrada de materiais recicláveis) massa & $\mathrm{Kg} / \mathrm{Kg}=1$ \\
\hline & & (Entrada total de materiais) massa & \\
\hline & Consumo específico de & (Consumo de água) volume & $\mathrm{m}^{3} / \mathrm{UP}$ \\
\hline$\stackrel{\frac{\pi}{2}}{\frac{\pi}{2}}$ & água & Produção & \\
\hline ¿ & Fração do custo deágua & Custo da água & $R \$ / R \$=1$ \\
\hline 年 & & Custo total da produção & \\
\hline 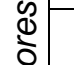 & Fração em massa de & Massa de produtos com selos ambientais & $\mathrm{Kg} / \mathrm{Kg}=1$ \\
\hline శ్రి & & Massa total de pr & \\
\hline है & Fração dos lucros obtidos & Lucros obtidos de eco-produtos & $\mathrm{R} \$ / \mathrm{R} \$=1$ \\
\hline & & Lucro total & \\
\hline & Fração de embalagens & Massa das embalagens & $\mathrm{Kg} / \mathrm{Kg}=1$ \\
\hline & & $\overline{\text { Massa total de produtos }}$ & \\
\hline & Fração de embalagens & Massa de embalagem reutilizável & $\mathrm{Kg} / \mathrm{Kg}=1$ \\
\hline & & Massa total de embalagens & \\
\hline & Custo com embalagens & Custo das embalagens & $R \$ / U P$ \\
\hline & & $\begin{array}{l}\text { Produção } \\
\end{array}$ & \\
\hline & Quantidade específica de & Massa específica por tipo de resíduo sólido & $\mathrm{Kg} / \mathrm{UP}$ \\
\hline & & Produção & \\
\hline & Fração de reciclagem & Massa de resíduos sólidos reciclados & $\mathrm{Kg} / \mathrm{Kg}=1$ \\
\hline & & Massa total de resíduos sc & \\
\hline
\end{tabular}


Quadro 16 - Indicadores de produção sustentável (continuação).

\begin{tabular}{|c|c|c|c|c|}
\hline & & Fração de disposição & Massa de resíduos sólidos não recuperad@s & $\mathrm{Kg} / \mathrm{Kg}=1$ \\
\hline & & & Massa totalde resíduossólidos & \\
\hline & & Fração de resíduos perigosos & Massa de resíduos sólidos perigosos & $\mathrm{Kg} / \mathrm{Kg}=1$ \\
\hline & & & Massa total de resíduos sólidos & \\
\hline & & Fração do custo dos resíduos & Custo total dos resíduos sólidos & $\mathrm{R} \$ / \mathrm{R} \$=1$ \\
\hline & & & Custo total da produção & \\
\hline & & Volume específico de águas & Volume total de água residuária & $\mathrm{m}^{3} / \mathrm{UP}$ \\
\hline & & & Produção & \\
\hline & & Fração em massa de & Massa de carga poluidora (P, N, DBO, etc) & $\mathrm{Kg} / \mathrm{UP}$ \\
\hline & & & Produção & \\
\hline.$\frac{\Phi}{d}$ & & Concentração de poluentes & Massa de poluentes & $\mathrm{Kg} / \mathrm{m}^{3}$ \\
\hline ह & ?ָּ & na agua residuarıa & $\overline{\text { Volume de água residuária }}$ & \\
\hline$\stackrel{\mathscr{2}}{\beth}$ & ஸे & Fração de custo com águas & Custo total com águas residuárias & $\mathrm{R} \$ \mathrm{R} \$=1$ \\
\hline ర్లి & & & Custo total da produção & \\
\hline 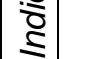 & & Fração de gases do efeito & Massa total de equivalentes de $\mathrm{CO} 2$ & $\mathrm{Kg} / \mathrm{Kg}=1$ \\
\hline & & & Massa total de produtos & \\
\hline & & Intensidade de gases do & Massa total de equivalentes de $\mathrm{CO} 2$ & $\mathrm{Kg} / \mathrm{R} \$$ \\
\hline & & & Valor total de produtos vendidos & \\
\hline & & Fração em massa de & Massa total de equivalentes de $\mathrm{SO} 2$ & $\mathrm{Kg} / \mathrm{Kg}=1$ \\
\hline & & & Massa total de produtos & \\
\hline & & Fração de potencial de & Massa total de equivalentes de etileno & $\mathrm{Kg} / \mathrm{Kg}=1$ \\
\hline & & fotoquímico & Massa total de produtos & \\
\hline & & Fração em massa de & Massa total de equivalentes de fosfato & $\mathrm{Kg} / \mathrm{Kg}=1$ \\
\hline & & & Massa total de produtos & \\
\hline & & $\begin{array}{l}\text { Investimentos em } \\
\text { desenvolvimento sustentável }\end{array}$ & $\begin{array}{l}\text { Investimentos em P\&D como fração das } \\
\text { despesas da companhia }\end{array}$ & $\mathrm{R} \$$ \\
\hline & & $\begin{array}{l}\text { Investimentos em proteção } \\
\text { ambiental }\end{array}$ & $\begin{array}{l}\text { Investimentos feitos pela companhia em } \\
\text { projetos de proteção ambiental }\end{array}$ & $\mathrm{R} \$$ \\
\hline$\stackrel{\circlearrowleft}{E}$ & & Reclamações específicas de & Número de reclamações & $1 / \mathrm{Kg}$ \\
\hline$\delta$ & & & Massa de produtos vendidas & \\
\hline 岃 & & $\begin{array}{l}\text { Números de contratos } \\
\text { desfeitos }\end{array}$ & $\begin{array}{l}\text { Número de contratos desfeitos com } \\
\text { fornecedores devido a discordâncias com } \\
\text { conduta ambiental e de segurança e saúde }\end{array}$ & 1 \\
\hline$\stackrel{0}{5}$ & & $\begin{array}{l}\text { Investimentos em capacitação } \\
\text { de funcionários }\end{array}$ & $\begin{array}{l}\text { Investimentos em desenvolvimento pessoal } \\
\text { e profissional dos funcionários }\end{array}$ & $\mathrm{R} \$$ \\
\hline & & $\begin{array}{l}\text { Melhorias sugeridas por } \\
\text { funcionários }\end{array}$ & $\begin{array}{l}\text { Número de sugestões de melhorias na } \\
\text { qualidade, meio ambiente, sociais e } \\
\text { segurança e saúde feitas por funcionários }\end{array}$ & 1 \\
\hline
\end{tabular}

Fonte: Modificado de Krajnc e Glavic (2003). 
Segundo Graedel e Allenby (2002), a definição de indicadores sociais é mais difícil em relação aos indicadores ambientais por duas razões principais. A primeira porque diferentemente das questões ambientais, as questões sociais não têm o suporte de uma área específica do estudo, como as ciências ambientais e a ecologia. A segunda deve-se ao fato de as questões sociais apresentarem um alto conteúdo cultural, muito maior do que as questões ambientais. Essas razões impõem uma tendência de as discussões sociais se tornarem ideológicas e controversas.

É difícil determinar quais indicadores são aplicáveis a uma determinada situação, uma vez que um mesmo indicador pode ser efetivo para uma companhia e não para outra. Como destacam Larson e Brown (1997), variações nas matérias-primas, processos, produtos, resíduos, tamanho da companhia, fornecedores, localização física e geográfica e demanda por parte dos consumidores, influenciam o que precisa ser monitorado. Mesmo duas companhias que usem um mesmo indicador, terão variações no método de frequência de monitoramento, bem como nas necessidades de comunicação de desempenho. A questão-chave segundo os autores é: "monitorar o suficiente para entender e melhorar o sistema produtivo, sem perder-se no meio de dados e análises excessivas".

É conveniente ressaltar que não se deve esperar que os indicadores por si só provoquem mudanças radicais nos padrões de produção, uma vez que a produção sustentável necessita de estímulos de diversas partes (pressões regulatórias, de grupos, fornecedores, consumidores, empregados, organizações comerciais, etc). Os indicadores de produção sustentável são uma ferramenta de apoio às companhias, para que estas possam avaliar seu desempenho, levantar questões a serem resolvidas e determinar suas metas ambientais (KRAJNC e GLAVIC, 2003).

Tyteca (1996) ressalta que do ponto de vista político e econômico, o indicador ambiental (ou um conjunto de indicadores) deve permitir a análise do efeito de vários tipos de regulações ou ferramentas econômicas, tais como padrões de poluição e taxas ou licenças de comercialização, sobre a performance ambiental. Por outro lado, a informação obtida através da avaliação da performance ambiental pode fornecer aos tomadores de decisão na esfera pública, orientações para a implantação de instrumentos econômicos e/ou regulatórios relevantes. 


\subsection{Considerações Finais}

Neste capítulo foram apresentados e discutidos os requisitos essenciais à implantação e ao bom desempenho de um programa de prevenção à poluição, com base em uma avaliação sistêmica, descritiva do processo produtivo. Foram apresentadas ferramentas que usadas em conjunto ou separadamente, colaboram de forma efetiva para a implantação de alternativas de prevenção à poluição, sintetizadas na Figura 54.

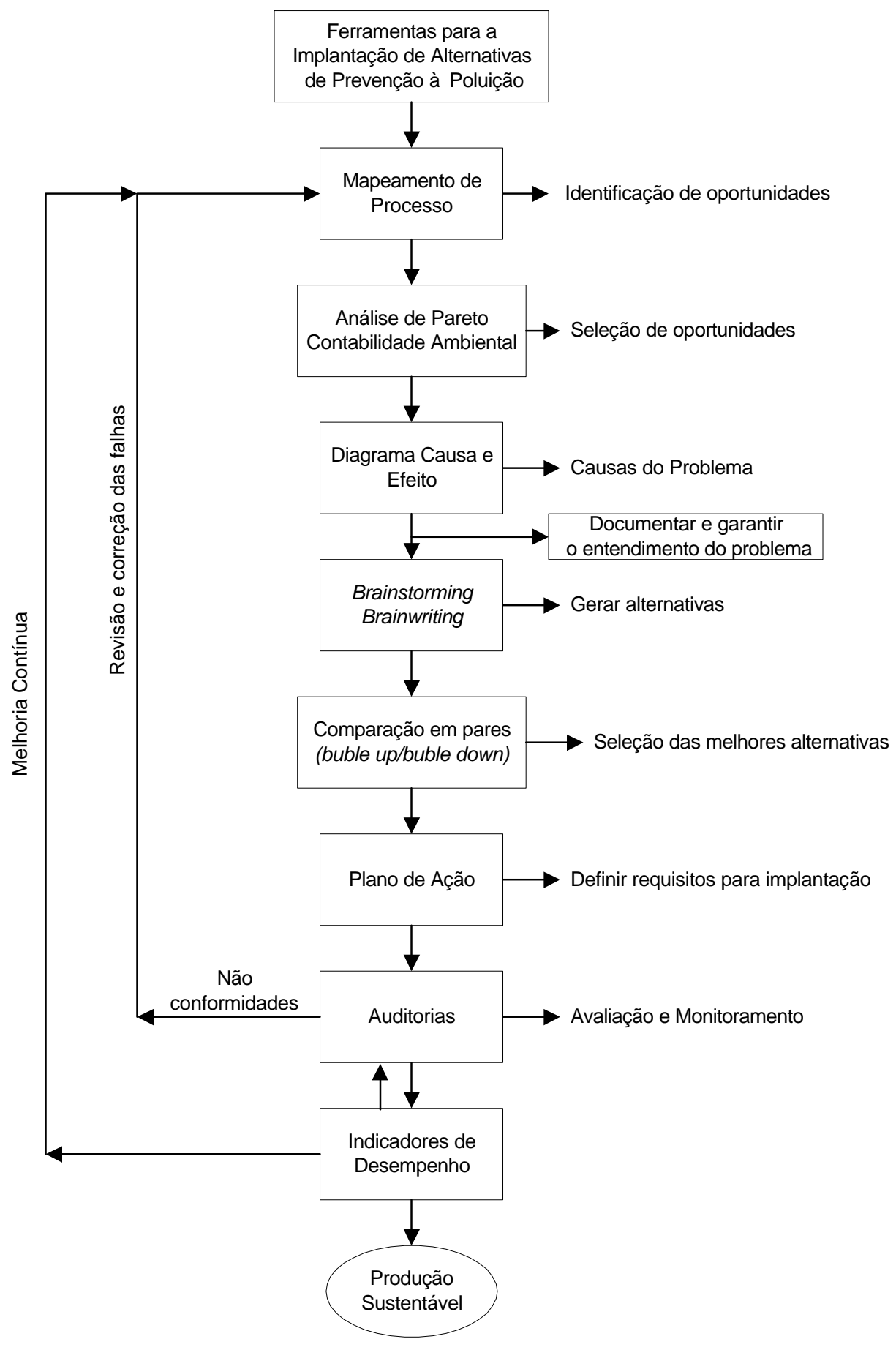

Figura 54 - Síntese das ferramentas para implantação da prevenção à poluição. 


\section{CAPÍTULO V}

\section{A INDÚSTRIA DE PRODUTOS METÁLICOS}

\subsection{Considerações Iniciais}

Neste capítulo é realizada uma caracterização da indústria de produtos metálicos, que representa a principal atividade do processo produtivo escolhido para a análise preliminar de identificação de oportunidades de prevenção àpoluição.

A indústria de produtos metálicos envolve processos metal-mecânicos e de acabamento de metais, como corte, molde e usinagem de peças metálicas, processos de limpeza e tratamento de superfícies e pintura, para a produção de bens de consumo, como mostra o mapa de processo da Figura 55.

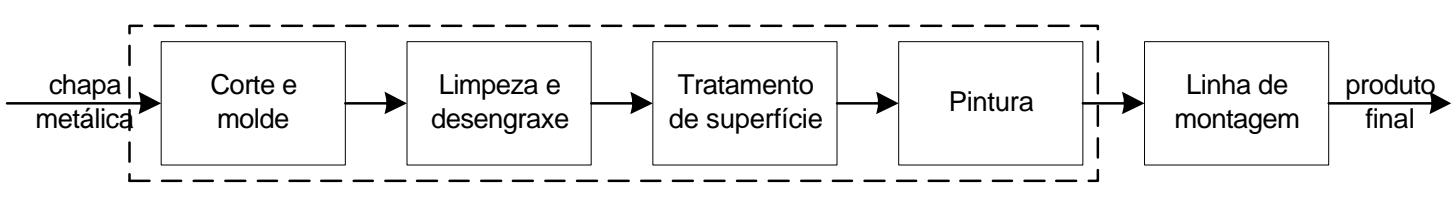

Figura 55 - Mapa de processo da indústria de produtos metálicos.

Os processos metal-mecânicos e de acabamento de metais são característicos de um grande número de setores da indústria, como o automotivo, aeroespacial, de defesa, equipamentos eletro-eletrônicos, móveis e eletrodomésticos, entre outros, e envolvem uma série de operações, processos e materiais. De modo a buscar um embasamento que possibilitasse a discussão de possíveis soluções para os problemas ambientais relacionados a estes processos foi realizada uma revisão da literatura técnica especializada. Foram levantadas informações sobre fontes poluidoras e as alternativas de prevenção à poluição disponíveis. As principais fontes de informação utilizadas foram manuais da US EPA, da NEWMOA (Northeast Waste Management Official's Association) e do TURI (Toxics Use Reduction Institute). Outras fontes incluem artigos de revistas científicas. 


\subsection{Corte e Molde de Peças Metálicas}

Nas operações de corte e molde de peças metálicas, a matéria-prima (chapa ou outro substrato metálico) é submetida àforça mecânica para a obtenção de peças do tamanho e das formas desejadas. Estas operações de maneira geral não produzem resíduos perigosos. Entretanto, podem gerar volumes significativos de fluidos de corte gasto, que precisam ser adequadamente estocados e gerenciados, além de sucatas, cavacos (chips) e limalhas de metal. Outros processos podem também estar presentes dependendo da indústria, como tratamentos a quente, soldagem, fusão e junção por meio da aplicação de adesivos, que podem gerar resíduos perigosos e outras emissões (NEWMOA, 2001).

\subsubsection{Fluidos de Corte}

Os fluidos de corte são compostos basicamente de óleos graxos e minerais, soluções sintéticas e água, além de aditivos (emulsificantes, inibidores de corrosão, estabilizantes, anti-espumantes, biocidas, etc) à base de cloro, enxofre, nitrito de sódio, fósforo e aminas (IGNÁCIO, 1998). Podem ter aplicações específicas em diferentes processos, e desempenham uma série de funções nas operações de corte e molde de partes metálicas, tais como:

- Resfriamento da peça de trabalho e da ferramenta de corte;

- Remoção de chips e limalhas da área de corte;

- Lubrificação da peça de trabalho e da ferramenta de corte;

- Prevenção de corrosão entre a peça de trabalho e a ferramenta;

- Prevenção de incrustrações (US EPA, 2001b; NEWMOA, 2001).

\subsubsection{Características dos Resíduos Gerados}

\subsubsection{1. Águas Residuárias}

As plantas onde são processados produtos metálicos geralmente apresentam diferentes fluxos de águas residuárias. As fontes mais comuns são águas contaminadas com fluidos de corte, água de resfriamento, descartes de tanques de enxágue, purga de caldeiras (blow down), água de limpeza na operação de corte, águas residuárias de tanques de fusão e de processos de jateamento. Os fluidos de corte são geralmente manuseados como resíduos perigosos devido aos seus componentes tóxicos e ao teor de óleos e graxas, que os impedem de ser lançados nas redes de esgoto (NEWMOA, 2001). 


\subsubsection{Emissões Atmosféricas}

O uso de fluidos de corte pode gerar emissões na forma de fumaças, névoas e vapores. As possíveis fontes de poluição atmosférica resultantes dos processos metalmecânicos, segundo NEWMOA (2001) são:

- Fumaças dos processos de remoção de camadas metálicas;

- Emissões de compostos orgânicos voláteis (COV's) de fluidos de corte;

- Névoas de fluidos de corte;

- Emissões de cianetos dos banhos;

- Perdas por evaporação de solventes em processos de adesão de partes metálicas;

- Vapores de solda.

\subsubsection{Resíduos Sólidos e Perigosos}

Os fluidos usados nos processos de corte, molde e usinagem que apresentam contaminação em excesso precisam ser periodicamente descartados, e são geralmente considerados resíduo perigoso. Sucatas, cavacos e limalhas metálicas são resíduos sólidos muito comuns na indústria metal-mecânica, que requerem cuidados especiais dependendo do teor de fluido de corte que possa estar presente em sua superfície. Estopas e absorventes contaminados com óleos representam outra fonte de resíduo perigoso, dependendo da quantidade de óleo e fluido presente.

Outros resíduos sólidos incluem pallets, caixas de papelão e outros tipos de embalagens e containeres. Estes materiais, desde que segregados e livres de contaminação, podem ser reciclados e/ou reutilizados (NEWMOA, 2001).

\subsubsection{Alternativas de Prevenção àPoluição}

As alternativas de prevenção à poluição são classificadas em estratégias de redução na fonte e opções de reciclagem no processo.

\subsubsection{Fluidos de Corte}

A primeira questão que deve ser avaliada quando se busca uma oportunidade para a eliminação e/ou redução do fluido de corte em operações de corte e usinagem é se existe de fato a necessidade do seu uso. Em dois casos o uso do fluido de corte pode ser dispensado: 
- Quando o substrato metálico puder ser adquirido com um filme de lubrificante suficiente para algumas aplicações;

- Quando o equipamento de corte não precisar de fluido em algumas operações de estampagem de substratos de pouca espessura e/ou maleáveis.

Quando o uso do fluido de corte for imprescindível, devem ser tomadas medidas para evitar a sua contaminação, prolongar a vida útil e minimizar a necessidade de descarte. O principal problema relacionado ao fluido de corte é a contaminação com óleo e as consequências resultantes desta contaminação, o que pode ser resolvido pela adoção de um programa de manutenção preventiva (US EPA, 2001b).

Segundo Ignácio (1998), a contaminação do fluido de corte ocorre principalmente devido ao descontrole na operação e na higiene do sistema circulador, onde podem ocorrer as seguintes situações, que devem ser evitadas:

- Contato dos fluidos com óleos lubrificantes de componentes das máquinas;

- Sedimentação de limalha e demais impurezas no fundo do sistema;

- Acúmulo de borras de óleo nas paredes do sistema;

- Bomba com mau funcionamento;

- Falta de aeração;

- Limpeza ineficiente do sistema;

- Reposição de fluidos de corte em sistemas contaminados por bactérias.

A manutenção do fluido de corte requer monitoramento constante de suas propriedades, remoção de contaminantes e adição de fluido de reposição. As fontes consultadas (US EPA, 1995b, 2001b; IGNÁCIO, 1998; NEWMOA, 2001), recomendam as seguintes medidas para a manutenção dos fluidos de corte:

- Medição diária de pH (que deve estar na faixa entre 8,5 e 9,3), concentração e crescimento bacteriano;

- Adição de fluido de reposição, água, biocida e outros aditivos sempre que necessário (de acordo com as indicações do monitoramento);

- Aquisição de fluidos estáveis e de qualidade;

- Uso de água deionizada, livre de minerais, que podem interferir na eficiência do sistema e de bactérias que provocam a deterioração do fluido de corte;

- Prevenção da contaminação por vazamentos de óleo dos equipamentos, corrosão, bactérias e fungos, chips e limalhas metálicas e outros tipos de 
contaminação provenientes de falta de higiene do local, através de melhoria nos procedimentos de housekeeping e treinamento de funcionários;

- Limpeza regular dos equipamentos e tanques de fluido;

- Filtração e centrifugação regular do fluido para remoção de óleos e partículas de contaminantes, de modo a evitar o crescimento bacteriano.

O fluido usado deve ser criteriosamente selecionado, o que envolve o conhecimentos das propriedades de resistência ao ataque bacteriano, resistência à corrosão e a presença de substâncias químicas perigosas que podem estar presentes na composição. Estas informações podem ser encontradas nas Fichas de Segurança de Produto (MSDS), maiores detalhes podem ser requisitados ao fabricante (US EPA, 2001b).

O uso de fluidos sintéticos pode resultar em um aumento sensível da vida útil do fluido. Fluidos sintéticos são constituídos de substâncias químicas como nitritos, nitratos, fosfatos e boratos e contém um teor baixo de óleos solúveis, que varia de 0 a $1 \%$, comparado ao teor dos fluidos de corte convencionais não-sintéticos, que apresentam um teor de óleo que pode variar de 30 a $90 \%$. Apesar do potencial de lubrificação ser inferior, os fluidos sintéticos apresentam a vantagem de não sofrer com a contaminação por óleos, devido a dificuldade que estes apresentam em entrar na emulsão do fluido sintético. Os fluidos sintéticos apresentam ainda maior estabilidade térmica e resistência àoxidação (US EPA, 2001b).

Deve-se ainda considerar a adoção de equipamentos modernos e otimização de técnicas de aplicação de modo a reduzir o volume de fluido usado, uso de ferramentas e tratamentos alternativos que eliminem a necessidade de fluido e de tecnologias alternativas como a usinagem a seco (NEWMOA, 2001).

A reciclagem de fluidos deteriorados ou contaminados pode reduzir os custos com disposição e com a aquisição de fluido de reposição. A reciclagem pode ocorrer dentro e fora do processo. Na reciclagem fora do processo, empresas especializadas empregam processos de separação de água e óleo, que é recuperado e refinado para uso como combustível. A reciclagem no processo tipicamente se resume a técnicas para prolongar a vida útil do fluido, como filtração por gravidade e a vácuo, separação por flotação de ar dissolvido, hidrociclone, centrifugação e pasteurização. Esta última consome uma quantidade considerável de energia e só apresenta resultados no controle de crescimento bacteriano (US EPA, 2001b). 


\subsubsection{Redução e Valorização da Sucata}

As partes metálicas usadas como matéria-prima na fabricação dos produtos chegam na forma de blankets, barras ou chapas. Estas partes ao serem processadas (cortadas, moldadas ou vazadas) produzem sucatas, chips e limalhas de metal que normalmente encontram-se contaminadas por óleos e fluidos de corte. As alternativas de prevenção à poluição neste caso envolvem a otimização do layout de corte e técnicas para reduzir a contaminação da sucata, aumentando seu valor na venda para reciclagem. Segundo NEWMOA (2001), as seguintes ações podem ser adotadas para reduzir o volume de sucata nos processos de corte e molde:

- Aquisição de matérias-primas nos tamanhos adequados: os blankets, barras e chapas metálicas devem ser especificamente selecionados para cada peça que se queira produzir, evitando a aquisição de chapas com tamanho maior do que o necessário, de forma a reduzir a geração desnecessária de sucata. As companhias devem contactar seus fornecedores e requisitar as matériasprimas já nos tamanhos necessários para confecção das peças na geometria desejada.

- Otimização do layout de corte: esta é outra medida que contribui para a redução de sucata. O layout de corte pode ser otimizado de modo a produzir um número maior de peças em uma determinada área de chapa. Para isso são necessários estudos e cálculos que podem ser realizados com apoio de softwares específicos.

- Remoção de fluido de corte: normalmente os resíduos na forma de chips e limalhas apresentam fluido de corte que precisa ser removido para viabilizar a reciclagem dos materiais metálicos. Os fluidos de corte apresentam risco potencial ao meio ambiente e àsaúde humana e ainda causam problemas no processo de reciclagem. Óleos minerais apresentam potencial de explosão em fornos e a fumaça gerada pode ocasionar o entupimento de filtros das chaminés dos fornos. O mecanismo empregado para remover o excesso de fluido depende do tamanho da partícula metálica e do tipo de fluido presente na partícula. Chips e limalhas podem ser armazenadas em tambores ou containeres que permitam a drenagem do fluido. Centrífugas podem ser empregadas para remover fluidos a base de óleo mineral. Hidrociclones são recomendados para a remoção de fluidos a base de água em partículas metálicas muito pequenas. A compactação é outra forma de remover fluido de partículas pequenas. Todos estes processos asseguram a recuperação de 
grande parte do fluido impregnado no metal e possibilita o aumento do valor de mercado da sucata metálica.

\subsubsection{Manutenção de Equipamento e Prevenção de Vazamentos}

Outra fonte de poluição nos processos de manufatura de produtos metálicos são os vazamentos de óleo hidráulico e de fluidos de corte nos equipamentos e nas válvulas e selos de bombas. Com o decorrer do tempo selos e gaxetas de bombas e equipamentos se desgastam provocando o vazamento de fluido no piso e em partes específicas de maquinários e, no caso de fluidos hidráulicos, no tanque de fluido de corte. A limpeza dos vazamentos no piso e nos maquinários é normalmente feita com o uso de panos, estopas e absorventes granulados. No caso de vazamento de fluidos hidráulicos nos tanques de fluido de corte, o fluido hidráulico e outros óleos indesejáveis atuam como meio de crescimento bacteriano e também provocam fumaça e problemas de odores, que resultam na necessidade de troca e descarte do fluido de corte (US EPA, 1995b).

Para eliminar estes problemas, segundo a NEWMOA (2001), as companhias devem estabelecer um programa de manutenção que inclui os seguintes requisitos:

- Listagem de todos os equipamentos da planta, incluindo sua localização;

- Plano de operação para cada equipamento;

- Histórico de utilização de cada equipamento;

- Histórico de manutenção; e,

- Manuais de manutenção para todos os equipamentos.

Para o caso de vazamentos persistentes, formas alternativas de limpeza devem ser adotadas:

- Uso de bandejas e coletores para a contenção e recuperação de fluidos;

- Uso de absorventes reutilizáveis no lugar de absorventes granulares e outros absorventes que precisam ser descartados após o uso; e,

- O emprego de lavagem do piso com água deve ser evitado, pois uma pequena quantidade de fluido pode gerar um grande volume de água que precisa ser tratada. 


\subsection{Limpeza e Desengraxe}

A limpeza de peças e partes metálicas envolve a remoção de sujeiras, óleos, impressões digitais, restos de solda e outras contaminações da superfície metálica. Este processo é importante para garantir a qualidade dos processos subseqüentes, e para a melhoria das condições estéticas das peças.

Segundo GNECCO et al. (2003), os contaminantes são classificados de acordo com sua natureza em:

- Óleos ou graxas: são óleos de usinagem, prensagem ou óleos protetivos temporários, lubrificantes ou combustíveis espalhados ou derramados sobre a superfície ou levados pelas mãos de operadores de máquinas.

- Suor: o suor produzido pelas glândulas sudoríparas tem pH entre 4,5 e 7,5 e contém água, gorduras, ácidos e sais. O toque das mãos em superfícies a serem pintadas produz manchas que causam bolhas e aceleram a corrosão.

- Compostos solúveis: em ambientes industriais podem ser encontrados compostos solúveis em água como nitratos, cloretos e sulfatos ferrosos. Estes compostos devem ser completamente removidos antes da pintura para evitar a formação de bolhas por osmose quando as peças forem submetidas a ambientes úmidos ou corrosivos.

\subsubsection{Solventes Clorados}

As tecnologias de limpeza e desengraxe tradicionalmente têm empregado solventes orgânicos clorados para a remoção de óleos e contaminantes, dentre os quais destacam-se o tricloroetano, tricloroetileno, percloroetileno, cloreto de metila e os clorofluorcarbonos (CFCs). Estes solventes são muito eficientes e no passado eram considerados 'seguros' àsaúde dos trabalhadores pelo fato de não serem inflamáveis. Entretanto, estudos que começaram a ser realizados ainda na década de 1970 têm colocado estes solventes como suspeitos de risco carcinogênico aos trabalhadores (através da inalação de seus vapores), e ainda como poluentes atmosféricos graves, devido a formação de smog fotoquímico e pelo potencial de destruição da camada de ozônio (THOMAS, LAPLANTE e BUCKLEY, 1997). Existem ainda registros de contaminação de águas subterrâneas devido a percolação destes solventes no solo. $\mathrm{O}$ tricloroetano e os CFCs têm sua fabricação proibida desde a promulgação do Protocolo de Montreal em 1996. Devido a todos estes problemas, os solventes clorados têm tido seu uso limitado e substitutos efetivos foram desenvolvidos e são correntemente empregados. O Quadro 17 sumariza as propriedades dos solventes clorados. 
Quadro 17 - Propriedades dos solventes clorados

\begin{tabular}{|cccccc|}
\hline \multicolumn{1}{|l}{ Propriedade } & Tricloroetano & Tricloroetileno & Percloroetileno & Cloreto de metila & CFC-113 \\
\hline $\begin{array}{c}\text { Reatividade } \\
\text { fotoquímica }\end{array}$ & não & sim & não & não & não \\
\hline $\begin{array}{c}\text { Potencial de } \\
\text { destruição da } \\
\text { camada ozônio }\end{array}$ & sim & não & não & não & sim \\
\hline $\begin{array}{c}\text { Poluente } \\
\text { atmosférico }\end{array}$ & não & sim & sim & sim & não \\
\hline $\begin{array}{c}\text { Densidade } \\
\text { (ar=1) }\end{array}$ & 4,63 & 4,53 & 5,83 & 2,93 & 6,5 \\
\hline $\begin{array}{c}\text { Ponto de } \\
\text { ebulição }\end{array}$ & $72-88^{\circ} \mathrm{C}$ & $86-88^{\circ} \mathrm{C}$ & $121,2{ }^{\circ} \mathrm{C}$ & $39,4-40,4{ }^{\circ} \mathrm{C}$ & $47,6{ }^{\circ} \mathrm{C}$ \\
\hline $\begin{array}{c}\text { Potencial } \\
\text { carcinogênico }\end{array}$ & suspeito & suspeito & suspeito & suspeito & não \\
\hline
\end{tabular}

Fonte: THOMAS, LAPLANTE e BUCKLEY (1997).

\subsubsection{Características dos Resíduos Gerados}

Os resíduos gerados nos processos de limpeza e desengraxe consistem basicamente em emissões atmosféricas resultantes da evaporação dos solventes e efluentes líquidos resultantes dos banhos saturados, que apresentam grandes quantidades de óleos, fragmentos metálicos e outros contaminantes. Os resíduos sólidos consistem de embalagens vazias dos produtos químicos e borras geradas na estação de tratamento que recebe os efluentes produzidos nos banhos.

\subsubsection{Alternativas de Prevenção àPoluição}

As alternativas de prevenção à poluição para os processos de limpeza e desengraxe visam reduzir ou eliminar o uso de solventes. As duas categorias principais envolvem o uso de produtos alternativos e modificações no processo.

\subsubsection{Uso de Desengraxantes Alternativos}

O uso de desengraxantes alternativos envolve a substituição direta do solvente com pouca ou nenhuma alteração no processo. Soluções alternativas são substâncias que não degradam a camada de ozônio, não são tóxicas ou perigosas, não têm odor, geram poucas emissões atmosféricas e são eficientes na remoção dos contaminantes. No Quadro 18 são apresentadas as alternativas de desengraxantes aquosos (alcalinos, neutros e ácidos), suas vantagens, fatores de projeto e limitações. No Quadro 19 são apresentadas as demais alternativas disponíveis. 
Quadro 18 - Alternativas de desengraxantes aquosos disponíveis para substituição de solventes clorados

\begin{tabular}{|c|c|c|c|c|c|}
\hline & Descrição e Fatores de Projeto & Benefícios Ambientais & Aplicações & Benefícios Operacionais & Limitações \\
\hline & $\begin{array}{l}\text { - pH da solução entre } 10 \text { e } 14 \\
\text { - Requer aditivos para melhorar eficiência } \\
\text { (sequestrantes, emulsificantes e } \\
\text { surfactantes) } \\
\text { - Temperaturas elevadas } \\
\text { - Requer enxague e secagem } \\
\text { - Custo baixo } \\
\text { - Tempo de vida do banho longo }\end{array}$ & $\begin{array}{c}\text { - Geram poucas } \\
\text { emissões de compostos } \\
\text { orgânicos voláteis }\end{array}$ & $\begin{array}{l}\text { - Todos os processos de } \\
\text { limpeza líquida (spray, } \\
\text { ultrasom, imersão) } \\
\text { - Removem graxas, } \\
\text { óleos, fluidos, ceras, } \\
\text { sais, incrustrações, } \\
\text { tintas a base de água }\end{array}$ & $\begin{array}{l}\text { - Eficiência varia com a } \\
\text { concentração e tempetura } \\
\text { permitindo ajustes para } \\
\text { fins específicos } \\
\text { - Possibilita a separação } \\
\text { da água e do contaminante } \\
\text { (óleo) e a reciclagem da } \\
\text { solução no processo }\end{array}$ & $\begin{array}{l}\text { - Requer maior espaço } \\
\text { físico que os sistemas } \\
\text { convencionais } \\
\text { - Provoca corrosão do } \\
\text { metal se não forem } \\
\text { usados inibidores ou a } \\
\text { peça não secar } \\
\text { rapidamente }\end{array}$ \\
\hline & $\begin{array}{l}\text { - } \mathrm{pH} \cong 7 \\
\text { - Requer o uso de aditivos } \\
\text { - Temperaturas elevadas } \\
\text { - Requer enxague e secagem } \\
\text { - Custo de operação baixo } \\
\text { - Tempo de vida do banho longo }\end{array}$ & $\begin{array}{l}\text { - A disposição do banho é } \\
\text { simples (ajuste de pH e }\end{array}$ & $\begin{array}{l}\text { - Casos onde não é } \\
\text { preciso solvatação } \\
\text { química para remoção } \\
\text { dos contaminantes } \\
\text { - Óleos leves, cloretos, } \\
\text { partículas e outros sais }\end{array}$ & $\begin{array}{l}\text { - Não requer grandes } \\
\text { modificações e ajustes no } \\
\text { processo } \\
\text { - Pode ser usada em } \\
\text { sprays e equipamentos a } \\
\text { vapor }\end{array}$ & $\begin{array}{l}\text { - Requer maior espaço } \\
\text { físico que os sistemas } \\
\text { convencionais } \\
\text { - Corrosão } \\
\text { - Não é recomendada } \\
\text { p/ banhos de imersão }\end{array}$ \\
\hline
\end{tabular}


Quadro 19 - Alternativas disponíveis para a substituição de solventes clorados em processos de limpeza e desengraxe.

\begin{tabular}{|c|c|c|c|c|}
\hline & Descrição e Fatores de Projeto & Vantagens & Aplicações & Limitações \\
\hline & $\begin{array}{l}\text { - Soluções de solventes orgânicos } \\
\text { naturais ou sintéticos(terpenos, ésteres } \\
\text { de cadeia longa, hidrocarbonetos e } \\
\text { ésteres glicóis), inibidores de corrosão, } \\
\text { surfactantes, e outros aditivos } \\
\text { - Podem requerer ou não enxágue } \\
\text { posterior } \\
\text { - Terpenos funcionam bem em } \\
\text { temperaturas baixas }\end{array}$ & $\begin{array}{l}\text { - Geram poucas emissões de COV's } \\
\text { - Pouca energia requerida } \\
\text { - Alguns permitem a recuperação e } \\
\text { reciclagem do solvente } \\
\text { - Permitem a adição de inibidores de } \\
\text { corrosão } \\
\text { - pH não alcalino previne ataque do metal } \\
\text { - Baixa tensão superficial permite a limpeza } \\
\text { de cavidades }\end{array}$ & $\begin{array}{l}\text { - Remoção de óleos pesados e } \\
\text { graxas } \\
\text { - Em grande parte compatíveis } \\
\text { com metais e polímeros } \\
\text { - Glicóis removem } \\
\text { contaminantes polares e } \\
\text { apolares } \\
\text { - Ésteres removem a maioria } \\
\text { dos compostos orgânicos }\end{array}$ & $\begin{array}{l}\text { - Podem atacar a derme, requer } \\
\text { uso de luvas no manuseio } \\
\text { - Névoas concentradas são } \\
\text { inflamáveis } \\
\text { - Odor no caso de terpenos } \\
\text { - Alguns tipos podem causar } \\
\text { danos a materiais poliméricos } \\
\text { - Podem ser tóxicos àvida } \\
\text { aquática } \\
\text { - Custos iniciais elevados }\end{array}$ \\
\hline & $\begin{array}{l}\text { - Compostos derivados de petróleo } \\
\text { como querosene, naftas e outros que } \\
\text { podem apresentar traços de benzeno e } \\
\text { outros compostos aromáticos } \\
\text { - Equipamentos precisam conter } \\
\text { dispositivos para evitar riscos de } \\
\text { explosão e incêndio }\end{array}$ & $\begin{array}{l}\text { - Não geram efluentes } \\
\text { - Recicláveis por destilação } \\
\text { - Compostos de cadeia longa tem pouco } \\
\text { odor, baixa toxicidade e baixo teor de } \\
\text { evaporação } \\
\text { - Não requer uso de água } \\
\text { - Potencial de corrosão baixo } \\
\text { - Compatíveis com diversos materiais } \\
\text { - Baixo custo e facilidade de obtenção }\end{array}$ & $\begin{array}{l}\text { - Em situações onde o contato } \\
\text { com água é indesejável } \\
\text { - Remoção de óleos pesados e } \\
\text { graxas } \\
\text { - Podem ser usados como } \\
\text { solventes nos processos semi- } \\
\text { aquosos } \\
\text { - Podem ser usados em banhos } \\
\text { de imersão }\end{array}$ & $\begin{array}{l}\text { - Inflamáveis, alguns com ponto } \\
\text { de chama baixo } \\
\text { - Produzem emissões de COV's } \\
\text { - Tempo de secagem baixo em } \\
\text { relação aos solventes clorados } \\
\text { - Custo elevado de } \\
\text { equipamentos de recuperação } \\
\text { de vapor } \\
\text { - Necessidade de ventilação } \\
\text { para evitar exposição a } \\
\text { emissões tóxicas }\end{array}$ \\
\hline
\end{tabular}


Quadro 19 - Alternativas disponíveis para a substituição de solventes clorados em processos de limpeza e desengraxe (continuação).

\begin{tabular}{|c|c|c|c|c|}
\hline & Descrição e Fatores de Projeto & Vantagens & Aplicações & Limitações \\
\hline $\begin{array}{l}00 \\
\text { U. } \\
\text { 노 }\end{array}$ & $\begin{array}{l}\text { - Tecnicamente capazes de substituir } \\
\text { os CFC's em muitas situações } \\
\text { - Podem ser utilizados nos mesmos } \\
\text { equipamentos que usam CFC-113 } \\
\text { - Apresentam potencial de degradação } \\
\text { da camada de ozônio e serão banidos } \\
\text { em um futuro breve }\end{array}$ & $\begin{array}{l}\text { - Propriedade químicas e físicas similares } \\
\text { às do CFC-113 } \\
\text { - Não produzem emissões de COV's } \\
\text { - Baixa tensão superficial } \\
\text { - Potencial de degradação da camada de } \\
\text { ozônio inferior aos CFC's } \\
\text { - Não geram efluentes }\end{array}$ & $\begin{array}{l}\text { - Substituto do CFC-113 no } \\
\text { desengraxe a vapor } \\
\text { - Compatível com a maioria } \\
\text { dos metais, cerâmicos e } \\
\text { polímeros } \\
\text { - Limpeza de precisão em } \\
\text { componentes eletrônicos }\end{array}$ & $\begin{array}{l}\text { - Apresenta potencial de } \\
\text { degradação de ozônio e de } \\
\text { aquecimento global } \\
\text { - Incompatível com acrílico, } \\
\text { estireno e ABS } \\
\text { - Caro }\end{array}$ \\
\hline 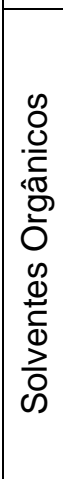 & $\begin{array}{l}\text { - Solventes orgânicos livres de } \\
\text { compostos halogenados: } \\
\text { - álcoois } \\
\text { - óleos vegetais } \\
\text { - cetonas } \\
\text { - éteres } \\
\text { - ésters } \\
\text { - Evaporação rápida }\end{array}$ & $\begin{array}{l}\text { - Não degradam a camada de ozônio } \\
\text { - Não geram efluentes quando usados } \\
\text { puros } \\
\text { - Solúveis em água } \\
\text { - Secagem rápida } \\
\text { - A maioria é considerada biodegradável }\end{array}$ & $\begin{array}{l}\text { - Pequenas operações } \\
\text { - Álcoois removem compostos } \\
\text { orgânicos e inorgânicos } \\
\text { - Óleos vegetais removem } \\
\text { tintas e são compatíveis com } \\
\text { a maioria dos elastômeros } \\
\text { - Cetonas removem polímeros } \\
\text { e adesivos, secagem rápida }\end{array}$ & $\begin{array}{l}\text { - Formação de smog } \\
\text { - Ponto de chama baixo, } \\
\text { representando risco de incêndio } \\
\text { - Inalação de vapores pode } \\
\text { representar risco a saúde } \\
\text { - Pressão de vapor elevada } \\
\text { para uso em equipamentos } \\
\text { convencionais }\end{array}$ \\
\hline 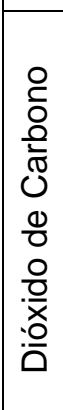 & $\begin{array}{l}\text { Existem quatro diferentes técnicas: } \\
\text { a) Abrasão com pellets de } \mathrm{CO}_{2} \\
\text { b) Névoa de } \mathrm{CO}_{2} \\
\text { c) } \mathrm{CO}_{2} \text { líquido } \\
\text { d) } \mathrm{CO}_{2} \text { supercrítico. } \\
\text { - Concentração do } \mathrm{CO}_{2} \text { precisa ser } \\
\text { monitorada para evitar danos àsaúde }\end{array}$ & $\begin{array}{l}\text { - Não geram emissões atmosféricas } \\
\text { - } \mathrm{CO}_{2} \text { é não-inflamável e inerte; } \\
\text { - Substitutos efetivos de CFC's e solventes } \\
\text { - Usa fontes naturais de } \mathrm{CO}_{2} \\
\text { - Não geram efluentes } \\
\text { - Carrega contaminantes no fluxo de } \mathrm{CO}_{2}\end{array}$ & $\begin{array}{l}\text { - Limpeza de peças especiais } \\
\text { e de materiais sensíveis } \\
\text { - Preparo de superfícies para } \\
\text { análise }\end{array}$ & $\begin{array}{l}\text { - } \mathrm{CO}_{2} \text { requer purificação } \\
\text { - Podem carrear particulados e } \\
\text { prejudicar a superfície } \\
\text { - Dificuldade de remoção de } \\
\text { óleos pesados }\end{array}$ \\
\hline
\end{tabular}


Quadro 19 - Alternativas disponíveis para a substituição de solventes clorados em processos de limpeza e desengraxe (continuação).

\begin{tabular}{|c|c|c|c|c|}
\hline & Descrição e Fatores de Projeto & Vantagens & Aplicações & Limitações \\
\hline & $\begin{array}{l}\text { - Emprega energia acústica para criar } \\
\text { bolhas que ao vibrar entram em } \\
\text { colapso criando uma ação esfoliante } \\
\text { que remove os contaminantes da } \\
\text { superfície do material } \\
\text { - Os banhos usam soluções de } \\
\text { limpeza aquosas } \\
\text { - Solventes aquosos como etil-lactato, } \\
\text { álcoois, cetonas, e éter glicol podem } \\
\text { ser usados para melhorar eficiência }\end{array}$ & $\begin{array}{l}\text { - Tempo de vida relativamente longo } \\
\text { - Sistema é bastante flexível } \\
\text { - Pode ser adaptado æ̀s instalações já } \\
\text { existentes } \\
\text { - Fácil integração como parte de um } \\
\text { sistema multi-estágios } \\
\text { - A eficiência depende do tempo de } \\
\text { contato, forma da peça, aditivos químicos e } \\
\text { temperatura }\end{array}$ & $\begin{array}{l}\text { - Remoção efetiva de } \\
\text { partículas e sujeiras } \\
\text { - Permite que se alcance } \\
\text { qualquer nível de limpeza. }\end{array}$ & $\begin{array}{l}\text { - Compatibilidade do material } \\
\text { precisa ser avaliada, para evitar } \\
\text { desgaste das peças } \\
\text { - Requer controle de tempo e } \\
\text { temperatura } \\
\text { - Requer remoção de } \\
\text { partículas resultantes do } \\
\text { desgaste das peças no banho }\end{array}$ \\
\hline 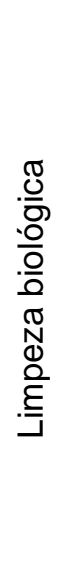 & $\begin{array}{l}\text { - Integra uma emulsão de limpeza com } \\
\text { a biorremediação. } \\
\text { - A emulsão de limpeza remove óleos } \\
\text { e graxas da superfície convertendo-as } \\
\text { em microglóbulos, que servem como } \\
\text { fonte de alimento para micróbios } \\
\text { presentes na solução de limpeza. }\end{array}$ & $\begin{array}{l}\text { - Tempo de vida da solução de limpeza é } \\
\text { relativamente longo } \\
\text { - Baixo consumo de água, energia e } \\
\text { aditivos } \\
\text { - Solução de limpeza é não corrosiva }\end{array}$ & $\begin{array}{l}\text { - Limpeza de peças e chapas } \\
\text { metálicas de grandes } \\
\text { dimensões }\end{array}$ & $\begin{array}{l}\text { - Controle de pH e temperatura; } \\
\text { - Requer aeração da solução } \\
\text { de limpeza e reposição de } \\
\text { nutrientes e surfactantes; } \\
\text { - Requer remoção de micro- } \\
\text { organismos e particulados; } \\
\text { - Requer a disponibilidade de } \\
\text { óleos e graxas no banho para } \\
\text { assegurar o alimento dos } \\
\text { micróbios. }\end{array}$ \\
\hline
\end{tabular}

Fonte: Construída com base em informações obtidas em THOMAS, LAPLANTE e BUCKLEY (1997); US EPA (1994, 2001b); HEATON et al.(2004). 


\subsubsection{Modificações no Processo}

As modificações no processo consistem na eliminação da etapa de limpeza e desengraxe ou na aplicação de técnicas que eliminem ou reduzam o uso de solventes. Os custos financeiros podem ser elevados, mas a redução de custos relativos à aquisição de insumos e à disposição de resíduos as tornam viáveis. Segundo a US EPA (2001b), as modificações de processo mais comuns são:

- Adição de controladores a processos de desengraxe a vapor já existentes

- Processos de desengraxe a vapor completamente fechados (cabines)

- Desengraxe aquoso automatizado

- Limpeza aquosa sob pressão

O Quadro 20 mostra as principais características destas tecnologias.

\subsubsection{Reciclagem e Reúso no Processo}

Segundo a PRC Environment Management, Inc.(1989), existem ainda métodos de reciclagem e recuperação que podem ser adotados nos processos de desengraxe e limpeza, tais como:

- Reúso do efluente dos tanques de enxague como afluente em outros tanques do processo, que podem ou não ser tanques de enxague;

- Reúso de banhos de limpeza ácidos ou alcalinos gastos para ajuste de pH na estação de tratamento de efluentes;

- Regeneração de soluções de desengraxe e limpeza gastas;

- Reciclagem de banhos e efluentes de tanques de enxague através de tecnologias de recuperação tais como evaporação, osmose reversa, troca iônica, eletrólise e eletrodiálise;

- Reciclagem de solventes gastos por destilação.

Todas essas práticas resultam na redução da quantidade de efluente a ser tratado, o que reduz o volume de borra produzida nas estações de tratamento de efluentes (ETE's). Ainda, com a diminuição do consumo de insumos e produtos químicos utilizados nos banhos desengraxantes, nos banhos dos tratamentos químicos e na ETE, reduz-se o volume de embalagens de produtos a serem dispostas ou encaminhadas para tratamento e reciclagem, e os custos totais do processo. 
Quadro 20 - Tecnologias disponíveis para processos de limpeza e desengraxe.

\begin{tabular}{|c|c|c|c|c|}
\hline & Descrição e Fatores de Projeto & Vantagens & Aplicações & Limitações \\
\hline 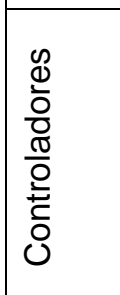 & $\begin{array}{l}\text { - Adição de controladores } \\
\text { automáticos a sistemas de } \\
\text { desengraxe a vapor }\end{array}$ & $\begin{array}{l}\text { - Reduz emissões de solventes } \\
\text { - Permite controle de emissões } \\
\text { - Não requer grandes modificações } \\
\text { - Custo relativamente baixo }\end{array}$ & $\begin{array}{l}\text { - Sistemas de desengraxe a } \\
\text { vapor convencionais já em } \\
\text { funcionamento }\end{array}$ & $\begin{array}{l}\text { - Não eliminam completamente } \\
\text { as emissões atmosféricas } \\
\text { - Eficiência depende do } \\
\text { sistema no qual o controlador é } \\
\text { instalado }\end{array}$ \\
\hline 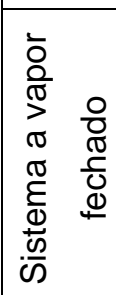 & $\begin{array}{l}\text { - Sistema de desengraxe a vapor } \\
\text { completamente fechado (cabines) }\end{array}$ & $\begin{array}{l}\text { - Elimina emissões de solventes e riscos } \\
\text { ocupacionais } \\
\text { - O princípio de limpeza é o mesmo } \\
\text { - Possibilita a recuperação do solvente } \\
\text { - Custos operacionais reduzidos }\end{array}$ & $\begin{array}{l}\text { Mesmas aplicações que os } \\
\text { sistemas de desengraxe a } \\
\text { vapor convencionais }\end{array}$ & $\begin{array}{l}\text { - Custo inicial elevado } \\
\text { - Consumo de energia } \\
\text { relativamente elevado }\end{array}$ \\
\hline 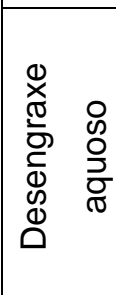 & $\begin{array}{l}\text { - Emprega soluções de limpeza } \\
\text { aquosas e produtos químicos } \\
\text { - Requer mais espaço do que } \\
\text { sistemas a vapor } \\
\text { - Requer tratamento do efluente }\end{array}$ & $\begin{array}{l}\text { - Elimina o uso de solventes (soluções à } \\
\text { base de água) } \\
\text { - Elimina riscos ocupacionais } \\
\text { - Reduz consumo de água } \\
\text { - Fácil de instalar e operar }\end{array}$ & $\begin{array}{l}\text { Limpeza de peças de } \\
\text { tamanho pequeno a médio }\end{array}$ & $\begin{array}{l}\text { - Pode não ser mais efetivo } \\
\text { que o desengraxe a vapor, na } \\
\text { limpeza de peças delicadas, } \\
\text { - Consumo elevado de energia }\end{array}$ \\
\hline 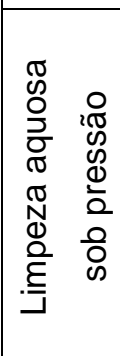 & $\begin{array}{l}\text { - Emprega soluções de limpeza } \\
\text { aquosas no lugar de solventes }\end{array}$ & $\begin{array}{l}\text { - Elimina riscos ocupacionais dos solventes } \\
\text { - Reduz tempo de limpeza }\end{array}$ & $\begin{array}{l}\text { Limpeza de peças grandes e } \\
\text { pequenas }\end{array}$ & $\begin{array}{l}\text { - Requer pressão e } \\
\text { temperatura elevadas } \\
\text { - Não aplicável a peças } \\
\text { delicadas } \\
\text { - Requer tratamento do } \\
\text { efluente }\end{array}$ \\
\hline
\end{tabular}

Fonte: Construída com base em informações obtidas em US EPA (1994, 2001b). 


\subsection{Tratamento de Superfícies}

O tratamento químico de superfícies metálicas é um processo no qual se deposita uma camada de conversão para aumentar as propriedades anti-corrosivas e de adesão do metal antes do processo de pintura (US EPA, 1996; 2001b). Um dos fatores de maior importância para o bom desempenho da pintura é o preparo da superfície. Segundo NEWMOA (1998), pode-se dizer que mais de $80 \%$ dos problemas relacionados a uma má pintura são decorrentes de uma superfície mal preparada.

As tintas aderem aos metais por ligações físicas, químicas ou mecânicas. As duas primeiras ocorrem através de grupos de moléculas presentes nas resinas das tintas que interagem com grupos existentes nos metais. A ligação mecânica requer uma certa rugosidade na superfície. Preparar a superfície do metal implica em executar operações que permitam obter limpeza e rugosidade. A limpeza elimina os materiais estranhos, como contaminantes e oxidações, que poderiam prejudicar a aderência da tinta. A rugosidade aumenta a superfície de contato e também ajuda a melhorar a aderência (GNECCO et al., 2003). A Figura 56 mostra o mapa do processo de tratamento de superfícies.

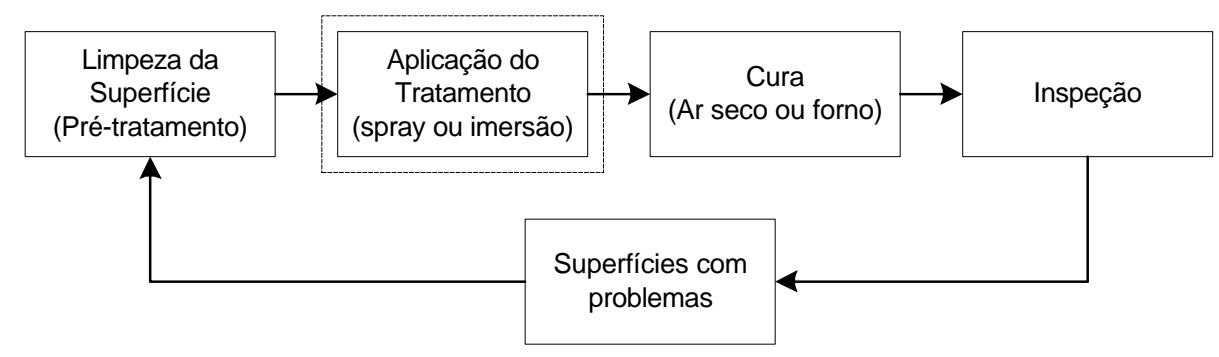

Figura 56 - Mapa do processo de tratamento de superfícies

Fonte: Modificado de NEWMOA (1998)

Os dois tipos de tratamento químico mais comuns são a fosfatização em aço ou zinco e a cromatização em alumínio. Para propósito deste trabalho será descrito apenas o processo de fosfatização em aço.

\subsubsection{Processo de Fosfatização}

A fosfatização produz cristais de fosfato na superfície metálica, convertendo-a à uma superfície não metálica. De maneira simplificada, a fosfatização consiste na reação de ácido fosfórico diluído e outras substâncias químicas formando uma camada de fosfato cristalino insolúvel (GNECCO et al., 2003). 
Segundo a US EPA (1996), no que diz respeito àpreparação de superfícies para a aplicação de tintas ou outro tipo de deposição, o processo de fosfatização tem as seguintes finalidades:

- Servir como barreira ao ataque do oxigênio do ar e da umidade na superfície metálica;

- Atuar como uma camada dielétrica que inibe o processo de corrosão;

- Fornecer a rugosidade necessária para a formação de ligações mecânicas entre a tinta ou outro tipo de deposição e a superfície.

Tipicamente o processo de fosfatização envolve cinco etapas (Figura 57). Este processo é normalmente usado no caso de peças que serão usadas em ambientes externos e corrosivos. Em operações onde são tratadas peças que requerem especificações de durabilidade ainda superiores (como por exemplo eletrodomésticos e outros equipamentos de grande porte) freqüentemente são empregados processos que envolvem sete ou mais etapas, como mostrado no Quadro 21.

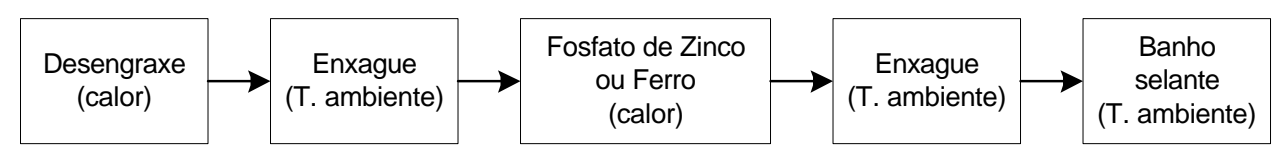

Figura 57 - Mapa de processo da fosfatização

Fonte: Modificado de US EPA (2001b)

Quadro 21 - Seqüência de etapas do processo de fosfatização

\begin{tabular}{llll}
\hline Etapa & Descrição & Processo & Tempo \\
\hline 1 & Desengraxe alcalino & Spray & $60 \mathrm{seg}$ \\
2 & Desengraxe alcalino & Spray & $30 \mathrm{seg}$ \\
3 & Enxágue & Spray & $30 \mathrm{seg}$ \\
4 & Enxágue & Spray & $30 \mathrm{seg}$ \\
5 & Fosfato & Spray & $60 \mathrm{seg}$ \\
6 & Enxágue & Spray & $30 \mathrm{seg}$ \\
7 & Passivante & Spray & $30 \mathrm{seg}$ \\
8 & Enxágue (água deionizada) & Spray & $30 \mathrm{seg}$ \\
$8 \mathrm{a}$ & Enxágue (água deionizada) & Spray & Variável \\
& Dreno e secagem & & 5 min \\
\hline
\end{tabular}

Fonte: US EPA (1996) 
O banho fosfatizante é normalmente constituído de fosfatos de zinco ou ferro, acrescido de aditivos (aceleradores). Na maioria das operações onde a resistência à corrosão nas peças acabadas precisa ser alta, como na indústria automobilística, de eletrodomésticos e de eletrônicos, são usados banhos a base de fosfato de zinco (US EPA, 1996; 2001b). A Figura 58 mostra as diferentes formulações de fosfatos de zinco existentes, e sua relação de eficiência.

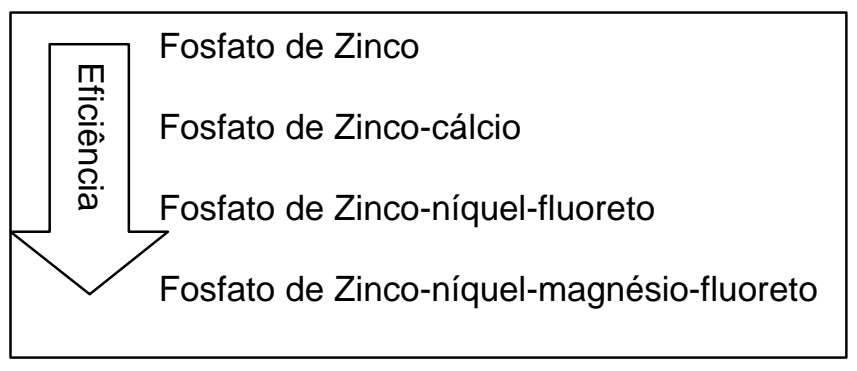

Figura 58 - Eficiência das formulações de fosfato

Durante o processo de fosfatização o ácido presente na solução ataca os sítios anódicos da superfície do aço, liberando íons de zinco no banho e produzindo gás hidrogênio. Um acelerador (agente oxidante) é adicionado para oxidar os íons de ferro na superfície do metal e consumir o hidrogênio. A diminuição do $\mathrm{pH}$ nos sítios catódicos faz com que o fosfato de zinco precipite na superfície do aço. Este processo continua até que todos os sítios catódicos estejam cobertos. Os aceleradores desempenham duas funções básicas:

- O excesso de íons de ferro na solução tende a retardar o processo de fosfatização. O acelerador aumenta a velocidade do processo através da oxidação dos íons de ferro, que precipitam na forma de uma borra de fosfato férrico, estendendo a vida útil do banho. A borra precisa ser removida do banho (normalmente por filtração) e disposta como resíduo perigoso.

- Através da reação com o hidrogênio formado nos sítios anódicos, o acelerador previne a formação de gás hidrogênio, que interfere na deposição do fosfato.

Os aceleradores usados com fosfatos de zinco podem variar de nitratos a peróxidos e cloratos. Compostos de cálcio são particularmente favoráveis como aceleradores por formarem uma camada de baixo peso e grãos compactos. De maneira geral os cristais resultantes da fosfatização com zinco apresentam baixa porosidade, formam uma base forte para a adesão da pintura e apresentam boa resistência à corrosão. O tamanho dos cristais também é afetado pelo método empregado para submeter a peça ao banho fosfatizante (spray ou imersão) e pela efetividade das etapas anteriores de desengraxe e enxágue (US EPA, 1996). 
A última etapa do processo consiste em um banho selante, denominado de passivação, que tem por finalidade aumentar a resistência àcorrosão e selar os poros deixados na camada de fosfato. As soluções passivantes tradicionalmente empregadas são constituídas por ácido crômico ou ácido crômico fosfórico (também conhecidas como 'selagem por cromo'). Atualmente devido a restrições ambientais em relação ao uso do cromo hexavalente são usadas soluções alternativas em substituição æ̀ soluções a base de cromo, como taninatos e ácidos orgânicos. Após a passivação as peças são enxaguadas em água deionizada para remover os sais insolúveis (NEWMOA, 1998; GNECCO et al., 2003).

\subsubsection{Características dos Resíduos Gerados}

Cada uma das etapas que constituem o processo de fosfatização geram emissões atmosféricas e resíduos sólidos, além do efluente líquido proveniente dos banhos gastos e da limpeza dos tanques de processo. A Figura 59 apresenta um diagrama de fluxo de materiais, relacionando todas as possíveis fontes de poluição envolvidas nos processos de tratamento de superfícies e pintura.

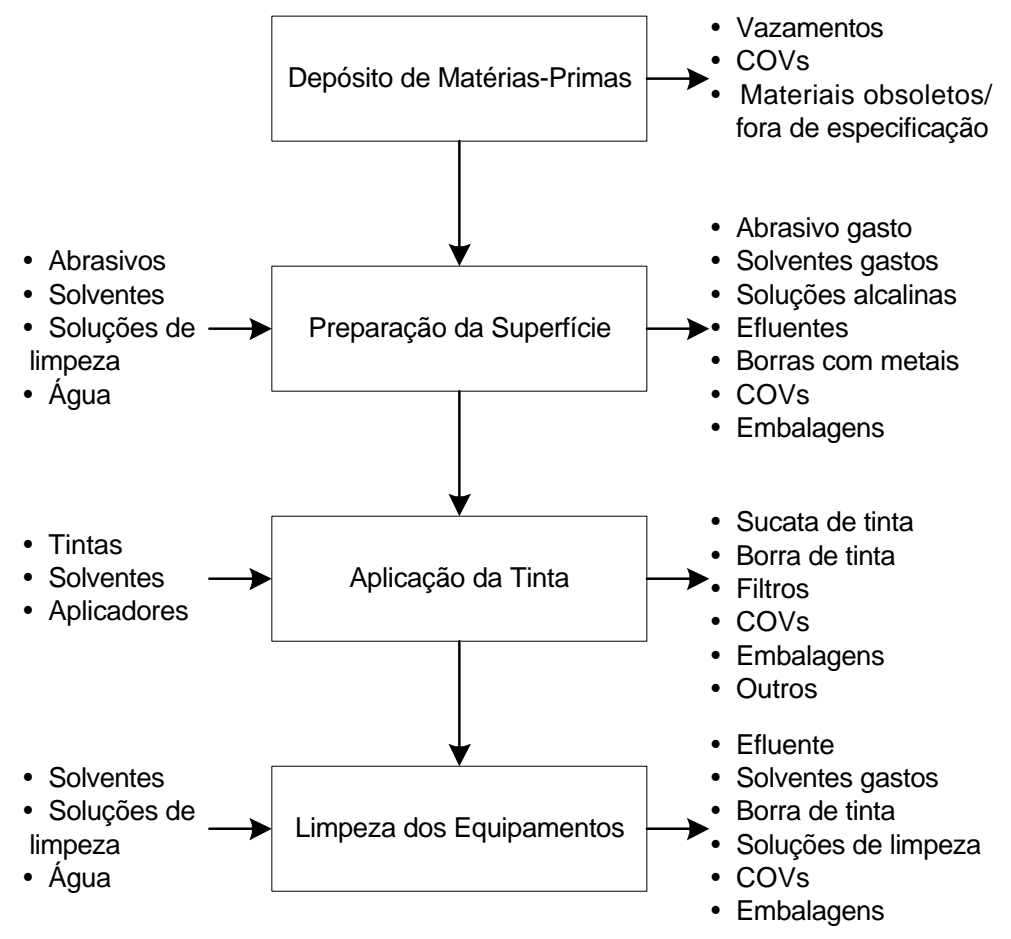

Figura 59 - Fontes de poluição no processo de tratamento de superfícies e pintura. Fonte: Modificado de NEWMOA (1998) 
Os principais resíduos perigosos gerados nos tratamento de superfícies, segundo PRC Environment Management, Inc. (1989), são:

- Borras gerada na planta de tratamento dos efluentes líquidos

- Banhos galvânicos saturados

- Soluções de limpeza e desengraxe saturadas

- Solventes saturados

- Resíduos sólidos diversos (containeres vazios, filtros, absorventes, etc.)

\subsubsection{Alternativas de Prevenção àPoluição}

As alternativas de prevenção à poluição disponíveis para os processos de tratamento de superfícies envolvem melhorias na eficiência do processo, uso de passivantes alternativos e reciclagem de água e banhos no processo.

\subsubsection{Melhorias na Eficiência do Processo}

Segundo a US EPA (2001b), a melhor forma de se reduzir a geração de resíduos nos processos de fosfatização é através de melhorias na eficiência do processo, prestando atenção aos seguintes pontos:

a) Formulação do banho compatível com o substrato metálico: o banho fosfatizante deve ser formulado utilizando as substâncias adequadas ao substrato metálico que será tratado. A formulação adequada do banho reduz a geração de lodos contendo metais pesados tanto nos banhos de imersão quanto nas operações que utilizam banhos na forma de spray. A variação de cor da camada depositada pode ser um indício de que o banho não está adequadamente formulado, está com sua capacidade exaurida ou está contaminado. Em geral, alguma quantidade de borra é sempre gerada. No entanto, o uso de produtos não compatíveis além de comprometer a qualidade final da peça, gera um excesso de borra.

b) Garantir a qualidade do desengraxe: a remoção de óleos e outros contaminantes da superfície é importante para a garantia da qualidade da peça que está sendo tratada e para o aumento da vida útil do banho fosfatizante, pois evita que contaminantes presentes na superfície sejam arrastados para o tanque de fosfatização.

c) Enxágue após o desengraxe: o enxague das peças após o desengraxe é fundamental na manutenção da qualidade do banho fosfatizante. Qualquer resíduo de produto químico usado no banho desengraxante deve ser removido para assegurar que estes não sejam carreados para o banho fosfatizante. A presença de surfactantes 
e outros contaminantes na peça prejudica a deposição de metais na superfície e a qualidade final da pintura. Nos desengraxantes alcalinos, um enxague ineficiente pode ocasionar a neutralização do banho fosfatizante, uma vez que os álcalis da solução desengraxante são carreados para o tanque de fosfato. O sistema de enxague pode ser na forma de tanques de imersão, de spray ou de fluxo contra-corrente.

d) Inspeção de limpeza: para garantir que a peça de trabalho está efetivamente livre de contaminantes antes que esta entre no banho fosfatizante é preciso fazer uma inspeção, que pode ser realizada através de testes simples, como o teste de quebra d'água. Neste teste, água deionizada é borrifada na superfície que, se estiver livre de óleos e graxas, permite que a água escorra de maneira uniforme sem a formação de caminhos preferenciais. Para verificar a presença de surfactantes, a superfície deve ser enxaguada com uma pequena quantidade de água deionizada. $\mathrm{O} \mathrm{pH}$ da água de enxague irá definir a presença de surfactantes. O Quadro 22 resume as vantagens e limitações destas alternativas.

Quadro 22 - Alternativas para melhoria da eficiência do processo de fosfatização.

\begin{tabular}{|c|c|c|}
\hline Alternativa & Vantagens & Limitações \\
\hline $\begin{array}{c}\text { Formulação } \\
\text { adequada do } \\
\text { banho }\end{array}$ & $\begin{array}{l}\text { - Garantia do recobrimento perfeito da } \\
\text { peça } \\
\text { - Reduz o volume de efluente e a } \\
\text { quantidade de peças defeituosas }\end{array}$ & $\begin{array}{l}\text { - Pode requerer testes de } \\
\text { laboratório para determinar a } \\
\text { formulação ótima } \\
\text { - A formulação ótima pode } \\
\text { representar riscos ao meio } \\
\text { ambiente }\end{array}$ \\
\hline $\begin{array}{l}\text { Desengraxe } \\
\text { eficiente }\end{array}$ & $\begin{array}{l}\text { - Remove contaminantes da peça de } \\
\text { trabalho } \\
\text { - Minimiza a contaminação do banho por } \\
\text { sais alcalinos } \\
\text { - Previne o aumento do pH do banho } \\
\text { - Aumenta a vida útil do banho }\end{array}$ & $\begin{array}{l}\text { - Pode usar produtos } \\
\text { químicos tóxicos para a } \\
\text { remoção dos contaminantes } \\
\text { - Produz efluente que requer } \\
\text { tratamento antes do descarte } \\
\text { na rede de esgoto }\end{array}$ \\
\hline $\begin{array}{l}\text { Enxague } \\
\text { eficiente }\end{array}$ & $\begin{array}{l}\text { - Remove surfactantes e outros } \\
\text { contaminates que podem prejudicar a } \\
\text { deposição dos metais na peça } \\
\text { - Reduz o arraste de álcalis e } \\
\text { contaminantes para o banho fosfatizante } \\
\text { - Aumenta a vida útil do banho } \\
\text { - Reduz o consumo de insumos de } \\
\text { reposição do banho fosfatizante }\end{array}$ & $\begin{array}{l}\text { - Requer grande espaço físico } \\
\text { - Custos de instalação e de } \\
\text { manutenção podem ser } \\
\text { elevados }\end{array}$ \\
\hline
\end{tabular}


Quadro 22- Alternativas para melhoria da eficiência do processo de fosfatização (cont).

\begin{tabular}{|cll|}
\hline & - Garante que óleos e graxas foram & - Testes consomem tempo e \\
& removidos & mão de obra e precisam ser \\
Inspeção da & - Minimiza contaminações no banho & realizados de forma criteriosa \\
limpeza & - Assegura a vida útil do banho e reduz a & para não se incorrer em erros \\
& descarga de efluente e o consumo de & de avaliação. \\
& insumos de reposição & \\
& - Indica a efetividade das etapas de & \\
& desengraxe e enxague
\end{tabular}

Fonte: Construído com base em informações obtidas em US EPA (2001b).

\subsubsection{Uso de Passivantes Alternativos}

O uso de uma etapa adicional de passivação após a fosfatização como forma de aumentar a resistência do material a corrosão é empregada em diversos processos industriais, especialmente naqueles que trabalham com peças de alto valor agregado.

Os processos de passivação a base de cromo hexavalente ou trivalente têm sido extensivamente usados pela indústria. Apesar de as duas formas de cromo produzirem poluentes, o cromo hexavalente é particularmente tóxico e suspeito de possuir propriedades carcinogênicas. Os resíduos de cromo hexavalente são perigosos e representam um custo adicional significativo.

Como forma de evitar os problemas decorrentes da utilização de cromo no processo, têm sido desenvolvidas formulações de passivantes isentos de cromo. De maneira geral estas formulações não apresentam a mesma efetividade daquelas a base de cromo, no que se refere a resistência a corrosão, entretanto, têm sido aplicadas com sucesso nos casos onde a corrosão do material não representa um fator crítico (US EPA, 2001b).

\subsubsection{Reciclagem e Reúso no Processo}

Segundo NEWMOA (1998), a redução do consumo de água é a alternativa de prevenção àpoluição mais valiosa a ser empregada nos processos de fosfatização.

A redução do consumo de água pode ser alcançada pela manutenção da vida útil dos banhos (para a qual se empregam as técnicas discutidas anteriormente) e pela reciclagem dos banhos de enxague e fosfatizantes, que também resultam na redução do uso de insumos e na redução do volume de resíduos (borras e embalagens de produtos químicos) gerados. 
A reciclagem é efetuada pela elevação do $\mathrm{pH}$ do banho exausto, que promove a precipitação do lodo contendo os metais pesados. O banho é centrifugado e o lodo é coletado na forma de borra concentrada (que precisa ser disposta como resíduo perigoso devido a elevada concentração de metais pesados). A seguir, o banho retorna ao tanque de processo onde é reutilizado.

Uma crescente tendência na reciclagem de banhos fosfatizantes é o uso da ultrafiltração para separar e reutilizar os banhos de enxague e concentrados. Esta etapa adicional maximiza o uso da água e reduz a quantidade de água residuária a ser enviada àestação de tratamento de efluentes (US EPA, 2001b).

\subsubsection{Minimização de Resíduos}

Algumas oportunidades para a minimização de resíduos são recomendadas por PRC Environment Management, Inc. (1989), e podem ser consideradas como complementação às alternativas de prevenção à poluição. Estas oportunidades envolvem basicamente práticas para reduzir a quantidade e a toxicidade da borra gerada na estação de tratamento de efluentes, e envolvem as seguintes práticas:

- Tratamento prévio da água usada como matéria-prima nos processos;

- Uso de produtos químicos alternativos no tratamento de efluentes, tais como soda cáustica e coagulantes polieletrolíticos;

- Segregação dos fluxos de efluentes de diferentes banhos e processos para promover a reciclagem, tratamento seletivo e tratamento em batelada;

- Utilização de filtros para remoção da água da borra (por exemplo, utilização de filtros-prensa) para redução do volume;

- Sistemas de tratamento tais como troca iônica, evaporação e eletrólise e outros que não empreguem métodos de precipitação/clarificação para a remoção dos poluentes eliminam a geração de borras com metais pesados. Estes sistemas podem ser usados para o tratamento dos efluentes e dos banhos gastos. 


\subsection{Pintura}

A etapa de pintura tem como objetivos oferecer proteção à peça e propiciar acabamento estético. Os processos de pintura podem variar de acordo com a tecnologia empregada e com o tipo de tinta usada.

\subsubsection{Características dos Resíduos Gerados}

Os resíduos gerados nos processos de pintura incluem emissões atmosféricas de compostos orgânicos voláteis (COVs), particulados e outros poluentes, sobras de tintas e produtos químicos, embalagens e containeres vazios, solventes e materiais diversos usados na limpeza e manutenção dos equipamentos, filtros usados nas cabines de pintura a pó e borras de tinta dos processos de pintura por imersão.

A periculosidade e toxicidade do resíduo depende da concentração de solvente presente nos resíduos e da presença de metais pesados como chumbo e cromo na composição da tinta usada.

A maior fonte de emissões atmosféricas se encontra na etapa de aplicação da tinta na forma de 'overspray'. Quanto maior o overspray, menor é a eficiência de transferência e maior é a quantidade de resíduo produzido na forma de emissões atmosféricas, materiais de limpeza e filtros ou borras (US EPA, 2001b). A Figura 60 mostra um sistema de pintura convencional por spray de ar atomizado com destaque para o efeito de overspray.

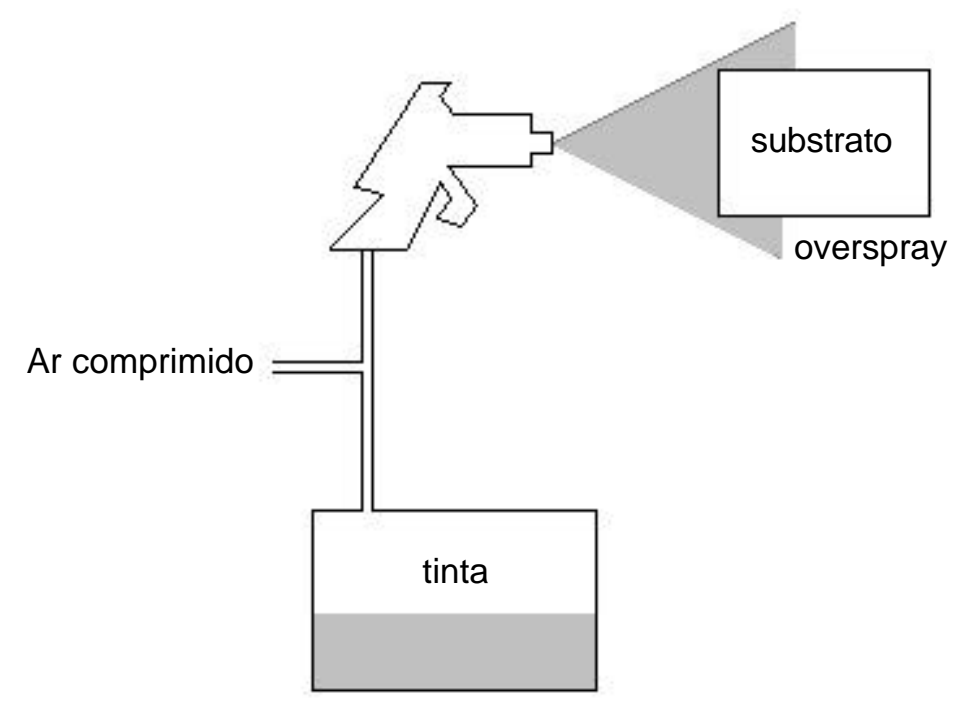

Figura 60 - Pintura por spray de ar atomizado (overspray)

Fonte: Modificado de HIGGINS (1995). 


\subsubsection{Alternativas de Prevenção àPoluição}

As alternativas de prevenção à poluição aplicáveis aos processos de pintura envolvem medidas para a redução na fonte, como a eliminação da necessidade de pintura em alguns casos específicos, o uso de materiais (tintas) e processos alternativos (formas de aplicação) e a melhoria da eficiência da transferência. Não existem opções viáveis de reciclagem no processo.

\subsubsection{Eliminação da Necessidade de Pintura}

A eliminação da necessidade de pintura em determinadas peças ou componentes da estrutura de um produto envolve a reengenharia do projeto do produto de forma a empregar materiais alternativos que combinem funções estruturais e estéticas. Um exemplo típico é a injeção de recobrimentos plásticos na estrutura de produtos eletrônicos. Entretanto, esta área tem sido pouco explorada, uma vez que as modificações dificilmente podem ser implantadas quando o produto já se encontra no mercado (US EPA, 2001b).

\subsubsection{Uso de Materiais e Processos Alternativos}

As tintas a base de solventes tradicionalmente empregadas nos processos de pintura contêm altos teores de compostos orgânicos voláteis que são emitidos para o ar durante a aplicação da tinta. As formulações de tintas com baixos teores ou isentas de COVs se apresentam como uma boa alternativa, e vêm sendo correntemente empregadas. Dentre as opções estão as tintas a pó, a base de água, a base de solventes e especiais. Cada formulação tem uma aplicação e eficiência específica. Uma visão geral de cada uma destas opções é apresentada a seguir.

\section{Tintas a pó}

As tintas a pó são muito populares devido ao seu baixo teor de compostos orgânicos voláteis. Em muitas aplicações este tipo de tinta oferece vantagens econômicas em relação aos processos que empregam tintas líquidas e a base de solventes. As vantagens ambientais incluem a não geração de poluentes atmosféricos, de efluentes e de resíduos perigosos.

A poluição produzida está relacionada aos processos associados ao processo de pintura. O primeiro envolve a preparação da superfície, discutido anteriormente, uma vez que as tintas a pó requerem o maior nível de limpeza possível da superfície. $O$ segundo está associado a remoção de pó que eventualmente possa se acumular em fendas e cavidades da peça e remoção da tinta de peças defeituosas. 
A aplicação da tinta pode ser feita por atração eletrostática ou por meio de leitos fluidizados. Nenhum dos métodos envolve o uso de solventes ou produz resíduos perigosos. Após a aplicação da tinta a peça é submetida a um processo de cura em fornos aquecidos a temperaturas que variam de 150 a $190{ }^{\circ} \mathrm{C}$ por um período aproximado de 8 a 20 minutos, onde tinta (pó) sofre uma reação de polimerização e se adere a superfície metálica da peça.

Durante a cura são produzidos vapores de água e compostos orgânicos (resinas formadas nas temperaturas elevadas do forno), que são emitidos para a atmosfera. Existem divergências se estes vapores, que representam cerca de 0,5 a $5 \%$ do peso da camada de pó aplicada na peça, podem ser considerados ou não como emissões de compostos orgânicos voláteis (US EPA, 2001b).

\section{Tintas a base de áqua}

Esta denominação descreve uma categoria de tintas onde o solvente principal é a água. Solventes orgânicos também entram na composição, mas em concentrações baixas. Na maioria das formulações a razão água para solvente orgânico é de 80:20. Os solventes orgânicos, neste caso denominados de co-solventes, aumentam a capacidade de formação do filme durante a secagem, quando a água evapora e a tinta adere na peça. A tendência das novas tecnologias de resinas que vêm sendo desenvolvidas é apresentar uma quantidade de solvente necessária para a formação do filme cada vez mais baixa. Existem novas formulações completamente isentas de solvente. As tintas a base de água se subdividem em quatro categorias, de acordo com a sua composição: a) a base de resinas alquídicas, acrílicas e híbridas acrílicaepóxi; b) a base de resinas epóxi; c) a base de poliuretanos; e, d) a base de resinas alquídicas modificadas e poliésteres acrílicos.

Os benefícios deste tipo de tinta são os seguintes:

- Baixo teor de compostos orgânicos voláteis;

- Podem ser aplicadas com equipamentos padrão;

- Apresentam baixo risco de incêndio, devido ao elevado teor de água;

- Geralmente apresentam baixa toxicidade;

- A limpeza dos equipamentos pode ser realizada com água comum;

- Podem ser utilizadas em substratos de aço, alumínio, galvanizados, plásticos, madeira e substratos arquitetônicos em geral;

- Estão disponíveis em uma ampla variedade de cores e brilho. 
Apesar do baixo teor de solventes na composição ser positivo do ponto de vista ambiental, esta categoria de tintas apresenta algumas limitações. Certas formulações apresentam durabilidade inferior e baixa resistência ao ataque de sais, umidade, produtos químicos e solventes. Algumas formulações a base de resinas epóxi contêm cromatos, e produzem resíduos perigosos (US EPA, 2001b).

\section{Tintas a base de solventes}

Embora as tintas a base de solventes venham sofrendo restrições ambientais devido ao seu potencial de emissões de compostos orgânicos voláteis, poluentes atmosféricos e compostos que provocam a degradação da camada de ozônio, esta categoria de tintas não foi completamente substituída até o momento, dadas as limitações técnicas apresentadas pelas alternativas até agora desenvolvidas. Entretanto, desenvolvimentos têm sido feitos no sentido de reduzir o conteúdo de solvente nas composições, diminuir a viscosidade e desenvolver novos solventes. As diferentes categorias de tintas a base de solvente englobam tintas a base de resinas alquídicas e alquídicas modificadas, a base de epóxi, de poliuretano em diferentes misturas. Cada categoria apresenta suas peculiaridades no que se refere a composição, temperatura de operação, processo de aplicação, etc. Os benefícios conferidos por estas categorias de tintas, que as tornam atrativas do ponto de vista técnico, e como resultado de novos desenvolvimentos, também ambiental, são os seguintes:

- Através de pesquisas, o conteúdo de COVs vêm gradualmente sendo reduzido;

- Novos produtos apresentam viscosidades reduzidas;

- São as opções mais baratas;

- Encontram-se disponíveis em diversas cores e níveis de brilho;

- Apresentam excelente performance, tais como resistência a produtos químicos e solventes, às intempéries e àradiação ultravioleta;

- Apresentam boa adesão em uma série de substratos, incluindo a maioria dos metais, plásticos, madeira, cerâmicas, vidro, etc.

As desvantagens são as seguintes:

- Os solventes contém compostos orgânicos voláteis, poluentes atmosféricos perigosos e compostos que degradam a camada de ozônio;

- Tipicamente o teor de COVs é mais elevado do que nos métodos alternativos;

- Os solventes conferem risco de incêndio e àsaúde dos trabalhadores; 
- A alta viscosidade em alguns casos pode afetar a qualidade do produto final;

- As formulações a base de epóxi apresentam baixa resistência às radiações ultravioleta, e a aplicação inadequada pode representar sérios riscos à saúde dos trabalhadores (US EPA, 2001b).

\section{Formulacões especiais}

Algumas formulações especiais têm sido desenvolvidas, entretanto representam uma faixa bastante estreita de aplicação, dentre as quais destacam-se os seguintes métodos:

a) Auto-deposição: neste processo uma resina latex é depositada eletroquimicamente na superfície. O processo é limitado à aplicação em aço, no entanto, o aço não precisa passar pelo processo de fosfatização. Por outro lado, é requerido um estágio de limpeza mais sofisticado, no qual o substrato é submetido a um banho alcalino em spray por 1 minuto, seguido por banho alcalino por imersão por dois minutos, enxágue por imersão ou spray e enxágue final em água deionizada. Não são usados solventes no processo.

b) Eletrodeposição: é usado predominantemente em grandes plantas industriais. O processo consiste em depositar a camada de tinta eletroquimicamente com auxilio de uma corrente elétrica. Antes da deposição da tinta o substrato passa por um processo de limpeza e tratamento multi-estágios, que inclui fosfatização, selagem por cromo e no mínimo um enxágue com água deionizada. Este método apresenta o mesmo teor de compostos orgânicos voláteis que os métodos convencionais a base de água. $O$ volume de efluente e de resíduos perigosos é consideravelmente menor.

c) Cura por radiação: a cura é realizada mediante exposição a comprimentos de onda de radiação ultravioleta específicos. As emissões de COVs são muito baixas mesmo em tintas com solventes, porque a cura da tinta ocorre sem que haja evaporação do solvente. Devido aos requisitos de posicionamento das lâmpadas, os substratos estão limitados às geometrias simples e uniformes. A adição de pigmentos àtinta pode retardar o tempo de cura.

d) Sistema unicarb: este método emprega dióxido de carbono $\left(\mathrm{CO}_{2}\right)$ líquido como solvente. Devido às excelentes características de solubilidade do $\mathrm{CO}_{2}$, este pode ser adicionado às resinas convencionais e com alto teor de sólidos. No sistema a resina e o $\mathrm{CO}_{2}$ são alimentados e misturados na pistola de spray. A viscosidade da tinta é reduzida permitindo uma boa atomização. 
Estes métodos apresentam as seguintes vantagens:

- Os métodos de cura por radiação e de pintura por auto-deposição apresentam teores de COVs próximos de zero;

- Os métodos de auto-deposição e de eletrodeposição geram quantidades mínimas de águas contaminadas, apresentam poucos riscos e nenhum risco de incêndio;

- As tintas empregadas na auto-deposição não são tóxicas;

- Os métodos de auto-deposição e de eletrodeposição apresentam eficiência de transferência elevadas, minimizando a quantidade de resíduo produzida;

- A eletrodeposição pode ser aplicada em aço comum e galvanizado e em alumínio, fornecendo uma cobertura forte, flexível e resistente àcorrosão;

- Os vapores resultantes da cura por radiação são facilmente exauríveis e não representam risco mensurável àqualidade do ar;

- A radiação por cura possibilita tempos de cura extremamente baixos;

- O sistema unicarb pode reduzir as emissões de COVs de 50 a 80\%, e aumenta a eficiência de transferência em até 30\%.

As limitações destes métodos são as seguintes:

- Não são aplicáveis em todas as situações;

- A auto-deposição e a eletrodeposição só são viáveis economicamente em grandes plantas;

- A cura por radiação está limitada a substratos com geometrias simples;

- A radiação por cura tem levantado suspeitas com relação à exposição de operadores a vapores perigosos;

- O investimento necessário à substituição de um sistema convencional pelo sistema unicarb é relativamente alto (US EPA, 2001b). 


\subsubsection{Melhoria da Eficiência de Transferência em Sistemas de Spray}

De todas as estratégias disponíveis para minimizar a poluição nos processos de pintura, a melhoria da eficiência é a que representa resultados mais efetivos. A eficiência de transferência em um processo de pintura é definida como a razão de massa (ou volume) de sólido depositado no substrato pela massa (ou volume) de sólido usado na aplicação. O aumento da eficiência de transferência do equipamento usado para aplicar a tinta reduz diretamente a quantidade de resíduos e de emissões atmosféricas produzidas durante a aplicação da tinta (US EPA, 1996; 2001b).

A tinta pode ser aplicada nos substratos de diversas formas. Em escala industrial a aplicação é geralmente feita por meio de técnicas em spray. De maneira geral os métodos de aplicação em spray usam pistolas especialmente projetadas para atomizar a tinta em um spray fino. A tinta é armazenada em um vaso de pressão e alimentada ao spray por meio de ar comprimido. Pistolas manuais ou automatizadas (montadas sobre braços mecânicos) são geralmente empregadas para aplicar tintas líquidas em substratos metálicos. Embora os sistemas de spray sejam fáceis de operar e tenham custos baixos, eles ocasionam uma certa quantidade de overspray e de retorno da tinta, o que contribui para a redução da eficiência de transferência. Cabines de pintura são normalmente usadas para reter o overspray e evitar sua propagação no ar. Estas cabines são equipadas com filtros para reter as partículas de tinta (NEWMOA, 1998).

As principais tecnologias de pintura por spray são descritas a seguir.

\section{Spray de Ar a Alta Pressão (LVHP)}

Esta tecnologia, conhecida por LVHP (low-volume/high-pressure) ou simplesmente spray convencional, usa uma pistola na qual ar comprimido a altas pressões (40-90 psi) atomiza a tinta líquida na forma de um spray fino. $O$ ar é fornecido àpistola por meio de um compressor e a tinta é alimentada através de um sistema pressurizado.

Este método de aplicação pode ser usado para diversos tipos de superfícies e oferece facilidade de controle do spray e um bom nível de atomização, resultando em uma boa qualidade final de pintura. Entretanto, produz grandes quantidades de overspray, resultando em uma eficiência de transferência baixa (30-60\%), usa grandes quantidades de ar comprimido, e devido ao alto nível de atomização, produz altos níveis de emissões de COVs. Cabines são frequentemente usadas para reduzir os volumes de emissões e manter a taxa de ventilação baixa, de modo a reduzir custos operacionais e de controle de emissões atmosféricas (NEWMOA, 1998). 


\section{Spray de Ar a Baixa Pressão (HVLP)}

Este é um sistema alternativo ao LVHP, e como o nome sugere, esta tecnologia emprega um volume grande de ar a baixas pressões (0,1-10 psi) para atomizar a tinta. Esta tecnologia reduz o overspray e aumenta a eficiência de transferência. As pistolas têm diâmetros das aberturas dos bicos maiores do que as do sistema LVHP. A eficiência de transferência destes sistemas variam de 65 a $75 \%$.

O sistema é portátil e de fácil limpeza. Entretanto a atomização proporcionada pelo sistema pode não ser suficiente para pinturas finas, de bom acabamento, e a taxa de produção é inferior a do sistema LVHP. O sistema HVLP funciona bem quando se empregam tintas de baixa viscosidade (NEWMOA, 1998).

\section{Airless Spray}

Este sistema não usa ar comprimido. A tinta é bombeada a altas pressões (5001500 psi) através de uma pequena abertura na pistola. Quando a tinta pressurizada entra na região de baixa pressão da pistola, a queda brusca de pressão provoca a atomização.

Este sistema apresenta série de vantagens em relação aos sistemas que usam ar para atomizar a tinta. A eficiência de transferência é maior, de 65-70\%, devido à menor turbulência que reduz o efeito de retorno da tinta. A taxa de produção é duas vezes maior e o sistema é capaz de operar com tintas de viscosidade alta sem a necessidade de adição de solventes. Entretanto, a qualidade da pintura é inferior e o sistema se limita a aplicação em substratos com áreas grandes. Outra grande desvantagem é o risco de entupimento do bico, que representa risco ao operador devido as elevadas pressões de operação (NEWMOA, 1998).

\section{Spray Eletrostático}

Neste método as gotículas de tinta atomizadas são carregadas na ponta da pistola por meio de um eletrodo. A tinta pode ser atomizada por meio de sistemas convencionais a ar, airless ou rotatórios. A parte a ser pintada, que é suspensa em um transportador é eletricamente neutra, e as gotículas de tinta carregadas são atraídas para a sua superfície. Se a diferença de carga é suficientemente grande, as partículas de tinta cobrem também as porções laterais e posteriores da peça. Este efeito aumenta a eficiência de transferência. O sistema de spray eletrostático é usado na maioria das indústrias de eletrodomésticos.

A maior vantagem deste sistema é a economia de material e mão de obra que ele proporciona. O sistema pode ser automatizado ou manual, e em ambos a mão de obra 
com limpeza do sistema é bastante reduzida. Outra vantagem é a habilidade de cobrir as peças de maneira uniforme, inclusive áreas normalmente inacessíveis quando outros métodos são empregados.

O investimento inicial para implantação do sistema é alto. O sistema precisa ser bem operado para reduzir riscos de incêndios e acidentes. Outro inconveniente é que a tinta é atraída por outros objetos, como transportadores, sistemas de proteção, paredes da cabine e pistolas (NEWMOA, 1998).

\section{Técnicas para melhoria da eficiência de transferência}

Segundo NEWMOA (1998) e US EPA (1996, 2001b), as seguintes técnicas podem ser usadas durante a aplicação da tinta para melhorar a eficiência de transferência:

a. Aproximar o spray da peça: as pistolas tipicamente têm um alcance de 20 a 30 centímetros. De maneira geral, quanto maior a distância, menor a eficiência de transferência. Entretanto, a uma distância reduzida o operador precisa reduzir a pressão do ar ou do fluido para evitar a aplicação de uma quantidade de tinta excessiva.

b. Otimizar a largura do jato: o operador precisa ajustar a largura do jato de tinta de acordo com o tamanho da peça a ser pintada. Isto não é difícil em linhas de produção que trabalham com peças de tamanhos padronizados. Para o caso de linhas onde as peças variam continuamente de tamanho, podem ser adquiridos adaptadores que acoplados ao aplicador permitem o ajuste do jato.

c. Reduzir a pressão de ar: nos processos que usam sprays HVLP, convencional e eletrostático, a pressão do ar no atomizador deve ser reduzida para a menor possível, de modo a aumentar a eficiência de transferência.

d. Reduzir a pressão do fluido: se a pressão e a vazão correspondente do fluido forem altas, o fluxo de tinta que sai da pistola percorre uma distância relativamente longa antes de se curvar e cair na superfície. Tal vazão tem um tempo de residência curto no spray e requer uma grande quantidade de energia para a atomização. Com a queda de pressão, o fluxo de tinta que sai da pistola diminui e menos energia é requerida para a atomização. Tempos de residência maiores resultam em uma atomização mais eficiente que resulta em maior eficiência de transferência.

e. Posicionar as peças mais próximas umas das outras: muitas plantas usam sistemas de transportadores onde as peças são suspensas espaçadas de 45 a 60 centímetros umas das outras. Este espaçamento é apropriado para peças de 
tamanho médio a grande, mas reduz a eficiência de transferência em peças pequenas. As fábricas devem usar sistemas com espaçadores especialmente projetados para as peças que queiram pintar, de modo a propiciar o afastamento adequado entre as peças.

f. Selecionar os equipamentos mais eficientes e adequados para cada aplicação.

\subsubsection{Cabines de Pintura}

Uma cabine de pintura é um compartimento fechado que direciona o overspray e as emissões de solventes para longe do operador. As cabines são projetadas para capturar os materiais particulados que são descarregados no ar durante a aplicação da tinta. Convém salientar que as cabines não funcionam como equipamentos para o abatimento de emissões de compostos orgânicos voláteis; sua função primária é proteger o operador e os outros funcionários da exposição de vapores potencialmente tóxicos e particulados. Outra função da cabine é prevenir incêndios decorrentes das altas concentrações de solventes inflamáveis e vapores.

As descargas das cabines de pintura consistem de particulados provenientes dos sólidos da tinta que não são transferidos para a peça, e de vapores orgânicos de solventes usados para reduzir a viscosidade da tinta. A maior parte dos particulados são retidos em filtros apropriados. Os vapores podem ser controlados ou recuperados por meio de tecnologias de condensação, compressão, absorção, adsorção ou combustão. A minimização pode ser alcançada através da utilização de equipamentos mais eficientes e de materiais isentos ou com baixos teores de COV's. O aumento da eficiência de transferência reduz emissões de solventes e particulados.

Existem três tipos de cabines de pintura, as cabines secas e úmidas, cuja diferença está no sistema de coleta do overspray, e as cabines de pintura a pó. As cabines secas usam filtros de papel, fibra de vidro ou poliestireno para coletar o overspray, enquanto que as cabines úmidas usam uma cortina de água com aditivos químicos. Nas cabines de pintura a pó, a tinta que não é aderida na superfície é recuperada e reusada no processo, otimizando o uso de material. O pó recuperado pode ser misturado com pó novo ou, dependendo da qualidade, pode ser retornado ao fabricante para refino (NEWMOA, 1998).

Alguns problemas relacionados com as cabines podem ocasionar um elevado índice de peças com defeito, dentro os quais destacam-se:

- Isolamento ineficiente da cabine na pintura eletrostática: neste caso a melhor alternativa é consultar a assistência técnica responsável para resolver o 
problema. O escape de sólidos também pode ocorrer devido a existência de fluxo de ar turbulento na cabine.

- Presença de partículas e sujeitas na pintura: esta é provavelmente a causa mais comum de retrabalhos e rejeitos nas operações de pintura. Para evitar este problema devem ser tomados os seguintes cuidados: realizar operações que possam gerar poeiras e particulados fora da cabine; assegurar que os filtros não estejam sujos ou que tenham um mesh muito grande; assegurar que a cabine esteja operando a pressões negativas; assegurar que o sistema de ventilação traga ar fresco para dentro da cabine e que não carregue partículas de sujeiras; manter as paredes e o chão da cabine livre de sujeiras, overspray seco e partículas; e, assegurar que o tamanho da cabine é o mais adequado.

- Perda de brilho na pintura: este problema ocorre quando a umidade é alta e mistura condensados na surperfície que acabou de ser pintada. Normalmente ocorre em cabines úmidas. Para evitar este problema, as peças devem sair da cabine imediatamente após a deposição da tinta (NEWMOA, 1998).

De maneira geral, a prevenção à poluição nos processos de pintura pode ser resumida nas seguintes estratégias:

- Eliminação da necessidade de pintura

- Substituição de solventes e tintas a base de solventes

- Aumento da eficiência de transferência

- Treinamento dos operadores para a adoção de práticas adequadas de aplicação

- Melhorar as práticas de housekeeping, manutenção e operação

- Usar sistemas de aquecimento para diminuir a viscosidade das tintas líquidas

- Adotar procedimentos padronizados (NEWMOA, 1998). 


\subsection{Considerações Finais}

Neste capítulo foi realizada uma caracterização dos principais problemas que podem ocorrer em processos de manufatura de produtos metálicos. As alternativas de prevenção àpoluição apresentadas representam opções generalistas, que podem ser adotadas (com as devidas adaptações) para os problemas mais frequentes.

Os manuais consultados se apresentam como boas fontes de informação, e podem fornecer informações mais detalhadas. O TURI (Toxics Use Reduction Institute) disponibiliza para acesso gratuito o manual 'Guidebook of Part Cleaning Alternatives' (THOMAS, LAPLANTE e ALAN, 1997). Este manual traz informações bastante detalhadas a respeito de diversas alternativas para os processos de limpeza de superfícies e pode ser obtido no site www.turi.org.

Todos os manuais da US EPA consultados também disponibilizam um grande volume de informações, e podem ser obtidos no endereço www.epa.gov/p2. 


\section{CAPÍTULO VI}

\section{IDENTIFICAÇÃO DE OPORTUNIDADES DE PREVENÇÃO À POLUIÇÃO}

\subsection{Considerações Iniciais}

Neste capítulo são apresentados e discutidos os resultados obtidos na avaliação preliminar de identificação de oportunidades de prevenção à poluição, que foi realizada em uma indústria de manufatura de eletrodomésticos da linha branca.

Foram avaliadas as áreas de metalurgia e pintura e as áreas de montagem dos produtos. Em cada área foram realizadas visitas para reconhecimento do processo e das operações envolvidas. Foram construídos mapas de processo para cada área. $O$ detalhamento do processo foi realizado através da construção de conjuntos de mapas de processo de todas as etapas de cada processo. Foram também realizadas visitas à Central de Resíduos, para obtenção de informações sobre o gerenciamento e a destinação final dos resíduos gerados nas áreas avaliadas.

As informações foram obtidas através da consulta às plantas e layouts das áreas e fluxogramas dos processos, inspeção e observação do fluxo do processo, consultas ao sistemas de controle de entrada e saída de materiais das áreas e através de informações verbais obtidas junto aos funcionários, geralmente o facilitador ou supervisor da área. Informações complementares foram obtidas através da consulta æ̀s Fichas de Segurança de Produtos (MSDS) disponíveis nos arquivos de cada área; dados de análises laboratoriais, licenças de destinação de resíduos e outros documentos disponíveis nos arquivos do Comitê Ambiental da Empresa. Foram realizados ainda alguns ensaios para caracterização de resíduos e efluentes.

Com base nas informações levantadas e disponibilizadas foram analisadas as oportunidades de prevenção àpoluição potenciais em cada uma das áreas. 


\section{2. Área de Metalurgia}

\subsubsection{Descrição do Processo}

$\mathrm{Na}$ área de metalurgia ocorre o processo de transformação metal-mecânico, onde tem início o processo de transformação das chapas metálicas em produtos acabados. A Figura 61 mostra o mapa de processo da área de metalurgia.

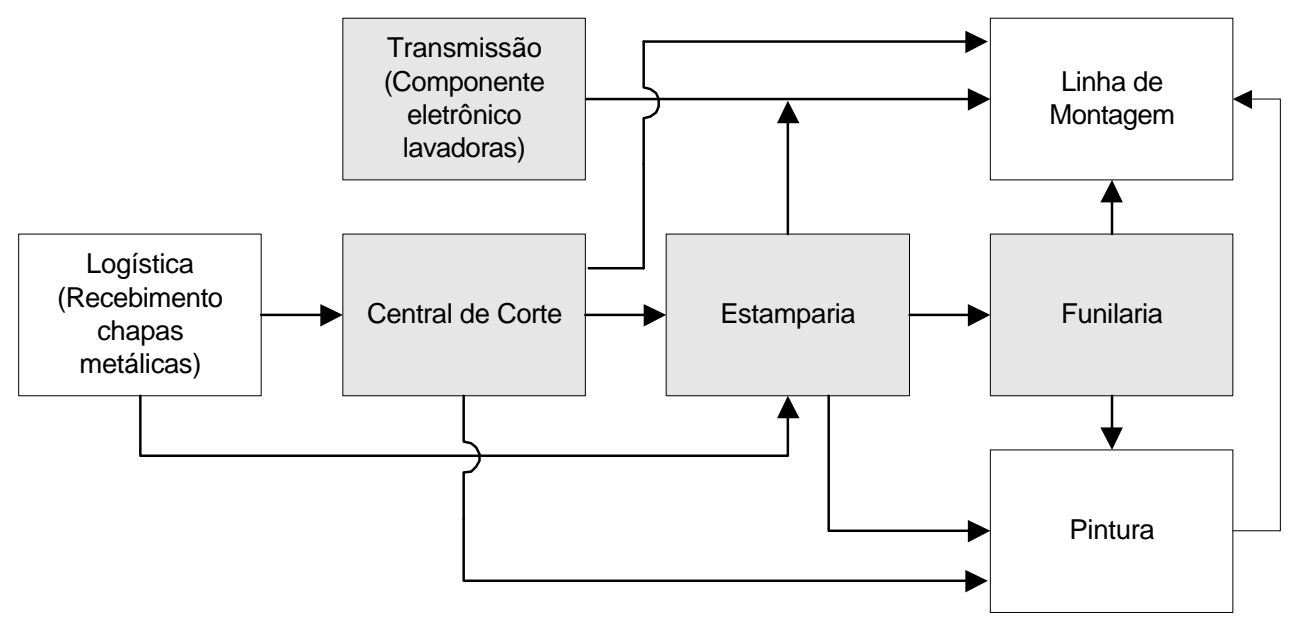

Figura 61 - Mapa de processo da área de metalurgia

A matéria-prima (chapas de aço zincado minimizado e de aço zincado galvanil) é recebida pelo setor de logística na forma de blankets e chapas, e segue para a central de corte, onde o material é cortado nos tamanhos pré-determinados pela estrutura dos produtos. Dependendo da função que irá desempenhar, as chapas cortadas podem seguir diretamente para a linha de montagem, ou para a estamparia ou ainda para a área de pintura.

$\mathrm{Na}$ estamparia, as chapas são moldadas e vazadas na geometria requerida para a função que a peça irá desempenhar através da aplicação de força mecânica. As diferentes geometrias são obtidas através da utilização de matrizes, que são encaixadas nas estampadoras. As chapas já chegam com um filme de óleo protetivo, que dispensa o uso de fluido de corte no processo.

A Figura 62 mostra uma foto da área de metalurgia, com detalhe para uma estampadora e um palet com as chapas a serem estampadas. A Figura 63 mostra as matrizes que são empregadas para obtenção das diferentes formas. A estamparia divide-se em estamparia leve (cargas variando entre 80 e 250 toneladas) e estamparia pesada (cargas variando de 250 e 400 toneladas). 


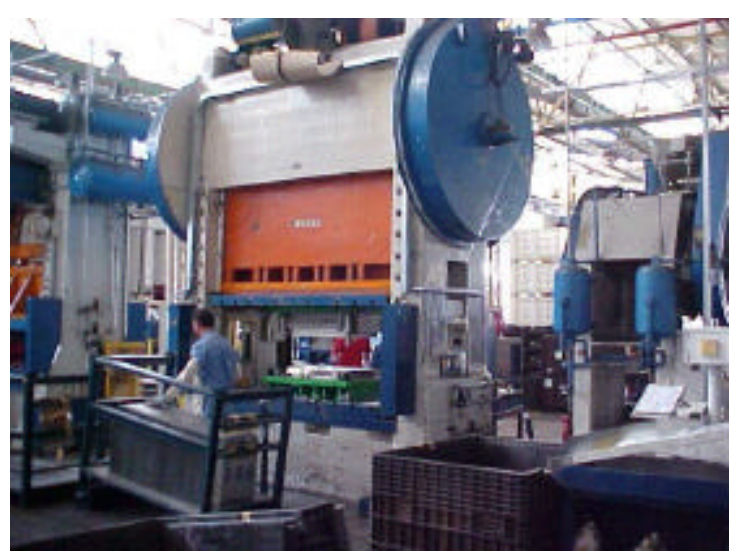

Figura 62 - Área de estamparia

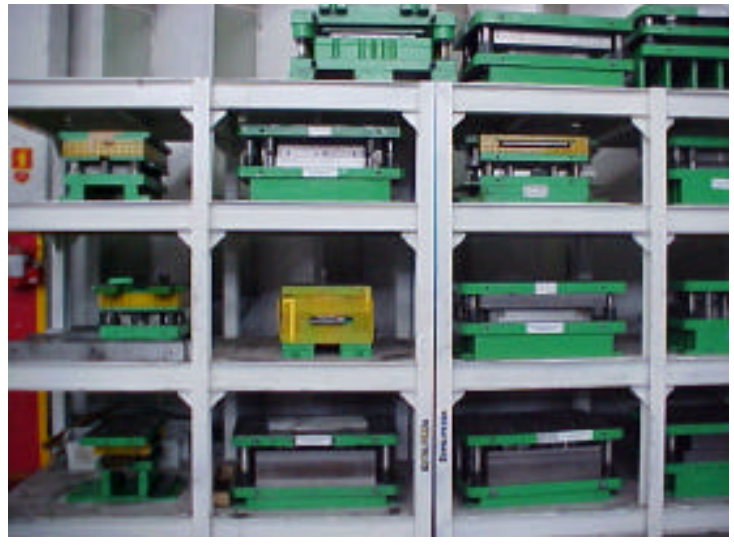

Figura 63 - Matrizes da estamparia

$\mathrm{Na}$ funilaria as peças são furadas e dobradas (perfilação) conforme a necessidade de cada peça. A área de metalurgia compreende ainda a linha de montagem da transmissão, onde são montados os componentes eletrônicos dos produtos.

\subsubsection{Características dos Resíduos Gerados}

A Figura 64 mostra o mapa de processo construído para a área de metalurgia, onde são indicadas as principais entradas e saídas de materiais.

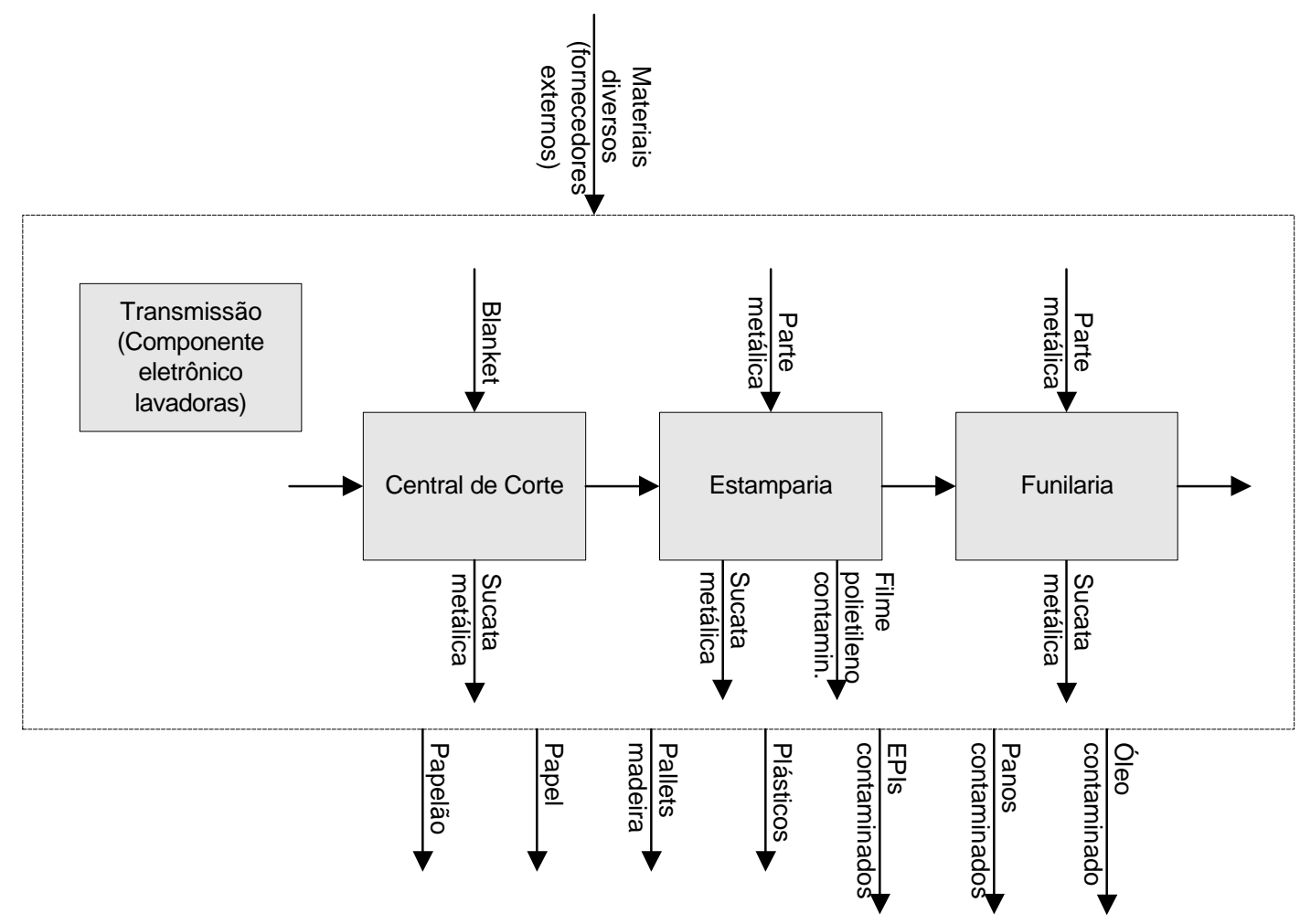

Figura 64- Mapa de processo da área de metalurgia. 
O resíduo gerado em maior quantidade é a sucata metálica, produzida em grande parte na estamparia. A Figura 65 mostra uma foto deste material, que é coletado em uma caçamba apropriada, na área interna, para então ser acondicionado em um container maior, que fica na área externa, (Figura 66), de onde segue para uma empresa de reciclagem de metal.

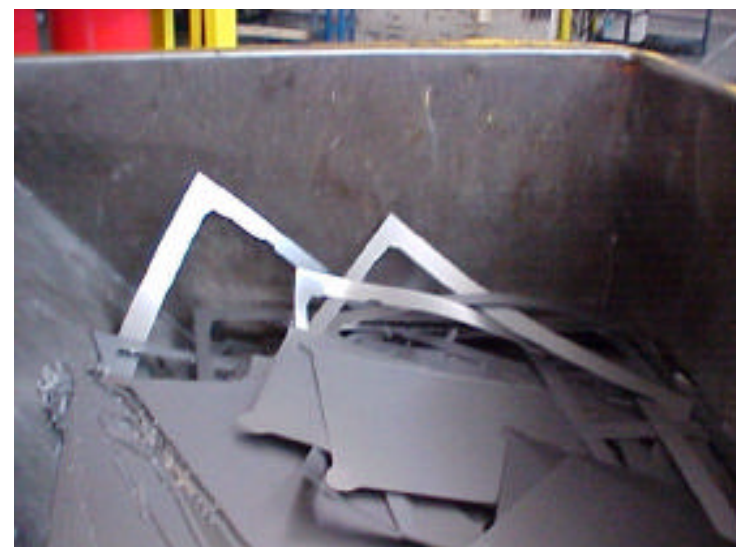

Figura 65 - Sucata metálica da estamparia

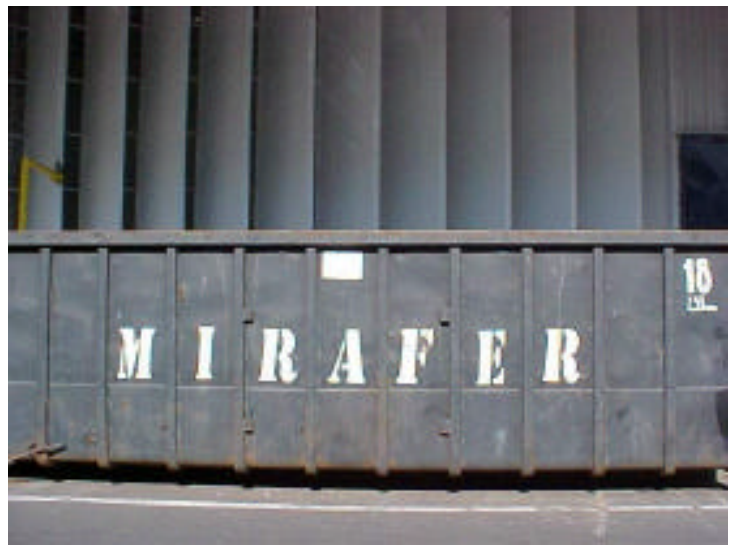

Figura 66 - Caçamba de sucata metálica

Outros resíduos consistem de materiais recicláveis (madeira, papel, papelão e plásticos) provenientes de embalagens de insumos utilizados na área. Estes materiais são coletados em caçambas específicas para cada tipo de material, e são encaminhados para a central de resíduos, onde são comercializados e encaminhados para empresas de reciclagem. A Figura 67 mostra a caçamba de sucata de plástico e a Figura 68 mostra os tambores da coleta seletiva, presentes em todas as áreas da planta, onde são coletados copos plásticos, papéis, plásticos e metais, em menor volume. Este material também segue para a central de resíduos, onde é agrupado e encaminhado para a reciclagem.

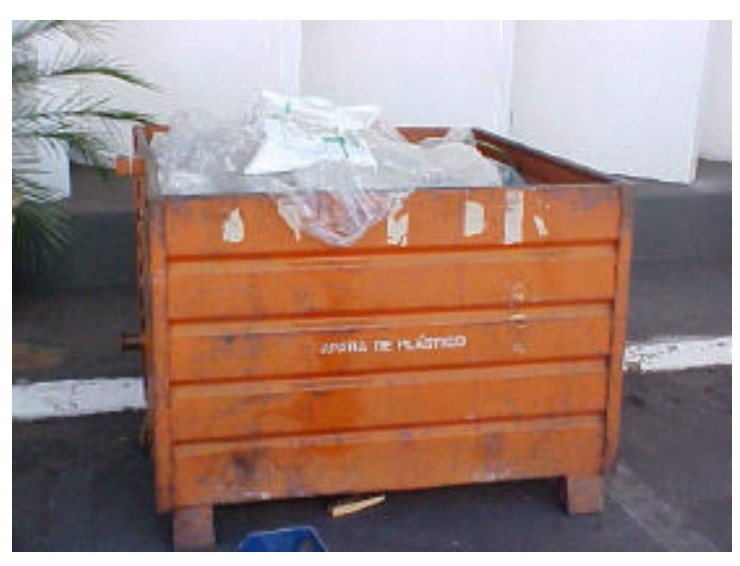

Figura 67 - Caçamba de sucata de plástico

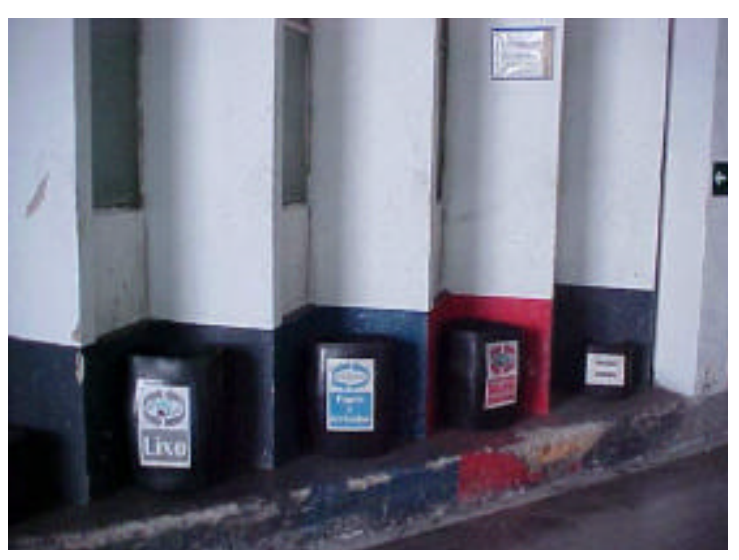

Figura 68 - Tambores da coleta seletiva 
Os resíduos especiais gerados incluem equipamentos de proteção individual (EPIs) usados, panos contaminados com óleo, filme de polietileno, tambores e óleo contaminado. A Tabela 8 mostra a classificação ${ }^{41}$ e destinação final que é dada para cada resíduo. Os resíduos Classe IIB são enviados para reciclagem e os demais para incineração e co-processamento.

Tabela 8 - Destinação final dos resíduos da área de metalurgia.

\begin{tabular}{lll}
\hline \multicolumn{1}{c}{ Resíduo } & Classe & Destinação Final \\
\hline Palets de madeira & IIB & Reciclagem \\
Embalagem plástica & IIB & Reciclagem \\
Madeira & IIB & Reciclagem \\
Papel & IIB & Reciclagem \\
Papelão & IIB & Reciclagem \\
Peças de alumínio & IIB & Reciclagem \\
Aço & IIB & Reciclagem \\
Aço inox & IIB & Reciclagem \\
Luvas PVC & IIB & Reciclagem \\
Panos contaminados c/ óleo & IIA & Incineração \\
Tambor contaminado c/ óleo & IIA & Incineração \\
EPIs contaminados & IIA & Incineração \\
Filme polietileno contaminado & IIA & Incineração \\
Lixas & IIA & Incineração \\
Óleo contaminado & IIA & Co-processamento \\
\hline
\end{tabular}

A Tabela 9 apresenta o inventário de sucata de aço gerada na metalurgia. Grande parte desta sucata é proveniente apenas da estamparia. No entanto, a central de corte e a funilaria também contribuem para a geração de sucata. Como este material é agrupado e enviado para a Central de Resíduos, não foi possível precisar qual a contribuição de cada uma das operações na geração deste tipo de material. Os dados da tabela foram plotados em um gráfico, que é mostrado na Figura 69.

\footnotetext{
${ }^{41}$ Não foram realizados ensaios de caracterização destes resíduos. Esta classificação segue os critérios adotados pela empresa, com base em caracterizações realizadas pela mesma em épocas anteriores a este trabalho.
} 
Tabela 9 - Inventário de sucata de aço da área de metalurgia.

\begin{tabular}{lcccc}
\hline \multicolumn{1}{c}{ Mês } & $\begin{array}{c}\text { Aço utilizado } \\
(\mathrm{kg} / \mathrm{mês})\end{array}$ & $\begin{array}{c}\text { Sucata planejada } \\
(\mathrm{kg} / \mathrm{mês})\end{array}$ & $\begin{array}{c}\text { Sucata processo } \\
(\mathrm{kg} / \mathrm{mês})\end{array}$ & $\begin{array}{c}\text { Total de sucata }^{2} \\
(\mathrm{~kg} / \mathrm{mês})\end{array}$ \\
\hline Janeiro & $551.136,2$ & 61.023 & 1.317 & 62.340 \\
Fevereiro & $837.210,7$ & 69.407 & 2.023 & 71.430 \\
Março & $562.529,0$ & 65.101 & 1.379 & 66.480 \\
Abril & $618.917,5$ & 60.303 & $1.886,83$ & 62.190 \\
Maio & $556.444,2$ & 66.212 & $1.167,53$ & 67.380 \\
Junho & $589.546,5$ & 61.408 & 1.032 & 62.440 \\
Julho & $704.302,5$ & 67.803 & 2.047 & 69.850 \\
Agosto & $675.635,9$ & 72.805 & 1.205 & 74.010 \\
Setembro & $821.563,13$ & 67.342 & 1.538 & 68.880 \\
Outubro & $982.209,4$ & 89.704 & $1.946,5$ & 91.650 \\
Novembro & $983.370,2$ & 72.773 & $2.516,92$ & 75.290 \\
Dezembro & $1.202 .396,7$ & 101.924 & $2.276,49$ & 104.200 \\
\hline
\end{tabular}

${ }^{1}$ Corresponde a sobra de aço prevista no projeto do produto.

${ }^{2}$ Corresponde a quantidade de aço perdida no processo, decorrente de peças refugadas.

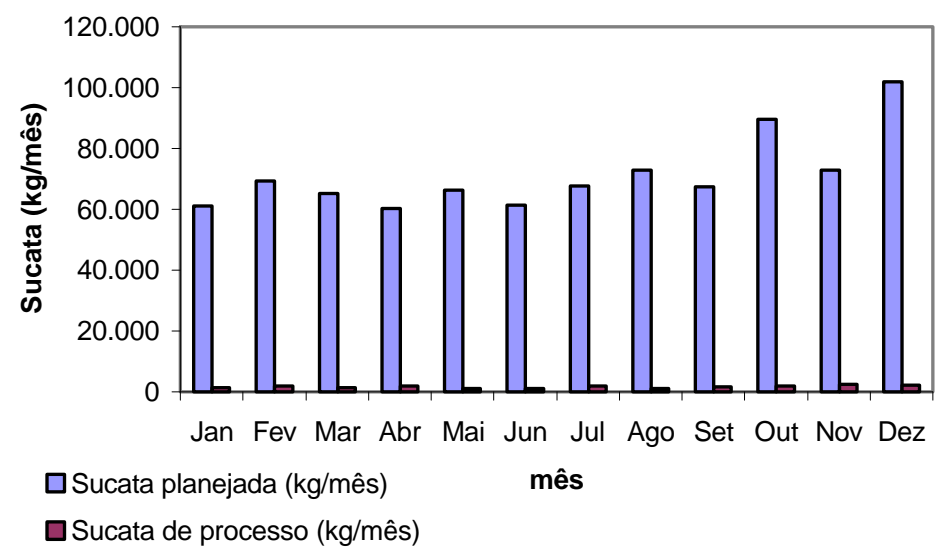

Figura 69 - Sucata planejada e de processo gerada na metalurgia

O inventário foi realizado com base em dados fornecidos pelo sistema de controle de qualidade da área (a sucata é o indicador de qualidade) e em dados fornecidos pelas planilhas de controle de movimentação de material da central de resíduos, referentes ao ano de 2003. 


\section{3. Área de Pintura}

\subsubsection{Descrição do Processo}

$\mathrm{Na}$ área de pintura as peças provenientes da metalurgia recebem tratamentos físicos e químicos, que tem como finalidade remover os contaminantes da superfície metálica, que em seguida é tratada quimicamente para receber a pintura. A Figura 70 mostra o mapa de processo construído para a área de pintura, onde pode ser visualizada a seqüência de etapas que compõem o processo.

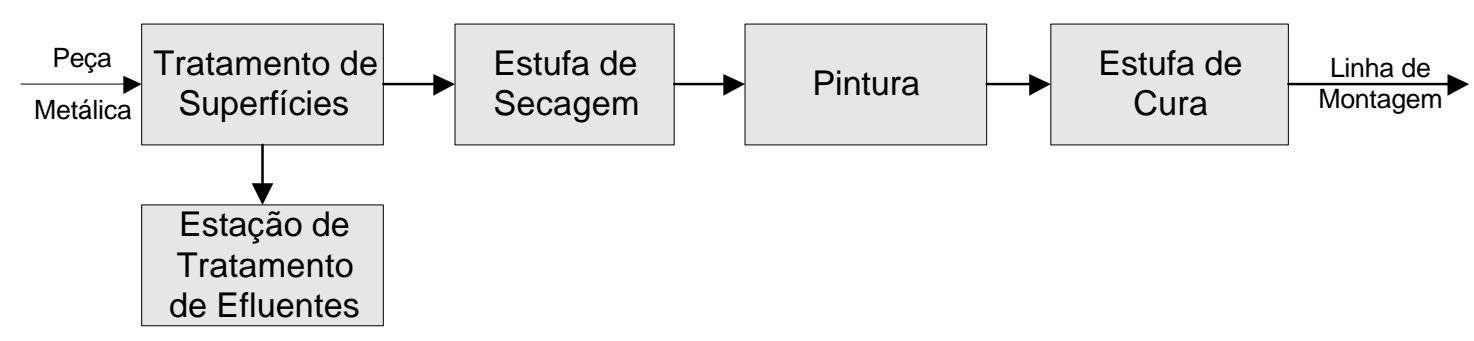

Figura 70 - Mapa de processo da área de pintura.

\subsubsection{Tratamento de Superfícies}

O tratamento de superfícies é formado pelas etapas de desengraxe, ativação, fosfatização e passivação, mostradas na Figura 71.

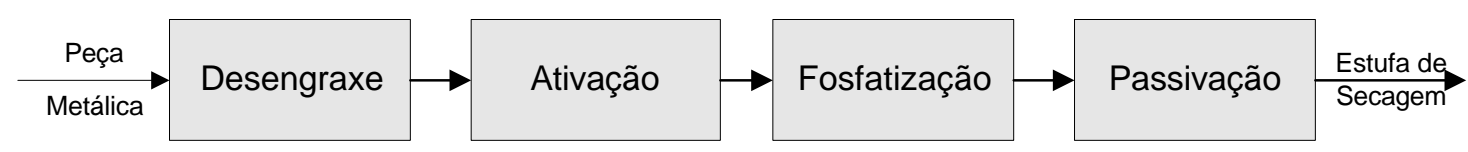

Figura 71 - Mapa de processo do tratamento de superfícies.

As peças que chegam das áreas de metalurgia e pré-montagem são colocadas em ganchos nos transportadores e passam por todas as etapas do tratamento de superfícies, que é formado por uma seqüência de tanques na forma de túnel. Os banhos são aplicados nas peças por meio de spray, e a água que escorre da peça retorna para o tanque, que fica posicionado na parte inferior do túnel.

A Figura 72 mostra um fluxograma detalhado de todas as etapas do processo, onde podem ser visualizados todos os fluxos de água que formam os banhos. 


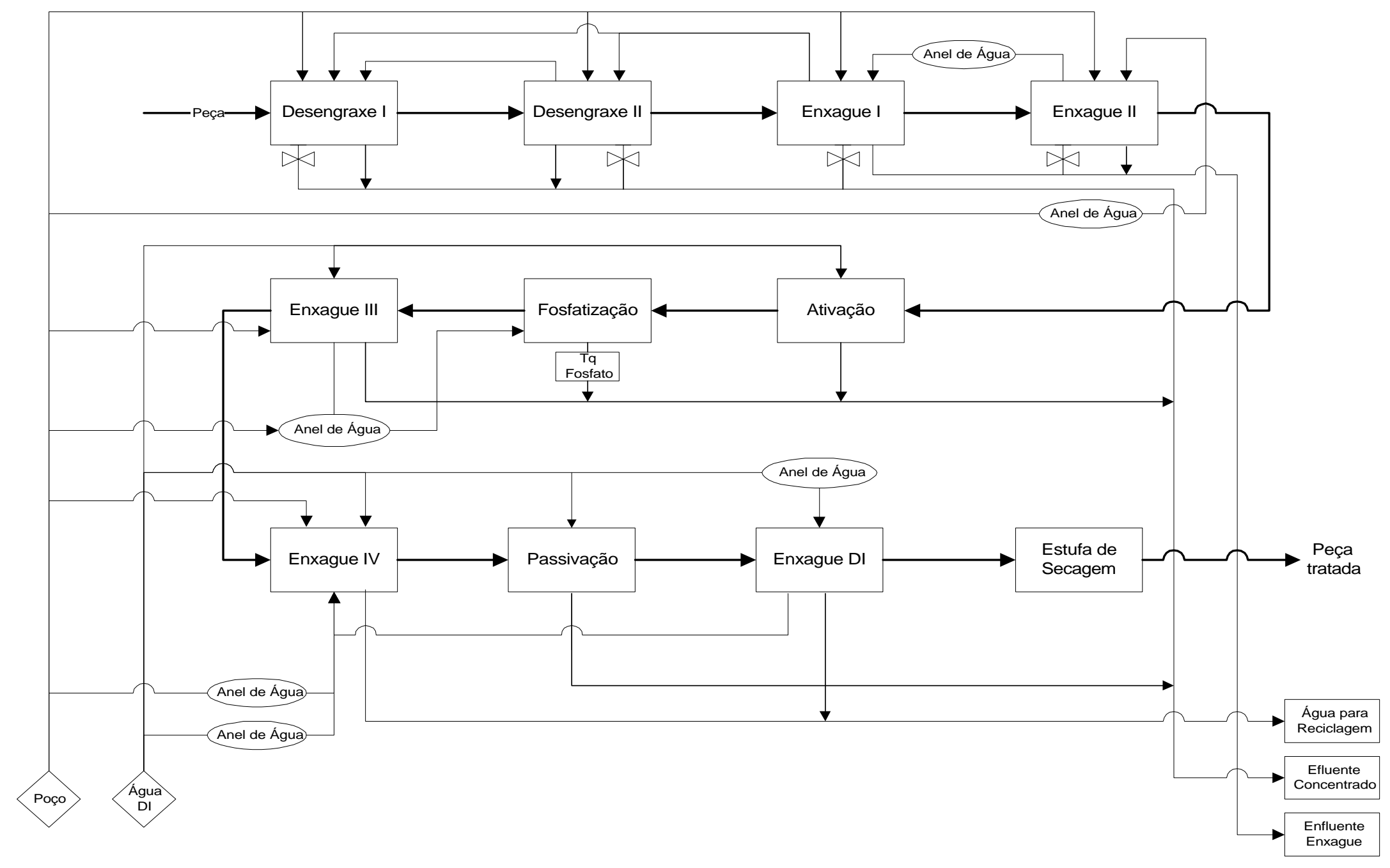

Figura 72 - Fluxograma do tratamento de superfícies. 


\subsection{Desengraxe}

O desengraxe tem por objetivo remover óleos e contaminações da superfície metálica, e é composto por quatro banhos: desengraxe I e II e enxague I e II, como mostra o mapa de processo da Figura 73.

\section{- Desengraxe I}

Esta etapa consiste de um banho alcalino a $65^{\circ} \mathrm{C}$. O agente de limpeza usado é um desengraxante alcalino a base de hidróxido de potássio e silicato de sódio. $O$ tanque com capacidade de $12 \mathrm{~m}^{3}$ recebe como carga $11 \mathrm{~m}^{3}$ do banho subseqüente (desengraxe II), o volume é completado pela adição de desengraxante fresco e água proveniente da lavagem I, até a concentração desejada. Durante a operação, o nível de água é mantido pela adição contínua de água do tanque de lavagem I e a concentração do desengraxante é mantida por meio de dosagem automática, e varia de 1 a $2 \%$ em peso. A cada duas horas são coletadas amostras e realizadas análises para o controle de qualidade do banho. O descarte do banho é feito, em condições normais, a cada 15 dias.

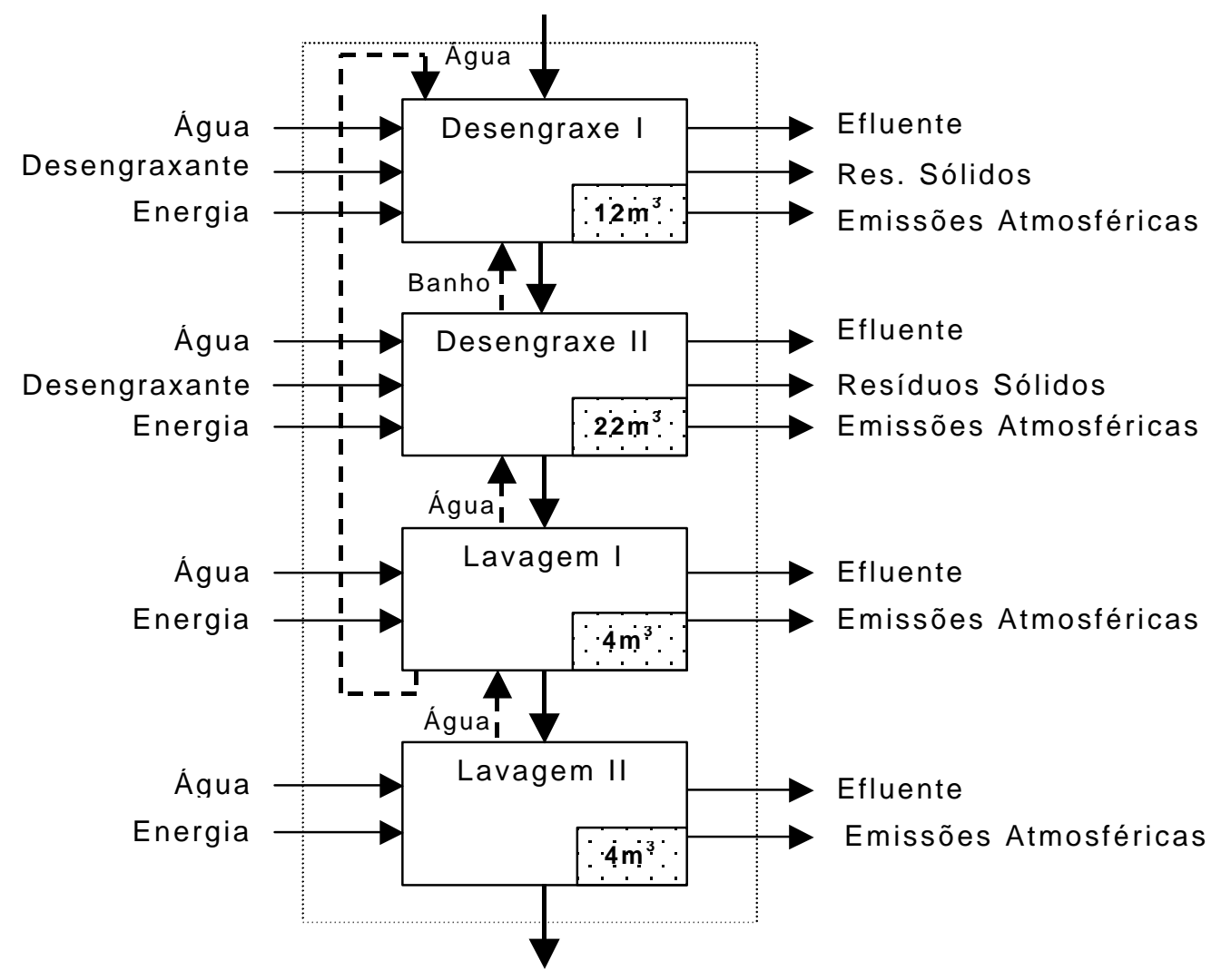

Figura 73 - Mapa de processo do desengraxe. 
Toda a carga do banho, constituída de óleos e outros componentes removidos das peças metálicas e de desengraxante alcalino é enviada ao tanque de efluente concentrado na estação de tratamento de efluentes. Após o tratamento este efluente é descartado na rede de esgoto. O desengraxante alcalino é recebido em bombonas de $250 \mathrm{~kg}$, que após o uso do produto são retornadas ao fabricante. As emissões atmosféricas são constituídas por vapores e névoas dos componentes dos banhos, que são captadas por um exaustor existente no túnel. Este exaustor capta as emissões provenientes de todas as etapas do desengraxe e aquelas provenientes da operação seguinte, de ativação.

\section{- Desengraxe II}

Nesta etapa as peças passam novamente por um banho alcalino a $65^{\circ} \mathrm{C}$, que consiste do mesmo produto usado no desengraxe I, porém com concentração do desengraxante de 0,5 a $1,5 \%$ em peso. O banho é preparado utilizando água fresca e desengraxante alcalino. Quando o banho utilizado no Desengraxe I é descartado, 11 $\mathrm{m}^{3}$ da carga do tanque de Desengraxe II é transferida para o tanque de Desengraxe I, e a concentração e o nível deste tanque são ajustados para atender as características do banho.

\section{- Enxague I}

No primeiro enxague o tanque é carregado com água fresca a temperatura ambiente e o nível é mantido pela adição contínua de água proveniente do tanque de enxague II. O tanque é drenado diariamente, a água segue para o tanque de efluente de enxague na estação de tratamento de efluentes, e após o tratamento é descartado no esgoto.

\section{- Enxague II}

Nesta etapa as peças são submetidas a um segundo enxague, com água a temperatura ambiente. O conteúdo do tanque é descarregado diariamente e enviado para a ETE, e o tanque é recarregado com água fresca. Durante a operação, é usada água deste tanque para a manutenção do nível do tanque de Lavagem I, e o nível é mantido pela adição contínua de água fresca. 


\subsection{Tratamento Químico}

Após a limpeza e desengraxe as peças seguem para o tratamento químico, e passam por um seqüência de sete etapas, mostradas na Figura 74.

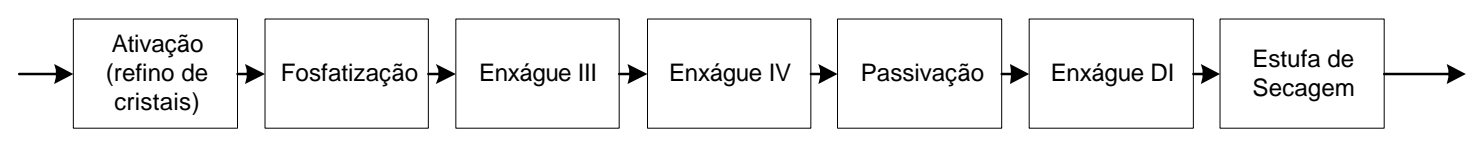

Figura 74 - Mapa de processo do tratamento químico

\section{- Ativação}

Esta etapa do processo que antecede a fosfatização, tem por finalidade criar pontos de nucleação na superfície metálica que induzam a formação de cristais pequenos e fortemente aderidos. O tamanho dos cristais é importante para um bom desempenho do processo de fosfatização e para a obtenção de uma camada de fosfato uniforme, densa e micro-cristalina, evitando falhas e imperfeições da camada de fosfato depositada, que podem comprometer a qualidade do processo de pintura. $O$ refinador utilizado é constituído de sais de titânio, e por ser um banho levemente alcalino funciona também como uma decapagem alcalina, que além de remover óxidos leves e oleosidades, condiciona a superfície, pois um $\mathrm{pH}$ residual alto promove a precipitação dos fosfatos, formando cristais pequenos.

O banho é preparado pela adição de 40 litros de fosfato de sódio dibásico (10-30\% em peso) no tanque cheio de água fresca a temperatura ambiente. Durante a operação é adicionado um reforço de refinador $(20 \mathrm{~kg}$ de produto diluído em $200 \mathrm{~L}$ de água) continuamente no tanque através de bomba dosadora. Este reforço é preparado em um reservatório externo ao tanque (tambor de 200L). O banho é descartado a cada dois dias, e todo seu conteúdo é enviado ao tanque de efluente concentrado da ETE.

\section{- Fosfatização}

$\mathrm{Na}$ fosfatização o banho inicial é montado pela adição de fosfato tricatiônico (a base de zinco, níquel e sódio), nitritos de manganês e níquel e aditivos a base de ácidos fluorsilícico e fluorbórico.

Durante a operação, são adicionados continuamente um acelerador a base de nitrito de sódio e fosfato tricatiônico de reposição. Durante a limpeza do tanque, todo o conteúdo do tanque é bombeado para um tanque de armazenamento próximo ao banho, e quando a limpeza do tanque é concluída a carga retorna ao tanque. No 
passado esta operação requeria uma etapa adicional, na qual o banho passava por um filtro àvácuo, onde eram gerados dois resíduos adicionais: borra de fosfato e filtro gasto. A substituição das chapas usadas como matéria-prima (de aço carbono) por chapas de aço zincado galvanílico e de aço zincado minimizado, eliminou a necessidade do filtro vácuo e a geração dos resíduos. O aço carbono apresenta problemas de oxidação, requer uma quantidade adicional de acelerador e gera grandes quantidades de borra.

Após a fosfatização as peças passam por uma seqüência de dois banho de enxague.

\section{- Passivação}

A passivação é uma etapa posterior àfosfatização, que tem por finalidade selar os poros deixados na camada de fosfato e melhorar a resistência àcorrosão. O processo é isento de cromo, a solução passivante usada é composta de ácido hexafluorzircônico. Após a passivação as peças passam por um banho de enxague com água deionizada (enxague DI) para eliminar completamente os sais insolúveis.

\section{- Estufa de Secagem}

Após sair do enxague DI as peças seguem para a estufa de secagem. A Figura 75 mostra a foto das peças saindo do túnel do tratamento e entrando na estufa de secagem. Os respingos são coletados na bacia de contenção mostrada no detalhe e enviados a um tanque de efluentes.

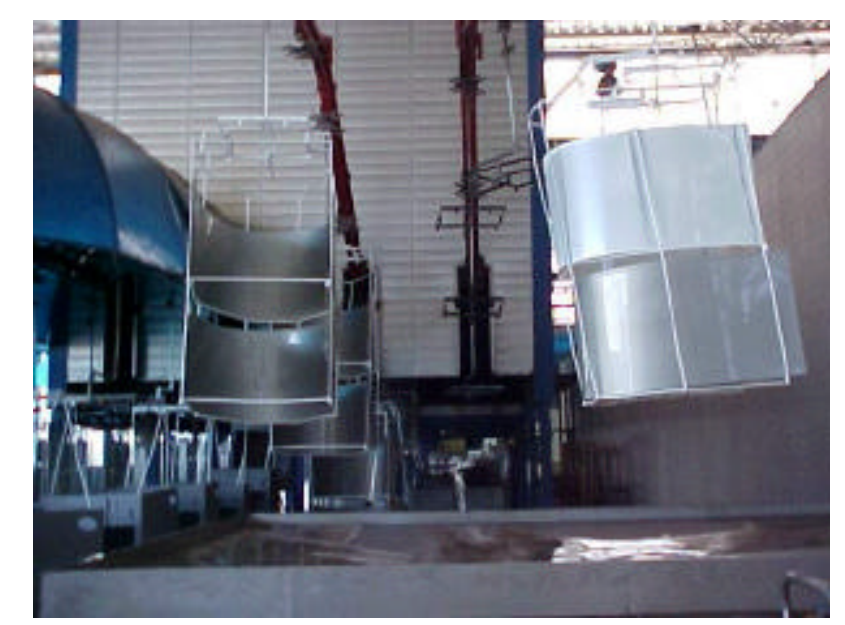

Figura 75 - Peças entrando na estufa de secagem. 


\subsubsection{Estação de Tratamento de Efluentes}

As águas residuárias produzidas em todos os banhos do tratamento de superfícies seguem para a estação de tratamento de efluentes, uma estação compacta, que fica alocada dentro da área interna da planta (Figura 76).

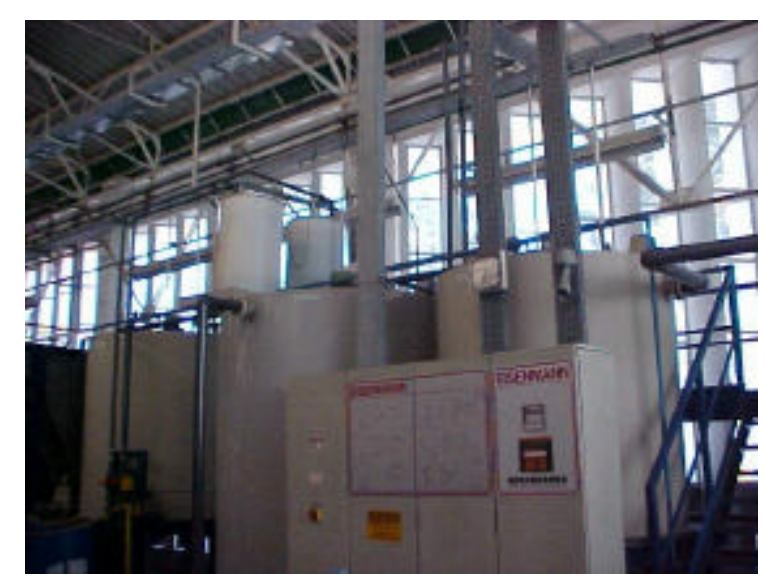

Figura 76 - Estação de tratamento de efluentes

Os descartes regulares dos banhos do desengraxe e do tratamento químico, bem como o efluente gerado na limpeza destes tanques são direcionados para três tanques de armazenamento distintos, de acordo com as características destes efluentes. $O$ tanque de armazenamento de efluente concentrado recebe o descarte dos tanques de desengraxe I e II, descarte dos banhos da ativação e da passivação, os efluentes da limpeza dos tanques de enxague I e III, da limpeza dos tanques de fosfatização, ativação e passivação. $O$ tanque de armazenamento de efluente de enxague recebe água do tanque de enxague I e II. O tanque de água para reciclagem recebe água do tanque de enxague IV e do enxague DI. A Figura 77 mostra um fluxograma da estação de tratamento de efluentes. 


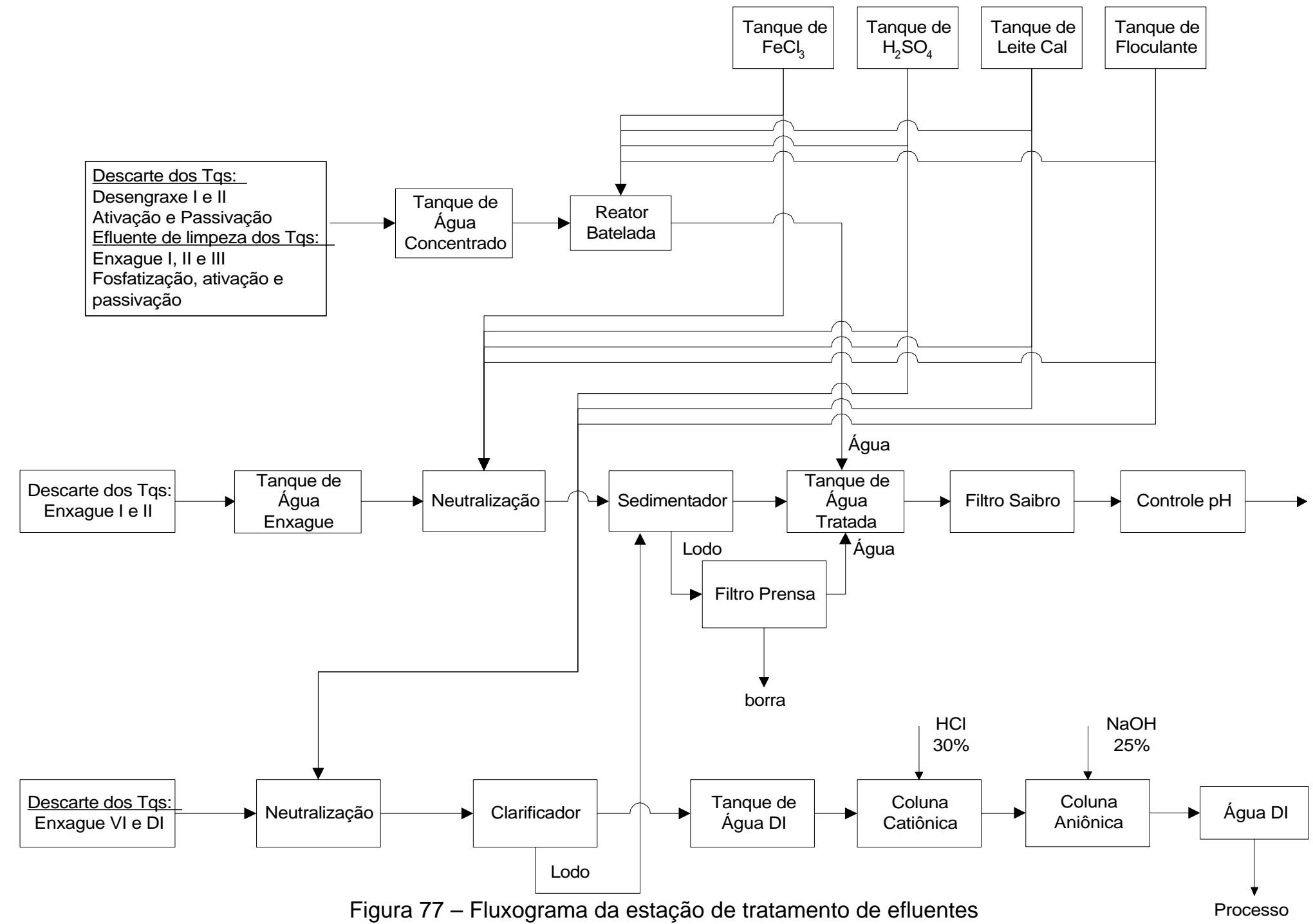


Após deixar o sedimentador e o clarificador, os efluentes provenientes do tanque de água concentrada e do tanque de água de enxague seguem para o tanque de água tratada, e o efluente proveniente do enxague IV e do enxague DI segue para o tanque de água $\mathrm{DI}$, e em seguida passa por colunas trocadoras de íons, e retorna para os tanques do processo. O lodo do fundo do sedimentador e do clarificador passa por um filtro prensa para remoção de água. A Figura 78 mostra o filtro prensa e a Figura 79 mostra a torta que é gerada após a remoção da água do lodo.

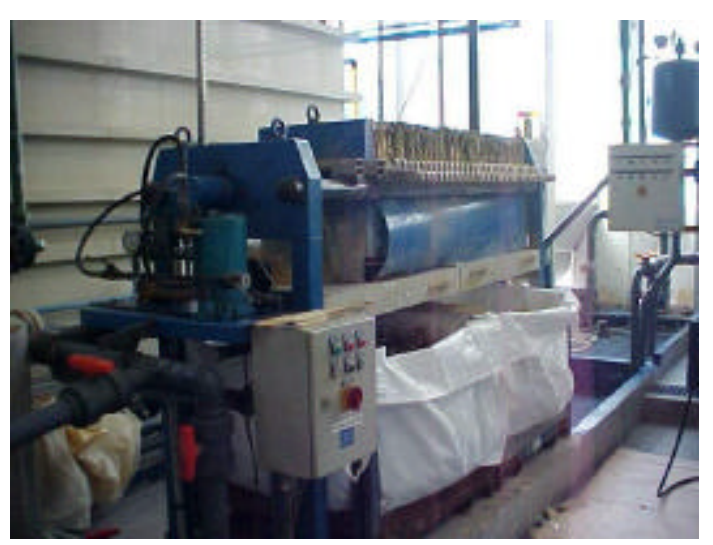

Figura 78 - Filtro-prensa

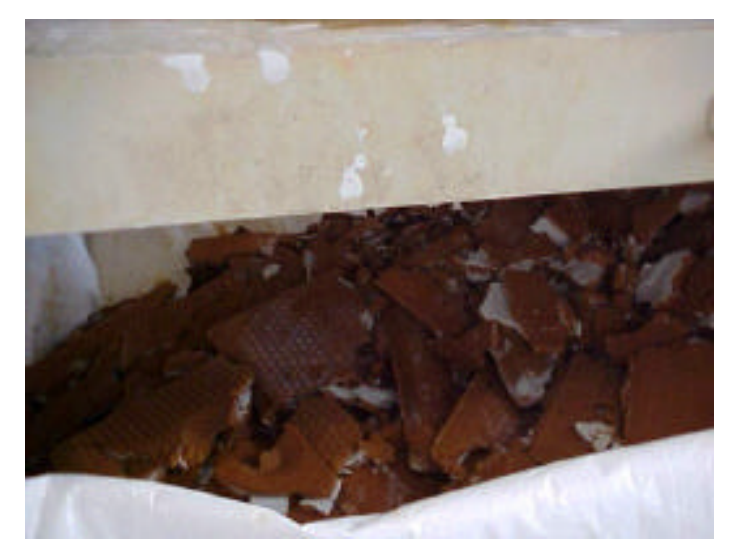

Figura 79 - Torta gerada na ETE

\subsubsection{Pintura}

Na pintura é empregado o processo de pintura eletrostática a pó. A tinta é recebida em big bags e é alimentada no sistema. As peças entram na cabine de pintura, por meio de transportador e recebem o jato de tinta em spray, que é controlado por um sistema automatizado, de acordo com a geometria da peça que está sendo pintada. Dentro do túnel de pintura existem aspiradores que coletam o pó que fica em suspensão e que cai no chão. Este pó é re-alimentado no sistema. A porção do pó, que apresenta partículas de diâmetro muito pequeno (finos) é enviada ao fabricante e recuperada. As Figuras 80 e 81 mostram os gabinetes dos produtos entrando no túnel de pintura e saindo após receber a camada de tinta a pó. As Figuras 82 e 83 mostram detalhes dos sprays dentro do túnel de pintura. 


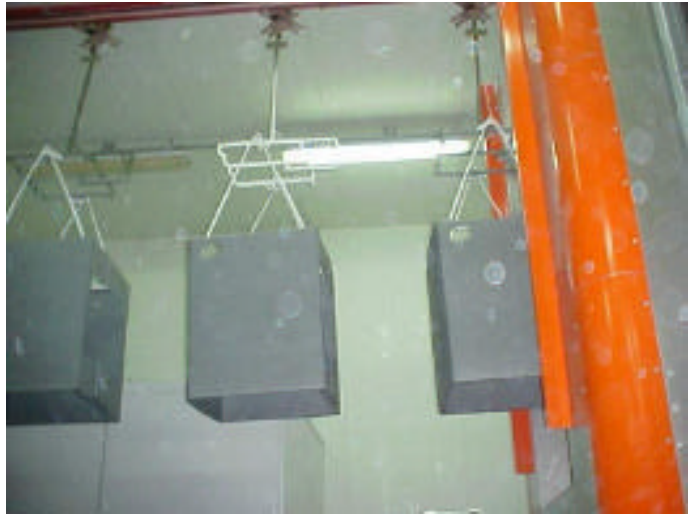

Figura 80- Gabinetes entrando na pintura

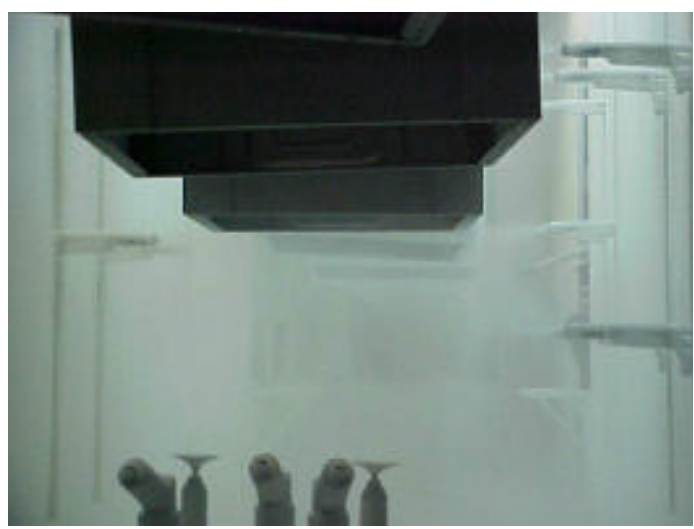

Figura 82 - Processo de pintura a pó

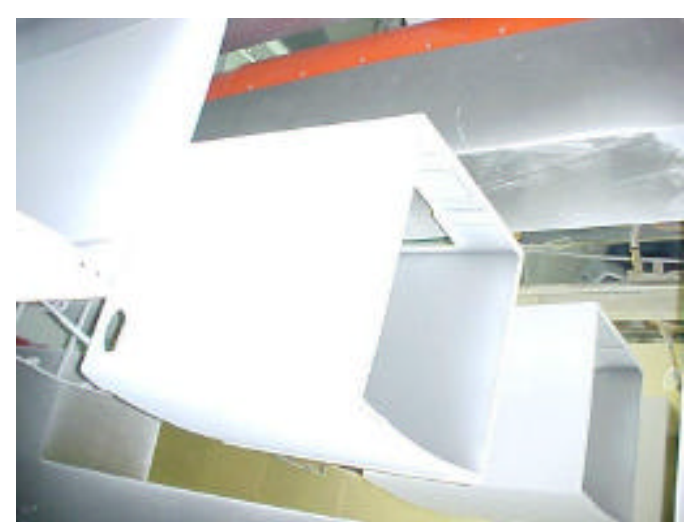

Figura 81- Gabinetes pintados

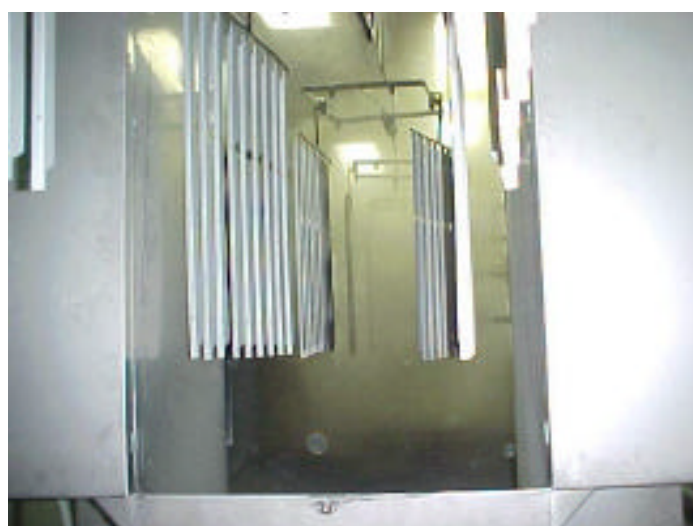

Figura 83 - Peças na cabine de pintura

Imediatamente após a saída do túnel de pintura, as peças seguem para a estufa de cura, onde ocorre uma reação de polimerização por meio do aquecimento, que adere a tinta a superfície, deixando-a com as características de recobrimento e brilho desejadas.

\subsubsection{Características dos Resíduos Gerados}

$\mathrm{Na}$ área de pintura são geradas emissões atmosféricas provenientes dos vapores exalados nos banhos e nas estufas de secagem e pintura; efluentes líquidos do desengraxe e do tratamento químico e resíduos sólidos, que consistem basicamente de embalagens dos insumos usados nos banhos e na estação de tratamento de efluentes, e da borra produzida no filtro-prensa da ETE.

Com base nos dados obtidos no sistema de controle de produção da área, foram construídos gráficos para analisar a variação mensal do consumo de insumos em cada etapa do tratamento de superfícies e na estação de tratamento de efluentes, 
mostrados nas Figuras 84, 85, 86, 87 e 88. Os dados utilizados referem-se ao ano de 2003, e foram normalizados para $\mathrm{kg}$ de insumo consumido por $\mathrm{m}^{2}$ de área tratada.

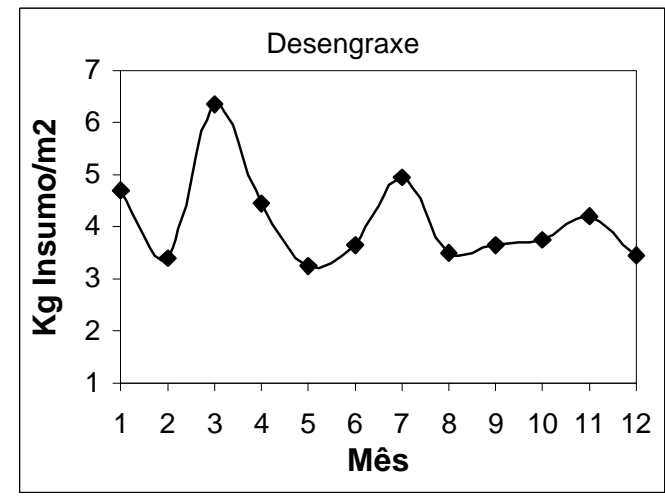

Figura 84- Variação consumo desengraxante

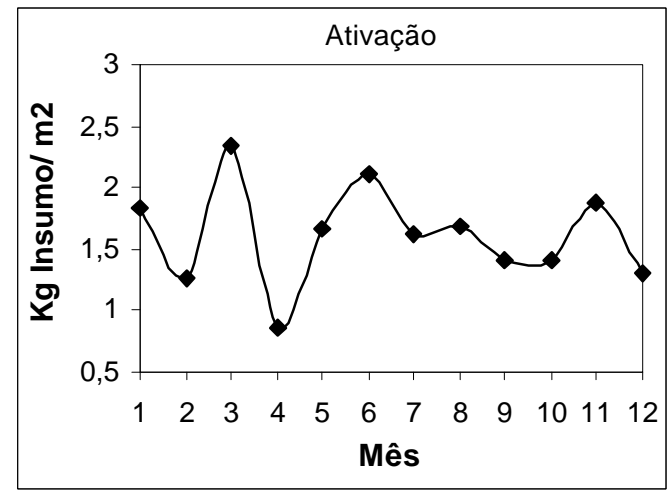

Figura 85- Variação consumo refinador

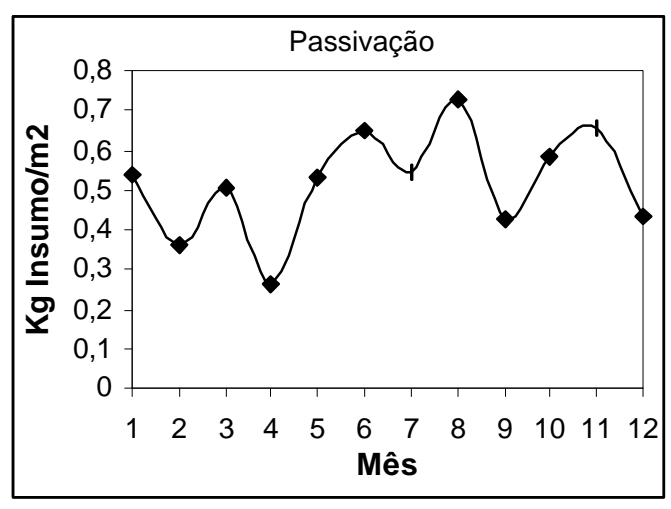

Figura 86- Variação consumo passivador inorgânico

Os resultados não sugerem uma grande variação do consumo de insumos, o que é um indicador de que o processo é bem controlado, e que não existe desperdício de insumos nos banhos. As pequenas variações existentes são decorrentes de peças que precisam ser retrabalhadas.

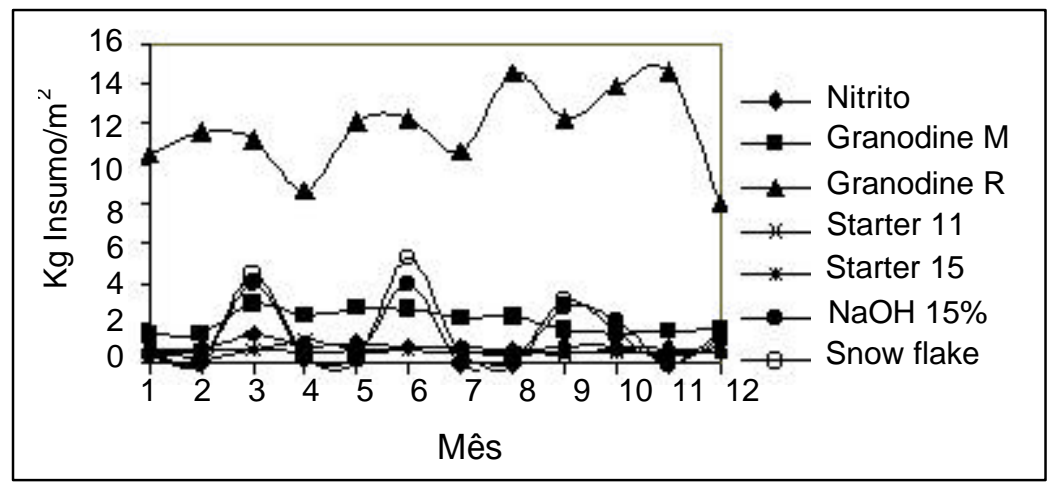

Figura 87- Variação consumo de insumos da fosfatização. 


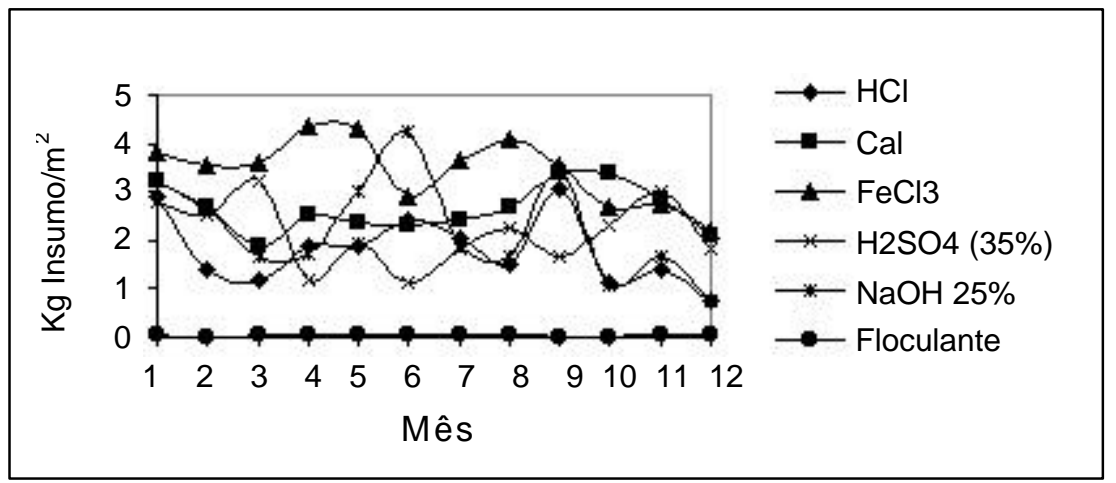

Figura 88- Variação consumo de insumos da ETE

Esta avaliação detalhada do consumo de insumos em cada etapa do processo permitiu uma constatação interessante e importante. Segundo o laudo que consta no CADRI emitido pela CETESB em agosto de 2003, a torta gerada na ETE é classificada como Resíduo Classe I - Perigoso (código K062 do anexo B da NBR 10.004 de 1986), devido a presença de cromo hexavalente e chumbo.

Entretanto, quando foi realizado o mapeamento do processo, foram consultadas as fichas de segurança de todos os produtos que entram na composição dos banhos, e não havia nenhum produto a base de cromo sendo usado. Diante deste fato, duas providências foram tomadas, com o objetivo de rastrear a possível presença de cromo no processo. Foram coletadas amostras dos tanques de desengraxe I, de ativação e de passivação, e submetidas a análise. Foi coleta ainda uma amostra da torta da ETE, que foi submetida a ensaios de lixiviação e de solubilização, de acordo com as respectivas normas NBR 10.005 e NBR 10.006. As análises foram realizadas no laboratório do Departamento de Saneamento da EESC/USP. O banho de fosfato e o efluente antes e depois da ETE são analisados mensalmente pela empresa para controle do processo. Os resultados das análises foram fornecidos pela empresa para ajudar na avaliação.

A Tabela 10 mostra o resultado das análises dos banhos de desengraxe, ativação e passivação, realizadas de acordo com a 20aำ edição do Standard Methods for the Examination of Water and Wastewater e uma média das análises realizadas no banho de fosfato, também de acordo com a mesma edição do Standard Methods for the Examination of Water and Wastewater. 
Tabela 10 - Caracterização dos banhos do tratamento de superfícies.

\begin{tabular}{lcccc}
\hline \multicolumn{1}{c}{ Parâmetros } & Desengraxe & Ativação & Passivação & Fosfatização \\
\hline Zinco & 3,75 & 3,44 & 3,50 & 1293 \\
Chumbo & 19,80 & $<0,02$ & 0,77 & n.a \\
Cádmio & 0,03 & $<0,0006$ & $<0,0006$ & n.a \\
Níquel & 0,36 & 0,75 & 8,05 & 788 \\
Ferro total & 5,20 & 0,37 & 0,55 & n.a \\
Manganês total & 0,81 & 1,27 & 2,60 & 590 \\
Cromo total & 0,08 & $<0,005$ & $<0,005$ & n.a \\
Cromo hexavalente & $<0,001$ & $<0,001$ & $<0,001$ & n.a \\
Fluoretos & 3,0 & 14,5 & 20,0 & 1658 \\
Óleos e graxas & 1530 & 29 & 36 & n.a \\
\hline
\end{tabular}

Analisando estes resultados, percebe-se uma quantidade de cromo total, que é mais elevada no banho desengraxante. Estão presentes ainda neste banho chumbo, cádmio e ferro, além dos metais que entram na composição do banho fosfatizante.

A Tabela 11 mostra os resultados obtidos nos ensaios de solubilização e de lixiviação da torta e os valores máximos de concentração para os ensaios de lixiviação e de solubilização, que constam respectivamente nos Anexos F e G, da NBR 10.004, segunda edição revisada de 2004.

A análise dos resultados mostra que na realidade a torta é classificada como Resíduo Classe II B -Não Inerte, devido a presença de manganês, sódio, fluoretos e fenóis. A empresa também solicitou uma nova análise da borra em um laboratório externo, e o resultado foi o mesmo. Segundo os responsáveis pela área de meio ambiente, o que aconteceu foi que, após o cromo ter sido banido do processo há alguns anos atrás, não foi realizada nova caracterização, já que o resíduo era Classe I e estava sendo adequadamente disposto. 
Tabela 11 - Resultados dos ensaios de solubilização e lixiviação da torta.

\begin{tabular}{|c|c|c|c|c|}
\hline \multirow[t]{2}{*}{ Parâmetros } & \multirow[t]{2}{*}{ Solubilização } & \multirow[t]{2}{*}{ Lixiviação } & \multicolumn{2}{|c|}{ NBR 10.004} \\
\hline & & & $\begin{array}{c}\text { Anexo F } \\
\text { (lixiviação) }\end{array}$ & $\begin{array}{c}\text { Anexo G } \\
\text { (solubilização) }\end{array}$ \\
\hline Zinco (mg Zn/L) & 0,21 & - & - & 5,0 \\
\hline Chumbo (mg Pb/L) & $<0,01$ & $<0,02$ & 1,0 & 0,01 \\
\hline Cádmio (mg Cd/L) & $<0,0006$ & $<0,0006$ & 0,5 & 0,005 \\
\hline Ferro total $(\mathrm{mg} \mathrm{Fe} / \mathrm{L})$ & 0,07 & - & - & 0,3 \\
\hline Manganês (mg Mn/L) & 0,12 & - & - & 0,1 \\
\hline Cobre total (mg Cu/L) & 0,55 & - & - & 2,0 \\
\hline Cromo total (mg Cr/L) & 0,03 & $<0,005$ & 5,0 & 0,05 \\
\hline Prata (mg Ag/L) & 0,02 & 0,01 & 5,0 & 0,05 \\
\hline Alumínio (mg Al/L) & $<0,01$ & - & - & 0,2 \\
\hline Sódio (mg Na/L) & 275 & - & - & 200 \\
\hline Fluoretos (mg F'/L) & 7,0 & 5,50 & 150 & 1,5 \\
\hline Nitratos (mg N/L) & 6,32 & - & - & 10,0 \\
\hline Cloretos (mg Cl$/ / L)$ & 160,0 & - & - & 250 \\
\hline Dureza $\left(\mathrm{mg} \mathrm{CaCO}_{3} / \mathrm{L}\right)$ & 258,0 & - & - & \\
\hline Sulfatos ( $\left.\mathrm{mg} \mathrm{SO}_{4}{ }^{2-} / \mathrm{L}\right)$ & 55 & - & - & 250 \\
\hline Cianetos (mg CN/L) & $<0,001$ & - & - & 0,07 \\
\hline Fenóis ( $\mathrm{mg} \mathrm{C}_{6} \mathrm{H}_{5} \mathrm{OH}$ ) & 0,105 & - & - & 0,01 \\
\hline
\end{tabular}

O cromo, chumbo, cádmio e ferro presentes nos banhos e que, como mostram os resultados na Tabela 10, estão presentes em concentração mais elevada no tanque de desengraxe. Provavelmente estes compostos entram no processo através do filme de óleo protetivo aderido àsuperfície metálica das chapas.

Existem três pontos de geração de emissões atmosféricas que captam as emissões produzidas no tratamento de superfícies, na estufa de secagem e na estufa de polimerização da pintura. A análise das emissões destas chaminés é realizada esporadicamente para controle pela empresa. São analisados óxidos de nitrogênio e particulados, e estes parâmetros estão sempre dentro dos padrões permitidos. 


\subsubsection{Gerenciamento dos Resíduos}

Os resíduos sólidos gerados na área de pintura compreendem as embalagens vazias dos produtos usados nos banhos e na estação de tratamento de efluentes e a borra da ETE. A Tabela 12 mostra a destinação final destes resíduos.

Tabela 12 - Destinação final dos resíduos da área de pintura.

\begin{tabular}{lll}
\hline \multicolumn{1}{c}{ Etapa } & \multicolumn{1}{c}{ Resíduo } & \multicolumn{1}{c}{ Destino Final } \\
\hline Desengraxe & Bombonas plásticas $250 \mathrm{~kg}$ & Retornadas ao fabricante \\
\hline Ativação & Bombonas plásticas de $25 \mathrm{~kg}$ & Reciclagem externa \\
\hline Fosfatização & Bombonas plásticas $250 \mathrm{~kg}$ & Retornadas ao fabricante \\
& Bombonas plásticas de $70 \mathrm{~kg}$ & Reciclagem externa \\
& Bombonas plásticas de $50 \mathrm{~kg}$ & Reciclagem externa \\
& Bombonas plásticas de $30 \mathrm{~kg}$ & Reciclagem externa \\
& Sacos plásticos de $25 \mathrm{~kg}$ & Reciclagem externa \\
\hline Passivação & Bombonas plásticas de $20 \mathrm{~kg}$ & Reciclagem externa \\
& Sacos de papel de $15 \mathrm{~kg}$ & Reciclagem externa \\
& Bombonas plásticas de $60 \mathrm{~kg}$ & Reciclagem externa \\
& Bombonas plásticas de $250 \mathrm{~kg}$ & Reciclagem externa \\
& Torta & Co-processamento \\
\hline
\end{tabular}

As bombonas plásticas vazias são segregadas e lavadas na fonte, e então encaminhadas a uma central de resíduos, de onde seguem para reciclagem em empresas externas especializadas. Apenas as bombonas de $250 \mathrm{~kg}$ dos produtos usados no desengraxe e na fosfatização são retornadas ao fabricante.

Estas embalagens correspondem a um total de 3,7 toneladas de resíduos plásticos gerados por ano, de acordo com valores estimados considerando o peso da embalagem vazia e a quantidade média mensal de produto utilizada em cada etapa. Descontando o peso que corresponde às embalagens retornadas ao fabricante, são geradas aproximadamente 2,2 toneladas de embalagens por ano, que são encaminhadas para reciclagem. A geração média anual de borra na ETE é de 120 toneladas. A torta é armazenada em caçambas e enviada para incineração em empresa especializada. 


\section{4. Área de Montagem do Produto 1}

\subsubsection{Descrição do Processo}

A área de montagem do produto 1 compreende uma linha de produção na qual são produzidos dois diferentes modelos do mesmo produto. A linha de produção divide-se em três subáreas distintas: a) montagem da caixa interna, b) montagem da caixa externa e, c) linha de montagem.

\section{- Montagem da Caixa Interna}

A célula de montagem da caixa interna recebe as chapas abertas provenientes da pintura. Nesta célula são executadas as operações mostradas na Figura 89.

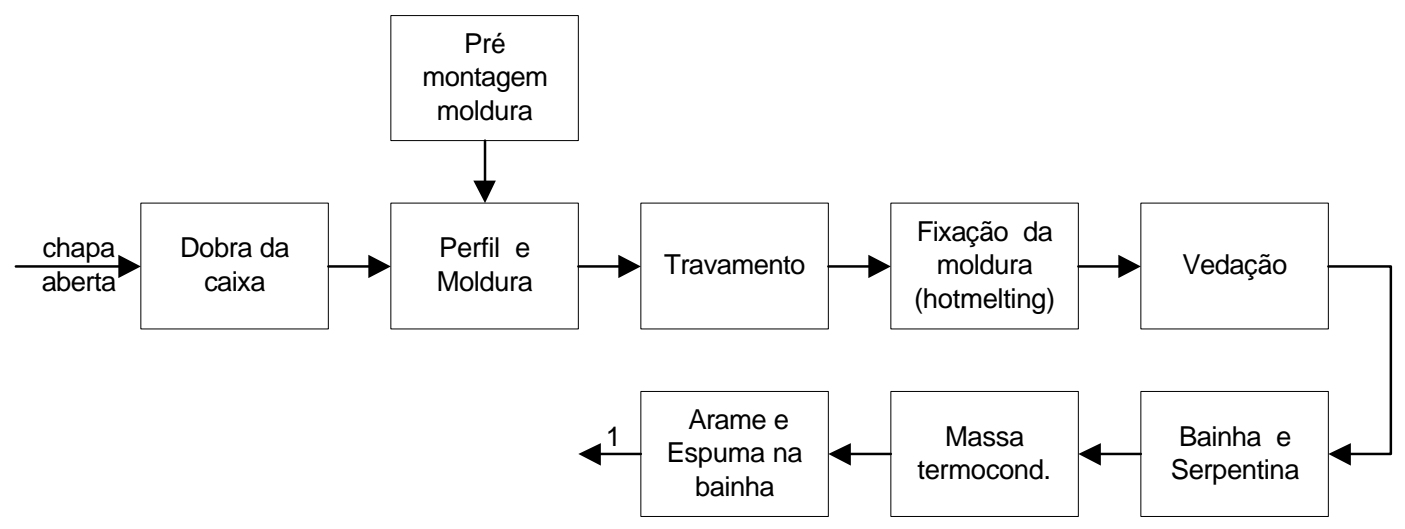

Figura 89 - Mapa de processo da montagem da caixa interna do produto 1.

As chapas metálicas abertas são dobradas na forma de caixa retangular, na qual são encaixados um perfil metálico e uma moldura plástica. Estas peças são fixadas à caixa metálica com fita adesiva, que posteriormente é removida e descartada. $\mathrm{Na}$ etapa seguinte, é realizado o travamento da caixa, no qual se insere o fundo da caixa metálica e a caixa interna de plástico, é utilizado silicone para fixação. Em seguida é feita a fixação da moldura com cola a quente (hotmelting) e a vedação dos cantos da moldura com massa de calafetar. Essa fixação é feita para evitar que ocorra vazamento durante a injeção de poliuretano (isolante térmico). Na próxima operação são inseridas a bainha e a serpentina. Estas peças são fixadas com fita adesiva, que segue junto com o produto final. A serpentina recebe uma camada de massa termocondutora e em seguida é recoberta com uma película plástica também termocondutora. Este recobrimento tem como objetivo manter constante a temperatura do produto. A última operação desta célula consiste em inserir um arame dentro da bainha (para evitar que esta se entorte nas etapas seguintes) e na colocação de uma espuma externa àbainha. 


\section{- Montagem da Caixa Externa}

A célula de montagem da caixa externa recebe a caixa metálica já montada da pintura. As operações realizadas nesta célula são mostradas na Figura 90.

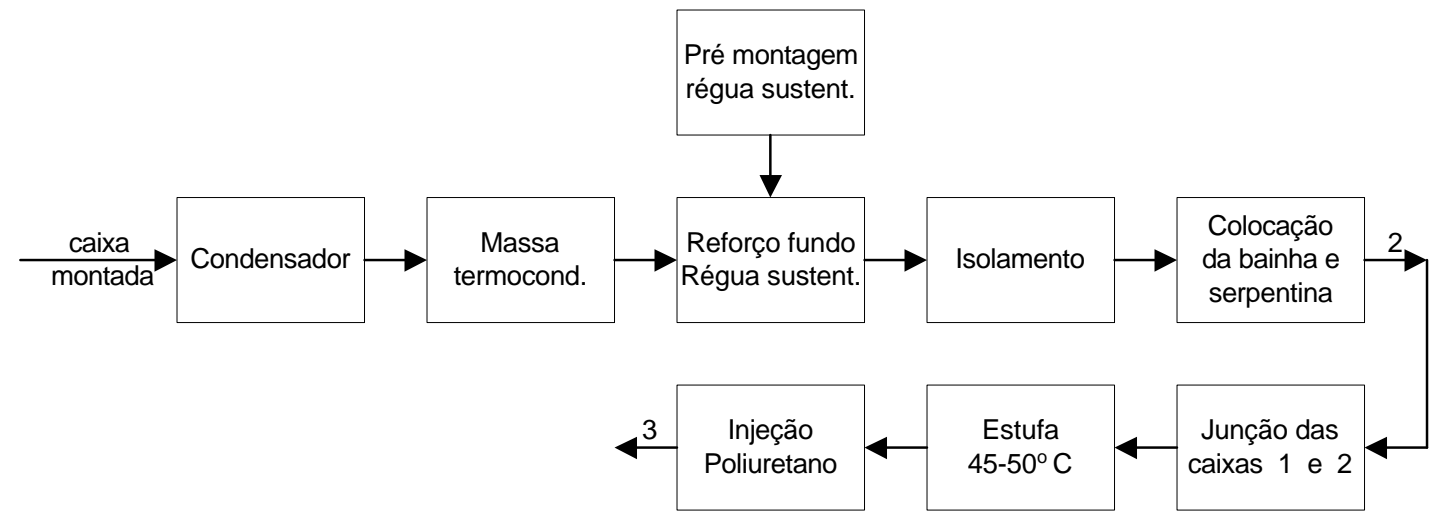

Figura 90 - Mapa de processo da montagem da caixa externa do produto 1.

O condensador é inserido à caixa e em seguida é revestido com uma película de massa termocondutora e sobre a qual é colocado um plástico termocondutor. Este revestimento tem como objetivo manter a temperatura do produto constante. Na etapa seguinte é colocado o reforço do fundo e a régua de sustentação, e em seguida é feito o isolamento. No fundo da caixa é colocada uma placa de papelão e os cantos são isolados com massa de calafetar (para evitar vazamentos durante a injeção do poliuretano). Em seguida é feita a junção da caixa interna (1) e da caixa externa (2), e é aplicada uma cola fria no reforço do fundo. O conjunto formado pelas caixas interna e externa segue para uma estufa com temperatura entre 40 e $50 \stackrel{\circ}{ } \mathrm{C}$. Esta operação tem por objetivo aquecer o conjunto para que na etapa seguinte ocorra uma boa fixação do poliuretano nas paredes internas.

\section{- Linha de Montagem}

Nesta linha são inseridas as peças e acessórios que compõem o produto final e são realizados testes de qualidade. A linha é dividida em quatro células.

\section{Célula 1}

O conjunto que vem da subárea de montagem da caixa externa (3) entra na célula na posição invertida (cabeça para baixo). A Figura 91 mostra as operações realizadas na célula 1. Inicialmente é colocado o termostato, a mangueira de drenagem e o compressor no conjunto. Em seguida é posicionado o filtro e aplicada solda na linha de sucção. Na etapa seguinte é feita a furação para a colocação da grade interna do produto. 


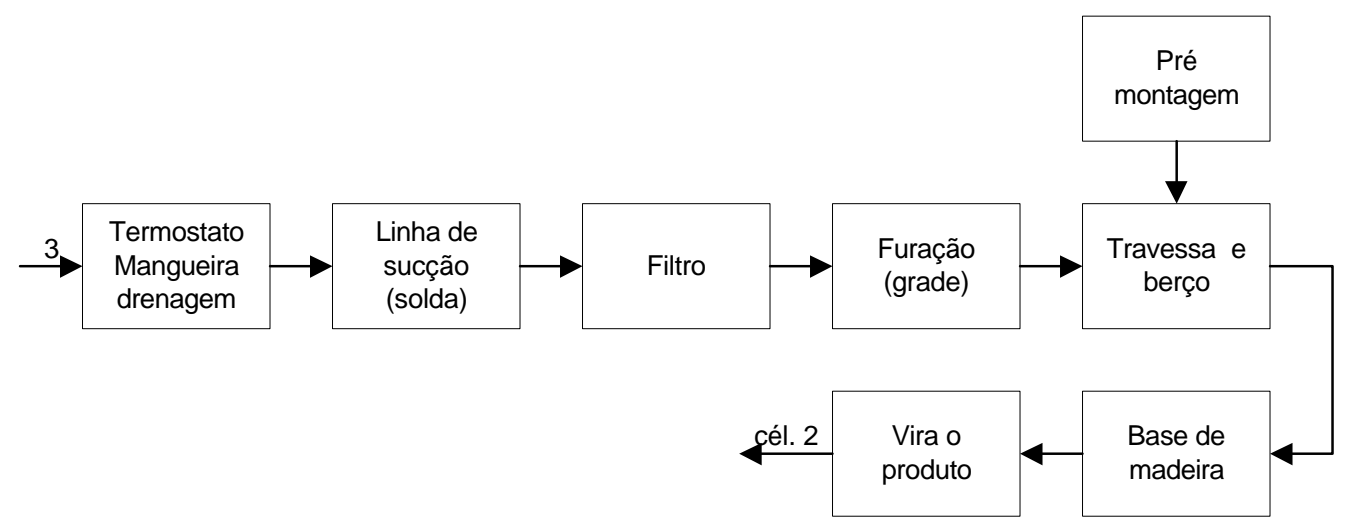

Figura 91 - Mapa de processo da célula 1 da linha de montagem do produto 1.

Em seguida, são parafusados ao conjunto a travessa e o berço (peças metálicas que agregam as rodinhas do produto) e é encaixada a base de madeira. Na última etapa desta célula o produto é virado para a posição normal (cabeça para cima), e segue para a célula 2.

\section{Célula 2}

A Figura 92 mostra as operações realizadas na célula 2. O compressor é posicionado na parte posterior inferior e o sistema de refrigeração é soldado. São colocados o cabo elétrico e o protetor térmico e é feita a limpeza do compressor (remoção de resquícios de solda). É feita ainda a limpeza manual do gabinete (a parte superior que ficou em contato com a esteira) usando um limpador comercial.

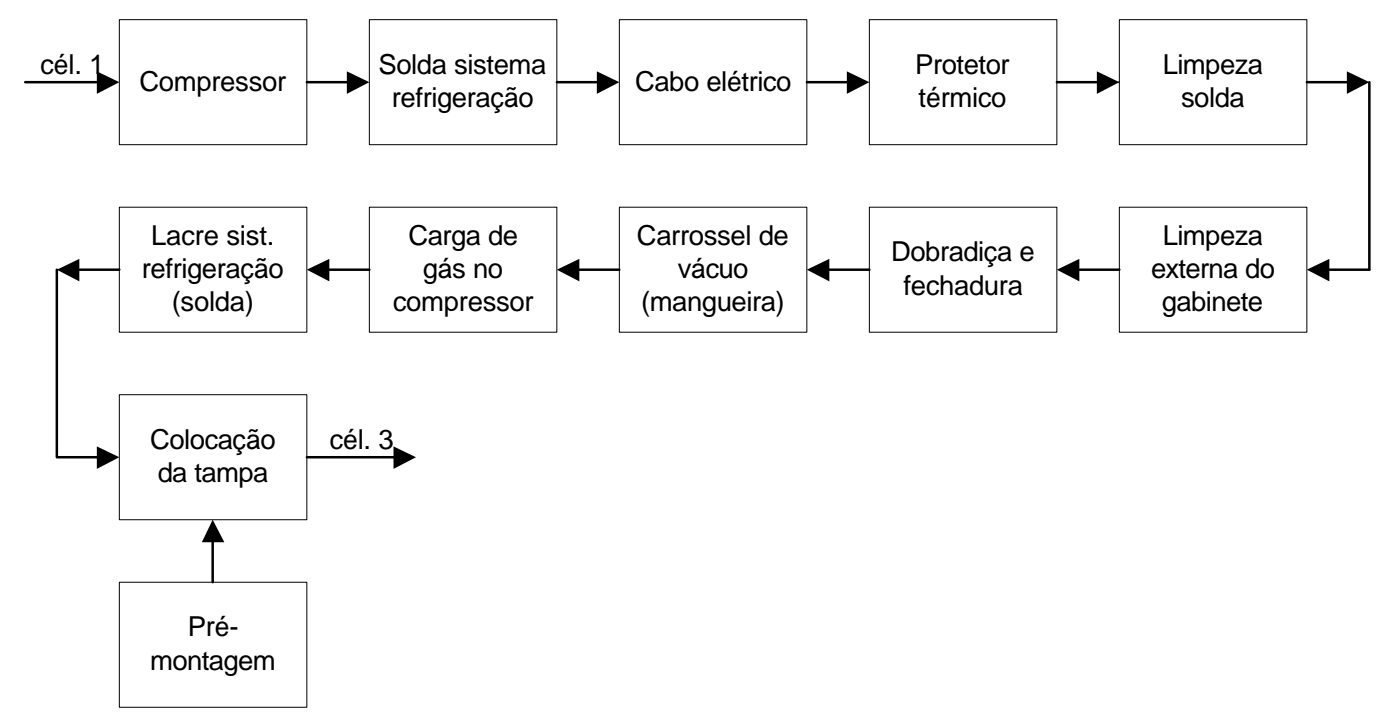

Figura 92. Mapa de processo da célula 2 da linha de montagem do produto 1. 
O gabinete é posicionado no carrossel de vácuo e são parafusadas as dobradiças, a fechadura e a mangueira de vácuo. Em seguida o compressor é carregado com gás e o sistema de refrigeração é lacrado com solda. Na última etapa é colocada a tampa do produto, que é montada em uma célula paralela, mostrada na Figura 93.

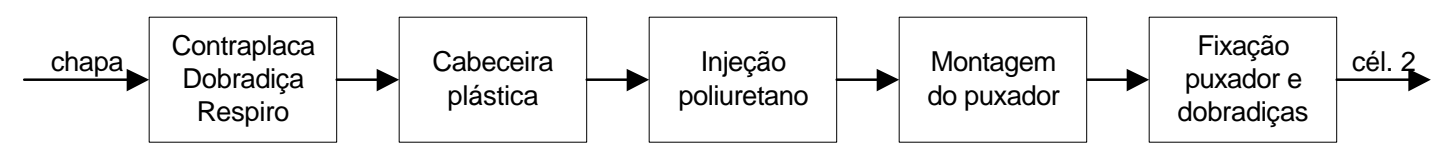

Figura 93 - Mapa de processo da célula de pré montagem da tampa do produto 1.

\section{Célula 3}

Na célula 3 são realizados testes elétricos e de vedação do produto, e os produtos que passam por esta inspeção recebem alguns acessórios, como grade, botão de controle e etiquetas de aprovação nos testes (Figura 94).

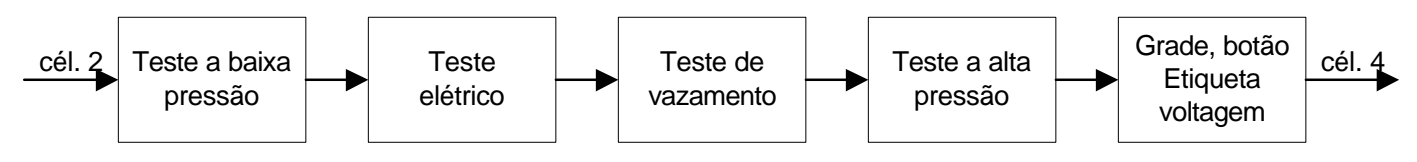

Figura 94 - Mapa de processo da célula 3 da linha de montagem do produto 1.

\section{$\underline{\text { Célula } 4}$}

Quando chega na célula 4 o produto já está pronto. Nesta célula são colocados outros acessórios, como o cesto aramado interno e os manuais de instrução. São colocados calços de EPS e de madeira no produto, que é então embalado em caixa de papelão (Figura 95).

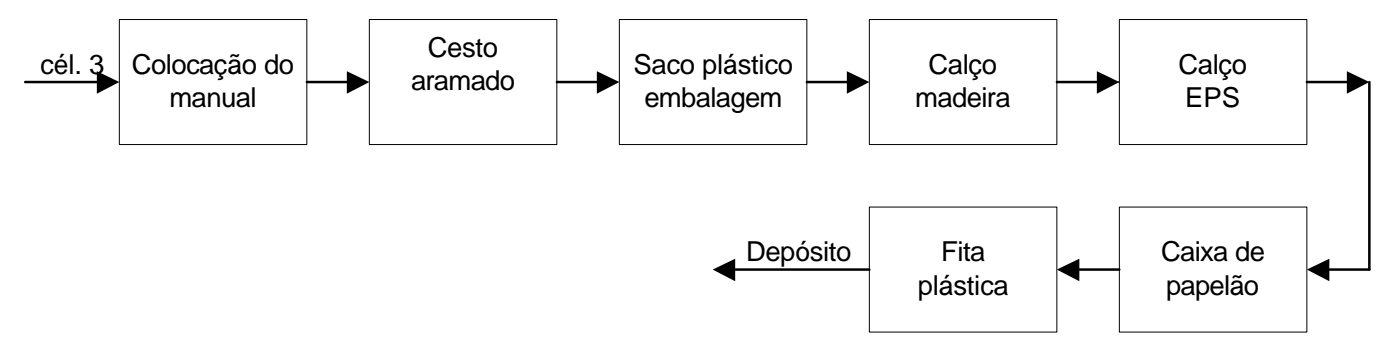

Figura 95 - Mapa de processo da célula 4 da linha de montagem do produto 1. 


\subsubsection{Características e Gerenciamento dos Resíduos}

O procedimento adotado para o levantamento dos resíduos gerados nas áreas de montagem dos três produtos foi o mesmo. Após a construção dos mapas de processo, onde procurou-se identificar todas as etapas e operações realizadas na linha de montagem, foi realizada uma nova inspeção, onde foram feitas anotações, seguindo o fluxo do processo, em uma tabela criada para tabular os dados coletados, que envolveram todas as principais entradas e saídas de cada operação, a quantidade de cada saída (estes dados nem sempre estiveram disponíveis) e a forma de gerenciamento. Também foi consultada a ficha de estrutura dos produtos, onde constam todos os itens estruturados (componentes agregados ao produto final) de cada produto. Os itens não estruturados (produtos auxiliares usados na linha de montagem) também foram considerados, e foram levantados na inspeção.

A maior parte dos resíduos gerados são embalagens dos componentes dos produtos, como caixas de papelão, plástico ou madeira, embalagens de produtos auxiliares, como graxa, lubrificantes, cola, tinta e produtos de limpeza. Ainda restos de plástico e papel de diversas origens, restos de fita crepe, buchas de limpeza gastas, EPI's, entre outros. Também é gerado resíduo de poliuretano, usado como isolante térmico. Os resíduos são segregados na fonte, de acordo com o tipo de material, e enviados à Central de Resíduos, onde são comercializados para reciclagem ou enviados para a disposição final. São denominados resíduos especiais aqueles resíduos que não são passíveis de reciclagem, que são segregados em containeres especiais identificados e encaminhados para a Central de Resíduos.

Este trabalho não envolveu a análise de aspectos relacionados ao projeto de produto. Sendo assim, como a parte mais significativa dos resíduos produzidos nas linhas de montagem são as embalagens, o critério usado para identificar oportunidades de prevenção à poluição foi a verificação das etapas do processo que empregam embalagens retornáveis $(R)$ e das etapas que empregam embalagens não retornáveis (NR). Os resultados obtidos no são mostrados na Tabela 13.

Não foram realizados ensaios de caracterização de resíduos. Empregou-se o critério adotado pela empresa, que classifica os resíduos das linhas de montagem como Resíduos Especiais (RE) e Recicláveis (R). Não é realizada a quantificação na fonte dos resíduos recicláveis. Apenas os resíduos especiais têm um controle na fonte. A abreviatura (n.d) na coluna da quantidade na Tabela 13 significa que a quantidade de resíduo não foi determinada. 
Tabela 13 - Inventário de resíduos da linha de montagem do produto 1.

\begin{tabular}{|c|c|c|c|c|c|c|c|c|}
\hline \multicolumn{2}{|c|}{ Operação } & \multirow[t]{2}{*}{ Entrada } & \multirow[t]{2}{*}{ Saída } & \multirow[t]{2}{*}{ Class. } & \multirow[t]{2}{*}{ Quantidade } & \multicolumn{2}{|c|}{ Embalagem } & \multirow[t]{2}{*}{ Destino } \\
\hline & & & & & & $\mathrm{R}$ & NR & \\
\hline \multirow{26}{*}{ 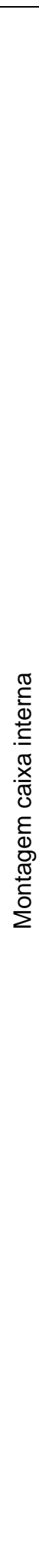 } & \multirow{4}{*}{ 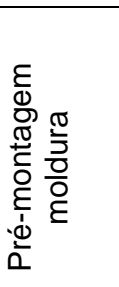 } & Moldura & Saco plástico & $\mathrm{R}$ & n.d & & $X$ & Reciclagem \\
\hline & & Cola adesiva & Lata de $800 \mathrm{~g}$ & $\mathrm{RE}$ & n.d & & $\mathrm{X}$ & Incineração \\
\hline & & Espuma & Fita plástica & $\mathrm{R}$ & n.d & & $\mathrm{X}$ & Reciclagem \\
\hline & & EPI's & EPI contaminados & $\mathrm{RE}$ & $20 \mathrm{~kg} / \mathrm{sem}$ & & $\mathrm{X}$ & Incineração \\
\hline & \multirow{4}{*}{ 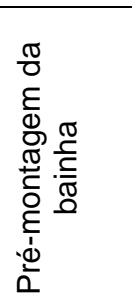 } & Fita crepe & Rolo de fita & $\mathrm{R}$ & n.d & & $\mathrm{X}$ & Reciclagem \\
\hline & & Guia bulbo & Sacos plásticos & $\mathrm{R}$ & n.d & & $\mathrm{X}$ & Reciclagem \\
\hline & & $\begin{array}{l}\text { Bainha } \\
\text { bulbo }\end{array}$ & Sacos plásticos & $\mathrm{R}$ & n.d & & $\mathrm{X}$ & Reciclagem \\
\hline & & Dreno & Sacos plásticos & $\mathrm{R}$ & n.d & & $\mathrm{X}$ & Reciclagem \\
\hline & \multirow{3}{*}{ 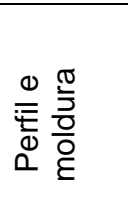 } & Perfil & Caixa papelão & $\mathrm{R}$ & n.d & & $\mathrm{X}$ & Reciclagem \\
\hline & & Moldura & Sacos plásticos & $\mathrm{R}$ & 1 caçamba & & $\mathrm{X}$ & Reciclagem \\
\hline & & Fita crepe & Rolo fita & $\mathrm{R}$ & n.d & & $\mathrm{X}$ & Reciclagem \\
\hline & \multirow[t]{2}{*}{$\begin{array}{l}\text { Trava- } \\
\text { mento }\end{array}$} & Fundo cx int. & Pallet metálico & - & n.d & $\mathrm{X}$ & & $\begin{array}{c}\text { Fornecedor } \\
\text { Interno }\end{array}$ \\
\hline & & Cola silicone & Embalagem plástica & R.E. & $4 \mathrm{~kg} / \mathrm{sem}$. & & $\mathrm{X}$ & Incineração \\
\hline & $\begin{array}{c}\text { Hot- } \\
\text { melting }\end{array}$ & $\begin{array}{l}\text { Cola } \\
\text { granulada }\end{array}$ & Caixa papelão & $\mathrm{R}$ & n.d & & $\mathrm{X}$ & Reciclagem \\
\hline & \multirow{3}{*}{ 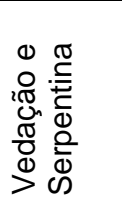 } & \multirow{2}{*}{$\begin{array}{l}\text { Massa } \\
\text { calafetar }\end{array}$} & Caixa papelão & $\mathrm{R}$ & n.d & & $\mathrm{X}$ & Reciclagem \\
\hline & & & Papel contaminado & R.E. & $8 \mathrm{~kg} / \mathrm{sem}$ & & $\mathrm{X}$ & Incineração \\
\hline & & Serp. compl & Baú madeira & $\mathrm{R}$ & n.d & & $\mathrm{X}$ & Reciclagem \\
\hline & \multirow{9}{*}{ 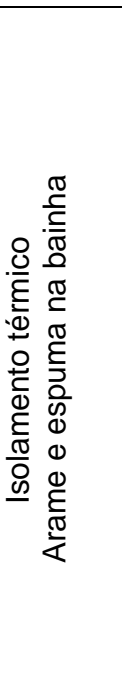 } & $\begin{array}{l}\text { Massa } \\
\text { térmica }\end{array}$ & Tambor $250 \mathrm{Kg}$ & $\mathrm{R}$ & n.d & $\mathrm{X}$ & & Fabricante \\
\hline & & $\begin{array}{l}\text { Película } \\
\text { termoc }\end{array}$ & Rolo/caixa papelão & $\mathrm{R}$ & n.d & & $\mathrm{X}$ & Reciclagem \\
\hline & & $\begin{array}{l}\text { Arame aço } \\
\text { galvanizado }\end{array}$ & Suporte plástico & $\mathrm{R}$ & n.d & $\mathrm{X}$ & & Reciclagem \\
\hline & & Massa calaf. & Cx papelão/papel & $\mathrm{R}$ & n.d & & $\mathrm{X}$ & Reciclagem \\
\hline & & $\begin{array}{l}\text { Tubo } \\
\text { isolante }\end{array}$ & Cx papelão & $\mathrm{R}$ & n.d & & $\mathrm{X}$ & Reciclagem \\
\hline & & Espuma & Saco plástico & $\mathrm{R}$ & n.d & & $\mathrm{X}$ & Reciclagem \\
\hline & & $\begin{array}{l}\text { Fita } \\
\text { polipropileno }\end{array}$ & Cx papelão & $\mathrm{R}$ & n.d & & $\mathrm{X}$ & Reciclagem \\
\hline & & \multirow[t]{2}{*}{ Abraçadeira } & Saco plástico & $\mathrm{R}$ & n.d & & $\mathrm{X}$ & Reciclagem \\
\hline & & & Cx papelão & $\mathrm{R}$ & n.d & & $\mathrm{X}$ & Reciclagem \\
\hline
\end{tabular}


Tabela 13 - Inventário de resíduos da linha de montagem do produto 1 (cont.).

\begin{tabular}{|c|c|c|c|c|c|c|c|c|}
\hline \multirow{2}{*}{\multicolumn{2}{|c|}{ Operação }} & \multirow[t]{2}{*}{ Entrada } & \multirow[t]{2}{*}{ Saída } & \multirow[t]{2}{*}{ Class. } & \multirow[t]{2}{*}{ Quantidade } & \multicolumn{2}{|c|}{ Embalagem } & \multirow[t]{2}{*}{ Destino } \\
\hline & & & & & & $\mathrm{R}$ & NR & \\
\hline \multirow{12}{*}{ 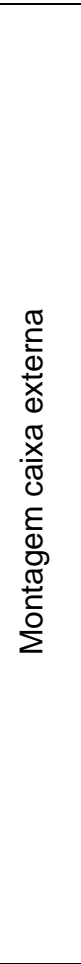 } & \multirow{2}{*}{$\begin{array}{l}\text { Conden- } \\
\text { sador }\end{array}$} & \multirow{2}{*}{$\begin{array}{l}\text { Condensa- } \\
\text { dor }\end{array}$} & Cx madeira & $\mathrm{R}$ & n.d & & $\mathrm{X}$ & Reciclagem \\
\hline & & & Borracha* $^{*}$ & $\mathrm{RE}$ & n.d & & & Incineração \\
\hline & \multirow{3}{*}{ 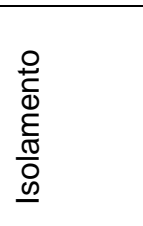 } & $\begin{array}{l}\text { Massa } \\
\text { termocond. }\end{array}$ & Tambor $250 \mathrm{Kg}$ & - & n.d & $\mathrm{X}$ & & Fabricante \\
\hline & & $\begin{array}{l}\text { Película } \\
\text { térmica }\end{array}$ & Rolo/caixa papelão & $\mathrm{R}$ & n.d & & $\mathrm{X}$ & Reciclagem \\
\hline & & Fita crepe & Cx papelão & $\mathrm{R}$ & n.d & & $\mathrm{X}$ & Reciclagem \\
\hline & \multirow{3}{*}{ 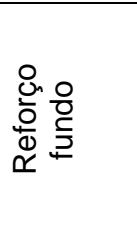 } & $\begin{array}{l}\text { Reforço } \\
\text { fundo }\end{array}$ & Forn interno & - & n.d & $\mathrm{X}$ & & $\begin{array}{c}\text { Fornecedor } \\
\text { interno }\end{array}$ \\
\hline & & Régua sust. & Forn interno & - & n.d & $\mathrm{X}$ & & $\begin{array}{c}\text { Fornecedor } \\
\text { interno }\end{array}$ \\
\hline & & $\begin{array}{l}\text { Fita dupla } \\
\text { face }\end{array}$ & Plástico verde & $\mathrm{R}$ & n.d & & $\mathrm{X}$ & Reciclagem \\
\hline & Vedação & Fita crepe & Cx papelão & $\mathrm{R}$ & n.d & & $\mathrm{X}$ & Reciclagem \\
\hline & $\begin{array}{l}\text { Junção } \\
\text { das }\end{array}$ & $\begin{array}{l}\text { Adesivo } \\
\text { sikaflex }\end{array}$ & lata & $\mathrm{RE}$ & $3 \mathrm{~kg} / \mathrm{sem}$. & & $\mathrm{X}$ & Incineração \\
\hline & caixas & $\begin{array}{l}\text { Fundo caixa } \\
\text { externa }\end{array}$ & papelão & $\mathrm{R}$ & n.d & & $\mathrm{X}$ & Reciclagem \\
\hline & $\begin{array}{l}\text { Injeção } \\
\text { PU }\end{array}$ & PU injetado & Resíduo PU & $\mathrm{RE}$ & $15 \mathrm{~kg} / \mathrm{sem}^{*}$ & & $\mathrm{X}$ & Aterro \\
\hline \multirow{15}{*}{ 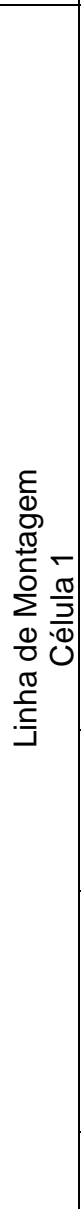 } & \multirow{9}{*}{ 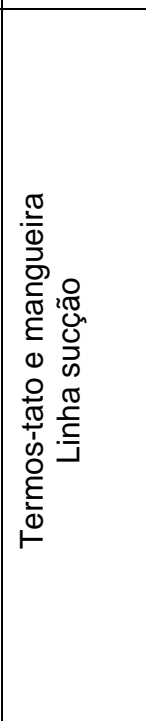 } & Mang. dreno & Saco plástico & $\mathrm{R}$ & n.d & & $X$ & Reciclagem \\
\hline & & $\begin{array}{l}\text { Adesivo } \\
\text { mangueira }\end{array}$ & Lata $800 \mathrm{~g}$ & $\mathrm{RE}$ & n.d & & $X$ & Incineração \\
\hline & & $\begin{array}{l}\text { Linha } \\
\text { sucção }\end{array}$ & carrinho & - & n.d & $\mathrm{X}$ & & Fabricante \\
\hline & & \multirow{2}{*}{$\begin{array}{l}\text { Etiqueta } \\
\text { código barra }\end{array}$} & Papel parafinado & $\mathrm{R}$ & n.d & & & Aterro \\
\hline & & & Saco plástico & $\mathrm{R}$ & n.d & & $\mathrm{X}$ & Reciclagem \\
\hline & & \multirow{2}{*}{$\begin{array}{l}\text { Diagrama } \\
\text { elétrico }\end{array}$} & Papel parafinado & $\mathrm{R}$ & n.d & & $\mathrm{X}$ & Aterro \\
\hline & & & Saco plástico & $\mathrm{R}$ & n.d & & $\mathrm{X}$ & Reciclagem \\
\hline & & Etiqueta & Papel parafinado & $\mathrm{R}$ & n.d & & & Aterro \\
\hline & & final & Saco plástico & $\mathrm{R}$ & n.d & & $\mathrm{X}$ & Reciclagem \\
\hline & \multirow[t]{2}{*}{ Filtro } & \multirow{2}{*}{$\begin{array}{l}\text { Filtro tubo } \\
\text { evacuação }\end{array}$} & Saco plástico & $\mathrm{R}$ & n.d & & $X$ & Reciclagem \\
\hline & & & Cx. papelão & $\mathrm{R}$ & n.d & & $X$ & Reciclagem \\
\hline & \multirow{3}{*}{$\begin{array}{c}\text { P.M } \\
\text { travessa } \\
\text { e berço }\end{array}$} & berço & Pallet metálico & - & n.d & $\mathrm{X}$ & & $\begin{array}{l}\text { Fornecedor } \\
\text { Interno }\end{array}$ \\
\hline & & Travessa & Pallet metálico & - & n.d & $\mathrm{X}$ & & $\begin{array}{l}\text { Fornecedor } \\
\text { Interno }\end{array}$ \\
\hline & & Rodízios & Caçamba ferro & - & n.d & $\mathrm{X}$ & & $\begin{array}{c}\text { Fornecedor } \\
\text { externo }\end{array}$ \\
\hline & $\begin{array}{c}\text { Base } \\
\text { madeira }\end{array}$ & $\begin{array}{l}\text { Base } \\
\text { madeira }\end{array}$ & Engradado madeira & - & n.d & $\mathrm{X}$ & & $\begin{array}{c}\text { Fornecedor } \\
\text { externo }\end{array}$ \\
\hline
\end{tabular}


Tabela 13 - Inventário de resíduos da linha de montagem do produto 1 (cont.).

\begin{tabular}{|c|c|c|c|c|c|c|c|c|c|}
\hline \multirow{2}{*}{\multicolumn{2}{|c|}{ Operação }} & \multirow{2}{*}{\multicolumn{2}{|c|}{ Entrada }} & \multirow[t]{2}{*}{ Saída } & \multirow[t]{2}{*}{ Class. } & \multirow[t]{2}{*}{ Quantidade } & \multicolumn{2}{|c|}{ Embalagem } & \multirow[t]{2}{*}{ Destino } \\
\hline & & & & & & & $\mathrm{R}$ & NR & \\
\hline \multirow{28}{*}{ 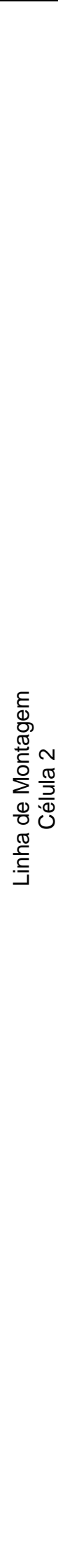 } & \multirow{8}{*}{ 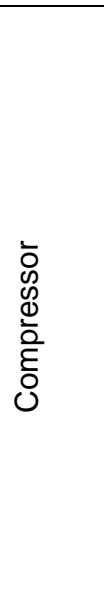 } & \multirow{2}{*}{\multicolumn{2}{|c|}{ Compressor }} & Pallet madeira & $\mathrm{R}$ & n.d & $\mathrm{X}$ & & Fabricante \\
\hline & & & & Saco plástico & $\mathrm{R}$ & n.d & & $\mathrm{X}$ & Reciclagem \\
\hline & & \multicolumn{2}{|c|}{$\begin{array}{l}\text { Caixa } \\
\text { ligação }\end{array}$} & Cx. papelão & $\mathrm{R}$ & n.d & & $\mathrm{X}$ & Reciclagem \\
\hline & & \multicolumn{2}{|c|}{$\begin{array}{l}\text { Protetor } \\
\text { térmico }\end{array}$} & Cx. papelão & $\mathrm{R}$ & n.d & & $\mathrm{X}$ & Reciclagem \\
\hline & & \multicolumn{2}{|c|}{ Rele } & Cx. papelão & $\mathrm{R}$ & n.d & & $\mathrm{X}$ & Reciclagem \\
\hline & & \multicolumn{2}{|c|}{ Amortecedor } & Cx. papelão & $\mathrm{R}$ & n.d & & $\mathrm{X}$ & Reciclagem \\
\hline & & \multicolumn{2}{|c|}{$\begin{array}{l}\text { Tubo } \\
\text { processo }\end{array}$} & Cx. papelão & $\mathrm{R}$ & n.d & & $\mathrm{X}$ & Reciclagem \\
\hline & & \multicolumn{2}{|c|}{ Grampo } & Cx. papelão & $\mathrm{R}$ & n.d & & $\mathrm{X}$ & Reciclagem \\
\hline & & \multicolumn{2}{|c|}{$\begin{array}{l}\text { Cabo } \\
\text { elétrico }\end{array}$} & Cx. plástica retorn. & $\mathrm{R}$ & n.d & $X$ & & Fabricante \\
\hline & & \multicolumn{2}{|c|}{ Presilha } & Saco plástico & $\mathrm{R}$ & n.d & & $\mathrm{X}$ & Reciclagem \\
\hline & & \multicolumn{2}{|c|}{ parafuso } & Cx. papelão & $\mathrm{R}$ & n.d & & $X$ & Reciclagem \\
\hline & .0.0 & \multicolumn{2}{|c|}{ parafuso } & Cx. papelão & $\mathrm{R}$ & n.d & & $\mathrm{X}$ & Reciclagem \\
\hline & $\begin{array}{l}0 \\
\text { O } \\
\text { 이 }\end{array}$ & \multicolumn{2}{|c|}{$\begin{array}{l}\text { Etiqueta } \\
\text { lacre }\end{array}$} & Cx. papelão & $\mathrm{R}$ & n.d & & $\mathrm{X}$ & Reciclagem \\
\hline & & \multicolumn{2}{|c|}{$\begin{array}{l}\text { Etiqueta } \\
\text { tensão }\end{array}$} & Cx. papelão & $\mathrm{R}$ & n.d & & $\mathrm{X}$ & Reciclagem \\
\hline & & \multicolumn{2}{|c|}{ Abraçadeira } & Cx. papelão & $\mathrm{R}$ & n.d & & $\mathrm{X}$ & Reciclagem \\
\hline & & \multicolumn{2}{|c|}{ Fio terra } & Cx. papelão & $\mathrm{R}$ & n.d & & $\mathrm{X}$ & Reciclagem \\
\hline & & \multicolumn{2}{|c|}{ Limpador } & Embal. plást. & $\mathrm{R}$ & n.d & & $\mathrm{X}$ & Reciclagem \\
\hline & $\stackrel{5}{ \pm} 0$ & \multicolumn{2}{|c|}{ Bucha } & Bucha gasta & RE & n.d & & $\mathrm{X}$ & Incineração \\
\hline & $\stackrel{\mathbb{N}}{N} \cdot \frac{5}{0}$ & \multicolumn{2}{|c|}{ Pano } & Pano sujo & - & n.d & $X$ & & Lavanderia \\
\hline & & \multicolumn{2}{|c|}{$\begin{array}{l}\text { Luva } \\
\text { borracha }\end{array}$} & Luva gasta & $\mathrm{RE}$ & n.d & & $X$ & Incineração \\
\hline & \multirow{8}{*}{ 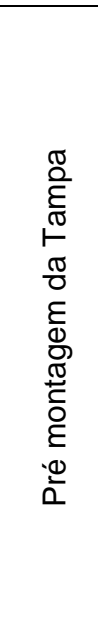 } & & Encaixe & Cx. papelão & $\mathrm{R}$ & n.d & & $\mathrm{X}$ & Reciclagem \\
\hline & & & Cabec. & Cx. papelão & $\mathrm{R}$ & n.d & $\mathrm{X}$ & & Fabricante \\
\hline & & & $\begin{array}{l}\text { Reforço } \\
\text { dobrad. }\end{array}$ & Pallet ferro & $\mathrm{R}$ & n.d & $\mathrm{X}$ & & Fabricante \\
\hline & & $\underset{\frac{0}{E}}{\text { త్ }}$ & $\begin{array}{l}\text { Reforço } \\
\text { cabec. }\end{array}$ & Cx. papelão & $\mathrm{R}$ & n.d & $\mathrm{X}$ & & Fabricante \\
\hline & & 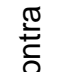 & $\begin{array}{l}\text { Válvula } \\
\text { tampa }\end{array}$ & Saco plástico & $\mathrm{R}$ & n.d & & $\mathrm{X}$ & Reciclagem \\
\hline & & & PF & Saco plástico & $\mathrm{R}$ & n.d & & $\mathrm{X}$ & Reciclagem \\
\hline & & & $\begin{array}{l}\text { Fita } \\
\text { crepe }\end{array}$ & Rolo papelão & $\mathrm{R}$ & n.d & & $\mathrm{X}$ & Reciclagem \\
\hline & & & $\begin{array}{l}\text { Massa } \\
\text { calafetar }\end{array}$ & Papel parafinado & $\mathrm{R}$ & n.d & & & Aterro \\
\hline
\end{tabular}


Tabela 13 - Inventário de resíduos da linha de montagem do produto 1 (cont.).

\begin{tabular}{|c|c|c|c|c|c|c|c|c|c|}
\hline \multirow{2}{*}{\multicolumn{3}{|c|}{ Operação }} & \multirow{3}{*}{$\begin{array}{c}\text { Entrada } \\
\text { PU injetado }\end{array}$} & \multirow[t]{2}{*}{ Saída } & \multirow[t]{2}{*}{ Class. } & \multirow[t]{2}{*}{ Quantidade } & \multirow{2}{*}{\multicolumn{2}{|c|}{ Embalagem }} & \multirow[t]{2}{*}{ Destino } \\
\hline & & & & & & & & & \\
\hline \multirow{9}{*}{ 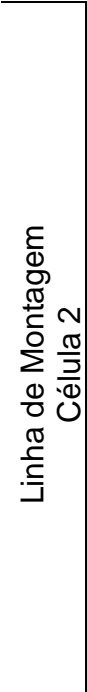 } & \multirow{9}{*}{ 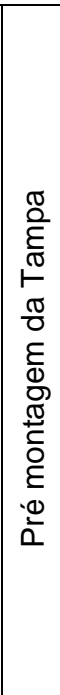 } & PU & & Resíduo de PU & $\mathrm{RE}$ & * & & $\mathrm{X}$ & Aterro \\
\hline & & \multirow{5}{*}{ 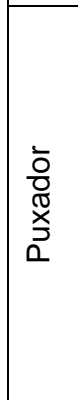 } & \multirow[t]{2}{*}{ Puxador } & Cx. papelão & $\mathrm{R}$ & n.d & & $\mathrm{X}$ & Reciclagem \\
\hline & & & & Plástico bolha & $\mathrm{R}$ & n.d & & $\mathrm{X}$ & Reciclagem \\
\hline & & & Adesivo & Papel parafinado & $\mathrm{R}$ & n.d & & & Aterro \\
\hline & & & Parafuso & Saco plástico & $\mathrm{R}$ & n.d & & $\mathrm{X}$ & Reciclagem \\
\hline & & & Etiqueta & Papel parafinado & $\mathrm{R}$ & n.d & & & Aterro \\
\hline & & \multirow{3}{*}{ 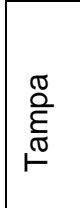 } & Dobr c/ mola & Cx. papelão & $\mathrm{R}$ & n.d & & $\mathrm{X}$ & Reciclagem \\
\hline & & & Dobr s/ mola & Cx. papelão & $\mathrm{R}$ & n.d & & $\mathrm{X}$ & Reciclagem \\
\hline & & & Parafuso & Saco plástico & $\mathrm{R}$ & n.d & & $\mathrm{X}$ & Reciclagem \\
\hline \multirow{4}{*}{ 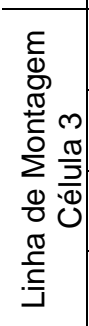 } & \multicolumn{2}{|c|}{ Testes } & Etiqueta & Papel parafinado & $\mathrm{R}$ & n.d & & & Aterro \\
\hline & \multicolumn{2}{|c|}{\begin{tabular}{|l|} 
Teste \\
elétrico
\end{tabular}} & Etiqueta & Papel parafinado & $\mathrm{R}$ & n.d & & & Aterro \\
\hline & \multicolumn{2}{|c|}{ Botão } & Botão & Cx. papelão & $\mathrm{R}$ & n.d & & $\mathrm{X}$ & Reciclagem \\
\hline & \multicolumn{2}{|c|}{\begin{tabular}{|l|} 
Etiqueta \\
voltagem
\end{tabular}} & Etiqueta & Papel parafinado & $\mathrm{R}$ & n.d & & & Aterro \\
\hline \multirow{13}{*}{ 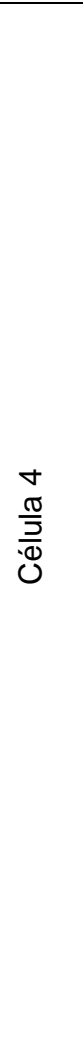 } & \multirow{4}{*}{\multicolumn{2}{|c|}{ 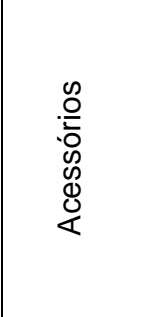 }} & \begin{tabular}{|l} 
Manual/ \\
folheto
\end{tabular} & Saco plástico & $\mathrm{R}$ & n.d & & $\mathrm{X}$ & Reciclagem \\
\hline & & & Grade & Pallet metálico & - & n.d & $X$ & & Fabricante \\
\hline & & & \begin{tabular}{|l|} 
Cabo \\
elétrico
\end{tabular} & Cx. papelão/plástico & $\mathrm{R}$ & n.d & & $\mathrm{X}$ & Reciclagem \\
\hline & & & \begin{tabular}{|l} 
Cesto \\
aramado
\end{tabular} & Carrinho retornável & $\mathrm{R}$ & n.d & $\mathrm{X}$ & & Fabricante \\
\hline & \multirow{9}{*}{\multicolumn{2}{|c|}{ 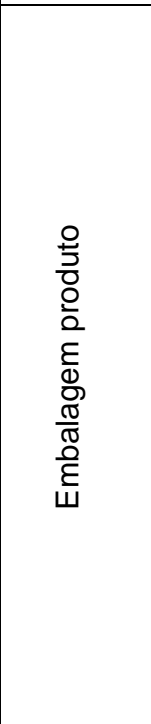 }} & Cx. papelão & Palet retornável & - & n.d & $\mathrm{X}$ & & Fabricante \\
\hline & & & $\begin{array}{l}\text { Coluna } \\
\text { lateral }\end{array}$ & Palet retornável & - & n.d & $\mathrm{X}$ & & \begin{tabular}{|l|} 
Fornecedor \\
interno
\end{tabular} \\
\hline & & & \begin{tabular}{|l|} 
Fita \\
polipropileno
\end{tabular} & Rolo fita & $\mathrm{R}$ & n.d & & $\mathrm{X}$ & Reciclagem \\
\hline & & & $\begin{array}{l}\text { Etiqueta } \\
\text { dupla ação }\end{array}$ & $\begin{array}{l}\text { Papel parafinado/ } \\
\text { plástico }\end{array}$ & $\mathrm{R}$ & n.d & & $\mathrm{X}$ & Reciclagem \\
\hline & & & $\begin{array}{l}\text { Etiqueta cód } \\
\text { barra }\end{array}$ & Papel parafinado & $\mathrm{R}$ & n.d & & & Aterro \\
\hline & & & Base embal. & Palet madeira & $\mathrm{R}$ & n.d & & $\mathrm{X}$ & Reciclagem \\
\hline & & & $\begin{array}{l}\text { Calço } \\
\text { madeira }\end{array}$ & Palet madeira & $\mathrm{R}$ & n.d & & $\mathrm{X}$ & Reciclagem \\
\hline & & & Calço EPS & Saco plástico & $\mathrm{R}$ & n.d & & $\mathrm{X}$ & Reciclagem \\
\hline & & & $\begin{array}{l}\text { Saco } \\
\text { plástico }\end{array}$ & Saco plástico & $\mathrm{R}$ & n.d & & $\mathrm{X}$ & Reciclagem \\
\hline
\end{tabular}




\section{5. Área de Montagem do Produto 2}

\subsubsection{Descrição do Processo}

Nesta área são montados três modelos do mesmo produto, e cada modelo tem uma linha de montagem separada. A inspeção, a construção dos mapas de processo e o inventário de entradas e saída foi realizado apenas para uma das linhas de montagem, uma vez que os componentes e os resíduos gerados nas três linhas de montagem são basicamente os mesmos. A linha de montagem avaliada está dividida em 6 células distintas.

\section{Célula 1}

Nesta célula são realizadas as operações mostradas na Figura 96, que incluem a perfuração do tanque interno, montagem da mangueira, da transmissão elétrica e do varão. É colocada a base de EPS na parte inferior (que faz parte da embalagem do produto final).

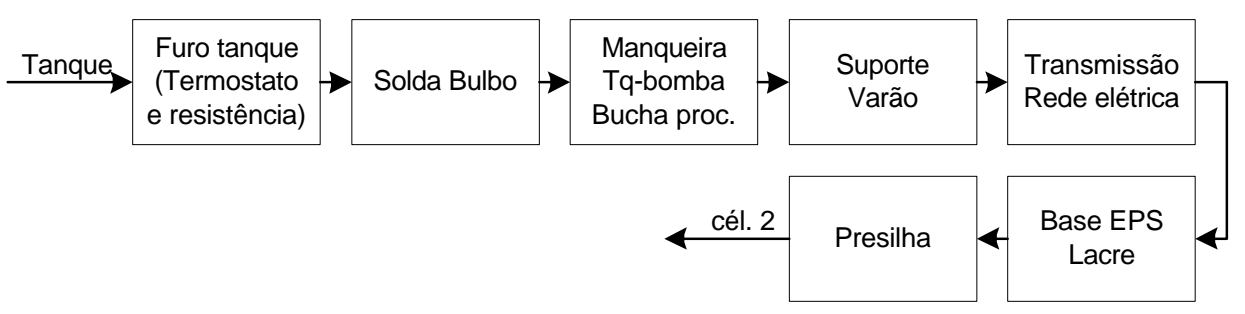

Figura 96 - Mapa de processo da célula 1 da linha de montagem do produto 2.

\section{Célula 2}

O conjunto montado na célula 1 segue para a célula 2, onde são inseridos o selo e o assento, o cubo e a chaveta da transmissão, o anel compensador, o agitador e a eletrobomba. Após a colocação de todos estes componentes, o conjunto é encaixado e soldado no gabinete (Figura 97).

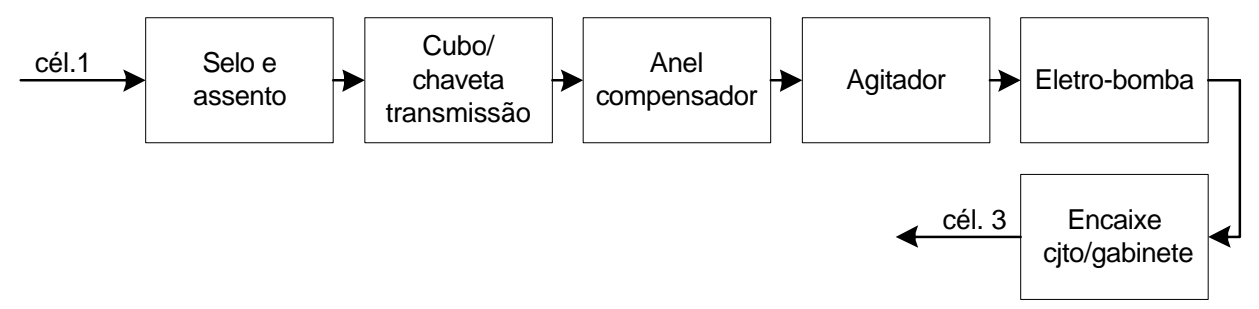

Figura 97 - Mapa de processo da célula 2 da linha de montagem do produto 2. 


\section{Célula 3}

Na célula 3, é feito o encaixe do topo no gabinete (montado na célula 4). A rede elétrica inferior é fixada no gabinete, e é feito o encaixe e fixação do capacitor e da rede superior no conjunto (Figura 98)

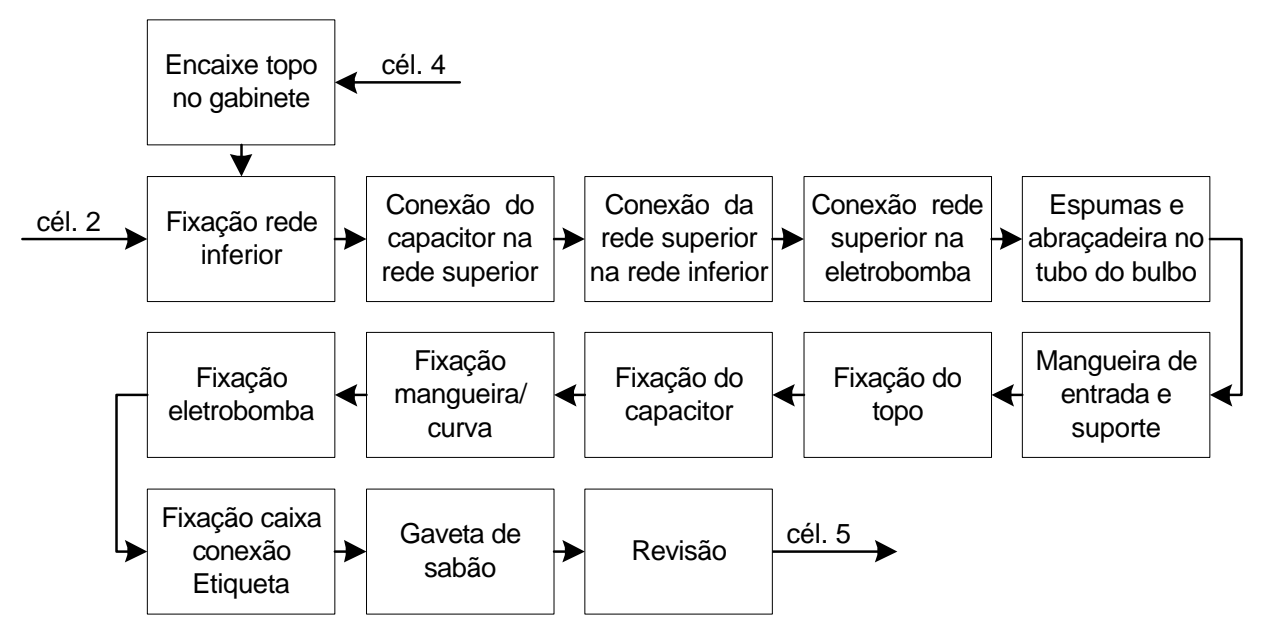

Figura 98 - Mapa de processo da célula 3 da linha de montagem do produto 2.

\section{Célula 4}

A célula 4 é uma célula paralela de pré-montagem, onde são montados o topo, a tampa, o temporizador e a placa do painel do produto (Figura 99). O subconjunto da tampa é encaixado ao gabinete na célula 3.

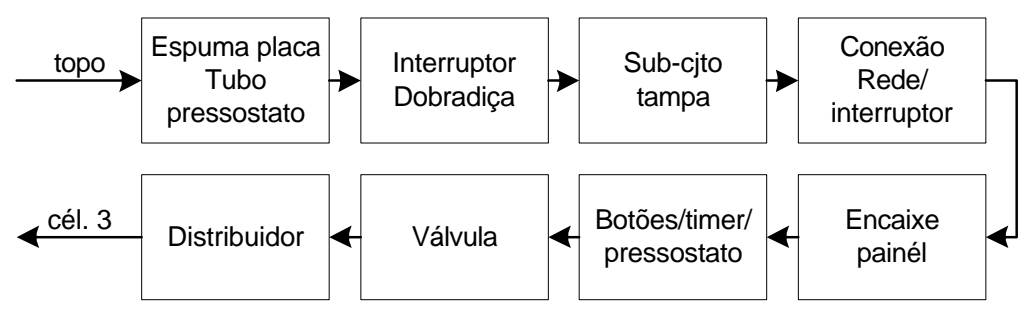

Figura 99 - Mapa de processo da célula 4 da linha de montagem do produto 2.

$\mathrm{Na}$ célula 5 são realizados os testes elétrico e funcional (Figura 100). O teste funcional é realizado em $100 \%$ dos produtos, e consiste no abastecimento do volume máximo de água em cada produto, para verificação da estanqueidade e funcionalidade dos componentes eletro-eletrônicos. A água utilizada nesse teste é bombeada a partir de um reservatório enterrado, com volume de $20 \mathrm{~m}^{3}$, localizado próximo da linha de produção, e retorna a esse mesmo reservatório após conclusão da etapa, funcionando em circuito fechado. Em um período variável entre vinte e cinco e trinta dias, todo o 
volume de água $\left(20 \mathrm{~m}^{3}\right)$ é descartado e substituído ${ }^{41}$. Cada produto permanece cheio durante 4 passos do processo produtivo, e com o funcionamento da linha em sua capacidade máxima, até 6 produtos poderão estar cheios simultaneamente com 80 litros de água cada um.

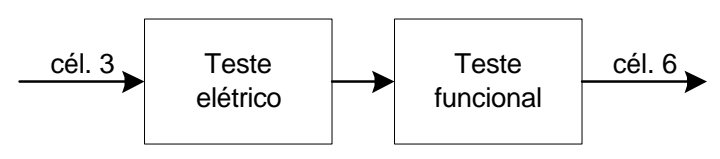

Figura 100 - Mapa de processo da célula 5 da linha de montagem do produto 2.

Ao sair da célula 5 o produto está pronto para ser embalado. Na célula 6 é colocada a embalagem no produto, etiquetas e eventualmente é feita a limpeza externa, com limpador comercial (Figura 101).

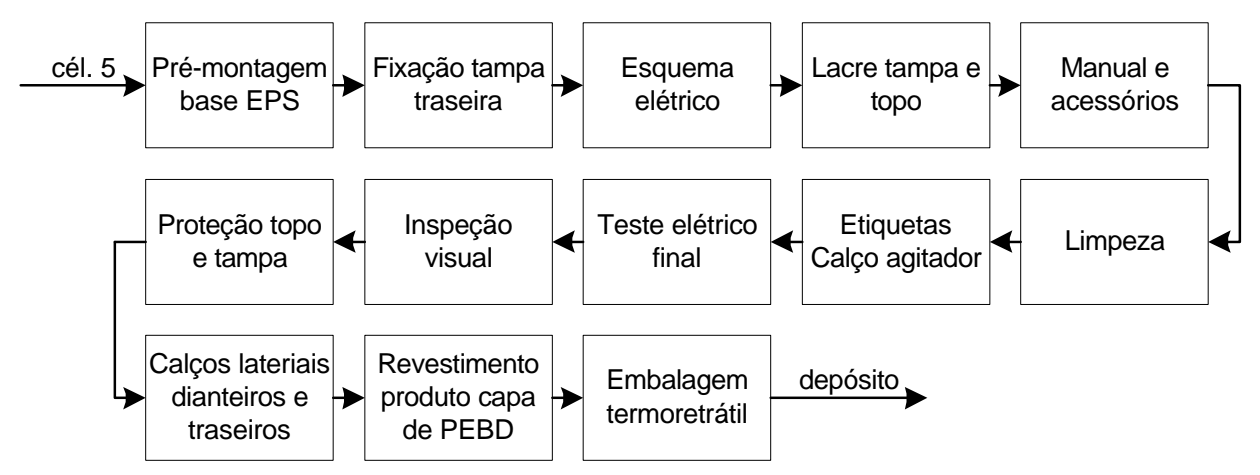

Figura 101 - Mapa de processo da célula 6 da linha de montagem do produto 2 .

\subsubsection{Características e Gerenciamento dos Resíduos}

Assim como ocorre na área de montagem do produto 1, a maior parte dos resíduos são constituídos de embalagens e sobras de materiais usados nas diversas etapas da linha de montagem. O gerenciamento dos resíduos também segue os mesmos critérios. Os resultados do levantamento realizado são apresentados na Tabela 14 a seguir.

\footnotetext{
41 Todo efluente é despejado diretamente na rede de esgoto. Existe uma proposta de projeto para o aproveitamento desse efluente na descarga das bacias sanitárias de uso dos funcionários da fábrica.
} 
Tabela 14 - Inventário de resíduos da linha de montagem do produto 2.

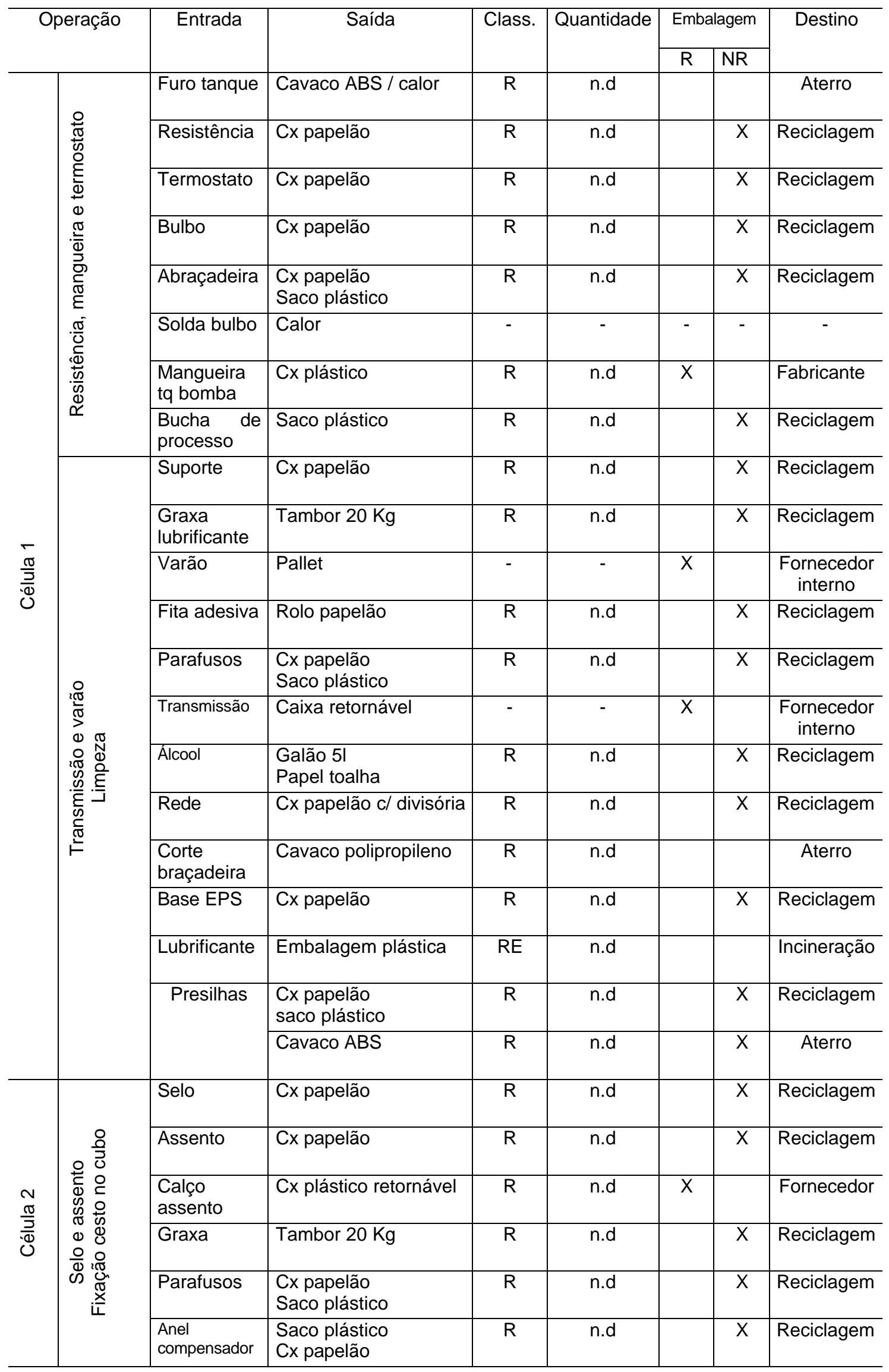


Tabela 14 - Inventário de resíduos da linha de montagem do produto 2 (cont.).

\begin{tabular}{|c|c|c|c|c|c|c|c|c|}
\hline \multirow{2}{*}{\multicolumn{2}{|c|}{ Operação }} & \multirow{3}{*}{$\begin{array}{r}\text { Entrada } \\
\text { Agitador }\end{array}$} & \multirow[t]{2}{*}{ Saída } & \multirow{3}{*}{$\begin{array}{c}\text { Class. } \\
\mathrm{R}\end{array}$} & \multirow{3}{*}{\begin{tabular}{|c|} 
Quantidade \\
n.d
\end{tabular}} & \multicolumn{2}{|c|}{ Embalagem } & \multirow{3}{*}{\begin{tabular}{|l|} 
Destino \\
$\begin{array}{l}\text { Fornecedor } \\
\text { interno }\end{array}$ \\
\end{tabular}} \\
\hline & & & & & & $\mathrm{R}$ & NR & \\
\hline \multirow{10}{*}{$\begin{array}{l}N \\
\frac{\pi}{5} \\
\frac{1}{d} \\
0\end{array}$} & \multirow{3}{*}{ 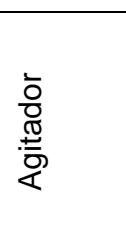 } & & Cx plástica retornável & & & $\mathrm{X}$ & & \\
\hline & & Parafuso & $\begin{array}{l}\text { Cx papelão } \\
\text { Saco plástico }\end{array}$ & $\mathrm{R}$ & n.d & & $\mathrm{X}$ & Reciclagem \\
\hline & & $\begin{array}{l}\text { Arruela } \\
\text { borracha }\end{array}$ & Saco plástico & $\mathrm{R}$ & n.d & & $\mathrm{X}$ & Reciclagem \\
\hline & \multirow{4}{*}{ 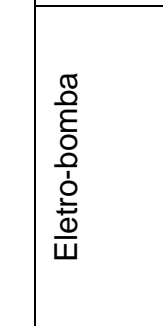 } & eletrobomba & $\begin{array}{l}\text { Cx papelão c/ divisória } \\
\text { Saco plástico }\end{array}$ & $\mathrm{R}$ & n.d & & $\mathrm{X}$ & Reciclagem \\
\hline & & Suporte & Engradado metálico & $\mathrm{R}$ & n.d & $\mathrm{X}$ & & $\begin{array}{l}\text { Fornecedor } \\
\text { interno }\end{array}$ \\
\hline & & Abraçadeira & Cx papelão & $\mathrm{R}$ & n.d & & $\mathrm{X}$ & Reciclagem \\
\hline & & Parafusos & $\begin{array}{l}\text { Cx papelão } \\
\text { Saco plástico }\end{array}$ & $\mathrm{R}$ & n.d & & $\mathrm{X}$ & Reciclagem \\
\hline & \multirow{3}{*}{ 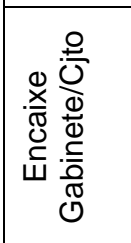 } & Graxa & Tambor $20 \mathrm{Kg}$ & $\mathrm{R}$ & n.d & & $\mathrm{X}$ & Reciclagem \\
\hline & & Parafusos & $\begin{array}{l}\text { Cx papelão } \\
\text { Saco plástico }\end{array}$ & $\mathrm{R}$ & n.d & & $X$ & Reciclagem \\
\hline & & Pivôs/molas & $\begin{array}{l}\text { Embalagem plástica } \\
\text { retornável }\end{array}$ & $\mathrm{R}$ & n.d & $\mathrm{X}$ & & Fornecedor \\
\hline \multirow{18}{*}{$\frac{m}{\frac{\pi}{5}}$} & \multirow{5}{*}{ 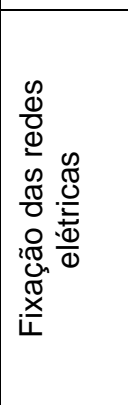 } & Presilhas & $\begin{array}{l}\text { Saco plástico } \\
\text { Cx papelão }\end{array}$ & $\mathrm{R}$ & n.d & & $\mathrm{X}$ & Reciclagem \\
\hline & & $\begin{array}{l}\text { Rede } \\
\text { superior }\end{array}$ & $\begin{array}{l}\text { Saco plástico } \\
\text { Cx papelão }\end{array}$ & $\mathrm{R}$ & n.d & & $\mathrm{X}$ & Reciclagem \\
\hline & & $\begin{array}{l}\text { Rede } \\
\text { inferior }\end{array}$ & $\begin{array}{l}\text { Saco plástico } \\
\text { Cx papelão }\end{array}$ & $\mathrm{R}$ & n.d & & $\mathrm{X}$ & Reciclagem \\
\hline & & Capacitor & Cx papelão c/ divisória & $\mathrm{R}$ & n.d & & $\mathrm{X}$ & Reciclagem \\
\hline & & Parafusos & $\begin{array}{l}\text { Cx papelão } \\
\text { Saco plástico }\end{array}$ & $\mathrm{R}$ & n.d & & $\mathrm{X}$ & Reciclagem \\
\hline & \multirow{6}{*}{ 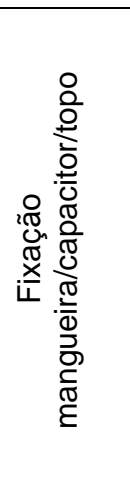 } & Espuma & $\begin{array}{l}\text { Cx papelão } \\
\text { Saco plástico }\end{array}$ & $\mathrm{R}$ & n.d & & $\mathrm{X}$ & Reciclagem \\
\hline & & Abraçadeira & Cx papelão & $\mathrm{R}$ & n.d & & $\mathrm{X}$ & Reciclagem \\
\hline & & $\begin{array}{l}\text { Mangueira } \\
\text { de entrada }\end{array}$ & Cx madeira retornável & $\mathrm{R}$ & n.d & $\mathrm{X}$ & & Fornecedor \\
\hline & & Presilhas & $\begin{array}{l}\text { Saco plástico } \\
\text { Cx papelão }\end{array}$ & $\mathrm{R}$ & n.d & & $\mathrm{X}$ & Reciclagem \\
\hline & & $\begin{array}{l}\text { Curva } \\
\text { mangueira }\end{array}$ & $\begin{array}{l}\text { Saco plástico } \\
\text { Cx papelão }\end{array}$ & $\mathrm{R}$ & n.d & & $\mathrm{X}$ & Reciclagem \\
\hline & & Presilhas & $\begin{array}{l}\text { Saco plástico } \\
\text { Cx papelão }\end{array}$ & $\mathrm{R}$ & n.d & & $\mathrm{X}$ & Reciclagem \\
\hline & \multirow{7}{*}{ 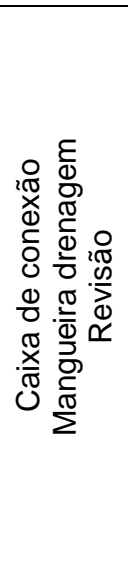 } & $\begin{array}{l}\text { Mangueira } \\
\text { drenagem }\end{array}$ & $\begin{array}{l}\text { Saco plástico } \\
\text { Pallet retornável }\end{array}$ & $\mathrm{R}$ & n.d & $\mathrm{X}$ & $\mathrm{X}$ & $\begin{array}{l}\text { Reciclagem } \\
\text { Fabricante }\end{array}$ \\
\hline & & Abraçadeira & Cx papelão & $\mathrm{R}$ & n.d & & $\mathrm{X}$ & Reciclagem \\
\hline & & Presilhas & $\begin{array}{l}\text { Saco plástico } \\
\text { Cx papelão }\end{array}$ & $\mathrm{R}$ & n.d & & $\mathrm{X}$ & Reciclagem \\
\hline & & $\begin{array}{l}\text { Etiqueta } \\
\text { identificação }\end{array}$ & Papel parafinado & $\mathrm{R}$ & n.d & & & Aterro \\
\hline & & $\begin{array}{l}\text { Caixa de } \\
\text { conexão }\end{array}$ & Cx papelão & $\mathrm{R}$ & n.d & & $\mathrm{X}$ & Reciclagem \\
\hline & & Parafusos & $\begin{array}{l}\text { Cx papelão } \\
\text { Saco plástico }\end{array}$ & $\mathrm{R}$ & n.d & & $\mathrm{X}$ & Reciclagem \\
\hline & & $\begin{array}{l}\text { Gaveta de } \\
\text { sabão }\end{array}$ & Engradado retornável & $\mathrm{R}$ & n.d & $\mathrm{X}$ & & $\begin{array}{c}\text { Fornecedor } \\
\text { interno }\end{array}$ \\
\hline
\end{tabular}


Tabela 14 - Inventário de resíduos da linha de montagem do produto 2 (cont.).

\begin{tabular}{|c|c|c|c|c|c|c|c|c|}
\hline \multirow{2}{*}{\multicolumn{2}{|c|}{ Operação }} & \multirow[t]{2}{*}{ Entrada } & \multirow[t]{2}{*}{ Saída } & \multirow[t]{2}{*}{ Class. } & \multirow[t]{2}{*}{ Quantidade } & \multicolumn{2}{|c|}{ Embalagem } & \multirow[t]{2}{*}{ Destino } \\
\hline & & & & & & $\mathrm{R}$ & NR & \\
\hline \multirow{25}{*}{ 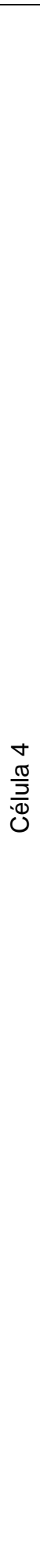 } & \multirow{7}{*}{$\begin{array}{l}\text { 음 } \\
0 \\
0 \\
0 \\
\frac{1}{0} \\
0 \\
0 \\
\stackrel{T}{ \pm} \\
\stackrel{0}{\Sigma}\end{array}$} & Topo & Engradado retornável & $\mathrm{R}$ & n.d & $\mathrm{X}$ & & $\begin{array}{l}\text { Fornecedor } \\
\text { interno }\end{array}$ \\
\hline & & Espuma & $\begin{array}{l}\text { Papel } \\
\text { Cx papelão }\end{array}$ & $\mathrm{R}$ & n.d & & $X$ & Reciclagem \\
\hline & & Etiqueta & Papel parafinado & $\mathrm{R}$ & n.d & & & Aterro \\
\hline & & Interruptor & Cx papelão & $\mathrm{R}$ & n.d & & $\mathrm{X}$ & Reciclagem \\
\hline & & Proteção & Bandeja retornável & $\mathrm{R}$ & n.d & $\mathrm{X}$ & & Fornecedor \\
\hline & & Bucha & $\begin{array}{l}\text { Cx papelão } \\
\text { Saco plástico }\end{array}$ & $\mathrm{R}$ & n.d & & $\mathrm{X}$ & Reciclagem \\
\hline & & Dobradiça & Bandeja retornável & $\mathrm{R}$ & n.d & $\mathrm{X}$ & & Fornecedor \\
\hline & \multirow{3}{*}{ 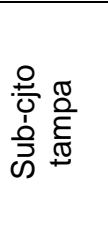 } & Visor & $\begin{array}{l}\text { Papel } \\
\text { Cx papelão }\end{array}$ & $\mathrm{R}$ & n.d & & $\mathrm{X}$ & Reciclagem \\
\hline & & Etiqueta & Papel parafinado & $\mathrm{R}$ & n.d & & & Aterro \\
\hline & & Parafusos & $\begin{array}{l}\text { Cx papelão } \\
\text { Saco plástico }\end{array}$ & $\mathrm{R}$ & n.d & & $X$ & Reciclagem \\
\hline & \multirow{6}{*}{ 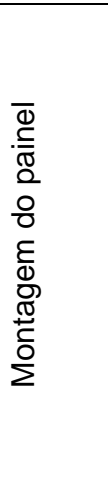 } & Timer & $\begin{array}{l}\text { Cx papelão/plástico } \\
\text { Cx plástico retornável }\end{array}$ & $\mathrm{R}$ & n.d & $\mathrm{X}$ & $X$ & $\begin{array}{l}\text { Reciclagem } \\
\text { Fornecedor }\end{array}$ \\
\hline & & Lâmpada & Cx papelão/papel & $\mathrm{R}$ & n.d & & $\bar{X}$ & Reciclagem \\
\hline & & $\begin{array}{l}\text { Vedação } \\
\text { lâmpada }\end{array}$ & $\begin{array}{l}\text { Cx papelão } \\
\text { Saco plástico }\end{array}$ & $\mathrm{R}$ & n.d & & $\mathrm{X}$ & Reciclagem \\
\hline & & Espuma & $\begin{array}{l}\text { Papel } \\
\text { Cx papelão }\end{array}$ & $R$ & n.d & & $X$ & Reciclagem \\
\hline & & $\begin{array}{l}\text { Chave } \\
\text { seletora }\end{array}$ & Saco plástico & $\mathrm{R}$ & n.d & & $\mathrm{X}$ & Reciclagem \\
\hline & & $\begin{array}{l}\text { Espuma } \\
\text { pressostato }\end{array}$ & $\begin{array}{l}\text { Papel } \\
\text { Cx papelão }\end{array}$ & $\mathrm{R}$ & n.d & & $\mathrm{X}$ & Reciclagem \\
\hline & \multirow{9}{*}{ 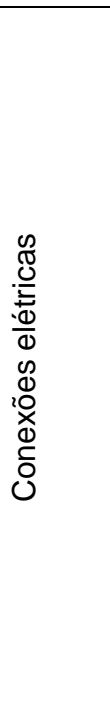 } & Placa & Cx papelão & $\mathrm{R}$ & n.d & & $\mathrm{X}$ & Reciclagem \\
\hline & & Parafusos & $\begin{array}{l}\text { Cx papelão } \\
\text { Saco plástico }\end{array}$ & $\mathrm{R}$ & n.d & & $\mathrm{X}$ & Reciclagem \\
\hline & & Abraçadeira & Cx papelão & $\mathrm{R}$ & n.d & & $\mathrm{X}$ & Reciclagem \\
\hline & & Válvula & Cx papelão & $\mathrm{R}$ & n.d & & $\mathrm{X}$ & Reciclagem \\
\hline & & $\begin{array}{l}\text { Proteção } \\
\text { válvula }\end{array}$ & Bandeja retornável & $\mathrm{R}$ & n.d & $\mathrm{X}$ & & Fornecedor \\
\hline & & $\begin{array}{l}\text { Botões } \\
\text { timer }\end{array}$ & Saco plástico & $\mathrm{R}$ & n.d & & $\mathrm{X}$ & Reciclagem \\
\hline & & $\begin{array}{l}\text { Etiqueta } \\
\text { tensão }\end{array}$ & Papel parafinado & $\mathrm{R}$ & n.d & & & Aterro \\
\hline & & Distribuidor & Cx papelão & $\mathrm{R}$ & n.d & & $\mathrm{X}$ & Reciclagem \\
\hline & & Parafusos & $\begin{array}{l}\text { Cx papelão } \\
\text { Saco plástico }\end{array}$ & $\mathrm{R}$ & n.d & & $\bar{X}$ & Reciclagem \\
\hline \multirow{2}{*}{ 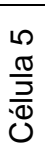 } & \multirow{2}{*}{ 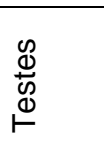 } & Água & Água recirc./efluente & - & - & - & - & $\begin{array}{l}\text { Tanque } \\
\text { Esgoto }\end{array}$ \\
\hline & & Etiquetas & Papel parafinado & $\mathrm{R}$ & n.d & & & Aterro \\
\hline
\end{tabular}


Tabela 14 - Inventário de resíduos da linha de montagem do produto 2 (cont.).

\begin{tabular}{|c|c|c|c|c|c|c|c|c|}
\hline \multirow{2}{*}{\multicolumn{2}{|c|}{ Operação }} & \multirow[t]{2}{*}{ Entrada } & \multirow[t]{2}{*}{ Saída } & \multirow[t]{2}{*}{ Class. } & \multirow[t]{2}{*}{ Quantidade } & \multicolumn{2}{|c|}{ Embalagem } & \multirow{3}{*}{$\begin{array}{l}\text { Destino } \\
\text { Reciclagem }\end{array}$} \\
\hline & & & & & & $\mathrm{R}$ & NR & \\
\hline \multirow{18}{*}{ 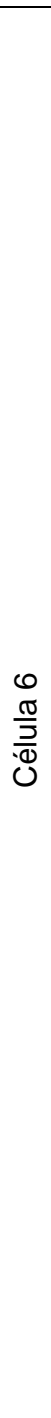 } & \multirow{4}{*}{ 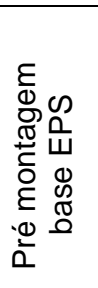 } & \multirow{4}{*}{ EPS } & Cinta aço & $\mathrm{R}$ & n.d & & $\mathrm{X}$ & \\
\hline & & & Pallet madeira & $\mathrm{R}$ & n.d & & $\mathrm{X}$ & Reciclagem \\
\hline & & & Plástico & $\mathrm{R}$ & n.d & & $\mathrm{X}$ & Reciclagem \\
\hline & & & Sobra EPS & $\mathrm{R}$ & n.d & & $\mathrm{X}$ & Reciclagem \\
\hline & \multirow{4}{*}{ 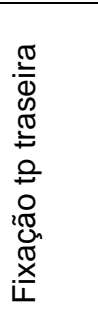 } & Tampa & Engradado retornável & $\mathrm{R}$ & n.d & $\mathrm{X}$ & & Fornecedor \\
\hline & & Parafusos & $\begin{array}{l}\text { Cx papelão } \\
\text { Saco plástico }\end{array}$ & $\mathrm{R}$ & n.d & & $\mathrm{X}$ & Reciclagem \\
\hline & & $\begin{array}{l}\text { Esquema } \\
\text { elétrico }\end{array}$ & Papel parafinado & $\mathrm{R}$ & n.d & & & Aterro \\
\hline & & $\begin{array}{l}\text { Lacre } \\
\text { parafuso }\end{array}$ & Saco plástico & $\mathrm{R}$ & n.d & & $\mathrm{X}$ & Reciclagem \\
\hline & \multirow{3}{*}{ 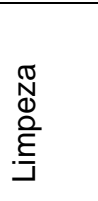 } & $\begin{array}{l}\text { Manual e } \\
\text { acessórios }\end{array}$ & Saco plástico & $\mathrm{R}$ & n.d & & $\mathrm{X}$ & Reciclagem \\
\hline & & Limpador & Embalagem plástica & $\mathrm{R}$ & n.d & & $\mathrm{X}$ & Reciclagem \\
\hline & & Pano & Pano sujo & - & - & - & - & Lavanderia \\
\hline & \multirow{7}{*}{ 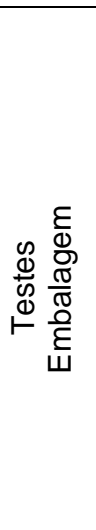 } & Etiquetas & Papel parafinado & $\mathrm{R}$ & n.d & & & Aterro \\
\hline & & $\begin{array}{l}\text { Calço } \\
\text { agitador }\end{array}$ & $\begin{array}{l}\text { Saco plástico } \\
\text { Cx papelão }\end{array}$ & $\mathrm{R}$ & n.d & & $\mathrm{X}$ & Reciclagem \\
\hline & & $\begin{array}{l}\text { Etiqueta } \\
\text { teste elétr. }\end{array}$ & Papel parafinado & $\mathrm{R}$ & n.d & & & Aterro \\
\hline & & $\begin{array}{l}\text { Proteção } \\
\text { topo/tampa }\end{array}$ & $\begin{array}{l}\text { Saco plástico } \\
\text { Cx papelão }\end{array}$ & $\mathrm{R}$ & n.d & & $\mathrm{X}$ & Reciclagem \\
\hline & & $\begin{array}{l}\text { Calços } \\
\text { laterais }\end{array}$ & $\begin{array}{l}\text { Saco plástico } \\
\text { Cx papelão }\end{array}$ & $\mathrm{R}$ & n.d & & $\mathrm{X}$ & Reciclagem \\
\hline & & $\begin{array}{l}\text { Revestim. } \\
\text { PEBD }\end{array}$ & Saco plástico & $\mathrm{R}$ & n.d & & $\bar{X}$ & Reciclagem \\
\hline & & Embalagem & Saco plástico & $\mathrm{R}$ & n.d & & $\mathrm{X}$ & Reciclagem \\
\hline
\end{tabular}

\section{6. Área de Montagem do Produto 3}

\subsubsection{Descrição do Processo}

Esta linha de produtos foi inaugurada em 2004. São produzidos seis modelos diferentes do mesmo produto. A linha de montagem é a mesma para todos os modelos, entretanto funciona em bateladas, sendo que um único modelo é produzido por vez. Os mapas de processo construídos, bem como o levantamento dos resíduos gerados foi realizado para um dos modelos. As etapas da montagem do produto 3 são descritas a seguir. 


\section{Célula 1}

A primeira etapa da linha de montagem do produto 3 consiste no recebimento da cavidade do produto, que já vem montada do fornecedor externo. É acoplado o suporte do injetor por meio de rebites e é encaixada a base de EPS (Figura 102).

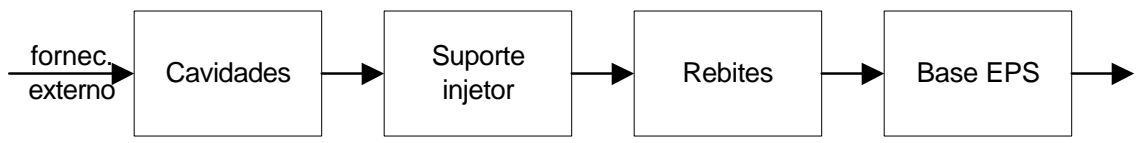

Figura 102- Mapa de processo da célula 1 da linha de montagem do produto 3.

\section{Célula 2}

Nesta etapa são realizadas as montagem da rampa, do manípulo e da mesa. É feita a junção da rampa e da mesa, que seguem para a célula seguinte (Figura 103).
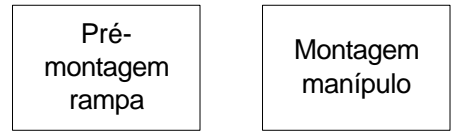

$$
\begin{gathered}
\text { Montagem } \\
\text { mesa }
\end{gathered}
$$

Figura 103 - Mapa de processo da célula 2 da linha de montagem do produto 3.

\section{Célula 3}

Na célula 3 são acoplados diversos componentes no conjunto rampa/mesa, é feita a junção entre a cavidade (preparada na célula 1) e a mesa, são realizados testes de vazamento, elétrico e de estanqueidade. São colocados a tampa de vidro superior e da estufa e a porta do forno, que são montadas nas células 4 e 5, respectivamente. Em seguida o produto está pronto para ser embalado. A Figura 104 mostra o mapa de processo desta célula.

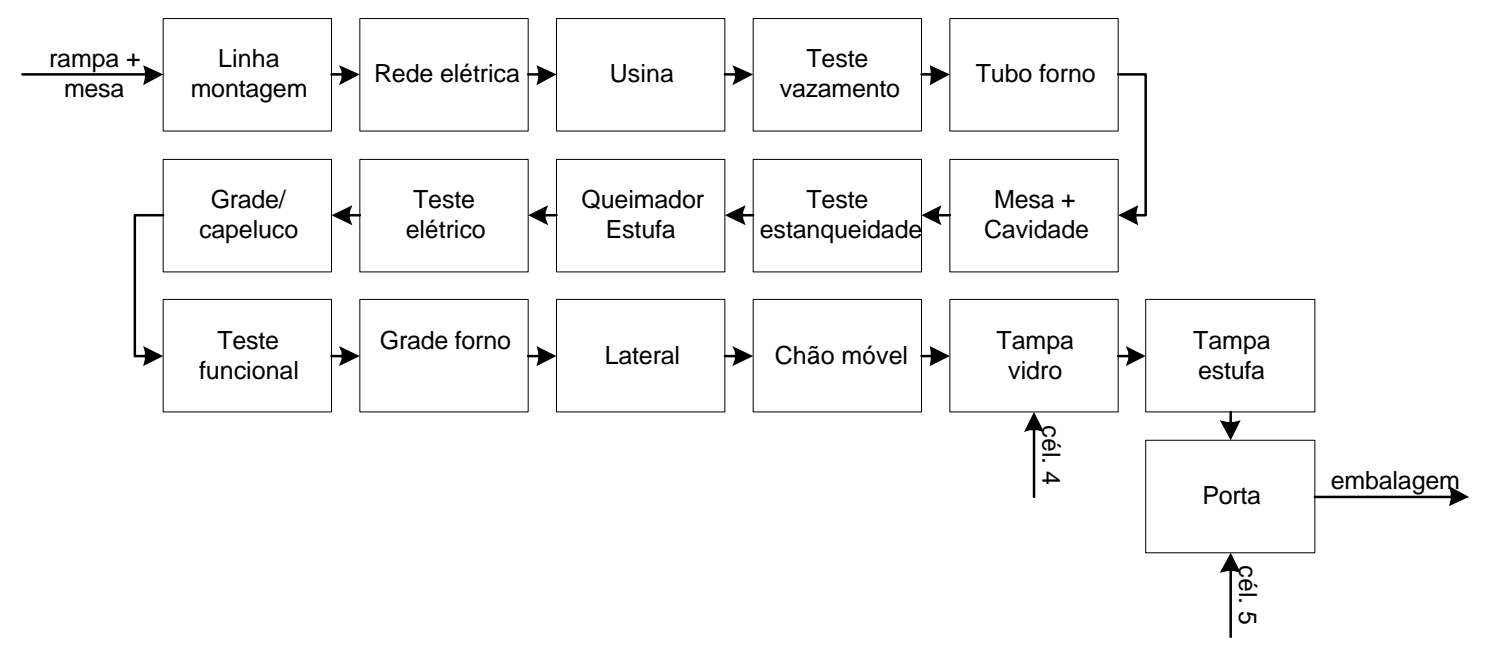

Figura 104 - Mapa de processo da célula 3 da linha de montagem do produto 3. 


\section{$\underline{\text { Célula } 4}$}

Na célula 4 é montada a tampa de vidro superior do produto, como mostra o mapa da Figura 105. Após montada a tampa segue para célula 3.

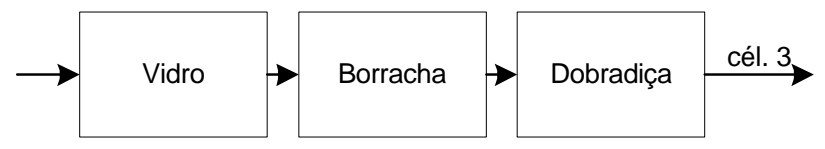

Figura 105 - Mapa de processo da célula 4 da linha de montagem do produto 3.

\section{Célula 5}

$\mathrm{Na}$ célula 5 é montada a porta do produto, que se divide em três operações distintas: montagem do vidro externo (Figura 106), montagem do vidro interno (Figura 107), e junção dos vidros externo e interno e montagem da porta (Figura 108).

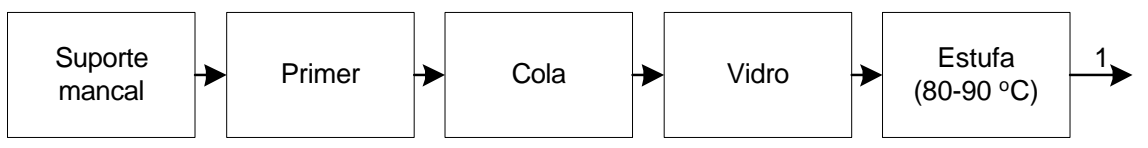

Figura 106 - Mapa de processo da montagem do vidro externo.

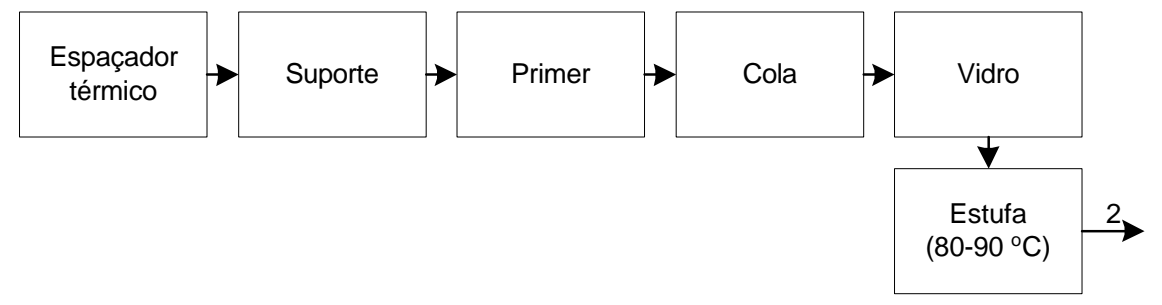

Figura 107 - Mapa de processo da montagem do vidro interno.

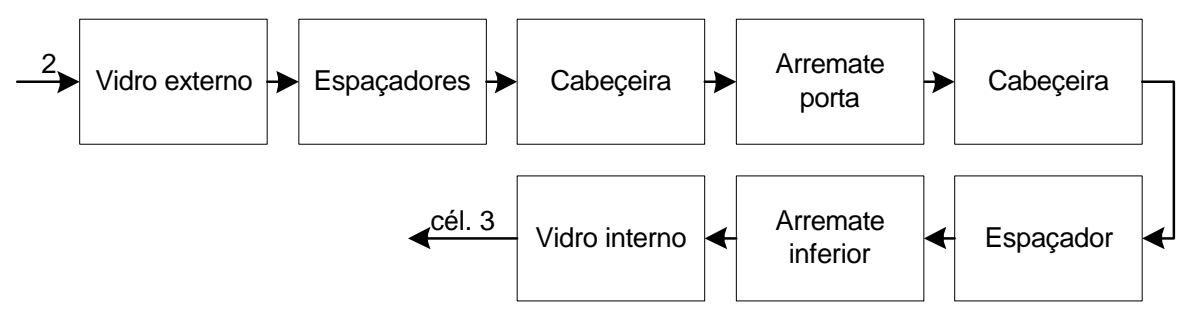

Figura 108 - Mapa de processo da montagem da porta 


\subsubsection{Características e Gerenciamento dos Resíduos}

O inventário realizado na montagem do produto 3, é mostrado na Tabela 15.

Tabela 15 - Inventário de resíduos da linha de montagem do produto 3.

\begin{tabular}{|c|c|c|c|c|c|c|c|c|}
\hline \multicolumn{2}{|c|}{ Operação } & \multirow[t]{2}{*}{ Entrada } & \multirow[t]{2}{*}{ Saída } & \multirow[t]{2}{*}{ Class. } & \multirow[t]{2}{*}{ Quantidade } & \multicolumn{2}{|c|}{ Embalagem } & \multirow[t]{2}{*}{ Destino } \\
\hline & & & & & & $\mathrm{R}$ & NR & \\
\hline \multirow{5}{*}{$\frac{\bar{\sigma}}{\frac{\sigma}{\bar{D}}}$} & \multirow{5}{*}{$\begin{array}{l}\frac{1}{0} \\
\frac{\pi}{0} \\
\frac{0}{2} \\
0 \\
0\end{array}$} & Cavidade & $\begin{array}{l}\text { Pallet } \\
\text { Jornal }\end{array}$ & $\mathrm{R}$ & n.d & $\mathrm{X}$ & & $\begin{array}{c}\text { Fornecedor } \\
\text { externo }\end{array}$ \\
\hline & & Calço & Saco plástico & $\mathrm{R}$ & n.d & & $\mathrm{X}$ & Reciclagem \\
\hline & & $\begin{array}{l}\text { Suporte } \\
\text { injetor }\end{array}$ & Cx papelão & $\mathrm{R}$ & n.d & & $\mathrm{X}$ & Reciclagem \\
\hline & & Rebites & Sucata aço/alumínio & $\mathrm{R}$ & n.d & & $\mathrm{X}$ & Reciclagem \\
\hline & & Base EPS & Fita plástica & $\mathrm{R}$ & n.d & & $\mathrm{X}$ & Reciclagem \\
\hline \multirow{8}{*}{$\frac{N}{\frac{\sigma}{J}}$} & \multirow{4}{*}{ 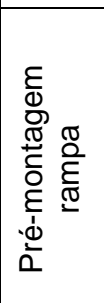 } & Suporte & Cx retornável & $\mathrm{R}$ & n.d & $\mathrm{X}$ & & Fornecedor \\
\hline & & Botões & Cx plástica retornável & $\mathrm{R}$ & n.d & $\mathrm{X}$ & & Fornecedor \\
\hline & & Registro & Cx papelão & $\mathrm{R}$ & n.d & & $X$ & Reciclagem \\
\hline & & Interruptor & Cx papelão & $\mathrm{R}$ & n.d & & $\mathrm{X}$ & Reciclagem \\
\hline & \multirow{4}{*}{ 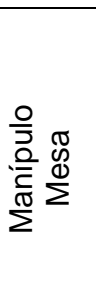 } & Manípulo & Cx plástica retornável & $\mathrm{R}$ & n.d & $\mathrm{X}$ & & Fornecedor \\
\hline & & Botões & Cx plástica retornável & $\mathrm{R}$ & n.d & $\mathrm{X}$ & & Fornecedor \\
\hline & & $\begin{array}{l}\text { Base } \\
\text { queimador }\end{array}$ & Cx papelão & $\mathrm{R}$ & n.d & & $\mathrm{X}$ & Reciclagem \\
\hline & & Cabo ignitor & Cx papelão & $\mathrm{R}$ & n.d & & $\mathrm{X}$ & Reciclagem \\
\hline \multirow{13}{*}{$\begin{array}{l}\frac{m}{\sigma} \\
\frac{\pi}{5} \\
\stackrel{d}{0}\end{array}$} & \multirow{6}{*}{ 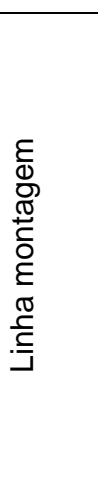 } & Tubo gás & Saco plástico & $\mathrm{R}$ & n.d & & $\mathrm{X}$ & Reciclagem \\
\hline & & Suporte & Caçamba retornável & $\mathrm{R}$ & n.d & $\mathrm{X}$ & & Fornecedor \\
\hline & & $\begin{array}{l}\text { Rede } \\
\text { elétrica }\end{array}$ & Cx plástica retornável & $\mathrm{R}$ & n.d & $\mathrm{X}$ & & Fornecedor \\
\hline & & Usina & Cx plástica retornável & $\mathrm{R}$ & n.d & $\mathrm{X}$ & & Fornecedor \\
\hline & & $\begin{array}{l}\text { Cabo } \\
\text { alimentador }\end{array}$ & Cx plástica retornável & $\mathrm{R}$ & n.d & $\mathrm{X}$ & & Fornecedor \\
\hline & & $\begin{array}{l}\text { Tubo do } \\
\text { forno }\end{array}$ & Cx papelão & $\mathrm{R}$ & n.d & & $\mathrm{X}$ & Reciclagem \\
\hline & \multirow{7}{*}{ 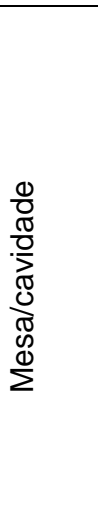 } & Parafusos & $\begin{array}{l}\text { Cx papelão } \\
\text { Saco plástico }\end{array}$ & $\mathrm{R}$ & n.d & & $\mathrm{X}$ & Reciclagem \\
\hline & & Chaminé & Pallet retornável & $\mathrm{R}$ & n.d & $\mathrm{X}$ & & Fornecedor \\
\hline & & $\begin{array}{l}\text { Queimador } \\
\text { forno }\end{array}$ & $\begin{array}{l}\text { Cx papelão } \\
\text { Embalagem retornável }\end{array}$ & $\mathrm{R}$ & n.d & $\mathrm{X}$ & $\mathrm{X}$ & $\begin{array}{l}\text { Reciclagem } \\
\text { Fornecedor }\end{array}$ \\
\hline & & $\begin{array}{l}\text { Tampa } \\
\text { traseira }\end{array}$ & Pallet retornável & $\mathrm{R}$ & n.d & $\mathrm{X}$ & & $\begin{array}{l}\text { Fornecedor } \\
\text { interno }\end{array}$ \\
\hline & & Lâmpada & Cx papelão & $\mathrm{R}$ & n.d & & $\mathrm{X}$ & Reciclagem \\
\hline & & $\begin{array}{l}\text { Protetor } \\
\text { lâmpada }\end{array}$ & Embalagem retornável & $\mathrm{R}$ & n.d & $\mathrm{X}$ & & Fornecedor \\
\hline & & Gaxeta & Cx papelão & $\mathrm{R}$ & n.d & & $\mathrm{X}$ & Reciclagem \\
\hline
\end{tabular}


Tabela 15 - Inventário de resíduos da linha de montagem do produto 3 (cont.).

\begin{tabular}{|c|c|c|c|c|c|c|c|c|}
\hline \multirow{2}{*}{\multicolumn{2}{|c|}{ Operação }} & \multirow{2}{*}{ Entrada } & \multirow[t]{2}{*}{ Saída } & \multirow[t]{2}{*}{ Class. } & \multirow[t]{2}{*}{ Quantidade } & \multicolumn{2}{|c|}{ Embalagem } & \multirow{3}{*}{$\begin{array}{l}\text { Destino } \\
\text { Reciclagem }\end{array}$} \\
\hline & & & & & & $\mathrm{R}$ & NR & \\
\hline \multirow{14}{*}{$\frac{m}{\frac{\pi}{5}}$} & \multirow{9}{*}{ 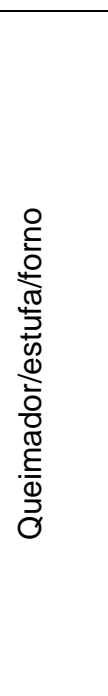 } & Parafusos & $\begin{array}{l}\text { Cx papelão } \\
\text { Saco plástico }\end{array}$ & $\mathrm{R}$ & n.d & & $\mathrm{X}$ & \\
\hline & & $\begin{array}{l}\text { Tampa } \\
\text { estufa }\end{array}$ & Pallet retornável & $\mathrm{R}$ & n.d & $\mathrm{X}$ & & $\begin{array}{l}\text { Fornecedor } \\
\text { interno }\end{array}$ \\
\hline & & $\begin{array}{l}\text { Grade } \\
\text { trempe }\end{array}$ & $\begin{array}{l}\text { Cesto aramado } \\
\text { Plástico }\end{array}$ & $\mathrm{R}$ & n.d & $X$ & & Fornecedor \\
\hline & & $\begin{array}{l}\text { Capeluco/ } \\
\text { coroa }\end{array}$ & Cx papelão & $\mathrm{R}$ & n.d & & $\mathrm{X}$ & Reciclagem \\
\hline & & Grade forno & $\begin{array}{l}\text { Pallet metálico } \\
\text { Papelão }\end{array}$ & $\mathrm{R}$ & n.d & $\mathrm{X}$ & & Fornecedor \\
\hline & & & Fita plástica & $\mathrm{R}$ & n.d & & $\mathrm{X}$ & Reciclagem \\
\hline & & Passador & Cx papelão & $\mathrm{R}$ & n.d & & $\mathrm{X}$ & Reciclagem \\
\hline & & Lateral & Pallet retornável & $\mathrm{R}$ & n.d & $\mathrm{X}$ & & $\begin{array}{l}\text { Fornecedor } \\
\text { interno }\end{array}$ \\
\hline & & Chão móvel & Caixa/jornal & $\mathrm{R}$ & n.d & $\mathrm{X}$ & & Fornecedor \\
\hline & \multirow{2}{*}{ 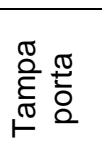 } & Rebites & Sucata aço/alumínio & $\mathrm{R}$ & n.d & & $\mathrm{X}$ & Reciclagem \\
\hline & & Parafusos & $\begin{array}{l}\text { Cx papelão } \\
\text { Saco plástico }\end{array}$ & $\mathrm{R}$ & n.d & & $X$ & Reciclagem \\
\hline & \multirow{3}{*}{ 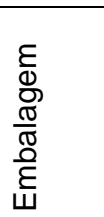 } & EPS & Fita plástica & $\mathrm{R}$ & n.d & & $\mathrm{X}$ & Reciclagem \\
\hline & & Manual & Cx papelão & $\mathrm{R}$ & n.d & & $\mathrm{X}$ & Reciclagem \\
\hline & & Folheto & Saco plástico & $\mathrm{R}$ & n.d & & $\mathrm{X}$ & Reciclagem \\
\hline \multirow{4}{*}{ 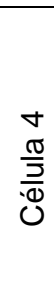 } & \multirow{4}{*}{ 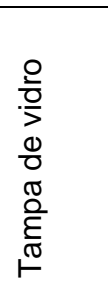 } & Vidro & $\begin{array}{l}\text { Cx madeira } \\
\text { Papel }\end{array}$ & $\mathrm{R}$ & n.d & $\mathrm{X}$ & & Fornecedor \\
\hline & & Borracha & Cx papelão & $\mathrm{R}$ & n.d & & $\mathrm{X}$ & Reciclagem \\
\hline & & Dobradiça & Pallet retornável & $\mathrm{R}$ & n.d & $\mathrm{X}$ & & $\begin{array}{l}\text { Fornecedor } \\
\text { interno }\end{array}$ \\
\hline & & Etiqueta & Saco plástico & $\mathrm{R}$ & n.d & & $\mathrm{X}$ & Reciclagem \\
\hline \multirow{10}{*}{$\begin{array}{l}\frac{0}{\pi} \\
\frac{\pi}{5} \\
\frac{1}{0} \\
0\end{array}$} & \multirow{4}{*}{ 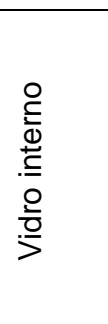 } & $\begin{array}{l}\text { Suporte } \\
\text { mancal }\end{array}$ & Pallet retornável & $\mathrm{R}$ & n.d & $\mathrm{X}$ & & $\begin{array}{l}\text { Fornecedor } \\
\text { interno }\end{array}$ \\
\hline & & Primer & Embalagem (lata) & $\mathrm{RE}$ & $\begin{array}{l}1 \text { tambor/ } \\
\text { sem }\end{array}$ & & $\mathrm{X}$ & Incineração \\
\hline & & $\begin{array}{l}\text { Cola } \\
\text { silicone }\end{array}$ & $\begin{array}{l}\text { Embalagem (310g) } \\
\text { Resíduo bico/perda }\end{array}$ & $\mathrm{RE}$ & $\begin{array}{l}1 \text { tambor/ } \\
\text { sem }\end{array}$ & & $\mathrm{X}$ & Incineração \\
\hline & & Vidro & $\begin{array}{l}\text { Cx madeira } \\
\text { Papel }\end{array}$ & $\mathrm{R}$ & n.d & $\mathrm{X}$ & & Fornecedor \\
\hline & \multirow{6}{*}{ 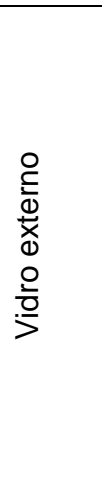 } & $\begin{array}{l}\text { Espaçador } \\
\text { térmico }\end{array}$ & $\begin{array}{l}\text { Cx papelão } \\
\text { Saco plástico }\end{array}$ & $\mathrm{R}$ & n.d & & $\mathrm{X}$ & Reciclagem \\
\hline & & Suporte & Pallet retornável & $\mathrm{R}$ & n.d & $\mathrm{X}$ & & $\begin{array}{l}\text { Fornecedor } \\
\text { interno }\end{array}$ \\
\hline & & Rebites & Sucata aço/alumínio & $\mathrm{R}$ & n.d & & $\mathrm{X}$ & Reciclagem \\
\hline & & Primer & Embalagem (lata) & $\mathrm{RE}$ & $\begin{array}{l}1 \text { tambor/ } \\
\text { sem. }\end{array}$ & & $\mathrm{X}$ & Incineração \\
\hline & & Vidro & $\begin{array}{l}\text { Cx madeira } \\
\text { Papel }\end{array}$ & $\mathrm{R}$ & n.d & $\mathrm{X}$ & & Fornecedor \\
\hline & & $\begin{array}{l}\text { Cola } \\
\text { silicone }\end{array}$ & $\begin{array}{l}\text { Embalagem (310g) } \\
\text { Resíduo bico/perda }\end{array}$ & $\mathrm{RE}$ & $\begin{array}{l}1 \text { tambor/ } \\
\text { sem }\end{array}$ & & $\mathrm{X}$ & Reciclagem \\
\hline
\end{tabular}


Tabela 15 - Inventário de resíduos da linha de montagem do produto 3 (cont.).

\begin{tabular}{|c|c|c|c|c|c|c|c|c|}
\hline \multirow{2}{*}{\multicolumn{2}{|c|}{ Operação }} & \multirow[t]{2}{*}{ Entrada } & \multirow[t]{2}{*}{ Saída } & \multirow[t]{2}{*}{ Class. } & \multirow[t]{2}{*}{ Quantidade } & \multicolumn{2}{|c|}{ Embalagem } & \multirow[t]{2}{*}{ Destino } \\
\hline & & & & & & $\mathrm{R}$ & $\mathrm{NR}$ & \\
\hline \multirow{8}{*}{$\begin{array}{l}\frac{\pi}{\frac{\pi}{3}} \\
\frac{3}{0} \\
0\end{array}$} & \multirow{8}{*}{ 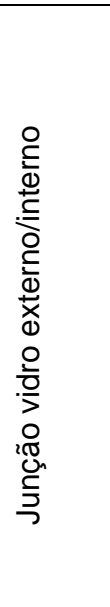 } & $\begin{array}{l}\text { Bucha } \\
\text { metálica }\end{array}$ & Saco plástico & $\mathrm{R}$ & n.d & & $\mathrm{X}$ & Reciclagem \\
\hline & & Cabeceira & Pallet retornável & $\mathrm{R}$ & n.d & $\mathrm{X}$ & & $\begin{array}{l}\text { Fornecedor } \\
\text { interno }\end{array}$ \\
\hline & & Arremate & $\begin{array}{l}\text { Cx madeira } \\
\text { Papel }\end{array}$ & $\mathrm{R}$ & n.d & $\mathrm{X}$ & & Fornecedor \\
\hline & & $\begin{array}{l}\text { Peças } \\
\text { borracha }\end{array}$ & Cx papelão & $\mathrm{R}$ & n.d & & $\mathrm{X}$ & Reciclagem \\
\hline & & Puxador & Cx plástica retornável & $\mathrm{R}$ & n.d & $\mathrm{X}$ & & Fornecedor \\
\hline & & & $\begin{array}{l}\text { Papelão } \\
\text { Saco plástico }\end{array}$ & $\mathrm{R}$ & n.d & & $\mathrm{X}$ & Reciclagem \\
\hline & & Dobradiça & Pallet retornável & $\mathrm{R}$ & n.d & $\mathrm{X}$ & & $\begin{array}{l}\text { Fornecedor } \\
\text { interno }\end{array}$ \\
\hline & & Rebites & Sucata aço/alumínio & $\mathrm{R}$ & n.d & & $\mathrm{X}$ & Reciclagem \\
\hline
\end{tabular}

\subsection{Central de Resíduos}

Os resíduos gerados em todas as áreas da empresa, e que não são retornados aos fabricantes são enviados para a Central de Resíduos, onde são agrupados por categoria e comercializados, no caso dos recicláveis, ou encaminhados para incineração, co-processamento ou disposição em aterro, no caso dos resíduos especiais. A Figura 109 mostra uma foto de parte da área da Central de Resíduos, com detalhe para uma caçamba de papelão. Na Figura 110 pode-se ver o kit de emergência, que é usado para a limpeza de derramamento de óleo nas áreas da planta industrial. Este resíduo, que é gerado eventualmente, é acondicionado em tambores em encaminhado para incineração.

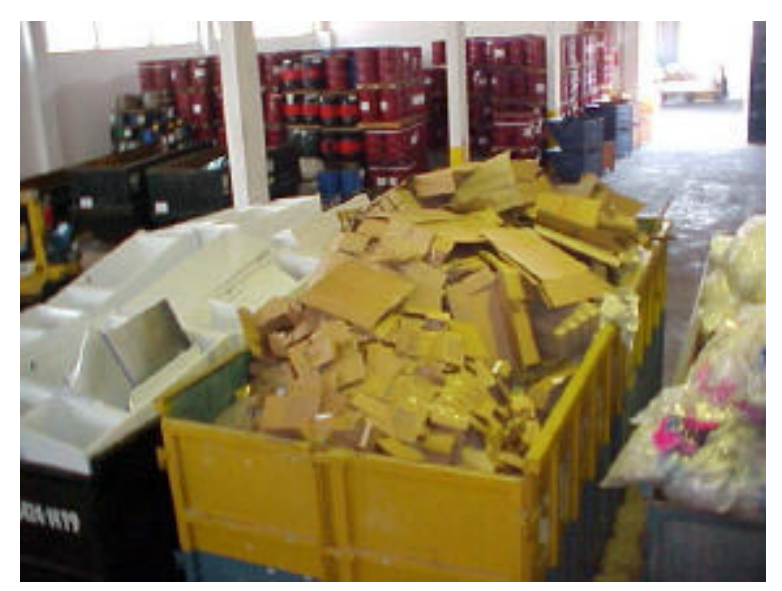

Figura 109- Central de resíduos.

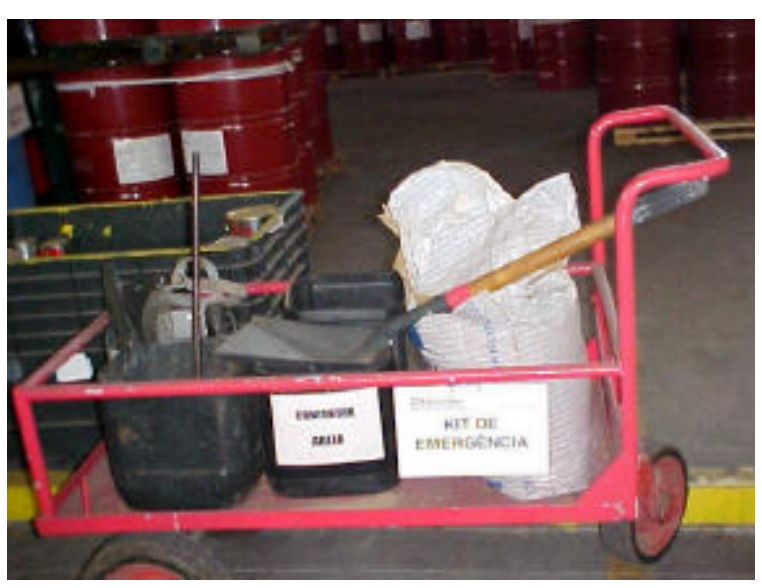

Figura 110- Kit de emergência. 
A Figura 111 mostra a área de armazenagem de tambores com resíduos para incineração e/ou co-processamento, e a Figura 112 mostra uma caçamba com resíduos de plástico.

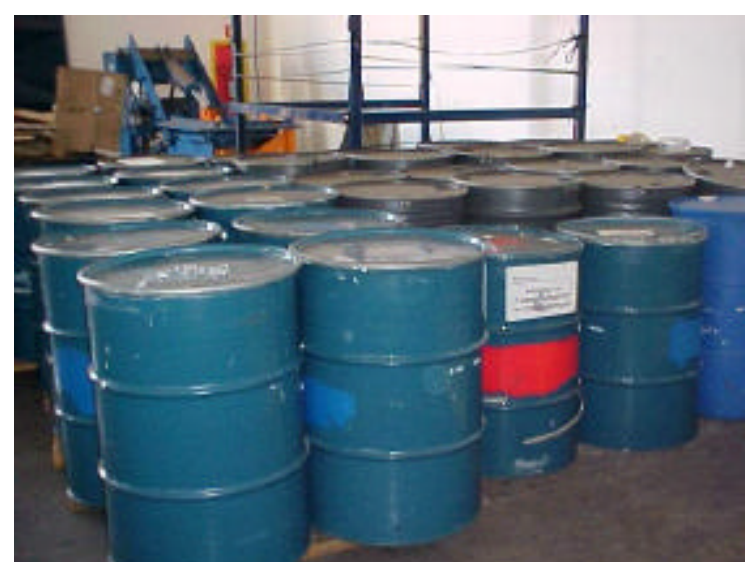

Figura 111 - Tambores com resíduos.

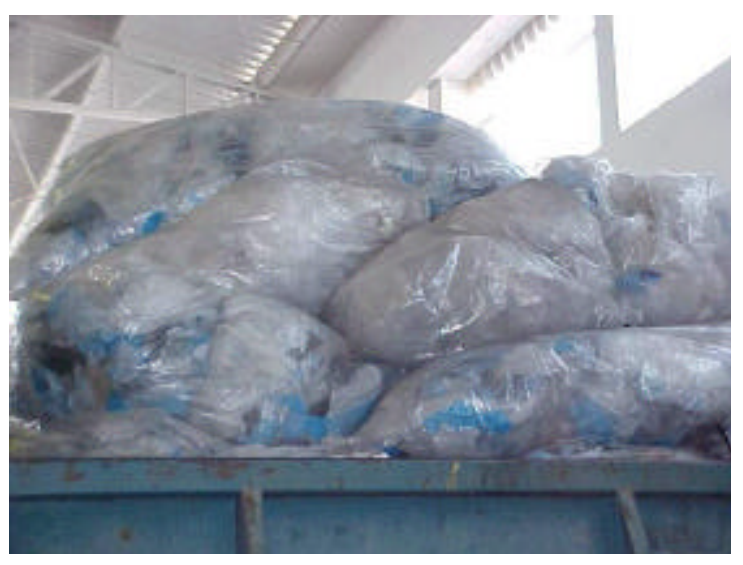

Figura 112 - Resíduos de plásticos.

A Figura 113 mostra uma caçamba com sucata metálica, constituída por gabinetes que já foram tratados e pintados, e que sofreram algum tipo de dano no processo (falhas na pintura, danos decorrentes do manuseio e transporte nas áreas de estocagem e nas linhas de montagem, etc). A Figura 114 mostra um cesto onde são acondicionadas as luvas gastas.

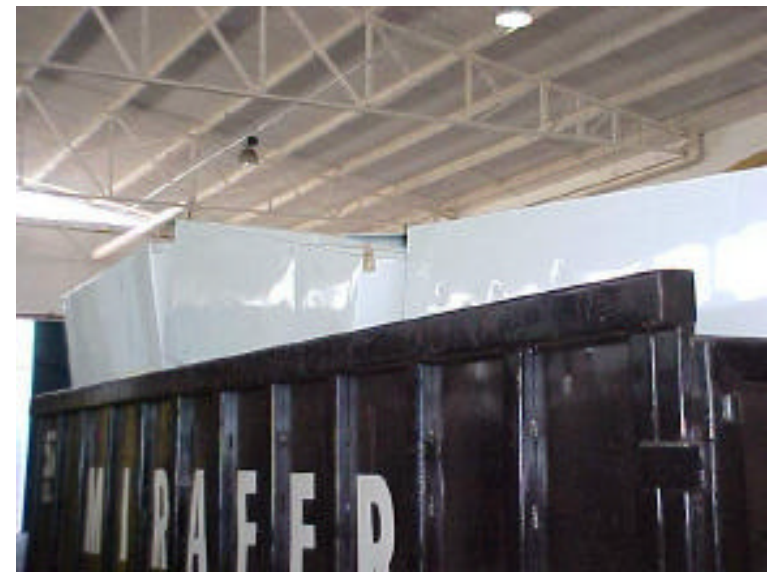

Figura 113 - Sucatas metálicas.

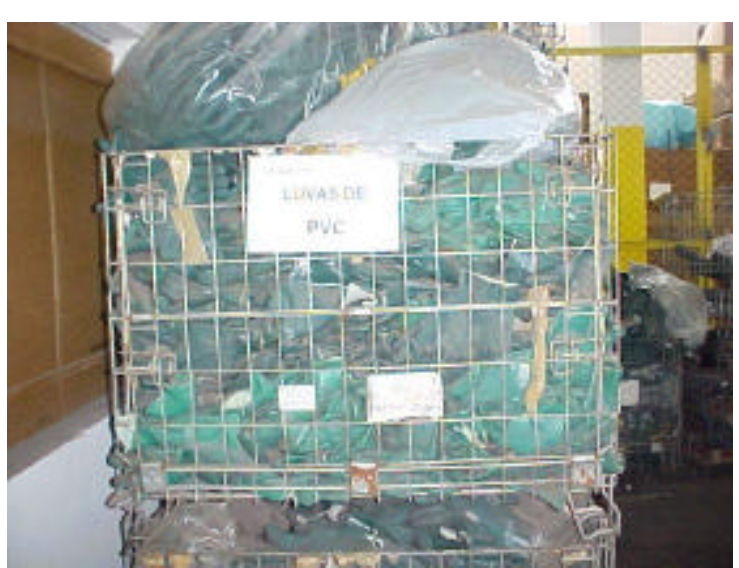

Figura 114 - Resíduos de luvas de PVC.

O gráfico da Figura 115 mostra a quantidade, em toneladas por ano, de resíduos recicláveis (papelão e plásticos) comercializada pela central de resíduos. Os plásticos são divididos em aparas de plástico, provenientes de sacos plásticos, em plásticos diversos (embalagens) e em plástico moído, proveniente de peças e perdas na área 
de plásticos. Neste gráfico não estão incluídos os resíduos de madeira e a sucata metálica produzida na área de metalurgia.

O gráfico da Figura 116 mostra a quantidade total de resíduos (incluindo os resíduos de madeira e a sucata metálica), em toneladas por ano, que são enviados para incineração, dispostos em aterro e comercializados para reciclagem. Os resíduos incinerados incluem o resíduo hospitalar gerado no ambulatório, resíduo de varrição da fábrica, terra e serragem contaminada com óleo, plásticos e EPI's contaminados com óleo e a torta da ETE. Os resíduos enviados para disposição em aterro incluem resíduos orgânicos de varrição e jardinagem, resíduos do restaurante e outros resíduos não recicláveis, gerados nas diversas áreas da planta. Os dados utilizados são referentes ao ano de 2003.

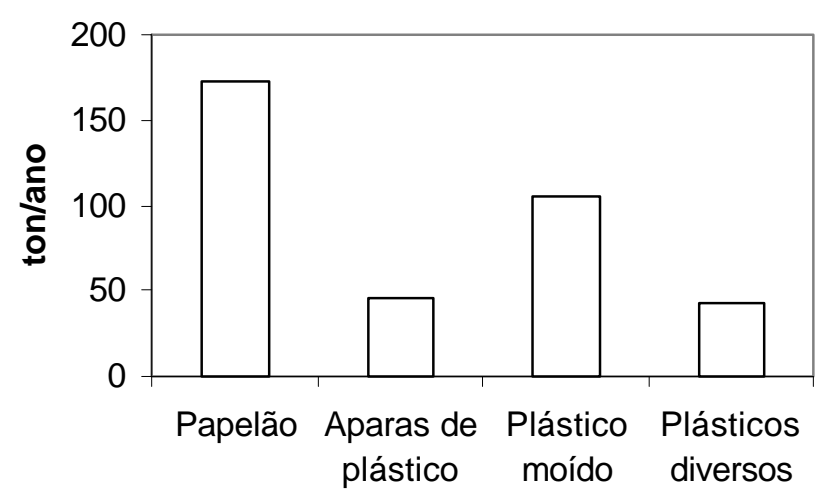

Figura 115 - Resíduos recicláveis

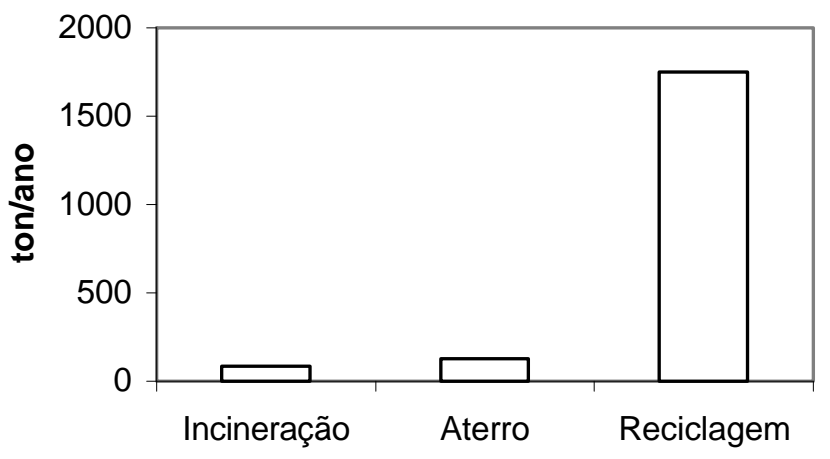

Figura 116 - Destinação final dos resíduos 


\subsection{Análise e Discussão dos Resultados}

\subsubsection{Ferramentas e Sistemática da Pesquisa}

A principal ferramenta de apoio usada no processo de identificação de oportunidades de prevenção àpoluição foi o mapeamento de processo. A construção dos mapas envolveu diversas visitas a área industrial para refinamento $\mathrm{e}$ aprimoramento dos mesmos. Esta ferramenta se mostrou bastante eficiente. A partir dos mapas de processo criados foi possível realizar o inventário de resíduos das áreas de montagem, que agregam um número muito grande de operações e muitas entradas e saídas, e de outro modo não seria possível realizar este levantamento. $O$ fato de ser uma ferramenta visual também ajudou na etapa de tabulação dos dados, facilitando o processo de busca de informações com o pessoal da área.

Particularmente no que se refere ao levantamento realizado na área de pintura, o mapeamento do processo possibilitou a reclassificação da borra gerada na ETE, que de Classe I para Classe IIA. Com isso a empresa pode avaliar outro método de disposição final, que não seja o co-processamento. Segundo a média dos valores que a ABRELPE fornece para as diferentes tecnologias de disposição/tratamento de resíduos, para co-processar 120 toneladas de borra, a empresa gasta em média $R \$$ $\mathrm{R} \$ 42.000,00$ por ano. Se o resíduo for enviado para um aterro Classe II, o custo fica em torno de $\mathrm{R} \$ 9.000,00$ por ano.

Através da avaliação realizada, identificou-se que a empresa já possui uma série de práticas de prevenção àpoluição implantadas, apesar de não possuir um programa formal de prevenção à poluição, e não fornecer treinamento específico aos funcionários.

Segundo o que foi apresentado no Capítulo IV desta Tese, todas as etapas do planejamento da prevenção à poluição requerem o envolvimento e o trabalho em grupo, para que um número maior de oportunidades sejam identificadas. Isso não foi possível neste trabalho, dadas as próprias limitações do mesmo. No entanto, mesmo assim foram identificadas algumas oportunidades que a empresa poderá avaliar de forma mais detalhada. 


\subsubsection{Práticas de Prevenção àPoluição Existentes}

Durante o mapeamento do processo verificou-se que a empresa possui uma série de estratégias de prevenção implantadas, algumas compatíveis com aquelas identificadas no Capítulo $V$, outras derivadas de idéias e práticas que surgiram da necessidade de melhorar operações de rotina nos processos.

\subsubsection{Metalurgia}

As características do processo de corte e estampagem das peças dispensa o uso de fluidos de corte. As chapas já chegam na planta cobertas por um filme de óleo protetivo, que fornece a lubrificação necessária.

Existe uma preocupação em reduzir a quantidade de material perdido na forma de sucata, e o indicador de qualidade da área é a quantidade de sucata produzida. Um projeto está atualmente sendo conduzido com o objetivo de otimizar o layout de corte e reduzir a quantidade de sucata por peça produzida.

Para reduzir a quantidade de EPI descartado, foi adotada uma planilha de controle, na qual é identificada quantas vezes cada funcionário requisita equipamentos de segurança, principalmente luvas. Esta prática reduziu sensivelmente o consumo de EPIs na área.

$\mathrm{Na}$ central de corte, as chapas cortadas eram empilhadas e arqueadas por uma cinta de aço, para possibilitar o transporte das mesmas para as outras áreas. Foi feita a substituição das cintas de aço, por tensionadores de nylon reutilizáveis (Figura 117).
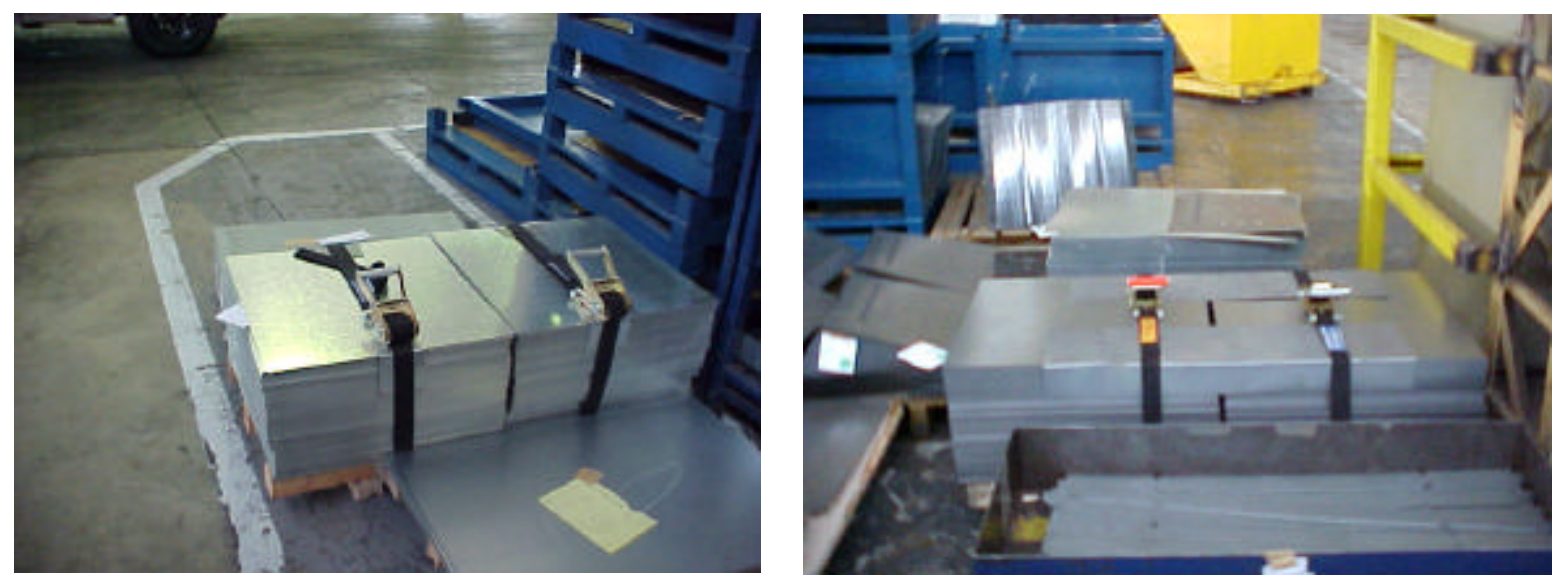

Figura 117- Tensionadores de nylon usados na central de corte.

Esta prática eliminou o uso e o descarte de cintas de aço, o que resultou em uma economia de $\mathrm{R} \$ 800,00$ por mês. Reduziu ainda o risco de os funcionários sofrerem cortes nas mãos ao desatar a cinta, e o consumo de luvas. 


\subsubsection{Tratamento de Superfícies e Pintura}

No tratamento de superfícies foram identificadas uma série de estratégias compatíveis com o que é recomendado na literatura técnica. Estas modificações vêm ocorrendo ao longo dos últimos anos, em decorrência da necessidade de aquisição de processos mais eficientes, da política corporativa da empresa, e do atendimento aos requisitos da ISO 14001, pela qual a empresa é certificada desde 2001.

No processo de desengraxe, é usado o desengraxe aquoso alcalino, um processo eficiente na limpeza de óleos e outras contaminações, de operação relativamente simples, que gera poucas emissões atmosféricas e não apresenta riscos àsaúde dos funcionários. O desengraxante é recebido em bombonas de $250 \mathrm{~kg}$, que são retornadas ao fabricante. Como foi mostrado na Figura 73, a solução do tanque de desengraxe II é enviada ao tanque de desengraxe I, ao invés de ser descartada. O mesmo acontece no tanque de enxague II. Estas práticas resultam na redução do consumo de água e de insumos.

No processo de fosfatização, o banho é formado por uma solução de fosfato tricatiônico, que segundo o que foi apresentado no Capítulo V, é a formulação mais eficiente. Uma modificação realizada neste processo, há cerca de três anos eliminou a etapa de filtragem a vácuo e a geração de borra de fosfato. A modificação consistiu na substituição das chapas usadas como matéria-prima principal do processo. Anteriormente eram usadas chapas de aço-carbono, o que gerava muita borra no processo e consumia uma quantidade maior de acelerador. As chapas foram substituídas por chapas de aço galvanizado minimizado (nas partes que não levam solda) e aço zincado galvanil (propício para peças que são soldadas).

No processo de passivação, é usado um passivante inorgânico a base de ácido hexafluorzircônico, isento de cromo. Esta modificação, além de eliminar riscos àsaúde dos funcionários, reduziu a toxicidade da borra do processo, que passou de Classe I para Classe IIA.

Parte da água usada no enxague da fosfatização é reciclada no processo, contribuindo para a redução do consumo de água. Existe um desejo por parte da empresa de fechar o circuito da água, entretanto, segundo o supervisor da área, isso iria requerer a expansão da estação de tratamento de efluentes, e na planta não existe espaço físico disponível para isso.

A pintura é realizada através do processo de pintura eletrostática a pó, em cabine fechada, o que elimina emissões atmosféricas e permite a recuperação do pó que não é transferido para a peça. A tinta é recebida em big bags, que são retornados ao 
fabricante, bem como o pó que é recuperado na cabine e que devido a especificação e granulometria não pode ser reutilizado no processo.

Nas estufas de secagem e de cura, o aquecimento é realizado pela queima de gás natural, o que produz uma quantidade menor de emissões atmosféricas.

\subsubsection{Linhas de Montagem}

Nas linhas de montagem são geradas grandes quantidades de embalagens dos mais diversos tipos. Até recentemente a maior preocupação da empresa era garantir a segregação das embalagens na fonte, para possibilitar a reciclagem deste material. A análise dos inventários realizados nas três linhas de montagem revela que a linha de montagem do produto 3 apresenta a maior quantidade de embalagens retornáveis. Isto decorre do fato da linha ser nova, foi inaugurada em 2004, e já na etapa de projeto do produto e do processo houve a preocupação de adquirir grande parte dos componentes em embalagens retornáveis.

\subsubsection{Oportunidades Identificadas}

De maneira geral, as oportunidades de prevenção à poluição identificadas envolvem a redução dos resíduos de embalagens.

$\mathrm{Na}$ área de pintura, como foi mostrado na Tabela 12, apenas as bombonas de 250 kg são retornáveis. Esta prática poderia se estender a todos os insumos usados no tratamento de superfícies e na estação de tratamento de efluentes. Outra questão que pode ser considerada é a possibilidade de usar o efluente tratado na ETE nas descargas dos sanitários da planta.

Na célula 1 da linha de montagem do produto 1 , o produto é tombado na esteira, para que o compressor seja acoplado na parte inferior. Quando o produto volta a sua posição original, é feita a limpeza manual da parte superior do produto, que ficou em contato com a esteira. Esta operação consome em média duas embalagens de um limpador comercial por turno, além de buchas, panos e luvas de borracha. Outro problema desta operação, é o esforço repetitivo que o funcionário precisa fazer para executar a limpeza (a cada duas horas é feito o rodízio do funcionário encarregado desta tarefa). Esta operação pode ser eliminada se for colocada uma placa de proteção entre o produto e a esteira, para evitar o contato do produto com graxas e outras sujeiras ali presentes. Esta placa pode ser confeccionada de plástico poli-onda, ser colocada na esteira no momento do tombamento do produto, e ser removida 
quando o produto volta a sua posição original, e retornada ao início da célula 1 para ser utilizada novamente.

Na célula 5 da linha de montagem do produto 3 é usada uma cola adesiva de silicone para fazer a junção dos vidros interno e externo. Essa cola é colocada em uma pistola aquecida para facilitar a aplicação. Quando a pistola fica parada, a cola seca no bico e dentro do tubo, e grande parte do material tem que ser descartado (dependendo do caso, o tubo todo é descartado). Esta operação, juntamente com a embalagem da cola, representa a maior fonte de geração de resíduos especiais, e deve ser analisada para verificar se não existe a possibilidade de substituir a cola usada atualmente por outra que não apresente este problema.

Os inventários realizados nas linhas de montagem trazem uma série de informações, como mostram as Tabelas 13, 14 e 15. Esta tabulação de dados requisitou diversas visitas a área, e consumiu grande parte do tempo empreendido no levantamento de dados. Estes dados podem ser usados como uma base inicial para elaborar um programa de trabalho junto aos fornecedores, visando aumentar a quantidade de embalagens retornáveis que entram no processo, e diminuir o volume de resíduos que precisam ser manuseados, armazenados e encaminhados para a reciclagem. Apesar da comercialização destes resíduos representar uma renda positiva, do ponto de vista ambiental e de acordo com o conceito de prevenção à poluição, a reciclagem fora do processo só deve ser empregada quando não existir uma alternativa viável para eliminar a geração dos resíduos.

\subsubsection{Recomendações para a Empresa}

Durante todo o período no qual foi realizada a pesquisa, percebeu-se que existe um comprometimento da empresa e dos funcionários em buscar a melhoria contínua do sistema de gestão ambiental, e existe entre os funcionários a consciência do seu papel neste processo. Todas as áreas que foram visitadas possuem boas condições de limpeza, aparência e higiene, e participam do programa de coleta seletiva da empresa. Não foi detectado nenhum uso de produto ou geração de resíduo que representasse risco à saúde dos funcionários, às áreas circunvizinhas e ao meio ambiente.

A empresa não possui um programa de prevenção àpoluição formalizado, apesar de o comprometimento com a prevenção à poluição estar presente na sua política ambiental institucional. Outro fato detectado, é que poucas pessoas conhecem ou ouviram falar de prevenção àpoluição e/ou produção mais limpa, no entanto, estas 
pessoas demonstram interesse em aprender mais sobre estes conceitos e buscar alternativas para implantação. Existem algumas estratégias de prevenção à poluição implantadas em diversas áreas, fruto de trabalhos isolados, na maioria dos casos visando resolver problemas pontuais de cada área.

A adoção de um programa de prevenção à poluição, integrado ao sistema de gestão ambiental, poderia estimular os funcionários a apresentar sugestões e a prestar atenção æ̀ suas rotinas de trabalho, buscando alternativas para melhorar as práticas operacionais e reduzir o desperdício de material. Em algumas situações durante a coleta de dados na planta, ouviu-se de funcionários: "(...) este material vai para a central de resíduos, mas acho que poderia retornar ao fornecedor...". Este tipo de comentário indica que, apesar destes funcionários não terem sido treinados sobre práticas de prevenção àpoluição, eles têm consciência de que existe uma alternativa melhor do que a reciclagem, que é a não geração do resíduo em primeiro lugar.

Com base nessas observações e nos dados obtidos na avaliação do processo, recomenda-se àempresa as seguintes ações:

* Fornecer treinamento em prevenção à poluição/produção mais limpa em um primeiro momento aos responsáveis pela área ambiental e pelo sistema de gestão ambiental, e aos supervisores das áreas;

* Promover palestras e treinamentos sobre prevenção à poluição aos funcionários de cada área (estas palestras podem ser proferidas por consultores externos ou pelos próprios funcionários que já estiverem treinados), como forma de estimular a participação e o surgimento de idéias, que muitas vezes existem e são muito boas, mas acabam sendo deixadas de lado pela falta de oportunidade de expressá-las;

* Criar objetivos e metas de melhoria contínua do sistema de gestão ambiental que envolvam práticas de prevenção àpoluição;

* Adotar indicadores de produção sustentável, que exprimam os objetivos e metas relacionadas àprevenção àpoluição;

* Criar um registro dos objetivos alcançados e da evolução dos resultados e benefícios. Divulgar os resultados internamente nos boletins informativos já existentes ou por meio de quadros de notas, e externamente por meio de folders ou publicação de notas técnicas e artigos em revistas da área, que tenham circulação no meio empresarial; 
* Participar ativamente de programas de prevenção à poluição/produção mais limpa, como a Mesa Redonda Paulista de Produção mais Limpa, incentivar os funcionários a participar dos treinamentos, palestras e seminários promovidos, divulgar os resultados alcançados, promovendo a troca de experiências; e,

* Usar as ferramentas estruturadas para identificação de oportunidades apresentadas neste trabalho, bem como os dados já levantados para dar continuidade ao processo de identificação de oportunidades, estendendo-o æ̀s outras áreas e contando com uma participação e envolvimento mais ativo dos responsáveis e funcionários.

\subsubsection{Limitações do Estudo}

O estudo realizado no processo produtivo possibilitou levantar questões gerais, sem muita especificidade, devido ao fato de ter sido realizado por uma pessoa externa à rotina diária da empresa, sem um conhecimento profundo de cada processo e operação executada nas áreas analisadas.

As áreas analisadas são relevantes devido a grande quantidade de operações e materiais envolvida. Entretanto, não foi realizada uma avaliação das operações de limpeza e manutenção, que normalmente geram quantidades consideráveis de resíduos e fornecem boas oportunidades de prevenção àpoluição.

Os dados coletados e apresentados neste trabalho são representativos da realidade, mas não foram normalizados em termos de unidades produzidas. A normalização fornece uma informação mais precisa da quantidade de resíduos e perdas que ocorrem na manufatura de determinado produto, possibilitando a priorização das ações a serem efetuadas e facilitando o processo de tomada de decisão.

Finalmente, a falta de indicadores de desempenho específicos para os processos estudados (bem como dados de monitoramento do desempenho destes processos), inviabilizou a avaliação das operações efetuadas nas áreas, no que se refere ao desempenho ambiental. Não foi possível contar com um parâmetro de comparação, que assegurasse que os processos, tecnologias e equipamentos usados na planta industrial, bem como as medidas de gerenciamento de resíduos e as práticas operacionais empregadas representam as melhores alternativas disponíveis. 


\section{CAPÍTULO VII}

\section{CONCLUSÃO}

Com base nos resultados obtidos neste trabalho, pôde-se concluir que a identificação de oportunidades de prevenção à poluição requer um planejamento sistêmico, apoiado por ferramentas estruturadas, que permitam o entendimento das causas do problema e a identificação de alternativas potenciais para a sua solução. Para se realizar o planejamento é necessário que em primeiro lugar seja efetuada a quantificação das perdas (desperdício de materiais, água, energia e outros recursos) do processo produtivo e da geração de resíduos, o que pode representar um grande desafio especialmente para as pequenas empresas, que geralmente apresentam elevados índices de desperdício, sem qualquer tipo de avaliação quantitativa destas perdas. Neste sentido, a contabilidade ambiental se apresenta como uma valiosa ferramenta de convencimento em favor da adoção de práticas de prevenção à poluição, ao mostrar os reais custos que a empresa pode ter com relação ao desperdício de recursos, com o tratamento e disposição de resíduos (além dos custos regulatórios ocultos), e também os custos contingenciais, relacionados a ações futuras necessárias àremediação de problemas decorrentes de suas ações presentes.

A falta de conscientização por parte das empresas em relação aos benefícios que a adoção de práticas de prevenção à poluição pode lhes trazer se apresenta como uma importante barreira a ser superada. De maneira geral, as empresas buscam soluções rápidas, com fórmulas prontas, que resolvam seu problema de imediato. Este tipo de postura não permite uma avaliação profunda das causas do problema, nem garante que a resposta encontrada seja a melhor alternativa disponível. É extremamente importante ressaltar que não existe uma receita pronta quando se pensa em prevenção à poluição. Cada processo produtivo, de cada empresa, apresenta particularidades que dependem de diversos fatores. Para que a melhor alternativa possa ser encontrada, o processo produtivo precisa ser pensado e re- 
pensado. Muitas vezes a melhor alternativa simplesmente não existe: precisa ser criada.

O processo de criação, por sua vez, está intimamente relacionado ao treinamento e a motivação, e estes, não podem estar desvinculados um do outro. Treinar implica em formar agentes multiplicadores motivados, capazes de ensinar fazendo, e de buscar alternativas dentro do próprio processo produtivo (com o qual estão familiarizados), expandindo a cultura da prevenção à poluição, suas conquistas e experiências aos demais funcionários.

A falta de treinamento, aliada à carência de informações sobre as práticas e as ferramentas de prevenção àpoluição se apresentam como desafios a serem vencidos para que o conceito de prevenção à poluição possa nortear as práticas de gestão ambiental nas indústrias. Assim sendo, as universidades podem contribuir de forma decisiva, adequando os currículos dos cursos de engenharia, para que os princípios de prevenção à poluição permitam aos futuros profissionais incluir as conseqüências ambientais nos seus processos de tomada de decisão, assim como o fazem em relação aos aspectos econômicos. Os centros de pesquisa podem contribuir na divulgação e propagação de práticas de prevenção à poluição, através do desenvolvimento de estudos de caso, da avaliação de ferramentas, do desenvolvimento de tecnologias limpas e do estudo e identificação de indicadores de desempenho.

A prevenção à poluição precisa ser difundida como cultura, o que exige a integração entre o poder público, as universidades e instituições de pesquisa, as empresas e a sociedade como um todo. É preciso integrar para somar esforços, e a partir da integração é que será possível atingirmos o nível da produção e do consumo sustentável. É preciso que sejam formados profissionais tecnicamente treinados e ambientalmente conscientes. É preciso que sejam criadas parcerias efetivas entre o setor produtivo e as universidades. É preciso que se desenvolva na sociedade uma consciência ambiental intuitiva, sem a necessidade de cobranças por meio de mecanismos regulatórios, e que esta mesma sociedade passe a atuar de maneira mais pró-ativa e ambientalmente responsável, mudando o foco dos 3R's (reduzir, reutilizar, reciclar), para os $5 R^{\prime}$ s: reduzir, reutilizar, reciclar, repensar e recusar. $O$ cidadão ambientalmente consciente e bem informado tem o direito de avaliar seus hábitos de consumo e de recusar o que julgar inadequado aos seus princípios ambientais. 
A avaliação do processo produtivo que foi realizada durante esta pesquisa foi fundamental para confirmar com dados práticos o que foi levantado na teoria. A metodologia empregada para a avaliação do processo produtivo mostrou-se adequada. Mesmo com as limitações da pesquisa, a avaliação realizada no processo confirmou que o uso da abordagem sistêmica na identificação de oportunidades permite identificar aspectos que normalmente passam desapercebidos nos métodos de avaliação tradicionais, baseados na identificação e solução dos problemas de forma pontual. Entretanto, convém salientar que um maior número de oportunidades de prevenção àpoluição teria sido identificado se tivesse havido uma maior discussão e envolvimento dos funcionários responsáveis por cada operação do processo produtivo, o que dadas as condições da pesquisa não foi viável.

É conveniente aqui novamente citar Wanzenried, et al. (1999), que relata que a abordagem sistêmica é mais adequada quando o processo é grande e complexo, e já passou por uma avaliação prescritiva, e quando a companhia não está interessada em uma modificação de alto custo, ou seja, quando as oportunidades de prevenção à poluição são extremamente sutis. Este relato se ajusta perfeitamente ao que foi detectado na prática. A empresa já possuía uma série de estratégias implantadas, a maioria envolvendo modificações do processo, com adoção de novas tecnologias, envolvendo custos relativamente altos. Para que novas oportunidades sejam identificadas, é preciso uma investigação detalhada e criteriosa, envolvendo aspectos relacionados æ̀ rotinas e práticas operacionais e a participação efetiva dos agentes envolvidos.

Ainda com relação àavaliação do processo produtivo, a comparação das práticas de prevenção àpoluição implantadas na empresa com aquelas sugeridas nos manuais de prevenção à poluição consultados, permitiu uma avaliação representativa, porém superficial da performance ambiental dos processos e operações analisadas. $O$ uso de indicadores (que refletissem as entradas e saídas de material por unidade de produto e de processo) teria permitido uma avaliação mais criteriosa e uma indicação mais precisa dos problemas que precisam ser avaliados e resolvidos. Cabe lembrar, que nem sempre um processo considerado limpo e eficiente, pode de fato estar refletindo estes adjetivos, pois é necessário que se avaliem as matérias-primas e insumos empregados, bem como o controle e a operação do processo.

Finalizando, esta pesquisa mostra que não há como desvincular a teoria da prática quando se busca o entendimento e soluções para os problemas ambientais. Dada a complexidade do tema, para que a teoria vá ao encontro da prática, é necessário muito esforço concentrado e muita motivação! Neste sentido, espero que este trabalho 
tenha contribuído como fonte de informação e de inspiração, e que possa nortear pesquisas futuras complementares a esta. 


\section{Sugestões de Pesquisas Futuras}

A partir dos resultados obtidos neste trabalho, sugere-se os seguintes estudos que permitiriam uma continuidade das atividades de pesquisa em prevenção àpoluição:

* Analisar os processos de desengraxe, tratamento de superfícies e pintura individualmente, buscando desenvolver indicadores de desempenho, e elaborar manuais para divulgação das melhores tecnologias disponíveis para estes processos, com base no conceito de prevenção àpoluição;

* Desenvolver conjuntos de indicadores de produção sustentável para diferentes processos e avaliar sua eficácia através da aplicação em diferentes processos de um mesmo setor;

* Levantar na literatura técnica especializada as alternativas de prevenção à poluição para diferentes processos industriais e serviços, aliando este levantamento a trabalhos de campo, de forma a elaborar manuais para divulgação de práticas de prevenção àpoluição que sejam compatíveis com as reais necessidades das indústrias;

* Desenvolver estudos de viabilidade econômica de diferentes alternativas de prevenção àpoluição aplicáveis a processos e serviços específicos;

* Desenvolver estudos de caso para os diversos processos industriais (podendo também considerar a aplicação do conceito de prevenção à poluição a serviços), utilizando as ferramentas estruturadas apresentadas no Capítulo IV;

* Desenvolver trabalhos de divulgação e conscientização sobre os benefícios das práticas de prevenção àpoluição em micro, pequenas e médias empresas;

* Desenvolver estudos de aplicação de práticas de prevenção à poluição em micro, pequenas e médias empresas. 


\section{REFERÊNCIAS BIBLIOGRÁFICAS}

A INICIATIVA privada já avança para o estágio da prevenção. (2002). Gazeta Mercantil, 27 jun. Seção Geral, p.1.

ADAMS, W.M. (1990). Green Development: Environment and Sustainability in Third World. London: Routledge.

ALLEN, D.T,. SHONNARD, D.R. (2002). Green Engineering - Environmentally Conscious Design of Chemical Processes. $1^{\text {st }}$ ed. New York: Prentice Hall Inc.

ALMEIDA, M.C. (2002). Estudo do Ciclo de Vida do Pneu Automotivo e Oportunidades para a Disposição Final de Pneus Inservíveis. Dissertação (mestrado). Departamento de Engenharia de Materiais. Universidade Federal de São Carlos. São Carlos, 2001.

ALMEIDA, J.R., MELLO, C.S., CAVALCANTI, Y. (2004). Gestão Ambiental: Planejamento, Avaliação, Implantação, Operação e Verificação. $2^{2}$ ed., rev. e atualizada. Rio de Janeiro: Thex Ed.

ALVES, F. (1998). O que está sendo feito com os Resíduos Industriais? Revista Saneamento Ambiental, no 54, p. 16-24.

ANASTAS, P.T., LANKEY, R.C. (2002). Sustainability through Green Chemistry and Engineering. In: LANKEY, R.L., ANASTAS, P.T. (editores). Advancing Sustainability through Green Chemistry and Engineering. International Workshop on Green Chemistry and Engineering. Washington: American Chemical Society, p.1-7.

ANDERBERG, S. (1998). Industrial metabolism and the linkages between economics, ethics and the environment. Ecological Economics, n.24, p.311-320.

ARANGO-ALZATE, C.T., KRUGLIANSKAS, I. (1999). A Indústria Química Brasileira e o Programa "Atuação Responsável": o caso de uma empresa nacional. Caderno de Pesquisas em Administração, São Paulo, v.1, n.8, $1^{\circ}$ Trim./99.

ÁREAS CONTAMINADAS: Ataques da Era Industrial. (2001). Revista Gerenciamento Ambiental, n. 17, dez.

ARMENTI, K. (2001). Primary Prevention for Occupational Health: Using the Pollution Prevention Model to Promote the Integratoin of Occupational and Environmental Health. Doctoral Dissertation. University of Massachussets, Lowel, USA. 2001.

ASIAN DEVELOPMENT BANK (2002). Policy Integration and Strategic Action Planning for the Achievement of Cleaner Production. Manila, Philippines: Asian Development Bank.

ASSOCIAÇÃO BRASILEIRA DE NORMAS TÉCNICAS - ABNT. (1996). NBR ISO 14.001 - Sistemas de gestão ambiental - especificação e diretrizes para uso. $1^{a}$ ed. Rio de Janeiro.

(2001). NBR ISO 14040. Gestão Ambiental - Avaliação de Ciclo de Vida Princípios e Estrutura. Rio de Janeiro.

(2004). NBR 10004 - Resíduos Sólidos - Classificação. 2 ạ ed. São Paulo. 
ABRELPE - ASSOCIAÇÃO BRASILEIRA DE RESÍDUOS ESPECIAIS E LIMPEZA (2003). Panorama dos Resíduos Sólidos no Brasil. São Paulo. Diponível em: www.abrelpe.com.br. Acessado em março de 2005.

.(2004). Panorama dos Resíduos Sólidos no Brasil. São Paulo. Diponível em: www.abrelpe.com.br. Acessado em março de 2005.

AZAPAGIC, A. (1999). Life cycle assesment and its application to process selection, design and optimisation. Chemical Engineering Journal, v. 73, p.1-21.

BARROS, R.L.P., PAIVA, M.F.F., SISINNO, C.L.S. (2003). Cleaner produciton challenges in Brazilian SMEs. UNEP Industry and Environment. OctoberDecember, p. 26-28.

BIDONE, F.R.A; POVINELLI, J. (1999). Conceitos Básicos de Resíduos Sólidos. São Carlos: EESC-USP.

BISHOP, P. L. (2000a). Pollution Prevention: Fundamentals and Practice. $1^{\text {st }}$ ed.

.(2000b). Pollution Prevention: A New Paradigm for Engineering Education. Water, Air and Soil Pollution, v. 123, p.505-515.

BRAGA, B., et al. (2002). Introdução à Engenharia A mbiental. São Paulo: Prentice Hall.

BREGA FILHO, D., MANCUSO, P.C.S. (2003). Conceito de Reúso de Água. In: MANCUSO, P.C.S., SANTOS, H.F. (Eds). Reúso de Água. Barueri,SP: Manole. p. 21-36.

BROWN, D. A., LEMONS, J. (1995). Sustainable Development: Science, Ethics, and Public Policy. $1^{\text {st }}$ ed. Netherlands: Kluwer Academic Publishers.

BUCHHOLZ, R. A. (1998). Principles of Environmental Management: The Greening of Business. $2^{\text {nd }}$ ed. New Jersey: Prentice-Hall.

CHAABAN, M.A. (2001). Hazardous Waste Source Reduction in Materials and Processing Technologies. Journal of Materials Processing Technology, v.119, p. 336-343.

CHEHEBE, J.R.B. (1998). Análise do Ciclo de Vida de Produtos: Ferramenta Gerencial da ISO 14000. Rio de Janeiro: Qualimark.

CICHOWICZ, J.A. (1996). ISO 14.000: New Opportunities for Expanding P2. Pollution Prevention Review, p. 1-11, Spring.

COGGINS, C. (2001). Waste Prevention - an issue of shared resonsability for UK producers and consumers: policy options and measurement. Resources, Conservation and Recycling, v.32, p.181-190.

COMPROMISSO EMPRESARIAL PARA RECICLAGEM - CEMPRE (2000). Reduzindo, Reutilizando, Reciclando: A indústria ecoeficiente. São Paulo.

CRAMPTON, N.J. (1998). Preventing Waste at the Source. Boca Raton: Lewis Publishers. 
DASGUPTA, S., LUCAS, R.E.B., WHEELER, D. (1998). Small Plants, Pollution and Poverty: New Evidence from Brazil and Mexico. World Bank Policy Research Department Working Paper, November.

DEMPSEY, C.R., OPPELT, E.T. (1999). Incineração de Resíduos Perigosos - Uma Revisão Crítica. Air and Waste Management Association - Seção Brasil, São Paulo.

DONAIRE D. (1995). Gestão Ambiental na Empresa. São Paulo: Atlas.

DVORAK, B.I. et al. (2003). Nebraska Pollution Prevention Project: Engineering Education through Technical Assistance. Environmental Quality Management, Spring, p. 43-57.

DUNCAN, A.P. (1999). What is Source Reduction? A critique and Comparative Analysis of Polish and American Students. Environmental Management, v. 23, n. 4, p. 495-505.

ENVIRONMENT CANADA - EC. (2001). Pollution Prevention Planning Handbook. Canadian Environment Protection Agency, Canada.

FEDERAÇÃO DAS INDÚSTRIAS DO ESTADO DE SÃO PAULO - FIESP (2001). Aplicação da Oferta de Energia através da biomassa. FIESP/CIESP: São Paulo. Disponível em http://www.fiesp.org.br/publica/documentos/relatorio\%20dma.pdf. Acessado em set. 2002.

FIKSEL, J. (2002). Sustainable Development through Industrial Ecology. In: LANKEY, R.L., ANASTAS, P.T. (2002). Advancing Sustainability through Green Chemistry and Engineering. Washington: American Chemical Society, p.13-29.

FREEMAN, H. M. (1995). Industrial Pollution Prevention Handbook. Cincinnati: McGraw-Hill.

FREITAS, O.S. (2001). Resíduos Industriais - um problema cada vez mais difícil e caro para resolver. Revista Meio Ambiente Industrial, ed 33, n. 32, p. 100-103.

FURTADO, J.S. et al. (1998). Prevenção de Resíduos na Fonte \& Economia de Água e Energia - Manual de Avaliação na Fábrica. Departamento de Engenharia de Produção e Fundação Vanzolini. Escola Politécnica. Universidade de São Paulo. Disponível em: <www.vanzolini.org.br/areas/desenvolvimento/producaolimpa>

.(2001). ISO 14000 e Produção Limpa: Importantes, porém distintas em seus propósitos e métodos. $<w w w . v a n z o l i n i . o r g . b r / a r e a s / d e s e n v o l v i m e n t o / p r o d u c a o l i m p a>$.

FURTADO, J.S., FURTADO, M. C. (1997). Produção Limpa. In: CONTADOR, J.C. et al. (editores). Gestão de Operações. São Paulo: Fundação Vanzolini \& Editora Edgard Blucher, p.317-329.

GARNER, A.; KEOLEIAN, G.A. (1995). Industrial Ecology: An Introduction. Pollution Prevention and Industrial Ecology. National Pollution Prevention Center for Higher Education. University of Michigan, United States.

GEISER, K., OLDENBURG, K.U. (1997). Pollution prevention and...or industrial ecology? Journal of Cleaner Production, v.5, n.1-2, p.103-108. 
GEISER, K. (2002a). What next in cleaner production technologies? UNEP Industry and Environment. July-December Issue, p.75-77.

. (2002b). Making Materials Matter. New Solutions, v. 12, n. 2, p. 157-175.

GNECCO, C., MARIANO, R., FERNANDES, F. (2003). Tratamento de Superfície e Pintura. CBCA: Rio de Janeiro.

GRAEDEL, T.E., ALLENBY, B.R. (2002). Hierarchical Metrics for Sustainability. Environmental Quality Management, v.12, n.2. p. 21-30.

GREEN, E., et al. (2000). Protecting Environmental Quality and Human Health: Strategies for Harmonization. The Science of the Total Environment, v. 256, p. 205213.

GREEN ZIA ENVIRONMENTAL EXCELLENCE PROGRAM. [200?] Nothing to Waste Manual: Incorporating Pollution Prevention into Small Business. Disponível em $<$ http://.nmenv.state.nm.us>.

GUTIÉRREZ-MARTIN, F., HÜTTENHAIN, S.H. (2003). Environmental Education: new paradigms and engineering syllabus. Journal of Cleaner Production, v. 11, p. 247251.

GUTIÉRREZ-MARTIN, F., DAHAB, M.F. (1998). Issues of Sustainability and Pollution Prevention in Environmental Engineering Education. Water Science Technology, v. 38 ,

HEATON, C.; NORTHEIN, C.; HELMINGER, A. (2004). Pollution Prevention: Opting for Solvent-free Cleaning Processes. Chemical Engineering, v. 111, n.1, p 42-48.

HIGGINS, T.E. (1995). Pollution Prevention Handbook. Boca Raton: Lewis Publishers.

HILSON, G. (2003). Defining "cleaner production" and "pollution prevention" in the mining context. Minerals Engineering, n.16, p.205-321.

HIMMELBLAU, D.M. (1984). Engenharia Química: Princípios e Cálculos. $4^{\mathrm{a}}$ ed. revisada. Rio de Janeiro: Prentice-Hall do Brasil.

HIRATA, R. (2004). Gestão de Aquíferos. In: Prevenção e Controle da Poluição do Solo e das Águas Subterrâneas. São Paulo: CETESB. Apostila.

HONKASALO, A. (1998). The EMAS scheme: a management tool and instrument of environmental policy. Journal of Cleaner Production, v.6, p.119-128.

IGNÁCIO, E.A. (1998). Caracterização da legislação ambiental brasileira voltada para a utilização de fluidos de corte na indústria metal-mecânica. Dissertação (Mestrado). Universidade Federal de Santa Catarina. Florianópolis, 1998, 140pp.

JELINSKI, L.W. et al. (1993). Industrial Ecology: Concepts and Approaches. Disponível em: <http://www.sustainable.doe.gov/articles/indecom.shtml $>$. Acessado em março de 2002.

KHAN, F.I., RAVEENDER, V., HUSAIN, T. (2002). Effective Environmental Management through Life Cycle Assessment. Journal of Loss Prevention in the Process Industries, v. 15, p. 445-466. 
KIRKWOOD, R. C., LONGLEY, A. J. (1995). Clean Technology and the Environment. $1^{\text {st }}$ ed. Great Britain: Chapman \& Hall.

KRAJNC, D., GLAVIC, P. (2003). Indicator for Sustainable Production. Clean Technology Environmental Policy, v.5, p.279-288.

LAGE, H. (2004). Como Controlar e avaliar as empresas para as quais se envia resíduos. Revista Meio Ambiente Industrial, ed. 47, n. 46, p. 62-64.

LA GREGA, M.D., BUCKINGHAM, P.L., EVANS, J.C. (1994). Hazardous Waste Management. New York: McGraw-Hill.

LARSON, T.J., BROWN, H.J. (1997). Designing Metrics That Fit: Rethinking Corporate Environmental Performance Measurement Systems. Environmental Quality Management. Spring issue, p. 81-88.

LEÃO, M.L.G. (1998). Gerenciamento de Resíduos Sólidos Industriais Perigosos - a Problemática da Região Metropolitana de São Paulo. Dissertação (Mestrado) Escola Politécnica, Universidade de São Paulo, São Paulo. 1998.

LIXO movimenta R\$240 milhões. (2002). Gazeta Mercantil, 27 jun. Seção Geral p. 1.

LOPES, A. A. et al. (2004). A Influência dos Resíduos Sólidos na Qualidade das Águas Subterrâneas: O Caso da Bacia Tietê-Jacaré (UGRHI-13). In: ESPÍNDOLA, E.; WENDLAND, E. (Org.). Bacia Hidrográfica - Diversas Abordagens em Pesquisa. São Carlos: Rima. P.259-276.

LOVINS, A.B., LOVINS, L., HAWKEN, P. (1999). A Road Map for Natural Capitalism. Harvard Business Review, May-June, p.145-158.

MANZINI, E., VEZZOLI, C. (2002). O Desenvolvimento de Produtos Sustentáveis - Os requisitos ambientais dos produtos industriais. São Paulo: EduSP.

MARTIN, M.J., RIGOLA, M. (2003). Incorporating cleaner production and environmental management systems in environmental science education at the University of Girona. International Journal of Sustainability in Higher Education, v.2, n. 4 , p. 329-338.

MAXWELL, D., VAN DER VORST, R. (2003). Developing Sustainable Products and Services. Journal of Cleaner Production, v. 11, p. 883-895.

McLAUGHLIN, S., ELWOOD, H. (1996). Environmental Accounting and EMSs. Pollution Prevention Review, Spring issue, p.13-21.

MEIO AMBIENTE INDUSTRIAL (2005). Projeto ISO 14.001. Disponível em $<$ www.meioambienteindustrial.com.br/projeto_iso_14001.shtml $>$ Acessado em maio de 2005.

MOREIRA, M.S. (2001). Estratégia e Implementação do Sistema de Gestão Ambiental (Modelo ISO 14000). Belo Horizonte: Editora de Desenvolvimento Gerencial.

MOTTA, R.S. (1996). Indicadores Ambientais no Brasil: Aspectos Ecológicos, de Eficiência e Distributivos. Texto para discussão. Rio de Janeiro: IPEA. 
NORTHEAST WASTE MANAGEMENT OFFICIAL'S ASSOCIATION - NWMOA (1998). Pollution Prevention in Metal Painting and Coating Operations. NWMOA: Boston. Boston.

. (2001). Pollution Prevention in Machining and Metal Fabrication. NWMOA:

NOURELDIN, B.M.; EL-HAWAGI, M.M. (1999). Interval-based targeting for pollution prevention via massa integration. Computers \& Chemical Engineering, v.23, p.1527-1543.

. (2000). Pollution prevention targets through integrated design and operation. Computers \& Chemical Engineering, v.24, p.1445-1453.

NOVAES, W. (2003). Dúvidas no esgoto e no lixo. O Estado de São Paulo, 18/04/2003. Espaço Aberto.

O'BRIEN, C. (1999). Sustainable Production - A new paradigm for a new millennium. International Journal of Production Economics, v. 60-61, p. 1-7.

OCHSNER, M. (2001). Can Hourly Workers Participate in P2 - and Can Worker Health and Safety Benefit? Pollution Prevention Review, p. 27-38, Summer.

PAÍS SUJO. (2002). Revista Istoé, n. 1696, 03 de abr. Reportagem de Capa.

PAULI, G. (1997). Zero emissions: the ultimate goal of cleaner production. Journal of Cleaner Production, v.5, n.1-2, p.109-113.

PELICIOLI, M.C.F. (2004). Fundamentos de Educação Ambiental. In: A. PHILIPPI Jr. A., ROMERO, M.A., BRUNA, G.C. (editores). Curso de Gestão Ambiental. Barueri, SP: Manole, p. 459-483.

PETILLO, V.L.S. (1997). Gestão Ambiental na Indústria Química Brasileira: uma Análise do Período de 1990 a 1995. 106p. Dissertação (Mestrado). Universidade Mackenzie, São Paulo, 1997.

PHILIPPI Jr. A., AGUIAR, A.O. (2004). Auditoria Ambiental. In: Curso de Gestão Ambiental. PHILIPPI Jr. A., ROMERO, M.A., BRUNA, G.C. (editores). Barueri, SP: Manole. p. 805-856.

PHILIPPI Jr.A., MALHEIROS,T.F., AGUIAR, A.O. (2004). Indicadores de Desenvolvimento Sustentável. In: Saneamento, Saúde e Ambiente: Fundamentos para um Desenvolvimento Sustentável. PHILIPPI Jr. A. (editor). Barueri, SP: Manole. p. 761-808.

PIOTTO, Z.C. (2003). Eco-eficiência na Indústria de Celulose e Papel - Estudo de Caso. Tese (Doutorado). Escola Politécnica, Universidade de São Paulo, São Paulo, 2003.

POJASEK, R.B. (1996a). Using Cause and Effect Diagrams in your P2 Program. Pollution Prevention Review. Summer issue, p.99-105.

(1996b). Identifying P2 Alternatives with Brainstorming and Brainwriting. Pollution Prevention Review. Autumn issue, p. 93-97. 
. (1997a). Understanding a Process with Process Mapping. Pollution Prevention Review. Summer issue, p.91-101.

. (1997b). Materials Accounting and P2. Pollution Prevention Review. Autumn issue, p. 95-103.

(1997c). Prioritizing P2 Alternatives. Pollution Prevention Review. Winter issue, p.105-112.

. (1997d). Implementing your P2 Alternative. Pollution Prevention Review. Spring issue, p.83-88.

. (1998a). Selecting P2 Opportunities. Pollution Prevention Review. Summer issue, p. 103-110.

. (1998b). Activity-Based Costing for EHS Improvement. Pollution Prevention Review. Winter issue, p.111-120.

PRC ENVIRONMENTAL MANAGEMENT INC. (1989). Hazardous Waste Reduction in the Metal Finishing Industry. $1^{\text {st }}$ ed. New Jersey: Noya Data Corporation.

PROBST, K.N., BEIERLE, T.C. (1999). The Evolution of Hazardous Waste Programs: Lessons from Eight Countries. $1^{\text {st }}$ ed. Washington: Resources for the Future.

QUINN, M.M., et al. (1998). Sustainable Production: a Proposed Strategy for the Work Environment. American Journal of Industrial Medicine, v. 34, p. 297-304.

RAMOS, V. (2004). SP detecta 750 novas áreas contaminadas. Folha de São Paulo, São Paulo, 10 nov. Caderno Ambiente, p.C4.

RECICLANDO Valores (2003). Revista Brasileira de Saneamento e Meio Ambiente, n. 28, p.16-17, out/dez.

RICHARDS, D.J. (1999). Metrics for Industrial Performance: a Status Report. Pollution Prevention Review, Summer 1999, 23-31.

ROCCA, A.C.C., et al. (1993). Resíduos Sólidos Industriais. 2 a ed. São Paulo: CETESB.

ROCCA, A.C.C. (2004). Fontes de Poluição de Solos e Águas Subterrâneas. In: Prevenção e Controle da Poluição do Solo e das Águas Subterrâneas. São Paulo: CETESB. Apostila.

RODHE, H. (2000). Preventive Environmental Strategies in Eastern European Industry - An analysis of donor support for cleaner production. Doctoral Dissertation. IIIEE, Lund University, Sweden.

ROELOFS, C.R., MOURE-ERASO, R., ELLENBECKER, M.J. (2000). Pollution Prevention and the Work Environment: the Massachussets Experience. Applied Occupational and Environmental Hygiene, v.15, n 11, p. 843-850.

ROHDE, G.M. (2004). Comparação das Principais Idéias Existentes para a Redução da Geração de Resíduos Sólidos na Produção Material Humana. In: I Congresso Interamericano de Resíduos Sólidos Industriais. Porto Alegre, 2004. CD-ROM. 
ROSENBERG, B.J., BARBEAU, E.M., MOURE-ERASO, R., et al. (2001). The Work Environment Impact Assessment: A Methodologic Framework for Evaluation Health-Based Intervations. American Journal of Industrial Medicine, v. 39, p. 218226.

ROSS, S., EVANS, D. (2002). Use of Life Cycle Assessment in Environmental Management. Environmental Management, v. 29, n.1, p. 132-142.

ROY, R. (2000). Sustainable Product-Service Systems. Futures, v. 32, p. 289-299.

SANCHES, C.S. (1996). A Evolução da Prática Ambiental em Empresas Industriais: Algumas Considerações sobre o Estado-Atual-da-Arte e o Caso Brasileiro. Dissertação (Mestrado). 166p. Escola de Administração de Empresas - Fundação Getúlio Vargas. 1996.

SÁNCHEZ, L.E. (2001). Desengenharia - O Passivo Ambiental na Desativação de Empreendimentos Industriais. São Paulo: EdUSP.

SANTOS, C.; DVORAK, B.I.; SCHALCH, V. (2004). Waste Brine Reclaim - Preventing Pollution from Salt Discharges. SIDISA 2004 - Simposio Internazionale di Ingegneria Sanitaria Ambientale. ABES/AIDIS. Taormina, Itália. 23-26 de Junho de 2004.

SCHALCH, V; et al. (2000). Curso sobre Gerenciamento de Resíduos Sólidos.(Apostila). São Carlos: EESC-USP.

SCHMIDHEINY, S. (1992). Mudando o rumo: uma perspectiva empresarial global sobre desenvolvimento e meio ambiente. Rio de Janeiro: FGV.

SCHNITZER, H. (1995). Sustainable Development \& Cleaner Production - How Do They Fit Together? In: FREEMAN, H.M., PUSKAS, Z., OLBINA, R. editors. Cleaner Technologies and Cleaner Products for Sustainble Development. Berlin: Spring Verlag. NATO ASI Series, Vol 2.

SHEN, T.T. (1995). Industrial Pollution Prevention. Berlim: Springer- Verlag.

SOARES, G.F.S. (2003). A Proteção Internacional do Meio Ambiente. Barueri, SP: Manole.

SPRIGGS, H.D. (1994). Design for Pollution Prevention. In: EL-HALWAGI, M.M., PETRIDES, D.P. (ed.) Pollution Prevention via Process and Product Modifications. American Institute of Chemical Engineers - Symposium Series. Vol. 90, p. 1-10.

STEWART, J.R. et al. (1999). Life Cycle Assessment as a tool for environmental management. Clean Products and Processes, v. 1, p. 73-81.

THOMAS, R. (2002). A Greater Understanding of Environmental Ethics and Need for Inculcating Environment-friendly Culture. International Review of Sociology, v.12, n.1, p.77-87.

THOMAS, S.T. (1995). Facility Manager's Guide to Pollution Prevention and Waste Minimization. $1^{\text {st }}$ ed. Washington: BNA Books.

THOMAS, K., LAPLANTE, J. ALAN, B. (1997). Guidebook of Part Cleaning Alternatives. Toxics Use Reduction Institute, University of Massachussets, Lowel. 
TOAKLEY, A.R., ARONI, S. (1998). The challenge of sustainable development and the role of universities. Higher Education Policy, v.11, p. 331-346.

TYTECA, D. (1996). On the Measurement of the Environmental Performance of Firms - a Literature Review and a Productive Efficiency Perspective. Journal of Environmental Management, v. 46, p. 281-308.

UNITED NATIONS ENVIRONMENTAL PROGRAMME-UNEP (2002a). Cleaner Production in the Latin America and the Caribbean. United Nations Publication. Disponível em http://www.uneptie.org/pc/cp/library/catalogue/regional_reports.htm. Acessado em Maio de 2003.

.(2002b). Glossary - Sustainable production and consuption: some frequently used terms. UNEP Industry and Environment. July-december, p.8.

.(2003). Cleaner Production Key elements. Disponível em: $<$ http://www.uneptie.org/pc/cp/understanding_cp/cp_policies.htm>. Acesso em maio de 2003.

UNITED STATES ENVIRONMENTAL AGENCY-US EPA (1988). Waste Minimization Opportunity Assessment Manual. Office of Research and Development. Ohio: EPA/625/7-88/003.

. (1992). Facility Pollution Prevention Guide. US EPA Pollution Prevention Office. Ohio: EPA/600/R-92/088. 92-004.

. (1993). Business Guide for Reducing Solid Waste. Washington: EPA/530-K-

. (1994). Guide to Cleaner Technologies: Cleaning and Degreasing Process Changes. Cincinnati: EPA/625/R-93-017.

- (1995a). An Introduction to Environmental Accounting as a Business Management Tool: Key Concepts and Terms. Washington: EPA/742-R-95-001.

. (1995b). Metalworking Fluids - Pollution Prevention Information Packet. US EPA Pollution Prevention Office. Ohio.

. (1996). Pollution Prevention in the Paints and Coatings Industry. Washington: EPA/744-R-00-011.

. (2000a). Integrated Environmental Management Systems - Implementation Guide. Washington: EPA 744-R-00-011.

. (2000b). Integrated Environmental Management Systems - Company Manual Template for Small Business. Washington: EPA 744-R-00-012.

. (2000c). The Lean and Green Supply Chain: A Practical Guide for Materials Managers and Supply Chain Managers to Reduce Costs and Improve Environmental Performance. Washington: EPA 742-R-00-001.

. (2001a). An Organizational Guide to Pollution Prevention. Washington: EPA 625-R-01-003. 
. (2001b). Guide to Industrial Assessments for Pollution Prevention and Energy Efficiency. Washington: EPA 625-R-99-003.

USO DE TECNOLOGIAS limpas movimenta US\$ 260 milhões. (2002). Gazeta Mercantil, 24 de jun. Seção Economia, pág. 1.

VALLE, C.E. (1995). Como se preparar para as normas ISO 14.000. $2^{\underline{a}}$ ed. São Paulo: Pioneira.

VELEVA, V., ELLENBECKER, M. (2001). Indicators for sustainable production: framework and methodology. Journal of Cleaner Production, v. 9, p. 519-549.

VIGON, B. W.; TOLLE, D. A.; CORNABY, et al. (1993). Life cycle Assessment: Inventory Guidelines and Principles. EPA/600/R-92/245. Cincinnati. OH. U.S. EPA.

VITERBO JR. E. (1998). Sistema Integrado de Gestão Ambiental. $2^{\underline{a}}$ ed. São Paulo: Aquariana.

WANZENRIED, B.; DVORAK, B.I.; WOLDT, W.E. (1999). Descriptive versus Prescriptive Comparison of P2 Opportunity Assessment Aproaches. Pollution Prevention Review, Summer 1999, 67-79.

WAREHAM, D.G., ELEFSINIOTIS, P. (1996). Environmental Ethics in Engineering Education: a Missing Fundamental. Water Science Technology, v. 34, n.12, p.197203.

WELCH, T. E. (1998). Moving Beyond Environmental Compliance: A handbook for integrating pollution prevention with ISO 14.000. $1^{\text {st }}$ ed. Lewis Publishers: Flórida.

WHITMAN, C.T; SHINN, R. C. Industrial Pollution Prevention Planning. New Jersey Departament of Environmental Protection (Office of Pollution Prevention), 1995.

WILSON, C.L. (1998). Preventing and Mitigating Environmental Enforcement with an EMS. Pollution Prevention Review. Summer issue, p. 29-37.

WORLD COUNCIL FOR SUSTAINABLE DEVELOPMENT - WCBSD. (1995). Sustainable Production and Consumption: A Business Perspective. WBCSD: Switzerland. Disponível para download em: <http//:www.wbcsd.ch> Acesso em Outubro de 2003.

(2000a). Ecoefficiency: Creating More Value With Less impact. WBCSD: Switzerland. Disponível para download em: <http//:www.wbcsd.ch> Acesso em Outubro de 2003.

(2000b). Measuring Eco-efficiency: a guide to reporting company performance. WBCSD: Switzerland. Disponível para download em: <http//:www.wbcsd.ch> Acesso em Outubro de 2003.

WORLD COMMISSION ON ENVIRONMENT AND DEVELOPMENT - WCED. (1987). Our Common Future. Great Britain: Oxford University Press.

ZOBEL, T. et.al. (2003). Identification and assessment of environmental aspects in an EMS context: na approach to new reproducible method based on LCA methodology. Journal of Cleaner Production, v.10, p. 381-396. 
ANEXO I

DESCRIÇÃO DO PROGRAMA PARCEIROS EM PREVENÇÃO À POLUIÇÃO DA UNIVERSIDADE DE NEBRASKA - LINCOLN, ESTADOS UNIDOS 


\section{Missão do Programa}

De forma a superar o desafio de fornecer assistência técnica a pequenas e médias empresas e ao mesmo tempo criar oportunidades de aprendizado prático para estudantes a nível de graduação e pós-graduação, a Universidade de Nebraska Lincoln, nos Estados Unidos criou o programa 'Partners in Pollution Prevention' - P3. Este programa completa, em 2005, dez anos de existência, e tem como principais metas:

- promover a educação ambiental por meio da experiência educacional intensiva a estudantes de engenharia e áreas afins;

- fornecer assistência técnica a pequenas e médias empresas e indústrias em todo o estado;

- disseminar conhecimento e educação ambiental para a comunidade, no que se refere às práticas de prevenção à população e à participação efetiva da comunidade na promoção da melhoria da qualidade ambiental; e,

- desenvolver projetos de pesquisa a nível de pós graduação, que envolvam problemas complexos.

Durante o programa os estudantes participam de um curso teórico intensivo de duas semanas após o qual estão aptos a colocar os conhecimentos adquiridos em prática. Cada estudante desenvolve, durante nove semanas, um projeto envolvendo assistência técnica específica em prevenção à poluição em uma indústria ou empresa. Para que um programa deste porte tenha sucesso muitos elementos são necessários, os quais são descritos a seguir.

\section{Selecão dos estudantes participantes do programa}

Podem se candidatar a uma vaga no programa alunos de universidades dos estados que compõem a região VII da USEPA (Nebraska, lowa, Kansas e Missouri), uma vez que o programa é financiado em parte pela EPA. Os candidatos precisam estar regularmente matriculados em um curso regular de engenharia ou áreas afins $e$ ter cumprido os créditos em disciplina de engenharia ambiental, e demonstrar forte embasamento técnico e teórico. A divulgação do programa para os estudantes das diversas universidades é realizado através de palestras proferidas pelos professores responsáveis pelo programa, pelo envio de folders e cartazes às universidades e pela divulgação informal por parte de estudantes que já participaram do programa para seus colegas. Existe ainda um website, com informações sobre o programa: (http://.ianr.unl.edu/p3). 
Ao se candidatar, o estudante preenche um formulário que além de incluir informações sobre a sua qualificação, também permite identificar o projeto mais adequado ao candidato, de acordo com seu perfil, área de interesse e localização geográfica. Os formulários são avaliados e os candidatos são entrevistados, de modo a eleger aqueles que apresentem qualificações tais como facilidade de comunicação, iniciativa e que demonstrem comprometimento e ética ambiental. Entre os anos de 1997 e 2001 foram selecionados 69 estudantes de graduação e 5 estudantes de pós graduação. Estes últimos atuaram no programa como assistentes nas atividades desenvolvidas pelos estudantes.

\section{Parceiros}

De modo a efetivamente fornecer treinamento em prevenção à poluição e disseminar ajuda e assistência técnica a uma gama de empresas, foram realizadas diversas parcerias. Os 'parceiros' podem ser profissionais de órgãos e instituições e participam colaborando nas atividades de treinamento. Como por exemplo, a Companhia de Energia do Estado de Nebraska que promove uma sessão técnica no curso sobre eficiência energética, ou a USEPA que presta assessoria em questões técnicas e fornece material e publicações, além de designar pessoal para responder a dúvidas dos estudantes ao longo de seus projetos.

A parceria pode envolver ainda a supervisão direta de um ou mais projetos. Neste caso o estudante desenvolve o projeto conjuntamente com o parceiro, como é o caso de projetos desenvolvidos junto ao Escritório de Prevenção à Poluição do Departamento de Qualidade Ambiental do Estado de Nebraska.

\section{Curriculum e Estrutura do Curso}

O grande diferencial do P3 é o curso intensivo de duas semanas, onde é fornecido o treinamento em prevenção à poluição aos estudantes. O curso é ministrado na forma de módulos por professores da Universidade de Nebraska, do Departamento de Qualidade Ambiental do Estado e demais parceiros, já citados anteriormente.

O treinamento tem como objetivos fornecer um amplo entendimento do conceito de prevenção à poluição e as diversas formas de aplicação; prover os estudantes no conhecimento de técnicas necessárias para a realização dos projetos, como técnicas de identificação de oportunidades e de identificação e quantificação de resíduos; desenvolver as habilidades de comunicação, verbal e escrita; treinar os estudantes no desenvolvimento de pesquisa aplicada, desenvolver habilidades para trabalhos em grupos, etc. A Tabela I mostra os principais tópicos abordados durante o curso. 
TABELA I - PRINCIPAIS TÓPICOS ABORDADOS NO TREINAMENTO.

\begin{tabular}{cl}
\hline Hora/aula & \multicolumn{1}{c}{ Tópico } \\
\hline 1 & Sustentabilidade e benefícios da prevenção à poluição \\
2 & Desenvolvimento histórico e regulatório da prevenção à \\
1 & poluição/legislação ambiental \\
1 & Como obter respostas a questões regulatórias \\
4 & Exercícios em grupo \\
1 & Técnicas para o levantamento de resíduos \\
2 & Técnicas de redação do relatório final \\
2 & Abordagens e métodos de prevenção à poluição \\
2 & Treinamento em saúde e segurança \\
2 & Aspectos econômicos da prevenção à poluição \\
1 & Eficiência Energética \\
1 & Avaliação de custos e de ciclo de vida \\
2 & Habilidades de pesquisa aplicadas \\
2 & Fontes de informação sobre prevenção à poluição \\
1 & Sistemas de Gestão Ambiental, Normas ISO 9000 e 14000 \\
& Obtenção de informação / interação com fornecedores
\end{tabular}

\section{Assistência Técnica}

Após a conclusão do treinamento teórico, durante nove semanas os estudantes desenvolvem seus projetos, em uma empresa, organização ou indústria, previamente definida, de acordo com a formação, habilidade e interesse específico de cada um. Os projetos podem ser focados em quatro diferentes grupos:

i) agências públicas: onde os estudantes atuam como membros da agência, recebendo supervisão dos funcionários. Dentre as agências participantes estão 0 Departamento de Qualidade Ambiental do Estado, a Companhia de Energia Elétrica e o Departamento de Saúde, e demais instituições que apresentem potencial para realização de atividades de prevenção à poluição. Os projetos compreendem pesquisas no sentido de atender à perguntas da comunidade, formular materiais informativos sobre conservação de energia e recursos, desenvolver manuais de prevenção à poluição, realizar visitas técnicas a prestadores de serviços (ex. oficinas mecânicas) e prestar assistência sobre minimização de resíduos e substituição de materiais poluentes, coleta seletiva de materiais, etc.; 
ii) consultoria para indústrias: neste caso o estudante presta consultoria a um ou mais cliente ao mesmo tempo, e o trabalho podem envolver o estudo de diversos processos e operações específicas de cada cliente. O trabalho é desenvolvido usualmente na Universidade, o contato do estudante com o espaço físico com cliente é esporádico, apenas para reconhecimento do problema e coleta de dados e informações;

iii) indústrias: neste tipo de assistência o estudante atua diretamente no site industrial, as tarefas realizadas são bastante similares àquelas realizadas pelos estudantes que atuam como consultores, exceto pelo fato de estarem alocados na área industrial e receberem auxílio diário e direto dos funcionários da indústria; e,

iv) pequenas empresas: cada estudante presta assistência para quatro a oito empresas (companhias com até 200 funcionários). Como exemplos de empresas estão oficinas mecânicas, lavanderias, cooperativas, estabelecimentos comerciais diversos, etc. Neste grupo os estudantes também desenvolvem trabalhos de educação ambiental com a comunidade local, sobre prevenção à poluição.

Em todos os casos os estudantes trabalham com os clientes pesquisando as operações e atividades, com ênfase no entendimento do processo, usando abordagens sistêmicas. Cada estudante desenvolve um levantamento dos resíduos gerados nas operações (ou em parte delas, de acordo com o porte da unidade ou do interesse do cliente), identifica as melhores e mais recentes tecnologias disponíveis e que podem ser adotadas para prevenir a geração de resíduos, realiza uma avaliação econômica da proposta de prevenção à poluição a ser implementada em relação ao processo corrente, e apresenta o resultado final do projeto ao cliente, na forma de um relatório técnico, conciso e objetivo.

O relatório consiste basicamente de um sumário executivo, uma descrição da unidade de estudo, recomendações gerais e sugestões de práticas de prevenção à poluição pertinentes, e um apêndice com informações e documentos, como listas de fornecedores de equipamentos e preços, detalhes técnicos de processos e práticas de tecnologias limpas, etc. Os relatórios são revisados e avaliados pelos professores antes que sejam entregues aos clientes. No último dia do programa cada estudante prepara uma apresentação breve de seu projeto, como forma de avaliação e também de transmitir aos colegas suas experiências. 


\section{Resultados do Programa}

Entre os anos de 1997 e 2001, os programa atendeu a 246 clientes, contemplando um total de 1600 oportunidades de prevenção à poluição identificadas através dos projetos desenvolvidos. Novas direções, englobando questões como conservação de energia, tem sido adotadas nos anos mais recentes do programa. A Tabela II mostra os resultados obtidos no programa nos anos de 1999 a 2001.

TABELA II - REDUÇÃo Potencial dE Custos e ReduÇÃo de ResíduOS

\begin{tabular}{|c|c|c|c|c|c|}
\hline & 1997 & 1998 & 1999 & 2000 & 2001 \\
\hline Número de alunos & 17 & 15 & 16 & 14 & 7 \\
\hline Pequenas empresas ${ }^{1}$ & 67 & 70 & 33 & 25 & 19 \\
\hline Indústrias ${ }^{1}$ & 7 & 3 & 9 & 9 & 4 \\
\hline Oportunidades identificadas & 617 & 538 & 228 & 148 & 65 \\
\hline $\begin{array}{l}\text { Redução de custos potenciais } \\
\left(10^{3} \$ / a n o\right)^{2}\end{array}$ & 258 & 275 & 676 & 1680 & 740 \\
\hline $\begin{array}{l}\text { Quantidade de resíduos que } \\
\text { deixou de ser enviada a aterros } \\
\left(10^{3} \mathrm{lb} / \mathrm{ano}\right)^{2}\end{array}$ & 700 & 3000 & 6530 & 9120 & 2134 \\
\hline $\begin{array}{l}\text { Redução de resíduos perigosos } \\
\text { (gal/ano) }\end{array}$ & 3500 & 3500 & 17000 & 7540 & 801 \\
\hline Redução de energia (Kw/h/ano $)^{2}$ & $\begin{array}{c}\text { não } \\
\text { estimada }\end{array}$ & $\begin{array}{c}\text { não } \\
\text { estimada }\end{array}$ & 465.000 & 970.000 & 313.800 \\
\hline
\end{tabular}

${ }^{1}$ Número de pequenas empresas e indústrias atendidas pelo programa.

${ }^{2}$ Redução de custos, energia e resíduos estimada considerando que as oportunidades identificadas pelos estudantes sejam integralmente implementadas.

Nos anos de 2001 e 2002, os estudantes desenvolveram projetos focados na assistência a clientes que já haviam sido atendidos nos anos anteriores, e que requisitaram novos projetos ou a continuidade ou a revisão de projetos já implantados pelo programa. Ao avaliar estes projetos, concluiu-se que em média, de 35 a $80 \%$ das recomendações sugeridas pelos estudantes nos anos anteriores haviam sido implementadas na prática.

O programa contribuiu ainda para a disseminação de informação na comunidade, através de palestras e workshops proferidos pelos estudantes em instituições e indústrias, e por meio de artigos e notas publicadas em jornais e outros meios de divulgação impressa. 
Além da disseminação de informação para diversos setores da comunidade e da prestação de assistência técnica, trabalhos de pesquisa a nível de pós graduação tiveram seus temas relacionados com estudos de caso desenvolvidos no programa. Dentre as pesquisas estão o desenvolvimento de ferramentas para a modelagem de estudos de avaliação de ciclo de vida, modelagem de imprecisões aplicada à prevenção à poluição, e comparação entre diferentes métodos de identificação de oportunidades de prevenção à poluição. 